ISNARD DE ALBUQUERQUE CÂMARA NETO

\title{
A AÇÃO ROMANIZADORA E A LUTA PELO COFRE: D. EPAMINONDAS, PRIMEIRO BISPO DE TAUBATÉ (1909 - 1935)
}

UNIVERSIDADE DE SÃO PAULO

SÃO PAULO

2006 
ISNARD DE ALBUQUERQUE CÂMARA NETO

\section{A AČ̃̃O ROMANIZADORA E A LUTA PELO COFRE: D. EPAMINONDAS, PRIMEIRO BISPO DE TAUBATÉ (1909 - 1935)}

Tese apresentada ao Programa de Pósgraduação da Faculdade de Filosofia, Letras e Ciências Humanas para obtenção do título de Doutor. Sob a orientação do Prof. Dr. Augustin Wernet 
Á Sandra, minha esposa, pelo constante incentivo.

À Gabriela, minha filha única, com a recomendação de fazer melhor e mais cedo, para que um dia possa brincar com seus filhos.

À Professora Maria Helena Apolinário, que me deu régua e compasso no decorrer do meu curso de graduação na Universidade de Taubaté.

À USP e à UNITAU, paixões à primeira vista. 


\section{Agradecimentos}

Os agradecimentos que aqui materializo extrapolam, em muito, a simples formalidade acadêmica. Os que encontrei pelo caminho reforçam em mim a certeza de que uma tese de doutorado, por mais ciúmes que dela possamos ter, não é obra realizada por apenas um indivíduo. Aos abaixo relacionados, portanto, o reconhecimento, a amizade e a gratidão pelo apoio a mim oferecidos ao longo desses anos.

Ao Programa de Pós-graduação da Universidade de Taubaté, na pessoa da Professora Doutora Maria Júlia Ferreira Xavier Ribeiro, Pró-reitora de Pesquisa e Pós-graduação, pela bolsa de estudos a mim concedida.

Ao meu orientador, Professor Doutor Augustin Wernet, pela oportunidade concedida e pela firmeza e serenidade na orientação, tornando-me assim não só seu eterno devedor, mas também um privilegiado.

Aos Professores Doutores Carlos Roberto Figueiredo Nogueira e Wilson do Nascimento Barbosa, pelas valiosas sugestões apresentadas quando de minha banca de qualificação.

Ao Professor Fred Humbert Reis Savino, Diretor da Divisão de Museus, Patrimônio e Arquivo Histórico de Taubaté, pela amizade e consideração com que fui distinguido ao longo de todo o meu período de pesquisa.

À Professora Lia Carolina Prado Alves Mariotto, paleógrafa da Divisão de Museus, Patrimônio e Arquivo Histórico de Taubaté, que juntamente com o Professor Fred tornaram o Arquivo Histórico de Taubaté um centro de excelência de pesquisa no vale do Paraíba.

Ao Rev. ${ }^{\text {mo }}$ Pe. Júlio João Brustoloni - prezado Padre Julinho - historiador redentorista, pela generosidade com que franqueou seu valioso arquivo.

À Sra. Carolina dos Santos, bibliotecária do Seminário Redentorista Santo Afonso, em Aparecida, pela colaboração amiga ao longo desse tempo.

Às bibliotecários da Universidade de Taubaté, pela consideração, apreço e amizade com que sempre fui recebido.

Aos prezados Jair Mongelli Júnior e Roberto Júlio Gava, do Arquivo da Cúria Metropolitana de São Paulo, pela valiosíssima colaboração.

A todos os funcionários da Cúria Diocesana de Taubaté, pela amizade. 


\title{
Resumo
}

A presente tese busca apresentar o governo diocesano de D. Epaminondas Nunes de Ávila e Silva, primeiro bispo de Taubaté. Em 1908 assiste-se à criação de cinco dioceses no estado de São Paulo, entre elas Taubaté. Em seu espaço territorial encontrava-se o Santuário de Nossa Senhora Aparecida, cuja administração coube, por decreto, à Arquidiocese de São Paulo. Iniciava-se uma disputa pela administração desse santuário entre o bispo de Taubaté e o arcebispo de São Paulo, cada qual visando defender seus interesses diocesanos. Além da atuação comum aos bispos da época, quais sejam, o controle sobre o clero, o enquadramento das irmandades leigas e a burocratização da diocese, a ação romanizadora de D. Epaminondas, como resposta ao confronto com D. Duarte, focou-se na devoção a Santa Teresinha, sendo construído em Taubaté o primeiro santuário do mundo em sua honra.

\section{PALAVRAS CHAVE}

\author{
Aparecida \\ Catolicismo \\ Epaminondas \\ Igreja \\ Taubaté
}




\title{
Abstract
}

The present thesis tries to shed some light on the government of the diocese of Taubaté by its first bishop, Dom Epaminondas Nunes de Ávila e Silva. In the year of 1908 five new dioceses have been established in the State of S. Paulo, including the Diocese of Taubaté. The sanctuary of Our Lady Aparecida comes to be located inside the territorial space of the newly established diocese. The administration of the sanctuary however was, by decree, under the government of the Archdiocese of S. Paulo. This conflicting situation incited a dispute between the Bishop of Taubaté and the Archbishop of S. Paulo with regards to whom the administration of the sanctuary should belong to. In addition to the usual diocesan obligations such as to exercise control over the clergy and give legal support to the laity brotherhoods, the "Roman " activity of D. Epaminondas, as an answer to the conflict with Dom Duarte, came to being focused on the devotion to St. Teresinha. This focus has then lead to building the very first world sanctuary devoted to St. Teresinha in the city of Taubaté.

\section{KEY WORDS}

\author{
Aparecida \\ Catholicism \\ Epaminondas \\ Church \\ Taubaté
}




\section{Índice}

INTRODUÇÃO

CAPÍTULO I - ENQUANTO O SENHOR BISPO NÃO VEM.............................. 27

1.1. Religião, catolicismo luso-brasileiro e política no vale do Paraíba ...... 27

1.2. A implantação do catolicismo ultramontano no vale do Paraíba .......... 64

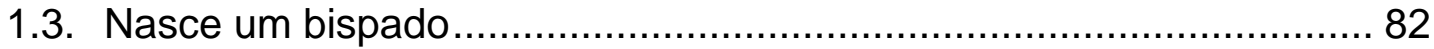

CAPÍTULO II - O "LEGADO WANDERLEY"......................................................... 96

2.1. As novas dioceses e as questões patrimoniais ................................. 96

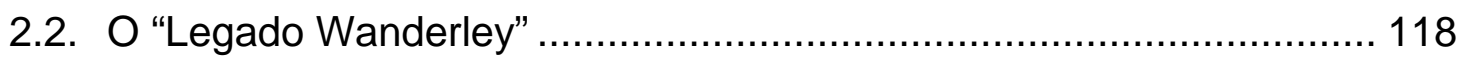

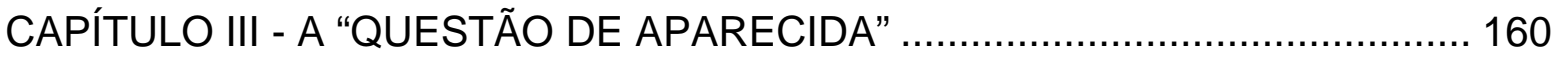

3.1. Aparecida: a arquitetura de uma devoção ........................................ 160

3.2. A luta pelo cofre: a Questão de Aparecida .......................................... 181

CAPÍTULO IV - DOM EPAMINONDAS: O BISPO DE SANTA TERESINHA ...... 230

4.1. D. Epaminondas, primeiro bispo de Taubaté .................................. 230

4.2. A resposta ultramontana: o Santuário de Santa Teresinha ................. 280

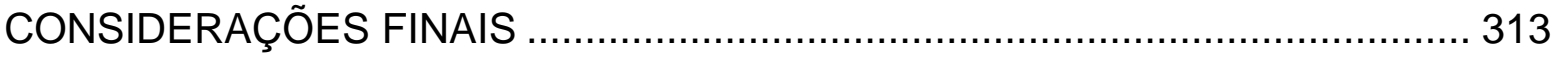

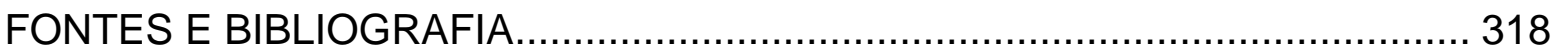




\section{INTRODUÇÃO}

A historiografia brasileira iniciou, a partir da década de 80 do século passado, uma reavaliação de respostas para antigas questões. Alguns modelos foram revisados e outros perderam sua validade, dando lugar a novas perspectivas historiográficas. Particularmente em relação à Igreja católica no Brasil, sua história passou a ser reescrita. Desta vez, porém, sem o cunho apologético que tanto caracterizou obras pretéritas.

As relações entre o catolicismo luso-brasileiro e o catolicismo oficial, o definhamento do catolicismo iluminista, a consolidação da romanização e a necessária reorganização de uma Igreja já separada dos laços jurídicos que a mantinham subordinada ao Estado, são apenas alguns exemplos de como o estudo da história da Igreja católica no Brasil ganhou novas perspectivas, sine ira et studio.

Todavia ainda perduram lacunas, particularmente no período da romanização que compreende as duas primeiras décadas do período republicano, a fim de que sejam apresentadas respostas mais completas e satisfatórias.

Dos estudos sobre a Igreja católica no Brasil ressalto os trabalhos dos historiadores Augustin Wernet, ${ }^{1}$ Maurílio José de Oliveira Camello, ${ }^{2}$ Marcus Levy Albino Bencostta ${ }^{3}$ e Evandro Faustino, ${ }^{4}$ bem como o do sociólogo Sérgio Miceli. ${ }^{5}$ Merecedores que são esses autores de maior destaque, julgo oportuno breve comentário sobre suas principais obras.

"A Igreja Paulista no Século XIX", de Augustin Wernet, é obra basilar nos estudos contemporâneos sobre a transição do catolicismo iluminista para o catolicismo ultramontano no Brasil, em geral, e na Igreja paulista, em particular, transição essa materializada pela ação de D. Antônio Joaquim de Melo no sólio da cidade de São Paulo. Resgatando de modo científico e metodologicamente orientado o processo de romanização da Igreja católica, essa tese de livre docência já é considerada referência entre os tratadistas do tema.

1 WERNET, Augustin. A Igreja paulista no século XIX. São Paulo: Ática, 1987.

2 CAMELLO, Maurílio José de Oliveira. Dom Antônio Ferreira Viçoso e a reforma do clero de Minas Gerais no século XIX. 1986. Tese (Doutorado em História Social) - Universidade de São Paulo, São Paulo, 1986.

3 BENCOSTTA, Marcus Levy Albino. Igreja e Poder em São Paulo: D. João Batista Corrêa Nery e a romanização do catolicismo brasileiro $(1908$ - 1920). 2002. Tese (Doutorado em História Social) Universidade de São Paulo, São Paulo, 2002.

4 FAUSTINO, Evandro. O renitente catolicismo popular. 1996. Tese (Doutorado em História Social) Universidade de São Paulo, São Paulo, 1996.

5 MICELI, Sérgio. A elite eclesiástica brasileira. (1890-1930). São Paulo: Bertrand do Brasil, 1988. 
Em sua tese de doutorado intitulada "Dom Antônio Ferreira Viçoso e a Reforma do Clero de Minas Gerais no Século XIX", Maurílio José de Oliveira Camello aborda as preocupações de um bispo eminentemente missionário e formador do clero, convicto de que toda reforma de caráter espiritual e pastoral passava pelo resgate das normas tridentinas. Estudando em Minas Gerais as especificidades da ação romanizadora, o autor se concentra nos esforços do prelado em marcar a autonomia da Igreja católica frente ao poder civil, realçando, no entanto, os aspectos espirituais, em detrimento dos aspectos políticos.

“Igreja e poder em São Paulo: D. João Batista Corrêa Nery e a romanização do catolicismo brasileiro (1908 - 1920)," é a tese de doutorado de Marcus Levy Albino Bencostta. Trabalho de metodologia weberiana, "Igreja e Poder..." privilegia a ação do primeiro prelado no sólio campineiro sob o viés da estruturação hierárquica e burocrática da nova diocese, contrapondo a ação de dominação de D. Nery à quebra dos pressupostos hierárquicos por parte do Padre Manuel Carlos de Amorim Correia, fundador da Igreja Católica Apostólica de Itapira. ${ }^{6}$

"O renitente catolicismo popular", tese de doutorado de Evandro Faustino, apresenta ao leitor minuciosa análise da "luta pela sobrevivência" do catolicismo popular em relação às práticas oficiais da Igreja católica. A contemporaneidade da pesquisa de campo, realizada numa São Paulo urbana e cosmopolita, sustenta de modo irrefreável as argumentações do autor quanto aos aspectos da permanência, ou melhor, da renitência das crenças populares em suas relações de intimidade e compadrio com os santos, confirmando plenamente que a hierarquia católica, não obstante todos os esforços empreendidos

não conseguiu vencer em profundidade a resistência dos antigos cultos. Estes continuaram a se manifestar, de forma sincrética ou mesmo camuflada, através de formas populares de fé católica, como as festas de santos e romarias. ${ }^{7}$

Por último, mas não menos importante, "A Elite Eclesiástica Brasileira", de autoria do sociólogo Sérgio Miceli, apresenta, também sob ótica weberiana, vasto panorama sobre a reorganização da estrutura burocrática da Igreja católica após sua separação do Estado brasileiro, e os conseqüentes e inevitáveis confrontos entre prelados, irmandades e Estado, em virtude da necessária obtenção, por parte dos

6 Para uma visão introdutória dessa questão e do reaparecimento da Igreja Brasileira em 1945, por D. Carlos Duarte Costa, ex-Bispo de Maura, encaminho o leitor a MATOS, Henrique de Morais. A Igreja brasileira de Itapira In: Revista Eclesiástica Brasileira, v.13, fasc. 3, setembro de 1953. pp. 641-654. 7 AZZI, Riolando. A cristandade colonial: um projeto autoritário. São Paulo: Paulinas, 1987. p.79. 
primeiros, de uma estrutura patrimonial com que pudessem conduzir os destinos das dioceses a eles confiadas. Carece a obra, entretanto, de uma incursão sobre desavenças ocorridas entre os próprios bispos, o que na presente tese é abordado.

É preciso ressaltar, no entanto, que a História da Igreja não se confunde com a Teologia. Esta é disciplina eclesiástica, sumamente voltada aos aspectos da espiritualidade. Aquela, disciplina histórica, abarcando os naturais conflitos institucionais, endógenos e exógenos, e suas conseqüentes acomodações, visando assim a reconstrução do passado de homens que compuseram a sociedade eclesiástica católica no decorrer dos séculos.

Na senda do que hoje se denomina de "autocompreensão" da Igreja, objeto da análise de Émile Poulat, ${ }^{8}$ me reporto à frase que encerra a obra de Augustin Wernet, há pouco apresentada:

"Mas esta é uma outra história, e certamente história fascinante"

Lida na integralidade de sua contextualização, Wernet aponta o caminho dos estudos desta autocompreensão da Igreja no período republicano, e seu convite não poderia ser mais auspicioso. Auspicioso, sim, mas também desafiador, à medida que o estudo de sua reestruturação burocrática após o decreto da separação passa, inevitavelmente, pela necessária "humanização" dos atores sociais envolvidos nessa quadra melindrosa. À semelhança de Janus, o deus grego bifronte, a "história fascinante" possui dois lados, e à sedução do puro fascínio que as paixões humanas despertam, deve o historiador apegar-se mais e mais na sobriedade pretendida pelo sine ira et studio.

Isto posto, creio que a atuação do primeiro bispo da diocese de Taubaté, D. Epaminondas Nunes de Ávila e Silva (1909 - 1935), ainda se ressente de análise histórica verticalizada, seja pelo processo de dominação de modelo burocrático em moldes ultramontanos por ele imposto à nova diocese, seja pelos problemas surgidos no processo de tentativa de acumulação patrimonial que se viu obrigado a conduzir.

Nascido em Serro, antiga Serro Frio, no estado de Minas Gerais, seu múnus paroquial naquela cidade se caracterizou fundamentalmente pela implantação de um catolicismo romanizado, de forte coloração européia, fruto de sua educação no

8 POULAT, Émile. Compreensão histórica da Igreja e compreensão eclesiástica da História, Concilium: Revista Internacional de Teologia. n. ${ }^{\circ}$ 67, 1971/7. pp. 811-824. Ver também WEILER, Anton. História eclesiástica como autocompreensão da Igreja, Concilium: Revista Internacional de Teologia. n. ${ }^{\circ} 67,1971 / 7$. 
Seminário de Diamantina, cadinho de sacerdotes educados no espírito romanizador.

Sendo os homens filhos do seu tempo, o único livro existente em sua homenagem - escrito por seu secretário e amigo Padre Ascânio Brandão ${ }^{9}$ - não foge ao caráter encomiástico e apologético de outros tantos escritos à época, particularmente os que tratam da biografia de prelados.

Mas se em virtude da humana emoção com que os autores dessas obras se revestiram ao escreverem, eclipsando, portanto, a real e por vezes até maior dimensão histórica que seus biografados alcançaram, nem por isso tais obras devem ser relegadas ao limbo, uma vez que

se seus primeiros arquitetos se limitaram tão somente a arquivar documentações, coletar dados, traduzir e transcrever fontes, muito lhe somos devedores, pois é daí, auxiliados por muitas outras ciências, que pudemos construir um equipamento mental robusto o suficiente para nos lançar à aventura de dividir, classificar e por fim interpretar aquilo que hoje se denomina a "autocompreensão" da Igreja. ${ }^{10}$

Mesmo desaconselhada em obra científica, peço a indulgência do leitor para um único momento de emotividade, ao render minhas homenagens ao Padre Ascânio Brandão e a D. Epaminondas. Ao primeiro, que este trabalho materialize, em novos tempos, a simples e secundária continuação de seus escritos. Ao segundo, pelo exemplo de persistência e dignidade que imprimiu, ao longo de seu episcopado, ao sólio de Taubaté.

\section{"Duas palavras..."}

No decorrer da elaboração de minha dissertação de mestrado trabalhei com os percursos da ação reformadora que, desde meados do século XIX, se processava na Igreja católica no Brasil. Não obstante o objeto daquele trabalho fosse focalizar, especificamente, a ação romanizadora dos padres da Congregação do Santíssimo Redentor ${ }^{11}$ na cidade paulista de Aparecida, uma das fontes pesquisadas, as Correspondências da Província Redentorista de São Paulo, possibilitaram-me visão bem ampla do estado religioso da região, à época.

9 BRANDÃO, Ascânio. D. Epaminondas. São Paulo: Oficinas gráficas da Ave Maria, 1941.

10 CÂMARA NETO, Isnard de Albuquerque. Um caso de sobrevivência: os redentoristas e a festa de São Benedito em Aparecida (1894-1922). 2000. Dissertação (Mestrado em História Social) Universidade de São Paulo, São Paulo, 2000. p.9.

11 A Congregação do Santíssimo Redentor foi fundada por Santo Afonso de Ligório em 9 de novembro de 1732 em Scala, na região de Nápoles. Seus religiosos são denominados de redentoristas, e a Congregação destina-se fundamentalmente a assistir as almas mais abandonadas, aqui entendido como um amparo espiritual aos camponeses. Encaminho o leitor a WERNET, Augustin. Os redentoristas no Brasil. Aparecida: Santuário, 1995. 3 volumes. 
Costuma-se dizer que satanás mora nos detalhes. É verdade. O interesse pelas cartas me tornava desatencioso para com as notas introdutórias do amigo Padre Júlio Brustoloni, fazendo-me sempre passar ao largo das suas "Duas palavras...", expressão por ele empregada à guisa de apresentação dos volumes, em que o historiador redentorista ressalta os principais fatos ocorridos no período. Certo dia, porém, acidentalmente, li o seguinte trecho da apresentação de um dos volumes:

Embora não sejam nossas as cartas do Cardeal Arcoverde dirigidas a Dom Duarte, incluímos nesta coleção porque nos revelam todos os trâmites a respeito de Aparecida quando da divisão de São Paulo em dioceses. A luta pelo cofre. ${ }^{12}$

Julgando interessante a observação, fichei-a para uso posterior, retomandoa em meus guardados quando por ocasião das primeiras tentativas de elaboração do projeto de doutorado. A luta pelo cofre. Então os conflitos extrapolavam os limites do santuário. Havendo conflitos, houve acomodações. Então há História. Movido pela leitura dessas "cartas exógenas" que Padre Júlio providencialmente acolheu nos volumes, predispus-me, inicialmente, a estudar a relação existente entre Aparecida e a "divisão de São Paulo em dioceses".

É razoável que se pergunte o motivo pelo qual essas cartas, contidas em volumes inicialmente compulsados na elaboração do mestrado, não foram objeto de minha atenção. Respondo, amparado na precisão metodológica do Padre Júlio, pálida tentativa de justificativa: à leitura de todas precede um resumo dos assuntos nelas contidos, e as que não se referiam aos temas que me eram caros ao mestrado foram, em virtude da limitação de tempo, naturalmente postas de lado.

A leitura agora atenta dessas cartas comprovou, de modo claro, a total ingerência por parte de D. Joaquim Arcoverde de Albuquerque Cavalcanti nos assuntos referentes à Basílica, fosse no decorrer de todo o seu período como bispo coadjutor de D. Lino Deodato Rodrigues de Carvalho na diocese de São Paulo, fosse na condição de bispo titular da mesma diocese. A diocese querelante era a de Taubaté. As possibilidades se configuravam.

Iniciei, em 2002, a pesquisa nos Arquivos da Cúria Diocesana de Taubaté, pelo manuseio de dezenas de papéis avulsos e de duas pastas. Em sua capa, o título: Avisos, Circulares, Pastorais e Mandamentos. Não era o que eu buscava. $\mathrm{O}$ Correspondência da Província Redentorista de São Paulo - COPRESP, v. V (1909-1912. p. 6. 
desiderato era a "luta pelo cofre". Mas já que lá estava, decidi demorar-me um pouco mais, iniciando com fonte tão burocrática leitura descompromissada. Nessa minha primeira incursão, porém, constatei que o primeiro bispo de Taubaté se enquadrava de modo singular no modelo reformador propugnado pela Igreja católica: um bispo que, pela dominação burocrática, obtinha controle sobre sua diocese e sobre seu clero.

Sim, havia a possibilidade de um doutorado sobre a ação de D. Epaminondas, mas ainda perseguia-me o desejo de desvendar os detalhes dessa "luta pelo cofre".

Ao findar a segunda visita, reuni os documentos para guardá-los. Ao lado dos cadernos, em um canto, um outro maço de papéis que havia passado despercebido na visita anterior: Em 154 folhas ali estavam os relatórios Ad Limina Apostolorum, de D. Epaminondas, inteiramente escritos em latim. Como é sabido, o relatório Ad Limina Apostolorum ${ }^{13}$ é documento cobiçado pelos historiadores da Igreja, dado o seu caráter de correspondência entre a diocese e os altos escalões da Santa Sé.

A visita Ad Limina Apostolorum é o compromisso formal dos bispos católicos de todo o mundo em comparecer perante o papa a cada cinco anos, apresentando naquela ocasião um relatório qüinqüenal onde se discorre sobre o estado geral das dioceses a ele confiadas. A expressão latina pode ser entendida como "no portal dos apóstolos", ou "nos limites dos apóstolos", uma vez que implica uma peregrinação aos túmulos dos apóstolos Pedro e Paulo, este último sepultado fora dos muros do Vaticano.

Aos bispos que, por qualquer motivo, se vejam na impossibilidade de realizar a visita, lhes é permitido o envio do relatório, como se deu com D. Epaminondas, perseguido ao longo de sua vida por problemas de saúde. Não obstante o acesso a documento tão precioso, a "luta pelo cofre" ainda me era desconhecida.

Compulsadas essas fontes passei à leitura do jornal 'O Lábaro', órgão oficial da diocese e ativo até nossos dias, verificando que D. Epaminondas, bispo romanizado e sufragâneo de D. Duarte, arcebispo de São Paulo, nem por isso lhe devotava obediência integral. Pelas linhas de seu órgão de imprensa, o prelado enviava claro e público recado ao seu metropolita de que a situação de Aparecida (20 de dezembro de 1585). 
não seria aceita do modo passivo. Sendo certo de que D. Epaminondas permitira o vazamento da crise, é certo também que "[...] tendencialmente, a administração burocrática é sempre uma administração que exclui o público. A burocracia oculta, a medida do possível, o seu saber e o seu fazer da crítica." ${ }^{14}$ As cartas entre D. Duarte e D. Joaquim Arcoverde, enfim, enquadraram-se na trama.

Tratando-se de D. Duarte e de D. Arcoverde, a investigação conduziu-me ao Arquivo da Cúria Metropolitana de São Paulo. Encontrei correspondência estabelecida entre esses dois prelados versando sobre a questão de Aparecida e, também, agradável surpresa, documentos sobre uma questão que passou a ser conhecida como "O Legado Wanderley", para a qual tributo a mesma importância que à "Questão de Aparecida". Ambas representam, a meu ver, o empenho pela obtenção de uma formação patrimonial das dioceses, natural necessidade da Igreja católica no Brasil quando da criação das novas dioceses, particularmente nas duas primeiras décadas do século passado.

A pesquisa nos arquivos da Cúria Metropolitana também me possibilitou acesso ao documento intitulado "Da Constituição de Nova Província Eclesiástica em São Paulo - Brasil", no qual pude iniciar o entendimento do processo de desmembramento da diocese de São Paulo e a conseqüente criação do sólio de Taubaté, processo esse que denomino de projeto regional de romanização. Ali se lê:

[...] Ao território da Arquidiocese de São Paulo também pertencerão as ilhas: Queimada grande, Queimada pequena, Santo Amaro e as adjacentes, bem como o templo sob o título de Nossa Senhora Aparecida, dentro dos limites da nova diocese de Taubaté. Os limites deste templo seguem a linha que tem início no lugar onde o rio Paraíba faz confluência com o ribeirão Sá, e daí pelo curso deste rio, atinge o cume do morro Pelado e pelas fraldas deste morro chega às margens do rio Ponte Alta, e daí a outro rio, Paraíba, segue seu curso até dele se afastar. ${ }^{15}$ (os grifos são nossos)

A questão se fechava. A recém fundada diocese taubateana, não obstante incluir a Basílica de Aparecida em seus limites territoriais, estava antecipadamente excluída de participar da sua administração. A luta pelo cofre.

Isto feito, decidi estender a pesquisa no Arquivo Edgar Leuenroth, da Universidade de Campinas, procurando na revista 'A Lanterna' o ponto de vista de

14 WEBER, Max. Economia e Sociedade: fundamentos da sociologia compreensiva. v. 1. 4. ed. Brasília: Editora da Universidade de Brasília, 2000. p. 21.

15 Arquivo da Cúria Metropolitana de São Paulo, doravante denominado ACMSP. Sagrada Congregação Consistorial: "Da Constituição de Nova Província Eclesiástica em São Paulo - Brasil", Item II. 7 de julho de 1908. Fotocópia datilografada. Inédito. 
seus redatores, anarquistas e anticlericais, sobre as questões estudadas, ou mesmo sobre D. Epaminondas. O material recolhido foi mínimo, não obstante a amplitude dos números pesquisados, tendo em vista que o foco dos ataques da revista era essencialmente o clero de São Paulo, capital, e o das regiões adjacentes, particularmente Campinas. O pouco, no entanto, aqui se faz presente.

A pesquisa na hemeroteca de Guaratinguetá também não me possibilitou grandes avanços, pois os jornais disponíveis sofrem substanciais soluções de continuidade em sua organização cronológica no período estudado. Tal não se deu, porém, na Hemeroteca Antônio Mello Júnior, pertencente à Divisão de Museus, Patrimônio e Arquivo Histórico de Taubaté, uma vez que a coleção é bem mais completa, havendo possibilidade de uma análise mais aprofundada sobre a situação sociopolítica e religiosa de Taubaté e regiões adjacentes, antes e, com menores possibilidades, após a chegada de D. Epaminondas.

É importante ressaltar, entretanto, que a imprensa de meados do XIX, tanto a taubateana, em particular, quanto a valeparaibana, em geral, caracterizava-se muito mais pelo aspecto opinativo e passional que pelo informativo, alterando sua orientação política de acordo com o editor e com os interesses do momento. Daí a dificuldade de se traçar um perfil acabado das orientações políticas dos grupos atuantes e, principalmente, das pessoas que formavam esses mesmos grupos.

Essas fontes compulsadas aliaram-se às cartas, e possibilitaram aclarar e situar a atuação de mais três personagens: Monsenhor Antônio Nascimento Castro, Cônego José Valois de Castro e Monsenhor Miguel Martins da Silva. Os dois primeiros, irmãos e políticos. O terceiro, pregador apostólico e proprietário de imóveis disponibilizados em favor da formação patrimonial da diocese. A D. Epaminondas, D. Duarte e D. Joaquim Arcoverde unem-se, portanto, três sacerdotes. À semelhança da peça de Pirandello, seis personagens em busca de um autor.

Da interação dos mesmos, e considerando a ação burocrática de D. Epaminondas no sentido de dar prosseguimento ao processo romanizador, assim como seus embates junto aos superiores hierárquicos visando que o Santuário de Aparecida fosse subordinado a sua diocese, apresento e procuro constatar, com o devido rigor metodológico, a seguinte hipótese:

Que a implantação e o desenvolvimento, por iniciativa de D. Epaminondas, de um núcleo de fé ultramontana em Taubaté, qual seja, a devoção à Santa 
Teresinha e a construção de um Santuário em sua honra, não foi parte integrante do projeto regional de romanização por parte de hierarquia da Igreja católica, mas uma tentativa de deter a afluência de fiéis ao Santuário de Aparecida, mormente os de classe média urbana, canalizando-a em benefício da diocese de Taubaté, sob o manto de uma nova tradição devocional.

Em processo marcado pela decadência de uma aristocracia de fazendeiros enobrecidos pelo Império, a cidade de Taubaté, considerada a mais próspera da região do Vale do Paraíba paulista, apresentava-se como um sítio urbano empobrecido e adormecido. Ruas estreitas de calçamento irregular e casas de taipa de aspecto sombrio e regularidade monótona, cujos quintais serviam de roçados aos seus moradores, denunciavam uma sociedade urbana marginal.

Com cerca de 30.000 habitantes em meados da década de 1870, entre eles aproximadamente 15.000 escravos, a cidade, em seu sítio urbano, contava com cerca de 2.600 casas para uma população urbana de 20.000 almas, das quais mais de 8.000 tinha menos de 15 anos de idade. ${ }^{16}$

Com a grande lavoura, a cidade tornou-se com poucas exceções, durante o ano, uma cidade morta. O café não era levado para a cidade, mas diretamente para os portos, primeiramente no dorso de mulas e a partir de 1876 pela ferrovia. [...] Mil oitocentos e setenta marcou o momento em que o mundo rural passou por transformações profundas, devido à decadência da cultura cafeeira na região, cuja importância foi transferida para o Oeste da Província. ${ }^{17}$

Até essa data a cidade pouco se diferenciava da vila colonial que existia, de maneira precária, à sombra das fazendas, movimentada por uma economia de subsistência paralela tocada nos roçados improvisados nos quintais do sítio urbano, e em algumas faixas de terra de pequenos produtores, já que o capital da grande lavoura era continuamente aplicado na compra de novas terras e escravos para alimentar a voracidade decadente do cafezal.

Os fazendeiros do Vale, unicamente fazendeiros (em comparação aos empresários do Oeste), persistiam em continuar a plantar café em uma área decadente e por isso aplicar todo o capital disponível nessa atividade, utilizando-se do trabalho escravo, e depois de 1888 da mão-de-obra dos antigos escravos e agregados, evitando o máximo possível a

16 Censo realizado pela Intendência Municipal de Taubaté, 1877 Apud TOLEDO, Francisco de Paula. História do município de Taubaté. 2 ed. Taubaté: Prefeitura Municipal, 1976. Apêndice.

17 RIBEIRO, Maria Alice de Morais. Taubaté e a alternativa industrial: 1891-1933. 1982. Dissertação (Mestrado em História Social) - Universidade de São Paulo, São Paulo, 1982. pp. 58-60. 
utilização do colono imigrante. $^{18}$

A voracidade com que os solos se exauriam, pela utilização inadequada da técnica agrícola nas terras destinadas à grande lavoura, pouco se modificou com a abolição da escravatura, propiciando um produto de qualidade inferior e de custo maior do que o fornecido pelas fazendas do Oeste.

Nesse processo de decadência que inviabilizava a competitividade do vale do Paraíba, pequenos e médios fazendeiros optaram pelo abandono da lavoura. Outros, mais insistentes, viram-se empobrecidos e incapacitados de resgatar suas terras, perdidas pelas dívidas. Nos dois casos, a maioria dos fazendeiros integrou o ciclo de micro-migrações do setor rural para o sitio urbano, iniciando a constituição de uma classe média proprietária voltada ao pequeno comércio e aos serviços em geral. Os camponeses, naturalmente, agregaram ao espaço rururbano sua própria miséria.

A partir de 1870 as micro-migrações impulsionaram o homem pobre para a cidade, aumentando o exército de miseráveis sem emprego e que paradoxalmente emprestavam não só a sua miséria para o sítio urbano, mas também suas próprias vidas. ${ }^{19}$

Do campo para a cidade uma realidade rururbana caracterizou a cidade de Taubaté até a década de 1910, traduzindo-se em um relativo crescimento populacional do sítio urbano, mas desvinculado do crescimento econômico.

O resultado natural desse processo é a fixação, em áreas adjacentes ao centro da cidade, de uma população desocupada cuja fonte de sustento básica residia nos produtos extraídos de roçados improvisados, o que contribuía para reforçar o caráter rural da paisagem urbana. Em decorrência da falta de oportunidades de trabalho a criminalidade, a violência e a indolência eram constantes.

A existência de grupos de vagabundos, sem ocupação constante, de freqüentadores assíduos da cadeia, estava longe de ser um caso esporádico. A monótona repetição desses casos é uma constante que vai se desdobrando com o tempo. [...] Alcunhas como "José Joana" ou "Maria Galinha" permitem que se imagine uma sociedade indicadora das fraquezas, dos desníveis sociais... ${ }^{20}$

18 RIBEIRO, Maria Alice de Morais. Taubaté e a alternativa industrial: 1891-1933. 1982. Dissertação (Mestrado em História Social) - Universidade de São Paulo, São Paulo, 1982. p. 63.

19 RIBEIRO, Maria Alice de Morais. Taubaté e a alternativa industrial: 1891-1933. 1982. Dissertação (Mestrado em História Social) - Universidade de São Paulo, São Paulo, 1982. p. 77.

20 MEIHY, José Carlos Bon. Vale de lágrimas: História da pobreza em Taubaté. 1980. Tese (Livre docência) - Universidade de São Paulo, São Paulo, 1980. p. 88. 
Entre 1870 e 1900 a população da cidade cresceu cerca de 23\%, passando a quase 37.000 habitantes. ${ }^{21}$ Esse crescimento populacional, acompanhado do crescimento espacial, evidenciava uma série de problemas econômicos, sociais e sanitários que, até então, não eram observados com a devida prioridade tanto pelos fazendeiros que estavam perdendo seu espaço político, quanto pelo próprio Estado republicano, que tomava as rédeas da cidade pelas mãos da Intendência Municipal.

A rapidez do crescimento da população e do espaço urbano, a nova postura de uma cidade caipira que se rururbanizou, dando origem a uma nova forma de ação social exigia um novo modo regulamentação da existência espacial da coletividade... ${ }^{22}$

A partir de 1896 a Intendência Municipal de Taubaté baixou uma série de regulamentações para o controle do espaço e da atividade econômica citadina, visando a demarcação legal dos perímetros urbanos e suburbanos, a definição e regulamentação de áreas destinadas ao comércio e, principalmente, de quem poderia comerciar. Segue-se a isso a especialização burocrática e administrativa, visando aperfeiçoar a eficiência do poder público, especialmente no que diz respeito ao poder de polícia e à cobrança de impostos.

Agindo de imediato sobre dois problemas considerados relevantes pelo estado republicano, higienização e desocupação, a Intendência Municipal estabeleceu sua administração em secretarias e lançou mão da massa de desempregados para o preenchimento de pequenas ocupações em grande escala, tais como lixeiros, carteiros e empreiteiros para os serviços água, luz, esgotos e gás.

Para tanto, esses diversos órgãos administrativos municipais ofereciam empregos burocráticos aos integrantes da minoria alfabetizada local, partindo de uma legislação que previa penas e multas para os mais diversos delitos, inclusive para os funcionários da administração municipal. Pela ação direta do poder público, a cidade de Taubaté chegou à década de 1910 com quase 40.000 habitantes em um cenário urbano mais racionalizado.

Embora se situasse em uma área decadente à cultura cafeeira, nem todos os produtores da cidade fracassaram. Alguns, mais expressivos, ainda conseguiam se manter com o café, possuindo casarões e solares que contribuíam para a

21 MÜLLER, Daniel Pedro. Ensaio d'um quadro estatístico da Província de São Paulo. 3. ed. São Paulo: Governo do Estado, 1978. p. 88.

22 RIBEIRO, Maria Alice de Morais. Taubaté e a alternativa industrial: 1891-1933. 1982. Dissertação (Mestrado em História Social) - Universidade de São Paulo, São Paulo, 1982. p. 78 
qualificação da cidade, - dentro de uma noção de progresso característica do período da Primeira República - que se traduzia no embelezamento e importação de cultura, costumes e estilos urbanos da Europa.

Além disso, Taubaté possuía uma elite letrada e ativa, cujos embates políticos, religião inclusa, justificava a existência de jornais que surgiam e desapareciam ao sabor de suas conveniências e possibilidades financeiras.

Dentro dessa lógica de progresso, a cidade de Taubaté se destacava como o centro urbano mais expressivo em âmbito regional, e que naturalmente se materializava como um dos centros articuladores e difusores das idéias do projeto romanizador.

Se o objetivo principal da tese não despreza a análise das perspectivas da reforma ultramontana na recém criada diocese, seu foco de concentração reside em dimensões pouco consideradas pela historiografia que se ocupa da Igreja católica no Brasil, qual seja, o processo de acumulação patrimonial de uma nova diocese, seus conflitos e conseqüentes acomodações, tudo consubstanciado pela ação heterodoxa e raramente documentada de um bispo em relação a seu arcebispo.

Tal abordagem, portanto, se por um lado privilegia um modelo de catolicismo adequado aos postulados romanizadores implantados por D. Epaminondas sob o viés da burocracia, nem por isso deixa de mostrar o caráter questionador e o viés político de um bispo em relação à hierarquia à qual devia deferência, na defesa dos interesses de sua diocese.

A partir de meados do século XIX a Igreja católica, em contínua repressão desde as jornadas de 1789, cristalizou seu encerramento em uma redoma refratária a tudo que evocasse o moderno e vislumbrou um tipo ideal de sociedade e de indivíduo, em que a necessidade de religião seria o elemento fundamental a permear as relações sociais e institucionais, inclusive aquelas entre Igreja e Estado. Tudo, portanto deveria girar em torno da religião. O aspecto harmônico da sociedade, em todas as suas formas de manifestação, deveria estar "[...] condicionado à intensidade de sua vida religiosa, ao cumprimento de seus deveres sacramentais." 23

A valorização do religioso sobre o que é mundano passou a ser o arcabouço

23 REIS, Fábio José Garcia dos. Os Redentoristas, o Cônego Antônio Marques Henriques e a romanização da Igreja paulista (1888-1917). 1993. Dissertação (Mestrado em História Social) Universidade de São Paulo, São Paulo, 1993. p. 27. 
de uma ideologia que apresentava, como fim último, a necessidade de sobrepujar os desafios que se levantaram contra a instituição. A Igreja lançava ao mundo a tentativa de imposição de uma ordem vigente praticamente incompatível com os progressos materiais e políticos, obtidos à custa de muito sangue pelas sociedades. No entanto, como se poderia garantir a posse do poder e ao mesmo tempo assegurar sua legitimidade perante os fiéis? Em outras palavras, como assegurar a legitimidade dessa ordem?

Para Max Weber, uma das maneiras para que a legitimidade de uma ordem possa estar plenamente garantida é pela atitude interna que o indivíduo exterioriza de modo afetivo, entregando-se à manutenção dessa ordem de modo sentimental ou de modo racional, e a crença em valores supremos assim o conduz, ou por intermédio de um modo religioso, ou "[...] pela crença de que de sua observância depende a obtenção de bens de salvação." 24

Dessa relação entre a crença na observância e a obtenção dos bens de salvação, as posições tornam-se claras: de um lado, o crente; de outro, o detentor desses bens de salvação, detentor esse que vai de um único indivíduo - um feiticeiro tribal, por exemplo - chegando-se a uma instituição, o que nos interessa mais de perto.

Esse crente, portanto, no intuito de obter sua salvação, deve ceder à dominação da hierocracia, que concederá ou recusará esses bens de salvação.

Para Weber, uma hierocracia institucionalizada é denominada de Igreja "[...] quando e na medida em que seu quadro administrativo pretenda para si o monopólio da legítima coação hierocrática." 25

Ora, se nos ocupamos da Igreja católica, é preciso, portanto, tentar fazê-la chegar "[...] a se explicar o significado último da sua própria conduta." ${ }^{26}$ Em outras palavras, é mister reunir elementos que nos façam entender a compreensão da hierocracia católica em torno do "outro", bem como a de sua autocompreensão.

Com Pio IX (16/06/1846 a 7/2/1878), que em 1854 proclamou solenemente 0 dogma da Imaculada Conceição de Maria, e em 1856 o culto ao Sagrado Coração de Jesus, a alta liderança da Igreja fez com que o ultramontanismo europeu

24 WEBER, Max. Economia e Sociedade: fundamentos da sociologia compreensiva. v. 1. 4. ed. Brasília: Editora da Universidade de Brasília, 2000. p. 21.

25 WEBER, Max. Economia e Sociedade: fundamentos da sociologia compreensiva. v. 1. 4. ed. Brasília: Editora da Universidade de Brasília, 2000. p. 34.

26 WEBER, Max. La ciencia como vocación. In: Hans Gerth e Carl Wright Mills (org.) Ensayos de sociología contemporânea. Barcelona: Martínez Roca, 1975. p. 187. 
canalizasse com muito engenho as necessidades de piedade antropocêntrica dos católicos, enquanto projetava sua ira contra a secularização dos costumes, tendo como seus principais alvos o protestantismo, a maçonaria, e quaisquer aspectos do liberalismo.

Durante o processo de romanização da Igreja em nosso país houve intensa mobilização, por parte dos bispos, no sentido de se combater o socialismo e o comunismo, em virtude da ameaça que tais doutrinas representavam à forma de dominação imposta aos católicos, forma que passasse, necessariamente, pela exacerbação de emoções, mas de emoções inteiramente depuradas e inteiramente controladas pela hierocracia católica.

Assim, Pio IX apresentava um discurso em que apontava o afastamento da religião na sociedade civil como o afastamento da justiça e do direito, significando que a força material teria lugar de destaque nas relações sociais. Por fim, a centralização ultramontana atingiu seu ponto culminante quando Pio IX, em 1870, proclamou a infalibilidade papal, infalibilidade essa que João Camilo de Oliveira Torres denomina a "[...] quase a suprema bofetada na face do século." 27

Alguns aspectos, em particular, merecem especial atenção, já que possibilitam o dimensionamento da intencionalidade no processo de romanização da Igreja católica no Brasil.

De sua permanência em nosso país, do século XVI até o advento da república, a Igreja, em virtude da instituição do Padroado, era subordinada aos ditames do Estado, e sua manutenção junto aos fiéis prescindia de estrutura burocrática forte, sendo seus negócios considerados apenas como mais um dos tantos assuntos governamentais portugueses, tratado neste particular pela Mesa de Consciência e Ordens, no período colonial, e pelo Ministério dos Negócios Eclesiásticos e de Justiça, no decorrer do Império.

\begin{abstract}
Estreitamente sujeita ao poder civil, a Igreja católica, no Brasil em particular, seguiu-lhe também estreitamente as vicissitudes e circunstâncias. Em conseqüência do grão-mestrado da Ordem de Cristo, sobretudo depois de confirmada em 1551 por sua santidade o Papa Júlio III. na bula Praeclara carissimi, sua transferência aos monarcas portugueses com o patronato nas terras descobertas, exerceram estes, entre nós, um poder praticamente discricionário sobre os assuntos eclesiásticos. ${ }^{28}$
\end{abstract}

27 TORRES, João Camilo de Oliveira. História das idéias religiosas no Brasil. São Paulo: Grijalbo, 1968. p. 165.

28 HOLANDA, Sérgio Buarque. Raízes do Brasil. 26. ed. São Paulo: Companhia das Letras, 1995. p.118. 
$\mathrm{Na}$ medida em que a complexidade das tensões políticas envolve a instituição hierocrática católica, novas imposições se fazem cumprir para a sua sobrevivência. Na república, pois, vê-se a Igreja na contingência de aproveitar o êxito da ação reformadora iniciada em meados do XIX, e achada em luta com outras crenças em um Estado livre, resta-Ihe o caminho de se ater a uma axiologia do sobrenatural. Combatendo, entre outros adversários, uma maçonaria com a qual conviveu cordialmente durante todo o império e ávida pela eliminação das confrarias que sustentaram o catolicismo em "tempos difíceis", sua sobrevivência nesse terreno hostil a conduziria a uma forma de dominação racional, estruturada segundo o modelo burocrático, particularmente para emprego interno, utilizando a emoção religiosa junto às massas.

Desse modo, a teoria dos tipos puros de autoridade legítima de Weber está em harmonia com o desiderato da autoridade hierarquizada, da qual não poderia deixar de fazer uso a Igreja Católica. A romanização, em curso final, representou, no Brasil, a sobrevivência da hierocracia católica.

"Poder", para Weber, representa "[...] toda probabilidade de impor a própria vontade numa relação social, mesmo contra resistências, seja qual for o fundamento dessa probabilidade." Evidentemente não é o caso da Igreja católica no Brasil imperial, posto que "poder", na acepção do termo weberiano, não caberia em uma Igreja que praticamente viu começar sua estruturação no país somente a partir de 1889.

"Dominação", no entanto, "é a probabilidade de encontrar obediência a uma ordem de determinado conteúdo, entre determinadas pessoas indicáveis". ${ }^{29}$

Verifica-se, pois, que o conceito de dominação é mais consentâneo ao nosso estudo do que o conceito de poder, uma vez que nele está intrínseca a maior probabilidade de encontrar obediência a uma ordem.

Quais seriam, no caso do nosso estudo, as pessoas indicáveis a que Weber se refere? Pode-se considerar, para efeitos de trabalho, os fiéis, o clero em geral, e os bispos.

A Igreja católica, nessa fase de sua vida institucional, baseia sua legitimação no exercício da autoridade. É fundamental, pois, obter obediência às ordens por ela emanadas. Pode-se evidentemente encontrar submissão determinada pelo afeto,

29 WEBER, Max. Economia e Sociedade: fundamentos da sociologia compreensiva. v. 1. 4. ed. Brasília: Editora da Universidade de Brasília, 2000. p. 34. 
pelos interesses, ou mesmo pela força do costume. Para Weber, no entanto, sendo instável a autoridade que repousa apenas nessas bases, torna-se compreensível que a relação entre dominadores e dominados encontre sua fundamentação em bases jurídicas.

Partindo dessas premissas, é natural que o aprimoramento da formação sacerdotal tenha sido o mais importante ponto da ação reformadora dos bispos ultramontanos, daí a necessidade do estabelecimento de seminários romanizados, regulamentos disciplinadores, mandamentos, editais, ordens ao clero exaradas pelos prelados que, por sua vez, também se vêem na condição de sufragâneos dos arcebispos, exemplos da dominação burocrática que também atinge os fiéis quanto às imposições canônicas afeitas em relação a batizados, proibições e permissões para festas populares, casamentos, crismas e compromissos de irmandades, entre outros.

O estremecimento dessa legitimidade, na proporção direta da autoridade que o provocou, normalmente acarreta conseqüências que abalam a estabilidade hierocrática, já que alguém, desviando-se da coação psíquica, recusa seu acesso aos 'bens de salvação'.

A dominação busca despertar e cultivar uma crença em sua legitimidade, conforme se verifica nos pressupostos da ação implementada pela Reforma Ultramontana, e Weber cita três tipos puros de dominação legítima:

1) De caráter racional: crença nas ordens estatuídas e do direito de mando dos que estão nomeados para exercer a dominação;

2) De caráter tradicional: crença na santidade das tradições vigentes desde sempre;

3) De caráter carismático: veneração da santidade, do poder heróico ou do caráter exemplar.

Destarte nos interessa, de maneira mais profunda, somente as referências da autoridade legal, entendidas como aquelas mantidas entre o bispo e o corpo de sacerdotes, e a tradicional, vista como a relação entre o bispo e os leigos.

Tal fenômeno se deu, segundo Weber, em virtude da rotinização do carisma, ou seja, pela tradicionalização, pela racionalização (legalização), ou por ambas, em vários aspectos da dominação carismática. Nesse caso o sociólogo se reporta, naturalmente, aos tempos da Igreja primitiva e ao seu desenrolar histórico. $\mathrm{O}$ conceito, no entanto, não se invalida nem para o tempo estudado, nem para o caso 
brasileiro.

Separada do Estado que a dominava burocraticamente, ainda que isso representasse instrumento para a própria rotinização do carisma, a Igreja católica viu-se na contingência de, por sua própria conta e risco, dar prosseguimento, e rapidamente, a essa rotinização. É natural que a dominação burocrática da qual se ressentia fosse solução para a sua própria sobrevivência, acelerando sua velocidade de implantação no exato momento em que o sacerdócio procurou organizar-se como grupo autônomo em relação ao poder político. Daí as pastorais coletivas, os mandamentos e todo um emaranhado de regulamentos que disciplinassem clero e fiéis. Aos bispos cabia, pois, o papel de gerenciadores dessa máquina burocrática, alimentada por uma avalanche também burocrática, pouco importando a potencialidade carismática do prelado. Selecionava-se, sim, dentre os seminaristas preparados pela Igreja, os que melhor se adaptassem ao modelo de dominação proposto. Aprovados nessa fase inicial, e uma vez padres, prosseguia o investimento nos sacerdotes mais capacitados ao comando eclesiástico, não poucas vezes com longas permanências em Roma. Eleitos bispos, formariam a elite burocrática católica dos diversos países e da própria Santa Sé. Se fossem santos e piedosos, tanto melhor, posto que essas pretensas qualidades serviriam para a aproximação com o povo.

Em outras palavras, racionalizar para sobreviver, e aqui os 714 Avisos de D. Epaminondas encontram a justificativa, mantendo assim "[...] o interesse ideal ou material dos adeptos na persistência e reanimação contínua da comunidade." 30

\begin{abstract}
Uma burocracia, uma vez plenamente realizada, pertence aos complexos sociais mais dificilmente destrutíveis. A burocratização é o meio específico por excelência para transformar uma "ação comunitária" (consensual) numa "ação associativa" racionalmente ordenada. Como instrumento da transformação em "relações associativas" das relações de dominação, ela era e continua sendo, por isso, um meio de poder de primeira categoria para aquele que dispõe do aparato burocrático, pois, com possibilidades de resto iguais, uma "ação associativa", ordenada e dirigida de forma planejada, é superior a toda "ação de massas" ou "comunitária" contrária. Onde quer que a burocratização da administração tenha sido levada consequentemente a cabo, cria-se uma forma praticamente inquebrantável das relações de dominação. O funcionário individual não pode desprender-se do aparato do qual faz parte. [...] Os dominados, por sua vez, não podem nem
\end{abstract}

30 WEBER, Max. Economia e Sociedade: fundamentos da sociologia compreensiva. v. 1. 4. ed. Brasília: Editora da Universidade de Brasília, 2000. p. 162. 
prescindir de um aparato de dominação burocrático, uma vez existente, nem substituí-lo, porque este se baseia numa síntese bem planejada de instrução específica, especialização técnica com divisão do trabalho e firme preparo para exercer determinadas funções habituais e dominadas com destreza. ${ }^{31}$ (o grifo é nosso)

Evidencia-se o momento em que a forma de dominação da Igreja passa de um estágio em que se tolera o padre comerciante, maçom, amasiado e com filhos, bem como a confraria leiga no comando do culto, para um estágio mais avançado e necessário de formatação burocrática: os quadros de funcionários serão treinados segundo um modelo e um objetivo a ser alcançado. Daí reforço a importância dos seminários, assim como os espaços de influência desses funcionários que deverão ser dimensionados de tal forma a permitir eficiência e eficácia ao modelo de dominação, argumento que justifica a criação de um maior número de dioceses. Momento, portanto, de a dominação puramente carismática ceder lugar à dominação racional e legal.

Considerando a avalanche burocrática que a Igreja católica, particularmente na pessoa de seus bispos, impõe a si própria visando uma dominação legal, prosseguimos na trilha de Weber quando o mesmo afirma que "[...] o tipo mais puro de dominação legal é aquele que se exerce por meio de um quadro administrativo burocrático" ${ }^{32}$, e esse quadro administrativo burocrático a que se refere o sociólogo se compõe de funcionários individuais, os quais são pessoalmente livres, obedecendo somente às obrigações objetivas de seu cargo. Pode-se, com propriedade, ampliar a característica do conceito weberiano, afirmando-se que tal liberdade se reporta ao fato de serem mesmo voluntários, ou seja, optaram livremente, no caso da Igreja católica, pelo ingresso em seus quadros, cabendo-lhes, portanto, aceitar as normas impostas, dentre as quais destaco:

a) São nomeados. Ao serem nomeados, e não eleitos, numa hierarquia rigorosa dos cargos, entende-se que estão técnica, e não politicamente, aptos para o desempenho das funções que Ihe são atribuídas, podendo ser "desnomeados", aí entendida a suspensão de ordens, em caso de desobediência às normas instituídas;

b) Têm competências funcionais fixas, ou seja, cada grau hierárquico possui seu próprio raio de ação operacional e jurídico;

31 WEBER, Max. Economia e Sociedade: fundamentos da sociologia compreensiva. v. 2. Brasília: Editora da Universidade de Brasília, 2000. p. 222.

32 WEBER, Max. Economia e Sociedade: fundamentos da sociologia compreensiva. v. 1. 4. ed. Brasília: Editora da Universidade de Brasília, 2000. p. 144. 
c) Exercem seu cargo como profissão única e principal;

d) Têm perspectiva de uma carreira. No caso da Igreja católica, as aspirações de um padre tornar-se vigário, bispo, secretário na Santa Sé, ou mesmo papa, podem fazer parte, legitimamente, de suas pretensões profissionais;

e) Estão submetidos a um sistema rigoroso e homogêneo de disciplina e controle de serviço, o que pode ser materializado nas visitas pastorais, na atuação dos padres visitadores e na própria carga documental que os sacerdotes são obrigados a enviar, regularmente, às suas dioceses;

Assim, a obediência que a instituição Igreja Católica esperava dos eclesiásticos subordinados à autoridade de D. Epaminondas se dava, não em virtude de seu carisma, ou mesmo de sua autoridade pessoal, mas dos regulamentos estabelecidos por essa Igreja que, simultaneamente ao sagrá-lo bispo, estabeleceu os limites de obediência que os eclesiásticos deviam prestar-Ihe.

A Igreja romanizada, em tal contextualização, é analogamente comparável a uma forma qualquer de administração burocrática, uma vez que:

[...] os dispositivos específicos da dominação, baseiam-se numa relação associativa, e consistem, de modo geral, no fato de que determinado círculo de pessoas, habituadas a obedecer às ordens de líderes e interessadas pessoalmente na conservação da dominação, por participarem desta e de suas vantagens, se mantêm permanentemente disponíveis e repartem internamente aqueles poderes de mando e de coação que servem para conservar a dominação ("organização"). ${ }^{33}$

Em tal modelo de dominação, qual seja, o burocrático, existe o princípio da hierarquia oficial, que é a organização de instâncias fixas de controle e de supervisão para cada autoridade institucional, com o direito de apelação ou de reclamação das subordinadas às superiores. Em face disso, a forma de dominação burocrática revela-se absolutamente racional. A religiosidade irracional atua, no caso da Igreja católica, apenas como um meio de domesticação e coação sobrenatural, sem que se prescinda dos meios legais. O pensamento racionalista caracteriza a burocracia, e tal contexto revela exatamente a modificação da forma de dominação da Igreja, de carismática para burocrática, dando respaldo à implementação da Reforma Ultramontana.

Com essa qualificação de burocracia, Weber procura apresentar um tipo

33 WEBER, Max. Economia e Sociedade: fundamentos da sociologia compreensiva. v. 2. Brasília: Editora da Universidade de Brasília, 2000. p. 196. 
ideal de organização que é perfeitamente aplicável à estrutura organizacional da Igreja Católica, a partir da Reforma Ultramontana. A observação de Roberto Romano:

A Igreja Católica é caracterizada como um forte poder estereotipador, essencial na cultura do Ocidente; graças à racionalização jurídica de seu domínio, em continuidade idealizada com o Direito Romano, pela burocratização autônoma, que culminou numa suprema autoridade monocrática, e pela presença de uma autoridade dogmática responsável por ordenar suas representações teológicas. ${ }^{34}$

O entendimento da ação de D. Epaminondas junto ao seu clero, aos fiéis e no decorrer dos atritos que teve com o arcebispo de São Paulo, D. Duarte Leopoldo e Silva, passa pelo estudo dos conceitos weberianos acerca de dominação, que para Max Weber é:

[...] uma situação de fato, em que uma vontade manifesta ("mandato") do "dominador" ou dos "dominadores" quer influenciar as ações de outras pessoas (do "dominado" ou dos "dominados"), e de fato as influencia de tal modo que estas ações, num grau socialmente relevante, se realizam como se os dominados tivessem feito do próprio conteúdo de mandato a máxima de suas ações ("obediência"). ${ }^{35}$

Considerando que em 1908 a diocese de São Paulo perdeu território em favor da criação das dioceses de Campinas, Botucatu, Ribeirão Preto, São Carlos do Pinhal e Taubaté, passando, em virtude desse fato administrativo, à condição de arquidiocese, tem-se na pessoa de D. Duarte Leopoldo e Silva a autoridade máxima de uma cadeia hierárquica da qual D. Epaminondas, bispo de uma diocese sufragânea, é subordinado. No sólio taubateano, a presença da autoridade esteve representada, necessariamente, pela pessoa do seu bispo, qual seja, D. Epaminondas, neste caso, dominador, mas também, juntamente com seus sacerdotes, dominado pela autoridade do metropolita, encerrando de maneira abrangente o modelo organizacional da Igreja romanizada.

Utilizando-me desse modelo teórico, procurei compreender a esquematização do funcionalismo moderno, na forma de dominação burocrática, verificando que ela se enquadra no contexto da Igreja romanizada:

I - Rege o princípio das competências oficiais fixas, ordenadas, de forma geral, mediante regras: leis ou regulamentos

34 ROMANO, Roberto. Brasil: Igreja contra Estado. São Paulo: Kairos, 1979. p. 66.

35 WEBER, Max. Economia e Sociedade: fundamentos da sociologia compreensiva. v. 2. Brasília: Editora da Universidade de Brasília, 2000. p. 191. 
administrativos, isto é:

1. Existe uma distribuição fixa das atividades regularmente necessárias para realizar os fins do complexo burocraticamente dominado como deveres oficiais;

2. Os poderes de mando, necessários para cumprir estes deveres, estão também fixamente distribuídos, e os meios coativos (físicos, sacros ou outros) que eventualmente podem entregar estão também fixamente delimitados por regras;

3. Para o cumprimento regular e contínuo dos deveres assim distribuídos e o exercício dos direitos correspondentes criam-se providências planejadas, contratando pessoas com qualificação regulamentada de forma geral. ${ }^{36}$

II - Rege o princípio da hierarquia de cargos e da seqüência de instâncias, isto é, um sistema fixamente regulamentado de mando e subordinação das autoridades, com fiscalização das inferiores pelas superiores - sistema que oferece ao mesmo tempo, ao dominado a possibilidade fixamente regulamentada de apelar de uma autoridade inferior à instância superior desta.

Tal sistema permitia a ascensão hierárquica daqueles clérigos mais bem relacionados, ou que, pelo esforço próprio, poderiam acessar cargos eclesiásticos mais altos. Além disso, os clérigos de escalão inferior poderiam recorrer a autoridades eclesiásticas superiores, quando se julgassem injustiçados, no caso de imputação de alguma pena ou castigo. Essa característica é própria de sistemas organizacionais burocratizados.

III - A administração moderna baseia-se em documentos (atas), cujo original ou rascunho se guarda, e em um quadro de funcionários subalternos e escrivães de todas as espécies. ${ }^{37}$

A Igreja romanizada também prima pela escrituração detalhada de suas normas e regulamentos, e para isso conta com funcionários dedicados. Essa busca pela normatização de todos os espectros possíveis de atuação nada mais objetiva que a legitimação de sua dominação.

IV - A atividade oficial, pelo menos toda atividade oficial especializada - e esta é o especificamente moderno pressupõe, em regra, uma intensa instrução na matéria. ${ }^{38}$

Há preocupação com o ensino, pois ele assegura a dominação por intermédio de um treinamento que objetiva disciplinar e padronizar, ou seja, exercer

36 WEBER, Max. Economia e Sociedade: fundamentos da sociologia compreensiva. v. 2. Brasília: Editora da Universidade de Brasília, 2000. p. 198.

37 WEBER, Max. Economia e Sociedade: fundamentos da sociologia compreensiva. v. 2. Brasília: Editora da Universidade de Brasília, 2000. p. 199.

38 WEBER, Max. Economia e Sociedade: fundamentos da sociologia compreensiva. v. 2. Brasília: Editora da Universidade de Brasília, 2000. p. 200. 
dominação mental em relação aos fiéis. Esse aspecto apresenta caráter basilar na forma de dominação burocrática, pois a prática da educação e do doutrinamento é fundamental para o exercício da dominação.

[...] quanto mais importante se torna o conhecimento das escrituras, também para a condução dos negócios puramente mundanos - e quanto mais estes adquirem, portanto, o caráter de uma administração burocrática que procede por regulamentos e atas -, tanto mais a educação dos sábios e funcionários mundanos passa às mãos do sacerdócio letrado ou este ocupa - como as Chancelarias da Idade Média -, ele mesmo, os cargos que se baseiam na forma escrita dos processos. ${ }^{39}$

V - Quando o cargo está plenamente desenvolvido, a atividade oficial requer o emprego da plena força de trabalho do funcionário, independentemente da circunstância de que o tempo de trabalho obrigatório no escritório (na diocese) pode estar fixamente delimitado.

Há dedicação exclusiva ao serviço religioso por parte dos clérigos e funcionários dessa Igreja burocratizada. Exata dedicação, muitas vezes, ultrapassa sua esfera de obrigações.

VI - A administração dos funcionários (Clérigos) realiza-se de acordo com regras gerais, mais ou menos fixas e mais ou menos abrangentes, que podem ser aprendidas. ${ }^{40}$

Neste sentido os seminários são essenciais. Este é o motivo pelo qual a Igreja romanizada priorizou, como uma de suas mais importantes metas, a criação de seminários diocesanos para a formação de novos sacerdotes, inseridos nesse modelo de dominação e de doutrinamento dos fiéis, de uma forma geral.

Assim sendo, apresento a tese em quatro capítulos.

O Capítulo I é dividido em três partes. Na primeira procuro ambientar o leitor na evolução das condições de Taubaté, apresentando, à época da chegada do primeiro bispo na cidade, o caleidoscópio social, político e religioso a ser por ele enfrentado.

A preocupação essencial se prende à impossibilidade do emprego de uma situação mais aplainada, materializada em "ausência de bispo romanizado = indiferentismo religioso; presença de bispo romanizado = situação religiosa

39 WEBER, Max. Economia e Sociedade: fundamentos da sociologia compreensiva. v. 1. 4. ed. Brasília: Editora da Universidade de Brasília, 2000. p. 316.

40 WEBER, Max. Economia e Sociedade: fundamentos da sociologia compreensiva. v. 2. Brasília: Editora da Universidade de Brasília, 2000. p. 200. 
corrigida", tendo em vista que a diocese de Taubaté foi criada em 1908, e à chegada D. Epaminondas já coexistiam não só as permanências do catolicismo lusobrasileiro, mas também as formas ultramontanas, o que será estudado na segunda parte do capítulo.

A apresentação dos pontos de vista dos jornais taubateanos, assim como a ação dos padres envolvidos em política, objetiva uma "preparação do terreno" que justifique não só a ação dominadora e padronizadora do primeiro bispo, em âmbito interno, mas também a profunda relação do catolicismo com a sociedade da época, despertando assim os calorosos debates conduzidos pela imprensa escrita.

A terceira parte trata da fragmentação da diocese de São Paulo e da criação do bispado de Taubaté. Procuro nela as justificativas de tal ato administrativo por parte da Igreja católica, ressaltando, porém, como uma pista que conduza às questões posteriores, o fato do Santuário de Aparecida permanecer diretamente subordinado à administração da Arquidiocese de São Paulo e não da diocese de Taubaté, a despeito de encontrar-se em seus domínios territoriais.

A primeira parte do capítulo seguinte trabalha as naturais dificuldades que a grande maioria dos bispos enfrentou no sólio de novas dioceses. O auxílio de Wernet:

Com a proclamação da República, em 1889, a Igreja do Brasil alcançou plena liberdade religiosa, mas perdeu, embora exígua, a sustentação financeira que o governo lhe dava durante o regime do Padroado. Conforme o Decreto 119A do governo Provisório, de 7 de janeiro de 1890, o governo continuaria a dar o salário para os eclesiásticos - párocos e bispos - durante um ano, mas depois a Igreja deveria procurar seus próprios recursos financeiros para prover a subsistência das igrejas e do clero e para o apostolado. Muitas dioceses, como por exemplo, a de Goiás, caíram em extrema miséria. A diocese de São Paulo passou por dificuldades mas conseguiu equilibrar suas finanças, parcialmente, graças aos recursos provindos do Santuário de Aparecida. ${ }^{41}$ (os grifos são nossos)

Dessa forma, a missão imposta aos bispos das dioceses criadas em 1908 extrapolava o já pesado múnus pastoral. Além de seus próprios encargos episcopais, cumpria-lhes que conduzissem um processo de acumulação patrimonial diocesano previsto e exigido. Cônscios de sua missão, os conflitos decorrentes entre prelados podem ser tidos como perfeitamente naturais, bem como as próprias

41 WERNET, Augustin. Os redentoristas no Brasil. v. 2. Aparecida: Santuário, 1995. p. 171. 
paixões incendiadas pela imprensa. Os homens são fruto de sua época.

O "Legado Wanderley" ocorre em simultaneidade cronológica com a "Questão de Aparecida", objeto do capítulo posterior. Caracterizando-se como uma disputa entre o Metropolita de São Paulo e o Bispo de Taubaté por uma herança imobiliária localizada na cidade de Jacareí, as querelas correm por conta das controversas interpretações das cláusulas constantes no testamento e dos pareceres dos advogados de ambas as partes.

O objetivo do terceiro capítulo é o de, em primeiro momento, apresentar ao leitor a evolução histórica e administrativa do Santuário de Aparecida, tendo como principais atores históricos o então bispo de São Paulo, D. Joaquim Arcoverde, e os padres redentoristas, configurando a importância desse Santuário não só como catalisador do projeto regional de romanização, mas também como fonte de rendimentos para o sustento da diocese de São Paulo. Esse primeiro momento do capítulo trata, portanto, de basear as razões pelas quais serão travadas as disputas entre D. Duarte, arcebispo de São Paulo, e D. Epaminondas, bispo de Taubaté.

Após esse trecho preparatório, apresento a "luta pelo cofre" do Santuário, retomando, assim, as 'pistas' apresentadas no capítulo anterior, mediante a apresentação e análise das correspondências entre os prelados envolvidos.

A "Questão de Aparecida" pretende apresentar, mediante o corpus documental compulsado, um aprofundamento de aspectos que, não obstante citados pelos historiadores da História da Igreja que nos antecederam, ainda permitem conduta exploratória suficientemente densa para demonstrar que as lutas dos prelados ultramontanos não se deram tão somente contra padres rebeldes, irmandades religiosas insubmissas ou governos rapaces, mas também entre si, pelo natural desejo de proporcionar a exigida acumulação patrimonial às suas dioceses. O desfecho da questão busca fundamentar a atitude de D. Epaminondas no sentido de implantar em Taubaté a devoção a Santa Teresinha.

O quarto e último capítulo apresenta, em sua primeira parte, a amplitude romanizadora de D. Epaminondas. Se nos capítulos anteriores o prelado surge na condição de querelante, diferenciando-se dos demais de sua época como um bispo pronto a enfrentar seu metropolita em questões por ele julgadas de direito em favor do sólio taubateano, surge agora o pastor de almas e o burocrata, aplicado e diligente, que por meio de suas visitas pastorais, mandamentos e circulares, organiza e dá à diocese de Taubaté as feições ultramontanas e conservadoras que 
até hoje conserva. Seu processo de dominação racional e sistemático, ao longo do tempo enquadrou o clero em uma disciplina burocrática e litúrgica aos moldes romanizados, enquanto que em seu jornal 'O Lábaro' desferia ataques ao espiritismo, ao socialismo e a tudo mais que fosse de encontro ao espírito religioso católico da época.

Na segunda parte do capítulo trato do desenvolvimento da devoção à Santa Teresinha conduzida pelo clero taubateano, buscando apresentar à comunidade científica o que entendo como uma "resposta ultramontana" de D. Epaminondas.

Poder-se-ia afirmar que a saga dos dois primeiros 'bispos ultramontanos' se referencia com os trabalhos de Augustin Wernet e Maurílio José de Oliveira Camello. De fato, a cada um coube o mérito da primazia da abordagem paulista e da mineira.

Ao buscar nesse capítulo a relevância histórica do "meu" bispo, julgo lícito ressaltar que o que distingue D. Epaminondas dos demais prelados da 'Igreja paulista' foi a sua engenhosa forma de obter acumulação patrimonial em favor de sua diocese sem se desviar do projeto regional de romanização, materializado nos esforços de canalização da piedade popular em favor do Santuário de Aparecida.

Coerente com a missão que Ihe fora confiada, no sentido de realizar a acumulação patrimonial de uma diocese que sofria os efeitos de sua proximidade com Aparecida, cumpria a D. Epaminondas dois caminhos: ou deter o fluxo de fiéis àquela localidade, o que seria impossível, ou apresentar uma nova e original solução.

Para isso, implantou em Taubaté o culto a Santa Teresinha, bem como alterou o nome do órgão oficial da diocese para "Santuário de Santa Teresinha", alusão clara ao jornal redentorista "O Santuário de Aparecida", fazendo construir, também, o primeiro santuário do mundo em honra a uma santa branca, jovem e ultramontana.

Em minhas considerações finais, reflito sobre os principais aspectos abordados ao longo da presente pesquisa, buscando referendar os caminhos percorridos que amparam minha hipótese.

Isto feito, passo a algumas ressalvas e a outras confissões prévias que julgo apropriadas ao momento.

Em meu treinamento metodológico e epistemológico, obtido desde 1998 pelo prazeroso contato com meus orientadores e professores dos diversos cursos do Programa de Pós-graduação da Universidade de São Paulo, terminei por crer que a 
elegância de uma obra de cunho científico reside, fundamentalmente, nos limites auto-impostos pelo pesquisador em relação ao dimensionamento da mesma.

Digo isso pois, ao iniciar a coleta do corpus documental em período anterior ao meu ingresso no doutorado, passei pela leitura de aproximadamente mil e quinhentos jornais 'O Lábaro', quase três centenas de outros, dezenas de correspondências eclesiásticas e outras tantas centenas de documentos. Seria incoerente, portanto, afirmar que não fui feliz na busca por fontes primárias.

O ator social estudado, entretanto, apresenta a avalanche burocrática documental de 26 anos de governo diocesano, e suas posições em relação aos debates da época, como o divórcio, a escola leiga e o ensino moderno, a liberdade de imprensa, o suicídio, a ação católica, o anarquismo, o comunismo, as tomadas de contas de irmandades e demais regulamentações de todo o aparato diocesano, apesar de por mim conhecidas, não poderiam, em sua totalidade, estar incluídas nos naturais e razoáveis limites de uma tese.

Refreando a tentação de, a cada revisão, incluir "só mais um documento", tentação por vezes irresistível em uma tese de doutorado, acredito, todavia, que a busca pelo perfil romanizador do "meu" bispo, imbricado à quadra histórica da Igreja católica nas primeiras décadas do período republicano, tenha atingido, ainda que modestamente, a eficácia esperada. Esta portanto, é uma história de D. Epaminondas: não pretende ser a história de D. Epaminondas. O que há de erro, assumo integralmente. Meu orientador, junto às minhas limitações, combateu o bom combate. 


\section{CAPÍTULO I \\ ENQUANTO O SENHOR BISPO NÃO VEM}

\subsection{Religião, catolicismo luso-brasileiro e política no vale do Paraíba}

O Concílio Ecumênico de Trento (1545-1563) marca uma das principais etapas da contra-reforma católica, em resposta aos anseios e questionamentos formulados, não só com Lutero, mas com a própria marcha do humanismo.

Respondendo a um desejo de reorganização doutrinária da Igreja, pois "não era outra coisa que se reivindicava em todo o mundo cristão e cada vez com maior urgência", ${ }^{42}$ Trento marcará a retomada dos rumos do catolicismo após o golpe da Reforma.

Tendo entre seus objetivos "extirpar as heresias e reformar os costumes, motivo principal de estar reunido", ${ }^{43}$ buscava também o Concílio expurgar o que a hierarquia tinha na conta de superstição, bem como disciplinar, da parte dos fiéis, as manifestações de religiosidade que fugissem à ortodoxia, tais como as romarias de caráter espetacular e a relação por demais íntima com os santos. Observe-se, sob essa ótica, o que ocorre na Europa:

Assim, nos fins da Idade Média, pode-se notar uma concepção ultra-realista da fé popular em tudo o que se relaciona com os santos. Tinham-se estes se tornado tão reais e tão familiares na religião corrente que se encontravam ligados aos mais superficiais impulsos religiosos. Enquanto a profunda devoção se encontrava ainda centrada em Cristo e sua mãe, uma multidão de crendices e fantasias enxameava em volta dos santos. Tudo contribuía para os tornar familiares e quase vivos. Vestiam-nos com trajos populares. Todos os dias se encontravam os 'Senhores' S. Roque e S. Jaime nas pessoas vivas dos peregrinos e de doentes. ${ }^{44}$

O contributo de João Alfredo Montenegro:

O medievalismo europeu se inclinará aos valores religiosos vazios de tensão espiritual, numa época tipicamente de decadência, em que o materialismo se ergue sobranceiro nas superstições e no ritualismo mágico. E a um ponto tal que se torna impossível separar o sagrado do profano. Tudo é elevado

à categoria do religioso, num movimento avassalador $\mathrm{e}$

42 DUFFY, Eamon. Santos \& Pecadores - História dos Papas. São Paulo: Cosac \& Naify Edições Ltda., 1998. p. 151.

43 CONCíLIO ECUMÊNICO DE TRENTO. Coleção 19. Documentos Pontifícios. n. ${ }^{\circ}$ 95. Petrópolis: Vozes, 1959. p. 3.

44 HUIZINGA, Johan. O declínio da Idade Média. Lisboa: Ulissea, 1996. p.174. Sobre o tema ver também KOHNEN, Mansueto. Feição cultural da Igreja na Alta Idade Média, Revista Eclesiástica Brasileira, v. 14, fasc. 2, junho de 1954. 
afetado. $^{45}$

O regime do Padroado, por sua vez, remontando à Ordem dos Templários, baseava-se em uma relação estabelecida entre o papa e os soberanos portugueses, visando a defesa e a dilatação da fé católica. Em termos práticos, permitia, a esses últimos, em todos os seus domínios, inclusive os coloniais, exercer os direitos referentes à cobrança dos dízimos eclesiásticos e de apresentação dos bispos destinados ao governo das dioceses, padres para as paróquias, construção e conservação de igrejas, e remuneração do clero. O apoio de Riolando Azzi:

O direito de Padroado só pode ser plenamente entendido dentro de um contexto de história medieval. Não se trata de usurpação de atribuições religiosas próprias da Igreja por parte da Coroa lusitana, mas de forma típica de compromisso entre a Santa Sé e o governo português. Consistia especificamente no direito de administração dos negócios eclesiásticos, concedido pelos papas aos soberanos portugueses. ${ }^{46}$

Tendo seus direitos políticos unidos à titulação de grão-mestre da Ordem de Cristo, e exercendo conjuntamente o governo civil e o religioso, máxime nas colônias portuguesas, os monarcas lusitanos, ao longo do tempo, terminaram por imbricar o Padroado de uma Ordem ao Padroado de uma religião.

Era no começo um privilégio, quase que decorrência de situações específicas: afinal um direito. No nosso caso: começou como privilégio de uma organização mais ou menos eclesiástica, a Ordem de Cristo. Terminou, à época da Independência, como direito de Estado. ${ }^{47}$

Excluído que fora da ação do Concílio, em virtude da instituição do Padroado, o catolicismo em Portugal conservou suas heranças advindas do medievo; no Brasil, consequentemente, à manutenção das práticas católicas lusas somaram-se influências africanas e indígenas. Essa forma religiosa, leiga, social e familiar, é denominada, conceitualmente, pelos principais tratadistas ${ }^{48}$ do tema,

45 MONTENEGRO, João Alfredo de Souza. Evolução do catolicismo no Brasil. Petrópolis: Vozes, 1972. p. 7.

46 AZZI, Riolando. A cristandade colonial: um projeto autoritário. São Paulo: Paulinas, 1987. p. 21. A esse respeito ver também FONTOURA, Ezechias Galvão In: Lições de Direito eclesiástico. Volumes I, II e III. São Paulo: Jorge Seckler \& Comp., 1887.

47 TORRES, João Camilo de Oliveira. História das idéias religiosas no Brasil. São Paulo: Grijalbo, 1968. p. 30.

48 Sobre o conceito de "catolicismo luso-brasileiro" encaminho o leitor a AZZI, Riolando. Elementos para a história do catolicismo popular, Revista Eclesiástica Brasileira, 36, 141, março de 1976. pp. 9530; Catolicismo popular e autoridade eclesiástica na evolução histórica do Brasil, Revista Religião e Sociedade, 1, 1, maio de 1977. pp. 125-149; O catolicismo popular no Brasil: aspectos históricos. Petrópolis: Vozes, 1978. OLIVEIRA, Pedro A. Ribeiro de. Catolicismo popular e romanização do catolicismo brasileiro, Revista Eclesiástica Brasileira, 36, 141, março de 1976. pp.131-141. 
como "catolicismo luso-brasileiro". A intervenção de Wernet:

Leigo por causa da destacada presença dos leigos nos organismos eclesiásticos. A direção e a organização das associações religiosas mais importantes, a das irmandades ou confrarias, estavam em mãos de leigos. Fé e cultura caminharam de mãos dadas, numa inter-relação tão íntima que não poucas vezes era difícil distinguir o elemento cultural do religioso. A Igreja no Brasil se apresenta, desta maneira, como "cristandade", estado de interpenetração estreita entre "religião" e "sociedade", "Igreja e Estado", sagrado e profano, em que o poder político e o religioso se confundem, sendo que a supremacia pode pertencer ao religioso ou ao político, como no Brasil. ${ }^{49}$

A Igreja católica no Brasil, a partir dos anos quarenta do século XIX, assistiu, ainda que lentamente, e em virtude da ação reformista de alguns poucos bispos, a uma tentativa de distanciamento daquilo que se poderia denominar de catolicismo luso-brasileiro, "aquele tipo de religião afetiva e sentimental, tão ao gosto dos portugueses, em geral traço marcante do cristianismo ibérico". ${ }^{50} \mathrm{Em}$ outras palavras, iniciava-se o processo de reforma ou, como é mais conhecido, de romanização do catolicismo brasileiro, processo esse também denominado de Reforma Ultramontana.

O clero brasileiro, de modo geral, ainda não primava, em sua plenitude, por um comportamento consentâneo às especificidades do processo de romanização do catolicismo por que passava a Igreja. Longe das vistas de seus superiores, e alocados em vilas e cidades onde o catolicismo luso-brasileiro era a cadência, entregavam-se os padres às mais diversas atividades, dentre elas o comércio e a política, enquadrando-se perfeitamente no que declarou Pio IX: "Sicut populus, sic Sacerdos." 51

Em Minas Gerais, por exemplo, D. Antônio Ferreira Viçoso, primeiro bispo de Mariana, assim encontrou sua diocese em setembro de 1843:

A maior lástima era a incontinência, porque muito grande parte vivia como se fossem casados, e pela muita freqüência e continuação destes exemplos, já o povo quase não fazia reparos em tais procedimentos, e menos estranhava um viver tão encontrado com a profissão, com os votos, e com a dignidade sacerdotal...

49 WERNET, Augustin. A Igreja paulista no século XIX. São Paulo: Ática, 1987. pp. 17-18.

50 CAMELLO, Maurílio José de Oliveira. Caraça, centro mineiro de educação e missão (1820-1830). Belo Horizonte: Imprensa oficial, 1973. p. 16.

51 PIMENTA, Silvério Gomes. Vida de D. Antônio Ferreira Viçoso. Mariana: Tipografia do Bom Ladrão, 1876. p. 110. Do latim: Qual povo, tais sacerdotes. 
Como se pode verificar, no entanto, o exemplo vinha de cima:

Por maior desgraça o mal partia do alto: pois onde os demais sacerdotes deviam de achar modelos em que se espelhassem, achavam tristes exemplos de manifesta desordem. Porquanto o Cabido da Catedral, primeira autoridade na vacância das dioceses, era com poucas, mas honrosas exceções, composto de padres publicamente amasiados. ${ }^{52}$

Ideal típico de bispo reformador, D. Antônio Ferreira Viçoso investia esforços para a implantação de um seminário, ao mesmo tempo em que tentava disciplinar seu clero: "[...] dois são os males que tornam o Sacerdote inútil e grandemente danoso aos mais fiéis: a ignorância no entendimento e o desgoverno do coração." 53 Em São Paulo, a ação reformista de D. Antônio Joaquim de Melo ${ }^{54}$ caracterizou-se, entre outros atos, que serão vistos mais à frente, pela criação de um seminário, pelas quatro visitas pastorais em sua diocese e pela forte tentativa de disciplinar o clero.

Quando D. Antônio Joaquim de Melo (1851-1861), primeiro
brasileiro e paulista (de Itu) no sólio da Sé Catedral de São
Paulo, indicou como meta primordial de sua gestão episcopal a
reforma do clero paulista no sentido de uma maior "moralização
e ilustração" não se percebeu, talvez, com toda clareza as
conseqüências a curto e longo prazo deste procedimento. Na
realidade deu ele o início ao processo de suplantação do
"catolicismo iluminista" pelo "catolicismo ultramontano".
Obviamente, esta substituição não se deu de um dia para
outro. O "catolicismo iluminista", ou "pombalino" como também
é chamado, entrou a partir da atuação de D. Antônio Joaquim
de Melo numa fase de definhamento, e, ao mesmo tempo,
aumentou continuamente a influência do catolicismo
ultramontano. 55

Após o falecimento de D. Antônio Joaquim de Melo, no entanto, o processo de reforma só seria conduzido, ainda que modo bastante acidentado, a partir de 1873, tendo em vista a formação pombalina de seu sucessor, D. Sebastião Pinto do Rego (1763 - 1868).

52 PIMENTA, Silvério Gomes. Vida de D. Antônio Ferreira Viçoso. Mariana: Tipografia do Bom Ladrão, 1876. p. 110-111.

53 PIMENTA, Silvério Gomes. Vida de D. Antônio Ferreira Viçoso. Mariana: Tipografia do Bom Ladrão, 1876. p. 197.

54 Disponível em <http://www.catholic-hierarchy.org/bishop/bdemello.html> Consulta em 12 de agosto de 2005. D. Antônio Joaquim de Melo nasceu em Itu, em 29 de fevereiro de 1791, vindo a falecer nesta mesma cidade em 16 de fevereiro de 1861. Por decreto imperial de 5 de maio de 1851 foi nomeado bispo de São Paulo, sendo sagrado em 6 de junho de 1852. Sua posse se deu a 3 de agosto do mesmo ano.

55 WERNET, Augustin. Os primórdios do ultramontanismo em São Paulo (1851-1906), Revista da Sociedade Brasileira de Pesquisa Histórica (SPBH), Anais da IV reunião. São Paulo: SBPH, 1985. p. 2. 
A esse respeito pode-se evocar a correspondência dos padres missionários da Congregação do Santíssimo Redentor, responsáveis pela pastoral e administração do Santuário de Aparecida desde 1894.

Padre Lourenço Gahr, em carta ao Padre Geral Matias Raus, datada de 9 de fevereiro de 1895, sintetiza o que os redentoristas encontravam em suas Missões, ao longo da vasta extensão territorial que, anos mais tarde, comporia a diocese de Taubaté: "A ignorância do povo é enorme; pessoas de 17, 18 e 30 anos sem instrução, católicos de batismo só."

Ao informar sobre tal situação ao bispo de São Paulo, afirma que D. Joaquim Arcoverde de Albuquerque Cavalcanti "[...] também deplora, mas espera que melhore", e a carta se encerra apontando um certo padre que, ouvindo queixas de um paroquiano em relação à própria mulher, assim o aconselha: "[...] mande-a embora e pegue uma outra, como eu o faço." 56

A situação do clero e a prática do catolicismo em Taubaté e região não se desviavam do caleidoscópio acima exposto: padres políticos, insinuações da imprensa sobre envolvimentos de frades com mulheres, mas também religiosos enquadrados na disciplina reformista.

Sendo assim, o "desgoverno do coração" a que se referia D. Silvério, também era sentido entre os frades franciscanos do convento de Santa Clara, tendo em vista que "estas ordens encontravam-se no século XIX em plena decadência, e a partir do período republicano passaram por um processo de reforma, restauração e reavivamento da vida religiosa monástica." 57

'O Paulista', jornal simpatizante do Partido Liberal, sob a direção de Antônio Joaquim Daniel do Prado, não poupava um certo Frei Miguel, retrato sem retoque do clero pré-romanizado, envolvido em política e em diversões mundanas:

O frade do Paiolhinho / É frade da mão furada

Nas eleições de setembro / Fez parte da derrubada

No batuque e no deboche / Vence a todos com primor

Os seus olhos lançam chamas / Coriscos, setas de amor.

Bebe pinga / Bebe azeite

Bebe leite / E não respinga

De raposa / Tem catinga.

Trepa, trepa, trepa, meu moleque

Dança, dança, dança o sarambeque

56 ACPSR. Correspondência da Província Redentorista de São Paulo - COPRESP, v. I (1817-1896). p. 191-192.

57 WERNET, Augustin. A presença de beneditinos alemães na restauração da Ordem de São Bento em São Paulo. Inédito. p. 3. 
II

Tem olhos assim a guisa de farsola / Corpo que é um barrilote de entrecosto

Lustrosa testa que é de bater sola / Faz que não nasceu mas sim foi posto

A mulata, a negra o cercam / A todos encanta e seduz

Na viola também canta / É pagodista de truz

No fandango / É dengoso

No passeio / É buliçoso

Na política / É manhoso

E não deixa de ser jocoso/

Embriagado No gozo

Do Ganimedes

Famoso

Trepa, trepa, trepa, meu moleque

Dança, dança, dança o sarambeque

III

Quando passa ri-se a gente / Pois é o frade zangado

Nas conquistas amorosas / E na cabala danado

Tem duas moças também / Alto lá meu bom fradinho

Procure quem o ature / Lá fora do Paiolhinho

Veio do Rio / Consignado

E empalhado / Em um grande caixão de rapadura

Não sente frio / É encouraçado

Está fadado / A rezar o pater noster com frescura.

Trepa, trepa, trepa, meu moleque

Dança, dança, dança o sarambeque

IV

O missal? Ora isso é pata / Do hábito faz travesseiro

Protege o vício e o crime / É frei Miguel bem matreiro

Anda com jeito meu frade / Não leve alguma sapeca

Reze a missa e o breviário / $E$ deixe de ser peteca

Volte de novo ao convento / $E$ não ande por lá tão quente

Faça jejum, penitência / Tome o conselho é prudente

Não lhe seduzam as promessas / De capitãozinho de aldeia

Que o homem é diplomata / De finório tem a veia

Arranjado que seja o genro / $E$ feito ele brigadeiro

De comenda e cruz pendente / Ri-se de tudo, é brejeiro

Vá direito seu caminho / Vá para o claustro mansinho

E ande mui direitinho / E expurgue seus pecadinhos

Faça palitos de cera / E brochas de sapateiro

Encomende uma silha / Ao subdelegado seleiro

O delegado está vivo / Anunciou no jornal

É também da confraria / Tome com ele conselho ${ }^{58}$

Frei Miguel, portanto, "violeiro", "pagodista de truz", manhoso na política e dado às mulheres, personificava, em muitos aspectos, boa parte do clero da época, clero de pouca missa e de muita festa.

58 O Paulista, n. ${ }^{\circ}$ 50, IV. 6 de dezembro de 1868. 
E se o assunto é missa, ou serviços religiosos, a mesma edição d"O Paulista' nos traz uma nota de alguém que ironicamente se faz passar por "um que não está indignado". Com o sugestivo título de "Para o Ex. ${ }^{\text {mo }}$ Sr. Dr. Vigário Capitular saber e providenciar", a nota reclama de um sacerdote que, de longa data, exige 500 réis para ouvir a confissão anual e, para cada casamento, 1000 réis. O curioso da história reside no fato de que, se o penitente declarar que não se confessa a um certo número de anos, vê-se obrigado a pagar tantos mil réis quantos os anos que descumpriu a obrigação! A tabela de serviços do sacerdote também inclui o benzimento de imagens, ao preço de 200 réis, "[...] benzendo mesmo imagens de matéria reprovada pela Igreja", além de rezar missa "[...] em qualquer palheiro, contanto que lhe paguem bem". Apesar do reclamante não apontar diretamente o nome do padre, não seria difícil identificá-lo, pois "[...] do nome não é preciso comento - está abaixo do Conceição." E pelo prosseguimento da nota observa-se que o tal padre não estava só em suas atividades:

Existe um outro que, para locupletar-se, diz missa em qualquer espelunca ou palhoça, a questão é só ser chamado. Além disto é tão abelhudo que, por várias vezes, tem calcado aos pés nos direitos que assistem ao Vigário, abusando assim do coração bondoso do nosso pároco; se formos provocados explicaremos estes fatos porque estamos ainda bem lembrados da festa da Piedade. ${ }^{59}$

O "Padre que mora abaixo do Conceição", ou mesmo o "Padre abelhudo", a que a nota se refere, entretanto, não são novidade em nossa história, e é interessante observar-se a recorrência das acusações contra religiosos que, mediante recompensa pecuniária, transigem com os cânones. Veja-se, por exemplo, o juízo que Pero do Campo Tourinho, donatário da capitania de Porto Seguro, tem sobre os cardeais e o papa de seu tempo: "[...] eram todos uns bugirrões sodomitigos tiranos que por dinheiro casavam e descasavam a quem queriam". ${ }^{60}$

Abordada a situação geral do clero, pode-se perceber o caráter de intimidade em que o mesmo vivia em relação às populações que, por dever sacerdotal, deveria adotar procedimentos não passíveis de críticas. O "afastamento do mundo" seria, pois, objetivo perseguido pelo ultramontanismo, assim como a regulação e o disciplinamento das comemorações religiosas.

59 O Paulista, n. ${ }^{\circ}$ 50, IV. 6 de Dezembro de 1868.

60 SOUZA, Laura de Mello e. O diabo e a Terra de Santa Cruz. 5. ed. São Paulo: Companhia das Letras, 1995. p. 48. 
Até a chegada de D. Epaminondas, a religiosidade valeparaibana, Taubaté incluída, imbricava-se com disputas políticas e com festas, muitas das quais ainda alheias ao controle clerical, não obstante as anteriores ações de cunho romanizador, pois são nas festas que os conceitos de sagrado e profano se tornam solidários e o povo faz explodir seu sentimento religioso para além dos liames institucionais estabelecidos pela Igreja.

Em Taubaté, antes do advento do Bispado, muitas manifestações religiosas se misturavam, sem qualquer problema, às atividades festivas, e a "reza" vem emaranhada com as "papanças" e as "pilhérias", conforme publicação no jornal 'O Guarany', órgão do Partido Conservador:

Os convivas regressaram satisfeitos da festa de S. João do Senhor Cayera. Grande ajuntamento, variedade de divertimentos, boa papança, abundância de bebidas, fogueira, batatas, salvas, música, pilhéria, reza. Em suma, nada faltou. ${ }^{61}$

É importante ressaltar que a expressão "nada faltou", empregada pelo 'O Guarany', não possui laivo de ironia crítica. O "nada faltou" manifesta a total satisfação dos participantes, pois esse era o modelo de compreensão de uma festa religiosa. Essa exterioridade emocional é bem constatada em diversas ocasiões, como por exemplo, na carta do Padre Lourenço Gahr ao Padre Matias Raus, em 6 de maio de 1895, referindo-se às bandas de música que tocavam dentro das igrejas: "A ladainha é cantada pelo povo e pelo coro, o último naturalmente com música completa; após a missa é que se toca de verdade, a gente poderia pensar que a igreja vem abaixo." 62

Não bastasse a forma ruidosa de demonstrar a proximidade com o sagrado, as questões de caráter financeiro eram também recorrentes, e São José, por ainda faltar-Ihe uma irmandade ultramontana que o prestigiasse em Taubaté, viu-se objeto das "badalações" e do sarcasmo do jornal republicano exaltado, 'A Zagaia', sob a chefia e redação de Pedro Bastos. Com o mote "Badalaremos; não cessaremos de badalar", o jornal apontava tudo e todos que se desviassem, na política e na religiosidade, de pretensos padrões de correção:

Dinheiro de S. José - Perguntamos a quem compete o que é feito desse dinheiro e lembramos a necessidade de organizarse uma irmandade, tendo alguém digno com tesoureiro.

61 O Guarany, n. ${ }^{\circ}$ 39, I. 6 de julho de 1884.

62 ACPSR. Correspondência da Província Redentorista de São Paulo - COPRESP-B - Suplemento, v. I (1874-1897). p. 260. 
Dinheiro de santo não deve servir para afiançar criminosos!!! Providências, na certeza de que não abandonaremos o assunto. O Reverendíssimo vigário da paróquia é pessoa capaz de ocupar esse cargo sem dar origem a escândalos. Badalaremos; não cessaremos de badalar. ${ }^{63}$

A "badalação" referente ao dinheiro de São José merece algumas reflexões. Nota-se o que o "dinheiro de santo" está em mãos de pessoas leigas que, segundo o jornal, sequer formam uma irmandade. Sendo objetivo ultramontano afastar a gestão administrativa do leigo em relação às festas e às agremiações religiosas, substituindo-a por um padre, a Pastoral Coletiva de 1915 é bem enfática nesse particular: "[...] impeçam o desvio das esmolas, recolhidas a título de festas, para profanidades ou qualquer emprego alheio ao seu próprio destino." 64

A Festa do Santuário do Bom Jesus de Tremembé, fruto da penetração para o interior do ciclo bandeirante, datado de $1669,{ }^{65}$ reunia milhares de fiéis, ${ }^{66}$ sendo palco de fortes manifestações do catolicismo luso-brasileiro e de constantes reclamações e advertências por parte de D. Epaminondas. Com tais antecedentes, a festa não poderia deixar de ser objeto das "badalações" d"'A Zagaia':

Dinheiro do Bom Jesus - Perguntaremos ingenuamente ao Dr. Leal Bode quando faz tenção de restituir à irmandade respectiva o saboroso "Conto"...que sub-repticiamente passou ao não menos leal e não menos doutor Cadella. Esse assunto já foi enviado para o cadinho da "Forja"... Vamos lá ver o que sai em breve prazo. Estão iminentes grossas novidades. Reportagem, alerta! Badalaremos; não cessaremos de badalar...67

Além dos desvios de dinheiro que 'A Zagaia' aponta, outros aspectos tidos pelo clero católico, como negativos em relação às festas, são as brigas e o jogo.

O problema se prolonga no tempo e, no ano de 1912, em espaços diferenciados, Aparecida e Tremembé, essas questões se apresentam de forma clara nas Crônicas da Comunidade Redentorista de Aparecida e n"O Lábaro', órgão oficial da diocese taubateana, criado por D. Epaminondas em janeiro de 1910:

A 7 de abril, festa de São Benedito com grande pompa. Já na véspera, galopavam muitos cavaleiros pretos e brancos pelas ruas. P. Estevão fez a pregação. Correu tudo na maior ordem.

63 A Zagaia, n. ${ }^{\circ}$ 2, I. 30 de abril de 1896.

64 Pastoral Coletiva de 1915. n. ${ }^{\circ} 1111$.

65 Notar que Tremembé era a cidade-santuário do Vale do Paraíba antes da construção da estrada de ferro São Paulo - Rio de Janeiro, sucedida depois por Aparecida.

66 Jornal do Povo, n. ${ }^{\circ} 384,19$ de novembro de 1895.

67 A Zagaia, n. ${ }^{\circ}$ 4, I. 7 de maio de 1896. 
Só a noite houve umas brigas entre alguns moços. ${ }^{68}$

Festas de Tremembé - [...] Desgraçadamente, a jogatina antilegal e anticristã foi estabelecida naquela paróquia, com imenso dano para as famílias e grave quebra das leis religiosas e pátrias. O jogo tão pernicioso e tão formalmente condenado pelo Código Penal da nação pode-se dizer que foi a nota dominante das festas, razão pela qual o Ex. ${ }^{\text {mo }} \mathrm{Sr}$. Bispo diocesano, não querendo e não podendo sancionar com a sua presença tão grave abuso, desistiu do intento que tinha de nas mesmas pontificar, lavrando assim o seu protesto formal contra tamanha imoralidade, sendo sua resolução proibi-las no próximo ano se forem assim profanadas. ${ }^{69}$

A festa de Bom Jesus de Tremembé prossegue com as suas manifestações do catolicismo luso-brasileiro, e a imprensa taubateana a aborda de acordo com a linha editorial adotada.

Dentre as diversas manifestações do catolicismo luso-brasileiro, objeto de críticas por parte do clero romanizado, as festas da Santa Cruz, e a do Divino, assumem especiais cuidados. Fontes de violências, jogos e agressões por parte dos foliões, o jornal 'A Verdade', de orientação abertamente católica, em relação a uma festa da Santa Cruz no bairro do Areão, em Taubaté, conclama sua proibição por parte das autoridades policiais. Entendendo o jornal católico que essas festas não passam de verdadeiros bacanais, fontes de desordens e violências, "[...] os devotos da pinga e dos batuques" 70 deveriam ser alvo da repressão dos poderes constituídos. O caso é de longa data, e o Liberal Taubateense, órgão do Partido Liberal de São Paulo, explana o preconceito:

Não somos daqueles que procuram aumentar sempre 0 número de igrejas procurando estabelecer capelas em todos os cantos do Município. Quanto a nós, o Rev. ${ }^{\text {mo }}$ Vigário, de acordo com a Câmara Municipal, devia mesmo eliminar e destruir esses lugares de reuniões e bebedeiras, onde a religião é sempre vilipendiada. Principiam por determinar que se faça uma festa ou reza, para o que é indispensável alguns rojões e o maior número possível de garrafas de cachaça. O resultado é sempre o mesmo: muitas cabeças escaldadas pelos vapores espirituosos, rixas, bordoadas, facadas e, conseqüência imediata - a miséria no seio de muitas famílias de pobres cultivadores, algumas vezes acompanhada da orfandade e terminada pela prostituição para muitas órfãs. Do mesmo modo as cruzes que por aí andam dispersas em todos os cantos do Norte de S. Paulo, indicando ao viajante o número de assassinatos cometidos, só se prestam para indicar ao

68 ACPSR. Crônica da Comunidade Redentorista de Aparecida. v. II (1908-1922). p. 108.

69 O Lábaro, n. ${ }^{\circ}$ 137, III. 8 de agosto de 1912.

70 A Verdade, n. ${ }^{\circ}$ 125, III. 9 de maio de 1905. 
estrangeiro, exagerando é certo, o perigo de viajar-se em um país onde não há polícia e abundam os facínoras e pretexto para nesses lugares serem construídas novas capelas, verdadeiras precursoras de crimes, e reuniões antireligiosas. ${ }^{71}$

'O Norte', partidário moderado do catolicismo, ironiza a conduta de uma certa Nhá Felisbina, festeira da Santa Cruz. Comandando os preparativos da festança, "[...] todo lugar ajudava desde o enfeite da Santa Cruz até a tachada de doce que Nhá Felisbina preparava para regalar seus amigos da vizinhança e que eram convidados para tomarem parte no farrancho".

Já a zeladora de uma capela, subordinada, portanto, a um padre, tem conduta diversa de Nhá Felisbina, e não vacila em manter a compostura esperada pelo ultramontanismo, evitando a ação dos "meninos bonitos" que atrapalham a reza, mesmo que para isso tenha que suportar o apelido de "vigária". No entanto, a firmeza de suas atitudes é tal que, "[...] se continuar assim, a chave da igreja será entregue ao seu vigário". A comparação entre a atitude de Nhá Felisbina e a da "vigária" termina quando a primeira perde sua filha mais velha em uma reza. À Nhá Felisbina só resta afirmar que "[...] não há bem que sempre dure... quando há festa no bairro". 72

A festa do Senhor Bom Jesus em Tremembé era também era farta em música, pilhéria, papanças e muito jogo. A roleta, destinada às pessoas de maior poder aquisitivo, e um certo jogo denominado búzio, para as categorias sociais inferiores, atraíam milhares de pessoas, e inúmeras publicações, ao longo dos anos, citam a questão da jogatina como tema preocupante. Em 1880, a 'Gazeta de Taubaté', jornal de cor política indefinida, e sob a direção de Antônio José Garcia, após os elogios de praxe em relação à parte sacra da festa, aponta uma circunstância qualificada pelo jornal de "anormalíssima":

[...] não nos podemos eximir do dever que temos em chamar atenção de nossas autoridades para o vulto que vai tomando, entre nós, o vicio do jogo. A festa do Tremembé ressente-se de alguma beleza e moralidade. ${ }^{73}$

A recorrência da questão do jogo na festa do Tremembé (assim denominada na imprensa taubateana e do vale do Paraíba, em geral, para referir-se aos festejos do Senhor Bom Jesus) será sentida ao longo dos anos. Antônio Moreira dos Santos, 
festeiro do Divino em Redenção da Serra, faz publicar, em 1887, n"O Paulista', órgão que "advoga os interesses do Norte de São Paulo e do sul de Minas Gerais", dirigido por Antônio Daniel do Prado: "[...] em lugares apropriados haverá jogos de búzios e outras distrações", assim como na Vila do Buquira, atual Monteiro Lobato, o festeiro faz constar que "[...] a parte profana consta de búzios, roletas e jogos de diversas qualidades." 74

Em 1889, dias antes da festa de Tremembé, um curioso e certamente inútil pedido de Monsenhor Antônio de Nascimento Castro ${ }^{75}$ e do Cônego Benjamim de Melo é publicado no jornal 'O Noticiarista', autocompreendido como imparcial, mas de franca tendência monarquista:

Pedimos ao povo para deixar o jogo durante a celebração do Santo Sacrifício da Missa nos três dias de festa como uma homenagem ao Senhor Bom Jesus. Sendo o jogo um divertimento profano, que pode ser adiado por alguns momentos, confiamos no respeito que todos consagram à religião, e esperamos que tão justo reclamo não será em vão. ${ }^{76}$

A notinha dos dois padres não surtiu o efeito por eles desejado. Passada a festa, 'O Noticiarista' realiza extensa matéria, referindo-se à enorme concorrência de povo, representando todas as classes sociais, em absoluta confraternização de divertimentos e distrações, mas sem cenas de embriaguez ou violência. Cita também a grande profusão de barraquinhas, pavilhões, bancas ambulantes, ostensivamente adornadas de galhardetes e bandeirolas de cores vivas, cintilantes, pitorescamente iluminadas por mil lanternas e lampiões de diversos feitios e tamanhos. Não falta ao articulista a observação da infernal gritaria de pregões, jogadores, assistentes, entrecortada de ditos brejeiros, pilhérias apimentadas, gostosas gargalhadas. Envolvida em confusão, a informe onda de povo que, em contínuo vai e vem, move-se aos encontrões, pisadelas, empurrões, num intenso foco de luz e de poeira. A dinâmica frenética dos jogos é assim descrita:

As desastradas e perigosas roletas, com toda sua corte de olhares ávidos, sinistros, com toda sua atmosfera pesada, silenciosa, onde somente a voz do banqueiro, apregoando o

74 O Paulista, n. ${ }^{\circ}$ 50, I. 10 de setembro de 1887.

75 Natural de São Luiz do Paraitinga, ordenou-se no Seminário Episcopal de São Paulo a 16 de junho de 1881. Ver POLYANTHEA. Comemoração do cinqüentenário de fundação do Seminário Episcopal de São Paulo: 9 de novembro de 1856 a 9 de novembro de 1906, s.d.. p. 103. Antônio de Nascimento Castro é o nongentésimo sexagésimo sétimo ex-aluno de uma relação de 4.486 nomes, conforme constante no Apêndice da obra em tela.

76 O Noticiarista, n. ${ }^{\circ}$ 96, I. 1 de agosto de 1889. 
número sorteado, as pragas dos jogadores, amaldiçoando os números do azar, o ruído contínuo das fichas em movimento sobre a mesa, ouviam-se a fazer coro com a surda vozeria da multidão que formiga no largo; elas mesmo, as roletas, em carne e osso, estiveram na ponta..., bem contra todas as pragas e maldições dos jogadores, as roletas sempre ganham. A do Rocha, então, não se fale, apesar da simpatia e confiança que inspira o maganão do banqueiro. Foi nela e noutras, referidas do novo método, que muitos pobres diabos como eu, por exemplo, depois de andarem a experimentar a sorte, terminaram por decidi-la, rodando duma vez, a ponto de terem corrido o risco de vir a pé até a cidade. $O$ fato interessante, curioso, é que ninguém saiu ganhando um vintém...

Para os mais bem aquinhoados, a roleta era a preferência; os pobres convergiam para o jogo de búzios. E se a atmosfera do jogo de roleta era pesada, porém silenciosa, o articulista marca de modo indelével a diferenciação social dos freqüentadores de um e do outro ambiente: na roleta, homens com charutos na boca e mulheres elegantemente vestidas. Se para o articulista a jogatina já é considerada instituição genuinamente nacional de nossas festas populares, ele mesmo confessa que prefere "[...] a fina e diplomática roleta que o tosco e grosseiro búzio, jogo primitivo e rudimentar, pela sua rusticidade e brutalidade, próprio somente da taverna e do bordel." Eis o ambiente:

[...] E como estava repugnante e horroroso aquele barracão pesado, escuro, denegrido, carregado duma atmosfera enjoativa de fumo, de querosene, pontas de cigarro, roupa suja, onde indivíduos de fisionomias duvidosas cruzavam olhares rancorosos, punhos cerrados, palavras ameaçadoras, como se aquilo fosse verdadeiro antro de terror, fazendo arrepiar até os próprios búzios e buzistas [...]

O articulista encerra a matéria de modo irônico e divertido, apontando para os pobres dos jogadores que tristemente perderam suas esperanças, e para os rapazes que gastaram seu latim, mas não obtiveram sucesso com namoradas, dando por fim um 'viva' à Festa do Tremembé. ${ }^{77}$

Instalada a república, 'O Noticiarista' comenta a proibição dos jogos nas animadas festas do Tremembé, não obstante serem eles os grandes atrativos dos anos anteriores. ${ }^{78}$ Mesmo assim, o brilho da festa não foi empanado, e as pessoas, não tendo necessidade de se acumularem no barracão, dispersaram-se na extensão do largo, abrilhantando o movimento. 
A repressão, no entanto, dava-se de modo irregular, e o jogo, se em alguns anos por vezes desaparecia, em outros voltava com força total, dependendo, talvez, dos acordos entre banqueiros e autoridades. Pequeno salto no tempo mostra que, em 1900, por exemplo, às diversões da festa não se contabilizaram as tão desejadas e famosas roletas, e os versos apontam, não só o caráter de comparecimento de todas as camadas sociais, acompanhada da segregação espacial da festa com seus bailes, batuques e soireés, como também a sentida ausência dos saltos das bolinhas. Ao poeta restou, quem sabe, a clandestinidade de uma certa rifa das tigelas, conforme publicado no 'Jornal de Taubaté', de orientação autocompreendida como democrática e católica, conforme afirmação de seu editor, Francisco Monteiro Camargo:

\author{
Vamos ter no Tremembé \\ Cavalinhos e touradas \\ Saltos mortais e estocadas \\ Baile, batuque, soireé \\ Regatas e pescarias \\ Pic-nics n'Água Santa \\ Vai-se ali pintar a manta \\ Esquecer melancolias \\ Prá naquilo se por fogo \\ Só falta, diz o Seninha \\ Haver saltos do bolinha \\ $E$ as delícias do jogo \\ Eu, porém, sem mais aquelas \\ Com tudo fico contente \\ Contanto que possa a gente \\ Ir à rifa das tigelas. ${ }^{79}$
}

Diversas notícias da época insinuavam a conivência da polícia e de outras autoridades em relação à jogatina e, em 1892, o jogo volta em carga plena à Festa do Tremembé. O articulista do 'Jornal do Povo', órgão republicano cujas colunas eram franqueadas a maçons, solicita ao leitor entrar "como gato por brasas" pela rua da Palha, penetrando no largo de São Sebastião. Pede também que o leitor se dispa do pudor por alguns minutos, dizendo que basta espanar as roupas, quando da saída:

Estendes tuas vistas... Que vês? Um hospício de alienados, cuja mania é o pão nosso. - Uma bacanal com o dístico da prostituição. O esquecimento da própria dignidade.[...] Muitos pobres diabos ficaram livres de pesadelos; limpos, limpíssimos.

79 Jornal de Taubaté, n. ${ }^{\circ} 1178$, VI. 29 de julho de 1900. 
Em compensação alguns riram-se e nos arrebatamentos de suas glórias confessaram que não há nada como ganhar dinheiro puxado a rodo. ${ }^{80}$

As manifestações do catolicismo luso-brasileiro, no entanto, não eram exclusivas da Festa de Tremembé, e são inúmeros os desentendimentos entre padres e leigos quando falamos em festas religiosas. Buscando disciplinar as mesmas, o clero romanizado, por diversas vezes, viu-se envolvido em problemas.

É apropriado, pois, buscarmos fugir à unilateralidade, recorrendo a Augustin Wernet em seu relato sobre a Festa do Padre Eterno no Santuário de Trindade, em Goiás.

Além dos motivos pastorais, as irregularidades e abusos na festa anual do Divino Padre Eterno, em Goiás, foram um dos motivos principais que levaram Dom Eduardo a chamar os missionários redentoristas para Goiás. As mesmas irregularidades e abusos provocaram a grande crise inicial da obra redentorista em Goiás, a assim chamada "Crise de Trindade". ${ }^{81}$

O santuário mais importante de Goiás, o Santuário do Divino Padre Eterno da Santíssima Trindade, sofreu, na segunda metade da década de 1870, a apropriação de sua administração por leigos, e esta, durante um período de dez anos, "livrou-se do controle da hierarquia eclesiástica, favorecendo a introdução de costumes totalmente contrários ao espírito religioso de uma festa popular religiosa". 82

Quando por ocasião de sua primeira visita pastoral ao Santuário, realizada em 1892, D. Eduardo Duarte e Silva ${ }^{83}$ insistiu sobre a prestação de contas junto à comissão, sendo-lhe confessado, pelo tesoureiro, que o mesmo havia adquirido bois com o numerário. Isso para não se citar o "Regimento da Comissão", que destinava metade das rendas ao Presidente, sendo a outra metade dividida igualmente entre 0 tesoureiro e o zelador...

Retirando das mãos dos leigos a administração do Santuário, entregou-a D. Eduardo ao Padre Inácio de Souza, que nenhuma providência tomou, não obstante estar de acordo com o bispo em chamar os redentoristas para cuidarem do mesmo.

Pelos cálculos de 1895, ano em que, pela primeira vez, os redentoristas

80 Jornal do Povo, n. ${ }^{\circ}$ 59, VI. 11 de agosto de 1892.

81 WERNET, Augustin. Os redentoristas no Brasil. v. 1. Aparecida: Santuário, 1995. p. 72.

82 WERNET, Augustin. Os redentoristas no Brasil. v. 1. Aparecida: Santuário, 1995. p. 74.

83 Disponível em <http://www.catholic-hierarchy.org/bishop/bduasi.htm> Consulta em 12 de agosto de 2005. 
intervieram na festa, cerca de dez mil pessoas para lá acorreram. A administração dos missionários, obviamente, desagradou os antigos membros da comissão.

Aqueles e outros comerciantes do povoado não viram com bons olhos o fato de a romaria, a festa e seus rendimentos ficarem sob o controle dos padres redentoristas. Este desagrado ficou latente sob as cinzas e explodiu em revolta contra os redentoristas, quando, em 1898, Dom Eduardo editou medidas drásticas para moralizar a romaria e a festa, que seriam aplicadas em 1899. ${ }^{84}$

Dom Eduardo, em carta ao Padre Superior de Campininhas, José Wendl, dizia que "na romaria de Barro Preto, há muita coisa para corrigir-se e os padres devem ir começando a acabar com tanto incentivo ao mal, que ali reúne, como por exemplo: jogos, teatros, circos de cavalinhos e prostitutas". ${ }^{85}$

Isto posto, as medidas tomadas em 1898 não surtiram o efeito desejado, fazendo com que o bispo publicasse uma Portaria, em 15 de novembro de 1899, transferindo a data da festa e reduzindo, ainda, a partir de 1900, sua duração. Em caso de oposição, diga-se, a igreja seria declarada interdita "e para sempre suprimida a romaria do Barro Preto". 86

Tomando conhecimento do decreto, o povo posicionou-se contra 0 procedimento do bispo, ao mesmo tempo em que se iniciava uma série de correspondências entre o prelado e os redentoristas sobre a questão. A crise prosseguia, até que chegou às mãos do prelado um jornal que anunciava a festa em sua data original.

A reação de Dom Eduardo não tardou, tendo sido determinado o fechamento da igreja. Encontrando-a trancada no dia 6 de julho, a massa ficou revoltada; dois cidadãos a arrombaram, bem como o cofre e o sacrário, e tocaram o sino, visando com isso a reunir os fiéis.

No dia seguinte, quando da chegada do bispo em Trindade, determinou ele que a imagem fosse retirada da igreja, e à revolta popular contrapôs-se a ação do juiz de direito, que solicitou a D. Eduardo ceder em sua ordem. O prelado anuiu, mas imediatamente lançou interdito sobre o Santuário e a localidade de Trindade. Por três anos seguidos a festa prosseguiu sem padres, e o envolvimento de políticos da região, bem como o prejuízo daí advindo, complicou a situação. Dom Eduardo

84 WERNET, Augustin. Os redentoristas no Brasil. v. 1. Aparecida: Santuário, 1995. p. 72. 85 WERNET, Augustin. Os redentoristas no Brasil. v. 1. Aparecida: Santuário, 1995. p. 76. 86 WERNET, Augustin. Os redentoristas no Brasil. v. 1. Aparecida: Santuário, 1995. p. 78. 
mostrava-se irredutível, não obstante vozes redentoristas, e do próprio episcopado, se mostrarem contrárias.

Segundo Wernet, "a iniciativa para solucionar o impasse partiu dos redentoristas". ${ }^{87}$ Padre Gebardo Wiggermann, diplomaticamente, procurou mostrar a D. Eduardo que o abandono de Trindade açulava a ação de pastores protestantes. Em vista disso, o bispo resolveu por conta própria ir até lá para tentar uma reconciliação, e após as conversações de praxe, levantou o interdito em 27 de outubro de 1903. O processo romanizador vencera, e a partir daí, os redentoristas "podiam começar com o processo da cristianização da festa e da romaria da Trindade, ou seja, adaptar a romaria e a festa às exigências do catolicismo oficial e ultramontano, preconizado pela Reforma Católica do século XIX". ${ }^{88}$

Volvendo ao tema, as questões entre Igreja e Estado encontravam-se na pauta do dia, e 'O Noticiarista' dispõe de quatro colunas completas para apresentar uma discussão legal sobre ser ou não crime a celebração do casamento religioso antes do ato civil. Denominando de "perseguidores da religião católica" os que sustentam o fato da celebração das cerimônias religiosas antes do ato civil constituírem crime, como definido no artigo 284 do Código Penal, o artigo tece longos comentários sobre a questão da precedência, terminando por afirmar que o parágrafo quarto do artigo setenta e dois do Decreto 510, de 22 de junho de 1890, onde consta que a república só reconhece o casamento civil, e que o mesmo precederá sempre as cerimônias religiosas de qualquer culto, já foi emendado pelo Congresso, demonstrando, com isso, o desejo dos legisladores em alterar a ordem de precedência.

A questão, no entanto, não residia tão somente em uma aula de direito, mas também na defesa do Padre Antônio Gomes Vieira, ${ }^{89}$ coadjutor da paróquia, pelo "criminoso" fato de ter celebrado o casamento religioso precedendo o ato civil. Afirmando que o ocorrido é um atentado à consciência religiosa e à Constituição, a matéria tem como endereço promotores públicos republicanos, fazendo ver que seu único móvel foi o ódio brutal e a vingança mesquinha. A república, pois, é taxada

87 WERNET, Augustin. Os redentoristas no Brasil. v. 1. Aparecida: Santuário, 1995. p. 83. 88 WERNET, Augustin. Os redentoristas no Brasil. v. 1. Aparecida: Santuário, 1995. p. 84. 89 Natural de Taubaté, ordenou-se no Seminário Episcopal de São Paulo a 26 de fevereiro de 1886. Ver POLYANTHEA. Comemoração do cinqüentenário de fundação do Seminário Episcopal de São Paulo: 9 de novembro de 1856 a 9 de novembro de 1906, s.d.. p. 118. Antônio Gomes Vieira é o milésimo quadringentésimo primeiro ex-aluno de uma relação de 4.486 nomes, conforme constante no Apêndice da obra em tela. 
como ditadura:

Se antes da constituição promulgada era um grande erro considerar criminoso a um sacerdote pelo fato de administrar o sacramento do matrimônio, quando o governo da ditadura já tinha decretado a separação da Igreja do Estado e, portanto, não cogitava mais dos atos religiosos, muito principalmente hoje que a constituição veio anular o célebre aviso do 'general da justiça', em que, com formal ofensa da liberdade religiosa, cominava penas para os sacerdotes de qualquer confissão que fizessem preceder o casamento religioso ato civil. ${ }^{90}$

Em relação ao envolvimento do clero com as coisas "do mundo de fora", percebe-se o imbricamento de questões religiosas e não-religiosas com as atividades políticas por parte do Vigário de Taubaté, Padre Cônego Antônio de Nascimento Castro (1857-1942), e de seu irmão, Padre José Valois de Castro (18561939), ${ }^{91}$ bem documentadas nas Atas da Câmara da cidade e na imprensa regional.

É interessante afirmar que, não obstante o desejo da romanização, particularmente no Brasil, em afastar os padres da política, ${ }^{92}$ nem por isso diversos padres políticos do período se desviaram do ultramontanismo em que foram educados, e o gosto pela polêmica e a pena afiada de Nascimento Castro são frisados por Antônio d’Almeida Moraes Júnior:

Mas a faceta mais fulgurante, e diríamos mesmo, genial, do talento do Monsenhor Nascimento Castro foi sua capacidade de polemista. Gênio forjado na têmpera de Atanásio ou Agostinho, jamais sua pena vigorosa deixou de desarvorar e aniquilar os inimigos do Dogma Católico. E terçou armas com os mais terríveis adversários, quer pela cultura, quer pela ousadia desumana com que procuravam ferir o seu contraditor. No Brasil, nenhum inimigo ousado da Igreja deixou de sentir os golpes de sua dialética. O protestantismo encontrou nesse admirável sacerdote um de seus mais temíveis adversários. ${ }^{93}$

De um jornal de Guaratinguetá pode-se fazer um juízo da atividade política de Valois de Castro, que nada fica a dever em relação à atualidade:

Fala do Valois - O Padre Valois em Taubaté declarou-se oposicionista, e graças a essa habilidade pescou uns votinhos

90 O Noticiarista, n. ${ }^{\circ}$ 270, III. 19 de abril de 1891.

91 Ordenou-se no Seminário Episcopal de São Paulo a 15 de dezembro de 1878. Ver POLYANTHEA. Comemoração do cinqüentenário de fundação do Seminário Episcopal de São Paulo: 9 de novembro de 1856 a 9 de novembro de 1906, s.d.. p. 109. José Valois de Castro é o octogentésimo décimo nono primeiro ex-aluno de uma relação de 4.486 nomes, conforme constante no Apêndice da obra em tela.

92 É preciso considerar as especificidades do ultramontanismo. Na Alemanha, por exemplo, tem-se o Partido Católico.

93 MORAES JÚNIOR, Antônio d'Almeida. Uma página de Mons. Antônio Nascimento Castro sobre "Misticismo e Histeria, Revista Eclesiástica Brasileira, v. 4, fasc. 2, junho de 1944. p. 315. 
da oposição. O mesmo Padre Valois em Guará é governista, e nessa qualidade constitui-se órgão para saudar o governo na pessoa do Coronel Virgílio. ${ }^{94}$

Onde houvesse fumos de política Padre Nascimento Castro estava presente, a começar pelo fato de que a proibição de sepultamentos no interior de igrejas era assunto facilmente contornável. $\mathrm{O}$ ato de morrer ainda não estava sob o domínio do desencantamento que a modernidade traria:

Além de ser bom morrer em terra firme, era também indispensável ser enterrado em solo sagrado e perto de casa. Para os luso-brasileiros, até pelo menos metade do oitocentos, esse lugar ainda era a igreja. Da mesma forma que os cortejos fúnebres imitavam a procissão do Senhor Morto, ter sepultura na igreja era como tornar-se inquilino na casa de Deus. [...] Ter uma cova dentro da igreja era também uma forma de os mortos manterem contato mais amiúde com os vivos, lembrando-lhes que rezassem pela alma dos que se foram. ${ }^{95}$

A Constituição republicana, de 24 de fevereiro de 1891, é bastante clara a esse respeito, e em seu parágrafo $5^{\circ}$ do artigo 72 reza que "[...] os cemitérios terão caráter secular e serão administrados pela autoridade municipal, ficando livre a todos os cultos religiosos a prática dos respectivos ritos em relação aos seus crentes, desde que não ofendam a moral pública e as leis." 96

A secularização dos cemitérios, no entanto, não era empecilho para a ação do padre e de seus companheiros de Câmara, principalmente por tratar-se de pedido do Padre Francisco Carlos de Alvarenga, ${ }^{97}$ e pelo fato de o morto ser ninguém menos que D. José Pereira da Silva Barros, ${ }^{98}$ denodado defensor do ultramontanismo em Taubaté, e irmão do peticionário:

94 Gazeta Paulista, n. ${ }^{\circ}$ 64, II. 11 de março de 1906. Guaratinguetá. (Diversos n. ${ }^{0} 11$ )

95 REIS, João José. O cotidiano da morte no Brasil oitocentista. In: Novais, Fernando A. (coordenador geral). História da vida privada no Brasil. v. 2. São Paulo: Companhia das Letras, 1997. pp. 124-125.

96 FERNANDES, Geraldo. A religião nas constituições republicanas do Brasil, Revista Eclesiástica Brasileira, v. 8, fasc. 4, dezembro de 1948. p. 841.

97 Natural de Taubaté, ordenou-se no Seminário Episcopal de São Paulo a 20 de abril de 1873. Ver POLYANTHEA. Comemoração do cinqüentenário de fundação do Seminário Episcopal de São Paulo: 9 de novembro de 1856 a 9 de novembro de 1906, s.d.. p. 118. Francisco Carlos de Alvarenga é o ducentésimo octogésimo sétimo ex-aluno de uma relação de 4.486 nomes, conforme constante no Apêndice da obra em tela.

98 Nascido em Taubaté, em 24 de novembro de 1835, D. José Pereira da Silva Barros, bispo de Olinda (1881) e do Rio de Janeiro (1891), estudou no Seminário Episcopal de São Paulo, recebendo de D. Antônio Joaquim de Melo as ordens sagradas em 27 de dezembro de 1858. Nomeado vigário encomendado da paróquia de Taubaté em 1862 e empossado em 15 de maio de 1864, imprimiu forte ação romanizadora em seu longo paroquiato. Ver POLYANTHEA. Comemoração do cinqüentenário de fundação do Seminário Episcopal de São Paulo: 9 de novembro de 1856 a 9 de novembro de 1906, s.d. pp. 17-19. D. José Pereira da Silva Barros é o sexagésimo ex-aluno, conforme constante no Apêndice da obra em tela. 
Taubaté representa, em boa parte, o resultado da ação incessante desse padre excepcional. Aí está a igreja matriz, com a majestade que the deu a reforma realizada pelo sacerdote infatigável. Aí estão o Ginásio de Nossa Senhora do Bom Conselho e o Externato São José, que ele fundou e orientou, para se tornarem os estabelecimentos modelares em que as jovens taubateanas adquirem os conhecimentos científicos indispensáveis à luta pela existência, ao mesmo tempo que vão tornando mais sólidos os fundamentos de sua moral cristã. ${ }^{99}$

Eleito deputado provincial, a formação ultramontana de D. José Pereira da Silva Barros, bem como a defesa que fazia em prol dos interesses da Igreja católica, transparecem em seus debates contra o Padroado. Para combater o protestantismo uniu-se, já como bispo do Rio de Janeiro, a Monsenhor Nascimento Castro, fundando em 11 de maio de 1892 o Externato São José, para meninas, bem como o Hospital Santa Isabel, ambos em Taubaté.

O despacho da Câmara Municipal, ressaltando ser "o ilustre morto digno dessa concessão excepcional", não poderia ser outro: "Deferido. Ao Senhor Intendente Municipal". 100

A ação de Nascimento Castro, no entanto, não se limitava tão somente aos assuntos políticos temporais em si. Atento a qualquer tipo de avanço protestante em terras taubateanas, o vigário entrou em franca discussão com seus colegas de Câmara quando por ocasião de um "expediente" provocado pelo requerimento de João Batista de Carvalho, ministro evangélico da Igreja Metodista de Taubaté. Pedia o ministro isenção do imposto predial da casa situada na rua Marquês do Herval, 73, por ser ela destinada exclusivamente ao culto da Igreja Metodista. Entendendo que a casa em tela era templo dessa confissão, João Batista de Carvalho amparou sua petição no Código de Posturas Municipais, que previa a não tributação de templo de qualquer religião. Na tentativa de ilustrar a petição, o ministro anexa à mesma um recibo, provando as cobranças de imposto à Igreja Metodista,

[...] mas espera, em vista do expendido da imparcialidade e justiça da ilustre edilidade, que o referido prédio ficará isento do imposto predial, enquanto for exclusivamente destinado para o culto da Igreja Metodista.

O assunto foi tratado em 6 de outubro de 1898, na 54a Sessão ordinária, sob a presidência de José Benedito Marcondes de Mattos, e na presença dos

99 GUISARD FILHO, Félix. D. José Pereira da Silva Barros - sua vida e sua obra. São Paulo: Empresa Editorial Universal, 1945. p.21.

100 ATAS DA CÂMARA, Taubaté, 16 de abril de 1898. p.11 e 11v. 
vereadores Marcondes de Mattos, Dr. Pereira Corsino, Augusto Monteiro, Ramos Ortiz, José Francisco de Moura e do próprio Padre Nascimento Castro. Posto em discussão o tema, Nascimento Castro protesta contra a equiparação da Igreja católica às seitas religiosas, afirmando ser aquela um patrimônio nacional, e a religião, a formadora da índole do povo brasileiro, não podendo ser comparada, em condições de igualdade, com "[...] essas seitas de meia dúzia de adeptos, planta exótica no meio desta católica população". Nascimento Castro prossegue em suas diatribes, declarando que o próprio governo provisório e a Constituição da República, "[...] embora eivadas do sectarismo positivista, deram provas de reconhecimento da supremacia da Igreja Católica", deixando expressa a garantia de seus direitos adquiridos, o que é um testemunho de que o catolicismo possui preciosos títulos de grandeza nacional, "[...] não podendo ser comparada a uma seita que aqui vegeta atrofiada, completamente estranha e refratária à nossa educação". Nascimento Castro conclui que, se a Câmara Municipal quiser ser escrupulosa diante da interpretação literal da Constituição, precisa ter informações verídicas: se o culto protestante metodista é uma associação que goza dos direitos de personalidade jurídica, e se assim reconhecida possui casa com forma exterior de templo, condições estas necessárias para a isenção de imposto respectivo. E que, uma vez dada a exatidão destas informações, a Câmara Municipal procederá, inspirada em seu critério, como julgar de justiça.

O Sr. Dr. Pereira Corsino pede a palavra e, após ligeiras considerações sobre o assunto, diz concordar com o seu colega; entretanto, como representante do Município, e filiado à bandeira do governo que os rege, não pode deixar de votar a favor do pedido, embora católico, porque se o prédio é exclusivamente destinado para templo dessa seita, está no caso de ser atendido, em face da Constituição, que dá plena liberdade às crenças religiosas.

Portanto, se o prédio estiver neste caso, como nos pode informar o Senhor Intendente não pode deixar de obedecer a lei. O Sr. Intendente pede adiamento da matéria, dizendo não estar pronto para dar o seu parecer. É aprovado o adiamento. ${ }^{101}$

O jornal católico 'A Verdade' representava em Taubaté a ortodoxia ultramontana. Inimigo ferrenho do espiritismo, empregava todos os métodos e exemplos possíveis empregados contra a doutrina de Allan Kardec. Da leitura do 
jornal depreende-se não faltar aos seus redatores boa erudição clássica:

[...] mas é principalmente sob este ponto de vista que consideramos o espiritismo como doutrina perigosa e absurda na teoria e na prática. As suas revelações só podem ser influenciadas pelos maus espíritos. [...] O espiritismo é um novo culto comum ao dos faquires da Índias, formando um sistema de comunicação dos maus espíritos, de que o gênio natural de Shakespeare nos dá no Macbeth um fiel e horrível espécime. ${ }^{102}$

O Padre Nascimento Castro não poupava pressões junto aos demais companheiros, obtendo concessões que, pretensamente, o fim do Padroado havia dado por encerradas, e que o parágrafo $7^{\circ}$ do artigo 72 da Constituição de 1891 bem previa: "Nenhum culto ou igreja gozará de subvenção oficial, nem terá relações de dependência ou aliança com o Governo da União ou dos Estados." ${ }^{103}$ Mesmo assim, a Ordem do dia da 59a Sessão ordinária da Câmara, mediante a Resolução n. ${ }^{\circ} 70$, concedia ao vigário de Taubaté a quantia de dois contos de réis para as reformas da igreja matriz.

Resolução n. ${ }^{\circ} 70$ - Considerando que a Igreja Matriz é um edifício público que por sua importância social, moral e religiosa mais salienta-se no meio de uma população e pelo qual aquilatava-se do adiamento de sua civilização e da sua louvável generosidade; - considerando que, na cooperação dos melhoramentos desse edifício, a que precedem-se as tradições mais gloriosas deste município, satisfaz-se o desejo desta população católica; - considerando que em várias localidades as Câmaras Municipais tem longamente contribuído para o mesmo fim com geral contentamento de seus respectivos munícipes, resolve esta câmara Municipal. Art. $1^{0}$ - Fica o Intendente autorizado a auxiliar o Padre Vigário da Paróquia com a quantia de $(2: 000 \$ 000)$ dois contos de réis para ser aplicada às obras de reconstrução do exterior da Igreja Matriz desta cidade. Art. $2^{\circ}$ - Esta importância será paga pela Intendência Municipal em qualquer tempo do corrente ano, podendo o Intendente abrir crédito suplementar e fazer a apuração de crédito suplementar e fazer a apuração de crédito que julgar necessária. Art. $3^{\circ}$ - Prorrogadas as disposições em contrário. Taubaté, 2 de janeiro de $1902 .{ }^{104}$

A questão da subvenção de dois contos de réis para a igreja matriz provocou intensa celeuma. Em uma série de artigos intitulados "Escândalo! Para onde vamos? A Câmara Municipal embrulhada", o periódico republicano 'O Taubateano' iniciou ferrenha oposição ao caso, afirmando que se tal situação ocorresse em um local 
onde o povo fosse ignorante e os eleitos não fossem republicanos, até se poderia compreender que a proposta, denominada de criminosa pelo jornal, ficasse em silêncio, "[...] mas como o Taubateano é jornal e sentinela avançada das leis republicanas, não podemos deixar esse ato escandaloso sem protesto." 105

O jornal avança, e pergunta se a subvenção da Câmara Municipal é condizente ao particular interesse do município, apontando que, com esses dois contos de réis, seria possível a aquisição pela Câmara de um carro dotado de aparelhos para desinfecção, ou então melhorar a farmácia do hospital. Em última análise, até mesmo multiplicar e melhorar os mictórios da cidade. O artigo, verdadeira aula de direito constitucional, com citação de todos os artigos que caracterizam o Estado laico, encerra sua longa exposição fazendo ver, de modo irônico, que para o auxílio de obras de igreja há a boa vontade dos crentes, bastando, para isso, a contribuição dos católicos quando os "deuses terrenos" passarem a sacola.

A entrega do dinheiro destinado às obras da igreja matriz, entretanto, estava demorando, e Nascimento Castro não hesita em cobrar o que Ihe é devido:

Requerimento do Sr. Vigário Cônego Antônio Nascimento Castro ao Sr. Intendente Municipal que a sujeita a consideração da Câmara, pedindo, em virtude da deliberação da Câmara Municipal antecessora constante da resolução n. ${ }^{\circ}$ 70 de 2 de janeiro do corrente ano que destinou uma verba de 2:000\$000 para a realização das obras de segurança e de reparação do exterior da Matriz desta cidade, sem caráter de subvenção nem relação de dependência, mas unicamente como auxílio prestado para um edifício público que ameaça ruína, que lhe seja satisfeito o pagamento consignado naquela verba, mandando entregar-Ihe essa quantia. ${ }^{106}$

Ordenado em 1881, e obtendo por concurso o cargo de vigário colado dois anos depois, em 1906 a carreira eclesiástica do Padre Nascimento Castro é premiada: em 26 de fevereiro, o vigário de Taubaté recebe o título de monsenhor; 'A Verdade' é pródiga em elogios sobre o fato, e o texto empolado do jornal por vezes se perde, beirando a raia do cômico. Dentre tantos atos heróicos citados, para o jornal, "[...] o vigário Nascimento Castro foi para seus paroquianos a pérola difícil que o escafandro da diligência buscou nesse mar das atuais intemperanças." 107

A ação de dominação política de Monsenhor Nascimento Castro fazia-se

105 O Taubateano, n. ${ }^{\circ}$ 92, II. 5 de janeiro de 1902.

106 ATAS DA CÂMARA. Taubaté, 30 de outubro. p.83; 83v, 1902.

107 A Verdade, n. ${ }^{\circ}$ 213, III. 29 de março de 1906. 
sentir até mesmo em relação à tradicional distribuição de carne aos pobres por ocasião da festa do Divino. Sendo o vigário de Taubaté, planejou a distribuição de carne aos pobres da Confraria de São Vicente de Paulo e da Irmandade do Coração de Jesus, devendo, para isso, acharem-se os mesmos no açougue do Sr. Timóteo, apresentando, cada um, o cartão que comprovava pertencerem às referidas congregações. Em suma, não era qualquer pessoa que poderia receber a carne, mas os pobres sob o controle das associações religiosas e sob a esfera de influência de Monsenhor Nascimento Castro.

Ficam, portanto, avisados os diretores das congregações, a fim de que sejam entregues os cartões às pessoas que forem receber carne. Em seguida, sairá uma carroça conduzindo carne ao Asilo, Hospital e Externato São José. Às 2 horas da tarde partirá da rua do Humaitá uma vitela destinada ao convento de Santa Clara, e à noite, finda a novena, haverá leilão de prendas. ${ }^{108}$

Se, de modo geral, a imprensa taubateana criticava a ação política dos irmãos Castro e, com maior veemência, a má conduta dos frades do Santa Clara, é certo que esses últimos encontravam refrigério e paz nas palavras do Dr. Júlio César de Moraes Carneiro, o futuro Padre Júlio Maria, pelas páginas d"A Verdade'. Atacando a imprensa que acusava serem os capuchinhos malcriados e grosseiros, Moraes Carneiro compara seus críticos a crianças que depositam matéria fecal nas calças engomadas dos adultos, e considerando as acusações como simples ofensas, termina por afirmar que "Eu ignoro se o capuchinho não sabe ser manso, nem levo a mal que não o seja, quando sois tão bravos que a veemência daqueles lábios não corresponde ainda às fúrias da vossa impiedade!" 109

Nas páginas d"A Verdade' são inúmeras as referências elogiosas aos frades, referências essas que se entrelaçam à visão triunfalista da linha editorial do periódico e da própria Igreja católica no período estudado. Novenas, celebrações, festas, homenagens do povo por ocasião de aniversários dos capuchinhos, tudo era minuciosamente relatado. Por ocasião da partida de Frei Camillo e de Frei Fernando para a região do Paranapanema, em busca de índios "[...] para trazê-los ao convívio da civilização por meio da catequese persuasória e caridosa”, 'A Verdade' aborda o acontecimento emprestando-Ihe o espírito de uma cruzada, terminando por afirmar que:

108 O Norte, n. ${ }^{\circ} 165$, II. 31 de maio de 1906.

109 A Verdade, n. ${ }^{\circ}$ 150, III. 8 de Agosto de 1905. 
Só a Igreja católica é que sabe dar ao mundo o admirável exemplo da caridade evangélica dos seus missionários, que não temem expor a sua própria vida aos sofrimentos do martírio, derramando o seu sangue pela causa da salvação das almas, que é a causa de Deus e da civilização cristã. ${ }^{110}$

De Monsenhor Miguel Martins da Silva ${ }^{111}$ também não se descuidava 'A Verdade', e em meio às notícias de que o pregador estaria na Matriz da Consolação, em São Paulo, dando início a uma série de conferências religiosas, o jornal aproveita para reafirmar sua linha combativa e de defesa ao catolicismo informando que "[...] atualmente Monsenhor Martins acha-se em missão na cidade de Ubatuba invadida pela propaganda protestante." 112

À política misturava-se à religião, e a perseguição aos espíritas, protestantes e maçons ensejou matéria com o sugestivo título de "Derrubada", em que o 'Jornal de Taubaté' noticiou a demissão de um carcereiro. À alegação de que havia ele desrespeitado um suplente de subdelegado, o jornal desmente o boato, frisando terem as coisas se passado de modo inteiramente diverso, ou seja, uma comissão da festa do Divino, tendo se lembrado de fornecer a tradicional alimentação aos presos, apareceu na cadeia sem qualquer aviso e ainda acompanhada por músicos. Ocorre que o grupo se esquecera de pedir licença ao delegado. O carcereiro, sabedor de que a admissão sem a devida licença só era permitida aos advogados, impediu a entrada da dita comissão, constituída, entre outros, pelo suplente de subdelegado. Formada a confusão, o carcereiro foi demitido.

A história, em nosso entender, teria um motivo comum - abuso de poder -, não fosse a apuração do jornal sobre o fato do carcereiro, além de não ser católico, ser maçom. Assim, o articulista o compara ao burro que é espancado pelo simples motivo de não ser cristão e não acreditar em Nossa Senhora, indicando que a demissão estava adrede preparada, faltando, decerto, apenas um motivo:

Non é cristiano, non crede a la Santa Madona, tome demissão. É esta a verdade: o carcereiro foi demitido porque não era católico e era maçom. Alguém, muito do convento e da igreja,

110 A Verdade, n. ${ }^{\circ} 231$, IV. 9 de junho de 1906.

111 Natural de Taubaté, ordenou-se no Seminário Episcopal de São Paulo a 19 de junho de 1864. Ultramontano e combativo, de Monsenhor Miguel Martins da Silva lê-se no Correio d'O Norte, XI. n. ${ }^{\circ}$ 563, 1 de julho de 1900. Guaratinguetá. (Pasta Correio d'O Norte - 1900/1903): "S.S. o Papa Leão XIII acaba de conceder ao Rev. ${ }^{\text {mo }}$ Cônego Miguel Martins da Silva, que por muito tempo foi vigário da paróquia, nesta cidade, a elevada graça do título de Monsenhor protonotário apostólico". Ver POLYANTHEA. Comemoração do cinqüentenário de fundação do Seminário Episcopal de São Paulo: 9 de novembro de 1856 a 9 de novembro de 1906, s.d.. p. 93. Miguel Martins da Silva é o trigésimo primeiro ex-aluno de uma relação de 4.486 nomes, conforme constante no Apêndice da obra em tela. 112 A Verdade, n. ${ }^{\circ} 259$, IV. 26 de setembro de 1906. 
que sempre ia e vai à cadeia, andava a prometer essa demissão porque ele queria que os presos lessem somente folhetos católicos e o carcereiro dava a ler aos presos, com licença da autoridade, folhetos protestantes.

A finalização do artigo não é novidade:

Tudo está a indicar que o que determinou essa demissão foi a intolerância religiosa aliada ao ódio político. ${ }^{113}$

Também contra o espiritismo os ataques d"A Verdade' prosseguiam incessantes. Copiando o jornal carioca 'UNIÃO', 'A Verdade' noticia que a polícia da $14^{a}$ circunscrição urbana realizou um cerco na casa n. 56 da rua São Luiz Gonzaga, visando reprimir "a célebre medicina espírita e ilegal" em uma associação espírita. Com o título "Espíritas engaiolados", e denominando de "imbecis" os consulentes de um certo Luiz da Silva Durão, toma-se ciência de que as autoridades apreenderam também os objetos referentes ao culto, denominados pela 'A Verdade' de "bugigangas apropriadas às sessões". Reportado o incidente, 'A Verdade' estabelece um paralelo com as atividades dos espíritas em Taubaté, tidas pelo jornal católico na conta de "abusivas da credulidade ignorante e imbecil", e conclama as autoridades para as providências, encerrando por afirmar que "[...] aqui o Durão não é um vivente folgazão cá da terra, mas o espírito africano do feiticeiro pai Jacob, velhaco homoepatisador dos tolos e dos desequilibrados." 114

A imprensa espírita, não obstante modestíssima tiragem, e com periodicidade irregular, também se fez presente em Taubaté. Decerto com vistas a escavar o terreno do incognoscível para buscar uma verdade espiritual acabada, surge, em 1905, um jornal espírita denominado 'O Alvião'. 'A Verdade', atenta a qualquer manifestação de transcendência que fugisse dos limites católicos, assim recebe o novo "colega":

Como era de esperar apareceu no domingo o primeiro número desta folha semanal que se diz - órgão de propaganda do espiritualismo científico-filosófico sob a direção do Sr. Ernesto Penteado. Lemos e relemos o dito jornal, sem todavia nada encontrar que justificasse sequer a absurda pretensão do $\mathrm{Sr}$. Penteado... Vir das longínquas e formosas plagas da Paulicéia, de um meio onde há elementos para todas as crenças, incentivo para todos os ideais, louros para todas as vitórias, procurara o asilo hospitaleiro desta terra, tradicional pela extrema fé na sagrada Religião Católica apostólica romana, com o inaceitável intuito de aqui lutar pela propaganda espírita! Se lá na capital paulista não conseguiu sustentar $O$ Alvião, 
(como se depreende do seu artigo de fundo), não será aqui, por certo, que há de conseguir o seu ideal. A população de Taubaté não é tão ignorante como pensa o Sr. Penteado. Aqui há poucos pais Jacob. ${ }^{115}$

Pode-se constatar, portanto, o caráter tendencioso da imprensa local, muito mais opinativo do que informativo. Mantendo essa linha, o 'Jornal de Taubaté', palco de lutas políticas contra o católico moderado 'O Norte', não perdia ocasião para espicaçar o clero taubateano, e por ocasião do sexto aniversário d'A Verdade' o jornal católico foi mimoseado sob a forma de versos. Discretamente, em um canto de página, lê-se:

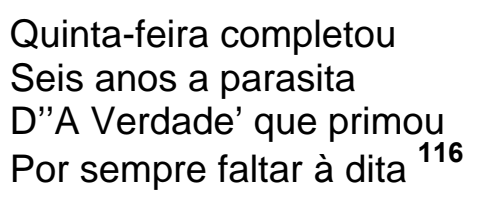

Os irmãos Castro continuavam em evidência na política, e dessa vez o 'Jornal de Taubaté' entra em conflito com 'O Norte', jornal católico que havia chamado para si a defesa do padre Valois de Castro na questão da remoção de um certo Sr. Alceu Pinto, escriturário da estrada de ferro central. Em artigo intitulado "É preciso reagir", o 'Jornal de Taubaté' afirma que tudo o que foi por ele censurado naquela remoção 'O Norte' aplaudiu como o mais justo e merecido dos atos. Afirmando que a remoção daquele funcionário foi "[...] uma vingança mesquinha e inqualificável do padre Valois de Castro", o 'Jornal de Taubaté' decidiu por reverberar seu protesto, acusando 'O Norte' de aplaudir a dita remoção como "[...] um ato de justiça pautado pelo amor à disciplina do funcionalismo." Perguntando sobre as razões da remoção de Alceu Pinto, o 'Jornal de Taubaté' levanta a hipótese e o funcionário ter abusado ou prevaricado no exercício do seu cargo ou cometido algum crime que devesse ser punido. À pergunta, vem a resposta: "Não, aquele funcionário foi removido única e exclusivamente por ser espírita e praticar a medicina e ser eleitor do partido municipal," reproduzindo um trecho do artigo d"O Norte', em que o jornal católico afirma que ninguém ignorava que o Sr. Alceu Pinto reunia muita gente para sessões espíritas, nas quais o Pai Jacó dava receitas até contrárias aos princípios higiênicos, todas ditadas pela prática do espiritismo, apontando que esse fato é crime punido pelos artigos 156 e 157 do código penal. O 'Jornal de Taubaté', no entanto, retoma o ataque pelo flanco político, afirmando que ninguém ignorava 
que Alceu Pinto trabalhara contra o diretório local na última eleição, concluindo ter ele sido removido por ser espírita, exercer a medicina, e ter cabalado contra o diretório político local. Em seguida, o 'Jornal de Taubaté' passa a atacar diretamente Valois de Castro:

Causa-nos até nojo essa afirmação d'O Norte', mormente quando, através daquelas linhas, lobrigamos o dedo de um padre, do vigário desta paróquia, escrevendo aquele artigo. Mas é crime ser espírita? Não é livre no Brasil o exercício de qualquer culto? A religião pregada e ensinada pelo padre Valois de Castro já não é mais a religião oficial. A constituição garante o exercício de qualquer culto desde que não traga ele ofensa à moral e aos bons costumes. É também crime exercer a medicina sem um diploma oficial? Se é, porque o padre Valois de Castro que arvorou-se agora em regenerador e reformador dos costumes não processou o Sr. Alceu Pinto? Por ventura a remoção será a pena que o código impõe aos que exercem a medicina sem um diploma oficial? Se o é como punir-se o vigário irmão do padre Valois de Castro que também pratica o charlatanismo?

O 'Jornal de Taubaté' prossegue, perguntando se também é crime cabalar contra o diretório político local, e se por acaso esse diretório é tão inviolável e sagrado, a ponto de não poder sofrer o embate de uma opinião. Pergunta também se não é livre a manifestação do pensamento, tanto em política, como em religião, afirmando que, para 'O Norte', é crime pensar livremente, é crime socorrer a pobreza dando-lhe remédios homeopáticos gratuitamente, bem como é crime cabalar contra o diretório político local. O ataque se estende, pois para 'O Norte’ só não é criminoso quem é católico, só não é criminoso quem é adepto da política dominante. Para o 'Jornal de Taubaté' os motivos que 'O Norte' apresenta para justificar a remoção do Sr. Alceu Pinto são bem sintomáticos e caracterizam perfeitamente o espírito do momento, pois o partido dominante local "estrebucha na mais irremediável das agonias" e, para salvá-lo, seria preciso implantar o regime de terror e lançar mão de meios extremos e violentos. Denominando 'O Norte' de "órgão oficial do padre Valois de Castro", o jornal de Taubaté encerra a matéria clamando por reação:

É preciso, pois, que reajamos também contra esse regime de terror, contra esses meios extremos e violentos manifestados pelas vinganças e perseguições do padre Valois de Castro e mostremos que a vontade popular é forte e não se curva ante a prepotência e a tirania de meia dúzia de beleguins enfatuados e impostores. Reajamos, mas, por meios suasórios e brandos, a fim de mostrar ao padre Valois de Castro que não é com a 
força da opressão que se consegue dominar uma opinião. ${ }^{117}$

O 'Jornal de Taubaté', apesar de admoestar um pastor protestante "[...] que se mostra tão intolerante como os católicos", não deixou de relembrar o combate às práticas, sermões ou conferências religiosas dos Monsenhores Miguel Martins, Nascimento Castro, e outros cujos nomes pouco importa. No dizer do jornal, o tal pastor, em uma conferência, dirigiu insultos grosseiros às irmãs do Colégio Bom Conselho, "com a agravante de fazer-se ouvir na rua". O 'Jornal de Taubaté' ressalta que, pelo sotaque, parece não ser brasileiro "e por certo não é nosso amigo". E aplicando a fórmula de um no cravo e outro na ferradura, equipara o pastor àqueles que se abrigam a uma religião fazendo-se ministro, não para espalhar a verdade ensinada pelo filósofo da Galiléia, "[...] mas para ter um meio de vida fácil, exatamente como fazem muitos padres católicos". Colocando protestantes e católicos na mesma caldeira, pede o jornal que, tanto os padres católicos, como os protestantes, quando quiserem ser intolerantes, usem ao menos a linguagem com mais medida e sejam mais delicados quando falarem das mulheres, "quem quer que elas sejam, e, se não sabem o valor das palavras que empregam, aprendam o português para depois anunciarem a Boa Nova." 118

A tradicional mistura de política com religião já é assunto do 'Jornal de Taubaté' no início de 1909. Denominando Nascimento Castro de "honrado e casto governador do bispado", o periódico anuncia que ele já havia começado a pedir votos para o irmão Valois de Castro. A se considerar a dupla atividade do Padre Nascimento Castro, e de seu irmão, nada mais apropriado do que a crítica do jornal, sintetizando a ação do padre político, que atravessou o período colonial e imperial, e que o processo de romanização procuraria, por diversos meios, extinguir ou, no mínimo, neutralizar: "A Igreja de sua Reverendíssima concilia perfeitamente os interesses políticos e os interesses das almas de seus paroquianos." 119

Dias depois, prosseguindo o ataque, e ironizando os mesmos irmãos, a publicação se anuncia como endereçada para o Arcebispo, simulando um pretenso pedido de voto do pároco de Taubaté, Monsenhor Nascimento Castro, também conhecido pela alcunha de "Monsenhor Periquito", em favor de seu irmão Valois de Castro, apelidado nas lides políticas como "Cônego Beija-Flor", candidato na 
próxima eleição de 30 de janeiro. No artigo, o pretenso solicitador afirma que o voto em Valois de Castro, além de ser dever de um bom cristão, tendo em vista ser um padre e defensor da religião, "[...] ainda muito me satisfará esse obséquio prestado, podendo o amigo contar com os serviços que puder prestar-lhe como agradecido por esse favor e como pároco que sou." 120

Em relação ao clero regular, a reputação dos frades do convento de Santa Clara também não era das melhores. Conhecidos por suas pregações de cunho dramático e escatológico, a imprensa taubateana, vez e quando, lançava em suas páginas artigos que procuravam delinear o caráter grosseiro desses religiosos, em sua maioria, à época, estrangeiros. Em 1901, por exemplo, o artigo "Frade ridículo", d'O Taubateano', reporta que certa pessoa das relações do jornal, tendo ido acompanhado da esposa a uma festividade religiosa no convento de Santa Clara, em certo momento sentou-se em um dos bancos do adro da igreja:

Antes o não tivesse feito: pois um dos reverendos marmanjos surgiu-lhe pela frente e, desprezando a civilidade com que se deve falar perto de uma senhora, intimou aquele nosso amigo a levantar-se dali imediatamente, sob pena de ser EXCOMUNGADO!!! Se não the obedecesse. Considerando que tinha perto de si uma senhora, o nosso amigo não pode dar uma resposta adequada às palavras do insolente frade.

Por fim, o juízo dos frades visto pela ótica d' 'O Taubateano', acompanhado da solução para o comportamento dos mesmos:

Eis aí o que são esses mal educados e atrevidos frades, que só poderão ter como resposta uma bem aplicada bofetada. ${ }^{121}$

De fato. E o tema do frade ridículo nos mantém em digressões a respeito da linha editorial d'O Taubateano'. Adeptos do "castigat ridendo mores", alguém que assina "La Palisse", o equivalente francês do nosso Conselheiro Acácio, apresenta na seção "Palitos" divertidos sonetos sobre os mais variados temas da política e da sociedade local, incluindo, naturalmente, padres, frades e jesuítas. O exemplo abaixo pode se prestar exatamente ao "frade ridículo":

\footnotetext{
Se o pândego Vicente quer que seja vinte por cento de café queimado, Ele que foi ministro e deputado E o bem da nossa pátria só fareja, terá suas razões...talvez esteja por probos comissários inspirado. E se o processo dá bom resultado
} 
por que não aplicá-lo até na Igreja?

Quando vinte por cento dos bojudos frades tomados entre os mais pançudos for bem torrado em colossal fogueira

o resto que ficar terá mais preço das consciências no mercado e apreço maior terá a pátria brasileira. ${ }^{122}$

Como se constata, os entreveros políticos tendo como pano de fundo a religião atingiam frades e clero diocesano, ocupando as páginas dos jornais com mútuas acusações. Dentre esses conflitos pode-se citar o que envolveu Monsenhor Miguel Martins e outras autoridades taubateanas, que resolveram dirigir críticas aos capuchinhos em virtude da má administração do cemitério do convento de Santa Clara, em funcionamento até nossos dias. Tomando conhecimento de sua expulsão da Ordem Terceira de São Francisco, pelas páginas d"O Norte', Monsenhor Martins ataca Frei Camillo:

Acabo de receber um ofício de um tal Frei Camillo, para mim ilustre desconhecido, em que chorando (com certeza lágrimas de crocodilo) me comunica que estou expulso de sua ordem terceira. Empregou a palavra expulso, porque ignora o manual da delicadeza, e não por crueldade, pois ele se confessava "ralado de dor". [...] Como homem honrado, como taubateano patriota, como sacerdote coerente com os meus deveres, eu sou o primeiro a me julgar inteira e completamente incompatível com essa ordem.

A seção "Engrossa", d'O Taubateano', assinada por um certo "Pandemônio", a ninguém poupava. Do presidente da república aos jogadores de roleta em Taubaté, tudo era assunto para pesadas críticas. Em junho de 1901, "Pandemônio" resolve investir sobre um tema bastante caro à imprensa taubateana, qual seja, os já tristemente famosos frades. Mas "Pandemônio", não se dando por satisfeito, "engrossa" também com os fiéis do convento de Santa Clara que, rezando em companhia dos frades, aprendem a ser hipócritas, pois

[...] as beatas passam a vida no convento em companhia dos santíssimos frades rezando e enganando a todos, deixando seus esposos e filhos sem almoço ou almoçando a deshoras [...] e falam continuamente da vida alheia, sabendo que o frade está sempre pronto a ouvi-las em confissão e absolvê-las.

Segundo "Pandemônio", isso não é catolicismo, mas sim uma religião 
denominada hipocrisia, e

[...] são hipócritas os próprios frades que em linguagem de bordel proferem asneiras aos seus parvos ouvintes chamandoos continuamente à igreja e falando mal dos maçons, protestantes e de todos aqueles que trabalham para viver honestamente e fazer progredir a pátria. São hipócritas esses falsificados representantes de Deus na terra que assassinam continuamente a bela língua de Camões e tornam-se cada vez mais pançudos à custa do povo. ${ }^{124}$

E se o assunto versa sobre padres, o momento é oportuno para uma "Engrossa" em um certo Padre Juca, que por ver-se objeto de outras críticas, resolveu devolver um exemplar d' $\mathrm{d}^{\prime} \mathrm{O}$ Taubateano' à redação do jornal. "Pandemônio", denominando o religioso de "ilustre cidadão que diz representar Cristo na terra", afirma que o mesmo merece ser engrossado "com todas as fibras de nossa alma", por intrometer-se em todos os lugares onde há moças honestas, não querendo compreender que sua impertinente atuação o fazia um intruso, "além de outros qualificativos que bem merece". Tido pelo articulista como teimoso, Padre Juca é aconselhado que "[...] continue no caminho encetado até encontrar alguém que Ihe vá às fuças, o que não custará muito, pelo que estamos informados."

E, usando de ironia, "Pandemônio" aproveita para aconselhar Padre Juca:

Ora, nós que somos padresca e fradescamente religiosos até o tutano dos ossos, que queremos ir para o céu, depois de mortos, bem entendido, ainda que seja a pau, não podemos de deixar de recomendar ao Padre Juca mais amor ao lombo, ainda que seja pelo seu amor em Cristo.

"Pandemônio" não pára por aí, e dizendo já estar "com a escova em punho", aproveita a ocasião para também engrossar um certo frade, que declarou na Semana Santa que as moças solteiras e as mulheres casadas não compareciam à igreja por apelo religioso, mas, sim, "[...] para terem entrevistas com os namorados e os amantes". Afirmando ser possível que o tal frade tenha dito uma verdade, o articulista diz também ser uma verdade que os frades são pornógrafos que fazem da tribuna um circo de cavalinhos, abusando da liberdade de serem burros.

Sendo assim, "Pandemônio" solicita a Monsenhor Nascimento Castro a chamar "[...] esses labregos ao caminho do dever e ensinasse-os a não serem malcriados empregando linguagem de bordel", ressaltando:

Como engrossadores de profissão que somos, aconselhamos aos ditos frades que não abusem, porque pode a porca sair-

124 O Taubateano, n. ${ }^{\circ}$ 63, II. 9 de junho de 1901. 
Ihes mal capada, e depois não se queixem sem razão do Pandemônio. ${ }^{125}$

É natural que os chistes e as provocações d'O Taubateano' tenham irritado o clero, particularmente o Padre Nascimento Castro. Este último, então, decide por enviar um "delicado cartão", nas palavras do jornal, informando aos redatores que, em 30 de junho, encerrado seu período de assinatura, não poderia mais continuá-la, e assim o fazia para evitar devolução. Mas se aos redatores pouco importa a devolução do jornal pelo Padre Juca, cabendo-Ihe tão somente uma "engrossa", tal já não é 'permitido' ao vigário de Taubaté. A resposta publicada n"'O Taubateano" fez com que Padre Castro, ao buscar lã, saísse tosquiado:

Sossegue, ilustre Reverendo. Nós, que temos jornal mais para apontar uns tantos males que revertem em prejuízo do povo que para fins especulativos, temos muita satisfação em remeter-Ihe gratuitamente "'O Taubateano"', pois temos certeza que o Reverendo será um dos muitos avezados leitores, embora às ocultas, desta folha que não é tão má! ${ }^{126}$

Especial interesse assume o "engrossamento" de 11 de agosto de 1901, tendo como alvo, naturalmente, Nascimento Castro, cuja persistência de uma época pretérita é clara na estrutura mental do sacerdote. Nascido em São Luiz do Paraitinga e pertencente a uma família de sobrenome tradicional na região, Nascimento Castro, por ocasião das comemorações ao Bom Jesus, profere um sermão cuja temática é a separação da Igreja e do Estado, merecendo assim, segundo o juízo do articulista, divertida ironia:

Assim pois os devotos do Tremembé devem estar muito satisfeitos com o senhor vigário que além do mais os mimoseou com um sermão de encher as medidas, uma verdadeira peça de literatura, na qual S.R., com a eloqüência habitual e a inspiração que lhe vem do céu profligou a separação da Igreja e do Estado, a secularização dos cemitérios, o casamento civil, o registro civil de óbitos e nascimentos e toda trapalhada de inovações que nos trouxe a república, que anda mal, porque divorciou-se de Deus. ${ }^{127}$

De fato, a Igreja livre dentro do Estado livre, perdendo aquilo que se poderia denominar de "reserva de mercado", buscava, a todo custo, em especial por meio da imprensa, manter em seu domínio o monopólio do sagrado. Sendo assim, tudo serve de motivo para a manutenção dos constantes atritos entre católicos e os 
protestantes, os espíritas e os maçons, em defesa dos pontos de vista defendidos por aqueles. 'A Verdade', por exemplo, em longo artigo, trata daquilo que seus articulistas entendem como "manifestações de heresia" dos protestantes.

Enumerando os ataques empregados pela "heresia", o jornal católico cita o ridículo atirado sobre as pessoas e as coisas eclesiásticas e de culto. As mulheres que freqüentam as igrejas e observam os preceitos religiosos são chamadas pela heresia de beatas; os homens, por sua parte, adquirem o qualificativo de carolas. A defesa d"A Verdade' assim se organiza:

Pouco importa a heresia que, entre as beatas apontadas, seja exposta ao ridículo que lhes atiram alguma pessoa da estima ou até da própria família do herege que tudo profliga. Esquecem-se de que chamando de beatas, longe de ridiculariza-las, elevam-nas até à santidade, porque os bemaventurados são os santos. (os grifos são deles)

'A Verdade' prossegue e diz que, não contentes com o ataque do ridículo, os hereges vão ao templo católico assistir às solenidades religiosas, fingindo, ao entrar, uma crença que não têm, mas verdadeiramente lá vão para profanar o templo, dando prova de que sua qualidade principal não é a da simples boa educação. Uns criticam os pregadores com insulsas pilhérias ditas entre dentes, com pretensões de posarem como espirituosos, "[...] enquanto outros exploram a fragilidade do belo sexo e a inexperiência da idade para fazerem com que ingênuas donzelas, supondo serem objeto de seu apreço sincero, tornem-se cúmplices do seu desacato a casa de Deus." Ignorando as especificidades do catolicismo no Brasil, onde as igrejas concentravam atividade social desde os tempos coloniais, 'A Verdade' aponta os "hereges" como únicos culpados do "namoro o mais desbragado" que campeia na igreja:

[...] e os hereges vão empolgando com carinha de bonecas de biscuit, as alminhas das crédulas mocinhas para o exército de Satanás. Bom é quando o escândalo não transcende as raias do simples namoro, e não chega a tornar-se em plena obscenidade, pela troca de palavras indecentes entre os moços, indo tais palavras profanar os ouvidos das cândidas donzelas.

Segundo o jornal, assim procedem esses "agentes da heresia", visando com isso dizer, depois, que a Igreja católica é um lugar de corrupção, ao passo que os templos protestantes são casas de oração em que reina o máximo respeito. E assim procuram atrair para lá a freqüência que Ihe falta. 
Para 'A Verdade', o respeito que se observa no templo protestante resulta, em primeiro lugar, da sua diminuta freqüência, a qual facilita a fiscalização do cumprimento, pelos circunstantes, do dever de respeito que lhes é imposto. A segunda causa da observância de seus deveres de disciplina é a necessidade que sente uma "seita", para impor-se, utilizar-se de exterioridades. Seja como for, a 'seita' pode ser comparada a um vírus:

Quando algum católico curioso vai ao templo protestante ou a outro qualquer, sabe ele portar-se na casa aludida, e assim não vai servir de elemento perturbador lá, como aliás os hereges de toda espécie fazem na igreja católica. Mas ainda desse escândalo, por eles promovido com o intuito de prejudicar o culto católico, resulta a prova da verdade da religião católica, apostólica, romana, que caminha sempre em progresso, a despeito de todo esse vírus com que ousam injetar seu organismo. ${ }^{128}$

A resposta não tarda, e 'O Taubateano' noticia que, em 2 de maio de 1903, ocorreu um incêndio na igreja do Santuário do Bom Jesus, na Bahia. O padre capelão e os fiéis tentaram penetrar na igreja, a fim de salvar as imagens, porém o fogo os impediu de realizar o intento. Uma mulher mais ousada, no entanto, conseguira tirar a imagem do Coração de Jesus do meio das chamas. Após o breve comentário, o articulista J. R. Carvalho afirma ter aí mais uma prova do que são as imagens que os católicos romanos adoram, pois seus adoradores crêem que elas, não só podem livrá-los de qualquer perigo, como até salvá-los do pecado. Dito isto, pergunta: "Pois se estas imagens não podem escapar do fogo, como é possível que elas tenham o poder de livrar os outros?", terminando por conclamar que não devemos ser como os pagãos idólatras que confiam em seus ídolos que nada valem. ${ }^{129}$

Religião e política em Taubaté, como se pode depreender, caminhavam ombro a ombro, operariado incluído. À Liga dos Operários Livres, de caráter leigo, contrapunha-se a Liga dos Operários Católicos, tendo esta, como patrono, São José. A primeira comemorava seu dia em $1^{\circ}$ de maio, enquanto a outra o fazia uma semana depois. Sabendo-se que o dia de São José, tradicionalmente, é 19 de março, a alteração da data, por parte do clero romanizado, visava minimizar, ou mesmo eliminar, o caráter político, máxime os de cunho socialista, em relação a 
comemoração. ${ }^{130}$

Para os operários livres as solenidades de 1904 se iniciaram às quatro da manhã, com a banda musical Lira Operária percorrendo as ruas da cidade. Em trajes dominicais, diretoria e sócios, juntamente com a banda, dirigiram-se para o Velódromo Taubateense, e às sete da noite, com pavilhões empunhados por "gentis senhoritas", os trabalhadores saem às ruas em passeata para saudar as autoridades. À noite, o baile. ${ }^{131}$ Conforme se verifica, a programação do Centro dos Operários Livres não incluiu evento religioso.

'A Verdade' lembra o já longínquo ano de 1855, quando terrível seca assolou a região, exterminando animais e plantações e trazendo o fantasma da fome. $\mathrm{Na}$ tentativa de empanar os aspectos profanos da festa, 'A Verdade' rememora a ocasião e afirma que a trasladação da imagem do Nosso Senhor Bom Jesus foi a causa de uma torrencial chuva, iniciada quando da chegada da imagem ao convento de Santa Clara.

Em 1904 o Senhor Bom Jesus não precisará ordenar chuvas, pois a questão agora é outra: agradecer pela extinção da febre amarela "[...] que ameaçou dizimar esta população e recorrer a Divina Misericórdia para que nos livre do calamitoso reaparecimento desse terrível morbus epidêmico." 132

A luta pelo monopólio do sagrado em Taubaté, vilas vizinhas, e região, principalmente contra o espiritismo e o protestantismo, vai se desenvolvendo em diversas frentes e de diversos modos. As Missões realizadas pelos padres redentoristas bávaros de Aparecida - que nos fornecem vasto material sobre o estado religioso da área -, as pregações dos padres e frades do clero taubateano, bem como a imprensa escrita, materializam formas de combate. A análise de Augustin Wernet em relação aos jornais católicos dos últimos quinze anos do Império encaixa-se perfeitamente às duas primeiras décadas republicanas em Taubaté. Seja pela própria distância de São Paulo, seja pela impossibilidade de distribuição de impressos por parte de uma diocese de vultosas extensões, até o surgimento d'OO Lábaro' os jornais católicos encontravam-se nas mãos de particulares.

130 Em 1870, o papa Pio IX proclamou São José "O Patrono da Igreja Universal" que, a partir de então, passou a ser cultuado no dia 19 de março. Em 1955, Pio XII. em franca tentativa de cristianizar a festa, fixou o dia $1^{\circ}$ de maio para "São José Operário, o trabalhador".

131 O Taubateano, n. ${ }^{\circ}$ 203, IV. 4 de maio de 1904.

132 A Verdade, n. ${ }^{\circ}$ 20, I. 13 de agosto de 1903. 
[...] circularam jornais católicos ultramontanos, dirigidos por leigos ou clérigos, que não se engajavam em nível políticopartidário. Tiveram por objetivo de abrir e ocupar em espaço, em nível cultural, para a divulgação e a defesa das idéias católicas. Estes jornais não tiveram uma dependência formal do governo da diocese. ${ }^{133}$

Em cumprimento desse alvitre surge, em 1904, o periódico "A Vila do Tremembé". De orientação católica ultramontana, se bem que menos contundente que 'A Verdade', seu surgimento foi vivamente saudado por esta:

Tivemos o prazer de receber o primeiro número de um jornal intitulado "A Vila do Tremembé", que se publica nesta localidade sob a regência do Sr. Inácio do Amaral Júnior. O seu escopo principal declarado em artigo de apresentação, traçado por mão de mestre, consiste em propagar a verdadeira devoção que afervore a crença de um povo, mantendo-se nos justos limites da ortodoxia pura, pela firmeza da fé nos ensinos da Igreja católica, depositária infalível das verdades reveladas. Ao nosso colega desejamos vida longa e perseverante em seus elevados e benéficos intuitos. ${ }^{134}$ (os grifos são nossos)

Monsenhor Miguel Martins da Silva, por sua vez, opera "prodígios de conversão", segundo o jornal católico 'O Norte'. Pregando nas paróquias onde é convidado e, segundo a notícia, já o tinha feito até aquele momento em oito delas, seu "trabalho insano" o fez merecedor de nada menos que um Breve papal ${ }^{135}$ publicado na íntegra pelo periódico - que concede aos que o ouvem indulgências bastante convidativas para uma região onde o calendário era medido pelas dezenas de festas:

[...] O Santo Padre, por seu turno, acaba de enviar a Monsenhor Miguel Martins um Breve Pontifício, em que concede duzentos dias de indulgências para assistência de cada uma de suas conferências, e indulgência plenária e a remissão de todos os pecados aos que assistem a metade do número de suas conferências realizadas em cada localidade e na última conferência receberem a benção papal, que deverá então ser dada pelo ilustre pregador. ${ }^{136}$

Se Taubaté e região, por um lado, já possuíam defensores do catolicismo ultramontano, por outro ainda mantinham práticas típicas do catolicismo luso-

133 WERNET, Augustin. A imprensa católica em São Paulo durante o segundo reinado, Revista Relações Humanas, n. ${ }^{\circ}$, São Bernardo do Campo: Instituto de Relações Sociais e Industriais (IRESI), 1986. p. 37.

134 A Verdade, n. ${ }^{\circ}$ 56, II. 21 de abril de 1904.

135 O "Breve" é um documento em que o Papa se manifesta sobre uma consulta ou pedido de caráter particular.

136 O Norte, n. ${ }^{\circ}$ 37, I. 5 de março de 1905. 
brasileiro, práticas essas que provocariam as devidas respostas da Igreja. O projeto nacional de romanização do catolicismo no Brasil passava, necessariamente, pela consecução de projetos regionais. Assim, a extensão territorial da diocese paulista impunha, nesse momento, sua fragmentação, e a conseqüente implantação de novas dioceses, devidamente governadas por bispos romanizadores.

\subsection{A implantação do catolicismo ultramontano no vale do Paraíba}

D. Epaminondas fez sua entrada em Taubaté em 21 de novembro de 1909. Seria, portanto, não só injusto, mas historicamente incompleto, desconsiderar-se o panorama da ação reformista legada pelos que o precederam, uma vez que a área da diocese, em toda a sua extensão geográfica, já havia passado por diversos processos romanizadores.

Por outro lado, seria pouco cauteloso também afirmarmos que, à chegada de D. Epaminondas, a mesma se encontrava totalmente romanizada. Na luta pela hegemonia religiosa no vale do Paraíba, ao ultramontanismo contrapunha-se, principalmente, o protestantismo e o espiritismo.

A dimensão do trabalho de D. Epaminondas, portanto, e em sua justa medida, foi o de, com melhores instrumentos que dispunham seus antecessores, tais como o jornal 'O Lábaro', a melhoria das vias de acesso e, principalmente, um clero de muito melhores condições, dar continuidade e fazer a manutenção das conquistas pretéritas.

Ao trabalho hercúleo realizado por D. Antônio Joaquim de Melo se une, por conseqüência, a ação romanizadora dos padres redentoristas, posto que,

Conquanto seu episcopado fosse breve, sendo apenas de nove anos, foi entretanto fecundíssimo em obras da mais elevada importância. Em tão curto espaço de tempo, ele percorreu quase toda esta vastíssima Diocese que então compreendia toda a Província de São Paulo e parte do Sul de Minas. Não somente ele administrava em suas visitas o sacramento da crisma, como pregava constantemente e dava importantes e enérgicos provimentos para reorganização do serviço paroquial. ${ }^{137}$

Isto feito, é lícito afirmar o abandono da região antes da chegada de D. Antônio Joaquim:

D. Mateus de Abreu Pereira foi o último bispo que visitou parte de sua diocese: o litoral sul e algumas vilas no interior de São

137 POLYANTHEA. Comemoração do cinqüentenário de fundação do Seminário Episcopal de São Paulo: 9 de novembro de 1856 a 9 de novembro de 1906, s.d. 
Paulo. Foi em 1798. A partir daí D. Mateus e, sobretudo, o seu sucessor, D. Manuel Joaquim Gonçalves de Andrade, apenas enviaram visitadores. Havia até padres que nunca tinham visto um bispo. ${ }^{138}$

Em pensamento diametralmente oposto a seus antecessores, D. Antônio Joaquim, em sua primeira Carta Pastoral, já lembrava que "iremos visitar-vos, levando o nosso amor e o nosso cuidado até a última aldeia do bispado", e o quase meio de século de ausência por parte da autoridade episcopal não passa despercebido ao antístite: "Farei em cinco anos o que não se fez em cinqüenta".

O bispo não blefava, visto que "em grande parte cumpriu sua promessa, pois nos nove anos do exercício efetivo do seu bispado, em mais de 45 meses dedicouse às visitas pastorais." 139

Nessas visitas pastorais consagrou-se uma prática, ou quase rotina de procedimento: fazia-se um levantamento geral da paróquia e, paralelamente, havia exortações, instrução e confissões. Em seguida, D. Antônio Joaquim administrava o sacramento do crisma e, se fosse necessário, procedia à "parte correcional do clero". Em cada paróquia organizava-se uma comissão para a arrecadação de fundos para a construção do Seminário Episcopal. O levantamento da paróquia incluía muitos itens: estado material das igrejas; limpeza e decência na decoração e conservação do Santíssimo Sacramento e do Batistério; exame dos livros de receita e despesa das diversas irmandades; exame de todos os livros paroquiais, inclusive dos que deviam registrar as Cartas Pastorais, especialmente as que se referiam aos emolumentos e à observância do Regulamento do Clero. Muitas vezes encontram-se anotações sobre o lamentável estado material das igrejas, fato este que também consta nos Relatórios dos Presidentes da Província...

Uma vez prometido, cumprido. O Seminário Episcopal, no entanto, sempre seria a "menina dos seus olhos".

...Com o intuito de moralizar o clero e revitalizar a fé da população, o bispo realizou um amplo plano de visitas pastorais. $\mathrm{Na}$ orientação religiosa do povo promoveu-se um afastamento do catolicismo luso-brasileiro tradicional, de caráter familiar, social e leigo, afirmando um catolicismo fiel ao papa, de tendência conservadora e com forte conotação moralizadora. ${ }^{140}$

138 WERNET, Augustin. A Igreja paulista no século XIX. São Paulo: Ática, 1987. p. 118. Para um estudo mais aprofundado sobre o período que antecedeu o bispado de D. Antônio Joaquim de Melo, encaminho o leitor a WERNET, Augustin. Vida religiosa em São Paulo (1554-1954), In: PORTA, Paula (org.) História da cidade de São Paulo, v.1: A cidade colonial. São Paulo: Paz e Terra, 2004. Sobre D. Mateus de Abreu Pereira ver a página 211.

139 WERNET, Augustin. A Igreja paulista no século XIX. São Paulo: Ática, 1987. p. 119.

140 WERNET, Augustin. Vida religiosa em São Paulo (1554-1954), In: PORTA, Paula (org.) História da cidade de São Paulo, v.1: A cidade colonial. São Paulo: Paz e Terra, 2004. p. 218. 
Depois de um ano completo de nossa residência na capital da diocese é que podemos, meus amados irmãos, dar começo à nossa promessa de visitar-vos. Não temos, é verdade, gasto o tempo inutilmente: era preciso que aplicássemos todos os meios para a criação de um seminário, para nós a primeira pedra do alicerce de nosso melhoramento moral na diocese. Isto fizemos, está começado. ${ }^{141}$

Em 20 de setembro de 1853, a visita pastoral do bispo de São Paulo tem início em Moji das Cruzes (20 a 29/09/1853), prosseguindo para as vilas de São José do Paraitinga (10/10/1853 a 6/10/1853) e de Santo Antônio de Paraibuna (10/10/1853 - ?). De Paraibuna, D. Antônio Joaquim, descendo a Serra do Mar, visita Caraguatatuba (25/10/1853 a 31/10/1853), São Sebastião (10/11/1853 a 15/11/1853), Vila Bela (16/11/1853 a 23/11/1853) e Ubatuba (29/11/1853 a 12/12/1853), sendo que em São Sebastião "começou a parte correcional, porque encontrou fatos contrários ao seu Regulamento do Clero".

A este propósito, ressalte-se, bem sabia o bispo os males que afetavam seu clero, como, por exemplo, a prática do comércio:

Comprar e vender com o fim de tirar lucro também nos é proibido. O ganho, que por este modo adquirir o sacerdote, o rebaixa, o leva a ações indecorosas, o faz perder a estima, porque sua vocação é outra. Admoestamos pois, que se alguém se dá a sórdidos ganhos, abandonem este comércio. ${ }^{142}$

Do litoral norte, seguiu D. Antônio Joaquim para Bairro Alto (19/12/1853 a 22/12/1853), dirigindo-se em seguida para São Luiz do Paraitinga (24/12/1853 a 16/01/1854), onde "preparou quatro diáconos para a ordenação sacerdotal que se deu no dia 16 de janeiro de 1854. No mesmo dia estes receberam também o uso de ordens". De 25 de janeiro a 6 de fevereiro de 1854 D. Antônio Joaquim permaneceu em Cunha, prosseguindo a visita pastoral pelas vilas de Bananal (07/02/1854 - ?), São José do Barreiro (17/03/1854 a 30/03/1854) e Lorena (31/03/1854 a 25/04/1854), onde celebrou as solenidades da Semana Santa, juntamente com muitos padres das vilas vizinhas que para lá se deslocaram. A visita pastoral prosseguiu, agora pelas vilas de Silveiras (26/04/1854 - ?), Areias (12/05/1854 - ?), Queluz (27/05/1854 - ?), Pinheiros (05/06/1854 a ?), Embaú ( ? - ?) e Guaratinguetá

141 Carta Pastoral em que o Ex. ${ }^{\text {mo }}$ Bispo avisa a seus diocesanos de sua primeira e próxima visita. 19 de agosto de 1853. Suplementos de Tombos da Paróquia da cidade Taubaté (1853-1881)

142 Carta Pastoral pela qual V. Ex. ${ }^{a}$ Rev.ma há por bem dar um Regulamento ao clero de sua diocese. 22 de agosto de 1852. Suplementos de Tombos da Paróquia da cidade de Taubaté (18531881). 
(23/06/1854 a 17/07/1854).

Ao longo dessa trajetória, entretanto, é natural que por vezes o bispo se indispusesse com os detratores da obra ultramontana, pois, no dizer de Wernet, "vinham à tona as 'paixões carnais e políticas," como, por exemplo, em São Sebastião, Cunha, Aparecida, Lorena e Pinheiros, onde padres se mantinham em concubinato, envolvidos em política, ou mesmo rezavam missa muito depressa. ${ }^{143}$

Visitando as capelas do Rosário, de São Gonçalo e de Nossa Senhora de Aparecida, entrou numa série de atritos com os mesários e o vigário de Aparecida, padre Antônio Luís dos Reis França, deputado provincial, um dos líderes mais ferrenhos da oposição à pessoa e à obra reformadora de D. Antônio Joaquim de Melo. Também em Pindamonhangaba (19/07/1854 a 16/08/1854) repetiu-se a cena. O motivo foi outra pessoa destacada na campanha contra o bispo diocesano: o padre Francisco de Paula Toledo, deputado provincial, destacado político desde o período regencial.

Não bastando alguns padres possuírem filhos, parecia ser comum trabalharem juntos nas mais diversas atividades eclesiásticas. Tais situações, no entanto, não passaram despercebidas por D. Antônio Joaquim de Melo:

Tanto tem havido o esquecimento de nossos deveres, tanto de desprezo as leis da Igreja, que muitos de nossos irmãos sacerdotes não se pejam de servir-se de seus filhos ilegítimos em atos religiosos e pertencentes a Igreja, fato este demasiadamente reprovado e reprovável. Portanto ordenamos que em ato algum religioso possa o filho estar com seu pai, servindo-o; não possa ser seu escrivão; cantar como músico onde o pai oficia; ser seu sacristão; se ambos são presbíteros, havendo só uma igreja um não poderá dizer missa estando o outro dentro da mesma; não poderão juntos acompanhar enterros e procissões. Se algum contrariar a este mandamento, se nos dará parte para ser punido. ${ }^{144}$ (os grifos são nossos)

Em seguida, Taubaté (17/08/1854 - ?), Caçapava (18/09/1854 - ?), Santa Branca (03/10/1854 - ?) e Jacareí (10/10/1854 - ?), segundo Wernet, "sem incidentes importantes", quando então, a 29 de outubro de 1854, oficiou o cabido, comunicando seu retorno. O resultado?

Voltando da sua primeira visita, viu os resultados iniciais da sua tentativa, já que ficou sabendo do pleno apoio do papa Pio IX e percebeu a confiança dos capuchinhos recém-chegados da

143 WERNET, Augustin. A Igreja paulista no século XIX. São Paulo: Ática, 1987. p. 136-138, com especial atenção às notas de rodapé 117 a 125.

144 Carta Pastoral pela qual V. Ex. ${ }^{\mathrm{a}}$ Rev $^{\mathrm{ma}}$ há por bem dar a segunda e última parte do Regulamento ao clero da diocese na forma acima declarada. 22 de agosto de 1852. Suplementos de Tombos da Paróquia da cidade Taubaté (1853-1881) 
Europa em sua pessoa.

Em 15 abril de 1855, parte D. Antônio Joaquim de Melo para a sua segunda visita pastoral, desta vez em regiões pertencentes à Província de Minas Gerais, visita essa que se estenderia até fevereiro de 1856, quando então, retornando a São Paulo, um mês após se deslocou para Campinas em "pequena visita pastoral". Sua maior obra, o Seminário Episcopal de São Paulo, centro irradiador da reforma ultramontana, seria inaugurado em 9 de novembro, "de grande satisfação pessoal e de esperança de um futuro melhor para a diocese de São Paulo".

Mas o bispo não se acomodou em sua ação reformadora, e já em 23 de janeiro de 1857 uma outra "pequena viagem apostólica" o conduziria a vilas próximas de São Paulo, como Bragança Paulista e Santa Rita da Extrema, retornando em meados do mês de abril. De Itu, sua terra natal, anunciou em 5 de julho sua terceira visita pastoral, novamente em vilas localizadas quase que exclusivamente na Província de Minas Gerais, com duração de aproximadamente dez meses, "destacando-se o seu encontro, no dia 15 de outubro de 1857, com D. Antônio Ferreira Viçoso em São Gonçalo da Campanha".

Encerrada a visita em 5 de setembro de 1858, em Itu, D. Antônio, finalmente, ali permaneceu em descanso por três meses.

Entre março e abril de 1859 outra pequena visita, desta vez a Santo Amaro, Itapecerica da Serra, Cotia, São Roque, Una, Sorocaba, Cabreúva, Araçariguama e Parnaíba, "incluindo, obviamente, uma rápida passagem por Itu". A 24 de abril de 1859 anunciou sua quarta visita pastoral, e, também, uma importante ação romanizadora, disciplinadora e padronizadora:

Ainda em Itu, no dia 20 de julho de 1859, anunciou a publicação de seu catecismo, que devia ser adotado obrigatoriamente em todas as vilas, freguesias e cidades da diocese, em substituição dos muitos catecismos em uso, sendo a maioria deles de orientação regalista e jansenista.

Publicado o catecismo, a quarta visita pastoral de D. Antônio Joaquim de Melo o levou à região oeste da Província de São Paulo. Mesmo adoentado antes do início dessa visita, percorreu diversas vilas e cidades, chegando mesmo a Ribeirão Preto, entre a segunda metade de 1859 e início de 1860.

Ao longo de 1860, sentindo faltar-Ihe as forças, passou acamado ao longo do ano. Segundo Augustin Wernet, foi nesse período que escreveu sua última Carta Pastoral, e "nela, diferentemente das outras, deixou de lado considerações sobre a 
calamitosa situação religiosa da diocese de São Paulo", reportando-se mais aos acontecimentos por que passava a Igreja católica na Itália. Falecido em 16 de fevereiro de 1861, o principal legado de D. Antônio Joaquim de Melo, o Seminário Episcopal de São Paulo, daria, ao longo do tempo, os frutos que necessitava o catolicismo ultramontano na região. ${ }^{145}$

O sucessor de D. Antônio Joaquim de Melo, paladino do ultramontanismo, foi D. Sebastião Pinto do Rego (1763 - 1868). Formado no Seminário São José, no Rio de Janeiro, aí recebeu uma formação de cunho pombalino e regalista, formação essa que provocaria solução de continuidade às metas ultramontanas. A exegese de Wernet:

Dom Antônio Joaquim de Melo foi o bispo reformador que iniciou a suplantação do "catolicismo iluminista" pelo "ultramontano". Portanto, a sua atuação é de importância fundamental. A sua obra reformadora sofreu um certo revés no período do seu sucessor, Dom Sebastião Pinto do Rego (18631868) que, no seu procedimento e nas suas atitudes, mostrou claramente a sua afinidade para com o "catolicismo iluminista". A reforma do clero e a orientação ultramontana não foram encaradas pelo prelado como necessidades primordiais. ${ }^{146}$

Trazer de volta seus padres aos compromissos romanizadores e ao alinhamento com a Santa Sé foi a difícil tarefa do próximo bispo, D. Lino Deodato Rodrigues de Carvalho (1871-1894).

Após cinco anos de vacância, precisamente em 26 de junho de 1873, D. Lino Deodato fez sua entrada solene na diocese de São Paulo. Sua nomeação "significava uma retomada ao veio romanizador e uma perspectiva de consolidação do catolicismo ultramontano". ${ }^{147}$ Aguardava-o, entretanto, uma série de desafios e dissonâncias, uma vez que

quer no âmbito da própria diocese com a influência do grupo de padres regalistas e pombalinos que na cúpula administrativa faziam oposições e resistiam às reformas eclesiais, quer na tessitura civil, leiga, onde o avanço crescente de cultos acatólicos e a exacerbação das doutrinas filosóficas contrárias aos princípios ultramontanos constituíam-se numa ameaça em diferentes faces de oposição aos seus desejos. Compreendeu D. Lino que diferentes "dragões da maldade" então o

145 WERNET, Augustin. A Igreja paulista no século XIX. São Paulo: Ática, 1987. pp. 118-133.

146 WERNET, Augustin. Os bispos de São Paulo durante o segundo reinado e a romanização da igreja paulista, Revista Relações Humanas, n. ${ }^{\circ}$ 8, São Bernardo do Campo: Instituto de Relações Sociais e Industriais (IRESI), 1987. pp. 54-55.

147 GAETA, Maria Aparecida Junqueira Veiga. Os percursos do ultramontanismo em São Paulo no episcopado de D. Lino Deodato Rodrigues de Carvalho (1873-1894), 1992. Tese (Doutorado em História Social) - Universidade de São Paulo, São Paulo, 1992. pp. 78-79. 
aguardavam, quer na esfera privada de sua diocese entre o clero e seus paroquianos, quer na âmbito do espaço público, local onde as diferentes religiões ameaçavam penetrar na Província, bem como, a aceitação das doutrinas modernas tais como o liberalismo, o socialismo, o anarquismo e a maçonaria. ${ }^{148}$

Não obstante esses percalços, D. Lino Deodato prosseguiu o processo de reforma já encetado por D. Antônio Joaquim de Melo, fundando o jornal católico "Pátria" e patrocinando "O Monithor Católico". Sua ação pastoral também se fez sentir, e segundo Gaeta, "logo que chegou à diocese D. Lino saiu em visita à região de Campinas e ao vale do Paraíba", bem como São João da boa Vista, Moji Mirim, Atibaia, Poços de Caldas, Batatais, Jaboticabal e Pirassununga, entre outras localidades. ${ }^{149}$

Em seu governo ocorreu a substituição dos padres capuchinhos de Sabóia pelo clero secular paulista na direção do Seminário Episcopal de São Paulo (1877), bem como "inaugurou a igreja de Nossa Senhora Aparecida como santuário episcopal e para lá se retirou ao adoecer", 150 tema que será abordado com maiores detalhes.

Autor de vinte e uma cartas pastorais ${ }^{151}$ versando sobre os mais diversos temas caros ao ultramontanismo, D. Lino Deodato foi sucedido por D. Joaquim Arcoverde de Albuquerque Cavalcanti, nomeado coadjutor da diocese de São Paulo em 1893. D. Joaquim Arcoverde, "apesar de ficar poucos anos à frente da Diocese, visitou quase todas as paróquias e promoveu a fundação de associações católicas para leigos". 152

Ressalte-se, ainda, que o esforço pela vinda dos religiosos redentoristas para Aparecida foi fruto da ação direta de Dom Joaquim Arcoverde de Albuquerque

148 GAETA, Maria Aparecida Junqueira Veiga. Os percursos do ultramontanismo em São Paulo no episcopado de D. Lino Deodato Rodrigues de Carvalho (1873-1894), 1992. Tese (Doutorado em História Social) - Universidade de São Paulo, São Paulo, 1992. p. 120.

149 GAETA, Maria Aparecida Junqueira Veiga. Os percursos do ultramontanismo em São Paulo no episcopado de D. Lino Deodato Rodrigues de Carvalho (1873-1894), 1992. Tese (Doutorado em História Social) - Universidade de São Paulo, São Paulo, 1992. p. 124, passim. Note-se que a substituição dos padres capuchinhos pelo clero regular deu-se por expresso desejo testamentário de D. Antônio Joaquim de Melo.

150 WERNET, Augustin. Vida religiosa em São Paulo (1554-1954), In: PORTA, Paula (org.) História da cidade de São Paulo, v.1: A cidade colonial. São Paulo: Paz e Terra, 2004. p. 219.

151 Sobre a temática das cartas pastorais de D. Lino Deodato ver SOUZA, Ney de (org.). Catolicismo em São Paulo: 450 anos de presença da Igreja católica em São Paulo (1554-2004). São Paulo: Paulinas, 2004. p. 349-351.

152 WERNET, Augustin. Vida religiosa em São Paulo (1554-1954), In: PORTA, Paula (org.) História da cidade de São Paulo, v.1: A cidade colonial. São Paulo: Paz e Terra, 2004. p. 219. 
Cavalcanti, bispo de São Paulo entre 1894 e 1897, tendo em vista que:

[...] uma das tarefas confiadas a Dom Arcoverde foi articular pessoalmente em países da Europa a vinda para o Brasil de congregações religiosas para atuar nas Missões e no ensino: lazaristas, redentoristas e premonstratenses. ${ }^{153}$

Materializa-se, com isso, não só o projeto ultramontano, em linhas gerais, mas também a própria implantação e fortalecimento do ultramontanismo, em caráter regional, com as Missões redentoristas em todo o vale do Paraíba.

Sendo assim, o que são as Missões populares? Baseadas na visita de um missionário a uma determinada comunidade, "foi a fórmula que provou ser a mais realista e a mais adaptada às condições concretas da evangelização do Brasil", ${ }^{154}$ tendo sido empregadas, em nosso país, por Jesuítas, Capuchinhos, Salesianos e Dominicanos. Sobre os epígonos de São Domingos , Azzi e Beozzo afirmam que "as missões populares ou 'santas missões' constituíram sem dúvida a atividade principal dos dominicanos". 155

Os discípulos de Santo Inácio, por seu turno, já realizavam Missões em solo brasileiro nos séculos XVII e XVIII. sendo que, entre 1748 e 1749, "pregaram Missões no vale do Paraíba, especialmente no Santuário da Senhora da Conceição Aparecida". 156

No caso particular dos Redentoristas, a estrutura básica das Missões foram elaboradas por Santo Afonso de Ligório, fundador da Congregação do Santíssimo Redentor. Visando em primeiro momento a evangelização dos camponeses do Sul da Itália, ao longo do tempo tornaram-se procedimento universal. Em nosso entender, a Missão popular se configurava, no caso brasileiro, à época, como solução bastante prática, talvez a única para aquele momento, visando minorar a insuficiência de clero na vasta abrangência territorial das dioceses.

Poderíamos defini-las como uma forma de "imersão espiritual" em uma dada localidade, onde o tempo profano e as ações da vida cotidiana seriam substituídos por um tempo sagrado. Reflexões sobre a salvação, preces, pregações, comunhões, procissões, regularização de casamentos e de batismos, seriam o escopo do povo

153 SOUZA, Ney de (org.). Catolicismo em São Paulo: 450 anos de presença da Igreja católica em São Paulo (1554-2004). São Paulo: Paulinas, 2004. p. 407.

154 BRUSTOLONI, João Júlio e GOMES, J. Pereira. História da Província Redentorista de São Paulo - 1894 a 1964. Aparecida. Inédito, 1991. p. 208.

155 AZZI, Riolando et BEOZZO, José Oscar (organizadores). Os religiosos no Brasil: enfoques históricos. São Paulo: Paulinas, 1986. p. 19.

156 BRUSTOLONI, João Júlio e GOMES, J. Pereira. História da Província Redentorista de São Paulo - 1894 a 1964. Aparecida. Inédito, 1991. p. 208. 
ao longo dos dias.

As Missões populares redentoristas, portanto, se prestavam a uma dupla finalidade: em primeiro lugar instrumentalizavam plenamente o projeto regional de romanização, dirigido pela elite eclesiástica, materializando a "ação de presença" de um catolicismo romanizado que buscava evitar, ou mesmo combater, particularmente, a ação do protestantismo e do espiritismo. Em segundo, imbricada à primeira, configurava-se em momento propício para os missionários despertarem no povo a religiosidade católica reformada, reconduzindo sua piedade popular à imagética de Nossa Senhora, "purificando-a" do catolicismo luso-brasileiro. Temas, portanto, como o juízo final, os pecados mortais, o inferno e o casamento eram fortemente abordados nos sermões, segundo técnica e método dos quais os redentoristas são especialistas.

Nesse escopo, de 4 a 17 de outubro de 1897, ocorreu uma missão redentorista em Areias:

No começo do mês de outubro, o P. Siebler e eu fomos a Areias para pregar uma missão. Estava tudo bem preparado pelo Vigário, um sacerdote italiano, auxiliado por zelosas senhoras, entra as quais Dona Teresa Leme, cunhada do nosso Tesoureiro; ela é considerada o "factótum" na vida paroquial $[\ldots]^{157}$

Em janeiro de 1898, por quinze dias, foi a vez de Silveiras, com 15.000 habitantes, tendo como resultado 2.000 comunhões e 113 casamentos legitimados, sendo feitos, nas próprias palavras dos redentoristas, "40 numa rodada só". vigário era, no conceito dos missionários, "um zeloso padre italiano", e a igreja não comportava o povo, sendo feitas as pregações ao ar livre. ${ }^{158}$

Em São Luiz do Paraitinga e Lagoinha os padres de Santo Afonso se demoraram entre fevereiro e março de 1898. São Luiz do Paraitinga, à época com 14.000 habitantes, e Lagoinha, com 5.000, distavam, a cavalo, respectivamente 14 e 8 horas. O Padre Riedl, por sua vez, deve ter reclamado dos desconfortos. O cronista, por dever de ofício, registrou:

Nessas Missões o P. Riedl mostrou que não suporta as peripécias das Missões aqui, pois não se habitua a montar, aos alimentos, sofre na saúde pelas noitadas de insônia. Suportou tudo com paciência. ${ }^{159}$

157 ACPSR. Crônica das Missões da Casa de Aparecida (1897-1954), Volume único. p. 5. 158 ACPSR. Crônica das Missões da Casa de Aparecida (1897-1954), Volume único. p. 16. 159 ACPSR. Crônica das Missões da Casa de Aparecida (1897-1954), Volume único. p. 17. 
De 21 de junho a 5 de julho, a missão ocorreu na Paróquia de Bairro Alto, município de São Luiz do Paraitinga, pregada pelo Padre Miguel Siebler. A atuação anterior dos redentoristas na área, bem como seu bom relacionamento com a quase totalidade do clero paroquial, se confirma pelo fato de que, em relação ao Padre Miguel Siebler, "por certas razões o vigário só queria a ele". O extenso relatório dessa visita é elucidativo em relação aos sucessos do processo romanizador já em curso, posto que, de passagem por São Luiz do Paraitinga em 17 de junho, Padre Miguel Siebler pregou cinco vezes na mesma tarde do dia da chegada, bem como nos dois dias seguintes. O redentorista se reporta à celebração da festa do Coração de Jesus e no dia 19 o encerramento do mês de Maria, com missa cantada e procissão de cada vez, informando também estar a igreja sempre cheia de gente. Em 20 de junho, "após ouvir confissões até 10 horas", Padre Miguel viajou com o vigário de Bairro Alto, Padre João Calisto Gorgerini, "um italiano de 60 anos". O percurso de 7 léguas ${ }^{160}$ foi vencido ao longo do dia, e o missionário recebido em Bairro Alto com foguetes, dirigindo-se à casa paroquial, "semelhante a um limpo presbitério tirolês". Não é de pouco interesse a prática redentorista em marcar as Missões com a presença da imagética de Nossa Senhora Aparecida para um povo que, se já bastante afastado dos sacramentos, o que se dirá das práticas católicas romanizadas.

Bem antes da chegada de D. Epaminondas, portanto, a imagem de Nossa Senhora Aparecida já era sobejamente conhecida por todos os habitantes do Vale do Paraíba, conduzida por mãos redentoristas que não vacilavam em embrenhar-se no mais recônditos lugarejos,:

No dia seguinte, às 4 horas da tarde, foi a entrada solene do missionário na igreja com dois quadros: de Nossa Senhora Aparecida e do Crucificado. Os quadros forma amarrados (levados) em vara de bambu e enfeitados de fitas. Nossa Senhora, levada por uma moça vestida de branco e a cruz e dois coroinhas com velas abriam a procissão. ${ }^{161}$

De 5 a 20 de julho de 1898, a missão de Padre Siebler foi em Vila Natividade, atual Natividade da Serra, distante 57 quilômetros de Taubaté, onde "a boa gente tinha levantado arcos de triunfo na estrada e ao passar o missionário, soltava foguetes." Os trabalhos de Padre Siebler, conforme o relato, se estendiam das 6:00 às 23:30h. Confissões e legitimações de casamentos eram a tônica, e a 
afluência de gente na igreja e no confessionário era tão grande que "o sacristão e o subdelegado deviam estar sempre presentes, para conservar a ordem"; muitos tiveram que esperar até 5 dias para poder confessar, enquanto outros ficaram em jejum até a tarde para poderem comungar. O protestantismo, alvo de ferrenhos combates por parte de todo o clero católico, já dava seus sinais de presença aqui e ali.

\footnotetext{
Mesmo uma família protestante moradora do lugar, não se privou de ouvir o missionário. O pai dessa família descrente procurou um lugar escondido na igreja, do qual ele pudesse ouvir o missionário sem ser por ele visto. ${ }^{162}$
}

A presença missionária redentorista em São Sebastião, Vila Bela (atual Ilha Bela), São Francisco Xavier, Caraguatatuba e Ubatuba se dá em setembro de 1898, onde os Padres Siebler e Hubbauer partiram a pregar por dois meses. A situação religiosa, no entanto, era desalentadora, máxime pela carência de clero:

Maior seria o resultado, se mais fossem os missionários. Só havia dois padres em toda a extensão das 5 paróquias e esses mesmos italianos de mais de 60 anos e falando mal a língua, meio esclerosados e surdos. Explica-se a ignorância dessas populações de mais de 40.000 habitantes. Compreende-se também a dor dos bons. ${ }^{163}$

Em 1899 foi a vez de Potim, Roseira e Cordeiro, entre 15 e 18 de fevereiro, enquanto que Cachoeira, atual Cachoeira Paulista, e Cruzeiro, foram missionadas entre 11 e 26 de novembro, onde o Cônego Vigário Geral, Dr. Vicente, havia feito uma prática, convidando e recomendando a todos a missão e os missionários. 0 trabalho certamente não foi pouco, pois ficaram os padres no confessionário de 5 às 10 horas da manhã e de 5 às 10 horas da noite. ${ }^{164}$

Lagoinha, distante 22 quilômetros de Taubaté, é visitada pela segunda vez em 1900, tendo com resultado dos trabalhos realizados de 12 a 19 de novembro, 800 comunhões e 1600 crismas. São Bento do Sapucaí, por sua vez, foi missionado entre 25 de novembro e 6 de dezembro, enquanto que Santo Antônio do Pinhal, onde "os prisioneiros também se confessaram e comungaram com piedade e devoção", recebeu os afonsinos em data ignorada, assim como Piquete. ${ }^{165}$

São Luiz do Paraitinga voltou a ser missionado entre 15 e 25 de março de

162 ACPSR. Crônica das Missões da Casa de Aparecida (1897-1954), Volume único. p. 13. 163 ACPSR. Crônica das Missões da Casa de Aparecida (1897-1954), Volume único. p. 18. 164 ACPSR. Crônica das Missões da Casa de Aparecida (1897-1954), Volume único. p. 21. 165 ACPSR. Crônica das Missões da Casa de Aparecida (1897-1954), Volume único. p. 22. 
1901, bem como Pilões e Bairro de Lemos, capelas da paróquia de Guaratinguetá. Em Lorena, o povo é tido como "zeloso e piedoso".

Atendido que foi São José dos Campos, bem como Aparecida, entre junho e julho de 1901, esta última tendo como missionários os redentoristas holandeses, a nova missão a Bairro Alto contraria os redentoristas, em face dos avanços feitos pelo protestantismo e pelos "barulhos e distrações", tão típicos do catolicismo lusobrasileiro, pois:

uma parte do povo mostrou grande zelo, mas também trabalhou o inimigo de todo o bem [...] Também prejudicou a missão a realização da festa do Divino no final, com todas as distrações e barulheira correspondente" 166

De 1 a 13 de outubro de 1901 durou a nova missão em Natividade da Serra, e se o povo da vizinhança tomou parte ativa na missão, as contrariedades também se revelam, uma vez que "na vila mesmo, reina muita indiferença na fé, pois lá entrou o protestantismo". ${ }^{167}$

Renovadas as Missões em Cachoeira Paulista e em Redenção da Serra, onde o "zeloso e experiente vigário Francisco Filippo havia organizado tudo do melhor modo", de 20 de dezembro de 1901 a 5 de janeiro de 1902 a missão foi em Bananal, onde "ingenuamente, disse um homem da roça: 'Esses padres têm uma coisa de feiticeiro que atrai a gente' " 168

Em Cunha, onde a presença redentorista se fez a partir de 21 de março de 1902, as Missões "quase fracassaram porque o velho vigário fez tanto como nada para preparar o povo e avisar a missão". 169 Retornando em 1906, as crônicas redentoristas esclarecem um pouco mais sobre o perfil do "velho vigário":

[...] A cidade não dá muita esperança duma fundamental renovação religiosa, pois o vigário é não somente muito negligente no cumprimento dos seus deveres sacerdotais como também dá o pior dos exemplos, pois vive amasiado e tem uma porção de filhos...

As observações sobre o estado moral da cidade prosseguem, e vê-se que, todavia, a lógica do povo é implacável:

...As pessoas de responsabilidade do lugar vivem igualmente em concubinato ou mantêm relações escandalosas. Quando o Padre Hahn insistiu com um deles para se casar, respondeu

166 ACPSR. Crônica das Missões da Casa de Aparecida (1897-1954), Volume único. p. 25. 167 ACPSR. Crônica das Missões da Casa de Aparecida (1897-1954), Volume único. p. 26. 168 ACPSR. Crônica das Missões da Casa de Aparecida (1897-1954), Volume único. p. 28. 169 ACPSR. Crônica das Missões da Casa de Aparecida (1897-1954), Volume único. p. 30. 
que primeiro o vigário deveria fazê-lo...

Por fim, a conclusão do relatório: “...Não se admira, pois, que em tais circunstâncias os protestantes penetrem cada vez mais, e já são mais de mil ". ${ }^{170}$

Prosseguem as Missões no decorrer de 1902 pelo Vale do Paraíba: Campos Novos de Cunha, onde "a comoção e o entusiasmo do povo foi grande nas comunhões gerais e na procissão final", Paiolinho e Cordeiro, capelas próximas a Guaratinguetá, e novamente em Areias e em Redenção da Serra. ${ }^{171}$

A região de Pindamonhangaba é completamente esquadrinhada: Moreira César, onde "os padres de Aparecida já tinham ido lá, muitas vezes, para atendimento do povo", Vargem Grande, Piedade, Fazenda do Dr. Machado, Piracuama, Bom Sucesso e Santa Rita do Mossain. ${ }^{172}$ Note-se, portanto, que os redentoristas não se limitavam, tão somente, aos aglomerados urbanos, penetrando também em áreas internadas, que denominavam de "roças".

Em Queluz, visitada entre 8 e 21 de novembro de 1902, "sentiu-se de novo, nesta missão, o poder da divina graça. Lá ninguém se lembrava de uma missão que tivesse havido." O apelo à imagética de Nossa Senhora Aparecida, naturalmente, também não faltou:

O que atraiu de modo extraordinário o povo foi uma imagem de Nossa Senhora Aparecida que levamos conosco e que expusemos à veneração do povo. Diante dela rezavam os fiéis sem cessar e mantinham guarda continuamente. ${ }^{173}$

Redenção da Serra foi missionada entre 16 e 26 de março de 1906, e "a concorrência de povo era grande, de modo que dois missionários não podiam vencer os trabalhos, embora trabalhassem muito." O reforço à imagética de Nossa Senhora Aparecida também não faltou naquela vila:

Muito tocante era a cerimônia da recepção de Nossa Senhora Aparecida e a despedida da mesma. Ficou lá um quadro de Nossa Senhora Aparecida como lembrança das sagradas Missões. ${ }^{174}$

Santa Ana do Paraitinga, bairro de Cunha, é missionada de 13 a 16 de maio de 1906, e Santa Ana dos Pilões, em Guaratinguetá, de 19 a 22 de maio. Natividade

170 ACPSR. Crônica das Missões da Casa de Aparecida (1897-1954), Volume único. p. 305. Suplemento.

171 ACPSR. Crônica das Missões da Casa de Aparecida (1897-1954), Volume único. p. 31.

172 ACPSR. Crônica das Missões da Casa de Aparecida (1897-1954), Volume único. p. 32.

173 ACPSR. Crônica das Missões da Casa de Aparecida (1897-1954), Volume único. p. 34.

174 ACPSR. Crônica das Missões da Casa de Aparecida (1897-1954), Volume único. p. 40. 
recebe, pela quarta vez, segundo o relato, a visita redentorista entre 4 e 15 de junho, onde, como de costume, um quadro de Nossa Senhora Aparecida foi ali deixado como lembrança.

Em Paraibuna, a missão ocorreu entre 16 e 30 de junho, simultânea à chegada de um circo de cavalinhos, "que queria aproveitar e estorvar a missão":

Porém, o povo que veio numeroso para os sermões não foi aos brinquedos e quando o chefe da empresa foi à igreja falar mal dos missionários entre o povo, ele se salvou a custo das mãos dos populares que lhe queriam dar um castigo merecido. ${ }^{175}$

A questão, no entanto, não se encerra por aí. O tal empresário, no mesmo dia, caiu da corda bamba, sendo tal acidente levado como castigo divino. A missão foi um sucesso, merecendo do relatório "menção especial" o vigário, "que por suas admoestações prepara otimamente as Missões." Encerrados os trabalhos, Padre Hahn percorreu ainda por uma semana as fazendas da região. ${ }^{176}$

Isto feito, na missão em Santa Branca, Igaratá, Santa Isabel e Salesópolis, ocorrida entre 30 de junho e 12 de julho de 1906, os primeiros dias não foram bons, tendo em vista que o vigário, Padre Cavalieri, "não sabia desempenhar-se dos preparativos para a missão. Depois, porém, o povo começou a correr bem", e a ação disciplinadora dos padres bávaros se fez sentir:

Aqui os missionários experimentaram pela primeira vez retirar para fora da igreja durante o "grande sermão" a criançada. O resultado foi ótimo. Com facilidade podia-se pregar, reinava ordem e silêncio. ${ }^{177}$

A imagem de Nossa Senhora Aparecida, também como de costume, foi adquirida pelas autoridades locais, para permanecer na igreja. Sua imagética, pois, se reforçava em todas as localidades e grotões do vale do Paraíba e Sul de Minas Gerais, dentre outras regiões, pela ação racionalizada e disciplinada dos discípulos de Santo Afonso:

Fizeram-se muitas procissões. Quando a imagem de Nossa Senhora Aparecida entrou na igreja em procissão, chegaram os grandes e declararam que a imagem não sairia mais e logo abriram uma subscrição para pagá-la. ${ }^{178}$

Também não faltaram Missões em Caçapava, Buquira e São Francisco

175 ACPSR. Crônica das Missões da Casa de Aparecida (1897-1954), Volume único. pp. 48-49.

176 ACPSR. Crônica das Missões da Casa de Aparecida (1897-1954), Volume único. p. 49.

177 ACPSR. Crônica das Missões da Casa de Aparecida (1897-1954), Volume único. p. 51.

178 ACPSR. Crônica das Missões da Casa de Aparecida (1897-1954), Volume único. p. 52. 
Xavier, ocorridas entre 18 e 28 de julho de 1907, ${ }^{179}$ bem como em Quiririm, Taubaté e Tremembé, essas três últimas cidades missionadas com a ajuda dos redentoristas holandeses. 180

Some-se ao trabalho pastoral dos antecessores do primeiro bispo de Taubaté a presença de Irmandades e Associações, bem como vasta rede educacional, da qual nos ocuparemos um pouco.

Assim sendo, levantamos as seguintes Irmandades e Associações no âmbito das vilas e cidades pertencentes à extensão territorial da diocese:

1) Apostolado da Oração do Sagrado Coração de Jesus ${ }^{181}$ (Areias, Bananal, Caçapava, Cachoeira Paulista, Cruzeiro, Embaú, Guaratinguetá, Igaratá, Jambeiro, Lorena, Paraibuna, Pindamonhangaba, Roseira, Salesópolis, Santa Branca, Santa Isabel, Santo Bento do Sapucaí, São José do Barreiro, São José dos Campos, São Luiz do Paraitinga, São Sebastião, Silveiras, Taubaté, Tremembé, Ubatuba, Vila Bela)

2) Associação das Damas de Caridade, fundada em 1876 (Areias, Cachoeira Paulista, Cunha, Guaratinguetá, Jacareí, Natividade da Serra, Paraibuna, Pindamonhangaba, Santa Branca, São José dos Campos, São Luiz do Paraitinga, Silveiras, Taubaté, Ubatuba)

3) Associação do Patrocínio de São José (Lorena)

4) Associação dos Santos Anjos (Paraibuna e Santa Branca)

5) Círculo de São José (Pindamonhangaba)

6) Confraria da Guarda de Honra do Sagrado Coração de Jesus (Taubaté)

7) Confraria do Sagrado Coração de Maria (Cruzeiro e Pindamonhangaba)

8) Confraria do Santíssimo Rosário (Caçapava, Lorena, Pindamonhangaba, Santo Bento do Sapucaí, Taubaté e Tremembé)

9) Congregação da Doutrina Cristã (Caçapava, Cachoeira Paulista,

179 ACPSR. Crônica das Missões da Casa de Aparecida (1897-1954), Volume único. p. 329-330. Suplemento.

180 ACPSR. Crônica das Missões da Casa de Aparecida (1897-1954), Volume único. p. 332-335. Suplemento.

181 A Pia Associação do Apostolado da Oração foi fundada em 1871 na cidade de Itu pelo Padre Jesuíta Bartolomeu Taddei. Espalhou-se rapidamente por todo o país, reacendendo nas paróquias as práticas sacramentais, adormecidas por influência do clero de tendências iluministas e jansenistas. Ver VIOTTI, Hélio Abranches. Expansão da Igreja no Brasil Independente, Revista de História. V. XVL. n. ${ }^{\circ}$ 92. ano XXIII. 1972. Apesar de não terem sido encontradas, ao longo da nossa pesquisa, referências à presença dos jesuítas no vale do Paraíba no decorrer desse período, é inegável a herança ultramontana jesuítica materializada no Apostolado da Oração do Sagrado Coração de Jesus. 
Guaratinguetá, Pindamonhangaba, Taubaté e Ubatuba)

10) Grêmio dos Moços Católicos (Guaratinguetá)

11) Irmandade das Almas (Guaratinguetá)

12) Irmandade de Nossa Senhora Auxiliadora (São José do Barreiro)

13) Irmandade de Nossa Senhora da Boa Morte (Taubaté)

14) Irmandade de Nossa Senhora da Piedade (Lorena)

15) Irmandade de Nossa Senhora da Soledade (São José do Barreiro)

16) Irmandade de Nossa Senhora das Dores (Areias e Cunha)

17) Irmandade de Nossa Senhora do Rosário (Cunha e Paraibuna)

18) Irmandade de Santa Ana (Bananal)

19) Irmandade de Santa Rita (Guaratinguetá)

20) Irmandade de São Benedito (Areias, Bananal, Caçapava, Cunha, Guaratinguetá, Igaratá, Jacareí, Jambeiro, Lagoinha, Lorena, Natividade da Serra, Paraibuna, Pindamonhangaba, Santa Branca, Santa Isabel, Santo Bento do Sapucaí, São Francisco Xavier, São José dos Campos, São Sebastião, Silveiras, e Taubaté)

21) Irmandade do Santíssimo Sacramento (Areias, Caçapava, Cachoeira Paulista, Cunha, Guaratinguetá, Igaratá, Jacareí, Natividade da Serra, Paraibuna, Pindamonhangaba, Salesópolis, Santa Branca, Santa Isabel, Santo Bento do Sapucaí, São José do Barreiro, São José dos Campos, São Luiz do Paraitinga, São Sebastião, Taubaté, Ubatuba e Vila Bela)

22) Ordem Terceira da Penitência (Guaratinguetá, São Luiz do Paraitinga, e Taubaté)

23) Ordem Terceira de Nossa Senhora do Carmo (Santo Bento do Sapucaí)

24) Pia União das Filhas de Maria (Bananal, Cachoeira Paulista, Cruzeiro, Guaratinguetá, Igaratá, Jacareí, Jambeiro, Lorena, Paraibuna, Pindamonhangaba, Santa Branca, Santo Bento do Sapucaí, São José dos Campos, Silveiras, Ubatuba e Vila Bela)

25) Sociedade de São Vicente de Paulo, fundada na França e estabelecida no Brasil em 4 de agosto de $1872{ }^{182}$ (Areias, Bananal, Buquira, Caçapava, Cachoeira Paulista, Cruzeiro, Cunha, Embaú, Guaratinguetá, Igaratá, Jacareí,

182 CHIZOTI, Geraldo. Os operários da caridade: a Sociedade de São Vicente de Paulo em São Paulo (1874-1946). 1991. Tese (Doutorado em História Social) - Universidade de São Paulo, São Paulo, 1991. p. 101. 
Jambeiro, Lagoinha, Lorena, Natividade, Paraibuna, Pindamonhangaba, Queluz, Redenção da Serra, Roseira, Salesópolis, Santa Branca, São Bento do Sapucaí, São Francisco Xavier, São José do Barreiro, São José dos Campos, São Luiz do Paraitinga, Silveiras, Taubaté, Tremembé, Ubatuba)

Os esforços romanizadores, pois, no sentido de fazer propagar as associações de forte coloração ultramontana, quais sejam, o Apostolado da Oração do Sagrado Coração de Jesus, a Associação das Damas de Caridade, a Irmandade do Santíssimo Sacramento e a Pia União das Filhas de Maria, imbricavam-se com as tentativas de reformas dos estatutos das velhas irmandades, como, por exemplo, a do Santíssimo Sacramento, a de São Miguel e Almas, a do Senhor Bom Jesus dos Passos e a de Nossa Senhora da Boa Morte.

Note-se, porém, que o catolicismo luso-brasileiro, materializado na Irmandade de São Benedito, ainda se mantém ativo. Por sua vez, muitas outras irmandades assumem apenas configuração local, e em muitos casos com a "concorrência" das associações religiosas reformadas.

O ensino em mãos religiosas também se fazia presente antes da criação da diocese de Taubaté: o Colégio São Joaquim (Lorena), o Colégio São Manoel (Lavrinhas), o Colégio Nossa Senhora do Carmo e o Colégio Nossa Senhora Auxiliadora, dirigidos por salesianos e fundados em 1890; o Colégio São José (Guaratinguetá), mantido pelos franciscanos. De reconhecida fama na região, temos também o Colégio Bom Conselho, fundado por D. José Pereira da Silva Barros, em Taubaté, o qual Augustin Wernet, ao tratar dos primórdios do ultramontanismo no Brasil, se reporta ao processo de expansão da Província brasileira das Irmãs de São José de Chamberry:

Em 1879, o Monsenhor José Pereira da Silva Barros, futuro bispo de Olinda e do Rio de Janeiro, então Vigário de Taubaté, reclamou as irmãs para dirigirem o Colégio Nossa Senhora do Bom Conselho em Taubaté. Na mesma cidade assumiram, no ano de 1891, o Externato e um Orfanato e em 1898 o Hospital Santa Isabel. ${ }^{183}$

A esse respeito vale considerar a importância atribuída à educação feminina, e o projeto romanizador de D. Antônio Joaquim de Melo, além de contemplar as visitas pastorais e a reforma do clero paulista, não omitia a preocupação de fundar

183 WERNET, Augustin. Os primórdios do ultramontanismo em São Paulo (1851-1906), Revista da Sociedade Brasileira de Pesquisa Histórica (SPBH), Anais da IV reunião. São Paulo: SBPH, 1985. p. 3. 
estabelecimentos não só para a educação da juventude masculina, mas também da feminina. Essa pauta, a educação da juventude paulista, se realizou em parte ainda durante a vida de D. Antônio Joaquim, "com a fundação do Colégio Nossa Senhora do Patrocínio de Itu, entregue aos cuidados das freiras saboiardas Irmãs de São José de Chamberry". ${ }^{184}$

Segundo Ivan Aparecido Manoel, o principal motivo que levou Monsenhor José Pereira da Silva Barros a levar as Irmãs de São José de Chamberry para Taubaté foi o de se contrapor à escola protestante fundada pela Sociedade Bíblica Norte-americana. Seja como for, a educação ultramontana voltada para o público feminino ia perfeitamente ao encontro do modelo desejado pela elite brasileira:

O que de fato a oligarquia desejava, naquele momento, era uma educação que cultivasse as suas filhas, mas que, ao mesmo tempo, garantisse a sua moralidade e sua religiosidade. Em suma, requeria uma educação conservadora, anti-moderna. Por isso, no momento histórico em que poderia organizar o sistema educacional que bem pretendesse para a educação de suas filhas a oligarquia foi buscar na França o conservadorismo ultramontano das freiras saboiardas para exercerem as funções de educadoras de suas famílias. Era a garantia de uma educação anti-moderna, anti-profissionalizante, anti-feminista como se dizia então. ${ }^{185}$

Como se pode verificar, a ação romanizadora no vale do Paraíba já se fazia sentir bem antes da chegada de D. Epaminondas, e presentes já se encontravam, na região, os Capuchinhos de Trento (desde 15 de fevereiro de 1892, no convento de Santa Clara, em Taubaté), ${ }^{186}$ os Franciscanos (Colégio São José, em Guaratinguetá), as Filhas de Maria Auxiliadora (Escola Agrícola Coronel José Vicente, em Lorena, e o Colégio São Manoel, em Lavrinhas, estes dois últimos

184 MANOEL, Ivan Aparecido. Igreja e educação feminina: os colégios das irmãs de São José de Chamberry (1859-1919). 1988. Tese (Doutorado em História Social) - Universidade de São Paulo, São Paulo, 1988. p. 56. A tese foi publicada pela Editora UNESP, em 1996, sob o título "Igreja e educação feminina (1859-1919): uma face do conservadorismo".

185 MANOEL, Ivan Aparecido. Igreja e educação feminina: os colégios das irmãs de São José de Chamberry (1859-1919). 1988. Tese (Doutorado em História Social) - Universidade de São Paulo, São Paulo, 1988. p. 191.

186 A implantação do ultramontanismo do Convento de Santa Clara se deu a partir de 15 de fevereiro de 1892, com a chegada dos Capuchinhos de Trento. D. José Pereira da Silva Barros, Bispo de Olinda e natural de Taubaté, convidou-os a tomar posse do convento, até então pertencente aos Menores Franciscanos Reformados da Antiga Província da Conceição, "mas quase abandonado e próximo a ruir completamente", segundo palavras de Frei Ricardo, à época cronista da Ordem. A ação missionária desses Capuchinhos pode ser inferida, segundo Guisard Filho: "A convite do Rev." vigário da paróquia, pregaram os capuchinhos, então, uma missão soleníssima na matriz da cidade, a qual durou 15 dias". Encaminho o leitor a GUISARD FILHO, Félix. Convento de Santa Clara: achegas à história de Taubaté. São Paulo: Athena Editora. 1938. pp. 91-127. passim. 
fundados em 1892). ${ }^{187}$ A nosso ver, um forte saldo favorável à hegemonia do catolicismo. E se em centros urbanos de maior densidade populacional, como Taubaté, registramos debates e críticas pelos jornais consultados, em relação ao clero e ao catolicismo, nada se nota em relação às vilas e pequenas localidades. Mas com a chegada de D. Epaminondas, mesmo em Taubaté as paixões envolvendo a religião serão, em primeiro momento, muito minimizadas na imprensa, para depois praticamente se extinguirem.

\subsection{Nasce um bispado}

Em 12 de junho de 1514, D. Manoel, o Venturoso, obtém do Papa Leão X a bula Pro excellenti praeeminentia, erigindo-se a diocese do Funchal, na ilha da Madeira, que assume a jurisdição episcopal sobre as regiões além do cabo Bojador, aí incluído o Brasil. Tal situação jurídica se estenderia até 25 de fevereiro de 1551 , com a criação da diocese de São Salvador da Bahia.

Fato decisivo para a Igreja no Brasil foi a criação, pela bula Super specula militantis ecclesiae, do bispado de Salvador, na cidade de Salvador da Capitania de Todos os santos, com a cláusula de que, enquanto ainda não houvesse outros bispados na colônia portuguesa, exercesse o novo bispo a sua jurisdição na em todas as terras e partes da colônia. ${ }^{188}$

Somente em 16 de novembro de 1676 assiste-se à criação dos bispados de São Sebastião do Rio de Janeiro e de Olinda, ambos sufragâneos da Bahia, mas qualquer controle, como se pode depreender, caracterizava-se como meramente formal, pois dificuldades de toda ordem se interpunham, desde as financeiras até a própria ação governamental. Tal situação tenderia a mudar apenas com a república. Em nosso auxílio, Bruneau:

O simples desenvolvimento organizacional era um ponto básico para a influência da Igreja, mas até então a Igreja no Brasil não tinha evoluído como instituição porque dependia inteiramente das estruturas do Estado, e porque o Estado nunca quis empregar recursos para o seu desenvolvimento, ou permitir a sua expansão. Depois de 1891, a Igreja teve que construir a sua organização a partir praticamente do nada. Em 1889 havia apenas onze dioceses e uma arquidiocese. Para um país do tamanho do Brasil esse era um número incrivelmente pequeno e a cobertura do território pelas estruturas da Igreja era

187 Arquivo da Cúria Diocesana de Taubaté, doravante denominado ACDT. Papéis avulsos: Criação do Bispado.

188 LACOMBE, Américo Jacobina. A Igreja no Brasil colonial. In: HOLANDA, Sérgio Buarque de. (org.). História da Civilização Brasileira - A época colonial: administração, economia e sociedade. Rio de Janeiro: Bertrand Brasil S.A, Tomo I, 2 v, 7. ed., 1993. p. 56. 
fisicamente impossível. ${ }^{189}$

Era preciso, pois, ao longo do tempo, corrigir tal disfunção, criando-se novas dioceses, e o processo nacional de romanização não se furtou a tal desiderato, optando por um projeto regional de romanização.

Entende-se como projeto regional de romanização uma estratégia de dominação pautada, basicamente, em dois objetivos. Um deles, cuja análise buscarse-á aprofundar oportunamente, é o de procurar dar cunho romanizador ao catolicismo luso-brasileiro, mais voltado às devoções de caráter regional. O outro se prendia em criar novas dioceses, reduzindo, destarte, vastidões territoriais praticamente impossíveis de serem eficazmente controladas pelos bispos, conforme até aqui apresentado. Na medida em que padres católicos brasileiros romanizados assumiram o múnus episcopal, incrementou-se a fragmentação de dioceses em proveito da criação de outras. Assim sendo, tem-se, em 1892, a criação da diocese de Curitiba, no território anteriormente pertencente à diocese de São Paulo. Em 1900, a redução geográfica da diocese de Mariana possibilita a criação da diocese de Pouso Alegre; 1902, por sua vez, assiste à criação da diocese do Piauí em terras da diocese de São Luiz do Maranhão. Em 1903, a diocese de Belém do Pará é desmembrada para o surgimento da diocese de Santarém, e em 1907 a diocese de São Paulo sofre nova redução em favor da implantação da diocese de Campanha, no estado de Minas Gerais, perda essa que também atingiu a diocese de Goiás, fazendo surgir a diocese de Uberaba. Tal objetivo facilitaria, na medida do possível, não só as visitas pastorais, mas também a própria administração diocesana sob os aspectos de pessoal e de material, atingindo o projeto ultramontano seus objetivos de modo mais eficiente e eficaz, com um maior número de dioceses de menor extensão. Datada de 20 de fevereiro de 1903, a carta do Núncio Apostólico ao Padre Gebardo Wiggermann, à época exercendo as funções de Superior dos redentoristas em Aparecida, materializa essa recorrente preocupação da hierarquia católica:

Rev. ${ }^{\text {mo }}$ P. Gebardo Wiggermann. Pelo imenso território do Brasil estão dispersos inumeráveis e importantes aglomerações de povo cristão, que estão impedidos de gozar do influxo salutar dos respectivos pastores, por causa da enorme distância que as separa das Sedes Episcopais, e que estão destituídas dos meios de salvação por causa da falta de sacerdotes. É Ihes impossível que chamem e despertem a

189 BRUNEAU, Thomas C. Catolicismo brasileiro em época de transição. São Paulo: Loyola, 1974. pp. 68-69. 
solicitude do Santo Padre, para que por meio daquele que representa sua autoridade, procura eficazmente os meios de socorrer a estes fiéis abandonados, que com todo empenho exigem oportunas providências... ${ }^{190}$ (o grifo é nosso)

A mais antiga notícia de que se tem conhecimento sobre a implantação de um governo diocesano em Taubaté é fornecida pelo 'O Norte', em 1905. Nota curta e repassada do jornal 'Sebastianense', seu caráter curioso reside no fato de que até o nome do futuro bispo já estaria sendo estudado. Vê-se, ao longo do texto, as diversas "barrigas" jornalísticas ocorridas em relação aos nomes escolhidos. Seja como for, pode-se inferir que os estudos para a criação da diocese já se processavam bem antes do que se poderia imaginar.

Novo bispado - Consta, ao "Sebastianense" que vai criado pela Santa Sé um novo bispado, tendo como sede Taubaté. Segundo o nosso ilustre confrade, para bispo está indigitado o Ex. ${ }^{\text {mo }}$ Rev $^{\text {mo }}{ }^{2}$ Monsenhor Victor da Soledade, atual vigário de Santos. ${ }^{191}$

Por sua vez, os jornais de Guaratinguetá demonstram clara disputa pela preferência da hierarquia católica na escolha da sede do bispado!

Espera-se a visita do Cardeal Arcoverde e conjectura-se que é isso mais um passo para a criação de um bispado nessa cidade. ${ }^{192}$

Passado o tempo, mas ainda podendo ser tida na conta de pioneira (ou, considerando de quem se trata, especulativa), a nota d"O Luizense', de São Luiz do Paraitinga, não é tão contundente como a d"O Norte'. Valois de Castro, o nosso já conhecido Cônego Beija-flor, é dessa vez o nominado. Da leitura d"O Luizense', e considerando o caráter de seus artigos em defesa de Valois de Castro, assim como o fato de o Cônego ser filho da terra, é lícito pensar-se em simples pressão. A se entender o projeto ultramontano, em que o "padre político" perdia espaço, a veracidade da nota perde credibilidade.

Dizem alguns jornais bem informados que, caso se dê a criação de uma diocese no Norte do estado, será eleito bispo para dirigi-la o Cônego Dr. José Valois de Castro, deputado federal. ${ }^{193}$

Os comentários corriam à solta e, dia a dia, os jornais da cidade lançavam

190 ACPSR.Correspondência da Província Redentorista de São Paulo - COPRESP, v. III (19021904). p. 216.

191 O Norte, n. ${ }^{\circ}$ 30, I. 9 de fevereiro de 1905.

192 Voz do Povo, n. ${ }^{\circ}$ 9, I. 3 de junho de 1906. Guaratinguetá. (Diversos n. ${ }^{\circ} 11$ )

193 O Luizense, n. ${ }^{\circ} 193$, III. 19 de julho de 1906. 
pequenas notas sobre o assunto, que a todos ocupava. Até 'O Caixeiro', jornal literário e humorístico destinado aos interesses dos empregados do comércio, e não versado nas lides políticas e religiosas do município, abordou o tema:

DIOCESE DE TAUBATÉ - É quase certa a elevação desta paróquia à sede de um bispado. O clero taubateano, segundo rumores que chegaram até nós, vai concorrer com quantum necessário para o patrimônio. Assim seja. ${ }^{194}$

\section{A notícia d’O Caixeiro estava correta.}

Em 14 de abril de 1907, por sua vez, D. Duarte Leopoldo e Silva fez sua entrada oficial e solene na diocese de São Paulo. Nascido em 4 de abril de 1867 e ordenado padre em 30 de outubro de 1892, seu nome é indissociável ao processo de reorganização disciplinar da igreja de Santa Cecília, "onde se destaca com um trabalho pastoral de combate à ignorância religiosa através de um programa de instrução dos fiéis", ${ }^{195}$ bem como ao de vivificação da fé católica na cidade de São Paulo:

Nos recuados anos do paroquiato em Santa Cecília, o bispo de São Paulo, D. José de Camargo Barros, fizera visita pastoral à matriz do Padre Duarte, já eleito bispo de Curitiba. Examinou todos os livros, esquadrinhou altares, móveis, sacristias. Assistiu às devoções inauguradas pelo moço pároco. E impressionou-se de tal maneira que, contra seus hábitos, não pôde conter expressões de verdadeiro entusiasmo: "Padre Duarte foi um homem providencial. Grande era o conceito que eu fazia desta paróquia, mas nunca supus ver o que estou vendo. Feliz a minha antiga diocese de Curitiba! Se Dom Duarte como vigário tanto fez, que não fará como bispo!" Admirara-se o bispo de São Paulo. Com razão. Porque, no dizer dos contemporâneos, "naquele tempo os sacerdotes sentiam escrúpulos de celebrar o santo sacrifício da missa na velha capelinha (de S. Cecília), tanta era a falta de respeito com que assistiam muitos à mais augusta das solenidades cristãs..." Entretanto, algum tempo depois, pôde dizer um dos sucessores de D. Duarte: "Quem se não admira desse espírito de piedade que reina entre os paroquianos de Santa Cecília, fruto de sua apostólica dedicação! Somente um vigário santo e por isso um vigário modelo poderia operar os prodígios que operou o primeiro vigário de Santa Cecília. ${ }^{196}$

Nomeado bispo de Curitiba em 10 de maio de 1904 e ordenado em 22 do mesmo mês, tomou posse da diocese em 2 de outubro de 1904. Em 18 de dezembro de 1906, foi nomeado bispo de São Paulo, fazendo sua entrada em 14 de 
abril de 1907.

A amplitude de sua atuação episcopal é dimensionada por Wernet:

Os principais líderes no empenho pela revitalização da fé em São Paulo foram os arcebispos Dom Duarte Leopoldo e Silva, Dom José Gaspar de Afonseca e Silva e Dom Carlos Carmelo de Vasconcellos Motta. Dom Duarte Leopoldo esteve à frente da Província Eclesiástica de São Paulo por trinta anos (1908 a 1938, quando faleceu) e pôde dar continuidade à ação de seus antecessores na reforma do catolicismo, insistindo na ampliação do estabelecimento de congregações masculinas e femininas; na promoção das associações para leigos; nas visitas pastorais e Missões populares; nas reuniões ou congressos católicos. Dedicou-se intensamente à construção da nova catedral, fundou a Liga das Senhoras Católicas e intensificou a obra das vocações sacerdotais. Procurou manterse acima das facções políticas, mas ganhou vulto durante a Revolta de 1924, quando a Cidade foi tomada pelos rebeldes e incessantemente bombardeada pelas forças governistas. O arcebispo não abandonou o seu posto e abriu as igrejas à população desabrigada, sem distinção de credo ou postura política. ${ }^{197}$

Taubateano de nascimento, D. Duarte representava esperanças de que seriam envidados esforços para a criação de uma diocese em sua cidade natal. Já era conhecida por todos a intenção do Vaticano em criar novos bispados no Brasil, desde que cada um tivesse seus rendimentos ou meios de subsistência. O 'Jornal de Taubaté', mesmo pouco dado a emoções exageradas nos assuntos de natureza religiosa, defendeu de modo veemente a instalação da diocese, afirmando que "[...] nenhuma hesitação pode haver quanto à escolha de Taubaté para sede do bispado", uma vez que a cidade é a que melhores elementos teria para garantir a subsistência de um bispo, quer se fale da subsistência material, quer se trate da subsistência moral. Enumerando como aspectos favoráveis os sentimentos religiosos do povo, o número de associações católicas, de instituições religiosas, de igrejas e de estabelecimentos de caridade em que a ação católica se faz sentir, O 'Jornal de Taubaté' informa que para uma população de 45.000 habitantes Taubaté possui cinco grandes igrejas, das quais a matriz é superior a muitas catedrais. Além disso, poderia informar também sobre a existência de dois estabelecimentos de ensino, de duas casas de caridade dirigidas pelas irmãs de S. José e duas ordens religiosas, a saber, capuchinhos e trapistas, tudo isso somado às irmandades e diversas sociedades católicas. O jornal encontra os mais variados argumentos em defesa de da cidade de São Paulo, v.1: A cidade colonial. São Paulo: Paz e Terra, 2004. p. 236. 
Taubaté, afirmando que a cidade impõe-se à preferência da Santa Sé pelo avultado número de sacerdotes que já tem dado, "[...] o que é indício seguro da enraizada crença do seu povo". Não bastassem os sacerdotes, "dos príncipes da igreja, três tiveram seu berço nesta legendária cidade: o Bispo Rodovalho, D. José de Barros e D. Duarte Leopoldo, que hoje assume, entre a geral satisfação do povo paulista, o seu supremo governo espiritual." Triunfalista, o jornal pergunta:

Qual é a cidade do Norte - perguntamos agora - que pode em seu benefício alegar tais e tantas razões, bastante poderosas para influírem na decisão que sua santidade Pio $X$ vai tomar, quanto à escolha da sede do novo bispado? Mas, não pára aí a lista das vantagens que Taubaté oferece para a instituição da diocese norte-paulista: os meios mais abundantes, os recursos mais fartos são postos à disposição do chefe da futura diocese. [...] A se realizar a intenção do Vaticano, grande injustiça seria preterir esta cidade, digna e merecedora, por todos os títulos, da distinção do chefe da igreja, por outra qualquer em condições em tudo inferior à nossa.

O 'Jornal de Taubaté', denominando seus pontos de vista em relação ao tema como "considerações desapaixonadas, pois partem de quem foi sempre tido e havido por desafeto a coisas religiosas", ainda lembra a disposição testamentária de D. José Camargo de Barros, segundo a qual deixava o seu báculo "à futura diocese de Taubaté", assim como recorda possíveis dons premonitórios de D. Antônio de Alvarenga, que, subindo a rua Duque de Caxias, parou em frente à igreja matriz, "[...] e em tom de quem estava profundamente convencido exclamou: - Eis a futura catedral de Taubaté!" 198

Em meio ao cipoal de conjecturas, reportagens e defesas pela instalação da diocese, vários jornais, entre eles o 'Jornal de Taubaté', anunciaram a presença de D. Duarte na cidade. Na parte da manhã o bispo de São Paulo crismou avultado número de pessoas, e "[...] na tarde desse mesmo dia, na sacristia da matriz, tratouse de negócios referentes ao futuro bispado de Taubaté."

O assunto caracterizava-se como de interesse geral, pois, além do clero, compareceram também importantes pessoas da sociedade. O principal objetivo da reunião prendia-se ao fato de que, para a constituição do futuro bispado, seria necessária a obtenção dos recursos necessários, aí incluído o montante referente a uma indenização a ser paga à diocese de São Paulo, em virtude de seu desmembramento. A comissão para isso formada tinha em Monsenhor Miguel 
Martins da Silva seu presidente.

Assim sendo, a referida comissão determinou a publicação desse curioso aviso, intitulado de "Futuro bispado":

A comissão nomeada pelo Ex. ${ }^{\text {mo }}$ Bispo diocesano para obter donativos que formem o patrimônio do bispado de Taubaté recebe de preferência dinheiro, mas aceita letras de pessoas abonadas, casas, terrenos e outros objetos que representem valores. ${ }^{199}$

O 'Jornal de Taubaté', desconfiado do destino a ser dado ao dinheiro, e levantando hipóteses maledicentes sobre o futuro bispo, saiu-se com esta:

Bispado de Taubaté - Consta que se vai adquirir para residência do futuro bispo de Taubaté uma casa velha ao lado de uma igreja também velha. Essa negociata cheira à simonia e as más línguas da terra falam em rabo de saia. ${ }^{200}$

A leitura dos jornais taubateanos apontam para um estado de efervescência em relação à futura diocese. Os encontros e desencontros vão tomando freqüência nas páginas dos periódicos que, por vezes, cometem enganos. 'O Norte', tão alinhado com o catolicismo, acompanhou os jornais do Rio de Janeiro e de São Paulo, e errou junto com eles:

Os jornais do Rio e de São Paulo noticiaram que o Ex. ${ }^{\text {mo }}$ Monsenhor João Alves Coelho Guimarães, ilustre sacerdote taubateano, será nomeado bispo da diocese de Taubaté. Parece que nada há assentado sobre a escolha do chefe da nossa diocese. Seja, porém, confirmada a notícia da nomeação do benemérito Monsenhor João Alves, e imensa será a satisfação dos taubateanos, que vê no venerando sacerdote o exemplo vivo de acrisoladas virtudes, ao par de reconhecido tino administrativo. ${ }^{201}$

O ano de 1908 inicia com notícias, no mínimo, preocupantes. Informados sobre uma viagem de D. Duarte, a questão versando sobre a subordinação, ou não, do Santuário de Aparecida à futura diocese de Taubaté, torna-se assunto público:

Diz-se que a viagem de D. Duarte Leopoldo, preclaro bispo diocesano, à Roma, prende-se mais à questão da criação da diocese de Taubaté. Segundo uns, o Santuário de Aparecida ficará dentro da arquidiocese de São Paulo; segundo outros, o santuário ficará dentro da nossa diocese.

'O Norte' tenta contemporizar, apelando para os sentimentos de D. Duarte:

Corre, porém, que D. Duarte Leopoldo deseja fique Aparecida

199 Jornal de Taubaté, n. ${ }^{\circ}$ 2309, XII. 9 de maio de 1907.

200 Jornal de Taubaté, n. ${ }^{\circ} 2337$, XIV. 15 de agosto de 1907.

201 O Norte, n. ${ }^{0} 334$, IV. 9 de janeiro de 1908. 
dentro da sua arquidiocese. Não cremos. S. Ex. ${ }^{a}$, taubateano de coração e de nascimento, conhecedor da diocese de Taubaté, há de pedir ao Santo Padre dar o Santuário da Aparecida à nossa diocese. Que o eminente taubateano, ao deixar agora as terras do Brasil, tenha pensamento voltado para o engrandecimento de sua terra natal, é o desejo do povo de Taubaté.

O jornal afirma que a principal causa da demora da criação da diocese de Taubaté reside na questão da subordinação do Santuário de Aparecida, uma vez que até mesmo a contribuição determinada por $D$. Duarte à Cúria de São Paulo,como indenização pela desagregação do território, já havia sido entregue.

Corre que uma das razões é o fato da retirada do Episcopal Santuário da Aparecida do domínio da mitra de Taubaté, mas se assim for estamos convencidos de que essa razão desaparecerá em breve, porque naturalmente o nosso atual diocesano, desinteressado como é, e taubateano de nascimento, não quererá que a diocese de Taubaté, que apenas conta duas paróquias de primeira classe e oito de segunda, fique privada desse auxílio do cofre do Santuário, que a Providência colocou nesta diocese, para compensar a falta de recursos da zona. ${ }^{202}$

E assim, conforme anunciado, D. Duarte seguiu para Roma. Mesmo nascido taubateano e, nas palavras d"O Norte', desinteressado, para lá seguiu muito provavelmente com o fito de acertar a subordinação do Santuário de Aparecida à arquidiocese de São Paulo.

A bordo do vapor Sicília, embarcou anteontem para Gênova, donde partirá para Roma, o nosso ilustre conterrâneo, D. Duarte Leopoldo, digno bispo de São Paulo. ${ }^{203}$

A ânsia por notícias gera, naturalmente, um mercado de especulações, boatarias e desinformações. O 'Jornal de Taubaté', dessa vez, é o responsável por transmitir notícias falsas. Anunciando a criação dos bispados, o jornal antecede em quase três meses o acontecimento, que só se daria em 7 de junho de 1908, quando Pio X assinou decreto criando a Província Eclesiástica de São Paulo, elevando-a, com isso, à condição de arquidiocese.

Telegrama recebido pelo "São Paulo" anuncia que foram criados os bispados de Campinas, Botucatu, Ribeirão Preto, São Carlos do Pinhal e Taubaté. É com imensa satisfação que o 'Jornal de Taubaté' transmite essa notícia aos seus leitores. ${ }^{204}$ 
E como um erro leva a outro, um certo "Zagaieiro", em versos divertidos intitulados "O Bispado", reclama a ausência do bispo:

No pau da câmara, a bandeira

Vi ontem com grande espanto

O dia será d'algum santo,

Ou mesmo santa ou padroeira?

Perguntei muito arreliado

A sua excelência o prefeito

Que respondeu satisfeito:

O telegrama chegado

Diz: Foi criado o bispado;

A matriz já transformada

Na catedral tão falada;

Só falta... o bispo nomeado ${ }^{205}$

Não satisfeito, o jornal provoca mais uma 'barriga'. Com acerto nos demais nomes, a informação errada é justamente sobre o bispo de Taubaté!

NOVOS BISPOS - Informam-nos com bons fundamentos que serão nomeados bispos das novas dioceses os reverendíssimos senhores D. Nery para Campinas, D. Homem de Melo para São Carlos, Monsenhor Alberto Gonçalves para Ribeirão Preto, Cônego João Câncio Reis Meirelles para Taubaté e para Botucatu um sacerdote da diocese de Mariana. O Cônego João Câncio, nosso futuro bispo, é mineiro, conta 64 anos de idade, é piedoso e há muitos anos é vigário da pequena paróquia de Encruzilhada, pertencente ao bispado de Pouso Alegre. Salvo alterações de última hora serão estes os bispos das novas dioceses. 206

A criação de um bispado em Taubaté gerou uma expectativa sem precedentes na cidade. É curiosa a matéria d"O Commércio', órgão dedicado à Associação dos Empregados no Comércio, que noticiou 0 fato sob a ótica...comercial:

D. Duarte, o primeiro arcebispo deste estado, viaja atualmente com destino ao Brasil. Permitam os céus que a S. Rev. ${ }^{\text {ma }}$ não aconteça o que a seu antecessor aconteceu: um naufrágio. Porém, agora não iremos tratar disso. Trataremos do nosso bispado.

A considerar as próximas palavras do articulista, é certo que o clero taubateano, capitaneado por Monsenhor Nascimento Castro, já providenciara subscrições para o bispado. Logo, nada mais justo do que verificar a materialização dos "cobrinhos":

Por certo, não existe um filho desta terra que queira vê-la com

205 Jornal de Taubaté, n. ${ }^{\circ}$ 2399, XIV. 22 de março de 1908.

206 Jornal de Taubaté, n. ${ }^{\circ}$ 2400, XIV. 26 de março de 1908. 
um palácio de bispo, como não há um só taubateano que ignore o reembolso de uns cobrinhos de seus conterrâneos para o patrimônio de um bispado. Necessariamente precisamos ver germinada a semente da criação, de um bispado nesta terra.

Outros jornalistas melhor informados já haviam garantido a "germinação da semente", mas a desconfiança ainda assaltava o articulista d' 'O Commércio':

É verdade que os jornais já nos disseram que essa semente germinou. Mas, como confiar desconfiando sempre é boa regra... Esperemos S. Rev. ${ }^{\text {ma }}$, o bispo que viaja, para ouvi-lo, a ver se nos traz esperança de em breve termos um bispo que more conosco.

As palavras seguintes são proféticas. De fato, além dos tais discursos, comes e bebes, e crônicas, o que na esperança do articulista traria o progresso e a esperança de maior circulação monetária, não faltariam mesmo notícias, e as contendas de D. Epaminondas com seu metropolita encheriam as páginas dos mais diversos jornais.

Como se poderá verificar, a "cidade paralítica", na opinião do jornal, teria um bispo bastante rápido na manutenção de sua autoridade e na defesa dos interesses diocesanos:

Ninguém duvida que com um bispado teremos que mostrar aos nossos hóspedes, e que ele dará motivo a muita coisa: discursos, comes e bebes, crônicas, notícias, etc. À Ribeirão Preto, deu-se um ginásio; à Taubaté, uma esperança...Mais tarde, quando pudermos nos estacar a frente do palácio episcopal de Taubaté, diremos que não é mais a cidade paralítica que a muito não dava um passo na estrada do progresso, e que seus filhos, entre os quase muito ilustres, sentiram a febre de um desejo de vê-la melhorada. Então, será compensada a má impressão que causa à vista o velho casarão da Praça Dr. Monteiro, onde corre o povo a aplaudir as companhias teatrais que nos visitam por generosidade talvez. ${ }^{207}$

Com a proclamação da república, a Igreja católica no Brasil viu-se livre das amarras do Padroado, e, em 27 de abril de 1892, a bula papal Ad universas orbis Ecclesias expressou o poder do papa de livremente fazer uma nova circunscrição nos limites das dioceses da República brasileira, quando assim julgasse oportuno.

Baseado em tal diploma, decretou Pio X que a Sé Episcopal de São Paulo fosse elevada à dignidade de Sé Metropolitana, e que fossem erguidas cinco igrejas catedrais, dentro de seus limites. Para a execução desse Decreto, passado em 207 O Commércio, n. ${ }^{\circ}$ 10, I. 31 de maio de 1908. 
Roma no dia 7 de junho de 1908, Pio X comissionou D. Alexandre Bavona, à época Núncio Apostólico do Brasil, conferindo-Ihe, para isso, todas e cada uma das faculdades necessárias e oportunas, com o poder de subdelegar a qualquer outra pessoa constituída em dignidade eclesiástica, e de se pronunciar definitivamente sobre qualquer oposição que, por acaso, pudesse surgir na referida execução. Suprimidos, portanto, os limites pelos quais estava circunscrita a diocese de São Paulo, foi ela dividida, surgindo assim as dioceses: de Botucatu, tendo como primeiro bispo D. Lúcio Antunes de Souza; Campinas, com D. João Batista Corrêa Nery à frente; São Carlos do Pinhal, com D. José Marcondes Homem de Mello; Ribeirão Preto, com D. Alberto José Gonçalves; e, Taubaté, com D. Epaminondas Nunes de Ávila e Silva, cujo governo diocesano compreendia a seguinte extensão geográfica:

O território da diocese de Taubaté termina pela linha adiantada começa no lugar do Oceano Atlântico, onde a Arquidiocese de S. Sebastião do Rio de Janeiro, e depois os limites que separavam as dioceses de Pouso Alegre São Paulo, como acima se disse, até as fraldas dos Montes da Mantiqueira, e a linha segue através deles ao chamado Morro Pelado; deste Monte a linha pela divisão das águas do Tietê e Paraíba atinge o cume do Monte Topeti, cujas fraldas dividem as águas dos rios Guararema e Parati, chega onde o Ribeirão Goiabal desemboca no Paraíba, de modo que os rios que deságuam no Ribeirão Goiabal ficam pertencendo à Arquidiocese de São Paulo. A linha a seguir pelo mesmo rio Paraíba chega às margens do Ribeirão dos Morros e em contraposição a este rio sobe ao cume do Monte dos Morros; e seguindo suas fraldas pelo Ocidente, vai ao Bairro da Lagoa Nova, donde pelos seus contornos chega ao Rio Una, pelo curso do qual entra no Oceano.

Até o presente momento, tem-se, simplesmente, uma precisa descrição de cortes geográficos que delimitam a nova diocese; o texto a seguir, no entanto, ratifica, como anteriormente apresentado, a sujeição do território da Basílica de Nossa Senhora Aparecida ao metropolita, e não ao bispo de Taubaté.

... O templo, porém, de Nossa Senhora sob o título da Aparecida, bem que compreendido nos limites supra indicados, será dependente do Arcebispado de São Paulo, no Brasil, conforme já ficou foi resolvido. [... ${ }^{208}$ (os grifos são nossos)

As especulações sobre a criação do bispado continuavam nas páginas dos

208 ACMSP. Sagrada Congregação Consistorial: "Da Constituição de Nova Província Eclesiástica em São Paulo - Brasil”, Item III. 7 de julho de 1908. Fotocópia datilografada. Inédito. 
jornais. Muitas eram as notícias, abordadas pelos mais diversos pontos de vista. Em meio a tantas, $\mathrm{O}$ 'Jornal de Taubaté' publica uma nota sobre o fato de estar correndo uma subscrição para angariar donativos a fim de formar o patrimônio do bispado, citando como subscritores Monsenhor Nascimento Castro, José Domingues Ribas, Ana Emília de Abreu Castilho e demais figuras da cidade. O jornal encaminha o texto para o terreno da maledicência, dizendo ser corrente na cidade o fato de que uns pagaram, e outros não, aproveitando para alertar que é preciso não só saber o destino do dinheiro recolhido, mas também se todos aqueles que subscreveram pagaram mesmo ou apenas desejavam "hacer figura".

O mais interessante da matéria, no entanto, é o caráter pioneiro do tema abordado: o fato de o Santuário de Aparecida pertencer ao arcebispado de São Paulo, e não ao bispado de Taubaté, tornar-se motivo de discussão.

[...] Andam, ao que se diz, a procura de um bispo para a nova diocese e parece que não o encontraram porque não concordam aqueles que são consultados em deixar o santuário da Aparecida fora do bispado e pertencente ao arcebispado. Não sabemos o que há de verdade nisso. [... ${ }^{209}$

A semente do bispado germinou e o 'Jornal de Taubaté', entre outros, noticiou a festa. É natural que não faltassem as "bombas e foguetes", artefatos pirotécnicos característicos de qualquer festa brasileira. Introduzidos no Ocidente pelo portugueses no século $\mathrm{XVI}$, os fogos de artifício originários da China não demoraram para serem conhecidos no Brasil, uma vez que, já em 9 de janeiro de 1610, eram proibidos por um alvará de D. João IV. com certeza não cumprido, pois a determinação necessitou ser reforçada pelos alvarás de 2 de agosto de 1641 e de 3 de agosto de 1689, "[...] tendo em vista os grandes incêndios que tais fogos iam causando, ameaçando com pesadas multas e até com degredo na África os que ousassem infringi-la." 210

A solene instalação da diocese de Taubaté foi dirigida por Monsenhor Nascimento Castro, que leu a pastoral de Dom Epaminondas, escrita em Serro em 1 de novembro de 1909, mencionando também as divisas da diocese. Ao término, declarou instalado o bispado "para glória e honra do povo taubateano." 211

209 Jornal de Taubaté, n. ${ }^{\circ}$ 2458, XV. 18 de outubro de 1908.

210 LEITE, José Roberto Teixeira. A China no Brasil. Campinas: Editora da Unicamp, 1999. p. 66. O autor apresenta as influências chinesas na sociedade e na arte brasileira. No capítulo dedicado aos fogos de artifício constam interessantes descrições de festas religiosas em São Paulo, Minas Gerais e Rio de Janeiro, todas marcadas pela utilização exagerada desses artefatos pirotécnicos.

211 Jornal de Taubaté, n. ${ }^{\circ}$ 2461, XV. 29 de outubro de 1908. 
As providências para a entrada festiva e a posse solene do primeiro bispo da nova diocese prosseguiam sob o comando de Monsenhor Nascimento Castro. Foram nomeadas diversas comissões para a construção dos arcos triunfais nas ruas Carneiro de Souza, Visconde do Rio Branco, Duque de Caxias e a Travessa Jacques Félix, por onde passaria o préstito de recepção. Monsenhor Nascimento Castro convidou os seus moradores daquelas ruas "[...] a enfeitarem as frentes de suas casas com colchas, flâmulas, guirlandas, flores e folhagens, e promovendo a iluminação geral das casas nas duas noites consecutivas de 21 e 22." 212

A recepção a D. Epaminondas não ocorreu pontualmente em Taubaté, conforme a leitura dos jornais. Na medida em que o trem que o conduzia atravessava as cidades, era o bispo homenageado das mais diversas formas, aumentando o aparato que o acompanhava. Monsenhor Nascimento Castro foi avisado, por telegrama, que D. Epaminondas embarcara em Curvelo-MG, no dia 18 de novembro.

Uma comitiva, composta pelo prefeito municipal de Taubaté, Gastão Câmara Leal, Monsenhor Nascimento Castro, Padre José Alves e outras autoridades, deslocou-se para Barra do Piraí, no Estado do Rio de Janeiro, a fim de ali já receber aquele que, dentro de poucos dias, assumiria o sólio taubateano.

Recebidos no luxuoso vagão especialmente destinado a D. Epaminondas, após as apresentações de praxe Monsenhor Nascimento Castro ofereceu um almoço a todas as autoridades, servido às 8:30h, no hotel da estação. Quando a composição, que partiu às 9:40h, atingiu a divisa do território da diocese, próximo da estação de Queluz, D. Epaminondas foi cumprimentado pelos membros do clero, da câmara e da prefeitura, que pediram sua primeira benção em território diocesano, "recebida de joelhos por todos os presentes".

Em Lorena, ao som da banda de música do ginásio, estavam a postos os alunos do Colégio São Joaquim, fundado em 1890 pelos salesianos, além de membros do clero. Em Guaratinguetá, grande massa popular. Presente à recepção, além do vigário, a fina flor da conquista ultramontana: as congregações do Sagrado Coração de Jesus e as Filhas de Maria, estas acompanhadas pela madre diretora salesiana do Colégio do Carmo.

A recepção em Aparecida teve caráter especial. Recebido pelos padres redentoristas, D. Epaminondas dirigiu-se em carro de praça a um outeiro, donde 212 Jornal de Taubaté, n. ${ }^{\circ}$ 2533, XVI. 7 de novembro de 1909. 
certamente pôde vislumbrar pequena parte da imensidão territorial de sua diocese. Após o curto recreio, dirigiu-se para a basílica, onde fez suas orações, seguindo então para a residência dos religiosos e ali permanecendo até o dia 21 de novembro, data de sua entrada solene em Taubaté. O cronista da congregação o descreveu como humilde e simples, mas um pouco reservado. Na véspera de sua partida, é natural que não faltassem as tradicionais e ruidosas manifestações do povo:

Foguetes subiram sem parar, as 2 bandas de música fizeram o seu possível, representantes das diversas classes da população fizeram discursos alusivos. O Sr. Bispo respondeu bonito, mas singelo, mostrando-se muito amável; no final as 2 bandas, que são pouco amigas entre si, tocaram juntas o hino nacional. ${ }^{213}$

Um jovem do Serro, de família empobrecida, tornava-se bispo de uma nova diocese. Em pouco espaço de tempo mostraria a todos não só sua face romanizadora, mas também a fina percepção política e a necessária coragem moral para demandar longos e desgastantes processos com D. Duarte.

213 ACPSR. Crônica da Comunidade Redentorista de Aparecida, v. II (1908-1922). p. 57. 


\section{CAPÍTULO II \\ O "LEGADO WANDERLEY"}

\subsection{As novas dioceses e as questões patrimoniais}

A exposição realizada na terceira parte do primeiro capítulo buscou, em essência, privilegiar as vantagens de cunho espiritual e de ação pastoral romanizada a serem obtidas no bojo da criação de novas dioceses, particularmente após o advento da república e do decreto de separação.

É inegável, pois, que a repartição dessas novas "frentes de combate" confiadas aos bispos, tenham proporcionado à Igreja católica não só maior amplitude de controle e de dominação burocrática, mas também uma maior possibilidade de fazer frente aos avanços do protestantismo.

Do ponto de vista político-organizacional, a separação cancela praticamente todos os direitos de intervenção sobre os negócios eclesiásticos de que dispunha o poder central conforme estipulava o regime de padroado. A criação de novas dioceses e paróquias, a fundação de seminários e de outras obras, a distribuição do clero pelos diversos cargos e carreiras alternativos, a indicação e nomeação de prelados, a fixação de normas e diretrizes de interesse para as atividades e serviços eclesiásticos, e outras tantas atribuições até então de competência do próprio imperador ou de seus altos prepostos, passavam a depender do alvitre da alta hierarquia eclesiástica. 214

A dificuldade reside, no entanto, em reconstituir os naturais conflitos, e as conseqüentes acomodações, por ocasião do nascimento dessas novas dioceses, abordados pelo viés logístico e pelo viés administrativo, tendo em vista que, ao decreto de separação, seguiu-se a conseqüente retirada de suporte financeiro dado à Igreja nos tempos do império.

Liberta a Igreja católica de um Padroado que desconsiderava qualquer norma canônica e bloqueava os caminhos de uma expansão organizacional ao impulso do espiritualismo romanizador, seguem, pari passu, inúmeras iniciativas.

Visa-se, pois, a curto, a médio, e a longo prazo, o fortalecimento institucional de uma Igreja que buscava as condições mínimas de sobrevivência, em meio ao caudal político, cultural e religioso de uma contemporaneidade que referendava a existência do homem que deseja viver só de pão.

Em outras palavras, "a Igreja, livre do Padroado, preocupa-se com sua 
reorganização interna. Procura marcar sua presença territorial criando paróquias, dioceses e províncias eclesiásticas". ${ }^{215}$

A eficiência desse impulso dependia diretamente de uma reorganização da sua estrutura, limitada nos primeiros anos da república a 12 dioceses, componentes de uma única Província Eclesiástica, responsável por um território de dimensões continentais: Salvador (1551 - Arquidiocese em 1676), Rio de Janeiro (1676), Olinda (1676), São Luís (1677), Belém (1745), São Paulo (1745), Mariana (1745), Cuiabá (1826), Goiás (1826), Porto Alegre (1848), Diamantina (1854) e Curitiba (1892).

Tal imensidão, aliada à dispersão populacional, exigia maior capilaridade da estrutura diocesana que, juntamente com a reformulação dos quadros eclesiásticos nos seminários romanizados, permitiria a efetiva aplicação das diretrizes tridentinas, particularmente no que diz respeito à disciplina do clero e à depuração das heranças do catolicismo luso-brasileiro.

Em quase 350 anos de presença no Brasil, até a mudança de regime, tivera a Igreja a expansão de seu episcopado limitada pelo Padroado, que submetia o clero ao Estado Imperial, em troca de recursos para sua subsistência.

Para a Monarquia de Bragança, o catolicismo era ferramenta fundamental para o controle social. Padres e bispos, como funcionários do Estado, pregavam a unidade, o contentamento e a obediência à ordem social instituída, o que servia para apaziguar os ânimos exaltados pelos fracassos de gestão governamental.

Mas como mero departamento de Estado, com um orçamento infinitamente menor que as possibilidades asseguradas pelo dízimo e doações dos fiéis, a Igreja católica estava em processo de transformação. Passava, portanto, de um catolicismo iluminista para um modelo ultramontano, unitário e oficializado.

Sua estrutura paroquial era desordenada e ineficiente; seu clero, indisciplinado e sujeito à promiscuidade; seu orçamento, reduzido; suas diretrizes e princípios, submetidos e adaptados aos interesses do Império.

No processo transformador dessa autocompreensão, a Igreja inicia a reformulação de seu clero, formando, nos novos seminários romanizados, sacerdotes preparados para comandar, administrar e reorganizar a estrutura, antes de expandi-la.

215 BARTHOLO, Maria Elisa Carvalho. Uma presença tardia: raízes históricas da rede paroquial brasileira, Revista do mestrado de história, v.3. Vassouras: Universidade Severino Sombra, 2000. pp. 258-259. 
A se considerar cada diocese na condição de corpo administrativo autônomo, no que tange às despesas decorrentes de sua administração, e da manutenção de seus quadros clericais, é de se avaliar como bastante grave o estado de penúria no qual alguns desses antigos bispados se encontravam quando da cessação desses recursos, ainda que parcos.

Fator complicador é o entendimento de um povo acostumado a um clero enquadrado na condição de funcionário público, a quem cabia o Estado prover-Ihe a subsistência. Wernet retrata essa situação:

Com a proclamação da República, em 1889, a Igreja do Brasil alcançou plena liberdade religiosa, mas perdeu, embora exígua, a sustentação financeira que o governo the dava durante o regime do Padroado. Conforme o Decreto 119A, do Governo Provisório, de 7 de janeiro de 1890, o governo continuaria a dar o salário para os eclesiásticos - párocos e bispos - durante um ano, mas depois a Igreja deveria procurar seus próprios recursos financeiros para prover a subsistência das igrejas e do clero e para o apostolado. Muitas dioceses, como por exemplo a de Goiás, caíram em extrema miséria. A diocese de São Paulo passou por dificuldades mas conseguiu equilibrar suas finanças, parcialmente, graças aos recursos provindos do Santuário de Aparecida. ${ }^{216}$

A população, de uma maneira geral, não tinha o costume de contribuir com suas paróquias, especialmente no interior, seja pela carência de recursos para o próprio sustento, seja por estarem mais próximas e acessíveis às confrarias leigas, típica configuração do catolicismo luso-brasileiro.

Avalie-se, portanto, a quadra melindrosa por que atravessaram os prelados de antigas e já tradicionais dioceses, pertencentes ao panorama católico brasileiro, bem ou mal já dotadas de bens patrimoniais, para que se possa entender, com o devido dimensionamento, o desafio imposto aos bispos das dioceses recém criadas.

Se bispados tradicionais, com patrimônio já constituído, passavam por dificuldades no momento do corte de recursos do Estado, ainda maiores seriam as restrições impostas às novas dioceses, criadas sob o novo regime.

Não se tratava, apenas, de dividir dioceses, mas de se expandir a estrutura paroquial e aproximá-la da população. Posteriormente, reorganizava-se o conjunto de paróquias de uma região em um novo bispado, para que a presença da hierarquia episcopal, de uma maneira mais efetiva, norteasse as atitudes dos sacerdotes, buscando cumprir, assim, objetivos anteriormente traçados:

216 WERNET, Augustin. Os redentoristas no Brasil. v. 2. Aparecida: Santuário, 1995. p. 171. 
Criai o espírito paroquial. Sede os mestres, os amigos, os confidentes, os conselheiros do povo confiado à vossa guarda. Todos se acheguem de vós, procurando a palavra que ilumina, a exortação que fortalece, o exemplo que edifica, o perdão que consola, a caridade que para todos se expande, e se faz tudo a todos para ganhar todos a Jesus Cristo! O protestantismo e a impiedade aí estão em campo, propagando seus erros com extraordinária atividade. ${ }^{217}$

Os objetivos romanizadores, e as condições estruturais dessas dioceses, exigiam de seus bispos uma postura racional, técnica, competente e empreendedora na administração e ampliação do patrimônio diocesano.

Trata-se, portanto, de um novo estágio do modelo burocrático, caracterizado pela atuação dos quadros episcopais formados e treinados nos seminários diocesanos.

Consagrados por nomeação, e não por eleição, o que lhes atribuía competência jurídica, e não política, os novos bispos, regidos de maneira voluntária por uma rígida hierarquia de cargos, tinham competências funcionais fixas, inerentes ao seu grau hierárquico, e o cargo como única profissão, além da perspectiva de carreira na Igreja, o que exigia disciplina, obediência às normas e desempenho no cargo.

Um bispo de uma diocese periférica, pode-se supor, procurava exercer sua função de maneira plena, na condução espiritual romanizada de seu clero diocesano, e na ampliação e administração dos bens patrimoniais do bispado, de forma a prosseguir na carreira eclesiástica, objetivando se destacar para uma promoção, representada pela nomeação para bispo de uma diocese de expressão, arcebispo de uma Província eclesiástica, ou mesmo secretário da Santa Sé.

O estudo em tela observa o caso da ascensão da diocese de São Paulo à condição de Província eclesiástica, com sua conseqüente redução territorial, em favor do nascimento de outras cinco dioceses, tendo como ponto pacífico a necessidade de uma maior ação de presença da Igreja católica em áreas, não só consideradas como economicamente promissoras, vinculadas à expansão do café, mas também ocupadas por fortes contingentes de estrangeiros, particularmente de italianos.

Cumprindo, pois, este desiderato, na região do Oeste paulista, servida pela 
Companhia Mogiana de Estradas de Ferro, e pela Companhia Paulista de Estradas de Ferro, foram implantadas as dioceses de Ribeirão Preto, São Carlos do Pinhal e Campinas e Botucatu. A Igreja católica acompanhava, atenta, as mudanças:

O período denominado República Velha ou Primeira República Brasileira (1889-1930) representou em nosso país o momento privilegiado dessas mudanças. O Estado brasileiro ajustou-se aos novos interesses do capitalismo em expansão e esses novos interesses internacionais provocaram no país apenas as mudanças necessárias a seus objetivos, sem rupturas ou transformações sociais radicais. A Igreja católica, por sua vez, gradativamente também se ajustou ao novo universo econômico e social em formação, sendo que nas áreas cafeeiras paulistas esse ajustamento traduziu-se em grande expansão patrimonial e cultural. ${ }^{218}$

A criação de uma diocese em Taubaté, área geográfica já marcada, à época, pelo traço do decadentismo econômico, pode ser creditada, salvo melhor juízo, mais pelo fato da cidade se constituir como centro regional do vale do Paraíba, do que por sua nascente formação urbano-industrial, materializada pelos cerca de quatrocentos funcionários da Companhia Taubaté Industrial (CTI), uma vez que "a região do Vale do Paraíba estava dividida em três comarcas eclesiásticas que tiveram como 'cabeças de comarca' as cidades de Bananal, Taubaté e Guaratinguetá". 219

A essas elucubrações, some-se outra: além da natural necessidade da Igreja católica operacionalizar uma postura marcadamente patrimonialista, visando com isso contornar as dificuldades materiais com as quais se defrontava, vislumbravam os sacerdotes as possibilidades de abertura de novos "postos de comando", com a ampliação da estrutura episcopal, uma vez que não só a república, mas também a Igreja católica, "tinham objetivos semelhantes de estabelecer influência por todo o país". 220

Isso, por conseguinte, faz vir à tona o peso político de antigos prelados na renovação daquilo que Sérgio Miceli denomina de 'elite eclesiástica brasileira'.

O reparte das circunscrições eclesiásticas expressa ainda o reconhecimento à folha de serviços prestados pelas principais lideranças do episcopado da época, refletindo o poder de pressão de que dispunham junto a seus pares, à nunciatura e ao próprio Vaticano. A margem de influência desses líderes pode ser aferida pela quantidade de promoções ao episcopado

218 PRATTA, Marco Antônio. Mestres, santos e pecadores: educação, religião e ideologia na Primeira República brasileira. São Carlos: Rima, 2002. p. 71.

219 WERNET, Augustin. A Igreja paulista no século XIX. São Paulo: Ática, 1987. p. 21.

220 BRUNEAU, Thomás C. Catolicismo brasileiro em época de transição. São Paulo: Loyola, 1974. p. 68. 
feitas sob sua chancela. A criação da província eclesiástica de São Paulo e a ampla redivisão do estado durante a Primeira República ocorrem na gestão de D. Duarte Leopoldo e Silva. ${ }^{221}$

Às considerações de Miceli cabem aqui outras, a respeito do que na terminologia eclesiástica se compreende como 'sucessão apostólica' e 'linhagem apostólica'.

Por 'sucessão apostólica' entende-se a seqüência dos bispos até o primeiro deles, Pedro, e que se transmite pela sagração canonicamente legítima dos que ocuparam uma mesma diocese ao longo do tempo. A D. Lino Deodato, por exemplo, sucedeu D. Joaquim Arcoverde de Albuquerque Cavalcanti, na então diocese de São Paulo, configurando-se, até nossos dias, a sucessão apostólica da atual arquidiocese paulistana. D. Epaminondas Nunes de Ávila e Silva, por sua vez, inaugura a sucessão apostólica no sólio taubateano.

De maior interesse são os aspectos que envolvem a 'linhagem apostólica', pois dela se depreende não só a quantidade de prelados consagrados por um bispo, mas também a importância política deste e daqueles.

Entendendo que uma consagração episcopal foge aos parâmetros de mera formalidade administrativa, envolvendo, sim, relacionamentos de gratidão entre mestres e ex-alunos de seminários, amizades consolidadas ao longo da vida eclesiástica e fortalecimento de relações políticas que, em muitos casos, transcendem o caráter regional e nacional, observe-se as relações de 'compadrio sagrado' entre os prelados envolvidos em nosso estudo:

O Cardeal Mariano Rampolla del Tindaro ${ }^{222}$, secretário de Estado da Cúria Romana, ${ }^{223}$ foi o consagrante de dezesseis prelados, entre eles D. Joaquim Arcoverde de Albuquerque Cavalcanti ${ }^{224}$ (nove consagrações, incluindo D. Lúcio

221 MICELI, Sérgio. A elite eclesiástica brasileira. Rio de Janeiro: Bertrand Brasil, 1988. p. 66.

222 Disponível em <http://www.cattholic-hierarchy.org/bishop/bram.html> Consulta em 19 de maio de 2005.

223 "A Cúria Romana é um conjunto orgânico de repartições que coadjuvam o Papa no desempenho do seu múnus de Pastor Supremo da Igreja universal. Tal múnus é designado também com os nomes de Santa Sé ou Sé Apostólica, o qual se aplica igualmente à mesma Cúria. [...] A Secretaria de Estado é o órgão central de execução das disposições dadas pelo Chefe da Igreja. Ela mantém as relações com os organismos da Cúria, com o Episcopado, com os representantes da Santa Sé nos vários países, com os governos e com os respectivos representantes, assim como com as pessoas particulares. O Cardeal Secretário de Estado reúne periodicamente, sob a sua presidência, os Cardeais-chefes dos demais organismos". CITTÀ DEL VATICANO. O Vaticano e Roma Cristã. Roma: Tipografia poliglota vaticana, 1973. pp.11-12.

224 Disponível em <http://www.cattholic-hierarchy.org/bishop/barcoverd.html> Consulta em 19 de maio de 2005. 
Antunes de Souza ${ }^{225}$, primeiro bispo de Botucatu).

Apesar de D. Lúcio Antunes de Souza ter sido formado no Seminário de Diamantina, pode-se enquadrá-lo, sem qualquer embargo, no "grupo paulista", em virtude de suas antigas relações com D. Joaquim Arcoverde de Albuquerque Cavalcanti) e de D. Merry del Val e Zulueta, ${ }^{226}$ também secretário de Estado, e com linhagem apostólica de vinte e dois prelados, aí incluídos D. Duarte Leopoldo e Silva $^{227}$ (nove consagrações, incluindo D. Alberto José Gonçalves, ${ }^{228}$ primeiro bispo de Ribeirão Preto) e D. José Marcondes Homem de Melo, ${ }^{229}$ primeiro bispo de São Carlos do Pinhal.

O Cardeal Girolamo Maria Gotti, ${ }^{230}$ Internúncio apostólico do Brasil, e com brilhante carreira na Santa Sé, com quinze consagrações em sua linha episcopal, impôs as mãos em D. João Batista Corrêa Nery, ${ }^{231}$ primeiro bispo de Campinas.

Cada bispo nomeado para uma diocese traz consigo a carga de influências, relativas, de um lado, à gratidão, amizade e reverência, ao prelado responsável por sua consagração episcopal; de outro, à hierarquia, disciplina e obediência, ao prelado que ocupa o comando da província eclesiástica em que se situa sua diocese, além da necessidade de dar continuidade ao projeto político e religioso movimentado pelo bispo a quem substitui.

O levantamento desses dados referenda dois importantes conceitos. Em primeiro lugar, traz à lume os imbricamentos das relações políticas e afetivas,

225 Disponível em <http://www.cattholic-hierarchy.org/bishop/bdesouzala.html> Consulta em 19 de maio de 2005.

226 Disponível em <http://www.cattholic-hierarchy.org/bishop/bmerry.html> Consulta em 19 de maio de 2005.

227 Disponível em <http://www.cattholic-hierarchy.org/bishop/bleos.html> Consulta em 19 de maio de 2005. O sítio registra erroneamente o nome do prelado como Leopoldo Duarte e Silva.

228 Disponível em <http://www.cattholic-hierarchy.org/bishop/bgonga.html> Consulta em 19 de maio de 2005. Ver também POLYANTHEA. Comemoração do cinqüentenário de fundação do Seminário Episcopal de São Paulo: 9 de novembro de 1856 a 9 de novembro de 1906. Alberto José Gonçalves é o nongentésimo vigésimo terceiro ex-aluno de uma relação de 4.486 nomes, conforme consta no apêndice da obra em tela.

229 Disponível em <http://www.cattholic-hierarchy.org/bishop/bhomel.html> Consulta em 19 de maio de 2005. Ver também POLYANTHEA. Comemoração do cinqüentenário de fundação do Seminário Episcopal de São Paulo: 9 de novembro de 1856 a 9 de novembro de 1906. José Marcondes Homem de Mello é o milésimo ducentésimo quadragésimo segundo ex-aluno de uma relação de 4.486 nomes, conforme consta no apêndice da obra em tela.

230 Disponível em <http://www.cattholic-hierarchy.org/bishop/bgotti.html> Consulta em 19 de maio de 2005

231 Disponível em <http://www.cattholic-hierarchy.org/bishop/bcone.html> Consulta em 19 de maio de 2005. Ver também POLYANTHEA. Comemoração do cinqüentenário de fundação do Seminário Episcopal de São Paulo: 9 de novembro de 1856 a 9 de novembro de 1906. João Batista Corrêa Nery é o milésimo ducentésimo trigésimo quarto ex-aluno de uma relação de 4.486 nomes, conforme consta no apêndice da obra em tela. 
consubstanciadas pelo que se pode denominar de 'compadrio sagrado' entre esses prelados, pertencentes àquilo que se pode compreender como 'Igreja paulista', aí orbitando, também, os altos dignitários da Santa Sé com os quais os bispos brasileiros assinalaram amizade.

Em segundo, ratifica as argumentações de Miceli sobre "o processo de 'estadualização' das políticas implementadas pelos detentores do poder eclesiástico", ${ }^{232}$ no qual, à semelhança da descentralização impressa pela "política dos governadores", a Igreja católica procurou emular a mesma estratégia de dominação: descentralizar a estrutura eclesiástica, com a criação de um maior número de dioceses com menor extensão territorial, ao mesmo tempo em que centralizava o seu controle na figura do bispo diocesano, romanizado e obediente à hierarquia, pelo exercício da dominação burocrática imposta ao seu clero, à semelhança da descentralização dos poderes executivos e legislativos federais, em favor das elites estaduais, desde de que seus governadores respeitassem os interesses do Governo Federal. Com a palavra, Pratta:

O maior número de dioceses e bispos intensificava o controle sobre a atuação dos párocos. Realizavam-se periodicamente encontros entre os sacerdotes diocesanos e o respectivo bispo, chamados de retiros espirituais, nos quais a discussão e a meditação sobre a doutrina eclesiástica eram sempre o ponto relevante. ${ }^{233}$

Nos dois casos, pelo controle da burocracia, eclesiástica e civil, conduzia-se o jogo de interesses e conflitos locais, caracterizados pelas disputas patrimoniais entre bispos, no caso eclesiástico, e pelos conflitos entre coronéis e processo eleitoral, no caso civil, sempre em favor de um objetivo central.

No processo de expansão e descentralização da estrutura episcopal, a redução geográfica das dioceses tradicionais, como, por exemplo, a de São Paulo, com sua elevação à condição de Arquidiocese, organizava a dominação burocrática em nível regional, ao mesmo tempo em que submetia o jogo político dos bispos ao arbítrio de uma liderança episcopal estadual.

Assim, a reprodução endógena dos quadros de comando eclesiásticos, nesses limites, não só fortalecia a ação política dessa liderança católica estadual, configurada, no nosso caso, por D. Duarte Leopoldo e Silva, arcebispo de São 
Paulo, como também a reforçava, uma vez que os bispos a ele ligados, pelos laços políticos e afetivos, reproduziam, em suas dioceses, um processo de dominação de feixe convergente a uma única unidade doutrinária. Enfim, uma só lei, uma só fé, um só rei.

A linhagem episcopal de D. Epaminondas ${ }^{234}$ se apresenta, por sua vez, em total dissonância com a 'Igreja paulista'.

Passando por D. Antônio Ferreira Viçoso, ${ }^{235}$ D. Pedro Maria de Lacerda, ${ }^{236}$ D. Silvério Gomes Pimenta ${ }^{237}$ e D. Joaquim Silvério de Souza, ${ }^{238}$ de quem recebeu a sagração episcopal, suas raízes são eminentemente pertencentes à 'Igreja mineira'.

Assim posto, que motivos teriam levado D. Epaminondas, pertencente ao clero mineiro, a ser transferido e ocupar o sólio taubateano? A única hipótese factível, até o presente momento, nos conduz ao seguinte raciocínio argumentativo: ausência de diocese disponível em Minas Gerais. Senão vejamos:Pela Bula Candor Lucis Aeternae, ${ }^{239}$ de 6 de dezembro de 1745, a diocese de São Sebastião do Rio de Janeiro ${ }^{240}$ desanexou território, em favor da criação das dioceses de São Paulo e de Mariana, desmembrando-se esta última para a ereção da diocese de Diamantina, em 6 de junho de 1854. ${ }^{241}$ Serro, cidade natal de D. Epaminondas, e também onde unicamente exerceu seu paroquiato, pertence à diocese de Diamantina.

Em 7 de outubro 1900, a diocese de Mariana novamente desmembra-se para a formação da diocese de Pouso Alegre, enquanto que, em 8 de setembro 1907, as dioceses de Campanha e Uberaba são reduzidas, respectivamente, de São Paulo e de Goiás. Até então, Minas Gerais contava com cinco dioceses.

234 Disponível em <http://www.cattholic-hierarchy.org/bishop/bavisil.html> Consulta em 19 de maio de 2005.

235 Disponível em <http://www.cattholic-hierarchy.org/bishop/bferrvi.html> Consulta em 19 de maio de 2005.

236 Disponível em <http://www.cattholic-hierarchy.org/bishop/blace.html> Consulta em 19 de maio de 2005.

237 Disponível em <http://www.cattholic-hierarchy.org/bishop/bgompi.html> Consulta em 19 de maio de 2005.

238 Disponível em <http://www.cattholic-hierarchy.org/bishop/bsiso.html> Consulta em 19 de maio de 2005.

239 LUSTOSA, Oscar de Figueiredo. Situação religiosa da capitania de São Paulo na palavra de seu bispo, D. Frei Manuel da Ressurreição, Revista de História, v. LII, n. ${ }^{\circ}$ 104, Ano XXVI. out./dez, 1975. p. 909.

240 Disponível em <http://www.catholic-hierarchy.org/diocese/dsase.html> Consulta em 19 de maio de 2005.

241 Disponível em <http://www.catholic-hierarchy.org/diocese/dmari.html> Consulta em 19 de maio de 2005. 
Note-se que, no decorrer do ano de 1909, ${ }^{242}$ apenas três bispos são consagrados no Brasil: D. Alberto José Gonçalves, consagrado em 2 de fevereiro por D. Duarte; D. Epaminondas, consagrado em 8 de setembro por D. Joaquim Silvério de Souza, e D. João de Almeida Ferrão, ${ }^{243}$ consagrado em 19 de setembro por D. Arcoverde.

Mariana já era, nessa época, uma Arquidiocese, e estava muito além das pretensões de um bispo recém consagrado. Diamantina, a segunda diocese do Estado, tinha como titular ninguém menos que o consagrante de D. Epaminondas.

D. João Almeida Ferrão, que fora padre na cidade sede dessa diocese, e D. Antônio Augusto de Assis, ${ }^{244}$ ambos consagrados por D. Arcoverde, foram nomeados respectivamente para as dioceses de Campanha, "extensão lógica do interior de São Paulo" ${ }^{245}$, e Pouso Alegre.

A última diocese mineira restante, Uberaba, era ocupada por D. Eduardo Duarte Silva, ${ }^{246}$ que fora consagrado pelo Cardeal Lúcido Maria Parocchi. ${ }^{247}$

Das cinco dioceses mineiras então existentes, somente duas, Pouso Alegre e Campanha, poderiam ser ocupadas por um bispo de consagração recente, e apenas a última abria-se para sucessão apostólica.

Sendo a diocese de Taubaté, como se sabe, criada em 7 de junho de 1908, a momentânea vacância da diocese de Campanha, parece, só se justifica ao admitirmos que a mesma foi adrede destinada a D. João de Almeida Ferrão, seja por uma maior proximidade com seu bispo, seja pelo 'compadrio sagrado' com D. Joaquim Arcoverde.

Não havia, portanto, para D. Epaminondas, diocese disponível em território mineiro; somente em 10 de dezembro de 1910 seria ereta, em Minas Gerais, uma nova diocese: Montes Claros.

A exposição anterior, em conseqüência, assume especial relevância para

242 Disponível em <http://www.cattholic-hierarchy.org/events/b1909.html> Consulta em 19 de maio de 2005.

243 Disponível em <http://www.cattholic-hierarchy.org/bishop/balmfer.html> Consulta em 19 de maio de 2005.

244 Disponível em < http://catholic-hierarchy.org/bishop/bdeassis.html> Consulta em 19 de maio de 2005.

245 WIRTH, John D. O fiel da balança: Minas Gerais na federação brasileira, 1889-1937. Rio de Janeiro: Paz e Terra, 1982. p. 41.

246 Disponível em < http://www.catholic-hierarchy.org/bishop/bduasi.html> Consulta em 23 de maio de 2005.

247 Disponível em < http://www.catholic-hierarchy.org/bishop/bparoc.html> Consulta em 24 de maio de 2005. 
um perfeito entendimento dos conflitos desenrolados em prol das questões envolvendo a necessidade de acumulação patrimonial das novas dioceses paulistas.

Perceba-se, pois, a inserção de um bispo do 'clero mineiro' no 'clero paulista', totalmente alheio ao jogo político desses prelados e completamente desvinculado do 'compadrio sagrado' que os unia.

Some-se a isso - apanágio e obrigação dos bispos - a consciência de D. Epaminondas em defender os interesses espirituais e patrimoniais de sua diocese, a drenagem de recursos provocada pela presença em seu território de nada menos que um Santuário de Aparecida, excluído que fora de sua órbita de administração, e potente catalisador de missas, batizados e donativos, para que se dimensione as dificuldades enfrentadas, pela diocese, em seus primeiros momentos.

É necessário perceber que a estruturação da Igreja católica, à época, exigia de seus bispos muito mais do que uma prosaica administração cotidiana. Esperavase uma postura agressiva, como parte do tipo-ideal desses prelados, semelhante aos atuais moldes empresariais, buscando, com isso, a hegemonia do catolicismo frente às demais religiões.

Um breve exame no excerto abaixo, da lavra do Padre Ascânio Brandão, biógrafo de D. Epaminondas:

O Primeiro Bispo de Taubaté teve, o que se poderia denominar, duas santas manias, dois ideais, duas idéias fixas durante todo o seu laborioso e fecundo episcopado: - Imprensa e Seminário. Mal se pôs em contato com o seu clero e povo já sem demora exige: - um Seminário, e um jornal Diocesano. ${ }^{248}$

As "santas manias" de D. Epaminondas se explicam, a despeito da emoção de seu biógrafo. A bem da verdade, essa nova elite de prelados se via compromissada em um programa de realizações que deveria ser levado avante, em consonância com as expectativas da hierarquia responsável por suas nomeações.

Nas mãos desses bispos-empresários, portanto, o projeto de edificação ou de melhorias do palácio episcopal, construções ou reformas de igrejas, criação de escolas, implantação de seminário diocesano e fundação de jornais católicos, constituíam muito menos uma simples e solta "santa mania", e muito mais uma obrigação a ser cumprida. À semelhança de uma manobra bélica de caráter ofensivo, o projeto nacional de romanização, desmembrado em diversos projetos

248 BRANDÃO, Ascânio da Cunha. Dom Epaminondas. São Paulo: Oficinas gráficas da Ave Maria, 1941. p. 92. 
regionais, encetava seu curso com a "conquista territorial", materializada pela criação e pela implantação jurídica das dioceses, devendo ser secundado com as diversas "ações de ocupação". O transcendente, portanto, poderia esperar. Valia o imanente. O futuro é agora.

Até pelo sentido da carreira eclesiástica, essas ações assumiam um sentido de necessidade que ultrapassava o material. Trata-se, ao mesmo tempo, de uma aplicação prática da dominação burocrática nas suas três esferas, e de uma propaganda pessoal em favor de uma promoção.

Racionalmente, o bispo e seus subordinados crêem nos estatutos que fundamentam o exercício do direito de mando do primeiro sobre os últimos. Sua nomeação assegura sua plena capacidade técnica nesse exercício, e a hierarquia a regulamenta.

Tradicionalmente, crêem na santidade e harmonia dessa relação hierárquica, fundamentada na obediência e na disciplina, o que assegura um completo comprometimento do clero paroquial para com seu bispo diocesano.

Carismaticamente, esses subordinados vêem seu prelado como exemplo de virtude, cujas ações e decretos visam somente o melhor para a comunidade diocesana.

Para que essas três esferas de dominação burocrática sejam aplicadas em sua plenitude, especialmente para as duas últimas, a ação do bispo deverá ser entendida pelo seu clero, e pela comunidade; daí a necessidade do jornal combativo, para a divulgação do projeto e para a depreciação dos protestantes e espíritas, e do seminário diocesano, para a formação de seu clero.

Quanto ao sentido de propaganda, a ação desse bispo, seu reconhecimento entre os subordinados e, principalmente, seus resultados na administração patrimonial de sua diocese, e no combate aos inimigos da Igreja, colocavam-no em evidência para seu arcebispo metropolitano, o que lhe serviria bem para sua carreira eclesiástica.

Num momento em que a Igreja católica lutava pelo monopólio do sagrado com as confrarias leigas e com as confissões protestante e espírita, esse instrumental, renovado e exacerbado pelo ultramontanismo, figurava como a principal ferramenta dos bispos na condução de suas dioceses.

O sucesso dessa condução, nos sentidos espiritual e material, servia à contenção dessas forças, e demonstrava o comprometimento dos prelados com a 
causa católica, destacando-os entre seus pares.

Depreende-se que a obra de D. Antônio Joaquim de Melo, portanto, prosseguia, e revivificava-se, agora não mais como 'reação' ao modelo aprisionador do Império, mas como 'ação' inteiramente apropriada ao modelo liberal republicano. O gargalo do Padroado não mais as refrearia, frente ao que trazia a nova realidade.

Destarte, foram comuns os conflitos entre os bispos, as confrarias e irmandades leigas, além das pendências judiciais com autoridades republicanas.

Expressões típicas do catolicismo luso-brasileiro, as confrarias e irmandades se distinguem pelo fato das primeiras se caracterizarem como agremiações cuja finalidade principal, mas não única, se prendia ao culto ao seu santo padroeiro, enquanto que as segundas concentravam seus esforços na construção e manutenção de hospitais e abrigos para indigentes. A intervenção de Wernet:

A direção de todas essas entidades religiosas estavam em mãos de leigos. Os confrades elegiam uma diretoria - A Mesa Provedora -, que tinha o poder para deliberar e decidir sobre todos os negócios da confraria, tendo o capelão exclusivamente atribuições religiosas, podendo, inclusive, o seu contrato ser renovado ou não. Também o ordenado do capelão era fixado pela "Mesa". Foram consideradas, entre outras, atribuições do padre: "rezar as missas", "distribuir os sacramentos", "fazer as bênçãos", "visitar os doentes", "encomendar os corpos" e "confessar os irmãos". Reconhecendo como "inspeção externa" o Imperador e o seu vice-regente, o Presidente da Província, as confrarias sobrepunham-se, muitas vezes, à autoridade eclesiástica, especialmente quando as pessoas que integravam a Mesa provedora eram da mais alta representatividade econômica e social. Cada confraria era, aliás, uma entidade autônoma não havendo confederação de confrarias, nem mesmo daquelas que se dedicavam ao mesmo fim. ${ }^{249}$

Tais instituições, como é sabido, ocupavam um espaço deixado vago pela estrutura paroquial, na medida em que esta estava incapacitada de atender as necessidades religiosas das populações, especialmente do interior, seja pela não presença, seja pelo discurso.

Essencialmente caracterizadas pela participação do leigo na direção administrativa e no "comando" do culto, as confrarias amealharam vasto patrimônio. Aplicando seus próprios recursos na construção de capelas e igrejas, essas instituições colhiam os frutos das esmolas e contribuições pias, além dos lucros das

249 WERNET, Augustin. A reforma do clero paulista de Dom Antônio Joaquim de Melo. In: Revista da Sociedade Brasileira de Pesquisa Histórica - SBPH - Anais da III reunião - São Paulo - 1984. p. 126. 
festas religiosas por elas promovidas, onde o catolicismo luso-brasileiro sempre teve local de destaque, criando quase que uma estrutura religiosa paralela, administrada por leigos.

O próprio D. Epaminondas, quando vigário em Serro, não descuidou de alinhar as irmandades ao espírito ultramontano:

Reformou as velhas Irmandades de Serro, já na rotina e descuidadas algumas dos seus Estatutos e tradições. Afastou elementos duvidosos, reformou compromissos, e, sobretudo exigiu de todos os seus membros a prática dos sacramentos. Quem conhece a força e o poder das velhas Irmandades brasileiras envenenadas de espírito maçônico e liberal há de saber avaliar a prudência e a luta do Vigário do Serro para reformá-las discreta e caridosamente, como o fez, sem alarde, sem barulho, sem ofender a quem quer que fosse. ${ }^{250}$

Referenda-se, pois, a influência dessas agremiações, conforme os ensinamentos de Augustin Wernet, que apresenta a existência de cinqüenta e cinco confrarias na região do Vale do Paraíba em meados do século XIX, "destacando-se numericamente as de Nossa Senhora do Rosário, do Santíssimo Sacramento e de São Benedito," ${ }^{251}$ para apenas vinte paróquias existentes.

As agremiações leigas, fruto da ausência eclesiástica efetiva nas regiões mais carentes e interiores, concorriam com as paróquias na questão patrimonial, colhendo recursos financeiros decorrentes de doações e festas, com vantagem, pelo seu discurso alinhado com o catolicismo luso-brasileiro.

Note-se que as confrarias dedicadas a Nossa Senhora do Rosário e a São Benedito representam uma expressão religiosa de uma população marginalizada, tanto pelas instituições civis quanto pelas eclesiásticas, desde os tempos coloniais.

Nossa Senhora do Rosário, já na época do ouro das Minas Gerais, era a principal padroeira das capelas dedicadas ao culto dos escravos africanos e alforriados, negros e mulatos. São Benedito é o santo negro com o qual essa população se identificava.

Tanto o catolicismo ultramontano, quanto a percepção político-cultural das elites que conduziam o Brasil no início da república, tinham uma noção essencialmente européia da realidade social brasileira, com forte traço racista,

250 BRANDÃO, Ascânio. Dom Epaminondas. São Paulo: Oficinas gráficas da Ave Maria, 1941. p.5354.

251 WERNET, Augustin. A Igreja paulista no século XIXIX. São Paulo: Ática, 1987. p. 21. Encaminho o leitor para WERNET, Augustin. Antigas Irmandades e Novas Associações Religiosas, Revista da Sociedade Brasileira de Pesquisa Histórica - SBPH - Anais da X Reunião - Curitiba - 1992. pp. 5561 , onde o autor especifica, detalhadamente, as invocações dessas cinqüenta e cinco confrarias. 
fundamentado nas teorias evolucionistas e deterministas do final do século XIX.

As capelas, igrejas e festas dessas confrarias atingiam populações que estavam fora do alcance da estrutura paroquial, em regiões onde muitas vezes representavam a única expressão do sagrado. Mesmo nas áreas onde a Igreja estava presente, essas agremiações atuavam de forma paralela às paróquias.

Tais populações, marginalizadas e mestiças, traziam consigo uma carga cultural de heranças africanas e indígenas, que se manifestavam na forma de sincretismo e de um catolicismo luso-brasileiro, tornando o discurso do catolicismo oficial ainda mais distante de sua realidade.

Nesse terreno, fertilizado por tais manifestações, floresciam confrarias leigas, regadas por contribuições e doações de uma população fiel, dissociada do catolicismo reformado, e muito distante da realidade urbana do centro sul.

Com a reforma ultramontana as resistências serão evidentes. Da lavra dos redentoristas bávaros de Aparecida, verificamos os leigos prosseguirem na tentativa de domínio do sagrado. Note-se que o cronista não se refere à confraria, preferindo o termo "sociedade civil". Presentes, como sempre, foguetes e música:

24 de junho de 1896 - Foi celebrada a festa de S. João, por uma sociedade civil. Na véspera, muitos foguetes no ar; na festa mesmo também, mas menos, desde alta manhã até a missa (10h) Celebrante foi o Cônego Joaquim, que está ligado aos promotores da festa; medonho porém, foi à noite; não podia faltar música, naturalmente... ${ }^{252}$

$\mathrm{Na}$ realidade social da paróquia, sacerdotes e confrades se conheciam, e muitas vezes cooperavam entre si, até porque a direção dessas sociedades civis, assim como a ampla maioria da população, era católica e seguia, sem maiores questionamentos, os ditames estabelecidos pela Igreja. A divergência estava no discurso, enquadrado no catolicismo luso-brasileiro e combatido pelo catolicismo romanizado.

Como se pode verificar, os usos e abusos, ainda remanescentes dos períodos colonial e imperial, faziam as mesas administrativas dessas confrarias não transigirem aos avanços da autoridade episcopal.

Os prelados, por sua vez, buscavam inicialmente um caminho de diálogo, procurando compartilhar a administração, com indicações de nomes de confiança, para os cargos de provedor ou tesoureiro.

252 ACPSR. Crônica da Comunidade Redentorista de Aparecida, v. I (1894-1907). p. 53. 
Esgotadas essas possibilidades de acomodamento, não Ihes restava outra solução senão a ameaça de interdição dos bens e, caso extremo, a destituição sumária dos dirigentes dessas sociedades, apoiados nas prescrições legais que os viam como responsáveis pelos assuntos temporais da Igreja.

$\mathrm{Na}$ medida em que o processo de expansão da estrutura eclesiástica se intensificava, com a crescente necessidade de garantir o 'monopólio do sagrado', também consubstanciado pelo aumento de bens patrimoniais para a operacionalização das novas dioceses, intensificava-se, também, a ação paroquial e episcopal contra essas confrarias, detentoras que eram de fontes de recursos de que as dioceses necessitavam para levar a cabo a obra desejada pela elite eclesiástica.

O fortalecimento dessa estrutura, sobre as confrarias, reduzia a concorrência na questão da coleta de doações, ao mesmo tempo em que agregava o seu patrimônio à diocese.

A ampliação de uma ação de presença efetiva da Igreja no território diocesano, ao mesmo tempo em que se desmontava o aparato leigo, espiritual e materialmente, aproximava da população marginalizada do interior o discurso do catolicismo oficial, minimizando ou eliminando qualquer discurso dissidente, e revertendo as doações destinadas a tal aparato à ação administrativa das paróquias.

Por sua parte, os administradores leigos, não desejando perder o controle dos consideráveis valores envolvidos, não hesitavam em conduzir o assunto para a esfera jurídica, mas "os prelados quase sempre levavam a melhor, obtendo ganho das causas julgadas em tribunais civis." 253

A interpretação da legislação da Primeira República pelas autoridades civis tendia a favorecer a Igreja. Trata-se da extensão da dominação burocrática em sua esfera tradicional, que permeava a mentalidade luso-brasileira na época, para além da instituição eclesiástica.

A retomada de bens imóveis, outrora pertencentes à Igreja e que, por abandono ou mesmo por transações legais, haviam se transferido para o governo, constituíram o cerne das querelas entre prelados e autoridades públicas.

Segundo Sérgio Miceli, o caso mais interessante envolveu inicialmente o já citado D. João Batista Corrêa Nery, primeiro bispo de Campinas, mas também o primeiro do Espírito Santo e de Pouso Alegre.

253 MICELI, Sérgio. A elite eclesiástica brasileira. Rio de Janeiro: Bertrand Brasil, 1988. p. 124. 
Por ocasião de seu múnus episcopal no Espírito Santo, D. Nery solicitou ao Vaticano a incorporação do convento e do Santuário da Penha à cúria diocesana, tendo sido atendido em sua pretensão em 1899.

Em 1911, o segundo bispo, D. Fernando de Souza Monteiro, ${ }^{254}$ demandou contra a iniciativa de seqüestro desses bens imobiliários por parte do Ministro da Justiça, obtendo ganho de causa. ${ }^{255}$

Mister se fazia, portanto, que cada um buscasse mostrar, nessa corrida pela dilatação e pela dominação territorial do catolicismo, seu talento e comprometimento com a causa de uma Igreja católica que tinha pressa, sendo natural, também, que tal procedimento tenha contribuído "para o acirramento da concorrência entre os próprios prelados". ${ }^{256}$ Em vista disso, deveriam os bispos providenciar, por si mesmos, o próprio sustento:

XI. Para o que pertence à côngrua de subsídios pecuniários tanto ao Arcebispo da Igreja metropolitana de São Paulo no Brasil, como aos outros bispos das novas dioceses e do que necessitem às despesas do culto e para outras coisas que ocorrem nas necessidades diocesanas, Sua Santidade constituiu e designou, por patrimônio, todas as rendas, proventos e bens que para este fim os fiéis de cada uma das mesmas dioceses já ofereceram e para o futuro oferecerem.

Visto como nestas novas dioceses, bem como nas outras da República Brasileira, não existem outros bens a não ser os que provêm da liberalidade dos fiéis, não duvida Sua Santidade que também no futuro os habitantes, quer da Arquidiocese, quer, principalmente, das novas dioceses, contribuam com os meios necessários para a sustentação dos bispos e dos clérigos e manutenção das obras diocesanas. ${ }^{257}$ (os grifos são nossos)

Em vista disso, pode-se entender, perfeitamente, esse espírito de concorrência entre os prelados, cada qual buscando garantir, aos olhos da hierarquia de uma Igreja que abria tantas frentes, promoções e melhores locais de serviço.

Esse desejo, perfeitamente humano, pode ser materializado nas ações pastorais de cunho europeizado e, também, em gritante maioria, nas questões movidas contra as irmandades, as confrarias e o governo.

254 Disponível em <http://www.catholic-hierarchy.org/bishop/bsoum.html> Consulta em 10 de julho de 2005.

255 MICELI, Sérgio. A elite eclesiástica brasileira. Rio de Janeiro: Bertrand Brasil, 1988. p. 134.

256 MICELI, Sérgio. A elite eclesiástica brasileira. Rio de Janeiro: Bertrand Brasil, 1988. p. 22.

257 ACMSP. Sagrada Congregação Consistorial: "Da Constituição de Nova Província Eclesiástica em São Paulo - Brasil", Item XI. 7 de julho de 1908. Fotocópia datilografada. Inédito. 
Dentro de uma mesma província eclesiástica, cada bispo procurava sobrepujar em brilho pastoral e administrativo os seus pares, ao mesmo tempo em que defendia os interesses de sua diocese nas diversas pendências, fosse com quem fosse, arquidiocese incluída.

De fato, uma relação complexa, em que pesavam sobre a cabeça de um bispo diocesano as responsabilidades para com a expansão da fé católica, materializadas nas ações contra o protestantismo e contra o espiritismo, nos compromissos para com seu clero e para com sua comunidade, compromissos esses consubstanciados na gestão e na defesa do patrimônio diocesano, além da obediência e da lealdade para com a hierarquia, figuradas no arcebispo metropolitano e no padrinho de consagração.

Isto posto, num caldo em que se cozinhavam ingredientes tão distintos e de temperos tão fortes, os dissabores entre prelados provavelmente acarretavam, por vezes, desarmonias e desentendimentos.

Tais situações, no entanto, são pouco trabalhadas, talvez devido à ausência de corpus documental ou, caso o mesmo exista, considere-se sua pouca acessibilidade aos pesquisadores, ficando os mesmos na conta dos conflitos havidos na ordem interna da Igreja católica.

Em outras palavras, as contendas envolvendo unicamente o próprio quadro episcopal, quando se trata de conduzir o inevitável, mas necessário, processo de acumulação patrimonial, são poucas, e as referências ao tema, por parte dos também poucos historiadores que nele transitam, são lacônicas.

Wernet, conforme visto em citação anterior, nos reporta à situação de miséria em que se viram expostas antigas dioceses, bem como o auxílio prestado pelo Santuário de Aparecida, para a manutenção da arquidiocese de São Paulo, quando de sua desanexação, possibilitando, assim, o levantamento desse problema, ainda que em termos abrangentes.

Ney de Souza, por sua vez, se reporta aos problemas decorrentes de gestão patrimonial, ocasionados após a instalação, em 1908, das dioceses no estado de São Paulo, citando o caso de Botucatu e o de Taubaté, ainda que em não mais de uma página.

O caso de Botucatu, bastante brando em relação ao de Taubaté, mas não menos digno de se configurar como uma questão envolvendo patrimônio, mereceu do historiador apenas um parágrafo. 
Pelo reforço que traz à questão, mostrando com isso que D. Epaminondas não foi o único bispo a reclamar, nesse sentido, os direitos de sua diocese e, principalmente, pela carência de material temático anteriormente escrito a este trabalho, transcrevemo-lo:

Após a instalação das dioceses, o arcebispo encontrou contrariedade com relação a duas novas sedes episcopais: Botucatu e Taubaté. O bispo de Botucatu, Dom Lúcio Antunes de Souza, sentia-se insatisfeito com as determinações fixadas na questão patrimonial. Dom Duarte e Dom Lúcio trocaram algumas cartas sobre o assunto, resultando disso um profundo mal-estar entre o metropolita e seu sufragâneo...

D. Lúcio, como sabemos, pertencia ao grupo 'paulista'. Além disso, foi consagrado por D. Joaquim Arcoverde, que teve como sucessor apostólico justamente D. Duarte. A solução não tardou:

...Durante uma visita do Cardeal Arcoverde ao seminário menor de Pirapora, Dom Duarte e Dom Lúcio tiveram a oportunidade de se encontrarem pessoalmente. Segundo a documentação, bastou esse encontro para resolver e esclarecer toda a situação pendente. ${ }^{258}$

Ao que parece, quando se trata de pendências entre bispos, as relações de amizade e lealdade do compadrio sagrado prevalecem sobre a hierarquia. O bispo diocesano contesta seu arcebispo metropolitano, mas acata a prescrição desfavorável de seu padrinho na linhagem apostólica. E tudo fica bem resolvido.

Por sua vez, o cardeal em questão estava vinculado ao arcebispo metropolitano, seu sucessor apostólico, quanto ao projeto desempenhado na diocese onde fora titular.

Júlio Brustoloni é mais pontual. Apesar de também não aprofundar o tema, o contributo do historiador redentorista configura, do mesmo modo, essa 'concorrência', materializada na "Questão de Aparecida”, objeto do próximo capítulo. Ei-lo:

A Arquidiocese de São Paulo foi criada pelo Papa Pio $X$ a 7 de junho de 1908. O vale do Paraíba, desde o município de Jacareí até o de Queluz ficou sendo território da nova diocese de Taubaté. Naturalmente o Santuário de Aparecida deveria pertencer a ela. Entretanto, a título de prover uma pastoral eficiente para o Santuário e, especialmente, para fundar e manter o Seminário Central do Ipiranga para toda a Província eclesiástica que coincidia com os limites do Estado de São Paulo, Dom Duarte Leopoldo e Silva, bispo de São

258 SOUZA, Ney de (org.). Catolicismo em São Paulo: 450 anos de presença da Igreja católica em São Paulo (1554-2004). São Paulo: Paulinas, 2004. p. 417. 
Paulo e Dom Joaquim Arcoverde, Cardeal-arcebispo do Rio de Janeiro, fizeram o jogo diplomático para reter para a Arquidiocese de São Paulo, o rendoso Santuário de Aparecida. A nova diocese de Taubaté ficou prejudicada com a divisão esdrúxula e amargas eram as queixas de seu primeiro bispo Dom Epaminondas, que contava com minguados recursos para manter sua diocese. ${ }^{259}$ (os grifos são nossos)

Note-se que uma das justificativas para a arquidiocese ter como legítima a sua gestão sobre rendas de Aparecida, estruturava-se na manutenção de um seminário central utilizado por todas as dioceses da província eclesiástica.

Tal fato traz a luz uma outra dimensão para a necessidade de abertura dos seminários diocesanos, particularmente o de Taubaté; se o seminário do Ipiranga deixasse de ser o único da província, os argumentos a favor da Arquidiocese de São Paulo quanto a questão das rendas de Aparecida seriam reduzidos.

A mesma Bula de criação das novas dioceses paulistas, que determina a administração direta da Arquidiocese de São Paulo sobre o Santuário de Aparecida, possui, porém, interessante ressalva no item XII.

Foi justamente essa ressalva que motivou todo o jogo diplomático, na expressão de Júlio Brustoloni, movido por D. Duarte e por D. Arcoverde, os atritos entre D. Epaminondas e aquele e, certamente, as contrariedades de D. Lúcio, estas rapidamente acomodadas.

Em atenção à preeminência da Igreja episcopal de São Paulo, no Brasil, e de suas peculiaridades necessidades, Sua Santidade concedeu, temporariamente, a faculdade de receber ofertas que sob qualquer ônus forem oferecidas pelos fiéis ao templo sagrado de Nossa Senhora Aparecida, de modo que depois de suprido o referido templo sagrado, tirando-se certa parte que o executor designado para este decreto consistorial constituiu, sejam aplicadas nas despesas que cada ano o Arcebispo de São Paulo no Brasil tiver em sua arquidiocese, o resto será aplicado em obras produtivas, destas rendas, conforme determina o mesmo executor; o Arcebispo de São Paulo, no Brasil, poderá dispor para atender às necessidades. Enquanto durar esta modalidade, o arcebispo será obrigado cada ano a dar conta aos bispos da sua província de sua administração. Logo, porém, que seja constituído o patrimônio para a mesa arquiepiscopal da Igreja de São Paulo no Brasil, as rendas provenientes das ofertas do templo sagrado sob o título de Nossa Senhora Aparecida, serão divididas entre as dioceses desta nova província eclesiástica, pela razão que a Sé Apostólica assim

259 BRUSTOLONI, Júlio J. História da administração do Santuário de Aparecida. Aparecida: Inédito, 1998. pp. 35-36. 
decidiu. ${ }^{260}$ (os grifos são nossos)

Havia, portanto, a clara perspectiva de que as rendas do Santuário de Aparecida fossem divididas entre as dioceses da província eclesiástica, mas, o decreto, como se pode verificar, é totalmente omisso em relação aos prazos.

Daí para a frente, ignora-se o período em que D. Duarte se obriga a prestar contas aos bispos sufragâneos e, em conseqüência, quando esses mesmos bispos poderão ter acesso à parte dessas rendas.

Em tempos de dificuldades de implantação dos novos bispados, e considerando a localização do Santuário em território da diocese de Taubaté, depreende-se a insatisfação gerada, máxime a de D. Epaminondas.

Como prelado diocesano de um bispado não contemplado com tão vultosa fonte de recursos, posto que, pelos critérios de divisão geográfica das dioceses paulistas, deveria pertencer o Santuário à gestão de Taubaté, D. Epaminondas, um bispo de raízes mineiras e de linhagem apostólica completamente diversa do quadro episcopal 'paulista', não sentia nenhum constrangimento ao defender os interesses diocesanos, utilizando-se das ferramentas que dispunha.

Logo no início de seu apostolado no sólio taubateano, D. Epaminondas funda o periódico 'O Lábaro', editado pelo secretário da Cúria Diocesana, para manifestar a palavra oficial da diocese. 'O Lábaro' apresentava-se para a comunidade fiel como um estandarte a guiar os católicos,

[...] flutuando sempre desfraldado, sobre o paupérrimo batel da Igreja Taubateana, até que Deus toque, com a força de sua divina justiça, os corações daqueles que lhe devem restituições, a fim de que seu timoneiro possa encetar as obras que lhe inspiram o seu zelo apostólico e as responsabilidades episcopais. ${ }^{261}$ (os grifos são nossos).

Tal maneira de se apresentar, de forma tão contundente, expõe à comunidade diocesana a divergência de seu bispo para com as autoridades eclesiásticas, representadas pelo Arcebispo Metropolitano de São Paulo, pelo Cardeal Arcebispo do Rio de Janeiro e pelo Núncio Apostólico, responsáveis pela Constituição da nova Província Eclesiástica de São Paulo, no tocante à exclusão do Santuário de Nossa Senhora Aparecida da esfera administrativa da diocese de Taubaté.

260 ACMSP. Sagrada Congregação Consistorial: "Da Constituição de Nova Província Eclesiástica em São Paulo - Brasil", Item XII. 7 de julho de 1908. Fotocópia datilografada. Inédito.

261 O Lábaro, n. ${ }^{\circ} 1$, I. 9 de Janeiro de 1910. 
Ocorre que, desde o início do ano de 1908, momento em que ainda se especulava sobre a divisão da diocese de São Paulo, e quanto a quem seria o bispo indicado para Taubaté, a questão da intenção de se subordinar o dito Santuário à futura Arquidiocese tornara-se pública, com a divulgação pela imprensa da viagem de D. Duarte à Roma, para tratar especificamente sobre esse assunto, o que de certa forma canalizava para a figura do futuro metropolita toda a decepção, do clero e da população fiel, quanto ao resultado dessa querela.

A população católica de Taubaté, em visão emotiva, punha na conta de traição a atitude de D. Duarte pelo simples fato de ser ele taubateano de nascimento. Não consideravam, todavia, suas atribuições e responsabilidades na gerência de uma Província Eclesiástica, localizada em uma região que despontava como maior centro econômico do país e, principalmente, palco de um projeto regional de romanização muito mais abrangente que os limites territoriais taubateanos. Cabia a D. Duarte, sim, prosseguir a amplitude da obra de D. Joaquim Arcoverde, planejada em 1890.

Dessa visão, acolhida por alguns órgãos da imprensa, resultavam inúmeras críticas à Arquidiocese, e à pessoa do arcebispo, publicadas em diversos periódicos da cidade, às vezes em forma de ofensas.

Em janeiro de 1909, em artigo atribuído a Monsenhor Miguel Martins, o periódico taubateano 'A Federação' publicou manifestações que tiveram forte repercussão na imprensa taubateana, e nas Cúrias episcopais de toda Província eclesiástica, encaradas como desrespeitosas à figura do Arcebispo Metropolitano, em questão compreendida como de exclusividade episcopal.

Tais proposições mobilizaram as Sés episcopais paulistas, de forma que os bispos de Botucatu, Campinas, São Carlos e Ribeirão Preto, manifestaram seu apoio ao arcebispo metropolitano por meio de correspondência privada e oficial, censurando e condenando D. Epaminondas e o suposto autor do artigo.

Monsenhor Miguel Martins apressou-se em se explicar. Durante um deslocamento para Uberaba, em visita a diocese de Campinas, o referido padre teria dito a D. João Batista Corrêa Nery que "[...] o que se escrevia em Taubaté não era dele; que sabia que haviam informado V. Ex. ${ }^{a}$ Rev. ${ }^{\text {ma }}$ [D. Duarte] de que ele era o autor dos artigos da Federação; mas que isso era calúnia”, e sobre a suposta complacência de D. Epaminondas: “[...] que o Sr. Bispo esteve fora, no Congresso Mineiro, e portanto não podia intervir". 
D. Nery, que como já sabemos, havia sido o primeiro bispo de Pouso Alegre, era o prelado mais próximo de D. Epaminondas dentro do episcopado paulista, talvez até por suas raízes mineiras. Em sua correspondência, procurou esclarecer a questão a D. Duarte: “[...] Não é verdade, portanto, que Monsenhor Martins me dissesse que o que se escrevia era com anuência de D. Epaminondas". ${ }^{262}$

A partir desses episódios, as relações entre o bispo de Taubaté e seu arcebispo metropolitano tornaram-se mais ásperas. O prelado diocesano não mais teria porque se furtar a estender sua divergência, tanto às esferas superiores da Igreja, por meio de reclamação ao Cardeal Secretário da Sagrada Congregação Consistorial, ${ }^{263}$ o que exigiria uma resposta por parte de D. Duarte, quanto à justiça civil. Bastaria apenas um pretexto que justificasse.

É nesse contexto, pois, que se enquadra a questão do legado 'Wanderley'.

\subsection{O "Legado Wanderley"}

Nas primeiras cartas, escritas por D. Epaminondas a D. Duarte, o tratamento epistolar não poderia ser mais cerimonioso e pleno em demonstrações de humildade e obediência.

Em diversos momentos o metropolita de São Paulo é tido por D. Epaminondas na conta de "meu venerando, distintíssimo e amadíssimo Pai - Ex. mo Sr. Arcebispo". Ao ler seus conteúdos, não se poderia imaginar as pesadas nuvens que em breve iriam pairar sobre o relacionamento dos dois prelados:

[...] Ainda não tive comunicação oficial de minha imerecida nomeação para indigníssimo Bispo de Taubaté e nem recebi os Breves a que aludis. [...] Aceitai a renovação da expressão sincera de minha profunda gratidão e lançai caridosamente a vossa santa bênção sobre este pobre ser (que mal serviria para padre e do qual querem fazer um bispo) acreditando nos sentimentos de respeitosa estima e imensa veneração com que honra-me de assinar-me vosso humilde servo, amigo e admirador. Serro, 17 de Janeiro de 1909 Pe. Epaminondas

262 ACMSP. Carta de D. Nery a D. Duarte. 28 de janeiro de 1910.

263 "A Sagrada Congregação para os bispos, outrora Consistorial, instituída em 1588, tem competência sobre as Igreja locais e seus pastores, em todos os países que não estão confiados às Sagradas Congregações para as Igrejas Orientais e para a Evangelização dos Povos. A congregação ao serviço dos Bispos cuida da criação e das modificações territoriais das dioceses, prepara as nomeações dos Bispos, interessa-se pela atividade pastoral dos mesmos e pelo estado das dioceses, acompanha o desenrolar-se dos Concílios Provinciais (ou seja, das províncias eclesiásticas que compreendem mais do que uma diocese da mesma nação) e os trabalhos das Conferências Episcopais Nacionais, examinando as respectivas atas. Estabelece os assuntos a tratar em Consistório. Nela estão inseridas duas Comissões Pontifícias: a Comissão para a América Latina e a Comissão para a Assistência aos Emigrados e aos Itinerantes (turistas, nômades, marítimos etc.)". CITTÀ DEL VATICANO. O Vaticano e Roma Cristã. Roma: Tipografia poliglota vaticana, 1973. p.16. 
Nunes de Ávila e Silva. ${ }^{264}$

Nesta carta D. Epaminondas faz reparos à demora de sua ordenação. No entanto, mais uma vez, não se julga merecedor da dignidade episcopal.

[...] Em cumprimento do que vos prometi em minha última carta escrita no Serro, levo ao vosso conhecimento que por enquanto, ainda não saiu minha nomeação e nem se iniciou o processo canônico. Sr. Bispo D. Joaquim disse-me que supunha nascer esta demora da reorganização das Congregações Romanas. Como havia pedido a ele obter-me espera de um ano, para poder dispor certos negócios penso se prender a este pedido a demora que tem havido. Sentindo-me cada vez mais desanimado de tomar sobre meus fraquíssimos ombros o peso de tamanha responsabilidade, me tenho julgado feliz com esta espera, resignando-me todavia a fazer o que for da vontade de Deus, único pedido que a ele faço constantemente. Se aprouver ao bom Deus que eu galgue tão temeroso calvário, levarei, incontinente, ao vosso conhecimento qualquer notícia que tenha com referência ao caso. [...] Padre Epaminondas Nunes de Ávila e Silva. ${ }^{265}$

A correspondência prossegue e, dessa vez, D. Duarte, além de tomar conhecimento da chegada dos Breves, também é informado de ser, ele próprio, um dos responsáveis pela aceitação de D. Epaminondas para ocupar o bispado.

[...] Somente há 3 dias foi que tive comunicação de já terem sido expedidos os Breves e me apresso a comunicar-vos que ficou combinado com o Ex. ${ }^{\text {mo }} \mathrm{Sr}$. D. Joaquim o dia 8 de setembro próximo para minha sagração. Escrevi ao Ex. ${ }^{\text {mo }}$ Mons. Castro no sentido de determinar ele, conforme deseja, o dia de minha posse. Antecipo-me em dizer-vos que muitíssimo concorreu para triunfar da repugnância que sentia em aceitar cargo tão tremendo a confiança que em mim desperta 0 conhecimento da magnanimidade de vosso coração verdadeiramente paternal e esclarecido. Diamantina, 2 de Agosto de 1909. Padre Epaminondas Nunes de Ávila e Silva. ${ }^{266}$

O tratamento de D. Duarte, em relação a D. Epaminondas é, também, bastante afetuoso: "V. Ex. ${ }^{a}$ poderá facilmente imaginar a alegria e consolação que senti à notícia da próxima sagração e posse do novo Moisés tão ansiosamente esperado e desejado. Que Nosso Senhor encaminhe os passos de V. Ex. ${ }^{a}$ e Ihe dê a fortaleza da sua graça e as consolações da sua infinita Misericórdia".

Ao tratar com Monsenhor Castro, com quem também estabelecia correspondência epistolar, e de quem se dizia amigo, sobre a posse de D. 
Epaminondas, propõe o dia de 10 de outubro para a solenidade, o que não ocorrerá.

S. Paulo, 10 de agosto de 1909. Ex. ${ }^{\text {mo }}$ Sr. Bispo de Taubaté. Louvado seja Deus. [...] Combinei com Mons. Castro em propor a V. Ex. ${ }^{a}$ o dia 10 de outubro para a cerimônia da posse, pois além de ser a oitava do Padroeiro da Diocese, essa data permitirá a $\mathrm{V}$. Ex. ${ }^{\mathrm{a}}$ tomar parte em uma pequena reunião do Bispo da Província que será a 12 de novembro. Travaremos conhecimento um com o outro e nos ajudaremos mutuamente na direção das nossas Dioceses. Venha, pois, Sr. Bispo. $\mathrm{Na}$ minha pessoa $V$. Ex. ${ }^{a}$ só poderá encontrar um coração de amigo e irmão que para nada serve, mas os diocesanos de $\mathrm{V}$. Ex. ${ }^{a}$ serão a glória e justo orgulho de um apóstolo. Queira V. Ex. ${ }^{\mathrm{a}}$ abençoar o amigo + Duarte. ${ }^{267}$

As desculpas de D. Epaminondas, no entanto, não tardaram. Interessante notar na correspondência a questão da saúde, problema que o acompanharia até seus últimos dias. Observa-se na carta, pela primeira vez, o sinal da cruz que antecede o nome, como é praxe na assinatura dos bispos.

[...] Dirijo-vos esta bastante acanhado; pois, não podendo tomar posse da Diocese no dia 10, como havíamos combinado, devido isto a incômodos de saúde, não me foi possível comunicar-vos, com a devida antecedência, esta falta, de que vos peço desculpa. Estou providenciando no sentido de ser o menos demorado possível o cumprimento deste dever. [...] + Epaminondas. $^{268}$

Findava o ano de 1909, D. Epaminondas já havia sido empossado, e a última carta de D. Duarte é seca e trata, principalmente, sobre assuntos de natureza financeira. Que razões teriam levado o metropolita a tal procedimento?

S. Paulo, 9 de dezembro de 1909. Ex. ${ }^{\text {mo }}$ Sr. Bispo de Taubaté. [...] Junto vai também uma nota da dívida da Arquidiocese para com a Diocese de Taubaté, e uma outra do que deve Taubaté ao Seminário Maior e ao Menor. Da primeira verá V. Ex. ${ }^{a}$ que a Arquidiocese lhe deve a importância de 2:947\$785. (dois contos, novecentos e quarenta e sete mil, setecentos e oitenta cinco réis). Pela segunda se verifica que a Diocese de Taubaté deve ao Seminário Maior 1: 250\$000 e ao Menor 3:400\$000, o que tudo faz 4:650\$000. Descontada uma da outra, verifica-se que a Diocese de Taubaté fica a dever à Arquidiocese $1: 702 \$ 215$. Isto vai para governo de V. Ex. ${ }^{\mathrm{a}}+$ Duarte. ${ }^{269}$

A resposta de D. Epaminondas, não obstante formal, limita-se tão somente às saudações de praxe, inexistindo as anteriores expressões de afeto, demonstrativas de calorosa proximidade inicial com o metropolita.

267 ACMSP. Carta de D. Duarte a D. Epaminondas.10 de agosto de 1909. 268 ACMSP. Carta de D. Epaminondas a D. Duarte. 11 de outubro de 1909. 269 ACMSP. Carta de D. Duarte a D. Epaminondas. 9 de dezembro de 1909. 
Ex. ${ }^{\text {mo }}$ e Rev. ${ }^{\text {mo }}$ Sr. Arcebispo. Beijando-lhe o anel, envio a V. Ex. $^{a}$ minhas respeitosas saudações e desejos de todos os bens. O Rev. ${ }^{\text {mo }}$ Secretário deste Bispado entregou-me uma conta corrente da Diocese de Taubaté com o Arcebispado de São Paulo, da qual se verifica um saldo de 2:876\$460 a favor deste Bispado e que ele disse-me reservara $\mathrm{V}$. Ex. ${ }^{\mathrm{a}}$ para as primeiras despesas que eu forçosamente teria de aqui fazer.

Depreende-se, da leitura acima, uma predisposição de D. Duarte, no sentido de auxiliar o Bispo de Taubaté em suas primeiras necessidades. É provável, no entanto, que, contrariado, D. Duarte tenha mandado considerar, como dívida ativa, despesas anteriormente consideradas irrelevantes, transformando um possível crédito em débito.

D. Epaminondas, por sua vez, além de não entrar no assunto abordado pelo metropolita, apresenta um suposto crédito em favor da diocese de Taubaté, no que pede rápida reversão!

De fato, vejo-me sem recursos e em face de compromissos e necessidades nascidos aqui. Rogo-lhe, pois, o obséquio de reverter-me a referida importância, que muito virá valer-me, visto como não poderei realizar agora a visita pastoral e nem valer-me dos rendimentos das casas que formam o patrimônio; pois, como sabe V. Ex. ${ }^{a}$, estão sendo empregados integralmente nos consertos dos referidos prédios. RogandoIhe queira desculpar-me a importunação, reitero-lhe os protestos de apreço e estima com que subscrevo-me. Taubaté, 9 de dezembro de 1909. + Epaminondas, Bispo de Taubaté. ${ }^{270}$

A resposta para o esfriamento das relações entre os dois prelados encontra sua origem exatos sete dias antes. Em carta de 2 de dezembro de 1909, Monsenhor Miguel Martins, provavelmente ordenado por D. Epaminondas, dá início à crise.

Amigo Cônego Ezechias ${ }^{271}$ - Peço-lhe para, depois de seguramente informado, informar-me: $1^{\circ}$ ) Quanto anualmente rendem todas as casas do Seminário? $2^{\circ}$ ) Quanto anualmente rendem as casas da Mitra? $3^{\circ}$ ) Quanto anualmente rende, para o Diocesano ou para o Seminário, o Colégio Diocesano atualmente? $4^{\circ}$ ) Quanto rende anualmente o Pirapora? $5^{\circ}$ ) Quanto rende anualmente na atualidade a Câmara Eclesiástica? $6^{\circ}$ ) O Seminário e a Mitra têm outros rendimentos além dos supra mencionados? E no caso afirmativo, quanto

270 ACMSP. Carta de D. Epaminondas a D. Duarte. 9 de dezembro de 1909.

271 Trata-se do Cônego Ezechias Galvão da Fontoura. Lente de História universal, de Direito eclesiástico e de Teologia moral no Seminário Episcopal de São Paulo. Foi também escrivão da Câmara eclesiástica, Secretário do bispado e Tesoureiro-mor do Cabido diocesano. É autor de várias obras, entre outras "Vida de D. Antônio Joaquim de Melo". POLYANTHEA. Comemoração do cinqüentenário de fundação do Seminário Episcopal de São Paulo: 9 de novembro de 1856 a 9 de novembro de 1906, s.d. pp. 43-46. Ezechias Galvão da Fontoura Guimarães é o décimo sexto exaluno de uma relação de 4.486 nomes, conforme constante no Apêndice da obra em tela. 
rende anualmente?

Verifica-se, portanto, o desejo de um súdito de D. Epaminondas em tomar conhecimento dos assuntos financeiros da arquidiocese, sem a devida autorização de D. Duarte. Note-se a contradição de Miguel Martins, ao levar em conta o caráter público da informação, ao mesmo tempo em que promete reserva.

Tenho certeza que não terá dificuldade em prestar-me essas informações, que versam sobre fatos públicos e a ninguém ofensivos. Se julgar conveniente, poderei guardar inteira reserva sobre a procedência. Lembrança ao Cônego Lessa ${ }^{272}$ e ao Monsenhor, ${ }^{273}$ que é consultado para tudo e tudo pode. Seu amigo velho Padre Miguel Martins. Taubaté, 2 de dezembro de 1909.

Finalizando, Miguel Martins se reporta às rendas do Santuário de Bom Jesus dos Perdões. A resposta, pois, deveria vir completa, incluindo até possíveis rendimentos por ele não citados!

Amigo Cônego Ezechias - Peço-lhe para me informar também sobre o Bom Jesus dos Perdões e sobre qualquer outra procedência de rendas, de que me tenha esquecido. Seu amigo obrigado. Padre Miguel Martins. Taubaté, 2 de Dezembro de 1909. ${ }^{274}$

Essas provocações, no entanto, possuem nomes: "Legado Wanderley" e "Questão de Aparecida". Inseridas na conta de questões patrimoniais, e ocorrendo em caráter simultâneo, apresenta-se o histórico do "Legado Wanderley".

Em 29 de setembro de 1885, o Vigário Colado da Paróquia de Nossa Senhora da Conceição de Jacareí, Cônego José Bento de Andrade, fundou, em sua cidade, uma instituição escolar, de natureza assistencial, para o recolhimento e educação primária, secundária e profissionalizante de meninos pobres e desvalidos.

Essa instituição, o Colégio São Miguel, era dirigida e administrada pelo referido vigário, juntamente com o Cônego Amador Bueno de Barros, e sobrevivia

272 Trata-se do Cônego Antônio Augusto Lessa, professor de Geografia e de Cantochão no Seminário Episcopal. Foi, além disso, Tesoureiro-mor da catedral e Promotor diocesano. POLYANTHEA. Comemoração do cinqüentenário de fundação do Seminário Episcopal de São Paulo: 9 de novembro de 1856 a 9 de novembro de 1906. pp. 48-50. Antônio Augusto Lessa é o octingentésimo qüinquagésimo ex-aluno de uma relação de 4.486 nomes, conforme consta no apêndice da obra em tela.

273 Trata-se do Monsenhor Dr. Francisco de Paula Rodrigues, presidente do Cabido de São Paulo, vigário geral e provisor do bispado. POLYANTHEA. Comemoração do cinqüentenário de fundação do Seminário Episcopal de São Paulo: 9 de novembro de 1856 a 9 de novembro de 1906, s.d. pp. 41-43. Francisco de Paula Rodrigues é o primeiro ex-aluno de uma relação de 4.486 nomes, conforme constante no Apêndice da obra em tela.

274 ACMSP. Carta de Monsenhor Miguel da Silva Martins para o Cônego Ezechias. 02 de dezembro de 1909. 
das esmolas e doações, conseguidas por seu fundador, às custas de sua dedicação pessoal.

Paralelamente, o colégio contava com um sistema de loterias, administradas por protetores, Coronel Francisco Antônio de Lima e Major José Bonifácio de Mattos, cujos lucros deveriam Ihe ser destinados.

Com um patrimônio próprio avaliado em cerca de 40 contos de réis, 0 colégio possuía, como bens imóveis, uma fazenda utilizada como laboratório profissional de seus alunos, de nome 'Figueira'; uma outra, menor, doada pela Câmara Municipal de Jacareí, destinada a ser sede da escola, de nome Coleginho, além de algumas casas em área urbana. Contava também, como bens móveis, diversos instrumentos, além de ferramentas agrícolas e profissionais.

A instituição, desde sua fundação, enfrentava dificuldades financeiras, decorrentes da natureza incerta de sua principal fonte de renda. No equilíbrio de suas contas, a escola dependia exclusivamente de seu mentor, conseguindo esse importantes doações, mesmo com pessoas que sequer residiam em Jacareí.

O pernambucano Joaquim Floriano Wanderley era morador em São Paulo, onde possuía considerável patrimônio, com terras nas regiões da Consolação e Avenida Paulista.

Por motivos pessoais, no inventário realizado por ocasião de sua morte, em 1892, Wanderley legou parte desse patrimônio a diversas instituições de natureza assistencial, tendo contemplado, na capital paulista, um colégio dirigido por um certo Dr. José Vicente, e em Jacareí, o do próprio Cônego José Bento.

Descontando-se a parte do primeiro, a instituição de São Miguel tinha a receber uma herança, avaliada entre 300 e 400 contos de réis, o que, além de ser mais que suficiente para que a escola resolvesse seus problemas, é possível que despertasse os interesses da Diocese.

Havia, no entanto, pendências para o recebimento desse legado. Familiares do finado Wanderley discordavam do testamento e, por essa razão, embargaram sua execução na justiça.

No caso do Colégio São Miguel, que tinha como agravante de suas dificuldades a fragilidade da saúde de seu mentor, o recebimento da herança estava vinculado justamente a sua pessoa, o Cônego José Bento.

Devido as suas condições de saúde, e a situação financeira da instituição, a demora no recebimento de tais recursos incorreria no fechamento da escola, fato 
que ocorreu com o cônego ainda vivo.

Em 1897, o Cônego José Bento de Andrade faleceu, sem que ainda tivesse sido resolvida a pendência judicial do caso Wanderley. Sua intenção e disposição, até o final de sua vida, fora entregar a administração de seu colégio para alguma ordem religiosa, ou instituição, que garantisse a sua continuidade, nas restrições estabelecidas por seu estatuto: basicamente servir à educação básica e profissional de meninos pobres e desvalidos.

José Bento acreditava que, se não conseguisse passar a instituição a tal tipo entidade, sua existência estaria ameaçada, pelo menos na cidade de Jacareí, na perspectiva de seu fechamento pela diocese de São Paulo para arremate dos recursos da herança, realidade que nos é elucidada pelas palavras de seu primeiro testamenteiro:

[...] Ainda vivia o Cônego quando the aconselhei que ligasse o colégio à Mitra de São Paulo, mas conversando ele com V. Ex. $^{a}$, hoje nosso Cardeal Arcoverde, ficou convencido de que - Sr. Bispo levaria o Colégio para S. Paulo, privando Jacareí desse benefício, e por isso pregou-me a peça em seu testamento, fazendo-me o seu $1^{\circ}$ testamenteiro em vez da Mitra, como tínhamos combinado. ${ }^{275}$ (os grifos são nossos)

Por ocasião de suas disposições testamentárias, entretanto, o referido Cônego, prevendo sua morte antes de entregar o colégio, encarregou como seu primeiro testamenteiro justamente o Cônego Amador Bueno de Barros, que participou da fundação da instituição, para fazer valer seus desejos em conformidade com os trechos do testamento abaixo expostos:

[...] Terceiro: se acontecer eu falecer antes de ter organizado a entrega deste Colégio a alguma congregação, fica encarregado desta missão o meu testamenteiro e sucessor. Quarto: delego ao meu testamenteiro a quem dou por abonado em juízo, todos os meus direitos enquanto ele viver afim de que ele possa completar esta obra, o Colégio São Miguel. Quinto: Se por sua morte ou por qualquer outra circunstância ele seja obrigado a deixar esta instituição, ficará então o Colégio São Miguel sob a direção, inspeção, cuidado, e zelo apostólico perpétuo do Excelentíssimo Prelado Diocesano. [...] Sétimo: se por algum acontecimento extraordinário em qualquer época futura, este estabelecimento deixar de ser ocupado por meninos pobres e desvalidos conforme os estatutos da casa, e se tiver então de dar-se outro destino ao prédio, terrenos e mais patrimônios que possua, passará a pertencer ao Excelentíssimo Senhor Bispo Diocesano D. Joaquim Arcoverde e a seus sucessores, que o destinará para qualquer outros

275 ACMSP. Carta do Cônego Amador Bueno de Barros para D. Arcoverde. 21 de fevereiro de 1906. 
estabelecimentos de casas pias. Oitavo: possui esta instituição como seu patrimônio os seguintes bens: um sítio distante três quilômetros desta cidade, onde tem funcionado o Colégio, doação feita ultimamente pelo benfeitor o Senhor Eduardo Prates; um terreno na rua Barão de Jacareí, onde se está começando o grande edifício e para onde deverá ser mudado o Colégio São Miguel, além disso conta mais com uma herança deixada pelo caridoso benfeitor Joaquim Floriano Wanderley pendente da realização e liquidação do inventário disposição testamentária sendo o cálculo desta herança para mais de trezentos contos, benefício feito em favor da orfandade exposta ao desamparo. - Nono: as disposições acima constituem a base do programa que à face de Deus me comprometi executar. Nomeio e constituo meu testamenteiro e sucessor o Senhor Cônego Amador Bueno de Barros, protetores o Coronel Francisco Antônio de Lima e José Bonifácio de Mattos... (os grifos são nossos)

Podemos perceber que tanto a passagem da administração do colégio ao bispo diocesano, por ocasião da impossibilidade de Amador Bueno, quanto a destinação de seus bens, pelo seu fechamento, constituíam recursos de último caso; não expressavam a vontade do testador.

Segundo o mesmo documento, os recursos financeiros e patrimoniais do Colégio deveriam ser utilizados para sua manutenção, enquanto o mesmo existisse.

Após a morte de José Bento, o Cônego Amador Bueno ficou encarregado da administração da instituição. Sem o mesmo carisma e comprometimento de seu antecessor, o novo administrador tentou reabrir o Colégio São Miguel como externato, em um pequeno prédio na cidade.

Sem poder contar a mesma predisposição caritativa dos fiéis, a duração de tal empreitada dependia da resolução do embargo ao legado.

O cônego José Bento, como líder da paróquia de Nossa Senhora da Conceição de Jacareí, exercia sobre seus fiéis, além da dominação burocrática de caráter tradicional, representada pela sua condição de sacerdote da Igreja católica, a de caráter carismático.

Esse caráter é claramente evidenciado na sexta cláusula de seu testamento:

[...] como é sabido o Colégio São Miguel é uma instituição fundada, parte com esmolas por mim obtidas de particulares que livre e espontaneamente fizeram sem condição alguma... ${ }^{276}$

Podemos supor, portanto, que a considerável doação realizada em

276 ACMSP. Testamento do Cônego José Bento de Andrade. 
inventário por Joaquim Floriano Wanderley, aos Colégios São Miguel e do Dr. Vicente se vinculou, em grande parte, ao carisma do Cônego José Bento de Andrade, mesmo porque o doador era radicado na cidade de São Paulo, onde certamente existiam outras instituições dessa natureza.

No final do ano de 1905 o Colégio São Miguel deixou de funcionar. Os recursos eram escassos, a pendência não se mostrava em processo de resolução, e o Cônego Amador Bueno foi nomeado para o Asilo Isabel, no Rio de Janeiro.

Em 1905, impossibilitado de comparecer freqüentemente à Jacareí para as audiências do Poder Judiciário, o Cônego Amador Bueno de Barros passou uma procuração para o Major José Bonifácio de Mattos, nomeado segundo protetor por José Bento em seu testamento, para responder pela questão do legado. O primeiro protetor e segundo testamenteiro, o Tenente Coronel Francisco Antônio de Lima, se recusou a substituir o referido cônego.

Nesse mesmo ano saiu a sentença favorável ao Colégio. Na execução do inventário de Joaquim Floriano Wanderley, o outro Colégio, o do Dr. José Vicente, tomou a iniciativa de vender, sem a anuência do referido Cônego, ou de seu representante, alguns dos terrenos em litígio, sem nada repassar ao Colégio São Miguel.

O Major José Bonifácio de Mattos que, além de protetor, era o responsável pelo sistema de loterias em favor da instituição, recebera cerca de 20 contos de réis de arrecadação. Numa transação desfavorável à instituição, Bonifácio preferiu ficar com o dinheiro e repassar à escola uma fazenda hipotecada que recebera de um devedor, no mesmo valor de 20 contos. Como o colégio não mais existia na prática, a administração dessa fazenda ficaria com seu antigo proprietário, que dela extrairia para si os seus lucros.

O Cônego Amador Bueno, ao saber de tal transação, tentou convencer o Major José Bonifácio de Mattos a restituir o dinheiro ao colégio. Sem resultados, e diante da impossibilidade de mantê-lo como seu procurador, diante de tal desacordo, Amador Bueno, cujos afazeres o prendiam ao Rio de Janeiro, procurou um advogado para resolver essa questão, tentando verificar se a sétima cláusula do testamento do Cônego José Bento, justamente a que legava o patrimônio do colégio ao bispo diocesano, diante do seu efetivo fechamento, poderia ser acionada.

Se considerarmos as esferas tradicional e carismática de dominação, perceberemos que o peso da presença de um bispo sobre as engrenagens da 
máquina jurídica e, principalmente, sobre a consciência das pessoas em questão, seria, certamente, mais eficaz que o do Cônego.

Amador Bueno de Barros desistiu do encargo de primeiro testamenteiro, e passou toda a responsabilidade pelas questões do colégio ao bispo de São Paulo, na época D. José de Camargo Barros (24/4/1904 - 04/8/1906), ${ }^{277}$ destituindo o Major Bonifácio da condição de seu representante. O prelado diocesano nomeou, como seu procurador, o Tenente Coronel Francisco Antônio de Lima.

Com o falecimento de D. José de Camargo Barros, em agosto de 1906, Francisco Antônio de Lima acumulou, em suas mãos, toda a responsabilidade sobre as questões do Colégio, bem como sua herança, já que o Cônego Amador Bueno estava no Rio de Janeiro, onde acreditava estar livre das obrigações de testamenteiro.

O colégio só existia no papel. Deixara de receber e educar os meninos desvalidos alguns anos depois da morte de seu fundador, que não tivera tempo de passá-lo à administração de alguma ordem religiosa. Sua existência jurídica existia em função de seu patrimônio e da execução do testamento de seu mentor, com o recebimento do legado Wanderley.

O Cônego José Bento de Andrade, todavia, no momento em que ditou o seu testamento, tinha em mente a manutenção da instituição que fundara, e a qual dedicara parte de sua vida.

Acreditava que, com sua morte, caso não deixasse expresso o contrário, o colégio São Miguel, e seu patrimônio, seriam absorvidos pela Diocese e retirados da cidade de Jacareí.

Devemos lembrar que a opção de destinar sua administração à Diocese, no caso de impossibilidade de Amador Bueno fazê-lo, e a prescrição de legar seu patrimônio à mesma, no caso do fechamento da instituição, configuravam última hipótese.

Com a instituição de São Miguel aberta apenas no nome, a administração de seus bens ficaria a cargo do primeiro testamenteiro, que havia tentado renunciar. Ocorre que, legalmente, Amador Bueno não fizera a transmissão de seus poderes

277 POLYANTHEA. Comemoração do cinqüentenário de fundação do Seminário Episcopal de São Paulo: 9 de novembro de 1856 a 9 de novembro de 1906. José de Camargo Barros é o milésimo quarto ex-aluno de uma relação de 4.486 nomes, conforme consta no apêndice da obra em tela. Também disponível em <http://www.catholic-hierarchy.org/bishop/bcamab.html> Consulta em 11 de julho de 2005. 
ao bispo de São Paulo, o que, consequentemente, invalidava a nomeação do Tenente Coronel Francisco como seu procurador.

Quando a sentença favorável ao Colégio chegou, Dr. Vicente começou a negociar alguns bens e, para tanto, o referido cônego fora chamado como representante da instituição de São Miguel.

Amador Bueno manifestou-se a favor da destinação das lides administrativas do Colégio São Miguel à Cúria Diocesana de São Paulo, especialmente depois que seu Vigário Geral explicitou que o manteria funcionando.

Mas o Tenente Coronel Francisco não entendia dessa forma. Como representante legal do bispo de São Paulo nessa querela, apesar de o mesmo não ter recebido legalmente os poderes para efetuar tal nomeação, Francisco de Lima ainda se mantinha como administrador do colégio, que já não existia há alguns anos.

A questão caminhava para uma solução amigável entre o Cônego Amador Bueno de Barros, a Arquidiocese, e o Tenente Coronel Francisco Antônio de Lima, pelo menos até 1907.

Como sabemos, D. Duarte Leopoldo e Silva assumiu seu apostolado em 14 de abril de 1907, o que deu uma dinâmica completamente nova à questão. Pelas vias judiciais, o novo prelado diocesano moveu um agravo cível ${ }^{\mathbf{2 7 8}}$ contra Francisco Antônio de Lima, questionando a legalidade de sua administração sobre o Colégio, sem alunos, e exigindo a destituição de seu cargo de testamenteiro, em favor da diocese de São Paulo. Em pouco tempo esse aspecto da questão foi resolvido pela justiça, de maneira favorável ao Bispo.

O Cônego José Bento não imaginava que, com o desmembramento da diocese de São Paulo, em 1908, e o conseqüente surgimento, neste caso particular, da diocese de Taubaté, surgiria uma disputa entre bispos, questão que viria a ser conhecida como "O legado Wanderley".

Seu princípio conceitual é simples: estando a cidade de Jacareí nos domínios territoriais da diocese de Taubaté, seu bispo entendia ser o legítimo herdeiro dos bens legados pelo Cônego José Bento. O Arcebispo de São Paulo, por sua vez, assim não entendia, considerando que, à época do testamento, a diocese de Taubaté não existia.

D. Epaminondas fora nomeado bispo de Taubaté em 8 de setembro de 1909, mas assumiu o seu apostolado somente no dia 21 de novembro do mesmo 278 ACMSP. Auto de Agravo Cível n. 4921, Comarca de Jacareí, 1907. 
ano.

Em sua fase adaptação e de tomada de conhecimento das questões relativas ao seu bispado, período de 2 meses, conseguiu indispor-se com D. Duarte, em função de acontecimentos já mencionados, e principalmente por sua postura na defesa de seus interesses diocesanos.

Ainda sob o calor dos supostos artigos de Monsenhor Miguel Martins, publicados pela 'Federação', no mesmo mês de janeiro de 1910, o bispo de Taubaté, terçando armas, submeteu o caso a uma consulta jurídica, materializada em duas perguntas:

$\left.1^{\circ}\right)$ A interrupção do funcionamento do colégio São Miguel importa a sua impossibilidade de preencher o fim colimado pelo testador? $2^{\circ}$ ) No caso de impossibilidade, a quem cabe a sucessão dos bens nos termos do testamento? Ao atual Arcebispo de S. Paulo, sucessor de D. Joaquim Arcoverde na Diocese de S. Paulo, ou ao Bispo da atual Diocese de Taubaté, em cujo território fica a paróquia de Jacareí, na qual foi instituído o Colégio pelo seu fundador, e onde se acha o núcleo inicial de bens imóveis de seu patrimônio? ${ }^{279}$

A morte do Cônego José Bento, de fato, provocou a interrupção do funcionamento do colégio. O advogado consultado foi Eusébio Inocêncio Vaz Lobo da Câmara Leal, "tido como um dos melhores, ou o melhor advogado do norte de S. Paulo", conforme nota escrita pelo próprio Bispo de Taubaté ao pé da última página do parecer.

Em sua longa resposta, o Dr. Eusébio Inocêncio cita em sua íntegra a cláusula sétima do testamento, onde consta que se por algum acontecimento extraordinário, em qualquer época futura, o colégio São Miguel deixar de ser ocupado por meninos pobres e desvalidos, conforme os seus estatutos, e tenha de ser dado outro destino então ao prédio, terrenos e mais patrimônio que possua, passará a pertencer ao Ex. ${ }^{\text {mo }}$ Sr. Bispo Diocesano D. Joaquim Arcoverde e aos seus sucessores, que destinará para qualquer outro estabelecimento de casas pias.

Eusébio Inocêncio afirma ser claro que o pensamento do Cônego José Bento de Andrade foi o de estabelecer a substituição do herdeiro somente quando a existência do colégio tornar-se uma impossibilidade, por algum acontecimento extraordinário, sendo assim forçoso dar outro destino ao patrimônio.

Dito isso, o advogado de D. Epaminondas entende que o prosseguimento da

279 ACMSP. Carta de D. Epaminondas ao Dr. Eusébio Inocêncio Vaz da Câmara Leal. 2 de janeiro de 1910. 
interrupção das atividades escolares do Colégio São Miguel, seja por falta do testamenteiro dar continuidade ao preceito testamentário, seja por falta da recepção da herança de Joaquim Floriano Wanderley, a fim de formar um patrimônio que garantisse o perpétuo funcionamento do mesmo colégio, não pode se constituir caso de impossibilidade de sua existência, entendendo, também, por "acontecimento extraordinário", causa que provocasse alterações no testamento, mas que esse mesmo caráter extraordinário só poderia ser assim entendido pelo testador, assim justificando e exarando seu parecer ao primeiro quesito:

A instituição - Colégio São Miguel - está de pé, suspensa temporariamente em seu funcionamento, e aguarda sua constituição legal de pessoa jurídica para receber o seu patrimônio, e prosseguir perpetuamente em seu alevantado ideal. Não deu-se, pois, ainda, nem pode dar-se a substituição estatuída pelo testamento para o caso de impossibilidade de sua existência para satisfazer o fim de sua instituição, condição indeclinável da mesma substituição. Assim respondo ao primeiro quesito: negativamente. (o grifo é dele)

Com referência ao segundo quesito, Eusébio Inocêncio considera que, em vista da resposta negativa ao primeiro, fica ele prejudicado enquanto não se realizar a condição da substituição: o regime que prevalece é o da cláusula quinta do testamento, que dá a direção, inspeção, cuidado e zelo do colégio ao Bispo diocesano. Prosseguindo, é certo que D. Epaminondas tenha gostado do trecho abaixo:

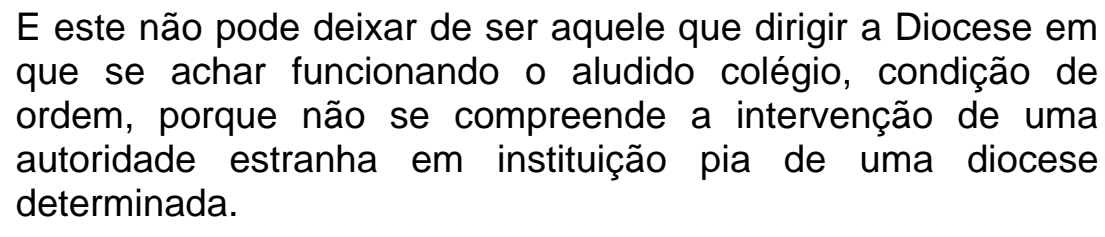

Justificando seu parecer, Eusébio Inocêncio se reporta ao fato de que, desmembrado o Bispado de Taubaté do de São Paulo, e elevado este à categoria de Arcebispado, sem que a Bula de sua criação estabeleça restrições em relação à jurisdição sobre instituições pias, existentes dentro dos limites territoriais da nova diocese, o jurisconsulto assevera que o que regula a questão é a vontade do testador, que é lei em tal matéria, pois o testamento, sendo uma lei, deve ser interpretado pelas regras de hermenêutica jurídica, entre as quais está a de confrontar e harmonizar suas diversas partes dele.

Ao confrontar as cláusulas quinta e sétima do testamento, Eusébio Inocêncio faz ver que na quinta fala-se apenas em Bispo Diocesano, e na sétima menciona-se, 
também, Bispo Diocesano, adicionando-se o nome de D. Arcoverde, pelo fato de que este antístite era o bispo diocesano de São Paulo na data do testamento.

Tendo na conta de que as cláusulas estão combinadas e harmonizadas, o advogado consultado reafirma resultar que o testador deu a direção e inspeção do colégio ao Bispo Diocesano, mencionando que então o era D. Joaquim Arcoverde, tanto que, se ele não existisse ao tempo da substituição, esta operar-se-ia para seus sucessores.

A instituição de D. Joaquim Arcoverde, em substituição ao Colégio São Miguel não mais existente, não é pessoal, nem o pode ser; porque, se assim fosse, importaria no absurdo de pertencer hoje tal patrimônio a ele como Arcebispo do Rio de Janeiro, e dever passar por sua morte aos seus sucessores, também Arcebispos do Rio de Janeiro.

Considerando não ser possível tal interpretação, Eusébio Inocêncio continua seu parecer, baseado no fato de que a harmonia das disposições testamentárias força a considerar a substituição como feita no termo 'Bispo Diocesano', isto é, aquele que estiver na Diocese em que tiver existido o colégio São Miguel.

E sendo essa Diocese, hoje, pelo desmembramento operado, a de Taubaté, cabe ao Bispo desta a direção e inspeção do mesmo, e sua futura substituição, quando tornar-se impossível a continuação do funcionamento daquele instituto colegial.

Prosseguindo, o parecerista justifica que nunca poderiam tais direitos assistir ao Arcebispo de S. Paulo, porque não será ele o Diocesano de que trata o testamento, na ocasião do desaparecimento do colégio São Miguel, e assim não estará D. Duarte compreendido nem na letra, nem no espírito do testamento. E joga com as palavras...

Na letra até por ter o título de Arcebispo, a que não se refere o testamento. No espírito, porque não foi o pensamento do testador dar a direção, a inspeção de um estabelecimento dessa ordem a uma autoridade estranha do território, onde ficava localizado o instituto de sua criação. E tal não foi sua intenção, pois o que ele quis foi beneficiar seu torrão natal, que é hoje um pedaço da Diocese de Taubaté. ${ }^{280}$

Em suas linhas finais, Eusébio Inocêncio diz que o contrário estabeleceria conflitos de jurisdição eclesiástica, pela direção confiada à autoridade estranha à Diocese, sobre uma instituição pia localizada dentro dos limites da nova Diocese, de 1910. 
aproveitando para, também, opinar em assuntos de competência eclesiástica, ao recomendar que "tais conflitos, por amistosamente que se resolvam, são pouco edificantes aos fiéis."

Em vista dos expostos fundamentos, respondo ao segundo quesito: No caso de impossibilidade do funcionamento do colégio São Miguel, como o quis seu instituidor, cabe a substituição na sucessão ao Bispo da Diocese de Taubaté. Tal é meu parecer, que humildemente submeto à correção dos mestres. Taubaté, 11 de janeiro de 1910 Eusébio Inocêncio Vaz Lobo da Câmara Leal.

É certo que o relato de Eusébio Inocêncio tenha sido encaminhado à Arquidiocese de São Paulo. Em vista disso, D. Duarte Leopoldo apela para um leigo da mais absoluta confiança da Igreja católica, Brasílio Augusto de Oliveira Machado, o Barão Brasílio Machado, ex-aluno do Seminário Episcopal de São Paulo: ${ }^{281}$

advogado, ex-presidente da Província do Paraná, professor da Faculdade de Direito, barão por concessão de Pio $X$, monarquista, candidato derrotado do Partido católico nas eleições para a Constituinte. Foi um dos fundadores do jornal 'O São Paulo', órgão oficial da Arquidiocese de São Paulo, até hoje circulando. ${ }^{282}$

O parecer de Brasílio Machado, datado de 16 de fevereiro de 1910, é claro:

A guardar a vontade do instituidor, minuciosamente esclarecida no testamento com que veio a falecer em 1897, data anterior ao desmembramento da antiga Diocese de S. Paulo, parece fora de dúvida que ao Arcebispo Metropolita de S. Paulo, e não ao Prelado de Taubaté, cabe a administração dos bens patrimoniais da extinta fundação denominada Colégio S. Miguel... ${ }^{283}$ (os grifos são nossos)

D. Duarte, antes mesmo de receber a resposta desse advogado, também confiou a questão a outro considerado leigo, advogado da Arquidiocese, Dr. Porphyrio de Aguiar, o qual respondeu de maneira detalhada em 18 de fevereiro de 1910.

Procurando desmontar as argumentações de Eusébio Inocêncio, Porphyrio de Aguiar inicia seu parecer afirmando que a consulta a que responde o advogado

281 POLYANTHEA. Comemoração do cinqüentenário de fundação do Seminário Episcopal de São Paulo: 9 de novembro de 1856 a 9 de novembro de 1906. Brasílio Augusto de Oliveira Machado é o centésimo quadragésimo quinto ex-aluno de uma relação de 4.486 nomes, conforme consta no apêndice da obra em tela.

282 PINHEIRO, Alceste. O Cardeal Arcoverde e a reorganização eclesiástica. 2003. Tese (Doutorado em História Social) - Universidade de São Paulo, São Paulo, 2003. p. 245.

283 ACMSP. Carta resposta do advogado Barão Brasílio Machado para D. Duarte. 16 de fevereiro de 1910. 
do Bispo de Taubaté tem como primeiro vício o fato de subordinar a definitiva existência do Colégio de São Miguel ao recebimento da herança Wanderley, asserção considerada por este como contrária ao fato afirmado pelo Cônego José Bento de Andrade em seu testamento.

O advogado da Arquidiocese se reporta ao testamento, referindo-se à data de fundação do Colégio de São Miguel, 29 de setembro de 1885, e ao fato do testador prevenir que, à falta de seu testamenteiro, o Cônego Amador Bueno de Barros, substitui-Ihe o Prelado Diocesano.

Porphyrio de Aguiar observa que, na cláusula sétima do testamento do Cônego José Bento de Andrade, nem há uma instituição de herdeiro, nem a podia haver. Para o jurisconsulto da arquidiocese, "extraordinário" significa qualquer acontecimento que se desvie de uma normalidade assentada, e com a qual se deva contar, aduzindo ser a palavra um sinônimo de imprevisto, sendo esse é o sentido natural e único da expressão na cláusula.

Vai em frente, afirmando que distinguir a possibilidade, seja do que for, em ordinária e extraordinária, não tem sentido, nem pode ser um requinte de dialética, e só a necessidade do argumento é que dá ao acontecimento extraordinário, do testamento, as proporções de um fato clamoroso, mais ou menos semelhante a um terremoto, donde se originasse a tal impossibilidade extraordinária, contrariando Eusébio Inocêncio quando o mesmo identifica o estabelecimento com o seu patrimônio, pois só nesse pressuposto é que está ele está de pé, mas então temporariamente suspenso.

A interrupção do funcionamento do Colégio, pela morte do testador, é um fato que Porphyrio de Aguiar diz tomar da consulta, e se essa interrupção continuou por falta de se dar vida ao preceito testamentário, pode ter sido ele motivado "por acontecimentos que não fosse, segundo o espírito de testamento, extraordinário?" Porphyrio de Aguiar pergunta então se não está ai o acontecimento que prudentemente acautelara o testador.

Deixou ou não, o estabelecimento de ser ocupado por meninos pobres e desvalidos? E não é desse fato só que fez o testador depender a devolução do seu patrimônio a quaisquer outros e a que os destinasse o Bispo D. Joaquim Arcoverde ou seus sucessores?

Isto posto, Porphyrio de Aguiar afirma que é contraditório, em seus termos, o acerto de que o colégio São Miguel está de pé até hoje, suspenso temporariamente, 
e aguarda a sua constituição legal de pessoa jurídica, pois se o colégio está de pé, e só temporariamente suspenso, há de o ser como pessoa jurídica; se ainda aguarda a sua constituição legal, não pode nem estar de pé, nem ter sido suspenso ainda que temporariamente, coisa que não chegou a existir, e carece de personalidade.

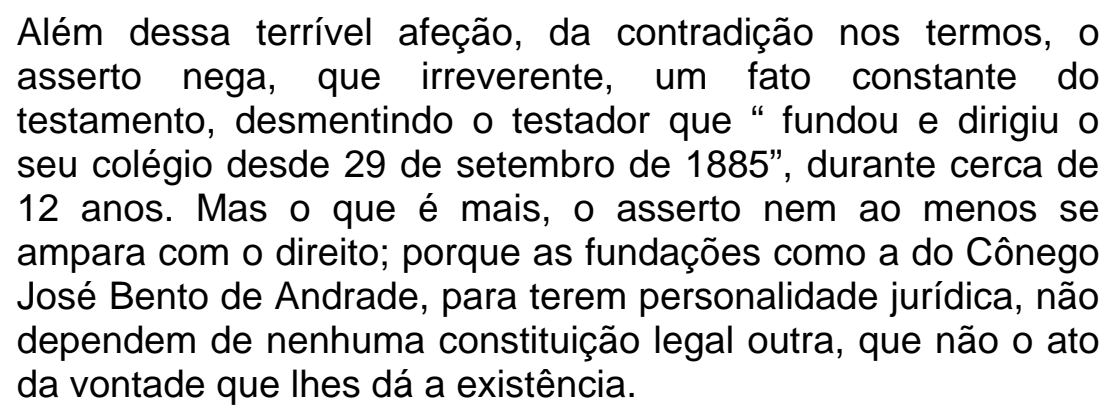

Dando por findo seu contraditório aos argumentos de Eusébio Inocêncio à primeira questão, Porphyrio de Aguiar afirma ser "tão infeliz como a primeira esta solução" ao criticar a linha de raciocínio do adversário, que o levou, no segundo quesito, a concluir ser D. Epaminondas o legítimo herdeiro do legado.

Para o advogado da Arquidiocese, a expressão "prelado diocesano", com o tratamento de "Excelentíssimo", só significa um prelado vivo e atual, ao tempo da abertura do testamento, posto que, para Porphyrio de Aguiar, nem os defuntos, nem os nascituros, têm excelência, passando a ironizar o parecer de Eusébio Inocêncio, uma vez que

só por uma antevisão milagrosa, antevisão de profeta, poderia ao fazer seu testamento o Cônego José Bento de Andrade, 10 ou 11 anos antes, contar com a existência da Diocese de Taubaté, e referir-se ao seu futuro Bispo quando usou a expressão "Prelado Diocesano".

Em vista disso, para o advogado da arquidiocese, o direito do Bispo, atualmente Arcebispo de S. Paulo, à administração do patrimônio do colégio de São Miguel, ex vi da cláusula Quinta do testamento do Cônego José Bento de Andrade, embora para ser efetivo, tenha carecido do Acórdão do Tribunal de Justiça do Estado, de 7 de outubro de 1907, era indiscutível.

Em sua linha de raciocínio, o posterior desmembramento da diocese de S. Paulo em várias outras; uma das quais, a de Taubaté, não fez cessar o direito, mesmo que Jacareí, nessa nova configuração, tenha passado a pertencer a Taubaté.

E se para Eusébio Inocêncio o que regula a questão é a vontade do testador, "que é lei na matéria", com o mesmo texto Porphyrio de Aguiar se escuda 
para rebater os argumentos, com que, nessa hipótese, conclui seu adversário pela devolução do patrimônio do colégio de São Miguel ao Bispo de Taubaté.

Assim, o advogado da Arquidiocese confirma as cláusulas quinta e sétima do testamento, fazendo ver que se na primeira consta a expressão "Prelado Diocesano", na sétima o testador indica por seu nome D. Joaquim Arcoverde.

Em última análise, os sucessores de D. Arcoverde são, agora, os arcebispos de São Paulo; não o bispo titular da diocese a que Jacareí pertença!

Portanto, contrapor à quinta a sétima cláusula do testamento só dá argumento a nosso favor. Com efeito indicado, o testador não pretendia que os sucessores de Sua Eminência D. Arcoverde fossem seus herdeiros pessoais. S. Em. ${ }^{a}$ era o Bispo Diocesano; seus sucessores seriam os Bispos Diocesanos. É perfeita a sinônima entre as expressões das $5^{a}$ e $7^{\mathrm{a}}$ cláusulas.

Terminando por jogar com o termo "prelado diocesano", o que de fato D. Arcoverde era, e o próprio nome do futuro cardeal, o jurisconsulto da Arquidiocese de São Paulo lança o seguinte questionamento:

Conclui-se porém daí, que vindo a Diocese de S. Paulo a ser
Arquidiocese, deixou por isso de ser o seu Arcebispo o
sucessor do Bispo cujo nome indicou o testador? Com a
criação do Bispado de Taubaté passaram a ser os sucessores
do Bispo Arcoverde os Bispos da Nova Diocese?

Preso a esse aspecto, Porphyrio de Aguiar afirma que, se o testamento houvesse sido aberto quando já da existência da diocese de Taubaté, seria ainda discutível que o Diocesano da cláusula $5^{\circ}$ fosse D. Epaminondas, uma vez que, mesmo nessa hipótese, os sucessores de D. Joaquim Arcoverde, nos termos da cláusula $7^{\circ}$, seriam sempre os Arcebispos de São Paulo, ressaltando que não se trata de uma questão de jurisdição episcopal, mas de execução de um simples mando testamentário.

Daí, prossegue Porphyrio de Aguiar, não se compreender o motivo pelo qual a criação de uma nova diocese resulte na cessação da competência pessoal do "Diocesano", hoje Arcebispo de S. Paulo.

Mas, o testamento se abriu quando nem o "Prelado Diocesano" da $5^{\text {a }}$ cláusula podia, por nada, ser o Ex. ${ }^{\text {mo }} \mathrm{Sr}$. Bispo de Taubaté. Sua Diocese só existia, a esse tempo, no mais problemático contingente dos possíveis; quando o "Diocesano" só podia ser o de S. Paulo.

Eusébio Inocêncio, como se sabe, baseia parte de sua argumentação 
falando em "letra" e em "espírito". No envoltório do que entende por "letra", defende a inexistência do termo "Arcebispo" no testamento; Na esfera do "espírito" afirma não ter sido o pensamento do testador ceder o comando do Colégio São Miguel a uma autoridade estranha ao território de Jacareí.

Porphyrio de Aguiar, por sua vez, afirma não ser ele, mas Eusébio Inocêncio, quem peleja contra a letra e contra o espírito do testamento.

Dito isso, aventa a hipótese da circunscrição da nova diocese de Taubaté não se estender para além da cidade de São José dos Campos, deixando como antes ao Arcebispado a Paróquia de Jacareí. Nesse caso, logicamente, os termos "prelado diocesano" e "arcebispo" não teriam qualquer importância.

Entendendo haver demolido a questão da "letra", a que Eusébio Inocêncio se prendia, Porphyrio de Aguiar aborda a questão do "espírito", perguntando por que motivo se deve traduzir o "Prelado Diocesano", da $5^{a}$ cláusula do testamento, por Bispo de Taubaté. Se a intenção do Cônego fosse a de beneficiar tão somente o seu torrão natal, na opinião do advogado da arquidiocese, custava-Ihe pouco definir-se tão claramente, como o fez determinando o Prelado a quem devolveu o destino do patrimônio de sua fundação, determinando-o por seu nome.

E teria sido mais cauteloso, efetivo e prático, sem se poder por isso acusar de bairrista, lembrando em sua disposição antes o Vigário, do que o Bispo; preferindo ao mesmo Vigário, dentre seus concidadãos e amigos filhos de Jacareí, qualquer dos que Ihe parecessem estremecer o seu torrão natal. Com a mesma indicação do Prelado podia perfeitamente bem determinar que só em Jacareí se fizessem as obras pias que fossem substituídas pelo Bispo em lugar da sua fundação. S. Paulo, 18 de fevereiro de 1910 Porphyrio de Aguiar. ${ }^{284}$

Elucubrações jurídicas à parte, a questão tivera sua dimensão ampliada. D. Epaminondas, um bispo de raízes mineiras, completamente desvinculado dos laços com a Igreja paulista, em suas atitudes, ora procurando saber sobre as contas da Arquidiocese, ora pedindo parecer jurídico a um advogado leigo, deixava claro a D. Duarte que defenderia os interesses de seu apostolado nas esferas que the fossem necessárias. Especialmente na questão da consulta ao Advogado Eusébio Câmara Leal, demonstrava que não teria nenhum melindre em levar essa pendência à justiça civil.

D. Duarte, por sua vez, não pretendia recuar de sua posição.

284 ACMSP. Carta resposta do Advogado da Arquidiocese, Porphyrio de Aguiar, a D. Duarte, 18 de fevereiro de 1910 
Ao receber, do bispo de Taubaté, um documento contendo a resposta à sua consulta, solicitou pareceres de dois advogados, católicos ultramontanos da mais absoluta confiança: Brasílio Machado, e Porphyrio de Aguiar.

De posse de referências legais favoráveis, o arcebispo metropolitano imaginava arrefecer os ânimos de D. Epaminondas. Estava enganado, assim como não conhecia seu gênio:

Era o Sinhozinho querido. [...] Apesar de franzino e doentio, o pequeno era irrequieto a travesso. Um azougue. Dificilmente o achavam quieto e sentado. Sempre alegre e travesso. De um gênio algo opinioso e autoritário. Por ser doentio não o contrariavam os irmãos, e o obedeciam e o chamavam seu Nondas! Dirigia e organizava os brinquedos. Quando não era obedecido havia barulho!... ${ }^{285}$

No mesmo mês de fevereiro, o Bispo de Taubaté oficiou o Núncio Apostólico do Brasil, D. Alexandre Bavona, expondo sua contestação sobre o caso do Colégio.

O Núncio, tendo já recebido reclamações verbais de D. Epaminondas, acerca da "Questão de Aparecida", recebe agora nova reclamação, dessa vez por escrito, sobre uma segunda pendência.

Isso exigia-Ihe um posicionamento.

Em Ofício à Arquidiocese de São Paulo, ${ }^{286}$ D. Alexandre resolveu dividir essas pendências em duas questões distintas, sendo a primeira referente a Aparecida, e a segunda ao Colégio São Miguel.

Considerando que a reclamação efetiva incorria, oficialmente, apenas sobre a segunda, propôs o Núncio ao Arcebispo deixar a primeira para momento mais oportuno, concentrando esforços sobre a questão que the parecia mais incômoda e imediata.

A participação da Igreja católica em disputas jurídicas na esfera civil, quando em defesa de seus interesses contra autoridades civis e personalidades leigas, apesar de não ser necessariamente considerada como a melhor solução, não sofria censuras da hierarquia eclesiástica. Pelo contrário, representava uma excelente projeção ao eclesiástico que a movia, elucidando a sua capacidade e comprometimento com a causa católica.

Se essa disputa, todavia, envolvesse eclesiásticos, estaria na conta de escândalo que mancharia não só o nome da Instituição, mas também o nome dos

285 BRANDÃO, Ascânio. Dom Epaminondas. São Paulo: Oficinas gráficas da Ave Maria, 1941. p. 18. 286 ACMSP. Ofício da Nunciatura Apostólica no Brasil n. ${ }^{\circ}$ 1669. 4 de março de 1910 
envolvidos.

Tal fato teria a capacidade de arranhar a dominação burocrática exercida pela Igreja nos seus três aspectos. De uma só vez, danificava o caráter racional de dominação legítima, por demonstrar ineficiência e desrespeito à hierarquia; ameaçava o seu caráter tradicional, por desmistificar o caráter sagrado e harmônico de dois sacerdotes, envolvidos em disputas públicas; prejudicava, por fim, o carisma dos envolvidos, pelas manifestações populares e de órgãos da imprensa que fatalmente se seguiriam.

Caso a disputa jurídica se concretizasse, sem dúvida D. Duarte e o Núncio Apostólico D. Alexandre seriam prejudicados, dados os efeitos de tamanha exposição negativa sobre seus cargos, mesmo porque D. Epaminondas, nessa contenda, contava com a boa vontade emocional de seus diocesanos.

D. Duarte, aproveitando-se de uma onda favorável, causada pela repercussão das atitudes de D. Epaminondas, e pelas declarações atribuídas a um de seus subordinados, procurou blindar sua posição, com o apoio dos demais bispos paulistas, que se manifestavam consternados com as críticas e ofensas vinculadas à imprensa de Taubaté.

O arcebispo percebia que o agravamento dessa pendência, para além da esfera eclesiástica local, Ihe seria prejudicial.

Embora contasse com o apoio dos bispos paulistas, sabia que isso contaria muito pouco para D. Epaminondas, que como sabemos tinha seu pé fincado em Minas Gerais.

A autoridade e a influência de D. Arcoverde era inquestionável, e por diversas vezes D. Duarte nele se apóia, particularmente na 'Questão de Aparecida”.

Alceste Pinheiro nos reporta detalhadamente a prática disciplinadora deste cearense de Cimbres, nascido em 17 de janeiro de 1850 e já em 1866 enviado a Roma, onde cursou ciências e letras, filosofia e teologia, concluindo seus estudos no Colégio Pio Latino-Americano. Na Basílica de São João Latrão, também em Roma, foi ordenado padre no dia 4 de abril de 1874.

Primorosamente educado na Europa, e bebendo nas mais puras fontes do ultramontanismo, D. Arcoverde não hesitava em subjugar as irmandades, suspender de ordens padres insubordinados e transferir outros tantos.

Isto feito, e tentando obter o apoio de D. Arcoverde, D. Duarte procurou convencer o Cardeal de que seu projeto, para a aplicação dos recursos da herança, 
seria mais bem estruturado e abrangente.

Circunstância providencial aparece-me agora meios e recursos de realizar o pensamento do saudoso Cônego José Bento, reabrindo o extinto colégio "São Miguel", sobre base sólida e estável. Tenho contratada a venda dos terrenos que constituem o lego Wanderley, de modo a poder apurar, descontadas as despesas de demanda e etc., a boa soma de 250 contos de réis. [...] posso fundar dois grandes externatos ou escolas profissionais, para 400 alunos pobres de ambos os sexos, no desditoso bairro do Brás, cuja população de 120 mil almas, aproximadamente, se encontra no mais total abandono...

Para D. Duarte, é a grande oportunidade:

[...] É o bairro operário da capital, onde crescem inúmeras crianças sem noção alguma de Deus, [...] Se lhe não acudirmos agora, que a Providência vem ao nosso encontro, o bairro do Brás se transferirá em perigoso ninho de elementos perniciosos à Igreja e à sociedade. Se passar a ocasião - e a ocasião é sempre calva - nunca mais, talvez teremos igual oportunidade...

A argumentação também passa pelo melhor apoio logístico:

[...] Para levar avante esse projeto e desenvolvê-lo ainda mais, conto com os salesianos e salesianas. Tenho ainda certeza do valioso apoio do governo do Estado...

Além de uma melhor localização:

[...] Poderá pensar alguém que seja possível fazer outros tantos com a mesma segurança e com tão bons auspícios, em um meio acanhado como é Jacareí?...

E principalmente, um ideal mais próximo do desejo do falecido cônego José Bento:

[...] e assim ficará corporificado o belo ideal do Cônego José Bento, de modo mais amplo, com horizontes mais largos e certamente benéficos...

Com esses argumentos, D. Duarte esperava o apoio de D. Joaquim Arcoverde, junto ao Núncio, ressaltando o fato de ser São Paulo a primeira diocese do Cardeal.

[...] Faço esta exposição a V. Ex. ${ }^{a}$ que tanto se interessa por esta sua primeira Diocese, para que possa dizer uma palavrinha ao Sr. Núncio. Convém que ele saiba quais os meus planos e intenções, antes de dar solução definitiva ao esquisito recurso que tem em mãos. Qualquer solução desfavorável à Arquidiocese redundaria em prejuízo imediato de enorme população e grave dano à Igreja. ${ }^{287}$ (os grifos são nossos)

287 ACMSP. Carta de D. Duarte a D. Arcoverde. 16 de abril de 1910. 
Mas essa solução não veio. No dia seguinte, nova carta ao Cardeal. O texto fala por si:

[...] Desejo agora merecer especial obséquio de V. Em. ${ }^{a}$. Está no Supremo Tribunal um recurso extraordinário interposto pelos herdeiros do finado Wanderley contra o Colégio São Miguel que, aliás, tem tido ganho de causa em todas as instâncias. Os autos estão convenientemente preparados e com parecer favorável do Procurador da República, tendo os herdeiros de Wanderley desertado a causa há uns três anos. Não obstante, permanece o recurso encalhado no Supremo Tribunal, sem que, até agora, tenhamos conseguido dar-lhe andamento. Se V. Em. ${ }^{a}$ não tivesse repugnância de falar ao Dr. Cavalcanti para que o desencalhe, me faria grande obséquio. Não se pede esta ou aquela solução (só por fatalidade o Colégio teria sentença contrária); mas tão somente que se apresse uma solução, cuja demora está causando e causará ainda notável prejuízo para uma obra pia de tanta relevância. Bastará que V. Em. ${ }^{a}$ indique ao Dr. Cavalcante o recurso de $\mathrm{S}$. Paulo sob número 312 , pedindo-lhe que se interesse pela conclusão da causa. Conto com a sempre preciosa bênção de V. Em. ${ }^{a}$ o servo em J. C. + Duarte. $^{288}$ (os grifos são deles)

No mês de julho de 1910, o Núncio Apostólico, sem ter uma resposta sobre a reclamação de D. Epaminondas, viu-se na contingência de encaminhar o caso ao Cardeal Secretário da Sagrada Congregação Consistorial. A questão do legado Wanderley agora chegava ao conhecimento de Roma.

Após tomar ciência desse fato, D. Duarte deve ter começado a pensar seriamente em ceder na questão da herança, embora acreditasse tê-la para a Arquidiocese, por questão de justiça.

S. Paulo, 3 de agosto de 1910 Ex. ${ }^{\text {mo }}$ e Rev. ${ }^{\text {mo }}$ Sr. Núncio Apostólico. Voltando de demorada excursão pastoral ao interior da Arquidiocese, tive a honra de receber o venerando ofício da Ex. ${ }^{\text {ma }}$ Nunciatura, sob n. ${ }^{\circ} 2129$, datado de 2 de julho próximo passado, anunciando-me que a reclamação do Sr. Bispo de Taubaté, a propósito do legado do falecido Cônego José Bento ao extinto Colégio São Miguel, foi afeta pelo Em. ${ }^{\mathrm{mo}} \mathrm{Sr}$. Cardeal Secretário à Sagrada Congregação Consistorial, à qual deverei alegar as razões que me parecerem oportunas. Agradecendo a V. Ex. ${ }^{a}$ Rev. ${ }^{\text {ma }}$ a delicadeza da comunicação, apresso-me em declarar a V. Ex. ${ }^{a}$ que, com aquela deferência, lealdade e prontidão que me merecem as ordens e determinações da Santa Sé, satisfarei a qualquer informação que me seja requisitada pela Consistorial, em favor de um direito de que me acho de posse por força da uma sentença judicial passada em julgado. Contando sempre com os sábios conselhos e inteireza direção de $V$. Ex. ${ }^{a}$, em negócio que tanto interessa à paz e tranqüilidade da Província, aproveito este novo ensejo para

288 ACMSP. Carta de D. Duarte a D. Arcoverde. 17 de abril de 1910. 
renovar a $V$. Ex. ${ }^{a}$ os meus protestos de muita estima e consideração, subscrevendo-me. De V. Ex. ${ }^{a}+$ Duarte $^{289}$

caso do Colégio São Miguel tornava-se público, e fonte de discordância entre a imprensa de Jacareí e a Arquidiocese.

Conforme sabemos, a instituição deixou de receber alunos em 1905, devido à saída do Cônego Amador Bueno para o Rio de Janeiro. Naquela ocasião, o referido Cônego nomeou o Major José Bonifácio de Mattos como seu procurador na administração do Colégio.

Ocorre que José Bonifácio de Mattos encerrou o funcionamento da instituição, alegando falta de recursos. O principal patrimônio do Colégio São Miguel não havia ainda sido liquidado, embora o embargo existente houvesse sido retirado pela justiça no mesmo ano de 1905. Vale lembrar que as disposições do testamento de Joaquim Floriano Wanderley distribuíam o patrimônio entre o Colégio São Miguel e o Colégio do Dr. Vicente. O fato de essa segunda instituição ter conseguido liquidar sua parte no patrimônio chamava a atenção de alguns órgãos de imprensa de Jacareí.

[...] não sabemos a razão porque não se deu cumprimento àquela disposição testamentária, quando é certo que o outro colégio (o do Dr. Vicente) a que o legatário deixou na mesma posição, está funcionando em São Paulo há muitos anos sem o menor obstáculo.

O periódico de orientação maçônica procurava estimular os ânimos da população de Jacareí em favor da reabertura do Colégio na cidade...

[...] Nessas condições, o povo jacareiense tem o direito de indagar dos motivos determinantes dessa desigualdade e onde se acham as importâncias que foram apuradas resultantes das vendas de terrenos deixados pelo legatário.

... e não poupava ataques contra D. Duarte, levantando suposições e suspeitas a cerca do destino desses recursos:

[...] Sabemos que grande parte desse patrimônio ou quase sua totalidade, acha-se em poder do Sr. Arcebispo de São Paulo. Por que S. Ex. ${ }^{a}$ Rev. $^{\text {ma }}$ ainda não mandou entregar a quem de direito as importâncias em seu poder, para a regular a instalação do Colégio em Jacareí, conforme determinou o legatário? ${ }^{290}$

Desde 1907, a Arquidiocese possuía legalmente o direito sobre a 
administração do patrimônio do colégio.

A situação estava se agravando. D. Epaminondas demonstrava não recuar diante de um possível questionamento judicial. A Câmara Municipal aprovara moção de salvaguarda aos interesses do Colégio em Jacareí. A imprensa local intensificava seus ataques, levantando questões, cuja reflexão reforçava a imagem de bispo mesquinho de D. Duarte.

[...]Consta-nos que um dispositivo testamentário diz, que na falta dos primitivos inventariantes, deveria assumir este posto o Sr. Bispo Diocesano. Toda gente sabe que nessa ocasião, o bispado de S. Paulo era o único no Estado, razão porque, na falta dos primeiros inventariantes, o legado destinado ao colégio foi parar às mãos do Sr. Bispo de $\mathrm{S}$. Paulo, na qualidade de inventariante. Há dois anos mais ou menos, foi criado o bispado de Taubaté, qual deveria ter sido o procedimento do atual Arcebispo de S. Paulo? (os grifos são nossos)

A crítica era incisiva. Ultrapassando a mera reflexão conduzia o pensamento ao seguinte raciocínio;

[...] entregar imediatamente ao Sr. Bispo de Taubaté, todos os valores e de mais documentos em seu poder em cuja zona funciona o estabelecimento legatário, afim de que este tomasse de pronto as providências de maneira a ser cumprida lisamente a última vontade do testador

à seguinte conclusão;

Sr. Arcebispo assim não procedeu, continuando a conservar em seu poder os capitais destinados ao patrimônio de um colégio, criado para agasalhar os desprotegidos da sorte, sem dar a menor atenção ao caso.

e à seguinte proposição:

[...] pondere o Sr. Arcebispo que o prestígio moral de sua autoridade eclesiástica ficará grandemente abalada se não der uma solução satisfatória ao caso, de modo a ficarem patentes a sua honestidade e o seu amor pelos desprotegidos da fortuna. 291

Mas sua dignidade de Arcebispo Metropolitano da província Eclesiástica de São Paulo exigia uma saída que lhe fosse favorável. Caso a questão caminhasse para uma solução na justiça civil, os efeitos sobre o seu apostolado e carreira eclesiástica não seriam de boa monta.

Isto posto, como resolver uma questão em que as duas partes dispunham de

291 A Liberdade, n. ${ }^{0}$ 9, I. 15 de fevereiro de 1911. 
excelentes amparos técnicos e jurídicos, sem apelar para a justiça dos leigos?

Findava a estação das águas do ano de 1911, e a situação permanecia inalterada. Depois de quase um ano de gestação, surgiu a idéia de se resolver a questão pela via arbitral, mediada por bispos das dioceses sufragâneas.

No mês de maio, D. Duarte deu início a essa nova tentativa de solução. Estando em Aparecida, a raiz de todas as querelas, o Arcebispo procurou D. Epaminondas, que se encontrava em Guaratinguetá, ao alcance de uma boa luneta:

Data vênia, venho convidar a $V$. Ex. $^{a}$ para uma conferência, esta manhã, aqui na Basílica da Aparecida, para assunto de importância e interesse de nossas Dioceses. Creio que, com um pouco de boa vontade e aos pés de N. Senhora, dois Bispos sempre se poderão entender... ${ }^{292}$

De fato, os bispos começaram a se entender, e desse encontro saiu a primeira concordância entre os dois prelados: submeter a questão do direito à administração do Colégio São Miguel, e seu patrimônio, ao arbítrio de outros dois prelados.

Com D. Duarte já em São Paulo, segue, pois, uma carta para D. Epaminondas, tendo como anexo uma minuta do "Compromisso" entre os dois prelados. Eis os documentos:

Em cumprimento do que tivemos a ventura de combinar na Aparecida, envio hoje a V. Ex. ${ }^{a}$ a minuta do compromisso que servirá de base ao julgamento dos árbitros, na questão do Colégio São Miguel. Se V. Ex. ${ }^{a}$ não tiver nenhuma modificação a fazer, fará o obséquio de assiná-la e devolver-me quanto antes. $\mathrm{Na}$ hipótese contrária, $\mathrm{V}$. Ex. ${ }^{\mathrm{a}}$ me dirá quais as modificações que deseja. Como quer que seja, peço vênia para dizer a V. Ex. ${ }^{a}$ que há a máxima vantagem para os interesses do Colégio em que esta nossa questão seja decidida com a maior brevidade possível. Assim, pois, ouso esperar que $\mathrm{V}$. Ex. ${ }^{a}$ tomará providências para apressar este negócio, dando por exemplo instruções a Mons. Castro para reunir documentos, etc., remetendo-os com urgência ao Sr. D. Nery. Seria ainda de bom aviso que $V$. Ex. ${ }^{a}$ apresentasse aos árbitros uma exposição, a fim de melhor esclarece-los, serviço esse que poderia confiar a um advogado amigo. Enfim, Sr. Bispo, creia $V$. Ex. ${ }^{a}$ que me valem muitíssimo mais a amizade e a bênção de um Bispo do que esses 300 ou 400 contos que constituem o objeto do nosso litígio. Pede a bênção $e$ recomenda-se o Servo em J. C.

COMPROMISSO Não se tendo dado andamento, por motivos supervenientes, à decisão provocada perante a Sagrada Consistorial, para interpretação do testamento do Cônego José

292 ACMSP. Carta de D. Duarte a D. Epaminondas. 8 de maio de 1911 
Bento e solução da pendência entre o Arcebispo de São Paulo e o Ex. ${ }^{\text {mo }}$ Sr. Bispo de Taubaté, de modo a saber-se com clareza a quem cabe atualmente a sucessão e administração dos bens patrimoniais do extinto Colégio S. Miguel, de Jacareí, e desejando as partes litigantes ter uma solução pronta que as habilite a agir com segurança e tranqüilidade de consciência, acordam entre si firmar o seguinte compromisso: 1) O Arcebispo de S. Paulo e o Ex. ${ }^{\text {mo }} \mathrm{Sr}$. Bispo de Taubaté, muito livre e espontaneamente, tendo em vista tão somente o bem das almas e os sagrados interesses confiados à sua guarda, concordam em submeter a questão denominada do Colégio S. Miguel ao juízo arbitral de dois Srs. Bispos da Província Eclesiástica de $\mathrm{S}$. Paulo, a cuja sentença desde já se submetem, sem reserva ou restrição. 2) O Arcebispo de S. Paulo escolhe para seu árbitro ao Sr. D. Lúcio Antunes de Sousa, Bispo de Botucatu; e o Ex. ${ }^{\mathrm{mo}} \mathrm{Sr}$. Bispo de Taubaté escolhe para seu árbitro ao Ex. ${ }^{\text {mo }} \mathrm{Sr}$. D. João Batista Corrêa Nery, Bispo de Campinas. 3) Os dois árbitros acima nomeados, como primeiro ato do seu laudo, designarão um terceiro árbitro escolhido entre os Srs. Bispos da Província, a quem tocará decidir, no prazo de três dias, qualquer divergência que entre eles possa surgir. 4) De posse dos documentos que lhes forem entregues pelas partes, os árbitros decidirão, em última instância, a quem toca atualmente, dada a subdivisão da antiga Diocese de S. Paulo, executar o testamento do Cônego José Bento, como seu legítimo sucessor e legítimo administrador de todos os bens patrimoniais que constituem o acervo do extinto Colégio S. Miguel. 5) A sentença dos árbitros será lavrada dentro de dez dias contados do dia em que lhes forem entregues este compromisso e os documentos que 0 acompanham, sendo-Ihes facultado o direito de ouvir advogados e canonistas, a fim de formarem a sua consciência. 6) A sentença arbitral, com os considerandos e outras considerações dos árbitros, será publicada integralmente no Lábaro e na Gazeta do Povo, a fim de evitar interpretações indignas do caráter e da honra das partes litigantes. 7) $\mathrm{Na}$ hipótese de ser o laudo favorável ao Ex. ${ }^{\text {mo }}$ Sr. Bispo de Taubaté , os árbitros, se o julgarem de direito e justiça, ordenarão que o Arcebispo se pague de todas as despesas que tem feito até o presente para defesa dos direitos e interesses do patrimônio em litígio. $\mathrm{E}$ por assim estarem combinados entre si, assinam as partes compromisso, que vai selado com o selo das suas armas, ao qual dão toda força de lei para o efeito de obrigá-las perante a sua consciência e Tribunal de Deus. ${ }^{293}$

Isto feito, D. Duarte envia, já no dia seguinte, mais duas cartas. Uma, para D. Lúcio, bispo de Botucatu, e a outra para D. Nery, bispo de Campinas, manifestando sua intenção de ceder, no caso da herança, mas de maneira honrosa e generosa...

293 ACMSP. Carta e minuta de Compromisso de D. Duarte para D. Epaminondas. 11 de maio de 1911. 
[...] Procurando um meio digno e honroso de fazer a entrega dos bens do Colégio $\mathrm{S}$. Miguel ao $\mathrm{Sr}$. D. Epaminondas, acabando assim com essa fonte de pecados e dissensões, provoquei uma conferência com o Sr. Bispo, por ocasião de minha estada em Aparecida. Aí combinamos em submeter a questão ao laudo de dois Bispos, escolhendo ele o Sr. D. Nery e eu a V. Ex. ${ }^{a}$ (o Bispo de Botucatu) [...] Se o laudo me for favorável, V. Ex. ${ }^{a}$ e o Sr. D. Nery estão desde já autorizados a declarar que o Arcebispo, livre e espontaneamente, tendo em vista o bem das almas, e desejando contribuir ainda mais para maior incremento da Província que tantos trabalhos e dissabores lhe tem causado,

cede 0 seu direito em favor da Diocese de Taubaté, constituindo como legítimo e único administrador dos bens do Colégio S. Miguel ao Sr. D. Epaminondas... ${ }^{294}$ (oS grifos são nossos)

A carta para D. Nery é mais longa. Nela, D. Duarte, além de fazer o convite para o arbitramento, faz também suas observações sobre o incidente:

Pax et gratia. A atitude do Sr. D. Epaminondas não pode deixar de incomodar-me, pelo que considero dever de consciência por um termo a esta escandalosa desunião, fonte perene de pecados, ocasião de futuras dissensões possíveis entre os nossos sucessores.

Para D. Duarte, é possível comprar a paz:

Custa-me dizê-lo, mas a causa de toda esta desavença é uma questão de dinheiro, e com dinheiro posso eu comprar a paz. Não é certo que a paz, sobretudo o bem das almas, vale mais do que esses 300 contos de reis do Colégio S. Miguel, que tanto barulho tem provocado?

Mas a que se deveria tal atitude? Por que razão o Arcebispo, crente de que possuía a herança por direito, dela abriria mão? A resposta a tais proposições talvez resida no seguinte raciocínio: D. Duarte, na defesa do patrimônio de sua Diocese, pela maneira arisca com que tratara a questão na via judicial, contra o antigo procurador de D. José de Camargo Barros e nos recursos apresentados pelos familiares de Joaquim Floriano Wanderley, e principalmente pelos reflexos da reclamação de D. Epaminondas na via eclesiástica, construiu sobre si uma impressão negativa, junto à comunidade fiel e à Consistorial, de um bispo mesquinho e materialista, que não se furtava em levar adiante uma pendência por uns poucos contos de réis.

Era necessário, para melhorar a sua imagem e garantir sua carreira, demonstrar generosidade e dignidade, e, consequentemente, abrir mão da questão.

294 ACMSP. Carta de D. Duarte a D. Lúcio. 9 de maio de 1911. 
[...] o que eu defendo agora não são esses 300 ou 400 contos de réis que não hesito em jogar pela janela fora; bato-me sim pelo reconhecimento do meu direito, pela minha dignidade de homem e de Bispo, procurando lavar-me da feia tacha que me tem sido imputada, sem contramedida nenhuma do nosso Irmão, a quem aliás venero.

Assim sendo, D. Duarte se vê como seguidor das palavras de Cristo, segundo Mateus, ${ }^{295}$ no sermão da montanha:

Reconhecido o meu direito (se for dentro da lei e perante a consciência), não hesitarei um instante em largar também a túnica a que me exige o manto...

A estratégia era simples: desviar o foco da questão material para a necessidade de defesa de um direito.

[...] Custa-me dizê-lo, mas a causa de toda esta desavença é uma questão de dinheiro, e com dinheiro posso eu comprar a paz. Não é certo que a paz, sobretudo o bem das almas, vale mais do que esses 300 contos de réis do Colégio S. Miguel, que tanto barulho tem provocado? [...] Os Bispos de Botucatu, Ribeirão, S. Carlos, com os quais aqui conversei, aprovaram esta minha decisão; é preciso, porém, achar um meio de salvaguarda a minha dignidade, para que não pareça isso uma confissão da ilegitimidade do meu direito... ${ }^{296}$ (os grifos são nossos)

D. Lúcio, que fora aluno do Seminário de Diamantina na mesma época que D. Epaminondas, embora estivesse ligado à 'Igreja mineira' e tivesse apreço pelo Bispo de Taubaté, tinha laços mais fortes com o episcopado paulista, em virtude do compadrio consagrado com D. Arcoverde. Como sabemos, D. Nery fora Bispo de Pouso Alegre, e tinha forte ligação com a 'Igreja mineira'. Era, sem dúvida, o bispo paulista mais próximo e favorável a D. Epaminondas naquele momento, tendo aceitado, no mesmo dia, a incumbência:

[...] respondo que, apesar das muitas ocupações, aceito o trabalho de árbitro, esperando que de tudo isso resulte perfeito sossego para $\mathrm{V}$. Ex. ${ }^{\mathrm{a}}$ Rev. ${ }^{\mathrm{ma}}$. Desde já tomo o compromisso de agir com a máxima imparcialidade e de procurar com minhas pobres orações os auxílios de que hei de precisar para tão delicada incumbência. Pede-lhe a bênção para esta Diocese e para si o servo e irmão + João, Bispo de Campinas. ${ }^{297}$

O compromisso entre os dois bispos, lavrado em cartório, estabelecia que os

295 "Ao que quiser pleitear contigo, e tirar-te a túnica, larga-lhe também a capa." (Mt, 5:40) BÍBLIA DE JERUSALÉM. São Paulo: Paulus, 1998.

296 ACMSP. Carta de D. Duarte a D. Nery. 9 de maio de 1911

297 ACMSP. Carta de D. Nery a D. Duarte. 11 de maio de 1911. 
dois árbitros, caso houvesse divergência entre os mesmos, deveriam submeter seus laudos (que poderiam ser preparados com o auxílio de advogados e canonistas) a um outro bispo, o de Ribeirão Preto, que examinaria os documentos e tomaria sua decisão, na qualidade de terceiro árbitro, de maneira irrevogável em um prazo de três dias. O resultado disso seria publicado nos periódicos Lábaro e Gazeta do Povo, a fim de torná-lo público e evitar interpretações que certamente ocasionariam mais desavenças.

No mesmo 11 de maio, D. Duarte escreve para D. Epaminondas, com a proposta de vender os terrenos, localizados em São Paulo, pertencentes ao Legado Wanderley:

Ex. ${ }^{\text {mo }}$ Sr. Bispo de Taubaté, Pax et gratia. Confirmando a minha carta de hoje, venho dizer a $\mathrm{V}$. Ex. ${ }^{\mathrm{a}}$ que acabo de receber uma proposta vantajosa para a venda do legado Wanderley. Explico-me. O Colégio S. Miguel assinou uma escritura de compromisso, em virtude da qual, logo que tenha decisão favorável do Supremo Tribunal, está obrigado a vender os terrenos chamados do Wanderley pela quantia de 295 contos, ou a pagar uma multa de 50 contos. Alguém agora propõe-se a receber a mesma escritura de compromisso, pagando ao Colégio 400 contos e mais a multa de 50 contos que se deve dar ao primeiro proponente. Como, porém, estamos nós combinados em submeter a nossa pendência ao juízo arbitral, tenho escrúpulo de agir por mim mesmo, bem que a lei me faculte esse direito. Assim, pois, na eventualidade de reverter o patrimônio para $\mathrm{V}$. Ex. ${ }^{\mathrm{a}}$ em virtude da decisão arbitral, concorda V. Ex. ${ }^{a}$ em que eu faça esse negócio que, aliás, numa ou noutra hipótese é vantajosa à instituição? Tenho de dar resposta até sábado, pelo que peço a $\mathrm{V}$. Ex. ${ }^{\mathrm{a}}$ o obséquio de responder-me por telegrama, imediatamente confirmado por carta. É escusado dizer que deixo inteira liberdade a V. Ex. ${ }^{a}$ de decidir como julgar in Domino. Recomendo-me etc. ${ }^{298}$

A proposta não poderia ser melhor. No dia seguinte, cumprindo a solicitação de D. Duarte, seguiu, de Lorena, o telegrama:

Respeitosas saudações. Peço bênção concordo plenamente venda terrenos Wanderley novo comprador. Escreverei correio Sigo Taubaté evocar papéis D. Nery Bispo Taubaté. ${ }^{299}$

Acompanhando o telegrama, a carta de D. Epaminondas confirmava o recebimento do "Compromisso" e a anuência na venda do terrenos:

Ex. ${ }^{\text {mo }}$ Sr. Arcebispo de S. Paulo. Beijando-lhe o sagrado anel, apresento a V. Ex. ${ }^{a}$ as minhas respeitosas saudações. Tenho em meu poder as duas estimadas cartas e o Compromisso que

298 ACMSP. Carta de D. Duarte a D. Epaminondas. 11 de maio de 1911.

299 ACMSP. Telegrama D. Epaminondas para D. Duarte. 11 de maio de 1911. 
V. Ex. ${ }^{a}$ mandou-me com data de 11 deste. Com esta remeto a V. Ex. ${ }^{a}$ o referido Compromisso - datado, assinado e selado, como ordena V. Ex. ${ }^{a}$ na sua $1^{a}$ Carta. Cumprindo as disposições da $2^{\mathrm{a}}$, declaro novamente a $\mathrm{V}$. Ex. ${ }^{\mathrm{a}}$, confirmando $\mathrm{o}$ meu telegrama, que concordo com a venda dos terrenos chamados do Wanderley ao novo comprador, que, como diz V. Ex. $^{\mathrm{a}}$, se obriga a pagar ao Colégio $S$. Miguel a quantia de 400 contos e mais a multa de 50 contos a que teria direito o primeiro proponente com a desistência. Encarreguei a Mons. Castro de pôr em ordem os papéis referentes à questão do Colégio e espero poder mandá-los ao Ex. ${ }^{\text {mo }}$ Sr. D. Nery sem demora. [...] De V. Ex. ${ }^{a}$ o menor dos servos + Epaminondas, Bispo de Taubaté. ${ }^{300}$

Por ocasião da reunião ocorrida em Aparecida, é certo que D. Duarte, nesse particular, se compôs com D. Epaminondas. Ao enviar notícias sobre o andamento das negociações, D. Duarte pede que seja dada publicidade sobre o acordo:

A sua preciosa bênção. Recebi o cartão de $V$. Ex. ${ }^{a}$ e logo depois a minuta do compromisso e a delicada cartinha que 0 acompanha. Mais uma vez agradeço a V. Ex. ${ }^{a}$ a boa vontade que demonstra na solução deste negócio, em que a tranqüilidade das nossas consciências de Bispos tem tudo a ganhar. Hoje mesmo enviei um portador a Campinas com os documentos necessários. A venda do legado Wanderley vai em bom pé, e tenho toda a esperança de alcançar ainda melhor preço. Trabalho neste negócio, sem preocupação pessoal, porque seja eu ou V. Ex. ${ }^{\mathrm{a}}$ o beneficiado, em qualquer hipótese, estou servindo à causa de Deus. Agora uma lembrança, simples lembrança que submeto ao inteiro critério de V. Ex. ${ }^{a}$. Como há tanta gente aí que, indevidamente, se tem apaixonado por uma questão que só entre Bispos deverá ser agitada, não acha $V$. Ex. ${ }^{a}$ que seria de bom aviso publicar no Lábaro uma noticiazinha, dizendo que a questão foi, livremente e de comum acordo, submetida pelos dois Bispos interessados ao juízo arbitral de distintos e piedosos Bispos? Essa notícia, creio eu, acalmaria os espíritos, deixando-nos tempo e vagar para agir com independência e superioridade. Entretanto, V. Ex. ${ }^{a}$ fará o que julgar mais acertado em sua muita prudência e sabedoria. Recomendo-me com muita instância ás piedosas orações e à preciosa Bênção de V. Ex. de quem sou Indigno servo. ${ }^{301}$ (os grifos são nossos)

D. Lúcio, o árbitro de D. Duarte, depois de saber de sua escolha e refletir sobre as conseqüências a ela relacionadas, procurou safar-se do encargo, justificando por motivo a falta de tempo:

Ex. ${ }^{\text {mo }}$ Sr. Arcebispo Metropolitano. Rogo a Deus conceda a V. Ex. ${ }^{a}$ todo o bem. Acuso recebida sua prezada carta de 9 do corrente mês. Sobre o assunto dela muito tenho pensado, e

300 ACMSP. Carta de D. Epaminondas a D. Duarte. 12 de maio de 1911. 301 ACMSP. Carta de D. Duarte a D. Epaminondas. 16 de maio de 1911. 
resolvi-me a rogar a $V$. Ex. ${ }^{a}$ vênia para declinar da honra que me faz em nomear-me árbitro na questão do Colégio S. Miguel. Faço-o por falta de aptidão, e por não me sentir bem como juiz em causa de meu querido Metropolita. Acresce não dispor absolutamente de tempo, sendo professor. Subscrevo-me. De V. Ex. ${ }^{a}$ Sufragâneo amigo e grato + Lúcio, Bispo de Botucatu.. ${ }^{302}$

Vale lembrar que D. Lúcio fora consagrado por D. Duarte, por quem, certamente, tinha apreço, a ponto de não querer decepcioná-lo com um julgamento desfavorável. Sua atitude, de certa forma, pode ser encarada como evidência de que não acreditava ser de D. Duarte o direito de possuir jurisdição sobre o patrimônio do Colégio.

D. Lúcio, todavia, não tinha escapatória. O Arcebispo, no mesmo dia em que tomou conhecimento de suas desculpas, enviou-lhe a seguinte carta:

Esta manhã passei um telegrama a $\mathrm{V}$. Ex. ${ }^{\mathrm{a}}$ pedindo-Ihe que não se recue à delicada missão de compor a pendência entre mim e o Sr. D. Epaminondas, a propósito da sucessão na administração dos bens do Colégio S. Miguel. É uma causa importante que monta a mais de 400 contos em dinheiro, fora propriedades. A solução deste negócio é indispensável para a paz e tranqüilidade da Província, para evitar novas dissensões e talvez escândalos.

Apelando para a disciplina de D. Lúcio, o Arcebispo é incisivo:

É, pois um serviço à Igreja, que $V$. Ex. ${ }^{a}$ não pode e não deve recusar.

Prosseguindo, D. Duarte insiste, fazendo ver que sua honra está em jogo:

Revendo, agora mesmo, a sua carta escusando-se, peço vênia para insistir, suplicando-lhe por amor de Deus que não desista do encargo. Provocando este arbitramento, só tive em vista achar um meio honroso de pôr termo a uma luta, da qual me sinto fatigado, e que não quero continuar por preço nenhum. Por esse motivo, autorizei a V. Ex. ${ }^{\mathrm{a}}$ a declarar, da minha parte, no caso do laudo me ser favorável, que desisto da administração desses bens, em favor do Sr. D. Epaminondas. A mesma autorização dei também ao Sr. D. Nery. À vista dos escrúpulos de $\mathrm{V}$. Ex. ${ }^{a}$ (escrúpulos que eu peço vênia para julgar infundados), declaro mais que, no caso de ter $\mathrm{V}$. Ex. ${ }^{a}$ qualquer dúvida sobre o meu direito, desejo e peço que $V$. Ex. ${ }^{a}$ julgue contra mim. Intencionalmente, já sacrifiquei todo aquele dinheiro com que preciso comprar a paz da minha Arquidiocese, evitando mais escândalos, e, se for preciso, sacrificarei também a minha honra, desistindo de defender-me perante os homens, para não prolongar a lamentável pendência.

302 ACMSP. Carta de D. Lúcio a D. Duarte. s/d. Recebida em 17 de maio de 1911. 
Explicadas suas razões, bem como sua intenção em proporcionar aos árbitros total liberdade, D. Duarte dá o golpe final em D. Lúcio: põe, dramaticamente, nas mãos do bispo de Botucatu, a possibilidade do mesmo ser o responsável pela malevolência do clero e dos fiéis de Taubaté em relação ao arcebispo...

Se, portanto, e apesar de tudo, V. Ex. ${ }^{a}$ insistir em não aceitar o encargo, não tentarei organizar novo tribunal. Considerando a recusa de $V$. Ex. ${ }^{a}$ como uma sentença contrária e a priori, mandarei entregar todos os bens do Colégio ao S. D. Epaminondas. Se é grande a responsabilidade de um julgamento, não me parece menor a de uma recusa. Decida $V$. Ex. ${ }^{a}$. A sentença de V. Ex. ${ }^{a}$, favorável ou contrária, salvará ao menos a minha dignidade; a recusa formal importará na entrega imediata do patrimônio e vale por uma sentença que me deixará entregue à malevolência do clero e dos fiéis de Taubaté, como também daqueles que não compreendem que um Bispo possa ter abnegação bastante para largar de tão avultada importância de dinheiro. Por que hesitar? Eu escolhi a V. Ex. ${ }^{a}$ precisamente por ser amigo do Sr. D. Epaminondas. O Sr. D. Nery já está de posse de todos os documentos, e espera apenas que $\mathrm{V}$. Ex. ${ }^{\mathrm{a}}$ lhe queira designar um ponto de reunião. Ele lembra o Colégio de S. Luiz em Itu, onde os árbitros terão a tranqüilidade precisa e oportunidade de consultar advogados e canonistas. Pedindo a V. Ex. ${ }^{a}$ se digne responder-me por telegrama, recomendo-me à sua bênção e piedosas orações. Servo e amigo em J. C. ${ }^{303}$ (os grifos são deles)

No mesmo dia, por telegrama, a resposta de D. Lúcio: "aceito ser jurado", ${ }^{304}$ seguido de breve carta:

Meus respeitosos cumprimentos. Confirmo meu telegrama de hoje. Visto instar V. Ex. a , apesar de minha inaptidão, etc., aceito o convite para ser árbitro na questão do Colégio São Miguel. Com sumo apreço, me subscrevo de $\mathrm{V}$. Ex. ${ }^{\mathrm{a}}$ sufragâneo amigo e grato + Lúcio, Bispo de Botucatu. ${ }^{305}$

O assunto é tratado pelo bispo de Taubaté, e a correspondência é de Lorena.

Ex. $^{\text {mo }}$ Sr. Arcebispo D. Duarte. Queira V. Ex. ${ }^{a}$ abençoar-me e a esta Diocese e aceitar a renovação de minhas saudações e votos de felicidades. Acabo de escrever ao amigo Mons. Castro, a quem encarreguei de publicar no "Lábaro", conforme o justo desejo de V. Ex. ${ }^{a}$ Rev. $^{\mathrm{ma}}$, a notícia de nossa deliberação. Não sei se poderá sair no $\mathrm{N} .^{\circ}$ próximo, que penso ter ficado impresso hoje ( $4^{\mathrm{a}}$ feira); entretanto, espero que sairá na próxima semana. Rogando a $\mathrm{V}$. Ex. ${ }^{\mathrm{a}}$ relevar-me o escreverIhe neste papel, por não ter aqui à mão, outro, reitero-lhe os protestos de elevado apreço e respeitosa estima com que

303 ACMSP. Carta de D. Duarte a D. Lúcio. 17 de maio de 1911.

304 ACMSP. Telegrama de D. Lúcio para D. Duarte. 17 de maio de 1911.

305 ACMSP. Carta de D. Lúcio a D. Duarte. 17 de maio de 1911. 
subscrevo-me. + Epaminondas, Bispo de Taubaté. ${ }^{306}$

As atividades envolvendo a questão, por sua vez, prosseguiam, e D. Nery, por telegrama, pede prorrogação: "Acabo receber papéis Taubaté. Julgo necessário prorrogação prazo dez dias devido muitos afazeres e ser indispensável entender-me pessoalmente bispo Botucatu. Telegrafei mesmo sentido bispo Taubaté aguardando resposta de ambos. Saudações Bispo Campinas." 307

D. Duarte tinha razões para acreditar na certeza de seu direito. Os pareceres jurídicos de seu advogado e do advogado da Arquidiocese Ihe eram favoráveis. Além disso, seu bispo árbitro havia consultado um terceiro advogado, Antônio Lobo, que também tivera a mesma impressão:

Campinas, 24 de maio de 1911. Ex. ${ }^{\text {mo }}$ Sr. Arcebispo. Particular. O meu Bispo pediu-me parecer sobre o caso do Colégio São Miguel; estudei os papéis de ambos os litigantes (os pareceres jurídicos consultados em janeiro 1910) e dei o parecer que envio, em reserva, para V. Ex. ${ }^{a}$ conhecer. [...] Trata-se de verificar uma condição de fato: "se o estabelecimento deixou de ser ocupado por meninos pobres". Esse fato consta dos documentos, parecendo ao Dr. Câmara Leal que ele importa numa simples suspensão temporária (vide parecer), e ao Ex. ${ }^{\text {mo }}$ Metropolita que o mesmo está extinto (fls. 11, memorial), isto é, segundo a frase do testador: deixou de ser ocupado pelos meninos pobres. Isto posto, e vendo o que resulta iniludivelmente da interpretação natural e lógica do testamento, entendemos que a frase "Prelado Diocesano" da cláusula $5^{\mathrm{a}}$ do testamento se referiu claramente ao Bispo de S. Paulo, tal como decidiu juridicamente o Acórdão do Superior Tribunal de Justiça em 7 de outubro de 1907. [...] Nem sabemos até se 0 Metropolita, depois da decisão judiciária do Tribunal de Justiça, poderia abrir mão e renunciar a um direito que não é seu, pessoalmente, mas da Arquidiocese... [...] è nosso parecer que a Diocese de Taubaté é estranha a ingerência na direção do Colégio e no domínio, posse e gestão do respectivo patrimônio, que compete ao Ex. ${ }^{\text {mo }}$ Arcebispo Metropolitano gerir e aplicar "sem reservas de tempo e nem de lugar".

Isto posto, o parecer de Antônio Lobo reforça a suposta de vitória de D. Duarte:

Li com o maior cuidado, todos os papéis referentes à questão do "Colégio de São Miguel", estabelecimento de ensino existente por sua situação em Jacareí, debatida entre o Ex. ${ }^{\text {mo }}$ Arcebispo Metropolitano D. Duarte Leopoldo e Silva e o Ex. ${ }^{\text {mo }}$ Bispo de Taubaté D. Epaminondas d'Ávila. Formo a minha consciência na leitura de todos os documentos, quer de uma quer de outra parte litigante, e nos arrazoados que vêm

306 ACMSP. Carta de D. Epaminondas a D. Duarte. 17 de Maio de 1911.

307 ACMSP. Telegrama de D. Nery para D. Duarte. 19 de maio de 1911. 
assinados pelo Ex. ${ }^{\text {mo }}$ Arcebispo e por Monsenhor Nascimento Castro. Não se trata, na espécie ventilada, de uma questão de ordem e jurisdição episcopal, que caiba ser resolvida em face do direito canônico e da legislação da Igreja. A matéria está subordinada ao direito civil privado e ela tem de ser considerada, pelo seu aspecto jurídico, diante do testamento do Rev. ${ }^{\text {mo }}$ Cônego José Bento de Andrade, assinado a 12 de Março de 1897. Os próprios litigantes assim o entenderam, quando declaram: "Trata-se apenas da sucessão na administração do patrimônio de um instituto particular, fato esse que se regula pelas disposições do direito civil". "Por vontade expressa do testador, única lei no caso presente ..." ( D. Duarte, memorial a fls. 6 ). "O que regula a questão é a vontade do testador, que é lei em tal matéria. "O testamento, sendo uma lei, deve ser interpretada pelas regras de hermenêutica jurídica ..." (Parecer do Dr. Câmara Leal, aceito pelo Ex. ${ }^{\text {mo }}$ Prelado de Taubaté). Estão, pois, as partes de inteiro acordo nesse ponto capital. Convém, pois, estudar o que quis instituir o testador nas cláusulas testamentárias. O testamento estabelece: que o Cônego José Bento de Andrade fundou e dirigiu um colégio, desde 1885, e que esse estabelecimento de ensino devia abrigar exclusivamente meninos pobres expostos ao desamparo e na miséria; determinou que, caso não estivesse completa e definitivamente organizado aquele instituto, por seu falecimento, se incumbisse dessa missão e também da parte financeira 0 seu testamenteiro e sucessor, que foi o Rev. ${ }^{\text {mo }}$ Cônego Amador Bueno de Barros, enquanto vivesse, e só na hipótese de sua morte ou qualquer outra circunstância que o obrigasse a deixar esta instituição, ficaria o "Colégio S. Miguel" sob a direção, inspeção, cuidado e zelo apostólico perpétuo do Ex. ${ }^{\text {mo }}$ Prelado Diocesano (cláusulas $4^{\mathrm{a}}$ e $5^{\mathrm{a}}$ ). O testamenteiro Cônego Amador renunciou o encargo e, nessas condições, passou a missão de dirigir o instituto e de administrar-Ihe o patrimônio para o Prelado Diocesano. O acórdão do Superior Tribunal de Justiça do Estado, de 7 de Outubro de 1907, julgando recurso de agravo, decidiu que fosse entregue o patrimônio do "Colégio $\mathrm{S}$. Miguel" ao agravante (o Arcebispo Metropolitano ), como seu único e legítimo administrador, reconhecendo dessa arte que o Prelado Diocesano era o de S. Paulo, pois nem existia, então, - Bispado de Taubaté, somente criado canonicamente em Novembro de 1909, dois anos mais tarde após a decisão judiciária irretratável. Entretanto, o testador instituiu que "por qualquer acontecimento extraordinário este estabelecimento deixar de ser ocupado por meninos pobres, passará a pertencer ao Ex. ${ }^{\text {mo }}$ Bispo Diocesano D. Joaquim Arcoverde e a seus sucessores, que o destinará para quaisquer outro estabelecimento de casas pias". Trata-se de verificar uma condição de fato: "se o estabelecimento deixou de ser ocupado por meninos pobres". Esse fato consta dos documentos, parecendo ao Dr. Câmara Leal que ele importa numa simples suspensão temporária ( vide parecer ), e ao Ex. ${ }^{\text {mo }}$ Metropolita que o mesmo está extinto ( fls. 11, memorial ), isto é, segundo a frase do testador: deixou de ser ocupado pelos meninos pobres. Isto posto, e vendo o que resulta iniludivelmente da 
interpretação natural e lógica do testamento, entendemos que a frase "Prelado Diocesano" da cláusula $5^{a}$ do testamento se referiu claramente ao Bispo de S. Paulo, tal como decidiu juridicamente o Acórdão do Superior Tribunal de Justiça em 7 de Outubro de 1907. O acervo da fundação do "Colégio S. Miguel" passou a ser administrado, perpetuamente, pelo prelado de S. Paulo. Ainda mais, a cláusula $7^{\mathrm{a}}$ do testamento, quando cogita da possibilidade de não funcionar o instituto e poder o mesmo ter outro destino em estabelecimentos de casas pias, se referiu à pessoa certa e conhecida; a confiança do testador se revelou em favor de D. Joaquim Arcoverde, Bispo de S. Paulo, e de seus sucessores - Bispo da mesma circunscrição eclesiástica, e a devolução é peremptória - " passará a pertencer" Não é possível nem curial dar outra interpretação, quando é certo que o Bispado de Taubaté não tinha existência na época da abertura do testamento e nem ao tempo em que se devolveu, de forma absoluta, o patrimônio do "Colégio" para a gestão do Prelado Diocesano de S. Paulo. Nem sabemos até se o Metropolita, depois da decisão judiciária do Tribunal de Justiça, poderia abrir mão e renunciar um direito que não é seu, pessoalmente, mas da Arquidiocese, segundo o testamento do Cônego José Bento, proclamado pelo poder judiciário legítimo. Naturalmente, queria 0 testador a permanência do "Colégio S. Miguel" em Jacareí, onde ele o fundou e serviu de pároco; mas das cláusulas testamentárias não se colige, explicitamente, essa intenção, e assim cabe ao Prelado Diocesano dar o destino que melhor lhe parecer ao patrimônio da fundação. É nosso parecer que a Diocese de Taubaté é estranha a ingerência na direção do Colégio e no domínio, posse e gestão do respectivo patrimônio, que compete ao Ex. ${ }^{\text {mo }}$ Arcebispo Metropolitano gerir e aplicar "sem reservas de tempo e nem de lugar". 308

Note-se que a intenção de D. Duarte de sair vencedor na questão e abrir mão de seu objeto estava ameaçada. O patrimônio em litígio destinar-se-ia à Arquidiocese e sua doação generosa à diocese de Taubaté poderia ser contestada...

D. Duarte estava confiante. Acreditava estar bem amparado em seus argumentos pela eficiência de seus advogados:

[...] facilmente pode o amigo imaginar a satisfação que sente a minha dignidade ingratamente ferida, ouvindo de um jurisconsulto de consciência que "as conclusões do meu memorial são inatacáveis". Se os árbitros assim o julgarem, dou-me por satisfeito, e não hesitarei em desfazerme desse grande patrimônio para o bem da paz, uma vez que o possa fazer em boa consciência. Se os árbitros decidirem que o Arcebispo não pode ou não deve entregar à Diocese de Taubaté a administração do patrimônio, uma coisa ao menos ficará bem patente; que o Arcebispo só defendeu o que julgava ser o seu direito; que mesmo na hipótese de um

308 ACMSP. Carta do advogado Antônio Lobo a D. Duarte, acompanhada de Parecer. 23 de maio de 1911. 
laudo favorável, estaria disposto e sacrificá-lo para o bem da paz; que só o não faz porque não pode e não deve. Creio que isto é bastante honroso... ${ }^{309}$ (os grifos são nossos)

Atendendo ao pedido de D. Duarte, D. Epaminondas fez publicar n"O Lábaro' o encaminhamento da questão, submetida, como se sabe, ao juízo arbitral dos dois bispos:

Para resolução definitiva da questão em litígio sobre a competência legal da aplicação do caridoso Wanderley, conforme as disposições testamentárias do fundador do Colégio "São Miguel", em Jacareí, a cujo benefício foi destinado o aludido legado, acha-se constituído um tribunal arbitral composto dos Ex. ${ }^{\text {mos }}$ Bispos de Campinas e de Botucatu, de comum acordo entre os Ex. ${ }^{\text {mos }}$ Arcebispos de São Paulo e Bispo de Taubaté. Do estudo consciencioso dos documentos submetidos a judiciosa e imparcial apreciação dos criteriosos árbitros, resultará a decisão determinante da questão, digna de ser acatada como a última expressão da verdade jurídica na exata interpretação da vontade do testador, que outra não é senão a aplicação do legado em litígio a qualquer outro estabelecimento de casa pia, dada a veracidade dos casos previstos em dispositivos testamentários. ${ }^{310}$

Atendendo ao compromisso em 28 de maio de 1911, na cidade de Itu, D.

Lúcio e D. Nery arbitraram:

Itu, 28 de Maio de 1911 Ex. $^{\text {mo }}$ e Rev. ${ }^{\text {mo }}$ Sr. Temos a honra de passar às mãos de $\mathrm{V}$. Ex. ${ }^{\mathrm{a}}$ o laudo que proferimos sobre a questão do Colégio S. Miguel. Procuramos desempenhar esse honroso e delicado encargo coram Domino, estudando o assunto com o máximo cuidado e ouvindo sobre ele pessoas de reconhecida competência e critério. Agradecemos a confiança que em nós depositou $V$. Ex. ${ }^{a}$, a quem reiteramos as seguranças da mais elevada estima. Deus guarde a V. Ex. ${ }^{a}$ Rev. ${ }^{\text {ma }}$. João, Bispo de Campinas + Lúcio, Bispo de Botucatu.

Ata da reunião única do tribunal arbitral, constituído pelos Ex. ${ }^{\text {mos }}$ e Rev. ${ }^{\text {mos }}$ Srs. Arcebispo de S. Paulo e Bispo de Taubaté, para resolver a questão suscitada a propósito do "Colégio S. Miguel", de Jacareí.

No dia vinte e oito de maio de mil novecentos e onze, a uma hora da tarde, em uma das salas do Colégio de S. Luís, Itu, presentes o Ex. ${ }^{\text {mo }}$ e Rev. ${ }^{\text {mo }}$ D. João Batista Corrêa Nery, bispo de Campinas e árbitro da Diocese de Taubaté, o Ex. ${ }^{\mathrm{mo}}$ e Rev. ${ }^{\mathrm{mo}}$ Sr. D. Lúcio Antunes de Sousa, árbitro da Arquidiocese de S. Paulo, Rev. ${ }^{\text {mos }}$ Padres Carlos Maria Bonina e Francisco José de Azevedo, consultores, e o abaixo assinado secretário ad

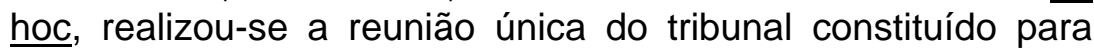
resolver a questão suscitada entre os Ex. ${ }^{\text {mos }}$ e Rev. ${ }^{\text {mos }}$ Srs.

309 ACMSP. Carta de D. Duarte ao advogado Antônio Lobo. 25 de maio de 1911

310 O Lábaro, n. ${ }^{\circ} 73$, II. 25 de maio de 1911. 
Arcebispo de Taubaté, digo de S. Paulo, e Bispo de Taubaté a propósito do "Colégio S. Miguel", de Jacareí. Tratou-se, preliminarmente, da competência dos árbitros para resolver sobre se está ou não restrito o Colégio. Decidiu-se pela afirmativa, ficando combinado que, se os Ex. ${ }^{\text {mos }}$ Prelados litigantes impugnarem o laudo, visto não constar no compromisso essa competência, os árbitros desistirão do encargo, por motivo de consciência. Ficou combinado igualmente que, em caso de divergência inconciliável entre os árbitros, caberia ao Ex. ${ }^{\mathrm{mo}}$ e Rev. ${ }^{\mathrm{mo}} \mathrm{Sr}$. Bispo de Ribeirão Preto resolver a divergência, como terceiro árbitro. Passou-se depois à discussão da questão, em fase dos documentos e do direito civil e canônico, sendo formulados os seguintes quesitos: $1^{\circ}$ Está ou não restrito o Colégio S. Miguel? $2^{\circ}$ - No caso negativo, deve ou não continuar em Jacareí ? $3^{\circ}$ - Continuando o Colégio em Jacareí, diocese de Taubaté, quem deve dirigi-lo e administrar seu patrimônio ? As respostas foram as seguintes: ao $1^{\circ}$ - negativa; ao $2^{\circ}$ - afirmativa; ao $3^{\circ}$ - o Ex. ${ }^{\text {mo }} \mathrm{Sr}$. Bispo de Taubaté.

As principais justificativas expressas pelos árbitros para tais decisões consideraram:

Os Ex. ${ }^{\text {mos }}$ Srs. árbitros formularam o seguinte Laudo: "Vistos e examinados todos os documentos que nos foram apresentados, relativos à questão do Colégio S. Miguel, fundado em Jacareí pelo falecido Cônego José Bento, questão que foi submetida ao nosso juízo arbitral :- Considerando que o fato de se ter interrompido o funcionamento do Colégio $\mathrm{S}$. Miguel, por falta de recursos, até que se liquidasse a questão do seu principal patrimônio não importa na sua extinção, o que se torna inegável em face da apelação civil n. ${ }^{\circ} 4$. 811, em que o dito Colégio figura como recorrente perante o Tribunal de Justiça de S. Paulo; Considerando que na interpretação dos testamentos como das leis em geral deve-se examinar todo o contexto, para se deduzir o seu verdadeiro sentido, e segundo esse princípio, para que o fato de deixar de ser o Colégio ocupado por meninos pobres e desvalidos importasse na hipótese figurada na cláusula sétima do testamento seria necessário que o acontecimento extraordinário de que fala 0 mesmo testamento fosse tal que se tivesse de dar outro destino ao prédio, terrenos e mais patrimônios; Considerando que ainda na hipótese da extinção nenhuma outra fundação de Casa Pia se aproximaria tanto da vontade do testador, expressa na cláusula sétima do testamento, como a restauração do próprio Colégio de $\mathrm{S}$. Miguel em Jacareí; Considerando que ex vi da cláusula quinta do testamento, sucedeu legalmente ao Cônego, hoje Monsenhor Amador Bueno na administração do Colégio $S$. Miguel e de seu patrimônio, o Ex. ${ }^{\text {mo }}$ Sr. Bispo, hoje Arcebispo de S. Paulo, a que esta sucessão foi reconhecida pelo Acórdão do Tribunal de Justiça de S. Paulo de 7 de Outubro de 1907;

A apelação a que o documento se refere trata do recurso impetrado pelo 
Tenente Coronel Francisco Antônio de Lima, na época da sentença favorável à D. Duarte. A caracterização da não extinção do Colégio, no seu sentido jurídico significava que a instituição existia e tinha capacidade legal para gerenciar seu patrimônio.

Além disso, os bispos entenderam que:

Considerando, finalmente, que o Ex. ${ }^{\mathrm{mo}} \mathrm{Sr}$. Bispo de Taubaté é, no respectivo território, sucessor do Ex. ${ }^{\text {mo }} \mathrm{Sr}$. Bispo, hoje Arcebispo de S. Paulo, in spiritualibus et temporalibus, sem restrição de pessoas ou coisas, e que fundações que ali tenham caráter diocesano dependem do Bispo local, e mais, que fomos autorizados pelo Ex. ${ }^{\mathrm{mo}} \mathrm{Sr}$. Bispo de Taubaté, ainda mesmo que fosse contrário a este o nosso laudo: - Acordamos no seguinte :- $1^{\circ}$ - Que continue ou seja restaurado em Jacareí o Colégio S. Miguel, com os recursos provenientes do seu patrimônio; $2^{\circ}$ - Que o Ex. ${ }^{\mathrm{mo}} \mathrm{Sr}$. Arcebispo de S. Paulo, administrador legal do Colégio $\mathrm{S}$. Miguel e de seu patrimônio até a presente data, passe legalmente esse encargo ao Ex. ${ }^{\text {mo }}$ Sr. Bispo de Taubaté, indenizando-se de todas as despesas feitas. Esta sentença será lavrada em duplicata e publicada integralmente na Gazeta do Povo e n"O Lábaro', para conhecimento de todos. Itu, 28 de Maio de 1911. " Nada mais havendo a tratar, deu-se por terminada a reunião, da qual eu, secretário ad hoc, lavrei a presente ata que assino. Cônego Otávio Chagas de Miranda, secretário ad hoc. + João, Bispo de Campinas + Lúcio, Bispo de Botucatu Carlos M. Bonanni S.J. Francisco José de Azevedo S.J. ${ }^{311}$

O desfecho da questão não deve ter tirado o sono de D. Duarte. Imbricada aos problemas do "Legado Wanderley" estava uma querela de muito maior importância financeira e política: a "Questão de Aparecida". Mesmo que o laudo arbitral se encaminhasse para um desfecho favorável ao arcebispo, é sabido que o mesmo entregaria os bens do legado à diocese de Taubaté. Interessava muito mais a D. Duarte, ao nosso ver, a administração dos recursos provenientes da Basílica de Aparecida, também reclamada por D. Epaminondas. Que a vitória do bispo de Taubaté sobre patrimônio do "Legado Wanderley", portanto, pusesse termo à outra questão, e tudo estaria resolvido. E muito bem resolvido.

Encerrada a reunião em Itu, D. Duarte apressou-se em parabenizar, por telegrama, a diocese de Taubaté pela vitória. A notícia da decisão foi publicada n"O Lábaro', permeadas de citações elogiosas a D. Duarte:

Decisão arbitral a favor desta diocese - Ciente de que se achava ausente desta sede episcopal o Ex. ${ }^{\text {mo }}$ bispo diocesano, em visita pastoral, o ilustre Arcebispo de São Paulo dirigiu ao

311 ACMSP. Ata da reunião do Tribunal Arbitral. Itu, 28 de maio de 1911. 
Monsenhor Vigário Geral do Bispado o seguinte telegrama: Sentença favorável diocese Taubaté. Obséquio comunicar ao Sr. Bispo com minhas sinceras felicitações. Tal foi a comunicação oficial da decisão definitiva do tribunal arbitral sobre a questão dos legados testamentários, relativos À uma instituição de ensino em Jacareí. Havendo dúvidas atinentes à efetividade dos casos previstos nas disposições do legatário testador, a quem competia então o direito da aplicação dos referidos legados a qualquer outro estabelecimento pio, por mútuo acordo ficou estabelecido que a solução dessas dúvidas fosse confiada ao alto critério de um julgamento arbitral, dado por dois ilustrados Bispos desta Província Metropolitana. O resultado decisivo é o que consta da comunicação do preclaro Arcebispo de São Paulo ao nosso amado Bispo Diocesano, a quem apresentamos nossas afetuosas felicitações, congratulando-nos com S. Ex. ${ }^{a}$ e toda a diocese. É ainda um dever de justiça e de gratidão salientar o procedimento correto e leal, com que o Digno Metropolitano orientou essa questão para uma solução satisfatória perante o direito e tranqüilizadora em face da consciência. ${ }^{312}$ (os grifos são deles)

Sem demora, a explicação pela decisão favorável a D. Epaminondas, veio por meio de D. Lúcio:

Sr. Arcebispo, embora não nos fosse dado poder expressamente saber e discutir e sentenciar quanto à extinção do Colégio S. Miguel, nós resolvemos sobre isto não só porque os memoriais e outros documentos se referem ao ponto, mas ainda porque julgamos capital esta primeira questão solvida para em consciência darmos o laudo. Depois, parece-me que admitida a extinção do Colégio antes de se receber o legado Wanderley, devolver-se-ia o legado aos herdeiros de Wanderley...

A questão do legado Wanderley, para seus familiares, não estava morta. Transitava ainda, nessa época, um recurso que contestava a decisão favorável ao Colégio São Miguel. Existiam, portanto, duas questões distintas: a primeira referia-se ao recurso dos familiares de Wanderley contra o Colégio, na figura do Tenente Coronel Francisco Antônio de Lima; a segunda, já em última instância, referia-se ao agravo de Arquidiocese contra o referido oficial, quanto a questão do direito sobre a administração do Patrimônio. Ou seja, havia a possibilidade de se perder a herança, por uma alegação de desacordo na interpretação do testamento. Ante essa possibilidade, prevaleceu a instituição Igreja Católica.

[...] Esta questão não figura-nos considerarmos, porque seria perigoso lembrar tal coisa aos herdeiros; e aqui só escrevo a $\mathrm{V}$. Ex. $^{\text {a em reserva. }}{ }^{313}$ (os grifos são deles)

312 O Lábaro, n. ${ }^{\circ} 74$, II. 1 de junho de 1911.

313 ACMSP. Carta de D. Lúcio a D. Duarte, 28 de maio de 1911. 
Além disso, havia uma ação ajuizada pela Loja Maçônica de Jacareí, contra a Arquidiocese, pela incorporação dos bens do Colégio à Mitra:

[...] Para que possa julgar como tudo isto tem sido mal encaminhado, imagine que a Loja Maçônica de Jacareí, depois de me ter insultado e caluniado pela imprensa da terra, quer agora obrigar-me a pagar direitos fabulosos ao Estado (uns 100 contos de réis), a pretexto de que os bens do colégio foram incorporados aos bens da Mitra. ${ }^{314}$

A questão do Colégio São Miguel, que permanecia fechado por falta de recursos, causava indisposição até com a Câmara Municipal de Jacareí:

A Câmara Municipal de Jacareí, por seus membros subscritos, a bem de relevantes e indeclináveis interesses desta cidade, pede vênia para levar ao conhecimento de V. Ex. ${ }^{a}$ Rev. ${ }^{\text {ma }}$ os fatos que ao diante, se especificam. Constando a esta Câmara que é intenção de S. V. Ex. ${ }^{\mathrm{a}}$ o Ex. ${ }^{\mathrm{mo}}$ e Rev. ${ }^{\mathrm{mo}} \mathrm{Sr}$. Arcebispo de São Paulo retirar desta cidade o estabelecimento denominado Colégio $\mathbf{S}$. Miguel, que, por testamento do saudoso Cônego José Bento de Andrade, aqui deve ter a sua sede inamovível, [...] se conclui evidentemente que aqui é forçoso continuar aquele estabelecimento, do qual apenas o funcionamento se acha suspenso. E o motivo do não funcionamento do estabelecimento referido tem sido a falta de recebimento do pecúlio que, em legado, Ihe deixou o benemérito Wanderley... ${ }^{315}$ (os grifos são nossos)

Mas a questão do Colégio estava resolvida. Sobre a cabeça de D. Duarte não mais pairariam tais agravos e indisposições, pois conforme o combinado nesse acordo arbitral, a decisão era irrevogável e não lhe cabia recurso. Restavam apenas as questões burocráticas referentes à transferência do patrimônio. Em novembro de 1911, o advogado de D. Duarte comunicou-Ihe da decisão favorável do Supremo Tribunal Federal na pendência com os familiares do Wanderley.

A administração sobre o patrimônio do colégio foi passada de São Paulo para Taubaté, mas a escola não foi reaberta.

Durante o processo burocrático de transferência dessa posse, os ânimos da Imprensa e Câmara de Jacareí mantiveram-se estáveis, sem maiores críticas ao não funcionamento do Colégio.

A decisão arbitral era clara: determinava a reabertura da Instituição em Jacareí. Mas isso não estava nos planos da diocese de Taubaté. Existia um objetivo maior que exigiria a aplicação desse recurso: o Seminário Diocesano em Taubaté.

314 ACMSP. Carta de D. Duarte ao advogado Antônio Lobo. 25 de maio de 1911.

315 ACMSP. Ofício da Câmara Municipal de Jacareí ao Arcebispo, s/d. 
Com o passar dos anos sem a solução para o caso do Colégio, a imprensa de Jacareí tornou à carga:

[...] De posse de todos os bens do Colégio, de grande soma de dinheiro, qual deveria ser a conduta do Ex. ${ }^{\text {mo }}$ Sr. Bispo da Diocese de Taubaté? Reabri-lo incontinente. No entanto, são passado cerca de 3 anos e os órfãos, deserdados da fortuna, aí estão crescendo sem gozarem os benefícios do Colégio, sem receberem a luz do ensino, que tanto Ihes podia servir para amanhã serem mais útil à Pátria e à Família.! Mas assim não pensa quem superintende os negócios desta Diocese, quer seja por capricho, quer seja por interesse.

O Paço Episcopal se justificava com a alegação de que não tinha disponibilidade de quadros clericais para assumir a licenciatura do Colégio São Miguel.

Mas o periódico retrucava:

[...] Felizes daqueles que têm suas consciências tranqüilas e que podem transpor este lodoso mundo, sem que a "baba da calúnia" Ihes atinja! Não é exato como murmuram, que esta folha se tem investido contra a dignidade do Ex. ${ }^{\mathrm{mo}} \mathrm{Sr}$. Bispo Diocesano de Taubaté. Apenas tem censurado o seu ato administrativo, em reter por muito tempo nos cofres da sua Diocese o dinheiro do Colégio e conservando esta casa de instrução e de caridade, eternamente fechada, com o pretexto de que não há sacerdotes religiosos para o dirigirem. Mesmo que assim fosse, se houvesse boa vontade para com este malfadado Colégio, estaria ele funcionando com um corpo docente provisório, até que se fizesse aquisição de mestres religiosos. ${ }^{316}$

Mas de nada adiantariam tais proposições. O bispo de Taubaté não tinha a intenção de reabrir uma instituição de ensino voltada exclusivamente para meninos desvalidos de Jacareí. Possuía um projeto maior, mais abrangente, e que atenderia a uma maior parcela da população da diocese, de projeção muito mais relevante aos seus objetivos, materializados na fundação do Seminário Episcopal.

Além disso, a justificativa de falta de quadros reforçava justamente a necessidade desse Seminário.

A questão do legado Wanderley estava resolvida, mas a dissidência entre os dois bispos, não. Faltava ainda resolver a questão referente a maior fonte de recursos e arrecadação de doações da Província Eclesiástica, e principal razão de desavença entre São Paulo e Taubaté: o Santuário de Nossa Senhora Aparecida.

316 A Liberdade, n. ${ }^{\circ}$ 187, V. 13 de maio de 1915. 


\section{CAPÍTULO III}

\section{A "QUESTÃO DE APARECIDA"}

\subsection{Aparecida: a arquitetura de uma devoção}

O Santuário e a devoção a Nossa Senhora Aparecida tiveram origem no encontro de uma imagem de barro cozido, medindo trinta e seis centímetros, nas águas do rio Paraíba.

A versão oficial da Igreja católica sobre o encontro se reporta a outubro de 1717, quando Domingos Alves Garcia, seu filho João Alves e Felipe Pedroso, pescadores encarregados de obter alimento para a comitiva do Conde de Assumar, governador e capitão-geral da capitania de São Vicente, após diversas tentativas infrutíferas, encontraram, na rede de pesca, o corpo mutilado de uma imagem de Nossa Senhora da Conceição.

Em seguida, sem apanhar peixe algum, veio presa, à rede, a cabeça da imagem. Após isso, a quantidade de peixes obtida foi tanta que os três homens, temendo o naufrágio da embarcação, viram-se na circunstância de retornar às margens do rio. A pesca abundante foi, naturalmente, atribuída a uma ação miraculosa de Nossa Senhora.

Felipe Pedroso levou a imagem para sua residência e, após colar a cabeça ao tronco da imagem com cera, depositou-a em seu oratório doméstico. Isso feito, e em pouco tempo, a família de Felipe, e seus vizinhos, deram início ao culto da imagem, que passou a ser denominada de Nossa Senhora da Conceição Aparecida, em virtude de seu "aparecimento" nas redes.

O pescador manteve consigo a imagem por quinze anos, quando então entregou-a a um de seus filhos, Anastácio, que construiu uma capelinha nas cercanias da região, conhecida como Porto Iguaçu.

À construção da capelinha começaram a suceder-se manifestações tidas como miraculosas pelo povo, como, por exemplo, o fato de velas inexplicavelmente terem se apagado durante a reza do terço, não obstante a noite estar calma e serena, e após isso terem acendido sozinhas.

No que se refere à expansão inicial do culto de Nossa Senhora Aparecida, a própria localização em muito o favoreceu. Situada na beira de uma estrada que conduzia ao litoral Norte paulista e às Minas Gerais, a devoção foi levada pelos viajantes para todas as direções. 
Entenda-se, pois, considerando o aspecto de natureza geográfica, a importância da localização de Aparecida e o conseqüente investimento do episcopado em torná-la pólo catalisador das massas, em reforço aos objetivos do projeto regional de romanização.

A uma légua de Guaratinguetá, passamos em frente da capela de Nossa Senhora da Aparecida. A imagem que ali se adora passa por milagrosa e goza de grande reputação, não só na região como nas partes mais longínquas do Brasil. Aqui vem gente de Minas, Goiás, Bahia cumprir promessas feitas a Nossa Senhora da Aparecida. ${ }^{317}$

A primeira capela em honra de Nossa Senhora Aparecida foi inaugurada em 26 de julho de 1745, ano de seu culto público, também aprovado pela Igreja católica, sob o título de 'Aparecida'. A devoção se expande, e conforme se pode verificar no testamento de Bárbara de Chaves, feito em 28 de Julho de 1760, na Vila de São Francisco das Chagas de Taubaté, atual Taubaté, missas são deixadas em louvor da santa:

\begin{abstract}
Declaro que se me digão três missas de corpo prezente em louvor das três pessoas da Santíssima Trindade e hua missa a Nossa Senhora do Parto e outra a Nossa Senhora das Dores e outra a Nossa Senhora da Conceyçam Aparecida e outra a meu Padre Sam Francisco e outra a Sam Miguel e outra ao Senhor Sam José. ${ }^{318}$
\end{abstract}

O trânsito de pessoas pelos mais diversos grotões do país é também forte impulsionador da devoção, como se demonstra no testamento de Antônio de Oliveira Martins. Feito em 10 de dezembro de 1761, na Vila Real de Cuiabá, viajou nas mãos do Vigário Antônio [...rasurado...], sendo aberto em 13 de julho de 1763, na cidade de São Paulo. A distância, no entanto, não fez Antônio de Oliveira Martins se esquecer de sua dívida para com Nossa Senhora Aparecida:

Declaro que sou natural da Vila de Jacareí, bispado da cidade de São Paulo [...] Declaro que não devo ao fazer este coisa alguma, e tão somente devo uma dobra para que se dizer em missas na capela de Nossa Senhora Aparecida sita junto a Vila de Guaratinguetá. ${ }^{319}$

A união da Igreja católica com o Estado, materializada na instituição do Padroado, refletiu na administração da capela, uma vez que "foram tantas as intervenções, os provimentos, leis e decretos, avisos e normas, emanados do poder

317 SAINT-HILAIRE, Auguste de. Segunda viagem do Rio de Janeiro a Minas Gerais e a São Paulo, 1822. Belo Horizonte: Itatiaia; São Paulo: Editora da Universidade de São Paulo, 1974. p. 74.

318 Arquivo Histórico Dr. Félix Guisard Filho - Cartório do $2^{\circ}$ Ofício de Taubaté (Caixa 1760 - 1764). 319 Arquivo Histórico Dr. Félix Guisard Filho - Cartório do $2^{\circ}$ Ofício de Taubaté (Caixa 1760 - 1764). 
secular, que seria impossível fazer uma síntese, ainda que superficial." 320

Em linhas gerais, de 1745 a 1803, a capela, filial da igreja matriz de Santo Antônio de Guaratinguetá, teve seus bens, assim como sua festa anual, administrados pela Irmandade de Nossa Senhora da Conceição Aparecida. O atendimento religioso era realizado pelo vigário da paróquia, enquanto que o bispo diocesano, geralmente por intermédio de seus visitadores, intervinha, vez ou outra, em assuntos pastorais ou administrativos, como, por exemplo, na reforma e ampliação da igreja em 1760.

Em 19 de outubro de 1800, uma resolução de D. João VI passou o Santuário para o controle secular, e em 21 de abril de 1803, um ofício do Juiz Ouvidor e Corregedor Geral da Comarca exigiu da mesa da irmandade a nomeação do capitão-mor ${ }^{321}$ da Vila de Guaratinguetá, Jerônimo Francisco Guimarães, para ocupar o cargo de tesoureiro do cofre da capela e da irmandade, sendo seu nome homologado em 24 de maio do mesmo ano, na qualidade de "Protetor da Capela". ${ }^{322}$

Interessante notar que, decerto destoante de uma paisagem constituída por habitações modestas, não passou despercebido a Spix e Martius o "grande e belo sobrado", localizado logo atrás do Santuário, ${ }^{323}$ que servia de residência ao tesoureiro. Por fim, em setembro de 1805, as esmolas, bem como o patrimônio da capela, foram oficialmente incorporados aos bens públicos, extinguindo-se a Irmandade de Nossa Senhora da Conceição Aparecida.

A ação secular no Santuário prossegue, e em 1809 foi instalada a Mesa Protetória, seguindo as mesmas normas contábeis da administração pública. Composta por um Protetor (ou tesoureiro), um escrivão e um procurador, prosseguiu Jerônimo Francisco Guimarães na condição de Protetor, agora nomeado pelo governo central do Rio de Janeiro. A ingerência da capela por parte do governo era tal que, por duas vezes, D. João VI determinou recolhimento de dinheiro para acorrer às necessidades do Estado.

Somente depois de 23 anos de gestão, o tesoureiro Guimarães foi deposto. Para isso foram necessárias duas provisões do

320 BRUSTOLONI, Júlio João. A Senhora da Conceição Aparecida: história da imagem, da capela e das romarias. 8. ed. Aparecida: Santuário, 1999. p. 80.

321 Como é sabido, o título de capitão-mor equivale, em nossos dias, ao de prefeito.

322 Arquivo da Cúria Arquidiocesana de Aparecida, doravante denominado ACAA. Livro de Atas da Irmandade de Nossa Senhora da Conceição Aparecida, fl. 17v.

323 SPIX. Johann Baptist Ritter von et MARTIUS, Karl Frederich Philipp von. Viagem pelo Brasil (1817 - 1820). Tomo I. São Paulo: Melhoramentos. 2. ed. s/d. p. 130. 
Imperador; a primeira a 10 de janeiro de 1824, exigindo a renovação da Mesa, e a segunda a 17 de julho anulando a reeleição do Capitão-mor Guimarães para o cargo de recebedor de esmolas. ${ }^{324}$

Em 1844 assiste-se a extinção da Mesa Protetória, surgindo em seu lugar a "Mesa Administrativa dos Bens e Esmolas de Nossa Senhora d’Apparecida", composta por também três membros, tesoureiro, escrivão e pároco, este último passando a fazer parte da Mesa como membro nato. Os funcionários efetivos (capelão, sacristão, organista, chaveiro das casas dos romeiros) eram nomeados pela Mesa e recebiam salário mensal. O pároco, conforme previa a lei, ${ }^{325}$ nada recebia, enquanto que cabia ao tesoureiro e ao escrivão, a título de remuneração, $5 \%$ de todas as rendas da Capela.

Os desmandos, por sua vez, na e da Mesa Administrativa, também eram freqüentes. Nomeados que eram seus membros pelo Juiz Municipal, as arbitrariedades e a política partidária davam as cartas, e "a Assembléia Provincial teve que intervir nomeando diretamente o tesoureiro por causa da incompetência e corrupção do tesoureiro Bento Barbosa." 326

Apesar do caráter inovador da composição da Mesa Administrativa, qual seja, o ingresso do pároco como membro, alguns desses, mais afinados com o bispo diocesano, ao não concordarem com certas decisões, faziam notar seu "voto vencido":

A principal inovação dessa lei foi a admissão do pároco como membro nato da Mesa; não deixando de ser, sem dúvida, um ensaio para dar participação da Igreja nas decisões atinentes à administração do Santuário. Dizemos ensaio porque, na realidade, quando interesses escusos entravam em jogo, o voto do pároco era sempre 'voto vencido', isto é, um contra dois. Freqüentemente, a partir a de 1850, o pároco assinava seu nome acrescentando os dizeres 'voto vencido'. 327

Os bispos reformadores, por sua vez, não se mantinham inertes. Já em

324 BRUSTOLONI, Júlio João. A Senhora da Conceição Aparecida: história da imagem, da capela e das romarias. 8 ed. Aparecida: Santuário, 1999. pp. 85-86.

325 Lei n. ${ }^{\circ} 43$, de 30 de março de 1844, que criou a Mesa Administrativa da Capela de Aparecida. Em seu artigo $2^{\circ}$ lê-se: "Esta Mesa será composta do pároco, que será o membro nato, e não perceberá isso gratificação, de um administrador que servirá também de tesoureiro, e mais um escrivão; e estes serão nomeados pelo Juiz Provedor de Capelas, e perceberão cinco por cento repartidamente de todos os rendimentos da dita Capela".

326 BRUSTOLONI, Júlio João. História da administração do Santuário de Aparecida. Aparecida: Marju, 1998. p. 15.

327 BRUSTOLONI, Júlio João. História da administração do Santuário de Aparecida. Aparecida: Marju, 1998. p. 14. 
1854, D. Antônio Joaquim de Melo exigia valer seus direitos junto a Mesa administrativa da capela, no sentido de exercer sua competência em julgar a idoneidade do capelão por ela nomeado, mas encontrou oposição dos responsáveis. Com a república, o Decreto $119 \mathrm{~A}^{328}$, de 7 de janeiro de 1890 , separou a Igreja do Estado, pondo fim às intromissões de juizes e chefes políticos. Em relação aos assuntos relativos a administração de Aparecida, "não houve problema nenhum: a autoridade civil simplesmente comunicou ao Sr. Bispo, Dom Lino D. Rodrigues de Carvalho que a assumisse". ${ }^{329}$ A capela, portanto, passou a ser administrada pela Igreja, e pela Portaria de 17 de janeiro de 1890 D. Lino Deodato constituiu uma comissão provisória para administrá-la, em lugar da Mesa nomeada pelo juiz municipal. ${ }^{330} \mathrm{Em}$ novembro de 1892, assumiu o cargo de tesoureiro leigo o Sr. João Maria de Oliveira César (1892 a 1900), "que passou a receber o salário de oito por cento das entradas anuais do Santuário". 331

Se D. Lino Deodato obteve êxito na resolução das questões referentes aos bens temporais, o mesmo não se deu em relação à administração espiritual. Em janeiro de 1890 era Frei Joaquim do Monte Carmelo o responsável por intensas reformas da capela, mas já em avançada idade. Além de Frei Joaquim, mais três sacerdotes ali residiam, todos padres que "celebravam missa, mas não tinham

328 Eis o decreto, em sua íntegra: O Marechal Manoel Deodoro da Fonseca, chefe do Governo Provisório constituído pelo Exército e Armada, em nome da Nação, decreta: Art. $1^{\circ}$ - É proibido à autoridade federal, assim como à dos estados federados, expedir leis, regulamentos ou atos administrativos estabelecendo alguma religião ou vedando-a e criar diferenças entre os habitantes do país ou nos serviços sustentados à custa do orçamento, por motivo de crenças ou opiniões filosóficas ou religiosas. Art. $2^{\circ}$ - A todas as confissões religiosas pertence por igual a faculdade de exercerem o seu culto, regerem-se segundo a sua fé e não serem contrariadas nos atos particulares ou públicos que interessem o exercício deste decreto. Art. $3^{\circ}$ - A liberdade aqui instituída abrange não só os indivíduos por atos individuais, senão também as igrejas, associações e instituições em que se acharem agremiados, cabendo a todos o pleno direito de se constituírem e viverem coletivamente, segundo o seu credo e a sua disciplina, sem intervenção do poder público. Art. $4^{\circ}$ - Fica extinto o padroado com todas as suas instituições, recursos e prerrogativas. Art. $5^{\circ}$ - A todas as igrejas e confissões religiosas se reconhece a personalidade jurídica para adquirirem bens e os administrarem sob os limites postos pelas leis concernentes à propriedade de mão - morta, mantendo-se a cada uma o domínio de seus haveres atuais bem como de seus edifícios de culto. Art. $6^{\circ}$ - O governo federal continua a côngrua, sustentação dos atuais serventuários do culto católico e subvencionará por um ano as cadeiras dos seminários, ficando livre a cada estado o arbítrio de manter os futuros ministros desse ou de outro culto, sem contravenção do disposto nos artigos antecedentes. Art. $7^{\circ}$ Revogam-se as disposições em contrário. Sala das sessões do Governo Provisório da República dos Estados Unidos do Brasil, 7 de janeiro de 1890, $2^{\circ}$ da República." Seguem-se as assinaturas.

329 WERNET, Augustin. Os redentoristas no Brasil. v. 2. Aparecida: Santuário, 1995. p. 172.

330 ACAA. Portaria de D. Lino. In: Documentos e Crônicas da Capela. p. 367. Constituíam essa Comissão provisória o Pároco de Guaratinguetá, Cônego Honório Benedito Ottoni, como presidente; o Cônego Joaquim do monte Carmelo, capelão do Santuário, e o Major Antônio Martiniano de Oliveira, como tesoureiro.

331 BRUSTOLONI, Júlio João. Contratos e Remuneração no Santuário de Aparecida. Inédito, 1990. p.12. 
outras atividades pastorais, como /aliás acontecia freqüentemente no tempo do Império," 332 entre eles o Cônego Antônio Marques Henriques, perfeitamente enquadrado naquele tipo de clero constante das memórias de Paulo Setúbal: "O vigário era homem tomador de rapé, chão, de bom conselho, amigo de toda gente, que vivia na sua sossegada chácara, ao pé da igreja, levando vida pouco sobrenatural...." 333

Com o clero que dispunha em Aparecida verifica-se que a situação não apresentava prognósticos favoráveis a D. Lino Deodato, em termos de encetar reformas. No entanto, sabedor de que a ação ultramontana passava necessariamente pelos centros de devoção popular, em 28 de novembro de 1893 o então bispo de São Paulo baixou Provisão nos seguintes termos:

[...] Havemos por bem pela presente declarar isento da jurisdição paroquial o dito Santuário com os limites seguintes: ribeirão do Sá até o alto do morro, cabeceiras do mesmo, que verte para o Santuário, pelos altos do dito morro até as cabeceiras do Ribeirão da Ponte Alta, e por este abaixo pelo Paraíba até a confluência do Ribeirão do Sá, onde principia. $[\ldots]$

D. Lino Deodato, ao isentar a capela da jurisdição paroquial de Guaratinguetá, elevando-a à condição de Curato (paróquia), na verdade criou um "enclave religioso", sob o comando único da diocese de São Paulo. Em outras palavras, Guaratinguetá não mais veria qualquer dinheiro dos cofres de Aparecida.

Para reafirmar sua ingerência sobre a capela, elevou-a, também, à condição de Santuário Episcopal, tomando posse nesse mesmo dia o primeiro capelão-vigário de Aparecida, Monsenhor Claro Monteiro do Amaral, homem de sua confiança:

[...] Querendo nós manifestar nossa devoção e amor ao dito Santuário e esperanças que nutrimos em Maria Imaculada, sua Padroeira, havemos por bem conceder ao referido Santuário de Nossa Senhora da Conceição Aparecida, o título de Episcopal Santuário... ${ }^{334}$

Com a morte de D. Antônio Joaquim de Melo o projeto ultramontano sofre solução de continuidade. D. Sebastião Pinto do Rego, aliado ao clero que tanta

332 BRUSTOLONI, Júlio João. A Senhora da Conceição Aparecida: história da imagem, da capela e das romarias. 8. ed. Aparecida: Santuário, 1999. p. 135.

333 SETÚBAL, Paulo. Confiteor. 3. ed. São Paulo: Companhia Editora Nacional, 1937. p. 66. Sobre a atuação do Cônego Henriques e suas contendas com os padres redentoristas encaminho o leitor a REIS, Fábio José Garcia dos. Os Redentoristas, o Cônego Antônio Marques Henriques e a romanização da Igreja paulista (1888-1917). 1993. Dissertação (Mestrado em História Social) Universidade de São Paulo, São Paulo, 1993.

334 Livro do Tombo da Paróquia de Nossa Senhora Conceição Aparecida (1893 a 1913). p. 2. 
resistência opôs à ação de seu antecessor, materializa em sua primeira carta pastoral a influência iluminista: "Certamente quem ama a disciplina, ama o estudo, a ciência; quem ama a disciplina ama o método, a ordem." 335

Ao sétimo bispo de São Paulo, falecido em 30 de abril de 1868, sucedeu D. Lino Deodato Rodrigues de Carvalho ${ }^{336}$, após cinco anos de sede vacante. Não obstante suas tentativas reformadoras, os constantes aborrecimentos de D. Lino Deodato com seu clero fizeram com que, ao final de sua vida, se mantivesse afastado de sua diocese, permanecendo a maior parte de seu tempo em Aparecida, ali falecendo em 19 de agosto de 1894.

Em geral alheio aos assuntos administrativos diocesanos, há muito D. Lino Deodato solicitava um bispo coadjutor, sendo nomeado para tal função D. Joaquim Arcoverde de Albuquerque Cavalcanti, que tomou posse em 11 de fevereiro de 1893.

Assim, a Santa Sé pretendia por fim a crise disciplinar na Igreja paulista, nomeando um prelado forte com total autonomia, em substituição a um já considerado incapaz de dirigi-la. ${ }^{337}$

No período em que D. Joaquim Arcoverde atuou na condição de coadjutor, mostrava a todos o pulso firme com que conduzia os negócios da diocese, máxime os do Santuário de Aparecida.

Já em maio de 1893, o futuro cardeal brasileiro, pelos termos de sua correspondência com o tesoureiro do Santuário, se mostra conhecedor do andamento dos assuntos de Aparecida, bem como deixa transparecer seus futuros projetos. O controle de Aparecida estaria, em todo o decorrer dos seus "anos paulistas", na expressão de Alceste Pinheiro, entre suas principais preocupações.

[...] O ponto em que me diz terem chegado os negócios do inventário, que prende aí de decisão do Juiz, dá esperanças de vermos, dentro de pouco, começados os trabalhos da grande sementeira que se projeta criar nesse abençoado lugar e V.S. ${ }^{a}$ como instrumento da Providência nessa grande obra, dirigindoa e fazendo com que a inauguremos o mais breve possível, será o alvo das bênçãos de muitas alminhas que se salvarão nas águas da Aparecida e à sombra dessa árvore que se vai

335 Carta Pastoral de D. Sebastião Pinto do Rego saudando seus diocesanos. 18 de maio de 1862. Suplementos de Tombos da Paróquia da cidade Taubaté (1853-1881)

336 Sobre o governo episcopal de D. Lino Deodato encaminho o leitor a GAETA, Maria Aparecida Junqueira Veiga. Os percursos do ultramontanismo em São Paulo no episcopado de D. Lino Deodato Rodrigues de Carvalho (1873-1894), 1992. Tese (Doutorado em História Social) - Universidade de São Paulo, São Paulo, 1992.

337 PINHEIRO, Alceste. O Cardeal Arcoverde e a reorganização eclesiástica. 2003. Tese (Doutorado em História Social) - Universidade de São Paulo, São Paulo, 2003. p. 226. 
plantar e que o Senhor do Campo entrega em começo aos seus cuidados e desvelos. É preciso que isto comece para que com ela comecem a vir as graças do céu... ${ }^{338}$

A salvação da almas nas águas da Aparecida, não era, entretanto, a única preocupação do bispo coadjutor. Verifica-se na carta de 3 de julho de 1893, e em muitas outras, os assuntos referentes a dinheiro:

[...] Recebi sua carta cobrindo a lista das missas encontradas na abertura do cofre dessa capela da aparecida em 30 do mês p.p.

D. Arcoverde, pelo que se constata, é quem determina o destino do numerário: "Distribua estas missas pelos sacerdotes que entender. Reservo-me para as deste mês". ${ }^{339}$

Prosseguindo em aproveitamento do êxito, materializado pela atitude de D. Lino Deodato em elevar a capela de Aparecida em Santuário Episcopal, D. Arcoverde é perfeitamente cônscio da tarefa que lhe foi confiada, posto que "duas eram as finalidades precípuas que os bispos almejavam com a vinda dos novos religiosos: sagradas missões e cuidado dos santuários populares." 340

Isto posto, a intenção de D. Arcoverde em trazer sacerdotes romanizados é bem clara no trecho abaixo:

5 de setembro de 1893. Estimo que vá aumentando a concorrência dos devotos ao Santuário da Aparecida, isto nos estimulará sempre mais para trazermos logo que for possível o pessoal de nossas esperanças, os apóstolos, que animados pelo auxílio de Maria, hão de encher esta diocese de bênçãos e de frutos de vida eterna.

Da leitura da correspondência, além das visitas que ocasionalmente fazia a Aparecida, fica clara a relação cordial que D. Arcoverde mantinha com o tesoureiro do Santuário. Há espaço, pois, para amenidades:

Então, e a onça ? Já deu-lhe caça ? É preciso estar muito de sobreaviso contra esses animais daninhos que tanto mal fazem aos rebanhos, e principalmente às ovelhas. Convém, porém, munir-se de boa arma, que o primeiro tiro seja certeiro e de matar logo; porque nos diz a experiência que os tirinhos de garrucha não espantam certos animais ferozes, pelo contrário, tornam-nos mais audaciosos e recalcitrantes. Cuidado, pois,

338 ACPSR. Correspondência da Província Redentorista de São Paulo - COPRESP-B - Suplemento, v. I (1874-1897). pp. 134-135. Carta de D. Arcoverde ao Sr. João Maria de Oliveira César.

339 ACPSR. Correspondência da Província Redentorista de São Paulo - COPRESP-B - Suplemento, v. I (1874-1897). p. 140. Carta de D. Arcoverde ao Sr. João Maria de Oliveira César.

340 AZZI, Riolando. A vinda dos redentoristas para o Brasil na última década do século passado, Revista Convergência, JUL/AGO - 1977 - Ano X - N. ${ }^{\circ}$ 104. p. 367. 
com o bicho. Adeus, Três Ave Maria por mim nesse Santuário. Amigo afetuoso em Jesus Cristo, + Joaquim Arcoverde, Bispo coadjutor de São Paulo. ${ }^{341}$

A intenção de substituir todo o antigo clero, senão grande parte dele, dos negócios referentes ao Santuário, é bem clara nesse trecho de carta. De fato, pouco tempo após a chegada dos redentoristas em Aparecida, o Padre Claro é exonerado de suas funções e transferido.

São Paulo, 3 de outubro de 1893 [...] Desejo que em confiança me informe que idade poderá ter o capelão desse Santuário e se poderia ser removido daí para alguma freguesia. Respondame com urgência. [...] Qual o ordenado que se dá ao capelão do Santuário ? ${ }^{342}$

O que na verdade ocorria era o cumprimento das metas anteriormente estabelecidas em agosto de 1890, por ocasião da primeira reunião do episcopado brasileiro, ocorrida em São Paulo, que "reunia os bispos brasileiros num momento de crise buscando construir uma nova identificação eclesial dentro de uma novo contexto: a República". ${ }^{343}$

Em termos de reuniões episcopais, no Brasil, apenas uma única ocorreu, o Sínodo da Bahia, em 1707, onde D. Sebastião Monteiro da Vide, seu presidente, implantou as Constituições Primeiras do Arcebispado da Bahia. Não houve, porém, ação de continuidade à obra de D. Sebastião Monteiro da Vide, posto que seu sucessor, D. Luís Álvares de Figueiredo, interessava-se mais pelos estudos de arqueologia. No período imperial, por sua vez, o padroado impossibilitou qualquer reunião.

Sob o comando de D. Antônio Macedo Costa, a importância do encontro, além de se configurar como a primeira e única ${ }^{344}$ reunião nacional de bispos brasileiros após o período colonial e imperial, representava, também, "um momento

341 ACPSR. Correspondência da Província Redentorista de São Paulo - COPRESP-B - Suplemento, v. I (1874-1897). p. 146. Carta de D. Arcoverde ao Sr. João Maria de Oliveira César.

342 ACPSR. Correspondência da Província Redentorista de São Paulo - COPRESP-B - Suplemento, v. I (1874-1897). p. 149. Carta de D. Arcoverde ao Sr. João Maria de Oliveira César.

343 GAETA, Maria Aparecida Junqueira Veiga. Os percursos do ultramontanismo em São Paulo no episcopado de D. Lino Deodato Rodrigues de Carvalho (1873-1894), 1992. Tese (Doutorado em História Social) - Universidade de São Paulo, São Paulo, 1992. p. 181.

344 WERNET, Augustin. O Auge da Romanização: o Concílio Plenário da América Latina, Revista da Sociedade Brasileira de Pesquisa Histórica - SBPH - Anais da X Reunião - Curitiba - 1991. p. 200. Wernet nos lembra que "após a reunião nacional dos prelados brasileiros na Capital paulista em agosto de 1890 (no Seminário Episcopal de São Paulo), não houve mais no Brasil outras conferências episcopais em nível nacional, já que o Brasil foi dividido em duas Províncias Eclesiásticas". 
de tomada de consciência quanto à necessidade de coesão nacional". ${ }^{345}$

Tratando dos mais diversos assuntos de natureza ultramontana (formação e moralização do clero, liturgia etc.), a discussão que mais interessa de perto se prende às questões dos centros de catolicismo luso-brasileiro, duas em especial, a saber: a primeira teria como objetivo a gradual marginalização das irmandades, entendida aqui como o afastamento do leigo do comando financeiro desses centros, e a segunda a de confiar a religiosos suas administrações.

No Brasil nenhum santuário de devoção popular contribuíra financeiramente com sua diocese. As Irmandades ou Comissões Administrativas consumiam todo o saldo. As Irmandades ricas, como as de Minas Gerais e do Rio de Janeiro, construíram ricas igrejas, as pobres faziam geralmente uma justa distribuição "pro rata parte", entre os membros da Comissão. Com o advento da República, as Irmandades ou Comissões continuaram a esbanjar as rendas do cofre.

Em 9 de maio de 1894, com o objetivo de obter religiosos para o trabalho da diocese, e de realizar, em nome de D. Lino Deodato, a visita Ad Limina Apostolorum, D. Joaquim Arcoverde se dirige à Roma. Antes da viagem, porém, o bispo escreve ao tesoureiro do Santuário. Preocupado com a boa apresentação do mesmo, lembra ao tesoureiro sobre a necessidade de paramentos. Para as despesas pessoais, como se depreende da leitura abaixo, é certo que não tenha tido problemas de ordem financeira:

[...] não será fora de tempo lembrar-lhe que talvez seja necessário comprar em Roma paramentos e vasos sagrados para esse Santuário, que por ter sido elevado à categoria de episcopal, convém que se mantenha com o correspondente decoro. [...] Continue a mandar-me as missas para Roma, em cheques $[\ldots] \ldots{ }^{347}$

Em 6 de agosto de 1894, dirige-se a Paris. De lá, envia correspondência ao Padre Matias Raus, Superior Geral dos redentoristas, a respeito da vinda dos missionários para Aparecida. O projeto de D. Arcoverde caminhava a passos largos.

Cheguei a Paris, e como prometi a V. Rev. ${ }^{\text {ma }}$, mando-lhe meu endereço para que tenha a gentileza de me comunicar a época da partida dos RR. Missionários. Em Paris hospedo-me à Rua

345 GAETA, Maria Aparecida Junqueira Veiga. Os percursos do ultramontanismo em São Paulo no episcopado de D. Lino Deodato Rodrigues de Carvalho (1873-1894), 1992. Tese (Doutorado em História Social) - Universidade de São Paulo, São Paulo, 1992. p. 183.

346 BRUSTOLONI, Júlio João. Contratos e Remuneração no Santuário de Aparecida, Inédito, 1990. p.6.

347 ACPSR. Correspondência da Província Redentorista de São Paulo - COPRESP-B - Suplemento, v. I (1874-1897). p. 162. Carta de D. Arcoverde ao Sr. João Maria de Oliveira César. 
de Serves, 95, onde espero as ordens de V. Rev. ${ }^{\text {ma }}{ }^{348}$

No dia 21 de agosto, D. Arcoverde é notificado por telegrama sobre a morte do bispo titular; retornando ao Brasil, assume a diocese de São Paulo em 30 de setembro de 1894.

O fato de assumir a titularidade da diocese não significou mudança alguma. Arcoverde tinha o total controle da Igreja em São Paulo desde que tomara posse como coadjutor, e já estava nos seus planos submeter e dar novo espírito aos centros devocionais e de romarias, o que, aliás, era uma estratégia de todos os bispos, adotada nas reuniões episcopais.

Além das razões de ordem teológica, os bispos possuíam também motivos de ordem política e econômica para desejar assumir a direção dos santuários. Tendo o governo suprimido qualquer subvenção às instituições eclesiásticas, já na reunião do episcopado de 1890 D. Macedo Costa despertara a atenção dos bispos sobre a possibilidade de prescrever uma contribuição das rendas dos santuários, quer para a manutenção dos seminários, quer das próprias dioceses. ${ }^{349}$

Em relação aos aspectos financeiros do Santuário, o agora bispo de São Paulo era inflexível:

São Paulo, 18 de outubro de 1894. Caríssimo Sr. João Maria. [...] Quanto a Aparecida, é minha ordem, de uma vez por todas: as missas que o Sr. Tesoureiro encontrar nas aberturas do cofre do Santuário Episcopal de Nossa Senhora Aparecida, deverão ser-nos entregues pelo mesmo Sr. Tesoureiro, o qual se tiver pedidos a fazer-nos a esse respeito, então no-los apresentará.

A preocupação em bem receber e acomodar os missionários redentoristas é também patente em suas missivas:

Sinto muito que os padres não encontrem o lugar que thes tínhamos destinado; mas louvado seja Deus, que apraz de darnos a esperança de dentro de uma semana estar tudo pronto. + Joaquim Arcoverde, Bispo de S. Paulo. ${ }^{350}$

A saga redentorista tem origem, no Brasil, a 5 de julho de 1893, quando os padres holandeses Matias Tulkens, e Francisco Xavier Lohmeyer, iniciaram viagem de Amsterdã para Hamburgo, ali embarcando no navio 'Ceará'. Chegados ao Rio de

348 ACPSR. Correspondência da Província Redentorista de São Paulo - COPRESP-B - Suplemento, v. I (1874-1897). p. 176. Carta de D. Arcoverde ao Padre Matias Raus. Paris, 12 de agosto de 1894. 349 AZZI, Riolando. As romarias no Brasil, Revista Vozes, n. ${ }^{\circ}$ 4, LXXIII. maio de 1979. pp. 291-292. 350 ACPSR. Correspondência da Província Redentorista de São Paulo - COPRESP-B - Suplemento, v. I (1874-1897). pp.. 203-204. Carta de D. Arcoverde ao Sr. João Maria de Oliveira César. 
Janeiro em 2 de julho, novo deslocamento, agora por trem, os conduziu a Juiz de Fora, Ouro Preto e, por fim, Mariana.

Foram os bispos de Mariana, Dom Antônio e Dom Silvério, que proporcionaram aos dois redentoristas holandeses a possibilidade de instalar definitivamente a obra redentorista no Brasil, pedida pelo seu antecessor, já em setembro de 1843. ${ }^{351}$

Por sua vez, os primeiros missionários redentoristas alemães, da Província da Alemanha Superior, hoje de Munique, chegaram ao Rio de Janeiro a 24 de outubro, parte seguindo para Aparecida, no Estado de São Paulo, e parte para Campininhas, no Estado de Goiás, "entrando naquela pobre vila a 12 de dezembro daquele mesmo ano de 1894", 352 vindos a pedido dos bispos respectivamente da diocese de São Paulo, Dom Lino Deodato Rodrigues de Carvalho, e de Goiás, Dom Eduardo Duarte e Silva.

A chegada a Aparecida deu-se em 28 de outubro de 1894, às 22:30h, instalando-se os redentoristas, oficialmente, no dia 30. Neste mesmo dia ocorreu, também, a posse do Padre Lourenço Gahr (1829 - 1905) como Superior da casa, conforme decisão do Padre Visitador Gebardo Wiggermann (1843 - 1920).

Uma vez instalados, em 4 de novembro de 1894 o Padre Lourenço Gahr escreve uma longa e minuciosa carta ao Padre Antônio Schoepf. Seu valor histórico não é nada desprezível, pois além de fazer menção aos vultosos valores monetários que circulam em Aparecida, apresenta todo um panorama religioso com que se defrontaria D. Epaminondas.

Isto posto, Padre Lourenço menciona o efetivo médio de romeiros que ali acorrem diariamente, romeiros esses vindos de todas as partes. Tinha início a projeção nacional do Santuário de Aparecida. A da imagem de Nossa Senhora, ali abrigada, viria depois.

[...] Todo o Brasil faz suas peregrinações a esta Imagem milagrosa. Grandes multidões chegam parte de trem, parte a cavalo e outros a pé. Em alguns dias, de 800 a 1.000 . Infelizmente somente poucos podem confessar-se...

As manifestações do catolicismo luso-brasileiro são presentes nas observações do sacerdote:

...Mas é muito comovente ver moços e mulheres, brancos e pretos arrastando-se de joelhos até ao altar, às vezes com uma 
ou duas velas acesas nas mãos; em todo o caso, todos vão beijar o altar ou a sagrada imagem...

Mesmo sendo ainda o idioma um empecilho, é bastante nítida a esperança de Padre Lourenço, que já avalia o afluxo de pessoas em relação ao Santuário mariano de Altötting, na Baviera:

[...] Muitos pedem para confessar-se, o que infelizmente não podemos conceder-lhes, enquanto não dominarmos 0 português. É certo que aqui vêm muito mais gente do que em Altöetting; este será, um dia, um grande centro de trabalhos para nós redentoristas...

A esse respeito, cumpre observar a prática redentorista bávara para com o catolicismo praticado pelo povo em relação ao Santuário de Altötting.

D. Joaquim Arcoverde é tido pelo Padre Lourenço Gahr como um bispo que encontraria problemas com seus subordinados. É fato. Mas D. Arcoverde, é certo, saberia lidar com todos.

[...] Na quinta-feira houve grande festa, o aniversário da sagração de S. Excelência. Às 11 horas houve, na catedral, missa soleníssima com assistência pontifical do Bispo. Infelizmente estava presente muito pouca gente, especialmente negros; o Sr. Bispo fez uma pregação de três quartos de hora diante do clero, em que ele o movia a ter piedade dele por causa de seu pesado ônus e a ajudá-lo. Ele parece que tem muito a sofrer da parte de seus cônegos; seu antecessor por isto morreu de desgosto...

Incontido, Padre Lourenço prossegue na descrição de tudo que vê e de tudo que ocorre desde o momento em embarcou na Europa. Os planos de D. Arcoverde também são, naturalmente, assunto da carta:

[...] Então ficamos sabendo dos grandiosos planos que ele tem conosco. Como aqui é oferecido muito dinheiro, ele quer construir um grande colégio com igreja; uma ala deve ser arranjada como seminário para a formação de padres, uma outra para nós missionários...(o grifo é nosso)

Dito isto, o narrador refere-se à Aparecida nem como aldeia, nem como cidade, mas afirma sua crença do local como mantenedor de uma fé católica que precisava ser burilada, além de tecer comentários sobre a ausência de blasfêmias e furtos:

...Aparecida é um lugar muito pobre, nem uma aldeia, mas também não é uma cidade, mas tem o nome bonito de "Santuário Episcopal" e está sujeito imediatamente ao Bispo de São Paulo. O Brasil agradece a este Santuário o fato de manter-se a fé católica; é digno de louvor que a gente jamais 
ouve blasfêmias; também quase não se rouba alguma coisa. Nosso diretor, Pe. Claro, deixa aberto todas as portas de sua casa e fica por horas fora, sem que jamais tivesse sido roubada qualquer coisa. ${ }^{353}$

O caráter autoritário da personalidade de D. Arcoverde é bem patente na missiva abaixo relacionada, datada de 29 de agosto de 1895. Não atendido prontamente em uma ordem, o tesoureiro João Maria de Oliveira César é submetido a uma descompostura...episcopal:

[...] Somos amigos e não the devo guardar reservas. Fico sempre muito contrariado quando minhas disposições e ordens não são cumpridas. Quando as dou tenho pensado detidamente sobre seu alcance; e se pelas circunstâncias, elas ligam-se a algum plano só de mim conhecido, o seu não cumprimento causa-me sempre abalo, como o de um corpo que cai num precipício, que se abriu inesperadamente quando corria suavemente por um doce declive.

Isto feito, D. Arcoverde tenta se mostrar razoável...

No entretanto, não sou irrazoavelmente apegado à minha opinião: desejo sempre acertar. Continue a executar o seu plano, como me mandou, e eu aí chegando e conversando intimamente com o Superior, discutirei o assunto, e então o que se deliberar será o que se executará.

...Para agora, então, voltar ao puxão de orelhas:

É preciso que nos entendamos para podermos viver no Senhor; e sendo o meu amigo um exemplar católico e um modelo de pai de família, que quer ser obedecido pelos seus filhos, estou certo que não se chocará, nem tomará e má parte o que com sinceridade de amigo aqui lhe digo.

Por fim, estende sua benevolência a todos os padres redentoristas, e só a eles, ressalte-se:

Recomendo-lhe que a cada um dos padres pertencentes à residência de Aparecida, isto é, a cada missionário sacerdote redentorista que pertencer à residência de Aparecida, dê mensalmente 100 mil réis, já isto se fazia com o Pe. Lourenço e o Pe. José. [...] + Joaquim Arcoverde, Bispo de São Paulo. ${ }^{354}$

As quantias que D. Arcoverde reserva para os missionários, no entanto, podem ser consideradas como ninharias, quando comparadas às vultosas quantias administradas pelo Bispo. Caso marcante é a carta destinada a D. Jerônimo Maria

353 ACPSR. Correspondência da Província Redentorista de São Paulo - COPRESP-B - Suplemento, v. I (1874-1897). pp. 212-214.

354 ACPSR. Correspondência da Província Redentorista de São Paulo - COPRESP-B - Suplemento, v. I (1874-1897). pp. 298-299. 
Gotti, ${ }^{355}$ Internúncio no Brasil, em 6 de outubro de 1894. Note-se, portanto, a preocupação de Arcoverde em apoiar-se nos quadros da hierarquia, não obstante sua dignidade e vaidade pessoal transformar um pedido de autorização em conselho:

Preciso de um conselho muito íntimo, que me tranqüilize. 'A Federação' Católica de São Paulo me pede 15 contos de réis, senão 30, para comprar uma tipografia para imprimir diariamente o "Jornal Pátria" e ainda para dar um salário (una retribuizone) aos empregados pelo serviço de escrever e compor etc. o jornal. Eu não teria de meu bolso nem sequer 15 escudos; peço a V. Ex. ${ }^{a}$ se poderei tirar este dinheiro do Santuário de Aparecida, sem perturbar minha consciência? O Santo Padre recomenda muito um jornal católico, e a utilização do dinheiro seria bom e útil à causa católica. O meu Vigário Geral acha que eu posso fazer e ainda chegou a dizer-me que é meu dever fazê-lo, porque o jornalismo - diz ele, e o diz muito bem - é o apostolado do século. ${ }^{356}$ (o grifo é nosso)

Encerrado o período de adaptação dos redentoristas em Aparecida, ia a situação assumindo prognósticos bastante favoráveis. Pouco a pouco disciplinava-se o culto religioso, romanizando-o, enquanto esgrimiam com a natural dificuldade da língua. A popularidade dos padres missionários bávaros crescia a cada dia, assim como se acumulavam as ofertas. A carta do Padre Lourenço Gahr ao Padre Antônio Schoepf, Superior Provincial, datada de 14 de maio de 1895, apóia nossa assertiva:

O Padre Wendl deve estar sempre presente quando o cofre é esvaziado; quanto ali é depositado é quase incrível. O Padre Wendl está presente à contagem. Ele continha, duas vezes seguidas, cada vez 50 mil réis em 12 dias, logo, 100 mil réis em 24 dias. Com isto ele pode sustentar a construção do colégio e da igreja. Também não nos falta dinheiro; no mês de abril tivemos 82 batizados por 415 mil-réis, por missas celebradas 380 mil-réis. Em maio, de $1^{\circ}$ a 14 já temos 40 batizados por 237 mil-réis.

Como é sabido, as atividades redentoristas em Aparecida iniciaram-se em 30 de outubro de 1894, e somente a confiança mútua entre D. Joaquim Arcoverde e os missionários pode explicar a ausência de qualquer contrato formal. Apenas uma carta, uma simples carta, entregue a 23 de janeiro de 1895, materializava os encargos da Congregação. Conosco, Wernet:

A referida carta, entregando provisoriamente aos missionários redentoristas a pastoral da paróquia e do Santuário, foi o único

355 Disponível em <http://www.catholic-hierarchy.org/bishop/bgotti.html>. Consulta em 24 de junho de 2005.

356 ACPSR. Correspondência da Província Redentorista de São Paulo - COPRESP-B - Suplemento, v. I (1874-1897). p. 234. 
documento escrito até a assinatura do contrato definitivo entre a Diocese de São Paulo e a Congregação, firmado dois anos mais tarde, no dia 3 de maio de 1897, tal a confiança que havia entre Dom Joaquim Arcoverde e os redentoristas. Não existem nem provisão nem decreto. ${ }^{357}$

É de se supor, em virtude da qualidade do relacionamento entre D. Arcoverde e os padres bávaros, que o contrato só tenha vindo à luz

porque D. Joaquim Arcoverde já estava sendo proposto pela Santa Sé para Arcebispo do Rio de Janeiro. Ele mesmo dizia em carta ao Pe. Gebardo Wiggermann que tinha pressa em assinar um contrato com a Congregação antes de sua transferência para o Rio de Janeiro. ${ }^{358}$

Assinado em Roma pelo Superior Redentorista a 22 de março de 1897, e em São Paulo, por D. Joaquim Arcoverde, em 3 de maio do mesmo ano, o contrato ratifica o usufruto da residência dos redentoristas, prevê as obrigações religiosas no Santuário, assim como nas Missões, permite aos redentoristas a fundação de outras casas na diocese, terminando por ressalvar que os mesmos não podem abandonar a diocese sem aviso prévio de um ano de antecedência. ${ }^{359}$

Lido o contrato, verifica-se que "ele não estipulava nenhum prazo para sua vigência; não tratava da administração financeira dos bens e não previa ainda um salário para os capelães do Santuário", ${ }^{360}$ e a ordenação das despesas prosseguia nas mãos de D. Arcoverde, mesmo porque, "em nenhum momento os missionários redentoristas pleitearam para si a administração do cofre e muito menos se utilizaram de suas rendas em favor da Congregação". 361

A análise de Wernet, expõe, a bem da justiça, e da verdade histórica, a completa isenção dos redentoristas sobre a "Questão de Aparecida". De fato, não se encontra, dentre as centenas de correspondências dos bávaros, observações, favoráveis ou desfavoráveis, a quem quer que seja, relativas à questão.

É, no entanto, digno de nota o desvelo e a generosidade que D. Joaquim Arcoverde dispensa aos missionários, e em várias cartas essa preocupação se materializa, como na carta data de 5 de junho de 1895:

[...] Recomendo-lhe instantemente que não se esqueça de

357 WERNET, Augustin. Os redentoristas no Brasil. v. 1. Aparecida: Santuário, 1995. p. 33.

358 BRUSTOLONI, Júlio João. Contratos e Remuneração no Santuário de Aparecida. Inédito, 1990. p.8.

359 Para a íntegra do contrato encaminho o leitor a WERNET, Augustin. Os redentoristas no Brasil. v. 1. Aparecida: Santuário, 1995. pp. 33-35.

360 WERNET, Augustin. Os redentoristas no Brasil. v. 2. Aparecida: Santuário, 1995. p. 172.

361 WERNET, Augustin. Os redentoristas no Brasil. v. 2. Aparecida: Santuário, 1995. p. 172. 
passar todos os meses (e comece desde que esta receber), ao Padre Superior, duzentos mil réis, sem querer indagar em que serão eles empregados; isto quer dizer que continue a assistilos em tudo, como até hoje tem feito, com grande consolação para o meu coração. O serviço que esses missionários nos prestam aí só nós o podemos avaliar, tendo passado pelo que já passamos. Assim convém ser com eles generosos e agradecidos. [...] Amigo afetuoso em Cristo, + Joaquim Arcoverde, Bispo de S Paulo. ${ }^{362}$

Até agosto de 1895, o salário para a comunidade foi o constante na carta acima, qual seja, 200\$000 Rs., com pequenas evoluções ao longo dos demais anos. Somente em 14 de maio de 1902, na gestão episcopal de D. Antônio Alvarenga, surge o Regulamento da Administração do Episcopal Santuário de Nossa Senhora Aparecida, "que dispôs sobre a formação da Comissão Administrativa, normas para a administração, atribuições do presidente, tesoureiro e secretário, bem como sobre os salários dos mesmos": ${ }^{363}$

$\S 9^{\circ}$ - O Tesoureiro fornecerá mensalmente ao Rev. ${ }^{\text {mo }}$ Superior dos Redentoristas a quantia de $500 \$ 000$ Rs. como gratificação dos serviços que a comunidade presta ao Santuário. O Tesoureiro perceberá oito por cento sobre as quantias que forem arrecadadas para o Santuário. O Secretário receberá $100 \$ 000$ Rs. mensais como gratificação do seu trabalho. ${ }^{364}$

Júlio Brustoloni analisa a remuneração dos membros da Comunidade em 1903, à época com seis sacerdotes e dois irmãos, tendo a mesma recebido um total de seis contos de réis, enquanto que o Tesoureiro percebeu, individualmente, 7:156\$980 Rs., e o Secretário, 1:200\$000 Rs. Do percentual destinado ao Tesoureiro, calcula-se que o montante apurado no cofre, ao longo do ano, foi portanto, de 89:462\$250 Rs.

O secretário, cuja única função era compor a ata de abertura do cofre mensalmente, recebia salário muito melhor do que cada um dos 6 padres e dois Irmãos individualmente...

O mesmo se dá em 1925, obtendo-se o montante anual nada desprezível de 338:351\$500 Rs, o que representa um aumento de aproximadamente $378,20 \%$ nas entradas do Santuário, em relação a 1903.

...Em 1925, o tesoureiro recebia a quantia anual de 27:068 $\$ 120$ Rs., que Ihe cabia pela percentagem de oito por cento, ao

362 ACPSR. Correspondência da Província Redentorista de São Paulo - COPRESP-B - Suplemento, v. I (1874-1897). p. 269.

363 WERNET, Augustin. Os redentoristas no Brasil. v. 2. Aparecida: Santuário, 1995. p. 172.

364 BRUSTOLONI, Júlio João. Contratos e Remuneração no Santuário de Aparecida. Inédito, 1990. p. 56. 
passo que a comunidade composta de 14 padres e dois Irmãos, necessários na portaria para atendimento dos peregrinos, recebia 6:600\$000 Rs. ...

Por fim, a solidariedade do historiador para com seus confrades:

...A conclusão que se deve tirar deste quadro demonstrativo é esta: nem sempre as autoridades eclesiásticas, e no caso o $\mathrm{Sr}$. Arcebispo de São Paulo, tinham o senso de justiça e a praticavam!... ${ }^{365}$

O viés analítico não abordado por Júlio Brustoloni prende-se ao fato de que, em última análise, os tesoureiros que atendiam o Santuário eram, na verdade, funcionários da Cúria Metropolitana, e os honorários de oito por cento e demais vantagens, é certo, ocorriam muito mais por pragmatismo político do que pelo valor do trabalho em si, desencorajando-se, assim, qualquer tentativa de desvio de numerário, com a consequentemente demissão de tão ambicionado cargo.

O tesoureiro, além de tudo, fiscalizava os redentoristas, sendo, por sua vez, fiscalizado por padres estrangeiros, romanizados e sem qualquer vínculo familiar e político com a terra. O sistema se fechava muito bem, e somente em 27 de maio de 1946 é que o Cardeal Arcebispo de São Paulo, D. Carlos Carmelo de Vasconcellos Motta, entregará o cargo de tesoureiro à Congregação.

Desde a chegada dos padres a administração da Basílica "in materialibus" estava confiada a um tesoureiro leigo, o qual percebia o honorário de oito por cento das rendas do cofre, com direito à casa por conta da Basílica e a certos produtos da chácara, como frutas, verduras e leite. $O$ tesoureiro administrava todos os imóveis da Basílica e, juntamente com o vigário e um secretário (mais tarde substituído pelo 10 sacristão), abria o cofre, contava o dinheiro e entregava o saldo na Procuradoria da Cúria Metropolitana de São Paulo. ${ }^{366}$

Volvendo ao curso, a Ânua de 1897 demonstra a pujança econômica e a organização administrativa de Aparecida. Documento raramente encontrado nas fontes primárias eclesiásticas, o balanço contábil daquele ano é um tema merecedor de apresentação, pois o saldo equivale ao valor de uma propriedade de, em média, 45 alqueires:

\begin{tabular}{|l|l|}
\hline Accepta - Entradas \\
\hline Juros fixos provenientes de capitalização & \\
\hline
\end{tabular}

365 BRUSTOLONI, Júlio João. Contratos e Remuneração no Santuário de Aparecida. Inédito, 1990. p. 14.

366 BRUSTOLONI, Júlio João. Contratos e Remuneração no Santuário de Aparecida. Inédito, 1990. p. 20. 


\begin{tabular}{|c|c|}
\hline \multicolumn{2}{|l|}{ Lucros dos bens imóveis } \\
\hline Contribuição anual recebida do Santuário & $2: 100 \$ 000$ \\
\hline Espórtulas de missas & $16: 080 \$ 640$ \\
\hline Contribuição feita por ocasião das missas & $1: 225 \$ 200$ \\
\hline Taxas de batizados e matrimônios & $4: 774 \$ 500$ \\
\hline \multicolumn{2}{|l|}{ Donativos dos nossos } \\
\hline Entradas diversas & $514 \$ 000$ \\
\hline Entradas extraordinárias & $870 \$ 000$ \\
\hline SOMA & $25: 564 \$ 340$ \\
\hline SALDO EM 31/12/1896 & $20: 487 \$ 640$ \\
\hline TOTAL & $46: 051 \$ 980$ \\
\hline \multicolumn{2}{|l|}{ Expensa - Saídas } \\
\hline \multicolumn{2}{|l|}{ Pagamento de impostos } \\
\hline Gastos com a sacristia & $111 \$ 000$ \\
\hline Alfaiataria & $614 \$ 000$ \\
\hline Mobílias da casa & 6:082\$000 \\
\hline Alimentação & $5: 763 \$ 500$ \\
\hline Vinho e cerveja & $2: 910 \$ 500$ \\
\hline Alfaiataria e sapataria & $4: 168 \$ 480$ \\
\hline Farmácia e médico & $351 \$ 080$ \\
\hline Combustível lenha e óleo & $102 \$ 900$ \\
\hline Viagens & $710 \$ 800$ \\
\hline Cartas e registrados postais & $225 \$ 700$ \\
\hline Biblioteca & 1:041\$000 \\
\hline Cultura agrícola & $1: 126 \$ 600$ \\
\hline \multicolumn{2}{|l|}{ Pago a província } \\
\hline \multicolumn{2}{|l|}{ Pago ao governo } \\
\hline Donativos e esmolas & $272 \$ 600$ \\
\hline \multicolumn{2}{|l|}{ Empitiones obligationum } \\
\hline \multicolumn{2}{|l|}{ Dinheiro dado de empréstimo } \\
\hline Gastos diversos & $811 \$ 500$ \\
\hline Gastos extraordinários & $2: 194 \$ 000$ \\
\hline SOMA & $26: 477 \$ 825$ \\
\hline SALDO & $19: 574 \$ 155$ \\
\hline
\end{tabular}

Fonte: Ânuas da Vice-província de São Paulo, v. I (1896-1918), pp. 18-19.

A ânua de 1901 é bastante detalhada, e o cronista não poupou tinta para detalhar os triunfos da Congregação. Alguns trechos são providenciais, e confirmam 
o estado de coisas em Aparecida nos albores do século XX. Neste, por exemplo, verifica-se a expansão devocional:

[...] A providência divina, conhecedora da miséria humana, compadecida dos filhos de Eva, deu-lhes uma Mãe de misericórdia e um refúgio na pessoa da Virgem Maria. Aos brasileiros dos Estados do Rio, São Paulo, Minas, Goiás, Paraná, Bahia, Pernambuco, deu auxílio e refúgio na imagem de Nossa Senhora Aparecida, num lugar de 2000 habitantes, situado no Norte do Estado de São Paulo, no município de Guaratinguetá, distante $3 / 4$ de horas. Foi providencial, pois a devoção a Nossa Senhora Aparecida propagou-se de tal modo em século e meio que, das regiões mais distantes e selvagens dos Estados de São Paulo, Minas, Cuiabá, Paraná, até mesmo do Rio Grande do sul e de outros pontos distantes, vêm peregrinos anualmente a Aparecida, viajando, às vezes, de 400 a 600 horas. São mais ou menos 120 e 150 mil anualmente...

A estrada de ferro, também providencial facilitadora logística para o transporte dos romeiros, também é considerada nas ilações contábeis do cronista,...

[...] O Chefe da estação, uns oito minutos afastada da igreja na EFCB que liga São Paulo ao Rio de Janeiro, asseverou que diariamente são vendidas umas trezentas passagens, quase exclusivamente de romeiros,,..

...o que não impede que o mesmo nos informe sobre os mais diversos meios utilizados pelo fiéis para ali chegar, mesmo porque, segundo o cronista, o clima ajuda:

...contando-se, além disso, os muitos romeiros vindos a pé ou a cavalo de perto ou de longe, durante o ano todo, pois no Brasil não há frio nem nevadas como na Alemanha, impossibilitando quase as viagens, e que são muitos todos os dias, compreende-se que o seu número seja tão elevado.

Indo adiante, nosso padre cronista ministra a seus pósteros pequena aula de História da Igreja católica no Brasil, demonstrando com isso, mais uma vez, a autoridade do bispo de São Paulo sobre o Santuário. Além disso, não se furtou em nos brindar com delicioso comentário sobre a administração das rendas do Santuário:

[...] Esse nome, "Episcopal", Ihe é dado porque desde a separação da Igreja e Estado no Brasil, essa igreja ficou com todos os seus pertences sob a jurisdição do Bispo Diocesano, tendo um tesoureiro próprio, S. Ex. ${ }^{a}$ o Camareiro Apostólico, João Maria de Oliveira César, que administra os bens, resultado dos donativos dos romeiros, uns 150 a 200 contos, em vez dos administradores do Estado, que roubavam mais do que administravam... 
A generosidade das espórtulas e a relação do fiel com o sagrado é aqui exemplarmente narrada, e o objeto ofertado se sacraliza mediante sua recompra. $\mathrm{Na}$ visão religiosa do romeiro, pois, o objeto passa a encerrar parcela do poder de Nossa Senhora Aparecida:

[...] Os brasileiros não oferecem só dinheiro, colocado generosamente no cofre na frente do lado da epístola do arco, mas oferecem, também, à querida Mãe, vestes que só usaram uma vez para visitar a igreja; especialmente muitos vestidos de noiva, de bela seda, após o casamento realizado diante do altar de Nossa Senhora. Oferecem anéis, correntes de ouro, comprando-as, às vezes, novamente da Mãe de Deus a fim de as guardarem como lembrança dela...

De uma administração racionalizada espera-se, pois, que nada se perca. $O$ cronista nos informa que o tecido dos vestidos de noiva, após desmanchados, servem como paramentos para os altares. As jóias, assim como os demais adereços de valor, são leiloados em uma barraca, a isso destinada, nas festas de Nossa Senhora.

À frente 0 cronista se reporta aos rendimentos do cofre e aos procedimentos que envolvem sua abertura, retomando, então, à generosidade e à espiritualidade dos romeiros:

[...] No cofre, aberto a cada 15 dias pelo tesoureiro, em presença de um padre, acham-se sempre uns 8000 marcos [...] Assim, são milhões o que esse povo gasta anualmente para ter a felicidade de ver a Virgem de Aparecida e recomendar ao seu coração a vida e a morte...

Prosseguindo em seus comentários sobre a administração do Santuário, a pessoa de D. Arcoverde não poderia estar excluída, sendo patente a atuação do mesmo no sentido de garantir a exclusividade para os redentoristas, exclusividade essa objeto de inveja por parte de outras Ordens religiosas!

[...] Dom Arcoverde se mostrou nosso grande amigo. É oblato. Obteve-nos o breve do Papa para administrarmos o santuário, de modo que nenhum bispo ou arcebispo nos pode dispensar, mas só Roma. Esse favor é tanto mais valioso, quando sacerdotes e até religiosos nos invejam por nos ter sido entregue o santuário de maior influência no Brasil, ao qual aspiram outras ordens religiosas, mormente os salesianos...

Com tal dádiva de D. Arcoverde, e com tal movimento de romeiros, é natural que os valores declarados não impressionem, bem como não surpreenderão as futuras queixas de D. Epaminondas sobre a evasão de seus paroquianos em favor de Aparecida! 
Os batizados são 800, de perto e de longe, com espórtula de 5 mil réis. Até 10, 20 alguns oferecem. Os casamentos chegam a 100 , com 18 mil réis de taxa. A renda chega a 25 a 30:000\$ anualmente...

Um dos pontos da reforma ultramontana foi o de incentivar a criação de novas irmandades, desde que, obviamente, subordinadas aos bispos. As Crônicas e as Ânuas, pois, são férteis em noticiar a criação de diversas dessas agremiações em Aparecida, sob a supervisão dos padres redentoristas. Irmandade de Nossa Senhora Aparecida, no entanto...não! Bastava, é certo, a que foi extinta em 1805. O cronista nos esclarece com candente sinceridade...

[...] Associação ou Irmandade de Nossa Senhora não há em Aparecida, porque há o mau costume no Brasil de essas irmandades, por exemplo, a do Rosário, quererem mandar na igreja e, em Aparecida, irem gostar de tomar parte na administração e de poder roubar um pouco, conforme a necessidade e a ocasião...

Não faltava, porém, quem se aventurasse a tentar...

Um certo Manoel Vintém me disse: "Semos (sic) todos filhos de Maria, deveríamos ter uma Irmandade de Nossa Senhora Aparecida para podermos tomar parte na sua riqueza."...

À fala de Manoel Vintém segue a reflexão do cronista, pelo visto desejoso em encerrar o assunto:

...De fato, não é má idéia para um preguiçoso e murmurador desse calibre. ${ }^{367}$

Isso, no entanto, não se configurava como um problema. Ao longo do tempo, os redentoristas palmilharam todo o território da diocese de Taubaté, conhecendo os hábitos religiosos do povo, e se fazendo conhecer como os detentores não só da administração do santuário, mas também, o mais importante, de um ícone sagrado cuja simbologia a cada dia tornava-se insuperável em devoção e popularidade. D. Epaminondas sabia que as forças eram desiguais. Afinal, "como as paróquias vizinhas são muito extensas e em alguns lugares o próprio pároco nunca apareceu, os fiéis continuam a procurar os padres de Aparecida." ${ }^{368}$

\subsection{A luta pelo cofre: a Questão de Aparecida}

Estudada que foi a evolução do Santuário de Aparecida no que concerne

367 ACPSR. Ânuas da Vice-Província de São Paulo, v. I (1896 - 1918). pp. 81-105.

368 ACPSR. Ânuas da Vice-Província de São Paulo, v. I (1896 - 1918). p. 277. A Ânua é de 1908. 
aos aspectos da devoção, afluxo de romeiros, e seu conseqüente movimento financeiro, e tendo em conta ser a diocese de Taubaté a última a entrar em atividade, é certo que, pelas correspondências, os bispos das demais dioceses sufragâneas tenham levantado a hipótese, junto a D. Duarte, de também se beneficiarem das rendas do Santuário.

Retroceda-se, ainda que brevemente, para que se confirme a hipótese, tomando como apoio a carta de D. Arcoverde para D. Alexandre Bavona, Núncio Apostólico:

[...] Peço desculpa a V. E. ${ }^{\text {ma }}$ por não ir, hoje, com o Sr. Bispo de São Paulo. Pela exposição que o Sr. Bispo de São Paulo me fez, julgo que V. Ex. ${ }^{a}$ Rev. ${ }^{\text {ma }}$ convirá que o Sr. Bispo fique com plena administração do Santuário de Aparecida. Ele se compromete a fundar um Seminário Central e a fundar também o patrimônio da diocese. Além disso, deve ele dar o necessário impulso ao Seminário Pequeno. Enfim, eu penso que o Sr. Bispo merece assumir essa administração para fazer todo o bem que ele deseja fazer. V. Ex. ${ }^{a}$ conversará com o Sr. Bispo e verá o que ele deseja. ${ }^{369}$

A correspondência epistolar entre D. Arcoverde e D. Duarte, versando sobre o assunto, prossegue em Roma:

[...] Vou iniciar, amanhã, as práticas relativas a conseguir que o Arcebispo de São Paulo não tenha que prestar contas aos sufragâneos das rendas do Santuário de Aparecida. Vamos ver como isso ficará. Como está é que não pode ficar [...] ${ }^{370}$

Ora, se não pode ficar como está é porque, certamente, como constava no texto inicial, o metropolita deveria prestar contas aos bispos das dioceses sufragâneas. ${ }^{371}$ D. Arcoverde, portanto, fazia ingerências no sentido de eliminar essa particularidade canônica, e o assunto volta à baila entre os dois prelados quando o Cardeal se encontra em Nápoles, recuperando-se de uma gripe,...

369 ACPSR. Correspondência da Província Redentorista de São Paulo - COPRESP-B - Suplemento, v. III (1906-1921). p. 126. Carta de D. Arcoverde para D. Alexandre Bavona. 17 de julho de 1908.

370 ACPSR. Correspondência da Província Redentorista de São Paulo - COPRESP-B - Suplemento, v. III (1906-1921). p. 195. Carta de D. Arcoverde para D. Duarte. 29 de outubro de 1908.

371 Aqui transcrito para maior conforto de leitura: "Em atenção à preeminência da Igreja episcopal de São Paulo, no Brasil, e de suas peculiaridades necessidades, Sua Santidade concedeu, temporariamente, a faculdade de receber ofertas que sob qualquer ônus forem oferecidas pelos fiéis ao templo sagrado de Nossa Senhora Aparecida, de modo que depois de suprido o referido templo sagrado, tirando-se certa parte que o executor designado para este decreto consistorial constituiu, sejam aplicadas nas despesas que cada ano o Arcebispo de São Paulo no Brasil tiver em sua arquidiocese, o resto será aplicado em obras produtivas, destas rendas, conforme determina o mesmo executor; o Arcebispo de São Paulo, no Brasil, poderá dispor para atender às necessidades. Enquanto durar esta modalidade, o arcebispo será obrigado cada ano a dar conta aos bispos da sua província de sua administração". 
Tratei diretamente com o Ex. ${ }^{\text {mo }}$ Cardeal sobre a conveniência de modificar-se o Decreto da criação da Arquidiocese de São Paulo, na parte relativa ao modo de o Arcebispo administrar as rendas daquele Santuário e dar conta de sua administração. Como estava no Decreto eu não reputei como decoroso e, por isso, disse-lhe que havia de reclamar. Reclamei e o Ex. ${ }^{\text {mo }}$ Cardeal prometeu-me que ia tomar em consideração minhas observações, e creio que já o fez autorizando o Sr. Núncio a modificar aquilo por um Decreto. ${ }^{372}$

...quando então, de volta à Roma, prossegue em sua contenda:

[...] Aqui tenho continuado a defender suas prerrogativas no delicado negócio do Santuário de Aparecida. Logo que aqui cheguei abordei o negócio diretamente e o Ex. ${ }^{\text {mo }}$ Cardeal Secretário ficou convencido da conveniência de modificar o decreto relativo a administração das rendas do Santuário [...] Desejo muito que esse negócio fique livre dos embaraços em que o deixara aquele decreto... ${ }^{373}$

Da correspondência estabelecida entre D. Duarte e o Cardeal Arcoverde é certo que aquele, em seu primeiro contato com o bispo de Taubaté, teve boa impressão. D. Arcoverde menciona o encontro em sua resposta:

Carta de D. Joaquim Arcoverde, Cardeal Arcebispo do Rio de Janeiro, a D. Duarte Leopoldo, Arcebispo de São Paulo, em 25 de dezembro de 1909. Ex. ${ }^{\text {mo }} \mathrm{Sr}$. Arcebispo Recebi sua carta de 22 deste mês em que me comunicou a boa impressão que the deixou o Sr. Bispo de Taubaté. Graças a Deus, parece ter sido escolhido a dedo para Taubaté...

Não se pode afirmar, todavia, que o encontro entre o metropolita e seu diocesano tenha se restringido a assuntos puramente triviais. Pela continuidade da carta de D. Arcoverde, um dos temas da conversa com certeza versou sobre a administração do Santuário.

...Quanto, porém, ao que se referiu com relação às reclamações que ele faz, estimulado pelo meio que o cerca, devo dizer-Ihe uma coisa, que poderá servir-lhe de regra de prudente e cauteloso procedimento:...

O conselho de D. Arcoverde materializa a forma de dominação legal com quadro administrativo burocrático, caracterizada, no caso, pelo princípio da hierarquia oficial. Sendo assim, caberia direito de apelação ou reclamação a D. Epaminondas, caracterizado como instância subordinada, às superiores.

372 ACPSR. Correspondência da Província Redentorista de São Paulo - COPRESP-B - Suplemento, v. III (1906-1921). p. 123. Carta de D. Arcoverde para D. Duarte. 26 de dezembro de 1908.

373 ACPSR. Correspondência da Província Redentorista de São Paulo - COPRESP, v. V (19091912). p. 101. Carta de D. Arcoverde para D. Duarte. 9 de fevereiro de 1909. 
...V. Ex. ${ }^{a}$ responderá a esse e aos outros senhores bispos que tocarem nesse assunto, no sentido de pedir-lhe contas: queiram se dirigir à Santa Sé... ${ }^{374}$

Não obstante a ausência de documentos onde conste especialmente as combinações para o evento, é certo ter havido uma reunião em Aparecida entre os três dignitários da Igreja: D. Joaquim Arcoverde, D. Duarte e D. Epaminondas. Segundo as Crônicas Redentoristas de Aparecida, ao meio-dia de 30 de dezembro de 1909, D. Duarte desembarcou na estação ferroviária de Aparecida. Ainda almoçava com os padres quando foi anunciada a chegada do bispo de Taubaté, e ambos se dirigiram à estação a espera do Cardeal. ${ }^{375}$

No dia seguinte, bem cedo, D. Epaminondas celebrou missa no altar-mor e voltou para Taubaté. O Cardeal celebrou na capela da casa e o arcebispo no altarmor. Entre uma missa e outra, "o assunto principal da reunião dos três distintos senhores foi: 'a qual bispo pertencerá Aparecida.' " 376

As conversações entre D. Arcoverde e D. Duarte prosseguiram sem a presença de D. Epaminondas. Infere-se, pela cronologia das cartas, que nesse meio termo D. Duarte não retornou diretamente para São Paulo, indo descansar em uma residência de Monsenhor Nascimento Castro, em Tremembé. A 3 de janeiro, D. Arcoverde despede-se de Aparecida com destino a Taubaté:

Padre Visitador acompanha o Cardeal até Taubaté, sendo tratado com muita deferência tanto pelo Cardeal como pelo bispo de Taubaté. ${ }^{377}$

Em meio às possíveis tentativas de acordo, Monsenhor Miguel Martins aguardava os resultados de sua ação investigativa. Não recebendo a resposta desejada, escreve ao reitor do seminário de Pirapora. A ação prosseguia a toda força.

[...] Caso não haja inconveniente, tenha a bondade de contarme os nomes dos moços desta cidade, que aí estão estudando grátis, e quanto rende anualmente de esmolas esse Santuário.

A justificativa de Miguel Martins é, no mínimo, risível.

Desejo saber para um fim muito justo e inofensivo. [...] Padre Miguel Martins, Taubaté, 31 de Dezembro de $1909^{378}$

374 ACPSR. Correspondência da Província Redentorista de São Paulo - COPRESP, v. V (19091912). p. 98.

375 ACPSR. Crônica da Comunidade Redentorista de Aparecida, v. II (1908-1922). p. 60.

376 ACPSR. Crônica da Comunidade Redentorista de Aparecida, v. II (1908-1922). pp. 60-61.

377 ACPSR. Crônica da Comunidade Redentorista de Aparecida, v. II (1908-1922). p. 64.

378 ACMSP. Carta do Padre Miguel Martins ao Seminário em Pirapora. 31 de dezembro de 1909. 
Miguel Martins tentava fechar a questão por todos os lados possíveis, e o diretor do Colégio diocesano também foi inquirido:

[...] Desejo saber, e para um fim muito justo, quanto o Sr. paga anualmente à Arquidiocese pelo arrendamento desse Colégio. Como trata-se d'um contrato público, penso que não há inconveniente algum em contar-me. [...] Padre Miguel Martins. Missionário Apostólico. Taubaté, 31 de Dezembro de $1909^{379}$

Puro segredo de polichinelo. A obediência devida ao metropolita, por parte de seu clero, fez com que as cartas rapidamente chegassem às mãos de D. Duarte.

A resposta a D. Epaminondas, provavelmente visando evitar um rompimento definitivo, conduz a questão no sentido preveni-lo contra "amigos ursos".

S. Paulo, 3 de janeiro de 1910 Ex. $^{\text {mo }}$ Sr. Bispo de Taubaté Laudatur Jesus Christus. Tenho em meu poder uma carta dirigida ao reitor de Pirapora, em que Mons. Miguel Martins Ihe pede informações sobre as rendas daquele Santuário. A outras pessoas tem ele escrito pedindo dados e informações sobre a situação financeira de minha Arquidiocese...

Considerando os rígidos critérios que movimentam a eleição de um bispo, seria no mínimo ingênuo qualificar $D$. Epaminondas como um marionete nas mãos de padres que mal conhecia. Ao deixar de comentar, segundo suas palavras, o desaforo de quem se arvora em fiscal de sua administração, D. Duarte procurava contemporizar, evitando assim um confronto e uma acusação direta a D. Epaminondas:

...Deixo de comentar o desaforo de quem se arvora em fiscal da minha administração. Entretanto, devo levá-lo ao conhecimento de V. Ex. ${ }^{a}$ para que esteja prevenido contra os amigos ursos que assim procuram malquistar dois Bispos, cujas preocupações pairam certamente acima destas misérias. + Duarte $^{380}$

O descanso pretendido por D. Duarte, se houve, foi muito curto. Uma forte discussão entre ele e D. Epaminondas, ocorrida em Tremembé, antecipou a chegada do metropolita a São Paulo.

São Paulo, 4 de janeiro de 1910. Caríssimo Monsenhor Castro. Pax e Gratia. A minha dignidade força-me a interromper o descanso que pretendi tomar no Tremembé. Venho, por isso, agradecer a V.Rev. ${ }^{\text {ma }}$ e suas boas sobrinhas todos os favores que me dispensaram, esperando merecer ainda de V. Rev. ${ }^{\text {ma }}$

379 ACMSP. Carta de Monsenhor Miguel da Silva Martins para o reitor do Colégio Diocesano. 31 de dezembro de 1909.

380 ACMSP. Carta de D. Duarte a D. Epaminondas. 3 de janeiro de 1910. 


$$
\text { uma piedosa Ave Maria. + Duarte }{ }^{381}
$$

Como se verifica, as cartas agora se dirigem a Monsenhor Nascimento Castro, que a partir de agora passará a ser o interlocutor de D. Duarte. A correspondência entre os dois prelados cessa. No momento de sua partida, porém, Monsenhor João Alves Coelho Guimarães, ${ }^{382}$ sacerdote do aparato de D. Duarte, passou na estação furiosa descompostura em Monsenhor Miguel Martins.

Monsenhor Miguel Martins, escolado pelos anos e pelas andanças que sua ação de pregador o incumbiu, escreve a Monsenhor João Alves uma carta que segue a linha de fina ironia, e de ofensa velada. Partidário de D. Epaminondas na contenda, Miguel Martins tem D. Duarte na conta de injusto, e apóia-se em Santo Agostinho:

Ao Mons. João Alves. Mons. - Não enfade-se com os que ficam indignados contra as injustiças de D. Duarte; porque terá de enfardar-se com o mundo inteiro. Escutemos o que a respeito nos ensina o sábio e caridoso Santo Agostinho. Deus, diz ele, não condena a indignação contra o mal e contra os que nele se obstinam; Deus condena a ira que se expande em violentas manifestações e que, com a condenação do ato, envolve ódio à pessoa...

D. Duarte é perseguidor da diocese taubateana. No entanto, Monsenhor Martins responde ao ódio...com amor.

\begin{abstract}
...Assim, eu fico indignado com a atroz perseguição de $D$. Duarte à nossa Diocese, mas em vez de ódio à sua pessoa, em vez de praguejar, que tanto ofende a Deus, todos os dias, na santa missa, peço a Nosso Senhor que o faça ser um santo Bispo: zeloso, humilde, manso, caridoso.
\end{abstract}

Na visão de Monsenhor Miguel Martins, a luta pelo cofre de Aparecida é um sagrado direito da diocese de Taubaté. Além disso, os gastos de D. Epaminondas serão destinados ao seminário, não sendo comparados aos de D. Duarte, pelo visto acostumado ao luxo de palácio e carruagens:

...Sejamos patriotas; auxiliemos ao santo Bispo que com

381 ACMSP. Carta de D. Duarte a Monsenhor Nascimento Castro. 4 de janeiro de 1910.

382 Nascido em Taubaté a 19 de julho de 1834, Monsenhor João Alves foi ordenado por D. Antônio Joaquim de Melo. Exemplo claro da ação romanizadora no interior do Estado de São Paulo, Monsenhor João Alves foi pároco em Monte-Mór e em Redenção da Serra, tendo, após isso, sido coadjutor do então vigário de Taubaté, Padre José Pereira da Silva Barros, futuro bispo. Exerceu as funções de Cônego catedrático da Sé Episcopal, de ecônomo e de reitor do Seminário Episcopal de São Paulo. Polyanthea. Comemoração do cinqüentenário de fundação do Seminário Episcopal de São Paulo: 9 de novembro de 1856 a 9 de novembro de 1906, s.d. pp. 55-62. João Alves Coelho Guimarães é o trigésimo sexto ex-aluno de uma relação de 4.486 nomes, conforme constante no Apêndice da obra em tela. 
coragem apostólica trata de reivindicar os sagrados direitos de sua Diocese. É um Bispo modelo, que se tiver recursos, não gastará em palácios e carruagens, mas em formar bons sacerdotes, de que tanto precisamos...

Miguel Martins, ao referir-se ao fato de amar a pátria, faz alusão a condição de taubateano de D. Duarte. Açulando a vaidade de seu interlocutor ao lembrar-lhe dos favores esquecidos, ao mesmo tempo faz insinuações veladas a masculinidade do Arcebispo!

...monsenhor, quem não ama sua pátria, não amará ninguém. A prova eloqüente o $\mathrm{Sr}$. tem tido: seus imensos favores são completamente esquecidos. Ao passo que meninos bonitos, que nenhum serviço prestaram, são vigários de Jundiaí, Santos, Santa Cecília, Brás, Sé; ao Padre Altino por muito favor toca Cambuci e ao Padre Arthur, São Roque...

Como é certo que a carta cairá nas vistas de D. Duarte, o momento é propício para intrigá-lo com seu próprio clero...

...Beija-se-lhe a mão, mas desprezam-se os seus desejos, e até se o trata de velho caduco. Esta é que é a pura verdade...l

Por fim, mais ironia. Monsenhor Martins recomenda a Monsenhor João Alves dedicação a Deus, que é sempre fiel. Entende-se, pois, que não se deva ser fiel a D. Duarte...

...monsenhor, há certas dedicações que só deve ter-se a Deus, que é sempre fiel. Queira desculpar-me estas ponderações, motivadas pelo seu furor ontem manifestado na Estação e dirigido à minha humilde pessoa. Deus que dê a $\mathrm{D}$. Duarte mansidão e humildade e a $\mathrm{V}$. Ex. ${ }^{\mathrm{a}}$ calma e saúde, são os ardentes votos do de V. Ex. ${ }^{a}$ servo humilíssimo. Padre Miguel Martins. Tremembé, 4 de janeiro de 1910. ${ }^{383}$

A contar pelas cartas que escreve em 4 de janeiro de 1910, é certo D. Duarte parece estar profundamente irritado. As conversas entabuladas em Tremembé vazaram para a imprensa, e o metropolita reporta a situação a D. Arcoverde.

S. Paulo, 4 de janeiro de 1910 Eminência Laudatus Jesus Christus. Incluo esse retalho de um jornaleco de Taubaté, para que $\mathrm{V}$. Em. ${ }^{\mathrm{a}}$ veja a imprudência e leviandade com que o $\mathrm{Sr}$. Bispo pretende encaminhar as suas disparatadas reclamações. À parte as inverdades, o resto é evidentemente inspirado pelo Sr. Bispo ou por alguém da sua privança...

Apontando para D. Arcoverde a possibilidade de envolvimento direto de D.

383 ACMSP. Carta de Monsenhor Miguel da Silva Martins para Monsenhor João Alves. 4 de janeiro de 1910. 
Epaminondas na questão, o que não fizera em correspondência com este prelado, D. Duarte cita as cartas de Monsenhor Miguel Martins:

...Além disso, há aqui em S. Paulo diversas cartas, uma das quais tenho em meu poder, pedindo informações minuciosas sobre o estado financeiro da minha Arquidiocese, rendas do Pirapora, da Basílica, da Cúria, do Seminário, recursos do Arcebispo etc. Estou sendo positivamente fiscalizado; se ao menos os fiscais quiserem dizer a verdade toda, ainda bem...

A questão assumiu foro público e D. Epaminondas é tido como leviano.

...Como vês V. Em. ${ }^{a}$ o escândalo está na rua, e já também nos jornais de S. Paulo, para onde o levaram a leviandade e a inexperiência do Sr. Bispo, com todo o cortejo de maledicências e calúnias...

A abrupta saída de Tremembé, tida como prudente por D. Duarte, é também comentada. A discussão, no entanto, é omitida.

... [...] Por medida de prudência, mandei buscar a minha bagagem que está no Tremembé, onde não me permitiram um descanso de que muito precisara. No fiar em Deus conservarme tranqüilo e superior a estas misérias. Abençoe $\mathrm{V}$. Eminência Servo e amigo em Jesus + Duarte ${ }^{384}$

O caso já estava nas ruas, e em matéria no jornal católico 'O Norte', intitulada de "Inconveniências", Benedito Euzébio de Toledo declarou que, em passeio pelas ruas, foi interpelado a respeito da questão da restituição do Santuário de Aparecida ao Bispado de Taubaté, sendo-Ihe exigida uma tomada de posição sobre o tema. Procurando se escusar, em virtude do assunto e da impropriedade do local, aduziu que sua opinião nada adiantaria ao caso. À insistência do interlocutor, no entanto, "não tivemos meio de evitar a resposta e a demos".

Assegurando que ninguém poderá duvidar da sinceridade da dedicação d' $O$ Norte' à causa do Bispo de Taubaté, e portanto, à causa dos interesses desta diocese, entendia o articulista que o Santuário de Aparecida dever ser restituído a Taubaté, como parte integrante do seu território. Procurando evitar intromissão maior, Benedito Euzébio também entendia que a missão da imprensa leiga, na atualidade, devia ser de mera expectativa, para depois, apreciar os fatos que se desenrolassem.

A se conhecer a linha editorial d' 'O Norte', não se esperaria outra atitude que não a de defesa a D. Epaminondas; Benedito Euzébio, não obstante posar em

384 ACMSP. Carta de D. Duarte a D. Arcoverde. 4 de janeiro de 1910. 
pretensa neutralidade, afirma ser de conhecimento público que "o nosso amado Bispo", julgando-se no dever de consciência de defender os interesses da diocese que recebeu por sua esposa, e a qual jurou proteção, já havia feito chegar ao Sr. Arcebispo de S. Paulo sua reclamação, cabendo a todos os taubateanos aguardar a solução da questão a ser decidida pelo poder competente da Igreja, "que certamente resolverá pelos princípios de justiça absoluta, tendo em vista as provas e os documentos que forem aduzidos."

Assim, Benedito Euzébio entende que não serão os artigos d' 'O Norte' que obrigarão D. Duarte a entregar para Taubaté o território que se acha colocado "como que no coração da diocese", e nem serão eles que convencerão ao papa sobre a justiça da causa. No entanto, não deixa de por lenha na fogueira:

[...] As partes vão ser o Sr. Bispo de Taubaté, pedindo a restituição daquilo que deve lhe pertencer, o que aliás foi concedido à arquidiocese temporariamente, e o Sr. Arcebispo de S. Paulo querendo a continuação dessa posse, desse gozo de rendimentos para a Arquidiocese...

Dito isto, apela para a emoção, acreditando que muito influirá no espírito do Arcebispo o fato de, além de ser ele taubateano, é sabedor de que, sem os rendimentos de Aparecida, a diocese de Taubaté jazerá inativa, em torpor, por falta de meios, e assim deixará correr à sua revelia, perante a Santa Sé, a reclamação do Bispo de Taubaté. Exposta a questão em sua realidade, o articulista, convenientemente, reassume a postura de isenção...

Não dificultemos os acontecimentos; deixemos as legítimas partes discutirem, defenderem seus direitos, e depois certo que estiver resolvido o pleito, apreciemos com o direito que nos cabe, a decisão final, que, certamente não será outra senão o reconhecimento do direito do Bispo de Taubaté. ${ }^{385}$

O artigo d' 'O Norte'”, no entanto, não ficou sem resposta, e 'A Federação' contra-atacou, discordando da posição assumida por Benedito Euzébio de Toledo de que a imprensa leiga deveria ficar na expectativa até final desenrolar dos fatos.

'A Federação' apresenta dois motivos pelos quais não pode concordar com o modo de pensar do colega: o primeiro é porque, depois do fato consumado, nada mais se poderia fazer, "e mais vale prevenir que lamentar"; o segundo é porque, na compreensão d'A Federação', trata-se de uma questão importantíssima, que interessa a todos, está em pleno domínio público, e que não ignora a pronunciada

385 ACMSP. O Norte, n. ${ }^{\circ} 447$, VI. 6 de janeiro de 1910. 
má fé do Arcebispo Metropolitano, "que se recusa a entregar ao seu legítimo dono aquilo que Ihe não pertence".

A argumentação prossegue, e 'A Federação' assegura que se é certo que seus artigos de defesa não influem no espírito dos que pregam à Cristandade, ainda um consolo lhe restaria, que é ter lavrado o seu protesto, defendendo os direitos da Diocese e a justa satisfação de estar com o jornal a população católica,

[...] sempre vítima da ganância insaciável e da ambição desmedida de sacerdotes ingratos que só reconhecem como seu Deus, - o ouro - esse metal vilíssimo que corrompe a alma dos fracos e enegrece os corações dos pusilânimes, dominando as suas consciências...

Prosseguindo, o jornal dispara que seu único desejo "é afastar o Arcebispo desse mau caminho, que fatalmente o conduzirá ao erro", terminando por admoestar o metropolita: "Que D. Duarte não macule o alto lugar que ocupa no sólio episcopal e que saiba, acima de tudo, ser patriota, cumpridor dos seus deveres. Nada mais. Basta de hipocrisia". 386

Não obstante a crise tornada pública, as atividades religiosas e administrativas da diocese taubateana prosseguiam sem interrupção. Poucos meses após a chegada de D. Epaminondas, exatamente em 9 de janeiro de 1910, ia a público o primeiro número do jornal ultramontano 'O Lábaro', órgão oficial da diocese:

O seu próprio nome bem o define; estandarte, bandeira, ele guiará os católicos desta mimosa diocese, flutuando sempre desfraldado, sobre o paupérrimo batel da Igreja taubateana, até que Deus toque, com força de sua divina justiça, os corações daqueles que the devem restituições, afim de que o seu timoneiro possa encetar as obras que lhe inspiram o seu zelo apostólico e as suas responsabilidades episcopais. ${ }^{387}$

O recado não poderia ser mais claro: as obras de D. Epaminondas só poderiam ser levadas avante após as devidas restituições.

Instalada a crise, é certo, pela carta resposta de D. Arcoverde, que D. Duarte o punha ciente de todo o ocorrido, buscando, na comprovada influência do Cardeal junto a Roma, o necessário apoio.

Falamos em crise, mas ao se ler a carta de D. Arcoverde para D. Duarte percebe-se a segurança daquele em relação ao andamento da questão. As orientações de D. Arcoverde para o metropolita demonstram, de sua parte, total 
domínio da manobra, assim como seu perfeito trânsito entre as autoridades da Nunciatura e da Cúria romana:

[...] Estive com o Sr. Núncio Apostólico, e a ele mostrei sua carta e o artigo relativo a Aparecida. Como todos nós, o Sr. Núncio reprovou essa leviandade e falta de senso. O nosso posto é o que nos colocou a lei e a palavra do Sumo Pontífice, guardemos pois toda a compostura, e a necessária reserva...

Sabedor da posição de D. Arcoverde em relação ao problema, é natural que sua presença em Taubaté não tenha inspirado suficiente confiança em $D$. Epaminondas para que o prelado fizesse qualquer comentário sobre o tema, uma vez que o Cardeal declara ali ter estado, constatando completa reserva e silêncio, por parte do palácio, no tocante a negócios de Aparecida.

Isto posto, é interessante notar a falaciosa argumentação de D. Arcoverde em relação ao Santuário. De fato, como se verificou no capítulo anterior, as determinações de Roma ressalvam que, após a formação de um patrimônio arquidiocesano, Aparecida passaria a pertencer a todas as dioceses de São Paulo. ${ }^{388}$

A questão, porém, não respondida pelo Cardeal, e mesmo por Roma, poderia consistir em se saber quando se concluiria a formação desse patrimônio, recordando-nos a política econômica de Delfim Neto sobre a repartição do bolo somente após seu crescimento...

[...] Estive provando ao Monsenhor João Alves que essa grita, levantada em Taubaté é fora de propósito, porque Aparecida, como Santuário, pertence a todo Estado de São Paulo; hoje está por ordem da Santa sé destinada a formar o patrimônio da Arquidiocese; quando estiver formado esse patrimônio, ficará a Aparecida pertencendo a todas as dioceses do Arcebispado de São Paulo; por conseguinte era um despropósito a grita que se levantava em Taubaté...

A influência de D. Arcoverde junto ao Núncio Apostólico é clara no texto abaixo. O assunto, pois, para o Cardeal, poderia se enquadrar como resolvido, tendo em vista que "temos o Sr. Núncio inteiramente de nosso lado, e ele defenderá o direito do Arcebispo perante a Santa Sé..."

Ao auxílio prestimoso cumpre, pois, comportamento adequado, não sendo oportuno qualquer ação esclarecedora junto à parte adversária. O poder é, por

388 Aqui transcrito para maior conforto de leitura: "[...] Logo, porém, que seja constituído o patrimônio para a mesa arquiepiscopal da Igreja de São Paulo no Brasil, as rendas provenientes das ofertas do templo sagrado sob o título de Nossa Senhora Aparecida, serão divididas entre as dioceses desta nova província eclesiástica, pela razão que a Sé Apostólica assim decidiu". 
excelência, silencioso:

...Por conseguinte a nossa política deverá ser a seguinte: 1 ) Não responder aos artiguetes de jornais; ad summum dar alguma explicação para esclarecer e dissipar nuvens e dúvidas razoáveis ou de boa fé.

Em contrapartida, é preciso evitar comentários desairosos à administração de D. Duarte. Cumprindo, portanto, investir na boa apresentação do Santuário, D. Arcoverde não manda recado:

Em segundo lugar, é preciso não dar lugar a certas críticas, isto toca a V. Ex.a: ouvi dizer em Taubaté que o exterior do Santuário está muito abandonado, sujo e descurado. Até certo ponto isto é verdade. Quero dar-lhe um conselho: V. Ex. ${ }^{a}$ mande gastar por ano uns cinco contos de réis em pinturas dos gradis, em conserto das lajes, calçadas etc. que contornam o Santuário; as paredes laterais, a torre etc. ...

O cardeal justifica essa ação, por parte de D. Duarte, baseando-se no conceito que tem dos fiéis, uma vez que em sua visão "isto agrada os visitantes e tapa a boca dos descontentes. O povo é um menino que se contenta com um agrado qualquer."

Volvendo aos aspectos de sua influência nos centros de poder eclesiásticos, D. Joaquim não poderia ser mais claro:

Quanto aos faladores de Taubaté, não nos perturbemos, eles se calarão por fim ou recorrerão à Santa Sé, e perante a Santa Sé temos o Senhor Núncio, que explicará tudo. V. Ex. ${ }^{\mathrm{a}}$ cumpra o que disse em sua carta: conserve-se tranqüilo e superior a essas misérias. Daqui a pouco já não se falará mais do negócio. ${ }^{389}$

Em 18 de janeiro de 1910, após curta viagem, D. Duarte escreve a D. Arcoverde, atualizando-o sobre os acontecimentos:

[...] Aí vão, para o arquivo, mais uns retalhinhos de jornal que encontrei, ao chegar, sobre a mesa de trabalho. O Lábaro é o órgão oficial da Diocese de Taubaté, segundo se depreende de um edital publicado oficialmente pelo secretário de Bispado $[\ldots] \ldots$

Lançando na carta o excerto d'O Lábaro', D. Duarte sublinha os principais trechos, fazendo ver ao Cardeal Arcoverde que, pela nota do órgão oficial católico, ele também deve restituições à diocese de Taubaté:

...Aí temos, pois, o Sr. Bispo de Taubaté, a criar um órgão

389 ACPSR. Correspondência da Província Redentorista de São Paulo - COPRESP, v. V (19091912). pp. 113-114. Carta de D. Arcoverde para D. Duarte. 13 de janeiro de 1910. 
oficial que será um lábaro a flutuar sobre o paupérrimo batel da Igreja Taubateana, até que Deus toque os corações daqueles (certamente o Arcebispo, o Cardeal e o Núncio) que Ihe devem restituições ! ....

Como afirmamos anteriormente, a carta de Monsenhor Martins para Monsenhor João Alves chegou às mãos de D. Duarte. Examinando a escrita, o metropolita conclui sobre o envolvimento de Monsenhor Martins nos escritos dos jornais.

...O outro artigo, o da Federação, é certamente de Mons. Miguel Martins, pois nele se reproduzem, quase nos mesmos termos, os insultuosos conceitos emitidos na carta dirigida a Mons. João Alves, de que V. Em. ${ }^{a}$ tem notícia...

Por fim, D. Duarte sugere punição para Monsenhor Martins. No entanto, se na visão de D. Duarte o bispo de Taubaté não possui força moral para conter Monsenhor Miguel Martins, acreditamos ser lícito perguntar o motivo pelo qual o próprio D. Duarte, um arcebispo, não continha um monsenhor. Ausência de força moral?

...Não parece a V. Em. ${ }^{a}$ que este padre está precisando de uma correção da parte da Nunciatura, uma vez que o bispo não tem força moral para contê-lo em seus insultos ao Metropolita? Deixo o caso ao juízo de V. Em. ${ }^{a} 390$

À carta de 18 de janeiro junta-se nova correspondência de D. Duarte, datada de 20, demonstrando com isso a ebulição da questão nos jornais:

[...] O arquivo está crescendo. Na outra pagina montará $V$. Em. $^{\mathrm{a}}$ três retalhinhos, todos do Diário Popular de hoje e todos do Miguel Martins. Uma beleza! ...

E como D. Epaminondas não se dispunha a enviar dinheiro para a Arquidiocese de São Paulo...

O Sr. Bispo de Taubaté mandou retirar as absorções do Pirapora, por não poder pagar a pensão! Ajude-me V. Em. ${ }^{a}$ com um memento nas suas orações e abençoe ao servo e irmão em J.C + Duarte ${ }^{391}$

E como os conselhos de D. Arcoverde são ordens, D. Duarte não demora em sua correspondência junto ao segundo tesoureiro leigo da Basílica, Sr. Augusto Marcondes Salgado (1900 a 1946), genro e substituto de João Maria de Oliveira César, falecido em 1900. É preciso, segundo o próprio D. Arcoverde, agradar o 
povo:

Havendo um saldo de que se poderá dispor em benefício da Basílica, lembrei-me que seria conveniente fazer uma limpeza geral externamente de toda a igreja, como também de se fazerem alguns consertos e reparos na rua por onde sobem os bondes. A Câmara de Guaratinguetá pouco faz em benefício do lugar, e eu entendo que não podemos deixá-lo em completo abandono. Para esse fim, poderíamos combinar uma verba anual.

Em meio a contenda, ressurge Monsenhor Nascimento Castro, que envia uma carta para D. Duarte. Essa carta, infelizmente, não foi encontrada, mas a resposta de D. Duarte nos leva a concluir que o assunto nela contido se prende à forte discussão entre o arcebispo e D. Epaminondas, em Tremembé, assim como às acusações que D. Duarte faz a Monsenhor Nascimento Castro, em relação ao seu envolvimento em toda a trama.

Denominando Monsenhor Nascimento Castro de "caríssimo" e "bondoso", D. Duarte informa que só a muita atenção que lhe deve, e a sincera afeição que sempre Ihe dispensou, Ihe podem aconselhar resposta confidencial à dita carta. Sentindo-se desprezado em sua própria terra, o metropolita apela para o dramático:

É o desabafo de um coração atribulado no coração de um amigo, é um grito d'alma de um pobre bispo cujo luto, estado de saúde e especial situação de hóspede da terra, não mereceu a menor atenção. $\mathrm{Na}$ franqueza das minhas expressões não vai uma censura, direta ou indireta à pessoa de V. Ex. a; mas, quando muito, um caridoso brado no meio das trevas que se vão acumulando sobre essa terra, onde tive um berço que se procura enodoar.

D. Duarte esperava de Monsenhor Nascimento Castro uma maior ação em sua defesa. Considerava o metropolita, pelo viés da hierarquia racionalizada, que o Vigário Geral de uma diocese sufragânea, entidade jurídica que forma uma só pessoa moral com o diocesano, cujos atos se entrelaçam nas mesmas responsabilidades públicas, tendo conhecimento de onde partem sucessivos insultos contra o Metropolita, a mais alta autoridade, enfim, da jurisdição eclesiástica, não deve se omitir na defesa. Mas para D. Duarte, o Vigário Geral

[...] assiste impassível, de braços cruzados, em um silêncio tumular, a um fato virgem ainda na história eclesiástica do Brasil: o desacato desleal, indigno e soez da suprema autoridade da Província por um súdito seu sufragâneo que,

392 ACPSR. Correspondência da Província Redentorista de São Paulo - COPRESP, v. V (19091912). p. 116. Carta de D. Duarte a o Tesoureiro da Basílica, Augusto Marcondes Salgado. 20 de janeiro de 1910. 
tacitamente o aprova e o autoriza. E depois disto, vem o Vigário Geral aconselhar ao Metropolita que não dê atenção às intrigas dos pescadores de águas turvas, e muito às pasquinadas de jornalecos!... O Vigário Geral sabe que, na sua diocese há intrigantes, pescadores de águas turvas, pasquineiros de jornalecos que insultam o Arcebispo; sabe, ou pelo menos deveria procurar saber quais são os intrigantes, os pasquineiros, os pescadores de águas turvas cujo lodo pode respingar sobre a sagrada pessoa de seu próprio bispo, e nem desmancha a intriga, nem desmascara o pasquineiro, nem procura clarificar as águas!...

Tentando acalmar os ânimos, Monsenhor Nascimento Castro procura convencer D. Duarte que os artigos da imprensa são apenas pasquinadas, mas D. Duarte, obviamente, não vê de tal forma a questão:

... [...] Desprezar pasquinadas de jornalecos!...Isso tenho eu feito, meu caríssimo Monsenhor, não com palavras, mas com fatos, impedindo que se propagasse o incêndio que aí se ateou imprudentemente, levianamente, deslealmente, muito deslealmente. Isso tenho eu feito, mandando, entretanto, ressalvar pela imprensa a pessoa e a dignidade do meu digníssimo sufragâneo, sem que dele me viesse a mesma atenção.

E já que a questão se prende a pasquinadas de jornalecos, D. Duarte pergunta como deve classificar certa folha oficial que aí se fundou para guiar os católicos desta mimosa diocese, flutuando sempre desfraldado, sobre o paupérrimo batel da Igreja Taubateana, até que Deus toque, com força de sua divina justiça, os corações daqueles que lhe devem restituições...

... Eu confesso a $\mathrm{V}$. Ex. ${ }^{\mathrm{a}}$ que teria imensa mágoa se fosse forçado pelos fatos, a classificar de jornaleco de pasquinadas o órgão oficial de uma diocese minha sufragânea que, a julgar pelo trecho acima citado, teria sido fundado para guiar os católicos na luta contra o arcebispo. E digo contra o arcebispo, mas acredito que na latitude da expressão - daqueles que the devem restituições - forçosamente se devem incluir o então metropolita de São Paulo, hoje cardeal Arcoverde, o Núncio Apostólico e a própria Santa Sé, sendo certo que todos eles são coniventes na rapinagem de que se pede restituição.

Na compreensão de D. Duarte, o problema residia na não obediência por parte de D. Epaminondas do conhecido axioma da Teologia Pastoral: episcopus, primo ano, oculus; secundo, manus, ou seja, no primeiro ano de governo um bispo deve sempre observar, para então agir. A noção de hierarquia, entretanto, é observada pelo metropolita:

[...] Não nos amofinemos, porém: a Santa Sé, pois que assim o querem, terá de julgar todas estas belezas... 
Em sua carta, Monsenhor Nascimento Castro chegara a afirmar que o intuito do bispo de Taubaté consistia em tratar questões que julga afetar interesses da sua diocese com lealdade e suavidade, sem quebra das relações pessoais e de mútuo acatamento. D. Duarte replica, lembrando um possível compromisso de silêncio firmado em Tremembé:

Acatamento mútuo? Acatamento de um sufragâneo para com seu metropolita é que é, e o metropolita, insultado com a tácita conivência de seu sufragâneo, soube não faltar ao respeito e consideração que deve ao caráter sagrado de um seu irmão. Lealdade? Essa Ex. ${ }^{\text {ma }}$ Sr. ${ }^{\text {a }}$ fugiu, para bem longe, desde o dia em que as paredes da casa de V. Ex. ${ }^{a}$ no Tremembé tiveram ouvidos para ouvir e quiseram ter boca para restabelecer a verdade. Não ficara aí combinado que todas as reclamações fossem sujeitas à Santa Sé?

Enquadrado em uma dominação com quadro administrativo burocrático, D. Duarte assegura não ter protestado, desde logo acatando submissão e docilidade a qualquer decisão superior, obviamente adrede escudado em D. Arcoverde. Mas não admitia que D. Epaminondas estivesse agindo com lealdade:

Lealdade? Porque, então, se permitiu que em torno de um negócio que só entre bispos se deveria tratar e ventilar, se formasse tão grave escândalo, com todo o cortejo de injúrias, maledicências e calúnias? Lealdade? Porque, então, sem um único protesto, sem uma única explicação, se deixou correr mundo que o Arcebispo havia dado diversa aplicação a bens que não pertenciam, eufemismo transparente que mal encobre o epíteto de ladrão, e ladrão de bens sagrados?

D. Duarte faz alusão aos cavalos e carruagens de seu palácio, mas reclama de conversas sobre o tema!

Lealdade? Como, pois, se permitiu e se permite ainda que a clamorosa injustiça, a pessoa e administração do Arcebispo, o seu palácio, os seus tapetes, carruagens e cavalos, sejam tema obrigado das conversações do palácio episcopal?

Ainda irritado com as cartas de Monsenhor Martins, D. Duarte pergunta onde estaria a lealdade quando se abriu a devassa sobre sua administração e sobre os recursos materiais da arquidiocese, "malgrado o meu inutilíssimo protesto perante o legítimo Superior do padre malcriado e intrigante". O arcebispo, embora não ache fundamento nas reclamações do Sr. Bispo, "coisa que outros mais autorizados do que o Arcebispo e menos suspeitos do que ele também Ihe fizeram sentir", afirma não ter o direito de magoar-se com D. Epaminondas por querer levar o caso à decisão de um tribunal superior, qual seja, o da Santa Sé. 
A revolta sentida por D. Duarte, segundo ele próprio, é ver envolvido, em questões de bispos, o povo e o clero, "seculares ignorantes sempre inclinados a julgar mal das coisas da lgreja e padres despeitados", clara alusão a Monsenhor Martins, cuja doação imobiliária à diocese de Taubaté o fez, na visão de muitos, arrogar-se ao direito de ser bispo. O desejo de D. Epaminondas em promover um abaixo assinado em relação a Aparecida, no entanto, causou grande preocupação no arcebispo:

No Tremembé eu já o tinha dito ao Sr. Bispo, quando me falou em promover um abaixo assinado entre os seus diocesanos, coisa nunca vista neste país e que a Santa Sé não poderá tolerar. Mas estes sentimentos o Sr. Bispo os julgou suspeitos, interessados talvez; paciência. Todavia, permita Deus que o Sr. Bispo e seu Vigário Geral não tenham de lutar com sérias dificuldades ocasionadas por uma imprudente agitação popular.

D. Duarte ressalva o fato de que Monsenhor Nascimento Castro declara guardar completa neutralidade no negócio, mas que tem de obedecer às exigências do seu cargo de Vigário Geral, que o obriga a devida solidariedade com seu Bispo.

Concordando com o vigário Geral, D. Duarte ironicamente escreve que "na atitude singular e nunca até hoje entre nós sonhada do sufragâneo de Taubaté em face do seu Metropolita, não há certamente sombra de pecado". Assim sendo, o lugar de Nascimento Castro é ao lado do seu "bondoso e amabilíssimo Prelado".

Encerrando a longa missiva, D. Duarte volta ao apelo emocional. Sendo um dos principais autores da criação da diocese de Taubaté, entendia que a obra o glorificaria perante Deus. Sendo taubateano, sentia-se desprezado.

É contrariada a obra de que eu julgava depender, em boa parte, a santificação da minha alma? Tanto melhor, pois é prova manifesta de que a obra era e é de Deus. Ainda uma vez se verifica o texto da Escritura: Non est propheta sine honore nisi in pátria sua, e o Arcebispo de São Paulo, repudiado, insultado, caluniado, maltratado em sua própria pátria, no adeus de despedida lhe deixa um suspiro de perdão, e vai pedir a Deus illam, quam mundus non potest, pacem. Adeus, Monsenhor, V. Ex. ${ }^{a}$ que foi outrora meu amigo, dê-me sempre o amparo das suas piedosas orações. ${ }^{393}$

Monsenhor Nascimento Castro, no entanto, não se deu por achado e, mesmo com o "adeus" de D. Duarte, respondeu ao metropolita. E uma vez que o Vigário Geral era ultramontano, mas também político, respondeu ao drama...com

393 ACMSP. Carta de D. Duarte a Monsenhor Nascimento Castro. 22 de janeiro de 1910. 
outro drama.

Firmando em sua carta a muita consideração de que D. Duarte era merecedor, e afirmando a inalterável amizade que ele, Monsenhor Nascimento Castro continua a devotar-Ihe, confessa-se o Vigário Geral obrigado a pedir autorização para explicar, com franqueza e lealdade, algumas passagens "da longa carta de V. Ex. ${ }^{a}$, que, se de um lado deixou-me desvanecido pala confidência que encerra, d'outro lado contristou-me pelas injustas recriminações que contém."

Assegurando ser a reclamação de D. Duarte "clamorosamente injusta", Nascimento Castro nega qualquer consentimento tácito por parte do Bispo Diocesano e dele próprio "as injúrias, calúnias e insultos publicadas por um jornaleco desta cidade, denominado "Federação", à propósito da Aparecida e outras", atribuindo o fato a querelas políticas locais:

[...] Permita V. Ex. ${ }^{a}$ que the afirme. A "Federação" é um jornaleco que aqui foi montado pelo Cel. José Benedito e entregue a um indivíduo de maus instintos especialmente para atacar-me e alguns amigos da política dirigente nesta localidade. É o mesmo indivíduo que já publicou pasquins saturados de calúnias contra o Valois e que, aqui, continua no mesmo procedimento assalariado pelo referido coronel...

Nascimento Castro faz ver a D. Duarte que não poderia descer de sua dignidade para implorar ao Coronel José Benedito para cessar os artigos insultuosos ao metropolita, lembrando que o arcebispo the havia declarado que não dava importância às leviandades da imprensa.

Sabedor do provável envolvimento de D. Epaminondas e de Monsenhor Miguel Martins na estratégia movida pela posse do Santuário de Aparecida, o padre logo se desincumbe de livrar seus aliados, afirmando que D. Epaminondas, ao ler o primeiro artigo, tratou de sindicar sua procedência, posto que de início desconfiava de Monsenhor Miguel Martins, mas foi plenamente verificado que isso não era verdade...

Prosseguindo em sua defesa, e na de seus amigos, ressalta que o Bispo de Taubaté fez chegar ao conhecimento do Coronel José Benedito a sua contrariedade, incumbindo o Padre José Alves de se entender com o mesmo,

para que obstasse a continuação de artigos referentes à questões que só devem ser ventiladas entre as autoridades competentes, fazendo ainda ver que toda publicidade nesse sentido e em termos menos respeitosos seria inteiramente prejudicial. 
Nascimento Castro, no entanto, declara que apesar dos esforços do Padre José Alves, a intervenção fracassou, e que D. Duarte haveria de admitir que o Bispo também não poderia descer de sua dignidade para tratar com bandidos.

A explicação sobre a nota d' 'O Lábaro', tantas vezes citada pelo metropolita em suas queixas a D. Arcoverde, e às demais autoridades, prima pelo descabido. Utilizando-se do método de inicialmente concordar com o antagonista para depois demolir a argumentação, Nascimento Castro sai-se com esta: "Refere-se V. Ex. ${ }^{a}$ ao trecho de um artigo inserido no primeiro número do Lábaro, jornal da diocese, em que se depara uma alusão que, de fato foi leviana."

Admitida a leviandade da nota, Nascimento Castro, redator do jornal até sua morte em 1942, desculpa-se informando que ele e D. Epaminondas estiveram ausentes entre o dia 3 e 15 de janeiro, em viagem que realizaram a Juiz de Fora, Petrópolis e Rio de Janeiro. Na direção d' 'O Lábaro' ficaram os Padres José Alves e José Coelho, encarregados de fazer sair, impreterivelmente, o primeiro número no dia 6 de janeiro, e tomando somente a incumbência do noticiário e da revisão, visto ter-Ihes sido deixado os artigos de apresentação e de saudação.

Eis agora, pois, o real motivo da "leviandade":

Faltando-Ihes por inexperiência a atividade ou por outra, a
malícia do jornalista, aceitaram e publicaram na íntegra o artigo
em questão sem suspeitar que, escrito por um colaborador
secular, católico prático, houvesse período algum
inconveniente. Ao ler o artigo, alguns dias depois que aqui
chegamos, foi que muito nos contrariou o trecho alusivo,
tomando então todas as precauções para que não se
reproduzisse fato tão desagradável e contrário à vontade do Sr.
Bispo, chegando o mesmo a levar essa contrariedade ao
conhecimento do colaborador.

Justificada a "leviandade", em que a total culpa recai em um colaborador leigo, Monsenhor Nascimento Castro procura fazer com que o assunto caia no esquecimento, prometendo a D. Duarte que o mesmo não mais se aborrecerá com o "humilde órgão da diocese":

Assim, do humilde órgão da diocese $\mathrm{V}$. Ex. ${ }^{\mathrm{a}}$ não terá mais ocasião de molestar-se e ficará convencido de que outro intuito não tem senão o de guiar os católicos ao conhecimento da verdade, à prática do bem e ao respeito das autoridades eclesiásticas.

Nascimento Castro prossegue, mas alfineta o metropolita ao se referir, em momento tão impróprio, às "dificuldades financeiras". Nascimento Castro, a bem da 
verdade, merece um estudo à parte...

Este é o seu programa, dentro do qual saberá travar o bom combate e empenhar-se para cumprir os bem intencionados desejos do nosso bispo que, não obstante suas dificuldades financeiras, procura satisfazer a necessidade da boa imprensa como palpitante em todas as dioceses.

Dando por encerrado o episódio d' 'O Lábaro', Nascimento Castro agora se declara plenamente favorável ao entendimento privado entre os dois prelados, assim como à resolução do problema de Aparecida pelos canais competentes...

Com V. Ex. ${ }^{a}$ quem não estará de acordo ser muito para desejar que as questões discutidas entre V. Ex. ${ }^{\mathrm{a}}$ e o Sr. Bispo de Taubaté, na entrevista realizada em nossa casa no Tremembé, ficassem exclusivamente em segredo entre ambos e que, na mesma intimidade, sejam decididas pelo poder competente?

E como para a habilidade de Nascimento Castro não há acusação que não possa ser desbordada, a responsabilidade pelo vazamento da discussão ocorrida em Tremembé ficou por conta de uma "alteração de voz", ou seja, a culpa deve ser unicamente atribuída a D. Duarte e a D. Epaminondas. No entanto, se Nascimento Castro se refere à intensidade da discussão como "alteração de voz", é de se imaginar a exaltação de ânimos ali ocorrida.

O Vigário Geral, em meio a toda a tensão, ainda encontra momento para fazer pilhéria, menção clara aos gritos da discussão:

Não sei como foram ecoar fora, infelizmente. Posso asseverar a V. Ex. ${ }^{a}$ que o Sr. Bispo guardou a máxima reserva sobre os detalhes que lá se deram, e muito nos surpreendeu quando, no dia seguinte, aqui soubemos que no Tremembé já se comentava o fim da visita, que era a questão da Aparecida, dizendo-se que $\mathrm{V}$. Ex. ${ }^{\mathrm{a}}$ passou pela prova de retemperamento de saúde resistindo com vigor a terríveis rajadas!

Gritos em cidade pequena são sempre desaconselháveis...

V. Ex. ${ }^{a}$ deve convir que a discussão sofreu alteração de voz, e que, em lugar pequeno, nessa circunstância, fácil é aguçar-se a curiosidade, que está sempre à cata de novidades, não perdendo oportunidade para apanhá-las.

D. Duarte, em sua carta, recrimina Monsenhor Nascimento Castro a respeito de convidar padres de sua arquidiocese para exercerem o sacerdócio em Taubaté. Nascimento Castro, de sua parte, afirma não ser exato que tenha havido aliciamento, mas concorda ser verdade ter havido acolhimento aos desejos reiterados de dois ou três padres que manifestaram desejo de pertencer à diocese. 
Afinal, diz Nascimento Castro, ninguém pode negar a um bispo o direito de acolher e, até mesmo, de aceitar a boa vontade de sacerdotes, que desejam incardinar-se à sua diocese, onde podem ser úteis, desde que venham a obter de seu bispo a necessária autorização.

Dito isto, e para não parecer que estava ministrando lições a D. Duarte, Nascimento Castro declara: "V. Ex. ${ }^{a}$ me perdoe dizer algo sobre isto, pois parece ousadia querer ensinar, eu, um humilde sacerdote, o Padre Nosso ao meu Arcebispo!"

Não se dando por satisfeito, Nascimento Castro agora defende D. Epaminondas das acusações que D. Duarte lhe imputou sobre estar instruído por alguém nas questões que desaguaram na crise estudada. Para Nascimento Castro o assunto é de foro íntimo do Bispo. No entanto, seria ingenuidade pensar que um prelado não esteja informado dos assuntos da Igreja em seu país, máxime dos temas que são caros à sua futura diocese. É certo, portanto, que o Vigário Geral de Taubaté estivesse apenas contemporizando, para se dizer o mínimo:

Posso asseverar peremptoriamente a V. Ex. ${ }^{a}$ (para que eu não continue a classificar de ingenuidade) que o Sr. Bispo de Taubaté, repetidamente, declarou que não trouxe instrução de quem quer que seja sobre a sua atitude nos negócios em questão. Antes de vir para a diocese sempre evitou conversar sobre esses assuntos e tomar qualquer informação. Apenas, em ligeira palestra com o Sr. Bispo de Diamantina teve ocasião de verificar na Analecta Pontifícia certas disposições que Ihe eram desconhecidas, atinentes a sua diocese. S. Ex. ${ }^{a}$ age por convicção própria, fundada sobre motivos que lhe parecem justos e que lhe afetam a consciência em face do juramento prestado na defesa dos direitos da diocese, estando incondicionalmente disposto a tranqüilizar-se por completo, desde que se torne líquida a justificabilidade ou não desses motivos pela decisão da Santa Sé em sua alta sabedoria e justiça indefectível. ${ }^{394}$

Em 23 de janeiro de 1910 'A Federação' volta ao ataque contra o arcebispo de São Paulo, em matéria particularmente forte. Acusando D. Duarte de ganância, e de, deliberadamente, prejudicar os interesses da religião católica na própria terra que o viu nascer, o artigo dessa vez afirma que a conservação do statu quo constitui um escândalo permanente. Se, entretanto, os príncipes da Igreja não querem ou não podem reconsiderar o ato, o jornal afirma ser preferível a supressão da diocese de Taubaté, passando à condição de diocese honorifica.

394 ACMSP. Carta de Monsenhor Nascimento Castro a D. Duarte. 5 de fevereiro de 1910. 
Levando a situação para o campo jurídico, o articulista faz ver que, conforme uma das condições da Nação, o seu patrimônio reverteria para a Santa Casa. D. Epaminondas, por sua vez, seria transferido para outra diocese, "onde poderia bem empregar toda a sua inteligência". Ao final, a sentença d'A Federação': "Ou a integridade da diocese de Taubaté ou a sua imediata e completa eliminação; eis o que reclama o bom senso, a razão, a justiça e a religião." 395

Os artigos d'A Federação' atribuídos como de autoria de Monsenhor Miguel Martins, certamente irritavam e ofendiam D. Duarte. Cumpria, pois, não só procurar confirmar o envolvimento de Miguel Martins, mas, também, o de D. Epaminondas, posto em total silêncio e, quem sabe, em sossego, em sua residência episcopal.

Quem não estava posto em sossego era o arcebispo, que em carta de 27 de janeiro de 1910 realizava diligências junto a D. Nery, bispo de Campinas:

[...] Caso não haja repugnância ou qualquer inconveniente da parte de V. Ex. a, rogo-lhe o obséquio de responder-me, ao pé desta, se é verdade que Monsenhor Miguel Martins afirmou a V. Ex. ${ }^{a}$ que os artigos a propósito da Basílica em Aparecida, estão sendo publicados no jornal 'A Federação', com anuência do Sr. Bispo de Taubaté. Autorizando-me a fazer da sua resposta o uso que me convier, queira V. Ex. ${ }^{a}$ aceitar os agradecimentos do Servo e amigo in J.C. + Quando V. Ex. ${ }^{a}$ vier a S. Paulo, the relatarei toda a questão por miúdo. Um horror ! + Duarte $^{396}$

A correspondência com D. Arcoverde demonstra o total conhecimento do cardeal em relação ao que se passava na arquidiocese paulistana, e em carta de 27 de janeiro de 1910 D. Duarte, que se refere à questão de Aparecida como "o caso irritante de Taubaté", afirma que o que se quer não é o incremento da nova Diocese, o bem das almas, a gloria de Taubaté ou mesmo a Basílica, mas tão somente o desdouro do Arcebispo, "custe o que custar".

Na missiva, o metropolita diz que a situação foi criada para a satisfação de uma vaidade tola, que foi despertada em momento de irreflexão. Segundo o decorrer dos acontecimentos, batia-se no ponto de que Miguel Martins alimentava o desejo de ser bispo, uma vez que havia disponibilizado boa parte de sua fortuna para a formação da diocese taubateana:

Suprimir uma Diocese ... porque Miguel Martins não é o Bispo? porque os seus disparates não encontram eco nos espíritos sensatos? 
D. Epaminondas é tido como pusilânime e Miguel Martins, como maluco. O caráter público que a crise assumiu é, mais uma vez, frisado por D. Duarte:

porque não há quem tenha força moral para chamá-lo à ordem? Por que o Bispo, enfim, sugestionado por aquele maluco, deixa que o escândalo mude para a rua ? Isto não se concebe.

D. Duarte demonstra ter certeza sobre o envolvimento direto do bispo de Taubaté. Nesse caso, teria Monsenhor Miguel Martins cometido tão ingênua inconfidência?

E todavia .... sei com certeza que Monsenhor Miguel Martins afirmou em Campinas, ao Sr. D. Nery, e em presença do Dr. João Ribas, que m'o referiu, que os artigos da Federação são publicados com anuência do Sr. Bispo! Aí está, se realizando, portanto, o que eu predisse: o Sr. Bispo queimando-se na fogueira que deixou atear, o Miguel Martins comprometendo imprudentemente ao seu próprio Prelado.

D. Duarte, pelo visto, aguarda melhor momento para o golpe final:

Não escrevi ainda ao Sr. Núncio, porque os fatos se vão acumulando, e convém enfeixá-los todos para um golpe único e certeiro. ${ }^{397}$ (os grifos são nossos)

Antes, porém, do golpe único e certeiro, D. Duarte também aprontava das suas, e isso com a orientação e o consentimento de D. Arcoverde, tendo em vista que os conselhos do Cardeal o faziam ir "resistindo assim, com a graça de Deus, á tentação! ".

Parece, no entanto, que o bom arcebispo, infelizmente, caiu em tentação, e tal assertiva se confirma na carta de 24 de janeiro, em que D. Duarte, apesar de haver prometido a si próprio e a Jesus Cristo guardar silêncio, ou só falar quando absolutamente necessário, solicita o parecer do Cardeal sobre a conveniência de uma carta que seria publicada sobre o nome de seu secretário.

A carta a ser publicada, segundo as próprias palavras do metropolita, "é manhosa, oculta o veneno". É certo, também, que D. Duarte estava ansioso pela anuência de seu aliado, pois "se V. Em. a julgar que nada devo responder, publicar ou escrever, fá-lo-ei como um sacrifício para glória de Deus”... ${ }^{398}$

A publicação determinada por D. Duarte atiçou o articulista d' 'A Federação'. E se o articulista conhecesse a correspondência de D. Duarte talvez não tivesse

397 ACMSP. Carta de D. Duarte a D. Arcoverde.

398 ACMSP. Carta de D. Duarte a D. Arcoverde. 24 de janeiro de 1910. 
realizado análise tão precisa da origem da fonte...

Afirmando que fazia aquilo a contragosto, e forçado por dever de ofício a dar uma satisfação ao público que o lia, via-se na circunstância de "dar algumas penadas" em resposta ao ato do Arcebispo Metropolitano pelas cartas de agradecimento que o mesmo escreve a uns tantos jornais que exploram a ingenuidade do público, que:

[...] defendendo os seus atos vergonhosos, cartas essas assinadas pelo inconsciente Padre Péricles, seu ex-secretário particular. A posição do tal ex-secretário particular é simplesmente crítica e merece toda compaixão. É o seu superior hierárquico que o manda, e ele, inconsciente, faz, julgando que pratica um ato louvável.

Visto isso, agora é o Padre Péricles que leva a sua parte no desaforo, sendo denominado de chaleirista de um metropolitano astuto... :

É que nem todos os Péricles são Péricles. Este Péricles, exsecretário deve ter um grande consolo: é, quando muito, uma antítese do grande Péricles ateniense: este, muito inteligente, se notabilizou pela sua eloqüência e liberalidade, e aquele, o ex-secretário, se popularizou, não pela sua inteligência, que não a tem, e sim pela sua vergonhosa posição de chaleirista e testa de ferro, que o reduziu o seu patrão, o astuto Arcebispo Metropolitano.

Decerto que a publicação afirmava ser 'A Federação' merecedora de perdão, pois o articulista escreveu que quem merece perdão não era ele, mas sim o infeliz ex-secretário chaleirista, que assina o que não escreve só para ser agradável ao seu superior. ${ }^{399}$

A diocese de Campinas, em defesa de D. Duarte, publica em seu órgão oficial, 'O Mensageiro', artigo denominado "Estão errados”, atacando as publicações constantes d'A Federação'. D. Duarte, em carta datada de 5 de fevereiro de 1910, agradece ao padre redator, ressaltando que o mesmo "cumpriu um dever de sacerdote exemplar e disciplinador." 400

'A Federação', por sua vez, não ficou para trás e respondeu à provocação d'O Mensageiro'. Com o título “Estamos certos”, e denominando ‘O Mensageiro' de "róseo periódico", afirma ter lido a defesa e, "palavra, que não vimos um só desmentido às nossas afirmações; é uma defesa por honra da firma".

$\mathrm{O}$ articulista afirma que $\mathrm{O}$ Mensageiro, em período cheio de cólera, verbera 
os termos empregados pela 'A Federação' na questão da Basílica da Aparecida, e lamenta, profundamente, há mais tempo não ter tido ciência da atitude desrespeitosa, afim de lavrar o seu protesto veemente em desagravo a "veneranda autoridade do nosso Metropolitano".

'A Federação' parece ter gostado do embate, e transmite ao órgão campineiro que também muito lamentava não ter achado, até o presente, um colega com "esse gênio"; mas agora está mais satisfeita porque encontrou aquilo que Ihe parecia difícil. Lembrando ao colega de imprensa que ainda é tempo para lavrar o seu protesto, "pois é preferível tarde do que nunca: todo tempo é tempo", 'A Federação’ diz aceitar qualquer embate.

O artigo vai adiante, e 'A Federação' mostra que 'O Mensageiro', se não quer discutir a anexação da Basílica da Aparecida à diocese de Taubaté, pois a taxa de "absurda", e porque não compete a ele, aos sacerdotes ou aos católicos tratar de semelhante questões, no entanto se propõe, com autoridade que 'A Federação' desconhece, a enumerar as razões que levaram a Santa Sé a conservar a Basílica dependente da Arquidiocese.

A matéria se encerra afirmando que os taubateanos não são católicos hipócritas, como o colega julga, e nem afivelam no rosto a máscara negra do fingimento. Mas não é por serem católicos que devem ficar calados ante essas questões e precisam pugnar pelos direitos da Igreja de Taubaté, que estão sendo conspurcados

por um prelado, por um príncipe da Igreja, que para a sua ostentação e desmedido orgulho, não trepida mesmo em deixar na maior das misérias esta pobre e pequenina terra, que the servia de berço. O bom católico não é impatriota. O colega empunhe a pena e venha, com argumentos sólidos, nos rebater. Tem a palavra "O Mensageiro", órgão das associações católicas de Campinas, para provar que estamos errados. Enquanto isso não se der, diremos: Estamos certos! ${ }^{401}$

Declarando que 'A Federação', em seu número de 6 do corrente, responde ao editorial Estão errados, com algumas palavras chochas, subordinadas à epígrafe - Estamos certos, em sua réplica 'O Mensageiro' afirma que o colega d'A Federação' não os entendeu, "apesar de haverem falado com clareza e simplicidade."

O jornal de Campinas segue, e faz constar que não se propôs defender o

401 ACMSP. A Federação. Recorte. 6 de fevereiro de 1910. 
Arcebispo de S. Paulo, pois o mesmo não precisa de defesa, e apenas protestaram contra a ingerência de católicos em questões que pertencem à alçada dos superiores eclesiásticos, assim como protestaram contra a atitude desrespeitosa em relação à pessoa do Arcebispo. A alusão ao despreparo do articulista d'A Federação' é clara:

Um católico, por menos preparado que fosse, facilmente nos compreenderia, como havia de compreender também que é um absurdo dizer-se católico fervoroso, sincero e convicto e escrever contra um Príncipe da Igreja o que temos lido, estupefatos, na Federação.

Em prosseguimento, 'O Mensageiro' afirma que o colega d'A Federação', insistindo nessa atitude, e por outro lado alegando que o faz como católico e em nome dos interesses da Santa Igreja, manifesta uma tal ignorância dos deveres rudimentares do católico e da organização da Igreja que, com franqueza e sem orgulho, nem a cortesia, nem a caridade os obrigaria ao extremo de terçar armas com antagonista de tal quilate. E dito isso, começa a fugir da luta:

Por isso, desculpe o colega, mesmo quando a matéria comportasse qualquer discussão, declinaríamos da súbita honra de levantar a luva que nos atira. Pode continuar com a palavra, tranqüilamente, que não encontrará na imprensa católica quem discuta com incompetentes sobre atos dos superiores da Igreja.

Manifestando o desejo de levantar a máscara da hipocrisia de "tão originais católicos" e de prevenir os incautos "contra esse espírito absolutamente anti-cristão que se vai manifestando na Igreja Brasileira", o jornal de Campinas faz uma alusão velada a Monsenhor Martins:

Não tardará muito para o colega, à semelhança de outro que nesta diocese enveredou pelo mesmo terreno, dar uma prova patente do espírito que o anima nessa campanha odiosa, indigna e merecedora da reprovação de todos os verdadeiros católicos.

Finalizando, 'O Mensageiro' permite que 'A Federação' o insulte, visto que "é sempre esse o epílogo de todas as polêmicas, por parte dos que se sentem pobres de razões. Nós é que absolutamente não voltaremos ao assunto." 402

Da discussão não poderia se isentar "A Lanterna", folha anticlerical e anarquista, sob a direção de Edgar Leuenroth. A notícia assim se inicia:

Extraímos do Diário Popular, de 20 do corrente, as três

402 ACMSP. O Mensageiro. Recorte. s.d. 
seguintes notas que obedecem, naturalmente, à mesma inspiração ... episcopal. Diz a primeira: PRELADO EM VIAGEM Uma carta do Rio noticia que provavelmente em março ou abril empreenderá uma visita a Roma o Rev. ${ }^{\text {mo }}$ D. Epaminondas, prelado da diocese de Taubaté. Diz essa missiva que na sua viagem S. Rev. ${ }^{\text {ma }}$, além de ir render suas homenagens ao pontífice, vai também pedir a entrega do Santuário de Nossa Senhora da Aparecida à diocese que administra. Parece que as condições em que se encontra este bispado determinam a viagem a Roma do seu prelado.

Feita a citação, 'A Lanterna' observa que, se o pretexto são as homenagens, o motivo real é a Basílica, "que o Sr. D. Duarte Leopoldo quer tirar para si." Isto posto, o articulista afirma que como D. Epaminondas não se acha disposto a perder aquela fonte de rendas, e considerando as vultosas quantias que ali circulam, sugere consulta a qualquer exemplar do jornal 'Santuário de Aparecida', vai à Roma e é mesmo capaz de ir até ao céu "a fim de encontrar quem ponha um paradeiro à ganância de D. Leopoldo".

Supondo que a querela entre os dois prelados seja "capaz de acabar em bordoada," 'A Lanterna' cita uma segunda nota do Diário Popular:

A atitude intransigente de uma alta dignidade eclesiástica brasileira em questão que a sua superioridade impede qualquer discussão, tem causado vivo ressentimento em rodas nas quais dispunha do mais alto apreço e estima.

'A Lanterna' diz que D. Epaminondas alega ser modesto, sóbrio, econômico, sem ostentação nem fausto, mas que de forma alguma larga a Basílica, porque necessita dos cofres para a educação dos sacerdotes pobres, pois é daquele bispado que saem as fornadas de padres para todo o Estado.

O jornal anticlerical, por sua vez, afirma que D. Leopoldo está "intransigente", e por ser ele uma alta dignidade não há discussão possível, o que não impede de ter perdido a estima dos que muito o apreçavam, apresentando então a terceira nota:

E como os bispos não se queixam a bispo resolveu $D$. Epaminondas ir se queixar ao papa. Para tal fim "Dizem que está sendo organizado um confronto dos recursos naturais das dioceses e arquidioceses brasileiras, para ser presente à Santa Sé, afim de demonstrar a opulência de umas e condições difíceis de outras. Esperam os organizadores desse serviço de informações que seja feita uma divisão eqüitativa de rendas para a boa manutenção dos administradores das dioceses.

Após isso, 'A Lanterna' comenta que esses magnatas do clero, ambicionando os maiores confortos da mais regalada vida, afirmam que houve um 
Cristo e que este ensinava a seus apóstolos, de que eles são sucessores, para que não possuíssem ouro, prata e cobre em seus cintos, além de outras citações referentes à pobreza. Encerrando a matéria, 'A Lanterna' previne:

Desarticulai as mandíbulas, ó fiéis; escancarai bem a boca no mais expressivo gesto de pasmo: os vossos pastores daqui a pouco jogarão o soco se o papa não dividir eqüitativamente o bolo. A menos que o Bepi $X$ não resolva guardá-lo todo para si ... ${ }^{403}$

O jornal paulistano e católico ‘Boa Imprensa' também participa da contenda, e lamenta

ver na imprensa anticlerical, quer vespertina quer periódica, a reprodução das mal intencionadas referências do semanário 'A Federação', de Taubaté sobre a Basílica de Aparecida, ofensivas ao nosso estimado Arcebispo Metropolitano, verificando-se desta forma o que já neste lugar fizemos sentir.

Criticada a posição do jornal taubateano, 'Boa Imprensa' chega onde realmente deseja chegar, qual seja, solapar a pessoa de Monsenhor Miguel Martins. O articulista, portanto, além de lamentar o conteúdo dos artigos d'A Federação', lamenta mais ainda ver envolvido no caso um velho e respeitado sacerdote, cheio de serviços, cujas experiências, idade, critério e zelo religioso o deviam forçar a outra posição mais nobre ao seu caráter sacerdotal. A referência a Miguel Martins é, portanto, óbvia.

O artigo avança, garantindo que não é pela imprensa, "buzinando às turbas ávidas de escândalos", que se procura uma suposta justiça, havendo meios mais decentes e mais elevados para que as coisas fiquem nos seus devidos lugares, assim finalizando:

\begin{abstract}
A serem verdadeiras as denúncias, o ilustre sacerdote, a quem nunca regateamos os nossos aplausos, espatifa num momento de irreflexão todo o seu glorioso passado, entristecendo a seus numerosos amigos. Oxalá, que não sejamos constrangidos a voltar a este desastrado e apaixonado negócio. ${ }^{404}$
\end{abstract}

Prestigiada pelos acontecimentos, 'A Federação' se diz incentivada pelas provas espontâneas e eloqüentes que tem recebido diariamente pela atitude por assumida pelo jornal "ante o desenrolar dos gravíssimos fatos que se prendem aos legítimos interesses desta amada Diocese."

Fazendo ver que os incentivos a fortalecem e a animam a prosseguir na rota 
traçada da causa justa que abraçou, o jornal assevera que não é por vaidade, "que não a temos", que registra essas provas a eleva no conceito público. Ressaltando "a alma sempre grande e generosa do povo desta Diocese," declara que o povo se levanta

como uma poderosa coluna em que se apóia S. Ex. ${ }^{a}$ para defender os interesses da Diocese de que é chefe, hoje ferida no seu patrimônio, tão ingratamente vilipendiada por um filho de Taubaté o ilustre arcebispo metropolitano.

Dizendo-se fortalecida por um santo entusiasmo e empunhando a arma potente e invencível da razão, o jornal se bate "com a firmeza de um sagitário" em prol da questão que afeta os interesses desta mimosa Diocese e fere o patriotismo de todos os taubateanos.

É, pois, com esse concurso poderoso e com a calma e prudência que lhe são inatas, que o venerando bispo de Taubaté sairá triunfante, a despeito da pretensão injustificável de $\mathrm{D}$. Duarte, que a de restituir integralmente o que de direito faz parte do patrimônio desta Diocese. ${ }^{405}$

Como sói acontecer, a chamada Questão de Aparecida foi perdendo fôlego junto a imprensa. Simultâneo a isso, deveria também ser dada por encerrada em âmbito interno, conforme decisão apresentada pela Sagrada Congregação Consistorial, órgão da Santa Sé responsável pelos bispos católicos de todo o mundo. Pela importância de seu conteúdo para o estudo e para o posterior entendimento da questão, opta-se pela integral transcrição da missiva de 27 de fevereiro de 1911, sob o protocolo de número 215/11:

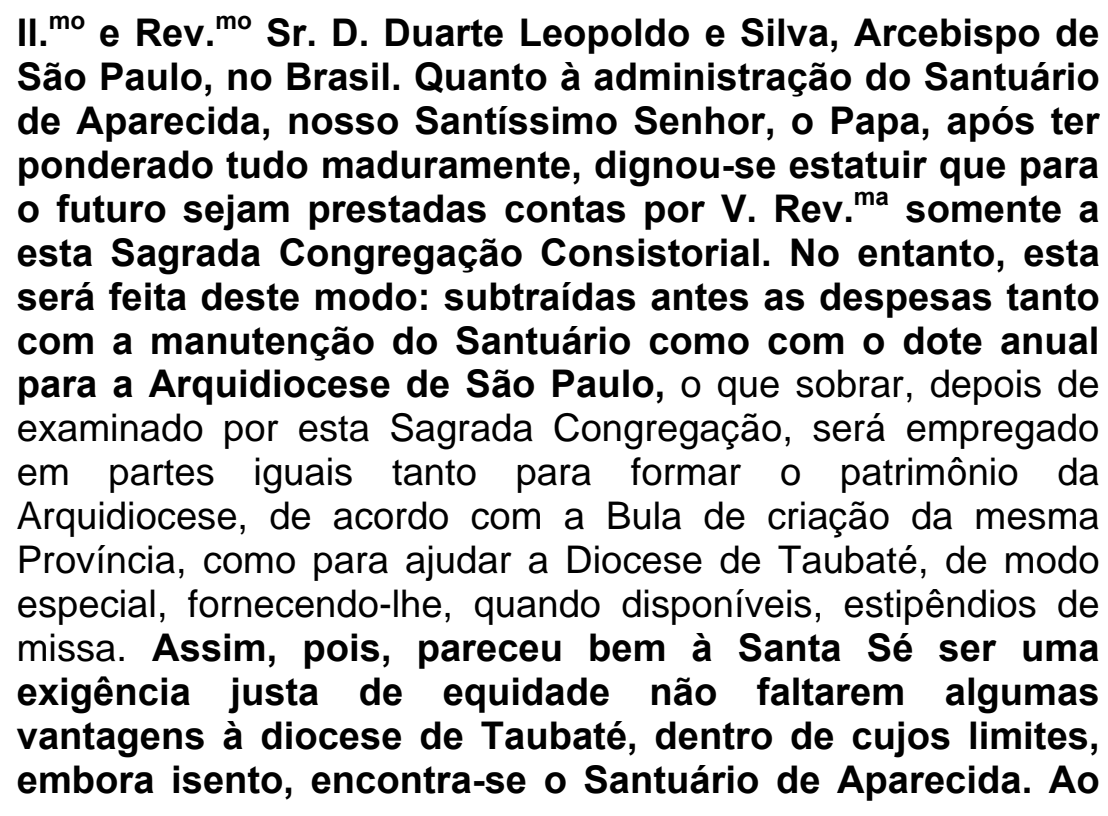

405 ACMSP. A Federação. Recorte. 9 de fevereiro de 1910. 
Ihe comunicar isso, confesso-me de V. Ex. ${ }^{a}$ irmão. C. Cardeal de Lai, Secretário. ${ }^{406}$ (os grifos são nossos)

A carta, porém, não foi enviada diretamente a D. Duarte, tendo sido primeiramente encaminhada, no Brasil, aos cuidados de D. Arcoverde, possivelmente em deferência a um pedido do Cardeal.

D. Duarte, pois, ao recebê-la, apronta-se em agradecer:

[...] Tenho a carta de V. Em. ${ }^{a}$ comunicando-me a solução da Consistorial sobre a administração da Basílica. Graças a N. Senhora chegamos a bom termo, e por tudo seja Deus louvado. A V. Em. ${ }^{a}$ devemos este triunfo que, assegurando a paz da Província, atende certamente a interesses de ordem superior e muito da glória de Deus. Beijo agradecido as sagradas mãos de $\mathrm{V}$. Em. ${ }^{\mathrm{a}}$ como do melhor e mais dedicado amigo desta Arquidiocese...

Anexo à carta, é também certo que uma outra carta tenha seguido. Pela resposta do metropolita a $\mathrm{D}$. Arcoverde verifica-se a solicitação de dinheiro no intuito de auxiliar o Núncio Apostólico. D. Duarte, evidentemente, não se opõe ao pedido do Cardeal, e mesmo se prontifica a enviar mais algum...

[...] Concordo que é preciso apressar a aquisição do palácio da Nunciatura. V. Em. ${ }^{a}$ pode contar com mais cinco contos por parte desta Arquidiocese, podendo requisitá-los quando estiver assentada a compra. Até lá, verei se me é possível contribuir com um pouco mais. ${ }^{407}$

Os agradecimentos de D. Duarte se estendem, também, às autoridades da Sagrada Congregação Consistorial:

[...] É me sumamente grato participar a V. Rev. ${ }^{\text {ma }}$ que recebemos a carta sob o protocolo n. ${ }^{\circ} 215 / 11$ de 27 de fevereiro de 1911, enviada pela Sagrada Congregação Consistorial acerca da administração do Santuário de Aparecida, desta Arquidiocese...

Prosseguindo, o Metropolita ressalta o respeito e a pronta resposta às decisões do Papa Pio X....

...Recebi com grande respeito as determinações do Sumo Pontífice, o Papa Pio X, e mandei-as executar imediatamente, sobretudo quanto aos estipêndios de missa, para ajudar a Diocese de Taubaté,...

...mas não resiste, e lembra da situação jurídica de Aparecida em relação à Taubaté!

406 ACPSR. Correspondência da Província Redentorista de São Paulo - COPRESP-B - Suplemento, v. III (1906-1921). pp. 202-203. Carta da Sagrada Congregação Consistorial para D. Duarte.

407 ACMSP. Carta de D. Duarte a D. Arcoverde. 8 de março de 1911. 
...dentro de cujos limites, embora isento, encontra-se 0 Santuário de Aparecida. ${ }^{408}$

Aparentemente tudo acabou bem. Ledo engano.

Em primeiro lugar por que motivo a Santa Sé não informaria a Nunciatura Apostólica sobre tão importante questão? Em segundo lugar, por que motivo, em nenhum local pesquisado, ou mesmo no próprio jornal 'O Lábaro', nenhuma manifestação de regozijo partiu de D. Epaminondas?

Se o bispo de Taubaté não alcançou seu desiderato por completo, pelo menos parte das rendas de Aparecida deveriam the ser destinadas, o que, considerando estar D. Arcoverde do "outro lado", pode ser tido como grande vitória.

A questão, portanto, prossegue, e em 11 de junho de 1911 já está instalado no Brasil D. José Aversa, novo núncio apostólico. Se leu ou não jornais, ou alguém Ihe fez comentários, a verdade é que D. José Aversa enviou carta de caráter confidencial para D. Epaminondas:

[...] Li num jornal que o Vigário de Guaratinguetá, Monsenhor João Filipo, deu a V. Ex. ${ }^{a}$ Rev. ${ }^{\text {ma }}$, como Bispo de Taubaté, alguns edifícios no valor de 200 contos de réis, para formação do patrimônio da Diocese...

O diplomata, parece, faz jus a sua posição, e utilizando-se de uma notícia que certamente Ihe passaria sem importância, não fossem as circunstâncias, vai ao ponto que deseja, sem no entanto citar o caso de Aparecida. D. Epaminondas, portanto, que soltasse o verbo... :

...Como estou interessado em o patrimônio de sua Diocese, peço a $\mathrm{V}$. Ex. ${ }^{\mathrm{a}}$ queira comunicar-me o que há de verdade em tal notícia. ${ }^{409}$

A cartinha atingiu seu objetivo, e D. Epaminondas enviou-lhe longa missiva, a primeira de uma série. Inicialmente o bispo de Taubaté responde ao Núncio que não é verdade que Monsenhor João Filipo tenha dado para a constituição do patrimônio da diocese os tais prédios. Afirmando que a imprensa, como é normal ocorrer, apanha as notícias no ar e as atira à publicidade com seu verdadeiro sentido alterado, D. Epaminondas informa que, de fato, Monsenhor Filipo possuía em Guaratinguetá um prédio e três pequenas casas. No prédio foi instalado um

408 ACPSR. Correspondência da Província Redentorista de São Paulo - COPRESP-B - Suplemento, v. III (1906-1921). p. 203.

409 ACPSR. Correspondência da Província Redentorista de São Paulo - COPRESP-B - Suplemento, v. III (1906-1921). p. 243. 
colégio sob a direção dos padres salesianos, colégio esse depois fechado.

Com o encerramento das atividades docentes no local, por parte daqueles religiosos, Monsenhor Filipo fez doação do referido colégio à Ordem Franciscana. Receoso, porém, de uma perseguição às Ordens religiosas, preocupação fundada pelos ocorridos particularmente em Portugal, o sacerdote passou escritura pública à Mitra diocesana, documento este anexado por D. Epaminondas à carta, transação essa tendo como personagens jurídicos o Provincial dos Franciscanos, o bispo de Taubaté e monsenhor Filipo. Ao final do tema, D. Epaminondas assim se expressa:

[...] V. Ex. ${ }^{a}$ terá dignado de desculpar-me, é o que sei a respeito de tal notícia espalhada pelos jornais. A Diocese diretamente nada lucrou com a doação, a não ser os ótimos serviços prestados pelos excelentes franciscanos.

Encerradas as considerações acessórias, as quais muito provavelmente D. José Aversa tenha lido na diagonal, o bispo de Taubaté parte o que interessa ao Núncio:

[...] Como V. Ex. ${ }^{\mathrm{a}}$ se mostra bondosamente interessado pelos bens desta diocese e para, aproveitando o ensejo, como um filho a seu pai (pois como tal considero o digno representante do Santo Padre diante dos cordeiros e ovelhas), falar-lhe sobre a situação desta diocese.

Afirmando que o patrimônio se resumia em alguns prédios na cidade de São Paulo, legados por Monsenhor Miguel Martins, ressalta a cláusula imposta pelo doador em receber mensalmente a quantia de 500\$000 de seus aluguéis durante sua vida e a de seus parentes, pertencendo a diocese apenas o remanescente.

Lamentando ter recebido os três prédios praticamente arruinados, viu-se na contingência de repará-los, despendendo com isso mais de trinta contos de réis. A renda líquida, destinada para a Diocese, montava em $800 \$ 000$ mensais, sendo isso "a única fonte de renda desta Diocese, com as quais sustento-me e sustento algumas obras pias."

D. Epaminondas se reporta ao Núncio de sua chegada a Taubaté e, sabedor da pobreza da região e das dificuldades em que se via numa diocese recentemente criada, e na qual tudo tinha que ser feito, procurou entender-se com D. Alexandre Bavona, núncio que antecedeu D. José Aversa, com D. Arcoverde e com D. Duarte, empenhando-se no sentido de obter uma modificação na exclusão de Aparecida, não só por causa das grandes dificuldades de caráter administrativo que tal limitação viria acarretar, como também por motivo da penúria de meios para a fundação e 
manutenção de obras julgadas pelo bispo como de natureza indispensável.

Infelizmente nada consegui, tendo-me dito o Sr. D. Bavona que tendo sido feita por ele a divisão, não poderia alterá-la. O Ex. ${ }^{\text {mo }}$

Sr. Cardeal disse-me que devia entender-me com o Ex. ${ }^{\text {mo }} \mathrm{Sr}$. Arcebispo de São Paulo. Este recusou-se a qualquer combinação neste sentido.

De fato, é de se acreditar, no dizer d'A Lanterna', que é inútil bispos se queixarem a bispos. Nesse caso, a solução foi a de apelar para Nossa Senhora, "para que ela as resolva como melhor lhe parecer, sem dar mais um passo sobre a questão." A incumbência dada a Nossa Senhora não impedia, entretanto, o concurso de D. José Aversa, e assim mais um passo foi dado...

Vendo, porém, a V. Ex. ${ }^{a}$ Rev. ${ }^{\text {ma }}$ se interessar sobre os negócios dessa pobre diocese, animei-me a pedir a $\mathrm{V}$. Ex. ${ }^{\mathrm{a}}$ para, como digno representante do Pai comum dos crentes, examinar bem esta questão e fazer o que a sua consciência lhe inspirar. Não peço que me ouça, mas que procure bem colher todas as informações de sorte que julgue mais seguro e urgente e verá V. Ex. ${ }^{a}$ se o Santo Padre bem informado examinará o estado de coisas atual.

Em continuidade, o Bispo de Taubaté se reporta ao fato de Aparecida ser o centro de convergência de inúmeros devotos, principalmente os da sua própria diocese e os do Sul de Minas, "segundo tenho ouvido sempre dos Rev. mos padres redentoristas".

D. Epaminondas se refere, também, à privilegiada localização do santuário, pois estando o mesmo engastado no coração da diocese, é para ali que aflui quase toda a sua vida e "segundo informações seguras que tenho, a maioria dos batizados, casamentos e missas para lá vão."

Reclamando pelo fato de seu clero não ter missas, D. Epaminondas comenta com D. José Aversa que uma pessoa competente Ihe havia dito que, em Aparecida, anualmente, entravam rendimentos referentes entre 5 e 6 mil missas, alcançando a renda do cofre a cifre de 14:000\$000 por mês.

Isto posto, o bispo diz ser fácil para o Núncio verificar a veracidade de suas informações, afirmando tê-las ouvido de pessoas de toda a fé, estabelecendo a seguinte comparação:

Imagine V. Ex. ${ }^{a}$ que no centro de uma casa qualquer se reservasse um quarto sobre o qual tenha plena administração um terceiro, com a exclusão absoluta da jurisdição do proprietário da casa, e terá uma idéia da situação que se acha em ponto administrativo o Ordinário desta Diocese. 
D. Epaminondas pede a atenção de D. Aversa para uma leitura atenta do documento pontifício que organizou a Província e o Decreto da Nunciatura, passado nos pontos referentes a Aparecida, assim encerrando:

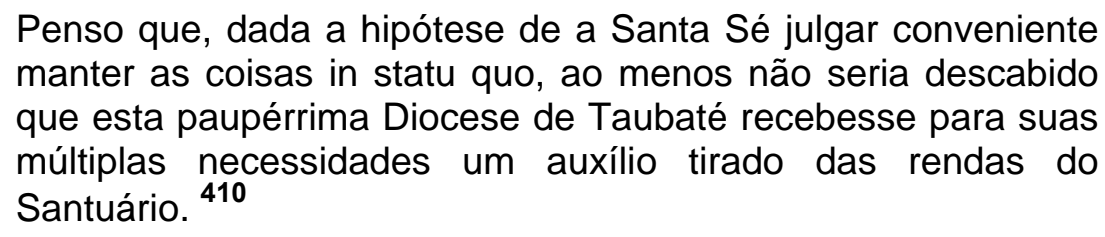

Não tardando em responder, D. José Aversa assevera que, em relação às condições financeiras da diocese de Taubaté e ao sustento do bispo, estudaria os assuntos no devido tempo, e com a necessária calma, uma vez que precisava reunir todos os documentos referentes ao tema.

Solicitando a D. Epaminondas guardar a maior reserva possível e não fazer transpirar nenhuma palavra sobre a questão, o Núncio muda de assunto, perguntando ao bispo sobre a veracidade de uma notícia contida no 'Jornal do Comércio' sobre um certo telegrama, no qual se diz que D. Epaminondas tinha a intenção de oferecer, ao governo do Estado, um edifício em Aparecida, para o fim de abrigar um asilo, faltando apenas a permissão do arcebispo, naquele momento em Roma.

Artimanhas de D. Duarte? Seja como for, o próprio Núncio, já iniciado nos subterrâneos de uma questão onde dinheiro, poder e dominação davam a cor dos tempos, se apressa em amainar eventuais preocupações de seu interlocutor, afirmando que "é possível que também esta notícia seja uma daquelas que os jornais soem publicar com pouco fundamento ou totalmente falsas." 411

$\mathrm{Na}$ carta de resposta D. Epaminondas demonstra-se surpreso, declarando ao Núncio seu completo desconhecimento sobre a notícia. O prelado de Taubaté, fazendo menção aos princípios burocráticos e hierárquicos envolvidos na questão, afirma que, além do seu próprio desconhecimento, não seria possível que ele, sabedor da jurisdição e administração de D. Duarte sob Aparecida, "cometesse tamanho absurdo," justificando o motivo de não the ter chegado ao conhecimento tal fato por razão de não receber o 'Jornal do Comércio', do Rio de Janeiro, nem os jornais de São Paulo, exceto a 'Gazeta do Povo'.

410 ACPSR. Correspondência da Província Redentorista de São Paulo - COPRESP-B - Suplemento, v. III (1906-1921). p. 244-245. Carta de D. Epaminondas a D. José Aversa. 12 de junho de 1912.

411 ACPSR. Correspondência da Província Redentorista de São Paulo - COPRESP-B - Suplemento, v. III (1906-1921). p. 247-248. Carta de D. José Aversa para D. Epaminondas. 16 de junho de 1912. 
Afirmando que D. José Aversa bem conhece as liberdades e o espírito maldoso dos correspondentes dos jornais não católicos, D. Epaminondas termina por declarar que "para destruir semelhante mentira, acabo de publicar na "Folha" desta Diocese um desmentido formal, como verá Vossa Excelência." 412

Tendo chegado ao conhecimento do Ex. ${ }^{\mathrm{mo}}$ e Rev. $^{\text {mo }}$ Sr. Bispo Diocesano, que de São Paulo foi passado um telegrama para o "Jornal do Comércio", do Rio, no qual dizia o remetente que o Ex. ${ }^{\mathrm{mo}}$ Prelado desta Diocese estava em negociação com o governo do Estado, ao qual quis vender um prédio grande existente em Aparecida, o mesmo Ex. ${ }^{\mathrm{mo}}$ Sr. Bispo declara que é absolutamente falsa tal notícia, pois nenhuma jurisdição tem sobre Aparecida, cuja administração foi pelo poder competente da Santa Sé entregue ao Sr. Arcebispo de São Paulo, único competente para realizar qualquer operação no referido sentido. ${ }^{413}$

Encerrada a primeira fase de conhecimento mútuo entre os dois bispos, particularmente, em nosso entender, o período investigativo de D. José Aversa em relação não só aos aspectos gerais do tema, mas também em relação ao posicionamento e ao proceder de D. Epaminondas, acredita-se que o Núncio tenha tido do prelado boa impressão, tomando para si a condução da "Questão de Aparecida" à maneira eclesiástica e diplomática, qual seja, com discrição.

Desejoso, porém, de colher uma segunda opinião sobre o caso, longa carta, classificada como reservada, é escrita por D. José Aversa a ninguém menos que D. Miguel Kruse, Abade do Mosteiro de São Bento, figura de proa da romanização na capital paulista e fundador da Faculdade Livre de Filosofia e Letras de São Paulo, cujo Conselho de Estudos Universitários era formado por sacerdotes e leigos ultramontanos, dentre eles os já citados Monsenhor Francisco de Paula Rodrigues e o Barão Brasílio Machado. ${ }^{414}$ Com a palavra, Wernet:

O Mosteiro de São Bento transformou-se, ao lado do Seminário Episcopal, em núcleo da nova orientação filosófico-teológica da Igreja, ou seja, do neotomismo. Dom Miguel Kruse (18641929), desejando ver a juventude universitária formada nos princípios da fé católica, para que ela fosse mais esclarecida, achou que o meio mais eficiente seria a fundação de uma faculdade católica. Recorreu ao Cardeal Mercier, fundador da Universidade Católica de Louvain (Bélgica), que lhe deu toda a orientação necessária e Ihe enviou um jovem e talentoso professor de Filosofia, o Monsenhor Sentroul (1876-1933), que

412 ACPSR. Correspondência da Província Redentorista de São Paulo - COPRESP-B - Suplemento, v. III (1906-1921). p. 247-248. Carta de D. José Aversa para D. Epaminondas. 16 de junho de 1912. 413 O Lábaro, n. ${ }^{\circ}$ 130, III. 20 de junho de 1912.

414 CASALI, Alípio. Elite intelectual e restauração da Igreja. Petrópolis: Vozes, 1995. pp. 145-146. 
se tornou o primeiro reitor da Faculdade de Filosofia de São Bento, fundada em 1907. ${ }^{415}$

O Núncio declara lhe ter sido comunicado que a diocese de Taubaté se encontra em situação de extrema miséria, sem esperança de sair dela num futuro próximo, se não se tomarem certas providências eficazes.

Informando ao Abade que o Bispo só poderá levar avante a Diocese, enquanto lhe é possível saber, com grande esforço e dificuldade, menciona que os párocos e vigários estariam em semelhante condição, senão pior. A causa desta penúria econômica do Bispo e do clero daquela Diocese, prossegue D. José Aversa, seria a situação anormal do Santuário de Aparecida, cuja administração está fora das atribuições do Bispo de Taubaté.

Foi-me informado que, por motivo da grande devoção para com a Virgem Aparecida, os fiéis deixam suas próprias paróquias para afluir em grande número ao Santuário, onde seriam administrados os sacramentos do batismo e fariam casamentos que pertencem a outras paróquias.

Apresentada a questão, D. José Aversa é claro em seu objetivo, fazendo ver ao Abade que sobre tudo isto, e sobre a situação econômica e financeira da Diocese, necessita de informações precisas e exatas. O sigilo, no entanto, é bastante frisado pelo Núncio:

Dirijo-me, pois, a V. Rev. ${ }^{\text {ma }}$, a fim de que, com prudência e circunspecção e sem deixar transpirar a finalidade, faça uma investigação secreta e me ponha a par com um relatório detalhado sobre o assunto. Os pontos principais sobre os quais chamo a sua atenção particular e que poderão servir-lhe de norma nas investigações são os seguintes:

O Núncio, nesse trecho, se reporta ao que já é sobejamente sabido...

1) Os párocos de Taubaté se queixam de sua condição miserável e afirmam que os seus fieis não só são generosos em levar suas ofertas ao Santuário, como também para lá se dirigem para celebrar o matrimonio e batizar seus filhos...

...referindo-se abaixo ao diploma "Decretum Ne Temere de Sponsalibus et Matrimonio," constante como apêndice da Pastoral Coletiva de 1910, onde se prevê a nulidade de casamentos realizados por padres de outras paróquias que não a dos nubentes sem a referida licença.

...O caso parece improvável não só porque violaria o direito dos

415 WERNET, Augustin. Vida religiosa em São Paulo (1554-1954), In: PORTA, Paula (org.) História da cidade de São Paulo, v. 1: A cidade colonial. São Paulo: Paz e Terra, 2004. p. 225. 
párocos, mas também porque poderia envolver a questão mais grave e delicada, a saber, a invalidade dos matrimônios. É preciso saber como de fato andam as coisas...

Prosseguindo nas informações, julgadas por D. Aversa essenciais ao bom êxito da sindicância a ser conduzida pelo Abade, é no mínimo curioso o fato da Nunciatura ignorar os principais termos da questão! Sabe-se, nesse ponto da exposição sobre o caso, a total interferência de D. Arcoverde no processo tratado em Roma. Teriam sido retirados documentos da Nunciatura que, pelo próprio caráter burocrático da instituição, ali deveriam permanecer?

...2) Depois que D.Epaminondas Nunes d'Ávila tomou posse da Diocese de Taubaté, surgiu uma questão entre ele e o Arcebispo de São Paulo sobre a administração e a propriedade das rendas do Santuário. A questão foi levada a Roma. A Nunciatura não soube nada a respeito da decisão da Santa Sé. No arquivo não se pôde encontrar nada sobre o assunto....

As cartas a D. Epaminondas, somadas ao pedido de busca ao Abade, leva a crer que D. José Aversa andava às cegas. O Núncio, no entanto, não se deixava vencer facilmente, e pelo visto parece ter revirado todos os arquivos de sua Nunciatura, encontrando por fim a já conhecida carta da Sagrada Congregação Consistorial, datada de 27 de fevereiro de 1911!

Em vez disso - e lhe comunico com o mais inviolável segredo unicamente para que Ihe sirva de norma - encontrei a cópia da carta da Sagrada Congregação Consistorial, com data de 27 de fevereiro de 1911, ao Arcebispo de São Paulo [...]

A cópia da Carta, no entanto, não veio de Roma, mas de São Paulo, provavelmente enviada por D. Duarte. A "Questão de Aparecida", portanto, devido ao poder e a influência de D. Arcoverde junto a Santa Sé, subverteu todos os pressupostos funcionais e hierárquicos.

...Parece que o Bispo de Taubaté não sabe nada desta resolução e não é prudente cientificá-lo a respeito, mesmo porque não sei explicar por que razão nada foi comunicado a esta Nunciatura por Roma. A referida cópia procede de São Paulo. Entretanto, é conveniente indagar se o Bispo de Taubaté recebe alguma quantia das rendas do Santuário...

D. José Aversa, representante da Santa Sé no Brasil, sequer estava informado acerca do "Legado Wanderley".

3) Uma outra questão surgiu entre o Bispo de Taubaté e o Arcebispo de São Paulo a respeito dos bens do extinto Colégio de São Miguel que está situado nos limites da Diocese de Taubaté. Uma pequena parte daqueles bens - avaliados em 
cerca de 30 contos de réis - estavam radicados na Diocese de Taubaté, na sua maior parte, porém, na Arquidiocese de São Paulo, e foram avaliados em cerca de 200 ou 300 contos. E foram vendidos, como suponho, por duzentos e cinqüenta contos. O Arcebispo parecia disposto a ceder ao Bispo de Taubaté os bens situados na Arquidiocese. A questão foi parar também em Roma. Não consta para esta Nunciatura se uma decisão; é conveniente perguntar com discrição.

D. José Aversa encerra o pedido ao Abade salientando, além dos três pontos por ele apresentados, que $\mathrm{D}$. Miguel Kruse também cuide de informar-se sobre tudo o mais que possa ter relação com a diocese de Taubaté, recomendandoIhe encontrar tempo disponível para dirigir-se por alguns dias a Aparecida, "onde poderá com facilidade obter informações e enviar-me um relatório completo do assunto." 416

D. José Aversa, parece, não poderia ter escolhido melhor investigador. Datada de $1^{\circ}$ de agosto de 1912, D. Miguel Kruse expõe minuciosamente a situação, conforme solicitado.

Declarando toda a boa vontade em servir D. José Aversa o mais depressa possível, justifica a demora da resposta pelo desejo de dar informação exata e precisa, sem que nada transpirasse.

Para isso, diz o Abade, "devia confiar-me com grande cautela e paciência, a pessoas imparciais e que estão ao corrente das coisas, esperando sempre o momento oportuno para não excitar suspeitas," ressaltando que em sua posição, bastante independente, de abade, deveria tomar o maior cuidado para não aparecer em tais assuntos. A situação propriamente dita se inicia com a exposição da situação econômica geral da região estudada:

[...] Antes de tudo, é preciso lembrar que a parte do Estado de São Paulo que fica entre São Paulo e Rio é a mais pobre; a agricultura, que antigamente florescia nesta região, está muito decaída em conseqüência do esgotamento dos terrenos e da falta de florestas; a imigração de estrangeiros é insignificante e esta vai só às pequenas cidades; assim é que as paróquias da Diocese de Taubaté já são per se mais pobres do que as outras dioceses deste Estado...

Isto posto, D. Miguel Kruse é contundente em sua opinião sobre a criação da diocese de Taubaté. Outrossim, vincula a existência daquele sólio ao Santuário de

416 ACPSR. Correspondência da Província Redentorista de São Paulo - COPRESP-B - Suplemento, v. III (1906-1921). p. 255-257. Carta de D. José Aversa para D. Miguel Kruse, abade do mosteiro de São Bento. 12 de julho de 1912. 
Aparecida. Sua capacidade investigativa, no entanto, é bem melhor que seus dons proféticos...

...Taubaté não devia ser feito Bispado, sobretudo considerando-se a facilidade de comunicação das suas paróquias com São Paulo; contudo, parece-me, ela pode existir especialmente havendo um arranjo satisfatório sobre os rendimentos do Santuário de Aparecida entre o Metropolita e o Bispo de Taubaté. Esta situação atual do Santuário é, certamente, anormal, e sendo artificial, há de desaparecer algum dia.

Defendendo o ponto de vista de que como também em outras dioceses, particularmente da Capital de São Paulo, há bastante romeiros e donativos para aquele Santuário, e como a Sé Metropolitana, segundo as instruções da Santa Sé, devia favorecer a todas as dioceses, "parece justo que a metrópole recebesse uma parte das rendas."

O Abade prossegue, concordando que a diocese de Taubaté tem razão de se queixar da criação de um enclave dentro de seus limites, e do desvio dos rendimentos do Santuário, rendimentos esses que, em grande parte, provêm dos paroquianos da diocese. Baseado no fato de que a maior parte dos batizados realizados em Aparecida são dos paroquianos de Lorena e Guaratinguetá, o beneditino assevera, porém, que os padres de Aparecida, obrigados a enviar aos respectivos párocos a parte das "jura stolae" que Ihes toca, segundo o arancel (tarifa) estabelecido, de fato assim o fazem.

No entanto, isto significa uma perda para o pároco, e esta perda pode ser considerável, pois os ricos e os mais bem situados dão muito mais do que exige a tarifa, fato esse comprovado pelas diversas cartas entre os redentoristas aqui anteriormente apresentadas.

Sobre a possibilidade dos casamentos serem considerados nulos, D. Miguel Kruse despreocupa D. Aversa, informando que nas outras paróquias da diocese, o número de batizados é pouco importante, e o mesmo vale a respeito dos casamentos, os quais sempre são feitos com a aprovação do respectivo pároco, de modo que não há de temer-se a possibilidade de matrimônios inválidos.

Quanto a intenções de missas, D. Miguel declara não ser possível obter dados exatos, mas afirma que as missas oficiais (sit venia verbum), como as de sétimo e trigésimo dias, são sempre ditas nas igrejas paroquiais. No entanto, as missas de devoção são em grande parte levadas a Aparecida. 
Encerrados os principais tópicos sobre Aparecida, D. Miguel Kruse se reporta à questão financeira entre a Arquidiocese e D. Epaminondas, demonstrando que as ordens da Sagrada Congregação Consistorial eram letra morta para D. Duarte e, por extensão, também para D. Arcoverde...

[...] Das rendas de Aparecida o S. Bispo de Taubaté nunca recebeu nada; uma única vez a Arquidiocese lhe enviou 100 missas...

Finalmente D. José Aversa, por meio de um religioso não pertencente aos seus quadros burocráticos regulares, se torna conhecedor da outra questão...

A dificuldade entre o Sr. Arcebispo e o Bispo de Taubaté sobre o legado para a fundação de um colégio foi resolvida em favor do Bispo de Taubaté, o qual está procurando uma congregação de religiosos para tomar conta do instituto, como exige o testador, em Jacareí. Informaram-me que todo o legado foi adjudicado ao bispado de Taubaté.

Já é de nosso conhecimento que D. José Aversa sabia das especificidades da doação de Monsenhor Miguel Martins, conforme documentos anteriormente apresentados. D. Miguel Kruse, no entanto, ignorando o fato, também se reporta ao tema, declarando que, além dos inconvenientes que está sofrendo a diocese de Taubaté, há um outro, "tratando-se de um venerando sacerdote, o qual contribuiu em grade parte para o patrimônio da diocese." A doação do sacerdote, entretanto, longe de ser absoluta:

está ligada a certas cláusulas onerosíssimas. Constando ela um prédio bastante velho, fica a diocese obrigada a custear os consertos e a administração, devendo ainda pagar a pensão considerável ao doador $\mathrm{e}$, depois da morte dele, a certos parentes.

Por último, a implantação de seminários pelos bispos, tida como feito louvável e abordada na grande maioria dos estudos de História eclesiástica do período, é reprovada pelo relator:

Um outro mal que a meu modo de ver, aflige não só a Diocese de Taubaté, mas também a outras do Estado de São Paulo (com exceção de uma ou duas), é o estabelecimento prematuro de seminários independentes. Estas dioceses não tem os meios e muito menos o pessoal suficiente e apto para isso. ${ }^{417}$

Estudado o assunto, passado o tempo, e munido dos documentos tidos

417 ACPSR. Correspondência da Província Redentorista de São Paulo - COPRESP-B - Suplemento, v. III (1906-1921). p. 263-266. Carta de D. Miguel Kruse, abade do mosteiro de São Bento, para D. José Aversa. 1 de agosto de 1912. 
como necessários, no início de 1914 D. José Aversa encaminha carta ao Cardeal De Lai, Secretário da Sagrada Congregação Consistorial. O Núncio declara que Dom Epaminondas acredita que sua diocese tem direito, ao menos por equidade, de receber parte das rendas do Santuário de Aparecida, pedindo-Ihe que trate disso com D. De Lai.

D. Aversa também diz que a questão não é nova, julgando um dever relatar ao Secretário da Cúria os fatos que aconteceram. Informando que o dito Santuário se encontra dentro dos limites da diocese de Taubaté, mas isento da mesma e sujeito à jurisdição do Arcebispo de São Paulo por força da Bula da criação da Província eclesiástica, cita o artigo de seu interesse. Eis, portanto, o artigo, fonte das inúmeras controvérsias até aqui expostas:

Cap. XII: Em vista da importância da igreja Arquiepiscopal de São Paulo, no Brasil, e suas necessidades especiais, sua santidade concedeu, ao Sr. Arcebispo, a faculdade de, por algum tempo, receber as ofertas que são entregues pelos fiéis ao Santuário de Nossa Senhora Aparecida, livres de qualquer condição. Isto, porém, sob a condição que uma certa parte que o executor desse Decreto Consistorial, que abaixo está designado, determinar seja empregada pelo Sr. Arcebispo de São Paulo na manutenção de sua Arquidiocese, sendo o resto, porém, das rendas, empregado na formação de um patrimônio, cuja rendas possam socorrer às necessidades da mesma Igreja metropolitana de São Paulo, conforme norma do mesmo executor.

Entende-se, pois, que as rendas do Santuário de Aparecida, não obstante as livres condições a favor de D. Duarte, mesmo assim estariam subordinadas à fiscalização do executor, no caso em tela D. Alexandre Bavona, antecessor de D. Aversa na Nunciatura.

O interessante, no entanto, vem abaixo, confirmando-se agora, documentalmente, a predisposição dos demais bispos sufragâneos em participar das rendas do cofre.

Entretanto, quando isto acontecer e a Mesa Arquiepiscopal de São Paulo estiver suficientemente provida, as rendas provenientes das ofertas que se fazem ao Santuário de Nossa Senhora Aparecida sejam divididas, conforme determinar a Sé Apostólica, entre as novas dioceses desta Província eclesiástica.

Sabedores que somos das estreitas ligações entre D. Arcoverde e D. Bavona, a trama não só se descomplica, como também se esclarece, com a declaração de D. Aversa. Até mesmo porque, em uma estrutura burocrática, o que 
não está escrito não existe...:

Monsenhor Bavona executou a Bula de criação da Arquidiocese de São Paulo, mas a respeito do Cap. XII da mesma, só cumpriu a parte que atribuía ao Arcebispo de São Paulo à administração do Santuário de Aparecida, esquivandose de determinar o modo com o decreto especial.

Que outra razão faria um Núncio Apostólico, representante direto do papa e dos interesses da Santa Sé, e por conseqüente a maior autoridade eclesiástica no país, esquivar-se, conforme a própria palavra de D. José Aversa, de cumprir o decreto em sua íntegra, senão movido pelo desejo de, procrastinando, dar tempo a D. Arcoverde para reverter a situação?

A conseqüência, já por demais conhecida, é apresentada por D. José Aversa, quando o mesmo afirma que "a entrega do Santuário à jurisdição do Arcebispado de São Paulo levantou protestos e queixas da parte do Bispo, do clero e do povo de Taubaté."

Dando continuidade à missiva, declara o Núncio que D. Bavona expôs ao Cardeal De Lai o estado da questão pelo despacho n. ${ }^{\circ}$ 2936, de 13 de abril de 1911, depois de ter mencionado a campanha movida contra o Arcebispo de São Paulo, e a conveniência do mesmo Arcebispo de prestar contas da administração do Santuário diretamente a Sagrada Congregação Consistorial, em vez de fazê-la aos bispos sufragâneos, enviando também os dados necessários para poder cumprir definitivamente o que faltava do referido Cap. XII.

Destes dados remetidos, D. Aversa afirma ter concluído que o saldo, deduzidas as despesas do Santuário, chegavam a 35 contos anuais e que destes, 30 eram empregados no sustento do Sr. Arcebispo, restando 5 contos para serem capitalizados em favor da formação do patrimônio do Arcebispado.

Nesse quadro, a contabilidade apresentada por D. Bavona é no mínimo desencorajadora para que providências fossem tomadas por parte da Cúria Romana, em benefício de qualquer diocese sufragânea, especialmente Taubaté! Disto pode-se depreender o tempo necessário e o real desejo de se formar o pretendido patrimônio...

Desejoso de bem esclarecer sua exposição, o Núncio procura resumir, detalhadamente, os principais passos do problema:

Resumo: Deduzir as despesas do mesmo Santuário. Uma parte que o executor determinará, servirá para a manutenção anual do Arcebispo e sua Arquidiocese. O restante das rendas servirá 
para formar o patrimônio ou dote da Arquidiocese. Quando o referido patrimônio estiver suficientemente formado, as rendas do Santuário serão divididas entre as dioceses da Província Eclesiástica da maneira determinada pela Santa Sé. O arcebispo de São Paulo é obrigado a prestar contas da administração do Santuário aos bispos sufragâneos.

Após tantos estudos e investigações, D. Aversa ainda se vê falto de documentos que, convenientemente, foram subtraídos da Nunciatura:

No dossiê sobre o assunto faltam muitas cartas. O mais importante seria encontrar a carta da Sagrada Congregação Consistorial ou do Secretário de Estado, na qual se comunicava as faculdades necessárias a Monsenhor Bavona e mediante as quais ele redigiu o decreto.

Vê-se, portanto, que a obrigação de D. Duarte em prestar contas aos bispos sufragâneos desaparece, bem como se desconsidera qualquer ajuda às dioceses antes da formação de um patrimônio cujo prazo de integralização ou quantitativo em dinheiro não é estabelecido!

Após outras exposições abordando pontos já apresentados, D. José Aversa, certamente sabedor das intervenções de D. Arcoverde, assim termina: "São muito estranhas estas decisões e estes decretos se atrapalham mutuamente." 418

Conhecedor da obrigação, por parte da Arquidiocese de São Paulo, em fornecer estipêndios de missa à diocese de Taubaté, mais uma vez D. José Aversa escreve a D. Epaminondas, dessa vez em 9 de fevereiro de 1914, solicitando-lhe que o comunique, reservadamente, se $\mathrm{D}$. Duarte tem observado quanto à subvenção da diocese de Taubaté com as rendas do Santuário, conforme determinada a carta da Sagrada Consagração Consistorial, de 27 de fevereiro de 1911.

Dito isso, afirma ser evidente que, pelo menos agora, não se pode apresentar à Santa Sé o pedido para que ela transfira a administração do Santuário e a jurisdição sobre o mesmo ao Bispo de Taubaté, uma vez que "o direito do arcebispo de São Paulo quanto às condições apresentadas na criação da Província Eclesiástica é indiscutível e prevalece." Retiradas quaisquer ilusões do prelado de Taubaté, mesmo assim D. José Aversa parece disposto em continuar em seu auxílio:

418 ACPSR. Correspondência da Província Redentorista de São Paulo - COPRESP-B - Suplemento, v. III (1906-1921). p. 319-325. Carta De D. José Aversa ao Cardeal De Lai, Secretário da Sagrada Congregação Consistorial. Jan. (?) de 1914. 
Mas se $V$. Ex. $^{a}$ julga que não são suficientes as disposições contidas na referida carta da Sagrada Congregação Consistorial para a Diocese de Taubaté, seria necessário que V. Ex. ${ }^{a}$ fizesse alguma outra proposta concreta, de tal modo que a Santa Sé a pudesse levar em consideração, salvaguardados sempre os direitos líquidos do Arcebispo de São Paulo.

Em tão vantajosa posição, é evidente que D. Duarte não fosse descumprir tão ínfima obrigação junto a Taubaté, afirmando ter recebido com grande respeito as determinações do papa, mandando-as executar imediatamente, sobretudo quanto aos estipêndios de missa para ajudar a diocese de Taubaté. Tendo D. Arcoverde por mestre, D. Duarte não incorreria em tamanha desídia. Mandaria, pois, o que melhor Ihe aprouvesse, demonstrando assim sua obediência à hierarquia, e D. Epaminondas que aguardasse a formação do patrimônio...

No dia 3 do corrente, ainda como secretário da Arquidiocese, tive do Ex. ${ }^{\text {mo }}$ Sr. Arcebispo Metropolitano a honrosa incumbência de remeter ao Ex. ${ }^{\text {mo }} \mathrm{Sr}$. Bispo de Taubaté, por intermédio da Cúria dessa Diocese, 100 intenções de missas, pedindo ao Rev. ${ }^{\text {mo }}$ Padre Secretário o obséquio de comunicarme as instruções do Ex. ${ }^{\text {mo }}$ Sr. Bispo quanto à entrega das respectivas espórtulas, que poderiam ser enviadas pelo correio, ou confiadas à pessoa previamente indicada. Mais tarde, insisti perante essa Cúria por uma resposta, e não obstante o caráter oficial dessa correspondência, não tivemos ainda nenhuma solução...

Mesmo com todas manobras veladas objetivando solapar as intenções de D. Epaminondas, na seqüência da carta D. Duarte, face ao silêncio do bispo de Taubaté, dá-se ao direito de melindrar-se e mesmo de suspender o auxílio...

Esse silêncio não pode deixar de magoar ao Ex. ${ }^{\text {mo }} \mathrm{Sr}$. Arcebispo que, à falta de uma explicação conveniente, se verá obrigado a interpretá-lo como uma recusa formal das intenções confiadas ao Ex. ${ }^{\text {mo }} \mathrm{Sr}$. Bispo, considerando-se, ao mesmo tempo, desobrigado, perante a Sagrada Consistorial, de qualquer encargo a que, neste particular, esteja adstrito. [...] ${ }^{419}$

A resposta a D. José Aversa é datada de 12 de fevereiro de 1914 e encerra, até onde se saiba, a correspondência. Nela, D. Epaminondas afirma nunca ter posto em dúvida o direito de D. Duarte sobre Aparecida, ressalvando que sempre o respeitou, e o respeita, pois conhece que esse direito foi sancionado por Pio $\mathrm{X}$, "embora não fosse ele bem informado das coisas, como sei de fonte seguríssima."

D. Epaminondas, portanto, demonstra que o caso foi trabalhado ao sabor 
das conveniências de D. Duarte e de D. Arcoverde, tendo este último conduzido suas argumentações em favor do metropolita, omitindo a real situação de sua diocese. O bispo de Taubaté, no trecho abaixo, se ressente de um interlocutor isento junto à Cúria romana, fazendo clara a opinião de outros bispos.

Quando pedi a V. Ex. ${ }^{\mathrm{a}}$ a intercessão no caso, foi justamente no sentido de V. Ex. ${ }^{a}$ colher todas as informações possíveis e resumidamente fazer uma exposição fiel de tudo à Santa Sé (que, penso, sendo bem esclarecida sobre o caso e suas conseqüências, possivelmente modificará as coisas). É o que tenho ouvido de distintíssimos prelados que fazem parte do Episcopado Brasileiro e se ouve de todos os lábios.

Enquadrando sua diocese na condição de "paupérrima", o bispo declara ter se visto na necessidade de unir duas ou mais paróquias para que se pudesse, modestamente, manter-se um só vigário. E cita o já conhecido motivo:

Aparecida absorve considerável parte da vida e recursos das freguesias, pois é, na apreciação de pessoas fidedignas e lá residentes desta diocese, que afluem para lá em maior número os fiéis, os batizados, os casamentos, as missas, as esmolas, etc. Poucos são os sacerdotes que nesta diocese têm missas para celebrar, pois a fé dos fiéis é que tudo se faça no Santuário de Aparecida. V. Ex. ${ }^{a}$ compreende que qualquer medida que tomasse iria melindrar ao Ex. ${ }^{\text {mo }} \mathrm{Sr}$. Arcebispo, deixando a Providência resolvê-lo como melhor for.

Quanto à pergunta de D. José Aversa, o bispo confirma que o único documento que recebeu da Santa Sé foi o que enviou ao Núncio, no qual a Sagrada Congregação dizia que o Arcebispo auxiliaria a diocese com intenções de missas.

Todos os meses ele tem enviado a esta secretaria deste Bispado 100(cem) missas de espórtulas de $3 \$ 000$. Nem um só vintém a mais tenho dele recebido até o presente. Estas cem missas as tenho destinado exclusivamente a ajudar-me na educação de alguns meninos pobres, aspirantes ao Seminário. É tudo quanto dele tenho recebido até o dia de hoje.

Retomando o assunto do patrimônio dos bispados no Estado, D. Epaminondas afirma que os jornais exageram, recapitulando, também, as especificidades que envolveram a doação de Monsenhor Miguel Martins. Na falta de dinheiro, entretanto, os padres devem se virar, uma vez que "para realizar algumas obras modestas, tive que lançar nas paróquias uma taxa que é bem clamada pelos párocos."

Sentindo na pele que o sagrado também se subordina à lei da oferta e da procura, a concorrência com Aparecida obrigou o bispo a baixar a taxa das crismas! 
No nosso modesto seminário empreguei o pouco que recebi como esmolas de crismas. Veja V. Ex. ${ }^{a}$ a pobreza dessa diocese. Todos os Srs. Bispos estabeleceram e recebem em todas as paróquias $2 \$ 000$ por ocasião de cada crisma e eu tentei sem consegui-lo, sendo forçado a reduzir a $1 \$ 000$ e com dificuldade.

Prosseguindo em suas reclamações, D. Epaminondas diz que seria impossível manter-se em Taubaté com a decência necessária à sua dignidade, não fosse a vida simples a que estava sempre afeito, e em relação a sua residência, afirma que "o notável escritor francês, Padre Gaffre, que há não muito tempo visitou o Brasil, disse em sua obra "L'Évéques du Brésil": a moradia do bispo de Taubaté não tem pretensão a palácio."

A exposição de motivos prossegue, e o bispo declara que, não há muito tempo, pessoa conhecedora do assunto o informou que o número de missas entradas em Aparecida era mais de 500 mensais, e que as rendas do Santuário regulavam a 14 contos por mês.

[...] Ora, como vê V. Ex. ${ }^{\mathrm{a}}$, é insignificante o auxilio dado pelo Arcebispo a esta diocese. Ainda mesmo que uma arquidiocese riquíssima como é a de São Paulo, não tivesse patrimônio (o que não se dá), já não era bastante o que excede às despesas do Santuário (que não são tão grandes) para que estivesse constituído? E não ordena a Bula da criação que, constituído ele, a renda do Santuário, tiradas as despesas de custeio, fossem divididas entre as outras dioceses?

Acreditando que D. José Aversa ignorasse tal fato, o bispo se reporta ao Núncio sobre a mudança referente a obrigação na prestação de contas aos bispos da Província, conforme constante na Bula original, manifestando-se, por fim, sobre o que entendia como uma ação paliativa que compensasse, conforme suas próprias palavras, os "lucros cessantes":

Assim, respondendo ao que determinava $V$. Ex. ${ }^{a}$ que seria de justiça que uma parte das rendas do Santuário fosse destinada a compensar, ao menos em parte, os lucros cessantes que sofre esta diocese, como atrás expus, julgo que uns 2 contos por mês não seria demais, atendendo-se às necessidades da diocese e ao rendimento mensal de cerca de 14 contos. ${ }^{420}$

A última carta de D. José Aversa, até onde sabemos, foi escrita em 2 de maio de 1914, reportando-se ao Cardeal Suget, novo secretário da Sagrada Congregação Consistorial.

420 ACPSR. Correspondência da Província Redentorista de São Paulo - COPRESP-B - Suplemento, v. III (1906-1921). pp. 329-332. Carta de D. Epaminondas a D. José Aversa. 
A longa introdução não traz novidades, e o Núncio se reporta às condições financeiras da diocese, a proximidade do santuário, e a conseqüente drenagem de ofertas, pois ao seu ver "o Santuário absorve a vida e os recursos da mesma; recursos que se destinam todos a beneficio exclusivo - poder-se-ia dizer - da arquidiocese de São Paulo," apresentando a sugestão de D. Epaminondas sobre a ajuda de 2 contos mensais para a diocese de Taubaté das rendas do Santuário.

[...] Ora, qual é a soma exata das referidas entradas eu não saberia dizê-lo e não me é fácil saber. V. E. ${ }^{\text {ma }}$ poderá melhor do que qualquer outro, porque o Sr. Arcebispo de São Paulo tem a obrigação de anualmente prestar contas a esta Sagrada Consagração Consistorial...

Dando continuidade ao relato, o Núncio faz ver que "em razão das queixas de $D$. Nunes d'Ávila eu fui obrigado a fazer uma investigação da qual lhe comunico o resultado em seguida", principiando pela localização geográfica e pelas condições financeira da região, seguindo, portanto, os levantamentos realizados pelo Abade do mosteiro de São Bento.

Em seguida, não ousa afirmar, como o Abade o fez ver, que considerada a pobreza da região e com a intenção de subtrair o Santuário de Aparecida da jurisdição de Taubaté, a criação daquela diocese tenha sido um erro ou, pelo menos, uma decisão precipitada. No entanto, julga ter sido um erro a nomeação de D. Epaminondas àquela nova diocese.

Uma vez, pois, aceito o fato da jurisdição e da administração do Arcebispo de São Paulo sobre o Santuário de Aparecida era preciso que se nomeasse para a Diocese de Taubaté um bispo amigo e sincero do Arcebispo de São Paulo. Em vez disso escolheu-se o atual bispo que é de Minas Gerais. Ora, é sabido que especialmente, em se tratando de administração, os "Mineiros" e os "Paulistas" não combinam.

O relato de D. Aversa é minucioso e trata da procedência das ofertas, das taxas de batizados e de casamentos que se fazem no Santuário, chegando ao requinte de afirmar que as espórtulas, entre 8 e 9 horas, são de $10 \$ 000$ réis, mas que no período da tarde são ainda maiores.

Também não omite em sua missiva que o patrimônio de Taubaté é constituído quase que exclusivamente de bens doados por Monsenhor Miguel Martins, pormenorizando não só a sua constituição, mas também as cláusulas referentes às rendas em favor do doador e de seus parentes. D. Aversa, portanto, não vê possibilidades imediatas em relação ao engrandecimento da diocese, uma 
vez que "assim se passarão muitos anos até que o patrimônio da Diocese de Taubaté fique completamente livre."

Tendo D. Epaminondas na conta de um prelado muito caridoso e animado das melhores e mais retas intenções, santo, virtuoso e apostólico, exime-o de qualquer acusação por queixar-se visando interesse pessoal, ou por apego ao dinheiro, ressaltando que "isto ninguém pode admitir e, de fato, ninguém admite."

No entanto, ao mencionar o Seminário de Taubaté, faz ver que muitos bispos têm uma espécie de paixão de possuir um Seminário próprio e não pensam nas conseqüências daí advindas, recusando o fato de que poderiam usufruir do Seminário da Arquidiocese.

Também em Taubaté fundou-se prematuramente o Seminário diocesano, que absorve os poucos recursos que a diocese possui e que, não obstante o zelo e o esforço do bispo, não produziu nenhum bom resultado, que eu saiba, seja pela falta de pessoal apto e suficiente, seja pela falta de meios financeiros.

Em relação aos "magros estipêndios" enviados por D. Duarte, o Núncio assevera serem eles os mais baixos que existem no Brasil, e que, fora isso, a Diocese de Taubaté não recebe nenhuma ajuda. Havendo, pois, necessidade de uma ajuste de contas, ninguém melhor que o próprio Secretário, posto que

V. Ex. ${ }^{\text {a Rev. }}{ }^{\text {ma }}$, que tem as contas do Santuário, pode conhecer as entradas e saídas das rendas e poderá julgar se e de que maneira se possam cumprir os desejos de Monsenhor Nunes d'Ávila.

Expostas as razões, D. José Aversa confessa que não deve esconder que Ihe agradaria muito se a pendência fosse resolvida de modo satisfatório, tendo em vista ser ela causa de muitas queixas, dissabores e críticas "que saem dos palácios dos bispos e andam de boca em boca entre os padres e chegam e se propagam entre o povo."

Prestes a finalizar a carta, o Núncio, ao nosso ver, dissolve qualquer laivo de hipocrisia ou formalismo, apontando, em poucas palavras, toda a extensão de uma querela eivada de tramas e conchavos, em benefício de uns e em prejuízo de outros, uma vez que, em obediência a ditames burocráticos que não estabeleceram qualquer prazo, nenhuma ajuda substancial chegaria às dioceses, principalmente a de Taubaté. 
Aparecida. Estas, porém - e por favor, Eminência, faço-o em linguagem clara, não podem ser tratadas com gozação...talvez até daqui a um século não chegará a hora de dividir entre as dioceses as rendas do Santuário. As soluções muito demoradas - é necessário que se diga - tornam-se inúteis.

D. José Aversa, em nosso entender, julgava bem. Não só em afirmar sobre a inutilidade das soluções demoradas, como também que nem um século após as rendas do santuário seriam distribuídas. A "Questão de Aparecida", portanto, pode ser resumida no desabafo íntimo e informal de um príncipe da Igreja para outro:

$\mathrm{Na}$ realidade, para se poder viver e trabalhar, é preciso ir à prática, e ninguém que eu saiba vive de fato com charlatanices. Por isso, no meu modesto modo de ver, seria muito bom definir as coisas para honrar o provérbio popular: é melhor ter um ovo hoje do que a galinha manhã. ${ }^{421}$

Como declarou D. Arcoverde, "daqui a pouco já não se falará mais do negócio". O assunto estiolou-se. Novos temas, novas paixões, novos rumos. A D. Joaquim Arcoverde, lenta mas seguramente, sucederia D. Sebastião Leme da Silveira Cintra (1882-1942) na condução dos negócios e da política da Igreja católica no Brasil.

Nesses novos tempos, em 4 de julho de 1924 surge a diocese de Sorocaba, e em 31 de julho de 1937 a diocese de Lorena, em território anteriormente pertencente a Taubaté. Aparecida tornar-se-ia arquidiocese em 19 de abril de 1958, e Taubaté não teria, por parte da burocracia oficial eclesiástica, qualquer resposta sobre as rendas do Santuário. A resposta viria com D. Epaminondas.

421 ACPSR. Correspondência da Província Redentorista de São Paulo - COPRESP-B - Suplemento, v. III (1906-1921). pp. 347-352. Carta de D. José Aversa ao Cardeal Suget. 


\section{CAPÍTULO IV}

\section{DOM EPAMINONDAS: O BISPO DE SANTA TERESINHA}

\subsection{Epaminondas, primeiro bispo de Taubaté}

A composição ainda resfolegava quando D. Epaminondas desembarcou. Da estação, apinhada de fiéis desde as primeiras horas da manhã, ouvia-se o repicar festivo dos sinos de todas as igrejas, misturando-se às explosões das girândolas de bombas e foguetes que comemoravam a triunfal chegada do primeiro bispo de Taubaté em 21 de novembro de 1909. Iniciava-se, sob o papado de Pio X (4/8/1903 a 20/8/1914), um governo diocesano de quase 26 anos.

Epaminondas Nunes de Ávila e Silva nasceu na cidade do Serro - MG, antiga Vila do Príncipe, em 4 de julho de 1869. Décimo quinto filho, e caçula do segundo casamento do Major Francisco de Ávila e Silva e de Dona Maria Cândida de Ávila e Silva, ficou órfão de pai aos 13 anos.

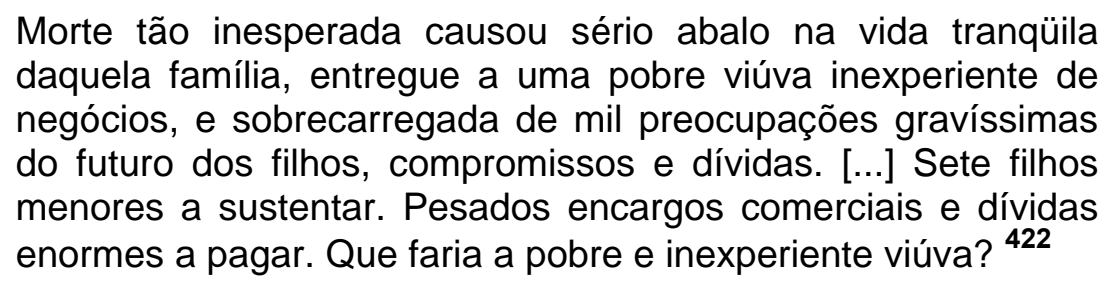

Sérgio Miceli, em seu estudo sobre a elite eclesiástica brasileira, aborda as origens sociais do episcopado na primeira república, dividindo-os em três contingentes: os "prelados da aristocracia imperial", "os filhos da Igreja" e "os bispos do patriciado decadente".

No primeiro grupo incluem-se os sacerdotes oriundos das antigas famílias aristocráticas imperiais, "e o cacife de relações e apoios políticos constituíam características sociais altamente cotadas pela hierarquia da época". ${ }^{423}$ Exemplo marcante nesse enquadramento é o de D. Antônio Xisto Albano, ${ }^{424}$ bispo da diocese de São Luís do Maranhão entre 1901 e 1905, e filho do barão e da baronesa de Aratanha.

O grupo denominado de "filhos da Igreja" é constituído por aqueles que, já de origem humilde, viam-se assombrados por desgraças de cunho social, qual seja,

422 BRANDÃO, Ascânio da Cunha. Dom Epaminondas. São Paulo: Oficinas gráficas da Ave Maria, 1941. p. 23-24.

423 MICELI, Sérgio. A elite eclesiástica brasileira. Rio de Janeiro: Bertrand Brasil, 1988. p. 86.

424 Disponível em <http://www.catholic-hierarchy.org/bishop/bxial.html> Consulta em 22 de julho de 2005. 
a morte dos pais, ou mesmo a perda das condições materiais para a sustentação da família, sendo, por conseguinte, entregues a algum membro do clero, ou ordem religiosa, que por eles se responsabilizavam. Em outras palavras,

deviam seus estudos, roupas, alimentação, títulos, promoções, vantagens e quaisquer possibilidades de êxito profissional, ou melhor, toda sua sobrevivência material e social à proteção e aos subsídios permanentes da organização eclesiástica. ${ }^{425}$

Os bispos do patriciado decadente formam, segundo Miceli, o grupo de maior predominância, provindo dos ramos empobrecidos ou declinantes do patriciado rural, caso típico de D. Epaminondas. Com a liquidação dos bens do Major Francisco de Ávila e Silva, pouco restou à viúva, e em relação aos filhos, "colocou-os todos em oficinas, ourivesarias e escolas. Epaminondas foi alguns meses discípulo de um ourives famoso na região, Belarmino José Pinto". 426

O parentesco próximo com o bispo de Diamantina, D. João Antônio dos Santos, possibilitou à Dona Maria Cândida abatimento na pensão de seus quatro filhos no seminário: Manoel e Aristides, internos antes do falecimento do Major Ávila e Silva, e Alcebíades e Epaminondas, ali chegados em 1882. O único, porém, que persistiu na formação clerical, foi Epaminondas.

Ordenado em 17 de julho de 1892 pelas mãos do próprio D. João Antônio dos Santos, foi nomeado coadjutor do Padre José Maria dos Reis, em Serro. Com a saída desse último, em 21 de agosto de 1896 assumiu o cargo de vigário de sua cidade natal. Sua atuação romanizadora é descrita por Miceli:

O rigor extremado em matéria litúrgica constituiu o traço marcante de sua gestão. Inteiramente identificado com o estilo europeizado de culto, importou paramentos de Paris e Roma, deu atenção especial à conservação das obras de arte, prataria, alfaias, privilegiou a adoração eucarística com exposições solenes do Santíssimo, horas santas, visitas coletivas, repartindo os cuidados de cada um dos altares entre as famílias piedosas e abastadas. ${ }^{427}$

Assim fazia caminhar seu paroquiato o Padre Nondas, como era conhecido, no Serro, o futuro bispo de Taubaté. "Firme como diamante", segundo seu biógrafo, das festas religiosas "conservou-as todas, dando-Ihes um cunho de grande piedade,

425 MICELI, Sérgio. A elite eclesiástica brasileira. Rio de Janeiro: Bertrand Brasil, 1988. pp. 96-97. 426 BRANDÃO, Ascânio da Cunha. Dom Epaminondas. São Paulo: Oficinas gráficas da Ave Maria, 1941. p. 24-25.

427 MICELI, Sérgio. A elite eclesiástica brasileira. Rio de Janeiro: Bertrand Brasil, 1988. p. 95. 
e delas afastando o profano", ${ }^{428}$ recebendo como primeiro reconhecimento de suas iniciativas romanizadoras o título de cônego honorário da sé diamantina. Em 29 de abril de 1909, por fim, foi indicado bispo, tendo ocorrido sua sagração em 8 de setembro do mesmo ano.

Sua única Carta Pastoral lida em Taubaté como já se sabe, ainda na ausência do mesmo, é um documento que alcança próximo de quarenta páginas. Apontando profunda erudição em História Geral, amplo uso de expressões em latim, e perfeita sintonia com os problemas que enfrentava a Igreja católica em sua época, o documento manifesta a sólida formação cultural do bispo e a rígida preparação moral e espiritual por ele obtida no Seminário de Diamantina.

Apreciava os clássicos: Vieira, Bernardes, e a antiga literatura portuguesa clássica tinham nele um apaixonado leitor. Não perdia hora vaga dos estudos em dias feriados. Aproveitava-as nas leituras dos seus clássicos. E notava-se de fato, no seu estilo simples, algo de um sabor clássico e uma correção de linguagem, hoje muito rara. ${ }^{429}$

Recebia catálogos das principais livrarias francesas e mal saía do prelo uma novidade em ascética, história, teologia, patrística, já a recebia logo o humilde Vigário do interior de Minas. Assinava ótimas revistas eclesiásticas, literárias e de cultura. ${ }^{430}$

O documento, obviamente, não contém especificidades da vida religiosa e social no âmbito da diocese de Taubaté, visto que D. Epaminondas exerceu seu múnus sacerdotal unicamente em Serro.

Nem por isso, contudo, a Pastoral se furta a apontar as preocupações desse primeiro governante da diocese, preocupações essas que se podem ter na conta de seu programa pastoral e administrativo, ao longo de seu período no sólio taubateano.

Ciente dos percalços por que passa a Igreja, percalços esses advindos da modernidade, D. Epaminondas assim os sintetiza:

Não se nos faz precisa mui atenta observação para afirmarmos, distintos colaboradores e filhos diletos, que a Igreja de Deus atravessa, na hora presente, uma das fases mais aflitivas e angustiosas de sua heróica vida de combates e de

428 BRANDÃO, Ascânio da Cunha. Dom Epaminondas. São Paulo: Oficinas gráficas da Ave Maria, 1941. p. 57.

429 BRANDÃO, Ascânio da Cunha. Dom Epaminondas. São Paulo: Oficinas gráficas da Ave Maria, 1941. p. 39.

430 BRANDÃO, Ascânio da Cunha. Dom Epaminondas. São Paulo: Oficinas gráficas da Ave Maria, 1941. p. 151. 
sofrimentos e que a desventurada humanidade, que ela tem por missão única beneficiar e felicitar, sofre, igualmente neste momento doloroso, uma crise agudíssima e universal, como poucas terá que registrar a história. Dir-se-ia uma anarquia geral nas inteligências e nos corações.

Na compreensão do Bispo, uma "universal conjuração" se processa contra a Igreja, e, mesmo sem apontar nomes, pode-se entender que aquilo que D. Epaminondas denomina de "funesto paganismo" engloba, certamente, o espiritismo e a maçonaria.

[...] combinados em um plano terrível de universal conjuração contra a Divina Esposa de Jesus, trabalham pertinazmente para reduzir os indivíduos, a família e os povos ao abismo insondável do mais grosseiro e funesto paganismo, tendo já, infelizmente, conseguido levar a efeito uma grande parte de sua obra de demolição e de descristianização, cujo termo final e almejado é o mais pernicioso e brutal anarquismo.

As principais questões da época não escapam à pena de D. Epaminondas, e o ensino leigo é assim tratado:

[...] a escola, em épocas felizes, um abençoado prolongamento do lar cristão, em nossos dias convertida unicamente em perigoso instrumento de ilustração da inteligência, com inteiro esquecimento da formação do coração pelos princípios da moral cristã, única eficaz para a educação da infância e capaz de afastar do abismo insondável a que vai ter a ciência sem a fé.

Especial atenção é dada à imprensa, e em breve tempo todos os esforços do primeiro bispo de Taubaté irão convergir para a fundação de um jornal por ele dirigido: "'O Lábaro'”.

E que vos diremos dos males incalculáveis, das desgraças imensas causadas pela imprensa, dantes formosa e utilíssima instituição nascida à sombra benéfica da Igreja e por ela abençoada em seu berço, hoje convertida em a mais formidável máquina de guerra contra sua moral santa, seu dogma sagrado, sua instituições divinas? [...] Ora, que fazermos, veneráveis irmãos e filhos diletíssimos, em situação tão contristadora e ameaçada? [...] Outro meio não vemos mais eficaz para a manutenção do equilíbrio moral do mundo, senão a proteção à boa imprensa e sua larga difusão; bem como uma guerra sem tréguas à imprensa perniciosa e anticristã. ${ }^{431}$

Anexo à Carta Pastoral, o "Mandamento" de D. Epaminondas. Nele, as primeiras ações de autoridade sob o clero, configuradas na determinação da coleta favor das necessidades do bispo, e da certidão de cumprimento de sua ordem:

431 ACDT. Carta Pastoral de D. Epaminondas, saudando seus diocesanos. $1^{\circ}$ de novembro de 1909. 
Mandamento - No intuito de atrair as bênçãos sobre o nosso episcopado, julgamos conveniente fazer as seguintes determinações: $1^{\circ}$ Os Rev. ${ }^{\text {mos }}$ Sacerdotes do clero secular darão na Missa, durante trinta dias, a coleta - Pro Episcopo observadas as prescrições litúrgicas; [...] $3^{\circ}$ Essa nossa Carta Pastoral será lida, à estação da Missa, em nossa Igreja Catedral e em todas as Matrizes, Capelas, Oratórios públicos e de Comunidades religiosas. Os Rev. ${ }^{\text {mos }}$ Párocos, Curas e Capelães a registrarão no competente livro do Tombo da Paróquia, mandando-nos uma certidão de haverem cumprido quanto nela se acha determinado. Serro, $1^{\circ}$ de novembro de 1909.

A diocese de Taubaté, desde sua criação, se encontrava sob o signo da burocracia romanizada. A Circular e o Aviso n. ${ }^{\circ}$, abaixo transcritos, e exarados ao tempo em que Monsenhor Antônio Nascimento Castro exerceu a função de governador do bispado, demonstram o caráter disciplinador das atividades administrativas.

De ordem do Ex. ${ }^{\text {mo }}$ Monsenhor Antônio Nascimento Castro, Governador da Diocese de Taubaté por S. Ex. ${ }^{a}$ Rev. $^{\text {ma }}$ o Sr. Arcebispo Metropolitano de São Paulo, faço ciente a V. Rev. ${ }^{\text {ma }}$ que, de hoje em diante, todos os negócios eclesiásticos das paróquias pertencentes a esta Diocese deverão ser tratados na Cúria Episcopal desta cidade de Taubaté, sede diocesana, podendo V. Rev. ${ }^{\text {ma }}$ dirigir-se ao Ex. ${ }^{\mathrm{mo}}$ Governador Diocesano, ou a mim, como Secretário do Bispado. Taubaté, 10 de novembro de 1908. ${ }^{432}$

De ordem do Ex. ${ }^{\text {mo }}$ Governador da Diocese, fará o favor de informar a esta Secretaria Eclesiástica, se essa Matriz tem Fabriqueiro e Sacristão, quais os seus nomes, se tem provisão e qual a data da mesma. Padre José Alves de Moura, Secretário do Bispado. ${ }^{433}$

Com a chegada do primeiro bispo, o processo não sofreu solução de continuidade. Ao contrário, às Circulares e aos Avisos seguiram-se os Editais e, em curto espaço de tempo, todas os procedimentos do clero e dos fiéis seriam acompanhados e regulados por D. Epaminondas.

Assim, e "até que se ordene o contrário", devia o clero introduzir determinada oração na missa, ${ }^{434}$ informava-se os dias de jejum e de abstinência,

432 ACDT. Circular n. ${ }^{\circ} 1$ do Monsenhor Governador do Bispado, avisando que os negócios eclesiásticos das paróquias da diocese devem ser tratados na Cúria própria do Bispado. 10 de novembro de 1908.

433 ACDT. Aviso do Monsenhor Governador, pedindo informações sobre Fabriqueiros e Sacristãos. 5 de maio de 1909.

434 ACDT. Aviso n. ${ }^{\circ} 3.1$ de janeiro de 1910. 
e buscando não só a padronização de procedimentos, mas também refrear qualquer tentativa de originalidade por parte dos padres no decorrer das missas, alertava-se sobre a necessidade de um único missal: "Na Secretaria deste Bispado acha-se à disposição do Rev. ${ }^{\text {mo }}$ Clero Diocesano o novo 'Ordo Missae', do qual devem munir-se quanto antes todos os Rev. ${ }^{\text {mos }}$ Srs. Sacerdotes Diocesanos". 436

A permanência de padres estrangeiros, regulares ou seculares, no Brasil, por vezes de modo irregular, e mesmo o exercício do sacerdócio por padres suspenso de ordens, foi o que motivou a existência do Aviso n. ${ }^{0}$ 6. Cumpria, pois, um exato controle sobre a condição jurídica dos sacerdotes na diocese, seus títulos e faculdades:

De ordem do Ex. ${ }^{\text {mo }}$ Sr. Bispo Diocesano, reitero a todos os Rev. ${ }^{\text {mos }}$ Sacerdotes Seculares e Regulares o aviso já dado de apresentarem sem demora suas provisões e demais faculdades de que gozam para serem visadas por S. Ex. ${ }^{a}$ Rev. ${ }^{\text {ma }}{ }^{437}$

A adaptação do novo prelado à cidade, à sua condição de autoridade eclesiástica máxima, e ao clero que o assistia, parece ter sido curta; já pelo início de 1910, D. Epaminondas alterava a configuração paroquial de Guaratinguetá, ao criar a paróquia de Roseira, entregando-a aos cuidados dos redentoristas. O pároco da cidade, parece, não aprovou, e os redentoristas, buscando evitar confrontos, puseram-se em expectativa:

22 de janeiro de 1910. Um padre veio hoje de Taubaté trazendo o decreto da nova paróquia de roseira; daqui foi a Guaratinguetá para comunicar lá o factum. Lá isso causou muita irritação, o que aborreceu muito o padre; contou isso em Aparecida. Aqui não se quis aceitar o decreto nessas condições, regressando assim o padre para Taubaté, sem a solução do caso...

As providências de D. Epaminondas não tardaram...

Mas, no outro dia veio um telegrama do bispo, convidando o visitador para uma visita. O bispo declarou que não the importam as conversas dessa gente; que se aceite a paróquia e marcou o dia 25 de janeiro para a instalação do novo vigário, Padre Reitor. ${ }^{438}$

...e a paróquia, sem maiores delongas, passou para a mão dos 
redentoristas, com eles permanecendo até 31 de dezembro de 1930:

25 de janeiro de 1910. Solene tomada de posse do novo vigário de Roseira. O Vigário Geral fez uma bela alocução. ${ }^{439}$

Contornado o incidente, em breve espaço de tempo passou à ação, mostrando ao que se propunha. Assim, em menos de dois meses após sua chegada, D. Epaminondas atinge seu primeiro objetivo: a fundação do jornal 'O Lábaro'.

De ordem do Ex. ${ }^{\text {mo }}$ Sr. Bispo Diocesano faço saber a todos os ilustres membros do Rev. ${ }^{\text {mo }}$ clero secular e regular deste bispado que fica criado nesta data, na sede do bispado de Taubaté, um jornal puramente católico, denominado "O Lábaro", que será doravante o órgão oficial desta diocese, devendo no mesmo serem publicados o expediente e os atos do governo diocesano, e sendo obrigatória para todos os sacerdotes desta diocese a assinatura do mesmo. S. Ex. ${ }^{\text {a }}$ Rev. ${ }^{\text {ma }}$ pede, insistentemente, e espera, a bondosa cooperação de todos os Rev. ${ }^{\text {mos }}$ Sacerdotes, corporações religiosas e fiéis no sentido de obterem o maior numero possível de assinaturas do órgão diocesano, para que se possa manter e realizar o seu nobre ideal. Taubaté, 1 de janeiro de $1910 .{ }^{440}$

Tendo o formato inicial de $37 \times 27 \mathrm{~cm}, 4$ colunas e 4 páginas, seu primeiro número é datado de 9 de janeiro de 1910, sem indicação do nome dos diretores.

Publicado primeiramente aos domingos, dois meses depois passou a sair às quintas-feiras, e "embora a ausência daquela indicação, sabe-se que Mons. Antônio Nascimento Castro foi seu redator-chefe desde o primeiro número, até 1942, ano do seu falecimento." ${ }^{441}$

Seria praticamente impossível, em virtude das limitações da presente tese, um aprofundamento dos assuntos abordados no jornal de D. Epaminondas. Das leituras efetuadas nas centenas de exemplares disponíveis, verifica-se, no entanto, que nenhum assunto caro ao catolicismo ultramontano escapava à pena do próprio bispo, ou à sua orientação: divórcio, suicídio, neutralidade escolar, questão operária, indiferença religiosa, entre dezenas de outros temas. O anticlericalismo, o espiritismo, e a maçonaria, no entanto, eram os assuntos mais privilegiados para o ataque:

Que o digam protestantes, os maçons, anticlericais e laicistas do seu tempo! As colunas do "O Lábaro" eram colunas de fogo,

439 ACPSR. Crônica da Comunidade Redentorista de Aparecida, v. II (1908-1922). p. 65. 440 ACDT. Aviso n. ${ }^{\circ} 4.1$ de janeiro de 1910.

441 MELLO JÚNIOR, Antônio. Imprensa Taubateana: contribuição à sua história (1861-1981). Taubaté: Empresa gráfica Editora Taubaté Ltda., 1983. p. 164. 
com a pena de fogo de D. Epaminondas. ${ }^{442}$

As atividades de cunho disciplinador e burocrático, em moldes inteiramente romanizados, buscavam abranger todos os rincões da diocese. Tendo 'O Lábaro' como seu principal instrumento de comunicação, as notícias sobre os bons e os maus exemplos, na compreensão de D. Epaminondas, corriam as diversas paróquias, por vezes com títulos sugestivos e pena irônica.

O catolicismo luso-brasileiro, ainda renitente em meio à ação romanizadora dos bispos predecessores, é assunto recorrente n"O Lábaro', e o relato da festa do Divino em São Luís do Paraitinga, em outubro de 1911, enfatiza as interferências do clero romanizado nos usos e costumes da festa, informando, também, seus custos. Cumpria, pois, disciplinar os abusos e, principalmente, carrear os investimentos para atividades de cunho romanizador e patrimonial:

O programa da festa foi, como de costume, um conglomerado de paganismo e de cristianismo, preponderando talvez aquela parte a esta. Felizmente, e com grande aplauso das pessoas sensatas, será esta a última festa assim celebrada, para o qual o nosso vigário, cumprindo as ordens da Autoridade Diocesana, nomeou uma comissão de festeiros (...) Esta comissão fará a festa com toda a pompa religiosa, e distribuirá esmolas para os pobres e estabelecimentos de caridade, sem comprometer-se a gastar 8 ou 10 contos, como até agora se fazia...

A missa de réquiem, como é sabido, é o ofício que se faz pelos mortos. Para o clero romanizado, neste caso para o vigário Ignácio Gioia, o boneco gigante João Paulino, e as casas de festas, onde o povo se reunia para as comilanças de praxe, recebiam o último adeus. Ledo engano.

...Um sentido e lacrimoso Requiem aeternam, em nome do povo culto de São Luís, às folias, João Paulino e casas de festas. ${ }^{443}$

Como era de se esperar, as reações não tardaram. Sofrendo o conhecido processo de conflitos e acomodações, a Festa do Divino, promovida em várias localidades, sendo particularmente grandiosa em São Luis do Paraitinga e mesmo proibida em 1922, ${ }^{444}$ mereceu de D. Epaminondas, por vários anos, diversas

442 BRANDÃO, Ascânio da Cunha. Dom Epaminondas. São Paulo: Oficinas gráficas da Ave Maria, 1941. p. 6.

443 O Lábaro, n. ${ }^{9}$ 94, II. 19 de outubro de 1911.

444 Encaminho o leitor a Raveli, Flávia Albergaria. A reforma ultramontana e a festa do Divino: São Luiz do Paraitinga entre os séculos XIX e XX. 1998. Dissertação (Mestrado em História Social) Universidade de São Paulo, São Paulo, 1998. 
"Circulares", onde, detalhadamente, eram transmitidas as instruções aos vigários,

É certo, também, que a preocupação do bispo não se restringisse tão somente em relação à festa do Divino, mas a todas ocorridas no âmbito da diocese, a ponto de citar um "Regulamento das festas religiosas da Diocese de Taubaté", que não sabemos se fato veio à lume, uma vez que não foi encontrado. De um modo geral, a Circular de 1918 não difere, em espírito, das demais:

Circular - Taubaté, 30 de abril de 1918. Prezado e Rev. ${ }^{\text {mo }}$ amigo Sr. Vigário - Era minha intenção organizar e pôr em vigor, antes das festas do Divino Espírito Santo, o "Regulamento das festas religiosas da Diocese de Taubaté", que está sendo elaborado. Infelizmente, não está ainda concluído o trabalho...

Primeiramente, o bispo adverte o vigário sobre a escolha dos festeiros, reprovando qualquer ato contrário aos moldes romanizadores:

Desejoso, porém, de atalhar certos males de todos bem conhecidos, resolvi determinar desde já o seguinte: $1^{\circ}$ - Fica absolutamente proibido em todas as paróquias desta diocese 0 sorteio de festeiros. $2^{\circ}-\mathrm{V}$. Rev ${ }^{\mathrm{ma}}$ escolherá uma pessoa ou uma comissão composta de pessoas de bons costumes, verdadeiramente religiosas, a qual encarregará da realização da festa, sob o compromisso expresso de: a) excluir da festa os graves absurdos tão reprovados pela Igreja e pelo bom senso, tais como: jogos, excessos de bebidas alcoólicas, bailes e outros divertimentos condenados pela moral cristã e tão impróprios das solenidades religiosas; ;..

Isto feito, relembra o vigário sobre a prestação de contas.

$[\ldots] 4^{0}-$ Quer a festa seja feita por V. Rev. ${ }^{\text {ma }}$, quer por outrem, 15 dias após ela, $V$. Rev. ${ }^{\mathrm{ma}}$ fica obrigado a mandar-me um balancete completo da mesma e a publicá-lo na imprensa local, se a houver... ${ }^{445}$

A festa do Bom Jesus de Tremembé, celebrada em agosto, também é alvo das críticas de D. Epaminondas, que lá se recusou a comparecer em 1912. Proibido desde 1903, o jogo volta com força total, e as ameaças do bispo são patentes:

Festas de Tremembé - Não tiveram, infelizmente, neste ano, o espírito cristão que as tem animado de nove anos a esta parte as tradicionais festas do santuário do Tremembé. Desgraçadamente, a jogatina antilegal e anticristã foi estabelecida naquela paróquia, com imenso dano para as famílias e grave quebra das leis religiosas e pátrias. O jogo tão pernicioso e tão formalmente condenado pelo Código Penal da nação pode-se dizer que foi a nota dominante das festas, razão pela qual o Ex. ${ }^{\text {mo }}$ Sr. Bispo diocesano, não querendo e não

445 ACDT. Carta Circular de Dom Epaminondas. 30 de abril de 1918. 
podendo sancionar com a sua presença tão grave abuso, desistiu do intento que tinha de nas mesmas pontificar, lavrando assim o seu protesto formal contra tamanha imoralidade, sendo sua resolução proibi-las no próximo ano se forem assim profanadas. ${ }^{446}$

Às voltas com as questões decorrentes dos embates entre 0 ultramontanismo e o catolicismo luso-brasileiro, não é difícil equiparar a visão de D. Epaminondas a respeito de festas religiosas conduzidas por leigos, com a curiosa visão de D. Eduardo, bispo de Uberaba em 1891:

Como sempre em tais lugares de Santuários há sempre jogo, besundelas, brequefetes, e reúnem-se as bilhardonas e calonas de todas as freguesias, bem como sujeitos avilanados e rapazes mariolas, que aproveitam essa reunião de gente ruim e de marafonas para saciarem a sua luxúria, e executarem suas vinganças, de sorte que não há um ano em que não haja assassinatos e ferimentos graves. ${ }^{447}$

O carnaval, em particular, irritava o clero romanizado, e são recorrentes n"O Lábaro' as reclamações em relação aos festejos de momo. Tendo na conta de uma perniciosa influência dos divertimentos carnavalescos sobre a moral da sociedade, "que os tolera e, mais do que isso, os incita e auxilia", o articulista volta sua fúria sobre um bloco denominado "Grupo pró Jesus". Referindo-se ao cunho eminentemente pagão do carnaval, lembra que os festejos carnavalescos não passavam sem formidáveis e ridículas troças às coisas e pessoas da Igreja, como missas, padres, freiras, confissão, mas que, porém, devido "à intervenção criteriosa das autoridades, esse abuso foi extinto; e assim é que os cortejos organizam-se sem aquelas alegorias desrespeitosas e quase sempre sacrílegas". Em meio às críticas, o articulista até se mostra leniente com os foliões, não admitindo, entretanto, brincadeiras que envolvam o catolicismo:

Que os carnavalescos metam em suas pândegas motivos políticos, se divirtam, chorem, riam, fantasiem, bisnaguem - vá, conceda-se, muito embora saiam sempre grossas imoralidades desse gênero de diversões. Mas que chamem para as suas diversões motivos religiosos, achincalhando o nome de Deus, isso é que não passará sem o nosso veemente protesto...

Encerrando, o autor do artigo reclama que às autoridades competiria olhar por essas gravíssimas afrontas, se não se envolvessem tanto em política de

446 O Lábaro, n. ${ }^{\circ} 137$, III. 8 de agosto de 1912.

447 SILVA, J. Trindade da Fonseca e. Lugares e pessoas: subsídios eclesiásticos para a história de Goiás. São Paulo: Escolas Profissionais Salesianas, 1948. p. 327. 
campanário, e olhassem mais a sério pelas coisas que dizem respeito a moralidade do povo, "que têm escrita obrigação de defender dos perigos que possam assediá-lo e maltratá-lo". 448

Em relação ao espiritismo não havia qualquer complacência, e o caso se passa em Jacareí, paróquia da diocese. No artigo intitulado "A carne ao diabo e os ossos a Deus" reclama o jornal que "é o que fazem, infelizmente, muitos dos pretensos católicos de nossos dias". Asseverando que durante a vida não se importam com a Igreja, desprezam suas leis, não respeitam seus ensinamentos, insultam a seus ministros, vivem com lhes apraz e morrem como pagãos, depois da morte surgem seus parentes fazendo questão de que ao defunto nenhuma homenagem religiosa falte, "e ai dos padres se, em obediência às racionais e sapientíssimas leis da Igreja, ousam negar-Ihes as honras de um acompanhamento fúnebre ou os sufrágios religiosos".

...É o que acaba de fazer um espiritista de uma cidade desta Diocese. Tendo morrido impenitente e na heresia um seu parente, chefe do espiritismo na referida paróquia, negou-se, multirracional e legalmente o pároco, a acompanhar o seu funeral. Rogado pela família do morto a sufragar-lhe a alma com uma missa, o vigário, depois de ouvir o Ordinário Diocesano, declarar não Ihe permitem as leis da Igreja...

Argumentando que, em tal emergência, restava aos parentes uma de duas saídas: ou submeterem-se dóceis, humildes e resignados às determinações da Igreja da qual se dizem membros, provando assim que realmente são católicos; ou levantarem-se contra a Igreja católica. Aos parentes do morto, todavia, não agradou a obediência à ortodoxia por parte do clero romanizado, e "infelizmente, preferiram sair por esta irracional porta, recorrendo às colunas do Estado de São Paulo, e pondo assim um relevo a alteza de seu catolicismo".

O articulista afirma que tal procedimento não o admira, pois a fé está casando com as obras dos reclamantes, concitando-os a imitarem Quintino Bocaiúva que, sendo maçom, ordenou em seu testamento que não queria padres em seu funeral, nem missas por sua alma, "pois, como maçom que sou, disse ele, não tenho direito a tais coisas".

Desse modo, o articulista indaga:

...E terão tal direito os espiritistas, seita funestíssima, diabólica, falsa, condenada pela sagradas escrituras, pela Igreja Católica

448 O Lábaro, n. ${ }^{\circ}$ 213, V. 29 de janeiro de 1914. 
e pelo nosso Código Penal? Desenganem-se, senhores espiritistas, «nenhuma convenção pode haver entre Cristo e Belial», entre Deus e o Diabo, entre a luz e as trevas, entre a verdade e a mentira, entre a virtude e o vício, entre o bem e o mal. É necessário mesmo que os campos se discriminem, que se arranquem as mascaras, que se separe o trigo do joio. Ou comigo ou contra mim, dizia Jesus...

Após o bombardeio, o espírito ultramontano não deixa de ser lembrado!

Não há meio termo. Já se foi o tempo de duas velas...Já se passou a época dos católicos espiritistas, dos católicos maçons, dos católicos protestantes, dos católicos liberais, dos católicos livres-pensadores, dos católicos...não romanos, dos católicos honorários. Hoje só tem cotação na praça da verdade e do bom senso os católicos, apostólicos, romanos - do Credo e do Decálogo $[\ldots]^{449}$

A revista Vozes, fundada em 1907 pela Ordem dos Franciscanos, bem como o Centro da Boa Imprensa, de 1910, não se limitavam, tão somente, ao combate da "má imprensa", "mas também aos "novos instrumentos de diversão e difusão de imagens, como o cinema, que faziam grande concorrência à Igreja, ocupando um espaço até preenchido pelas missas e pelas festas religiosas". ${ }^{450}$ As edições d"O Lábaro', acompanhando a constelação de temas da modernidade a serem vigiados, são pródigas em comentários e censuras sobre os filmes da época, buscando orientar os fiéis nesse novo tipo de diversão:

FILMES BONS E FILMES RUINS Por minha dama - Esse filme é daquele que se dominam policiais. É um bem feito trabalho cinematográfico, que prende a atenção dos telespectadores pelo encadear de suas cenas. É um filme que agradará as pessoas adultas e que deve figurar nos programas para crianças. A esses pode ser prejudicial. Sangue azul - Não é imoral. É um filme que não condenamos. Eterno tormento Mary Pickfort é uma artista que se impôs ao público. É uma artista de valor. Mais ainda: os filmes em que trabalha são todos encantadores. Não nos lembramos de ter visto Mary Pickfort em um filme imoral. Em Eterno tormento Pickfort tem magnífico papel. O filme é bom. Pode ser visto com prazer. Casamento «à la carte» - Este filme é alegre, interessante. DáIhe vida uma criaturinha que bem a encarnação da menina norte-americana, educada com toda a liberdade, mas que sabe compreender o que Ihe fica mal, procurando por isso trilhar a estrada do bem. Casamento "a la carte" é um filme bom. Cobarde - É um filme que, apesar do seu título, é belo. Não é

449 O Lábaro, n. ${ }^{\circ} 225$, V. 23 de abril de 1914.

450 ALMEIDA, Cláudio Aguiar. Meios de comunicação católicos na construção de uma ordem autoritária: 1907/1937. 2002. Tese (Doutorado em História Social) - Universidade de São Paulo, São Paulo, 2002. p. 2. 
imoral. Agrada. ${ }^{451}$

Tribuna do ultramontanismo, 'O Lábaro' não se descuidava em propagandear as atitudes ortodoxas do clero diocesano, e o artigo intitulado "Um ato corretíssimo" elogia o "zeloso e distinto Vigário da Cachoeira", atual Cachoeira Paulista, por haver suspendido do cargo o sacristão da Matriz daquela paróquia, tendo em vista ter o mesmo realizado o casamento de uma filha somente no civil, "apesar das delicadas advertências do seu virtuoso Pastor". 452

Não dando tréguas também ao anarquismo, o jornal noticia a expulsão de nove anarquistas de nacionalidade italiana e espanhola, "por serem nocivos a ordem e tranqüilidade públicas", encorajando o ato governamental com o título do artigo: "É assim mesmo..." 453

É certo, pois, que não havia medo, por parte da redação, em lançar diatribes a quem ou ao que quer que fosse inimigo do catolicismo, protestantismo incluso.

Afirmando que "igrejinhas protestantes" fediam à mandioca, ou que um certo debatedor "deve estar com saudades das boas sovas que Ihe passou esta folha, justificando o antigo adágio: 'Negro ruim gosta de couro'”, para 'O Lábaro' os jornais ‘Estado de São Paulo' e ‘Ordem', de Tremembé, eram redes dos esgotos, enquanto que um espírita era ironicamente admirado por haver excedido, na arte das descomposturas, a muitas "negras do chafariz". ${ }^{454}$

Também não tardou a segunda iniciativa de D. Epaminondas: a implantação de um seminário.

Sabemos que S. Ex. ${ }^{\text {a }}$ Rev. ${ }^{\text {ma }}$ o Sr. Bispo diocesano trata com todo empenho da fundação imediata de um Seminário Maior nesta Diocese. Sabemos que vão muito adiantadas as negociações para a fundação de um ginásio em nossa terra, com internato e externato, trazendo-nos ainda muitos progressos não só morais, como materiais. ${ }^{455}$

Tendo como ponto de partida um pequeno sobrado, em fase de construção, localizado em terreno pertencente ao Visconde de Tremembé, foi esse prédio inacabado adquirido à Ordem Terceira de São Francisco, enquanto que o terreno foi doado pelo próprio Visconde. Em 20 de fevereiro de 1910, reuniam-se professores, e vinte e quatro alunos, para a sua inauguração. 
E como o ótimo é inimigo do bom, mais valendo para os bispos, à época, concretizar, de modo célere, as expectativas da hierarquia católica em relação aos seus novos prelados, é certo ter o império do improviso, pois nas lembranças do Padre José Romão da Rosa Góes, "o sobrado era tão pequeno e modesto que, se embaixo tínhamos as salas de aula, encima, num mesmo salão, tínhamos o dormitório, o salão de estudo e até o refeitório." 456

Revestida de tocante solenidade, efetuou-se domingo último, no Convento de Santa Clara, a inauguração do Seminário de Taubaté, dirigido provisoriamente pelos Rev. ${ }^{\text {mos }}$ Frades capuchinhos, sendo reitor o venerando Frei Bernardino de Lavalle. O novo estabelecimento de instrução está funcionando, em caráter temporário, no prédio que a ordem terceira começou a construir para nele funcionar o Asilo de Santo Antônio e cedido para tal fim pela venerável ordem capuchinha. O número de alunos matriculado é animador e, nas proporções atuais, espera-se para o próximo ano um avultado número de candidatos ao honroso mister sacerdotal. Sendo uma das primeiras iniciativas do nosso distinto poderoso diocesano, o seminário de Taubaté, marca para nossa diocese um passo gigantesco na senda do progresso e registra de um modo brilhante o inexcedível zelo e força de vontade do ilustre prelado, que vai com toda serenidade, não medindo grandes dificuldades, dando à sua pobre diocese aquilo que ela mais precisa - instrução aos seu filhos. Até essa data não possuíamos casas de instrução superior, onde os nossos jovens conterrâneos pudessem receber as luzes vivificantes do saber. Graças, porém, aos esforços de D. Epaminondas já ai temos o seminário e em breve, promovido por S. Ex. ${ }^{a}$, o ginásio diocesano, satisfazendo todas as exigências da moderna pedagogia. Quem assim pratica, merece, por certo, a gratidão de um povo. ${ }^{457}$

Limitando o uso do dito refeitório ao café da manhã, as demais refeições, missas, e recreios, eram realizados no convento de Santa Clara.

Conquistada a posição, restava consolidá-la, e o terreno recebeu, inicialmente, um muro de taipa, substituído, posteriormente, por um de tijolos. Nesse ínterim, o deputado taubateano Pedro Costa obteve do governo do Estado uma verba de vinte e quatro contos de réis, construindo-se, então, a cozinha, outro dormitório, refeitório e quartos para os professores.

Frei Bernardino de Lavalle, guardião e romanizador do convento de Santa Clara, foi o primeiro reitor. Integrando o corpo docente, Monsenhor Nascimento

456 POLIANTÉIA. Homenagem da diocese de Taubaté ao seu amado bispo D. Epaminondas Nunes de Ávila e Silva no seu festivo jubileu episcopal (1909-1934). Taubaté: Oficinas gráficas do Santuário de Santa Teresinha, 1934. p. 24.

457 Jornal de Taubaté, n. ${ }^{\circ}$ 2561, XVII. 27 de fevereiro de 1910. 
Castro, Frei Fidélis Mota, Frei Felicíssimo e Frei Salvador Cavendine, na qualidade de sacerdotes. O apoio leigo não faltou, representado pelo Dr. Gastão Aldano Vaz Lobo da Câmara Leal e pelo Dr. Euzébio Inocêncio Vaz Lobo da Câmara Leal, advogado de D. Epaminondas quando do "Legado Wanderley", e por nós já conhecido. Por último, o irmão leigo Frei Diogo da Bahia exercia as funções de vigilante.

Da Pastoral Coletiva de 1890, onde a desconfiança e o ressentimento "Basta que o Estado fique na sua esfera. Nada tente contra a religião" 458 - pelo decreto de separação permeavam todo o texto, ao início da década de 10 do século passado, lentamente se iniciava o imbricamento dos caminhos do governo e da Igreja. Assim, o Estado laico não faltou à obra de D. Epaminondas, e mediante a intermediação política do Cônego Valois de Castro, o presidente do estado de São Paulo, Manuel Joaquim de Albuquerque Lins (01/05/1908 a 01/05/1912), concedeu, em favor do Seminário, isenção de impostos de transmissão no valor de cinqüenta e dois contos de réis.

Seguiu-se a construção de uma capela, inaugurada em 13 de junho de 1914, e nessa linha, Padre José Romão afirma terem passado 654 alunos pelos bancos do Seminário até 1934, ano em que D. Epaminondas completou 25 anos de episcopado, tendo consagrado da ordem de cinqüenta sacerdotes.

Um ponto sensível, entre todos os prelados, era a visita pastoral. A extensão territorial, as dificuldades de locomoção e transporte, ou mesmo a carência logística, nada os fazia recuarem de cumprir essa meta, considerada de máxima importância, e que, na sua maioria, durava meses.

As visitas pastorais visavam, principalmente, fiscalizar o fiel cumprimento das práticas ultramontanas, seja sob a ótica dos aspectos litúrgicos, seja sob o viés da escrituração burocrática. Informavam-se os bispos, pessoalmente, nessa ocasião, sobre a vida pessoal de padres e vigários, em matéria de costumes, bem como "quanto ao reparte das quantias arrecadadas e sobretudo quanto ao quinhão de que se apropriavam os membros locais do clero, propiciando a moldura organizacional adequada à imposição da autoridade episcopal". 459

Pari passu, as visitas pastorais também se configuravam como oportunidade

458 Pastoral Coletiva de 19 de março de 1890. In: A Igreja na república. Brasília: Universidade de Brasília, 1918. p. 57.

459 MICELI, Sérgio. A elite eclesiástica brasileira. Rio de Janeiro: Bertrand Brasil, 1988. p. 137. 
de uma maior arrecadação. A regularização de casamentos, os batismos, a concessão de indulgências e a administração do sacramento da crisma, esta última apanágio exclusivo do bispo, bem como sua própria presença, faziam com que as bolsas se abrissem com maior facilidade e generosidade.

A visita pastoral de D. Epaminondas revestiu-se de racionalidade e de minucioso planejamento logístico, iniciando-se, um mês antes, a correspondência ao clero da diocese:

Visita Pastoral. O Ex. ${ }^{\text {mo }}$ Sr. Bispo Diocesano dirigiu uma cartacircular, acompanhada de vários quesitos, feitos ao Rev. ${ }^{\mathrm{mo}}$ Clero Paroquial desta Diocese, tendo em mente dispor as causas em ordem à Visita Pastoral, que S. Ex. ${ }^{a}$ pretende iniciar logo após a Páscoa. Brevemente será publicado o itinerário que S. Ex. ${ }^{\text {a }}$ pretende seguir na visita. Espera o Ex. ${ }^{\text {mo }}$ Prelado que the sejam remetidos, dentro do prazo marcado na referida circular, as propostas correspondentes aos quesitos constantes do aludido documento para poder traçar a ordem da visita. De ordem, pois, de Ex. ${ }^{\text {mo }}$ Sr. Bispo relembro aos Rev. ${ }^{\text {mos }}$ Srs. Vigários a necessidade de remeterem quanto antes a esta Secretaria os esclarecimentos pedidos. Taubaté, 31 de janeiro de 1910. Pe. José Francisco Alves Moura, Secretario do Bispado. ${ }^{460}$

Os preparativos para a visita, todavia, não impediam reforços pontuais no processo romanizador, e desta vez as moças e os rapazes conversadores eram o alvo. A disciplina no interior das igrejas, por exemplo, é questão antiga, tendo em vista que "o que mais chamou a atenção dos viajantes e cronistas que visitaram as nossas igrejas coloniais, foi a falta de compostura por parte dos participantes". ${ }^{461}$

A propósito, fazer "reuniões profanas" nas igrejas era hábito em Guaratinguetá já em 1896, e a "Gazetinha" traz a queixa de um leitor. O motivo da reclamação é, no mínimo, pitoresca:

ABUSOS NA MATRIZ Tem por fim estas linhas, pedir ao nosso ilustre Vigário da Paróquia, a proibição de um grupo de rapazes sem emprego que, em todos os atos celebrados em nossa Matriz, põem-se nas tribunas, a conversarem em voz alta, o que torna-se incomodativo as pessoas que estão devotadamente fazendo suas orações. Ainda é mais grave eles, os vadios, formularem uma grande quantidade de bolas de papel molhado para, daquela altura, jogarem sobre as cabeças das famílias que entram ou saem pelas portas laterais. Raciocine bem, Sr. Vigário, é ou não é isto um abuso? ${ }^{462}$

460 ACDT. Aviso n. ${ }^{\circ} 15.31$ de janeiro de 1910.

461 MOTT, Luiz. Cotidiano e vivência religiosa: entre a capela e o calundu. In: NOVAIS, Fernando A. (org.). História da vida privada no Brasil, v. 1. São Paulo: Companhia das Letras, 1997. p. 161.

462 Gazetinha, n. ${ }^{\circ}$ 897, IX. 19 de abril de 1896. 
Se a situação em Taubaté não chegou ao extremo de bolas de papel molhado jogadas sobre as cabeças das famílias, é fato que a separação dos sexos foi definitivamente ordenada por D. Epaminondas, em reforço à tentativa anteriormente feita em 1900.

A medida posta em prática pela $\mathrm{V}$. Irmandade dos Passos, de acordo com o Rev. ${ }^{\text {mo }}$ Vigário, em 1900, vai ter agora o seu complemento, com a determinação do Ex. ${ }^{\text {mo }}$ Sr. Bispo Diocesano. Por maior que fosse a fiscalização e o policiamento na igreja, era impossível obter a completa separação dos sexos, e a palestra continuava, por parte daqueles que vão à Igreja - não para adorar a Deus, mas para matar o tempo. As nefastas coxias facultavam a fácil palestra de rapazes e moças de pouco pensar, que assim convertiam o sagrado templo em sala de palestra, pouco se importando, não dizemos só do escândalo decorrente do próprio ato, mas até do incômodo que causavam às pessoas que se achavam próximo, pelo sussurro da própria palestra. Com a longa prática que teve o Sr. Bispo do paroquiato, e tendo já coibido tais abusos na sua paróquia, e querendo modelar a catedral, para que possa ser seguida pelas matrizes de sua diocese, determinou uma nova divisão da igreja, por meio de balaustradas que a secionem em três partes - a primeira, próxima ao arco do Cruzeiro, para os homens, com entradas pelos corredores da sacristia; a segunda no corpo propriamente, da igreja, para as senhoras, com entradas por duas portas laterais, e finalmente a terceira, abaixo desta abrangendo a entrada pela porta principal. Reservou o coro à musica, capela mor ao clero e irmandades, e proibiu o acesso às tribunas, que ficarão como meios ventiladores do templo. Fica assim a nossa catedral em condições de poder ter o respeito e o silêncio necessário e indispensáveis á casa do Senhor, as famílias sérias garantidas dos importunos e ousados capazes que queriam converter o sagrado templo em casa de diversões e passatempo. Naturalmente serão colocadas, às portas, avisos, prevenindo os fiéis das portas praticáveis aos homens e as senhoras, e assim, já cada sexo terá sua entrada reservada na igreja. Louvado Deus, vai o nosso Rev. ${ }^{\text {mo }}$ Vigário conseguir o que sempre desejou e pelo que sempre trabalhou isto é, pelo respeito á casa de Deus, mas que dependia desta grande reforma de divisão do templo, que só com autorização, ou por determinação episcopal podia fazer, por ir de encontro aos perigosos e sempre alegados usos e costumes do povo, que aliás não devem e não podem constituir regras na igreja, quando em oposição, dos seus princípios. ${ }^{463}$

Volvendo à Visita Pastoral, a primeira localidade a ser visitada seria Tremembé. Em 29 de abril de 1908, no entanto, a igreja de Aparecida recebeu o título de Basílica Menor, as romarias àquele santuário se intensificaram, e "Taubaté 
e Tremembé sofrem as conseqüências imediatas desta unanimidade religiosa, estimulada pelo alto clero romano". 464

A atração gravitacional de Aparecida aumentava dia a dia, em cumprimento aos objetivos do projeto regional de romanização. O santuário do Bom Jesus era cada vez menos visitado, e a reação à decadência da diocese de Taubaté foi trabalho que D. Epaminondas conduziria ao longo de sua vida.

\begin{abstract}
Visita pastoral - O Ex. ${ }^{\text {mo }}$ Sr. Bispo diocesano segue no dia 12 do corrente a começar a visita pastoral no Santuário de Tremembé, onde deverá permanecer até o dia 19. Sabemos que S. Ex. ${ }^{a}$ Rev. $^{\mathrm{ma}}$, muito propositadamente, escolheu 0 Santuário de Tremembé para o início da visita pastoral, a fim de assim abri-la com chave de ouro, pois o Sr. Bom Jesus, na magnanimidade do seu generosíssimo coração, saberá enviar muitíssimas bênçãos ao nosso amado diocesano, para que ele veja sua visita pastoral coberta dos melhores frutos! $E$ esses são os sinceros votos do "Lábaro". 465
\end{abstract}

O Aviso n. ${ }^{\circ} 17$ trata da visita pastoral no âmbito da diocese, e o itinerário traçado percorria Redenção da Serra, São Luiz do Paraitinga, Natividade da Serra, Bairro Alto, Ubatuba, Vila Bela, São Sebastião, Caraguatatuba, Salesópolis, Santa Branca, Paraibuna, Jambeiro, Jacareí, Santa Isabel, Patrocínio, São José dos Campos, Caçapava, Buquira, Santo Antônio e Trapa. Excetuado os casos de necessidade de maior demora, D. Epaminondas alertava que pretendia permanecer em cada paróquia cerca de sete dias, levando consigo cinco sacerdotes, pedindo, também, aos vigários, que lhe providenciasse hospedagem, quanto possível, mais perto das igrejas matrizes.

Alerta o 'Aviso' que o tratamento seja simples, "para ser menos pesado aos vigários e aos fiéis". Antes da chegada do bispo, no entanto, a preparação para a visita ficaria a cargo dos párocos, devendo os mesmos instruir o povo sobre a importância, fins e utilidade da visita pastoral, fazendo-lhes ver que não era somente a administração do sacramento da confirmação o fim da visita, mas sim "remediar os males morais e prover a tudo quanto se prende ao bem das almas e glória a Deus."

Abordada a parte espiritual, a burocracia tem a sua vez e, pelo visto, não é de pouca importância:

[...] o Bispo fará a visita real e pessoal, examinado a Matriz, as Capelas, os Estabelecimentos pios, o Cemitério, o Sacrário, o

464 ALMEIDA, Jaime de. Foliões. 1987. Tese (Doutorado em História Social) - Universidade de São Paulo, São Paulo, 1987. p. 235.

465 O Lábaro, n. ${ }^{\circ}$ 5, I. 6 de fevereiro de 1910. 
Batistério, os Altares, os ornamentos e alfaias, os livros de Tombo e de registro de Batizados, Casamentos e Óbitos, as Irmandades, o estado moral da Paróquia, etc. [...] ${ }^{466}$

$\mathrm{Na}$ inspeção pastoral em Tremembé, assim como nos demais locais percorridos, ocorreu a visita ao sacrário, batistério, altares, livros, alfaias, comunhão de meninos e meninas, senhoras e homens, "e no sábado tivemos a comunhão geral, que excedeu inteiramente a expectativa".

Buscando disseminar, no âmbito de toda a diocese, a invocação do nome do Bom Jesus, ao nosso ver pálida contrapartida à intensa propaganda romanizadora em favor do santuário de Nossa Senhora Aparecida, D. Epaminondas, à medida que a percorre, cria a Associação do Senhor Bom Jesus de Tremembé em todas as paróquias sob sua jurisdição, somando 37 associações já em dezembro de 1911.

Dentro do espírito das novas associações religiosas "que já desde a sua fundação estivessem enquadradas nas estruturas hierarquizadas da lgreja", 467 fica patente a completa subordinação da Associação do Senhor Bom Jesus de Tremembé à D. Epaminondas: "Os presentes Estatutos somente poderão ser alterados com licença especial e aprovação do Ex. ${ }^{\text {mo }} \mathrm{Sr}$. Bispo Diocesano, não podendo também a referida Associação adquirir personalidade jurídica sem licença da autoridade diocesana". ${ }^{468}$

Assim, no dia 17 de fevereiro de 1910, em Tremembé, fez-se a solene instalação da Associação do Senhor Bom Jesus, destinada a cuidar da educação de moços pobres para a carreira sacerdotal. Alegando que "ninguém ignora a deficiência de bons vigários", 'O Lábaro' também afirma que a agremiação, "sob a proteção do milagroso Bom Jesus, vem preencher imensa lacuna, justamente com o óbolo do pobre e as pequeninas esmolas".

[...] Foi uma verdadeira inspiração este ato do Sr. D. Epaminondas, animado do zelo das almas e do santo amor de Deus. Após a missa, S. Ex. ${ }^{\mathrm{a}}$ comprovou a $1^{\mathrm{a}}$ diretoria desta Associação, composta pelo Rev. ${ }^{\text {mo }}$ Padre Antônio, Vigário, Presidente, Sr. Antônio Maria, Tesoureiro e Prof. João Batista de Oliveira Santos, Secretário. Antes, o Rev. ${ }^{\mathrm{mo}}$ Frei Lourenço fez a leitura dos Estatutos e o Sr. Bispo explicou claramente alguns pontos e convidou as pessoas presentes a se inscreverem na Associação. [...]

466 ACDT. Aviso n. ${ }^{\circ}$ 17. 23 de fevereiro de 1910.

467 WERNET, Augustin. Antigas Irmandades e Novas Associações Religiosas, Revista da Sociedade Brasileira de Pesquisa Histórica - SBPH - Anais da X Reunião - Curitiba - 1992. p. 57.

468 ACDT. Estatutos da Associação do Sr. Bom Jesus de Tremembé, em favor da Obra das

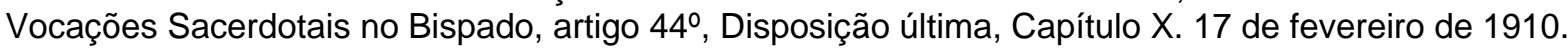


Sexta-feira, 18, o Bispo, assistido por Monsenhor João Alves e pelo Cônego Benjamim, bem como pelas demais pessoas da comitiva e por alguns assistentes, fez, também, a instalação da Conferência de S. Vicente de Paulo, na capela de Nossa Senhora da Guia, e o jornal diocesano a tem na conta de "um dos meios infalíveis de restaurar-se a caridade e ressurgir o verdadeiro espírito católico numa paróquia". 469

Inaugurada sob o signo de duas lutas com D. Duarte, as já conhecidas questões Wanderley e Aparecida, é nítida a recorrência, desde os primeiros escritos de D. Epaminondas, sobre a pobreza da diocese:

Obra das vocações sacerdotais - invocação do Bom Jesus de Tremembé - Padroeiro de um Santuário paupérrimo, de uma diocese sem recursos, o Sr. Bom Jesus certamente virá em socorro da diocese do seu grande imitador, S. Francisco de Assis, e fará crescer, prosperar e frutificar esta nova obra, devida ao zelo e solicitude do nosso bondoso bispo. ${ }^{470}$ (o grifo é nosso)

Nas linhas d"O Lábaro', a reportagem sobre a visita pastoral em Redenção da Serra, "a primeira destinada a gozar dos grandes favores de tão benéfica visita", assume, assim como nas demais, o tom triunfalista:

S. Ex. ${ }^{a}$ fez sua imponente entrada com as vestes pontifícias, acompanhado das duas corporações musicais e enorme massa popular, ao repique festivo dos sinos, ao espoucar das girândolas e às salvas das baterias. Foi extraordinária a concorrência da população da paróquia, notando-se a presença das autoridades locais e das Irmandades religiosas... 471

Dois padres redentoristas, no entanto, foram convidados a acompanhar D. Epaminondas; no retorno dos mesmos, e após as notícias, o cronista da comunidade, na quietude de seu escritório, redimensiona os fatos:

1910 - Os Padres Fishlaber e Gulhisl dirigem-se para Taubaté no dia 27 de abril e no dia seguinte saem como companheiros do Sr. Bispo em Visita Pastoral.

Redenção: de 1 a 5 de maio - como as autoridades não se interessaram, e não cuidaram de nada para a visita, o Pe. Gulhisl, a pedido do Sr. Bispo, bateu de porta em porta, munido das faculdades necessárias. Muitos não reagiram, a não ser depois de muitas resistências, súplicas e imprecações e até mesmo ameaças. Um certo coronel Queiroz, chefe político, que

469 O Lábaro, n. ${ }^{\circ}$ 8, I. 27 de fevereiro de 1910.

470 O Lábaro, n. ${ }^{\circ} 8$, I. 27 de fevereiro de 1910.

471 O Lábaro, n. ${ }^{\circ}$ 18, I. 5 de maio de 1910. 
há 20 anos vive em concubinato, de forma alguma pode ser levado a melhor sentimento. Houve 1663 confissões, 1783 comunhões, 24 sermões e 17 casamentos legitimados. ${ }^{\mathbf{4 7 2}}$

Grosso modo, a visita pastoral prosseguiu sem maiores incidentes. Em São Luís do Paraitinga, onde "os habitantes têm boa vontade, mas são ignorantes", justamente quando o Padre Fishlaber pregava sobre o inferno, parte do teto desabou. Na ilha dos Porcos, o bispo foi recebido com muita atenção, e, entre detentos e soldados, todos se confessaram, com exceção de um, "que disse que seria lançado no inferno com alegria juntamente com o demônio". Já em Salesópolis, segundo os redentoristas, "ali os habitantes são verdadeiramente bons, dando muito trabalho aos missionários durante 4 dias", enquanto que, em São Sebastião, "fazia 40 anos que bispo algum comparecia". 473

Para padres afeitos a um comportamento não compatível com a condição sacerdotal, é certo que D. Epaminondas não poupava medicina, não vacilando, também, em dar larga publicidade às suas decisões de caráter disciplinar. O Padre Eugênio Martini, portanto, além de ver-se sem uso de ordens, viu seu nome circular em todas as paróquias.

EDITAL N. ${ }^{\circ} 2$ - De ordem do Ex. ${ }^{\text {mo }}$ Sr. e Rev. ${ }^{\text {mo }}$ Sr. Bispo Diocesano, levo ao conhecimento dos Rev. ${ }^{\text {mos }}$ Vigários desta Diocese, que o Padre Eugênio Martins foi exonerado do paroquiato de Igaratá, ficando também sem uso de ordens, com consta de um oficio que lhe foi dirigido. S. Ex. ${ }^{a}$ determinou que os Rev. ${ }^{\text {mos }}$ Vigários de Jacareí, Santa Isabel e Igaratá, expliquem, na missa conventual, que o referido sacerdote não pode exercer ato algum do Ministério, nesta Diocese. Pe. José Alves de Moura, Secretário do Bispado.

O destemor de D. Epaminondas na defesa dos interesses da religião não se deixava vergar, e não obstante a ausência de documentos mais elucidativos, Ascânio Brandão afirma que em uma paróquia do interior dominada por chefes políticos, o vigário sofria "as conseqüências de pequeninas e mesquinhas vexações", o patrimônio da Igreja era defraudado, e "para cúmulo, foram ali chamados pastores protestantes para acinte ao vigário e aos católicos", tudo sob o conhecimento da Câmara Municipal. Inteirando-se dos fatos, D. Epaminondas, quando na Matriz, em dia de maior afluência de gente, declarou a excomunhão da Câmara Municipal.

472 ACPSR. Ânuas da Vice-Província de São Paulo, v. I (1896 - 1918)

473 ACPSR. Ânuas da Vice-Província de São Paulo, v. I (1896 - 1918)

474 ACDT. Edital n. ${ }^{\circ}$ 2. Não obstante a publicação do sobrenome "Martins", o verdadeiro sobrenome do sacerdote é "Martini", de nacionalidade italiana e proveniente da Diocese de Milão. ACDT. Pasta "Sacerdotes Falecidos", letra E. 
E prova, e argumenta e prega com tal veemente energia que pasma ver tanta coragem! $O$ povo treme. $O$ vigário, que bem conhece o meio, receia as conseqüências e vai ao encontro do Sr. Bispo ao vê-lo descer do púlpito. V. Ex. ${ }^{a}$, Sr. Bispo, exclama o padre, é o homem mais corajoso que já vi! Parece incrível! Que lição! No mesmo dia reúne o povo à praça da Matriz e ainda com os ornamentos pontificais, se apresenta às manifestações de fé que se iam realizar.

$\mathrm{O}$ ato de queimar, purificador por excelência e ao mesmo tempo eliminador da 'heresia' materializada pelas bíblias e folhetos protestantes, era, à época, bastante comum: ${ }^{475}$

Ao repique festivo dos sinos, e espoucar de foguetes, queimam-se em enormes fogueiras adrede preparadas as dezenas de bíblias protestantes e folhetos de propaganda metodista, aos aplausos delirantes do bom povo da terra. Não é preciso dizer que os protestantes deram às de Vila Diogo, e a Câmara Municipal curvou-se caladinha e engoliu a pílula amarga. ${ }^{476}$

Após três meses e meio de viagens, encerrou-se, de modo parcial, a visita episcopal de D. Epaminondas. Nas dezesseis paróquias que percorreu, segundo 'O Lábaro', "nada escapou a sua vigilância, nem os menores detalhes do serviço divino, nem as mais leves faltas de disciplina eclesiástica. Regularizou tudo, dirigiu tudo com escrupuloso cuidado". ${ }^{477}$

Rigoroso cumpridor dos regulamentos, o documento que por muitas vezes norteava D. Epaminondas em seus procedimentos administrativos era a "Pastoral Coletiva dos Senhores Bispos da Província Eclesiástica Meridional do Brasil comunicando ao Clero Secular e Regular o resultado das Conferências realizadas em São Paulo: de 3 a 12 de Novembro de 1901", fruto da Primeira Conferência Episcopal, realizada em São Paulo, de 3 a 12 de Novembro de 1901.

O bispo, quando era o caso, não omitia o amparo da Pastoral Coletiva em sua ordens: "O Ex. mo Sr. Bispo lembra aos Rev." ordenação contida na $1^{a}$ Pastoral Coletiva do Episcopado do Sul do Brasil, na qual se lê, sob o n. ${ }^{\circ} 72$, p. $51 . . . " 478$

475 Para os entreveros entre católicos e protestantes no início da república ver TARSIER, Pedro. História das Perseguições Religiosas no Brasil. 2 v. São Paulo: Edições Cultura Moderna, 1936.

476 BRANDÃO, Ascânio da Cunha. Dom Epaminondas. São Paulo: Oficinas gráficas da Ave Maria, 1941. p. 109-110-111.

477 O Lábaro, n. ${ }^{\circ}$ 33, I. 18 de agosto de 1910.

478 Pastoral Coletiva dos Senhores Bispos da Província Eclesiástica Meridional do Brasil comunicando ao Clero Secular e Regular o resultado das Conferências realizadas em São Paulo: de 3 a 12 de Novembro de 1901. Rio de Janeiro: Tipografia Leuzinger, 1902. p. 51. 
A padronização do culto não poderia deixar de atingir o catecismo, e novamente a Pastoral Coletiva de 1901 é lembrada:

De ordem do Ex. ${ }^{\text {mo }}$ Sr. Bispo comunico aos Rev. ${ }^{\text {mos }}$ Vigários que se acha na Secretaria deste Bispado, à disposição dos mesmos, grande número de exemplares do Catecismo, que todos os Párocos desta Diocese são obrigados a adotar em suas Freguesias, conforme a sábia resolução do Ex. ${ }^{\text {mo }}$ Episcopado Sul-Brasileiro, na $1^{a}$ Conferência realizada em São Paulo, de 3 a 12 de novembro de $1901 \ldots{ }^{479}$ (os grifos são nossos)

Em 1910, sob o título de "Pastoral Coletiva dos Senhores Arcebispos e Bispos das Províncias Eclesiásticas de S. Sebastião do Rio de Janeiro, Mariana, São Paulo, Cuiabá e Porto Alegre comunicando ao clero e aos fiéis o resultado das Conferências dos mesmos realizadas na cidade de São Paulo de 25 de setembro a 10 de outubro de 1910", o episcopado renova e aprimora a Pastoral Coletiva de 1901, dando prosseguimento à reforma ultramontana.

Com 1304 itens constantes em seis Títulos (Fé, Sacramentos, Culto, Disciplina do clero, Costumes do povo e Promulgação das resoluções e estatutos) e com 57 apêndices, a minuciosa padronização dos atos litúrgicos, bem como as prescrições a respeito do comportamento do clero e dos fiéis, não dão guarida à quaisquer desvios de procedimentos. Maçonaria e espiritismo, por exemplo, recebem especial atenção:

39. Afastem os fiéis das sociedades secretas, perversas e proibidas pela Igreja, das más companhias, das familiaridades com os ímpios e hereges, dos divertimentos e recreações em que correm risco as suas crenças religiosas, e, em uma palavra, dos espetáculos em que se zomba da Religião e dos seus ministros.

40. Todos os católicos se abstenham da superstição e das maldades do espiritismo $[\ldots]{ }^{480}$

Tentativa, entre tantas, de submeter as manifestações do catolicismo lusobrasileiro aos ditames da Igreja, a Pastoral de 1910 procura regular, e trazer para o seio da ortodoxia, os pontos nevrálgicos de uma religiosidade onde tudo era pretexto para festa, inclusive a morte. Regulava-se, entre outros pontos, os enterros, as

479 ACDT. Aviso n. ${ }^{\circ}$ 24. 16 de março de 1910.

480 Pastoral Coletiva dos Senhores Arcebispos e Bispos das Províncias Eclesiásticas de S. Sebastião do Rio de Janeiro, Mariana, São Paulo, Cuiabá e Porto Alegre comunicando ao clero e aos fiéis o resultado das Conferências dos mesmos realizadas na cidade de São Paulo de 25 de setembro a 10 de outubro de 1910. Rio de Janeiro: Tipografia Leuzinger, 1911. Doravante denominada Pastoral Coletiva de 1910. 
procissões, os oratórios, capelas e música nas igrejas, para citar alguns.

Sobre as festas religiosas, por exemplo, deveriam elas seguir modelo de virtude, onde estaria presente a oportunidade das práticas espirituais, estando condenados a preferência pelos comportamentos inconvenientes, dentre eles as danças e a embriaguez:

554. Com muito maior razão, os fiéis deverão evitar os pecados que não somente afastam o entendimento do afeto as coisas divinas, senão também nos separam completamente do amor de Deus. Reprovamos, portanto, a desídia dos que pensam que os domingos e dias de festa são destinados para o ócio e para os divertimentos, e, por isso, em vez de se aplicarem as práticas espirituais, se entregam somente aos espetáculos profanos, ao jogo e aos vícios, danças e embriaguez, e, abandonando os deveres de cristão, mancham sua alma e provocam a ira de Deus. ${ }^{481}$

Restringir a organização das festas ao corpo eclesiástico, afastando assim a influência laica das mesmas, é um dos objetivos constantes reforçados no parágrafo seguinte. Remover das comemorações os "espetáculos profanos" também foi ponto de ordem, procurando-se em todos os aspectos religiosos apenas um paradigma, qual seja, o modelo ultramontano de disciplina, de edificação espiritual e de obediência à Igreja:

556. Promovam os Rev. ${ }^{\text {mos }}$ Párocos, com todo o empenho, a instituição e desenvolvimento de associações pias que tenham por fim por em prática a observância dos dias de festa com verdadeira piedade, e facultar o descanso devido aos operários nos dias de preceito. Quanto for possível, removam os escândalos e espetáculos profanos que os provoquem, e induzam os fiéis a evitar os excessos de bebidas e danças, agradáveis aos homens sensuais e esquecidos de seus destinos eternos. ${ }^{\mathbf{4 8 2}}$

O bispo de Taubaté, logo após a publicação da Pastoral Coletiva de 1910, passou, quando era o caso, a enquadrar suas ordens em consonância com o documento. Lembrando, por exemplo, os procedimentos que deveriam tomar os párocos em relação aos dias de jejum e abstinência, o "Mandamento" veio acompanhado do devido 'amparo legal': "Nota - A instrução do Ex. ${ }^{\text {mo }}$ Episcopado encontra-se na Pastoral Coletiva de 1910, Apêndice XLV. no 'Ordo Divini Offici'." 483

Não obstante as lides administrativas de D. Epaminondas, sua preocupação 
em percorrer toda a extensão de sua diocese será logo retomada:

Visita Pastoral. «De ordem do Ex. ${ }^{\mathrm{mo}}$ Sr. Bispo Diocesano aviso aos Rev. ${ }^{\text {mos }}$ Párocos, cujas freguesias ainda não foram visitadas, que a Ex. ${ }^{a}$ pretende concluir este ano a Visita Pastoral a todas as paróquias não visitadas, devendo, portanto, dispor desde já os fiéis de suas respectivas freguesias para receberem com frutos a graça da Santa Visita. O mesmo Prelado deseja, quanto possível, que sua hospedagem, além da mais singela, seja perto da Matriz, para facilidade dos trabalhos da Visita e que se transfiram para outro tempo as festividades que costumam fazer anualmente nas Paróquias, afim de não se alterar a ordem da Visita. Taubaté, 17 de abril de 1911. Pe. José Alves de Moura, Secretário do Bispado. ${ }^{484}$

A ausência de D. Epaminondas, no entanto, não significava sua exclusão nos assuntos da diocese. Por meio de cartas, o bispo prosseguia em suas ordens, ${ }^{485}$ enquanto que, por sua vez, outras recomendações eram exaradas, na sua ausência, pelo Vigário Geral.

Não obstante os já conhecidos desentendimentos pontuais com D. Duarte, o processo romanizador prosseguia em seu curso, e ambos os prelados, quando necessário, uniam forças. A arquidiocese de São Paulo, em combate ao dono do jornal 'Luz de Aparecida', Cônego Antônio Marques Henriques, padre suspenso de ordens e tido como "lobo em pele de ovelha", desfechou furiosa campanha contra o mesmo, em claro apoio aos redentoristas e ao jornal oficial 'Santuário de Aparecida'. Mesmo não se podendo negar que a 'Luz de Aparecida', em momentos iniciais, tivesse tido grande peso na divulgação do Santuário, o monopólio do sagrado estava em jogo, e a diocese de Taubaté acompanhou D. Duarte:

O Ex. ${ }^{\text {mo }}$ Sr. Bispo Diocesano ordena a todos os Rev. ${ }^{\text {mos }}$ Vigários deste bispado que, na missa do primeiro domingo após o seu recebimento, leiam e expliquem aos fiéis de suas paróquias o «Edital» do Secretário do Arcebispado de São Paulo, estampado nesta folha, com referência ao jornal «Luz da Aparecida», que se publica naquela paróquia. Depois de explicarem aos seus paroquianos, afixem-no na porta da matriz Taubaté, 4 de junho de 1911. Pe. José Alves de Moura, Secretário do Bispado.

Segue o Edital:

De ordem do Ex. ${ }^{\text {mo }}$ Sr. Arcebispo Metropolitano, faço publico que o único jornal aprovado pela Autoridade Eclesiástica que se publica na Basílica de N.S. Aparecida, é o semanário intitulado «Santuário de Aparecida», e como tal é o único que pode merecer apoio, confiança e proteção dos fiéis devotos de

484 ACDT. Aviso n. ${ }^{\circ} 35.17$ de abril de 1911.

485 ACDT. Circular n. ${ }^{\circ}$. Piquete, em visita pastoral, aos 19 de maio de 1911. 
N. Senhora. O jornal intitulado «Luz de Aparecida», do qual se diz redator e proprietário um certo cônego há longos anos suspenso de todas as suas ordens, não tem e nunca teve nenhum apoio ou aprovação da Autoridade Eclesiástica, nem está absolutamente autorizado a receber esmolas ou intenções de Missas destinadas à Basílica de Aparecida, as quais deverão ser remetidas diretamente ao Vigário ou ao tesoureiro, para que hajam certeza de serem satisfeitas as piedosas instituições dos devotos. O Rev. ${ }^{\text {mo }}$ Vigário da Basílica fará distribuir um avulso o presente edital para todos os Rev. ${ }^{\text {mos }}$ Vigários desta Arquidiocese e de outras Dioceses do Brasil, para que se dignem tomar as providências que lhes inspirar a devoção a N. Senhora. São Paulo, 20 de maio de 1911. O Secretário do Arcebispo. C. G. de Oliveira. ${ }^{486}$

Augustin Wernet, ao analisar a resistência imposta aos redentoristas pelo referido cônego, afirma que a atuação do mesmo "contribuiu indiscutivelmente para que o Padre Wiggermann e os padres Redentoristas tomassem a resolução de fundar um jornal que fosse o órgão representativo do Santuário: o 'Santuário de Aparecida', cujo primeiro número saiu a 10 de novembro daquele ano." ${ }^{487}$

O catolicismo luso-brasileiro foi pródigo na ereção de capelas. Construídas por particulares, ou mesmo por comunidades, visavam não só a aproximação dos fiéis ao santo de devoção, mas também a minorar a ausência ou a grande distância das igrejas.

O viajante Saint-Hilaire não se descuidou de observar o gosto bem brasileiro de "construir o sagrado", apesar de toda e qualquer dificuldade:

A mãe do proprietário de Itaqué foi quem, apesar de muito pobre, fez construir a grande capela [...] Essa senhora, querendo assegurar, tanto quanto possível, a duração da capela, fez, ao morrer, o legado de uma pastagem, para com o seu rendimento garantir a conservação e manutenção da mesma... ${ }^{488}$

Agassiz, mais emocionado que Saint-Hilaire, afirmou:

Nenhuma igreja das nossas cidades, cuja construção haja custado milhões, pode comover como essa pequenina capela, obra da fé sincera, saída das próprias mãos dos fiéis, com as suas paredes de barro cobertas de pinturas infantis, sua torre coberta de palha e uma cruz de madeira no átrio. ${ }^{489}$

Eduardo Etzel, por sua vez, observa que:

486 ACDT. Aviso n. ${ }^{\circ}$ 39. 20 de maio de 1911.

487 WERNET, Augustin. Os redentoristas no Brasil. v.1. Aparecida: Santuário, 1995. p. 94.

488 SAINT-HILAIRE, Auguste de. Viagem à Província de São Paulo. São Paulo: Martins Editora - Ed. USP, 1972. pp. 203-204.

489 AGASSIZ, Jean Louis Rodolphe e AGASSIZ, Elizabeth Cabot Cary. Viagem ao Brasil (1865 1866). São Paulo: Companhia Editora Nacional, 1938. p. 387. 
a fundação de capelas continua até nossos tempos. Pode-se observar, na zona rural do Vale do Paraíba, inúmeras capelinhas toscas que abrigavam até poucos anos e, excepcionalmente, em nossos dias, os humildes caboclos, que lá se reuniam para suas rezas de pitoresco cantar. ${ }^{490}$

Essas capelinhas, "indícios da função integradora da religião" ${ }^{491}$ e local de reunião de devotos onde um leigo "puxava a reza", em virtude da própria ausência de padres, são elementos que também reforçam os aspectos característicos do catolicismo luso-brasileiro.

Os bispos romanizadores, todavia, imbuídos "no espírito clerical de ampliar sempre mais o domínio sobre tudo o que se refere ao culto", 492 não reconheciam como espaços sagrados as capelas que não obtivessem autorização de funcionamento, autorização essa denominada de 'provisão'.

De ordem de S. Ex. ${ }^{\text {a }}$ Rev. ${ }^{\text {ma }}$ o Sr. Bispo Diocesano, faço ciente aos Rev. ${ }^{\text {mos }}$ párocos e outros sacerdotes que é expressamente proibida a celebração de qualquer ato em suas capelas não provisionadas. Taubaté, 4 de julho de 1911. Pe. José Alves de Moura, Secretário do Bispado. ${ }^{493}$

A mão do bispo a tudo alcança, afinal "não é verdade que, ausente pela enfermidade, e retido em seu Palácio, sentíamos no entanto a presença de $D$. Epaminondas em qualquer recanto da Diocese?" 494 e a disciplina do clero continua a não ser esquecida. Afinal, além de possuírem jurisdição ordinária, e "autoridade plena e independente do todo o poder humano", cabe também aos bispos "ditar leis que liguem as consciências e regulem a disciplina exterior, e refrear os extravios e contumácia dos rebeldes com penas salutares". : ${ }^{495}$

De ordem do Ex. ${ }^{\text {mo }}$ Sr. Bispo Diocesano aviso ao Rev. ${ }^{\text {mo }}$ Clero secular e regular desta Diocese, aos fiéis, bem como aos Sr. zeladores de capela; que o Rev. ${ }^{\mathrm{mo}} \mathrm{Pe}$. Alino Petibon, ex-vigário de Santo Antônio do Pinhal, está sem uso de ordens nesta Diocese, na qual não pode, por conseguinte, exercer ato algum de jurisdição eclesiástica. ${ }^{496}$

Em 1912 inaugura-se o primeiro retiro espiritual do clero, onde D.

490 ETZEL, Eduardo. Imagens Religiosas de São Paulo. São Paulo: Melhoramentos - USP, 1971. p. 49.

491 WERNET, Augustin. A Igreja paulista no século XIX. São Paulo: Ática, 1987. p. 25.

492 AZZI, Riolando. O episcopado do Brasil frente ao catolicismo popular. Petrópolis: Vozes, 1977. p. 21.

493 ACDT. Aviso n. ${ }^{\circ} 42.4$ de julho de 1911.

494 BRANDÃO, Ascânio da Cunha. Dom Epaminondas. São Paulo: Oficinas gráficas da Ave Maria, 1941. p. 7.

495 Pastoral Coletiva de 1910. n. ${ }^{\circ} 803$.

496 ACDT. Circular n. ${ }^{\circ}$ 6. 13 de novembro de 1911. 
Epaminondas "convoca, sub gravi, para o referido Retiro a todos e a cada um dos Rev. $^{\text {mos }}$ Sacerdotes abaixo mencionados, devendo todos se acharem no nosso seminário no dia e hora acima determinados", lembrando-lhes que tragam consigo sobrepeliz, estola, barrete e os livros religiosos de que hão de precisar, e que nenhuma dispensa do Retiro será concedida, a ser em caso excepcional e por motivo grave, "a juízo da Autoridade Diocesana". 497

Regulando detalhadamente o passo de cada atividade, é ordenado aos vigários que as bandas de música não podem tocar no interior das igrejas, e "os Rev. ${ }^{\text {mos }}$ párocos deverão obstar a transgressão desta lei, que é grave", enquanto que as romarias só podem ser feitas com licença da autoridade diocesana, com programa previamente aprovado pela mesma, "sob a direção espiritual do Vigário da paróquia e com espírito verdadeiramente cristão". 498 As irmandades são lembradas que, por ocasião da Visita Pastoral às paróquias, faltou escrituração regular e legal nos livros de contas, "defeito que nos corre o grave dever de corrigir, por se tratar de matéria de suma importância e até de interesse dos próprios fiéis encarregados de tal serviço, pois tratamos de pôr ao abrigo de qualquer censura a sua própria honorabilidade". A partir de então, toda irmandade, ou associação religiosa, deveria

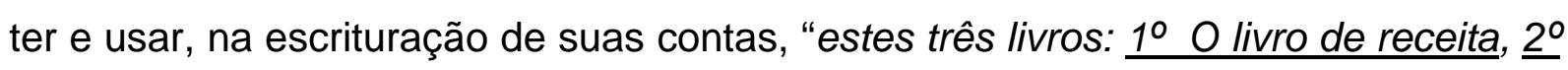
O livro de despesas, $3^{\circ}$ O livro de receita e despesa". ${ }^{499}$ (os grifos são deles)

Dando a parecer que o retiro espiritual do clero não agradou a muitos, para o Bispo também nos é dado que as contrariedades não mereceram, de sua parte, maiores preocupações, e "usando da forma invitatória, em vez da imperativa (que tínhamos o direito de empregar) convocamos o Rev. ${ }^{\text {mo }}$ Clero desta Diocese para o $2^{\circ}$ retiro espiritual, que se abrirá, do dia 13 do corrente mês, no prédio do nosso seminário".

O prelado, no entanto, aproveitou o momento e, em face dos muitos pedidos de dispensas, "contra o que nos era dado esperar de sacerdotes, em cujos corações deve arder mais do que nos dos simples fiéis, o zelo pela sua própria santificação", pedidos estes, na visão do bispo, baseados em razões sem maior fundamento diante de sua consciência, firmou sua determinação e autoridade:

É o que nos leva a dirigir a todo o Rev. ${ }^{\text {mo }}$ clero diocesano mais esta Carta Circular, pela qual intimamos a todos e a cada um

497 ACDT. Aviso n. ${ }^{\circ} 49.15$ de janeiro de 1912.

498 ACDT. Aviso n. ${ }^{\circ} 62.5$ de agosto de 1912.

499 ACDT. Circular n. ${ }^{0}$ 19. s.d. 
dos Rev. ${ }^{\text {mos }}$ Sacerdotes, por nós antes convidados, a comparecerem aqui no dia 13 do corrente mês, às 6 horas da tarde, sob as seguintes penas: $1^{\mathrm{a}}$ - de suspensão, ipso facto, no caso do não cumprimento desta determinação; $2^{\mathrm{a}}$ obrigação de fazer, em nosso seminário, dez dias completos de retiro, para que the seja levantada a referida censura. Esperando que $\mathrm{V}$. Rev. ${ }^{\text {ma }}$ tome na devida consideração a gravidade do assunto em questão, subscrevemo-nos com sincera estima e apreço. De V. Rev. ${ }^{\text {ma }}$ humilde servo e amigo obrigado + Epaminondas, Bispo de Taubaté. ${ }^{\mathbf{5 0 0}}$

Em 1914, já escaldado na matéria, o bispo, após suas "saudações afetuosas, bênçãos e votos de felicidades", anuncia o terceiro retiro espiritual do clero, "para o qual é V. Rev. ma novamente e de modo mais direto convocado. Tratando-se de obra de tamanha importância e gravidade, é inútil dizer que serei mui severo em admitir escusas nesta matéria, a que se prendem os mais caros interesses do clero e da Igreja." ${ }^{501}$ (os grifos são deles)

D. Epaminondas será pertinaz repressor das festas da Santa Cruz e de outras manifestações de fé heterodoxas às normas ultramontanas, procurando, de forma burocrática, sanear o espaço urbano de atividades religiosas que insistam em fugir do monopólio do sagrado, limitando-as, quando muito, ao espaço rural.

Com os exploradores de credulidade popular, os feiticeiros, e as falsas santas e eremitas de Santa Cruz da beira de estrada, era inexorável. Cortava abusos pela raiz. E tudo conseguia. E era obedecido. Ninguém mais destemido ao pregar a verdade. ${ }^{\mathbf{5 0 2}}$

Se o espaço urbano é severamente vigiado, procurando-se com isso, a manutenção da ortodoxia católica, nem por isso o espaço rural é descurado, posto que o bispo era veemente em determinar ao clero visitas paroquiais aos camponeses. ${ }^{\mathbf{5 0 3}}$ Uma pequena incursão em seu "Memorial de avisos, ensinamentos e advertências que, com proveito, poderão os reverendíssimos párocos dar aos fiéis camponeses, assim como bens que, frutuosamente, Ihes poderão dispensar" é bastante para verificar o rigor na matéria:

$14^{\mathrm{a}}$ - Regularizar e sanear as tais capelinhas de Santa Cruz das beiras de estradas, que são o teatro freqüente de embriaguez, jogos, danças, brigas, explorações sacrílegas e mil crimes, como a experiência e as estatísticas o confirmam.

500 ACDT. Carta Circular de Dom Epaminondas. 1 de janeiro de 1913.

501 ACDT. Circular n. ${ }^{\circ} 28.5$ de janeiro de 1914.

502 BRANDÃO, Ascânio da Cunha. Dom Epaminondas. São Paulo: Oficinas gráficas da Ave Maria, 1941. p. 111.

503 ACDT. Circular n. ${ }^{\circ} 29.20$ de fevereiro de 1914. 
Apontado o problema, D. Epaminondas também determina o remédio:

Para consegui-lo ajudarão as medidas seguintes: a) impedir novas edificações, fazendo valer as leis da Igreja; b) nomear para cada uma pessoa de toda seriedade, c) exigir a prestação manual de contas, como é de lei; [...]

É bem nítida, no constante da letra "d", a abordagem romanizadora em relação àquilo que se pode denominar de "caráter clerical". Em outras palavras, a "condução do sagrado" deveria ser apanágio exclusivo do padre romanizado. Cumpria, pois, afastar os leigos dos processos decisórios referentes às atividades religiosas, diminuindo com isso sua independência tão comum às lides devocionais advindas do catolicismo luso-brasileiro.

d) proibir festas e devoções, em que haja abusos e sem a presença do pároco ou de um delegado seu;

A ação repressora do Estado também se torna válida quando se trata do monopólio do sagrado,...

e) pedir o auxílio das autoridades civis e policiais para a eliminação dos abusos;

...assim como a ação repressiva contra as bebidas:

f) impedir a venda de bebidas alcoólicas nas proximidades das mesmas;

Por último, o apelo à burocracia:

g) providenciar o provisionamento das que estiverem em condições canônicas; $h$ ) exigir a escritura de doação do terreno em que estão edificadas, etc., etc. ${ }^{504}$

O ano de 1914 é particularmente especial. Em termos de completar cinco anos de episcopado, D. Epaminondas, em cumprimento às determinações da Santa Sé, envia seu relatório qüinqüenal, o já citado Relatório Ad Limina Apostolorum. Nele, a obediência de um bispo perante o papa, uma vez que o Sumo pontífice "tem pleníssimos poderes sobre as ovelhas e cordeiros, sobre os bispos e fiéis". 505

Beatíssimo Padre,

O Bispo de Taubaté, prostrado humildemente aos pés de Vossa Santidade, e rogando suplicemente a bênção apostólica, de acordo com a norma do Decreto editado pela Sagrada Congregação Consistorial, do dia 31 de dezembro de 1909, pede permissão para apresentar a Vossa Santidade a presente

504 ACDT. Memorial de avisos, ensinamentos e advertências que, com proveito, poderão os reverendíssimos párocos dar aos fiéis camponeses, assim como bens que, frutuosamente, Ihes poderão dispensar. 5 de outubro de 1914.

505 Pastoral Coletiva de 1910. n. ${ }^{\circ} 790$. 
Relação sobre o estado da Diocese de Taubaté, à sua indignidade confiada por vossa Benevolência. Antes, porém, de passar à exposição das coisas que devem ser relatadas...

A pobreza da diocese não foi esquecida, bem como não foi omitido, pelo prelado, seu estado de saúde. O relatório foi, portanto, apresentado por um procurador. Fica patente, também, que o relatório deveria seguir um modelo de perguntas preestabelecidas:

...declara reverentemente que, em razão de sua enfermidade e pobreza da Diocese, obteve da Sagrada Congregação Consistorial, por meio do Ilustríssimo e Reverendíssimo Núncio Apostólico no Brasil, a dispensa de ir pessoalmente às portas dos Apóstolos e a permissão para apresentar a Vossa Santidade a presente Relação por meio de Procurador, por si eleito, como consta de documento anexado. Anteposto isso, passa ao estado da Diocese de Taubaté, seguindo, enquanto possível, as normas da predita Sagrada Congregação Consistorial. ${ }^{506}$

A apresentação da diocese é otimista, e os prognósticos, favoráveis...

É geralmente boa a condição religiosa e moral da Diocese. A fé cresce de dia em dia; a freqüência aos sacramentos, maximamente à Eucaristia e à penitência, aumenta; as pias uniões, obras de caridade, confrarias, irmandades, os colégios católicos e outras obras semelhantes aos poucos se multiplicam e se mantêm prosperamente. Igualmente parece melhor a condição moral.

...não fosse a ação do espiritismo, - que o bispo fez questão de sublinhar do cinema, dos trajes tidos como indecentes, da escola laica, e da educação dada às crianças. A ação moralizadora do ultramontanismo a tudo abarcava, fazendo-nos lembrar Rui Barbosa, em sua interminável introdução d"O Papa e o Concílio', obra de autoria de Johann Joseph Ignaz Döllinger, na qual Rui, tradutor, sintetiza o pensamento de reação à Igreja ao afirmar que "a verdade portanto a respeito do catolicismo ortodoxo, na idade corrente, é que todas as liberdades, populares, individuais, políticas e civis estão por ele, sem exceção, nem reserva, nem atenuante, absolutamente condenadas." 507

Não se pode, contudo, esconder o grande dano que é dado às almas pela seita chamada espiritismo, pelas más exibições cinematográficas, pelos trajes indecentes, pela escola laica e

506 ACDT. Relatório Ad Limina de D. Epaminondas. 1914. pp. 1-2. Doravante denominado de Relatório Ad Limina.

507 BARBOSA, Rui (tradutor e prefaciador) In: O Papa e o Concílio. Obras Completas de Rui Barbosa. V. IV. Rio de Janeiro. Ministério da Educação e Cultura/ Fundação Casa de Rui Barbosa. 1977. p. 249. 
pela grande relaxação dos pais na educação dos filhos. ${ }^{508}$

O relatório nos informa a extensão de $20.000 \mathrm{~km}^{2}$ da diocese, bem como o número de 400.000 habitantes, "em sua quase totalidade católicos do rito latino romano, pouquíssimos, porém, do rito oriental". Os espíritas, os protestantes, e os maçons, por sua vez, fazem parte das preocupações de D. Epaminondas, uma vez que "em diversas paróquias, encontram-se vários hereges, maximamente das seitas chamadas espiritismo, protestantismo e maçonaria." ${ }^{509}$ (o grifo é deles)

Sobre si, D. Epaminondas relata que a casa onde tem residência é propriedade da Diocese, não aparentando luxo, "e embora modestíssima, é de tal modo aparelhada que convém à dignidade do Ordinário". Frisa também que sempre morou com pessoas do sexo masculino, portadores de prudência e integridade de costumes, mas, ultimamente, sobrevindo-lhe "grave e diuturna enfermidade", tem consigo a irmã e filhas da irmã, "que são dotadas de modéstia e bons costumes". 510

Sobre o clero sob suas ordens, D. Epaminondas informa sobre a suspensão para o sacerdote que celebra o sacrifício da missa com vinho adquirido em tavernas, não empregando cuidado em relação à sua legitimidade, bem como que, gozando de forças e de idade juvenil, nenhum padre vive ocioso na diocese, e estão adscritos ao serviço da Igreja, "com exceção de um, o qual, em razão de público concubinato, permanece privado do uso de suas ordens. Para a emenda do mesmo, ó dor!, toda diligência do Ordinário se tornou inútil". ${ }^{511}$

Os Avisos, Editais e demais documentos, em virtude da riqueza de detalhes por eles apontados, demonstram um bispo diligente e bem informado sobre o andamento de sua diocese. Parece, portanto, que a dor manifestada por D. Epaminondas em relação ao público concubinato de um membro de seu clero se estendia a outros tantos mais discretos, ainda que os mesmos, verdade seja dita, não lessem nem livros, nem jornais irreligiosos...

Sobre algum sacerdotes que levam vida menos honesta, fora o supramencionado, não me consta, nem a respeito de violação da lei sobre o que deve ser observado e evitado na satisfação das Missas manuais. Igualmente, abstêm-se da leitura de livros e jornais irreligiosos e ímpios.

O bispo, entretanto, mesmo acusando a fraqueza de sua saúde, não

508 ACDT. Relatório Ad Limina. 1914. p. 2.

509 ACDT. Relatório Ad Limina. 1914. p. 2.

510 ACDT. Relatório Ad Limina. 1914. p. 6.

511 ACDT. Relatório Ad Limina. 1914. p. 13. 
poupava esforços disciplinares, já que "para a correção salutar dos caídos, digo, houve admoestações, conselhos e exercícios espirituais anualmente." ${ }^{512}$

Sobre as paróquias D. Epaminondas declara que nem todas são providas de seu próprio pastor; há oito que são regidas pelos párocos mais próximos, quer por falta de clero, quer pela pobreza das mesmas. Segundo o bispo, os párocos, em geral, são prestativos em ouvir as confissões e distribuir a sagrada Eucaristia, mas nem sempre na assistência aos enfermos, sobretudo na visita deles e em ministrar o viático àqueles que moram no campo. E quanto às pessoas de diverso sexo que entram ou freqüentam as casas paroquiais, em geral são observadas as leis canônicas acerca dessa matéria; "e se às vezes consta da existência de algum abuso, o Ordinário procede contra os réus segundo as leis canônicas." ${ }^{513}$

O seminário diocesano recebe especial atenção. Ressaltando a pobreza da diocese, afirma o prelado que as rendas do estabelecimento são incertas, fora aquelas provenientes de alguma pia associação diocesana, e procedem das pensões de alguns, dos estipêndios das missas pelo povo e de alguma taxa sobre algumas paróquias da Diocese. A pensão anual de setenta libras de alunos ricos e as rendas supramencionadas auxiliam no sustento dos alunos pobres. Sobre os padres que ali professam, "todos satisfazem dignamente ao ofício comissionado e instruem os alunos em disciplina e piedade". ${ }^{514}$

Os estudos eclesiásticos na primeira metade do século XX no Brasil, e aqui certamente se localizam os que D. Epaminondas estabelece no seminário por ele fundado, são marcados pela orientação que o papa Leão XIII (20/02/1878 a 20/07/1903) desejou imprimir à formação do clero, sobretudo o diocesano, quando, pela encíclica Aeterni Patris (de 4 de agosto de 1879), estimulou e apoiou todas as iniciativas que voltassem à recuperação do pensamento deste Doutor da Igreja. Leão XIII, portanto,

Instituiu a Academia de São Tomás, em Roma, importou os mais célebres teólogos, filósofos e analistas de textos e encorajou o desenvolvimento dos estudos tomísticos na Universidade Católica de Louvain. A partir de 1882, o futuro cardeal Mercier foi nomeado para fazer preleções sobre São Tomás em Louvain, e suas aulas tornaram-se o centro de um renascimento teológico na universidade e fora dela. ${ }^{\mathbf{5 1 5}}$

512 ACDT. Relatório Ad Limina. 1914. p. 13.

513 ACDT. Relatório Ad Limina. 1914. p. 15.

514 ACDT. Relatório Ad Limina. 1914. p. 18.

515 DUFFY, Eamon. Santos \& Pecadores - História dos Papas. São Paulo: Cosac \& Naify Edições Ltda. 1998. p. 241. 
O primeiro cuidado ou atenção devia ser posto, necessariamente, na formação do clero nos seminários. Nesse sentido, induziu-se, para não se dizer, estabeleceu-se o uso de manuais que proporcionassem o conhecimento e as "convicções teológicas" ad mentem Sancti Thomae, ou seja, de acordo com a leitura que se tornara oficial dos textos e doutrina de Santo Tomás de Aquino. Leão XIII, e os papas posteriores, privilegiam a publicação e a leitura das obras de Santo Tomás (veja-se a famosa "edição leonina" de todo o corpus thomisticum), o surgimento de academias teológicas sob o selo de Santo Tomás, revistas e até Institutos de pesquisa, que se dão como objetivo sua "redescoberta". Nasce assim o "neotomismo", também conhecido como "Neo-Escolástica", numa rememoração do que fora o modelo medieval de estudos eclesiásticos.

Nesse cenário, adotam-se por toda parte, inclusive no Brasil, autores que, em geral professores de seminários, conseguiram confeccionar, para as diversas matérias do ensino dos seminários maiores, textos resumidos e práticos que possibilitassem aos seminaristas o conhecimento "básico" em teologia dogmática, teologia moral e teologia bíblica. Por sua natureza, eram textos que evitavam áreas controversas, limitando-se à ortodoxia e àquilo que podia constituir o instrumental conceitual indispensável dos pastores de almas.

Entre nós ficaram famosos, e perdurou seu uso até a segunda metade do século XX, os manuais de Noldin, S.J. (teologia moral), Tanquerey, S.S (teologia dogmática e ascética e mística) e Tiago Sinibaldi (filosofia). ${ }^{516}$

516 Hieronymus Noldin (1838-1922), jesuíta, foi professor na Universidade de Innsbruck e escreveu uma Summa Theologiae Moralis juxta Codicem luris Canonici (Suma de Teologia Moral, de acordo com o Código de Direito Canônico), De Principiis Theologiae Moralis (Sobre os princípios da Teologia moral) e um De Sexto Praecepto et de usu Matrimonii (Sobre o Sexto mandamento e o uso de Matrimônio). Há quem o critique por abrigar em sua teologia moral a tese da guerra justa, mas, sobretudo, por tornar a moralidade demasiado ligada à legalidade canônica, descaracterizando a essencial nota da moralidade, que é a liberdade e autonomia da vontade humana. Quanto ao tratamento que dá à sexualidade, seu manual é fortemente casuístico, inclinando-se para o rigorismo. Seus textos latinos não foram traduzidos para o português, segundo consta. Conserva-se na Biblioteca da Faculdade Dehoniana, de Taubaté, exemplar da Summa pertencente ao acervo de D. Epaminondas e por esse autografado. Adolphe Tanquerey (1854-1932), sulpiciano, lecionou em Nantes, Rodez e por fim em Baltimore. Foi muito apreciada sua Synopsis Theologiae Dogmaticae (Elementos de Teologia Dogmática) e o Précis de Theologie ascétique et mystique, que conheceu enorme fortuna, sendo traduzido até para o árabe. Suas obras são marcadas por qualidades pedagógicas e espírito prático, simplicidade de expressão e, como foi dito, intenção de passar ao estudante a doutrina comumente aceita, evitando pontos controvertidos. A tendência conciliadora atraiu-Ihe a reprimenda de não ser um tomista rigoroso; a preocupação com a clareza ditou-lhe divisões bem definidas dos temas, mas levou-o a perder de vista, às vezes, a unidade e complexidade da vida espiritual. Tiago Sinibaldi é como ficou conhecido entre nós o italiano Giacomo Sinibaldi (1856-1928), padre romano, indicado por Cornoldi para lecionar a filosofia escolástica, introduzida, logo após a Aeterni Patris, no Seminário de Coimbra. Ali o Padre Sinibaldi leciona a partir de 1886 e compõe, em língua latina, suas Praelectiones Philosophiae Christianae ad mentem S. 
Os especialistas em Santo Tomás de Aquino muitas vezes criticaram a superficialidade desses manuais, e de não serem demasiado fiéis aos escritos do Doutor Angélico.

Malgrado as críticas, foram esses manuais muito úteis para o propósito que se tinha em vista, e para o público a que eram endereçados. O seminário de D. Epaminondas, pelo que se pode verificar, os utilizava:

O Curso Filosófico consta de dois anos e o Teológico de quatro íntegros, completando cada ano escolástico dez meses. - O texto filosófico, em língua vernácula, é lido do Compendium Philosphiae de Jacob Sinibaldi, de Teologia Dogmática Ad. Tanquerey. SS. E moral H. Noldin S.J. Além das mencionadas, são ensinadas as seguintes disciplinas complementares: Direito Canônico, S. Escritura, Eloqüência sagrada, Cerimônias Sacras ou Liturgia, Canto Gregoriano, Língua hebraica e História Eclesiástica. Dão-se aos estudos de humanidades por seis anos, e perfazem as seguintes disciplinas: língua latina, grega, italiana, inglesa, francesa e vulgar; matemática, história profana, ciências físicas ou naturais, geografia, história pátria, história sagrada e Doutrina Cristã. ${ }^{517}$

Impregnando de sacralidade o espaço leigo citadino por meio de diversas ações romanizadoras, aí incluídas as inúmeras procissões que marcavam o calendário católico, terminou o clero romanizado por estabelecer um cinturão de ortodoxia religiosa branca e de classe média no núcleo urbano.

O espaço rururbano, por seu turno, pobre e camponês, e que tinha como divisa a estrada de ferro, ainda resistiria com suas festas de Santa Cruz e demais manifestações do catolicismo luso-brasileiro. As camadas sociais mais pobres, e certamente menos voltadas aos comentários sobre suas vidas particulares, resolviam suas pendências matrimoniais e amorosas de modo mais prático:

Abuso principal contra a santidade do matrimônio, que o mais das vezes da parte dos homens, é a infidelidade dos cônjuges e o divórcio quanto à habitação, o que freqüentemente se dá

Thomae Aquinatis (Coimbra, 1889) (Preleções de Filosofia Cristã segundo o espírito de Santo Tomás de Aquino), seguidas dos Elementos de Filosofia 2 volumes: Coimbra, 1891-1892). Fez parte da Academia de Santo Tomás, fundada em Coimbra em 1881. O manual de Sinibaldi foi muito usado no Brasil não apenas nos seminários, mas nas Academias de Direito, responsabilizando-se em larga medida pelo neotomismo brasileiro até a década de 50 do século XX. Como Tanquerey, era um autor extremamente didático, esquemático e simplificado (em alguns seminários foi sendo substituído por outros autores mais "profundos", como Joseph Gredt, Maritain, Maréchal, à medida que avançava o século XX). Sobre o tema encaminho o leitor a CAMPOS, Fernando Arruda. Tomismo no Brasil. São Paulo: Paulus, 1998; GRABMANN, Martín. Historia de la Teologia Católica. Desde fines de la era patristica hasta nuestros dias. Tradução espanhola de P. David Gutiérrez. Madrid: Espasa-Calpe, 1946. NOYE, Irénée. Tanquerey (Adolphe). In: Dictionnaire de Spiritualité ascetique et mystique. Doctrine et histoire. Paris: Beauchesne, 1990 (Fasc. XCVI-XCVII-XCVIII). p. 26-27.

517 ACDT. Relatório Ad Limina. 1914. p. 20. 


\section{nas paróquias junto à linha férrea. ${ }^{518}$ (o grifo é nosso)/}

Retornando mais detalhadamente na questão das "heresias", o bispo afirma que em cinco paróquias da diocese está presente "a seita secreta dos maçons", e dispersos por algumas outras alguns deles. O protestantismo sustenta algumas casas em cerca de sete paróquias e tenta a propagação em outras, enquanto que "nada consta do socialismo".

Entre as seitas que dano maior fazem às almas, o espiritismo agora é a pior e propaga-se celeremente, sobretudo nas paróquias que tem vias de comunicação fáceis. Contra todas as seitas são avisados os fiéis e ensinados pela pregação, pelas boas publicações nos jornais etc. ${ }^{\mathbf{5 1 9}}$

A política nacional não poderia estar ausente das observações do prelado, ao afirmar que os católicos, "em geral e miseravelmente" não se preocupam com as qualidades religiosas ou morais dos candidatos aos ofícios políticos, mas, sobretudo, estimam as circunstâncias de parentesco, amizade, ligação política etc., encerrando com uma observação clara à conhecida "política dos governadores": "E portanto é grande a dificuldade de melhora nesta matéria, pois os sufrágios de fato não têm realidade; o Estado ou Governo conhece e recebe os que quer como eleitos". ${ }^{520}$ (o grifo é deles)

Em termos de política externa, a romanização criava diversas obrigações aos prelados, "dentre elas o pronto atendimento às demandas pecuniárias pontifícias, a veiculação das disposições da Santa Sé em quaisquer matérias envolvendo os interesses da Igreja", ${ }^{521}$ além da própria regularidade no envio dos relatórios e nas visitas ao papa, reforçando, assim, as ligações entre os prelados e os diversos grupos de poder da Santa Sé. É preciso, portanto, prestar contas das coletas destinadas à Santa Sé:

Com módico resultado, fazem-se na Diocese pias coletas de esmolas que foram prescritas pela Santa Sé ou recomendadas, embora de sua necessidade e obrigação tenha falado o Ordinário Diocesano. ${ }^{\mathbf{5 2 2}}$

Quatro vezes no ano, fazem-se coletas especiais pelas necessidades da Diocese, mas pouco adiantam. ${ }^{\mathbf{5 2 3}}$

518 ACDT. Relatório Ad Limina. 1914. p. 22.

519 ACDT. Relatório Ad Limina. 1914. p. 23

520 ACDT. Relatório Ad Limina. 1914. p. 23.

521 MICELI, Sérgio. A elite eclesiástica brasileira. Rio de Janeiro: Bertrand Brasil, 1988. p. 138.

522 ACDT. Relatório Ad Limina. 1914. p. 25.

523 ACDT. Relatório Ad Limina. 1914. p. 25. 
D. Epaminondas encerra o documento. Nenhuma palavra sobre as questões Wanderley e Aparecida:

E são estas, Beatíssimo Padre, as coisas a relatar, que por ouvir dizer e respondendo ao Questionário, traz humildemente para diante dos olhos de Vossa Santidade, conduzindo a consciência e a verdade, o empenhadíssimo e amantíssimo de Vossa Santidade Bispo de Taubaté. Taubaté, 10 de agosto de 1914. +Epaminondas, Bispo de Taubaté. ${ }^{\mathbf{2 2 4}}$

Carece, por fim, pequena incursão sobre a visão política da diocese de Taubaté e de seu bispo. O distanciamento das questões políticas locais se consubstancia na ausência de artigos de jornais e de documentos a favor ou contra políticos regionais. Limitando-se aos cumprimentos por ocasião dos aniversários natalícios ou de sagração episcopal, visitas protocolares e demais efemérides, as relações entre $D$. Epaminondas e os representantes municipais podem se encaixar na condição de meramente formais. Ações de natureza política que porventura tenham havido, como a colaboração financeira por parte da Câmara Municipal de Taubaté para a construção do Santuário de Santa Teresinha, como veremos logo a frente, decerto estavam nas mãos de Monsenhor Antônio Nascimento Castro e de seu irmão Cônego José Valois de Castro, "político fino, representando Taubaté e toda esta região". ${ }^{525}$ A respeito dos acontecimentos políticos, internacionais ou nacionais, observa-se que as manifestações públicas de D. Epaminondas seguiam atreladas às posições de D. Duarte Leopoldo. Nesse particular, portanto, não se nota divergência entre os dois prelados.

Dentre as ocorrências internacionais, a Primeira Guerra Mundial e a Revolução Russa receberam atenções d' 'O Lábaro'. Morto Pio $X$, assume o papado Giacomo della Chiesa, que toma o nome de Benedito XV (3/9/1914 a 22/1/1922), em conclave iniciado um mês após a deflagração da Primeira Guerra Mundial. Era de se esperar, portanto, que a mesma viesse a marcar forte influência nos rumos de seu pontificado.

Sob o título 'A Guerra Européia', e em meio a inúmeras notas que reproduzem notícias de agências inglesas e italianas sobre o deslocamento de exércitos e de esquadras, 'O Lábaro' declara que o conflito tem "acabrunhado bastante o Santo Padre Pio X", e que o Giornale d'Italia noticia que foi a guerra um

524 ACDT. Relatório Ad Limina. 1914. p. 27.

525 PASSARELLI, Humberto. Contribuição à história de Taubaté. Taubaté: JAC Gráfica e Editora, 1996. p. 386. 
dos principais motivos que contribuíram para que o papa ficasse enfermo, "pois Pio $X$ se acha extremamente desgostoso com a conflagração", encerrando com um pedido de orações para o pontífice. ${ }^{526}$

Duas semanas após, 'O Lábaro' assevera que nunca se falou tanto em paz e que jamais se fizeram em sua busca tantos congressos, havendo até quem batizasse o século como o 'século da paz', mas que aí se apresenta a mais tremenda conflagração que vai registrar a história, confundindo a sabedoria presunçosa dos homens e se nulificando seus vãos esforços. A ausência do papa como intermediador das negociações é, portanto, a causa maior da questão.

É que os congressos da paz excluíram o legítimo medianeiro da paz, o Vigário de Jesus Cristo na terra, o representante do único Deus da paz e que também é o Senhor dos exércitos. Rejeitaram a paz de Deus, aí tem a paz que o mundo pode dar. ${ }^{527}$

Em 1915 as referências ao conflito se iniciam com a reprodução, em primeira página, do Decreto de Bento XV que estatuiu que "em todo mundo católico sejam dirigidas ao Senhor humildes preces para implorar da sua misericórdia a suspirada paz", e o Aviso Diocesano publicado no mesmo número regula a matéria no âmbito da diocese:

O Ex. ${ }^{\text {mo }}$ Sr. Bispo chama a atenção do Rev. ${ }^{\text {mo }}$ Clero e dos fiéis desta Diocese para a fiel observância das determinações de $S$. Santidade o Papa Bento XV, hoje estampadas na $1^{\mathrm{a}}$ página desta folha. No dia 21 do próximo mês de março, em todas as paróquias desta Diocese, deverão ser fielmente observadas as referidas prescrições. S. Ex. ${ }^{a}$ Rev. ${ }^{\text {ma }}$ deseja ardentemente que sejam as mencionadas cerimônias realizadas, igualmente, em todas as igrejas e capelas das casas religiosas deste bispado, do modo que for possível. ${ }^{\mathbf{5 2 8}}$

Ao longo de 1915 'O Lábaro' não perde a oportunidade de utilizar a guerra como apoio aos seus continuados ataques à maçonaria. Em coluna reproduzida de jornal de São Paulo e intitulada "Um golpe da maçonaria contra a catedral de Reims: os maçons provocaram e quiseram o bombardeio", o semanário publica uma carta onde um fugitivo francês acusa maçons de procurarem autoridades em Paris para solicitarem que fossem colocadas metralhadoras na torre daquela igreja a fim de que, bombardeada pelos alemães, fossem poupadas as casas. Para quem 
duvidasse, a matéria afirma que o texto original da carta "que abrirá os olhos a tantos cegos, acha-se em nosso poder". ${ }^{529}$

Com a epígrafe "Ecos da Guerra", 'O Lábaro' apresentava situações edificantes ao catolicismo, e com o subtítulo "Castigo divino" traz a história de um sacerdote cuja chegada às trincheiras excitou o furor de um soldado anticlerical. Declarando que não tinham necessidade de padres e convencido da inexistência de Deus, o soldado lançou um desafio: caso Deus existisse, que quebrasse a sua espingarda.

E juntando o gesto à palavra o desgraçado blasfemo ergueu a arma para o ar, segurando-a pelo cano. No mesmo instante, uma bala inimiga veio, quebrou a coronha da espingarda, ricocheteou sobre o cano e penetrou no crânio do infeliz, que logo caiu morto, em presença dos camaradas vivamente impressionados. ${ }^{530}$

Eamon Duffy, mesmo realçando a sensibilidade, a compaixão e o empenho do pontífice na busca de soluções diplomáticas que pusessem fim à questão, aponta a "rigorosa neutralidade" do Vaticano como um fator de descontentamento das nações envolvidas.

Numa guerra em que a opinião pública era constantemente abastecida de relatos de selvagerias em que abundavam os "bebês espetados em baionetas", ele se recusou a condenar até mesmo as atrocidades documentadas. O resultado foi que cada lado passou a acusá-lo de favorecer o outro. ${ }^{531}$

Em 1915, com a entrada da Itália na guerra, tornou-se particularmente desconfortável a situação do papa, visto que o Vaticano ainda não fora reconhecido como Estado autônomo. A 'Questão romana', pendente desde 1870, configurava-se como variável indesejada no momento.

O continuado conflito com a Itália em virtude da questão de Roma paralisou esses esforços pela paz. Temendo que Benedito tentasse mobilizar uma pressão internacional para recuperar Roma - como de fato ele esperava -, a Itália, num acordo secreto em 1915, convenceu seus aliados, inclusive a Inglaterra, a não negociar com o papa. ${ }^{532}$

Acompanhando-se a linha editorial adotada pelo 'O Lábaro', pode-se perceber, além da apologia ao catolicismo e dos ataques a maçonaria, o constante

529 O Lábaro, n. ${ }^{\circ} 269$, VI. 25 de fevereiro de 1915.

530 O Lábaro, n. ${ }^{\circ} 270$, VI. 4 de março de 1915.

531 DUFFY, Eamon. Santos \& Pecadores - História dos Papas. São Paulo: Cosac \& Naify Edições Ltda., 1998. p. 254.

532 DUFFY, Eamon. Santos \& Pecadores - História dos Papas. São Paulo: Cosac \& Naify Edições Ltda., 1998. p. 254. 
reclamar contra a exclusão de Bento $X V$ no processo de paz e a reprodução da "Alocução de S.S. Bento XV em 6 de dezembro - os esforços do pontífice em favor da paz" é assim comentada: "A situação do soberano pontífice é tal, sobretudo nas circunstâncias atuais, que nem possui sequer a liberdade absolutamente necessária para o governo da Igreja." 533

Os escritos que materializavam as inúmeras tentativas de Bento $\mathrm{XV}$ em favor da pacificação de um conflito por ele denominado de "suicídio da Europa" 534 eram editados pelo órgão da diocese taubateana, e seus redatores não hesitavam em culpar o governo francês, "radical e perseguidor", assim como o governo italiano, "maçonizado e livre-pensador" pela convocação e conseqüente transformação de padres católicos em soldados. ${ }^{535}$ Entrementes, a discreta preferência pela Alemanha, por parte de D. Epaminondas, é constatada na correspondência redentorista da época.

Todo o clero brasileiro, excetuados dois dos nossos brasileiros em Aparecida e um grupo de franceses, é a favor da Alemanha. [...] O maior amigo da Alemanha é o bispo de Taubaté que, embora doente, combate os inimigos da Alemanha com bons resultados no seu jornal. ${ }^{\mathbf{5 3 6}}$

As notícias em 1917, ainda que em menor número, seguem a mesma linha editorial anterior. O jornal, no decorrer do ano, publica uma nota sobre a revogação do decreto de neutralidade brasileira, ${ }^{537}$ assim como renova seus protestos contra a perda de imunidade dos padres católicos ao serviço militar por parte dos países envolvidos, acusando seus dirigentes de urdirem astuciosamente perseguições contra a Igreja católica e de espezinharem o clero, intenções essas disfarçadas em "proclamação ditirâmbica de patriotismo". ${ }^{538}$

Em continuidade às tentativas pacificadoras, Bento XV lança em $1^{\circ}$ de agosto de 1917 seu "Apelo aos chefes dos povos beligerantes", publicado pelo 'O Lábaro' três semanas após. ${ }^{539} \mathrm{O}$ documento apresenta, entre outras propostas, a "substituição da força material das armas pela força moral do direito" e a "instituição

533 O Lábaro, n. ${ }^{0} 313$, VII. 6 de janeiro de 1916.

534 O Lábaro, n. ${ }^{\circ} 329$, VII. 27 de abril de 1916.

535 O Lábaro, n. ${ }^{\circ} 335$, VII. 8 de junho de 1916.

536 ACPSR. Correspondência da Província Redentorista de São Paulo - COPRESP, v. VI (19131920). pp. 187-188. Não obstante nossos esforços em buscar altercações entre francófilos e germanófilos no âmbito da diocese, mesmo que pela imprensa leiga, nada foi encontrado.

537 O Lábaro, n. ${ }^{\circ} 386$, VIII. 31 de maio de 1917.

538 O Lábaro, n. ${ }^{\circ} 390$, VIII. 28 de junho de 1917.

539 O Lábaro, n. ${ }^{\circ}$ 398, VIII. 23 de agosto de 1917. 
do arbitramento obrigatório", recebendo de Rudolf Fischer-Wollpert a seguinte observação:

Os esforços pelo restabelecimento da paz encontraram expressão, entre outras tentativas, num manuscrito enviado pelo papa, em janeiro de 1917, ao imperador Guilherme II, a que este apôs, de próprio punho, a observação de que o papa e 0 presidente americano Wilson eram igualmente ingênuos. ${ }^{540}$

Além disso, a proposta do papa no sentido de que ambos os contendores abrissem mão das compensações pelos danos de guerra repercutiu pessimamente na França, país alvo dos maiores estragos realizados pela Alemanha. Esta, por sua vez, apoiou o plano, e Benedito XV tornou-se persona non grata entre os franceses, até mesmo pelo clero católico.

Ao findar-se 1917, a proximidade com o Estado se manifesta por meio de uma carta de solidariedade de D. Epaminondas para com o então presidente de São Paulo, Altino Arantes, onde "o Bispo, o clero e os fiéis desta diocese se declaram prontos a auxiliar a Nação na manutenção da ordem pública e defesa de seus sagrados direitos", ${ }^{541}$ enquanto que em 1918 somente duas notícias fazem menção à guerra: o armistício com a Alemanha ${ }^{\mathbf{5 4 2}}$ e a ordem de preces pelo papa "para o advento de uma verdadeira paz fundada nos princípios cristãos". ${ }^{\mathbf{5 4 3}}$

Findo o conflito, logo no início de 1919 'O Lábaro' passou a publicar extensas colunas intituladas "A ação do papa durante a guerra", onde as iniciativas de Bento XV para a libertação, troca e hospedagem de prisioneiros militares e civis, 544 correspondência episcopal proveniente das terras invadidas, ${ }^{545}$ socorros religiosos e morais, ${ }^{546}$ entre muitas, procuravam abrandar a exclusão de um pontífice que, mesmo afastado pelos países beligerantes das mesas de negociação, nem por isso se furtou a despender vultosa quantia - "82 milhões de liras, que deixaram vazios os cofres do Vaticano", ${ }^{547}$ objetivando minimizar os efeitos da guerra.

540 Fischer-Wollpert, Rudolf. Os papas: de Pedro a João Paulo II. Petrópolis: Vozes. 5. ed. 1999. p. 159.

541 O Lábaro, n. ${ }^{\circ} 410$, VIII. 15 de novembro de 1917.

542 O Lábaro, n. ${ }^{\circ} 463$, IX. 14 de novembro de 1918.

543 O Lábaro, n. ${ }^{\circ}$ 467, IX. 12 de dezembro de 1918.

544 O Lábaro, n. ${ }^{\circ} 477$, X. 20 de fevereiro de 1919.

545 O Lábaro, n. ${ }^{\circ} 478$, X. 27 de fevereiro de 1919.

546 O Lábaro, n. ${ }^{\circ} 484$, X. 10 de abril de 1919.

547 DUFFY, Eamon. Santos \& Pecadores - História dos Papas. São Paulo: Cosac \& Naify Edições Ltda. 1998. p. 254. 
Assegurando a posição da Igreja católica no pós-guerra por meio de diversas concordatas com os países europeus, a habilidade diplomática de Bento XV na busca por reconciliação com a França proporcionou, em 1920, a canonização de Joana D’Arc, "um gesto altamente imaginativo: oitenta deputados franceses compareceram à cerimônia, e o governo francês enviou representantes oficiais". ${ }^{\mathbf{5 4 8}}$ Estava aberto, junto ao clero e ao povo francês, o caminho para novas canonizações, como se verificará logo adiante.

Os acontecimentos de 1917 na Rússia, por sua vez, mereceram em julho de 1918 um editorial denominado "O catolicismo e a revolução", e o 'O Lábaro' passa a lançar, com maior ou menor intensidade ao longo dos anos, suas diatribes ao socialismo.

Afirmando que "a revolução foi preparada com o plano de confiscar, em seu proveito, a sociedade moderna" e que seu objetivo sistemático é o de desnaturá-la e desviá-la do caminho do dever e da justiça, da verdade e da virtude, ${ }^{549}$ em inúmeros artigos intitulados "O socialismo e seus erros", "A questão operária", "O socialismo coletivista e seus erros", "A utopia coletivista" e "O socialismo coletivista", entre outras chamadas, o órgão da diocese ataca o socialismo e o comunismo, tendo-os na conta de "sentina", termo pelo qual também se designa um vaso sanitário.

Escorado na Rerum Novarum de Leão XIII, o jornal propõe que o estudo do que denomina de 'questão social' seja baseado nos ensinamentos de Leão XIII, posto que "constituem o melhor compêndio da época". Além disso, a Rerum Novarum, na visão dos redatores da diocese, é matéria para "todos os legisladores e pessoas interessadas no assunto relativo à questão social, que convulsiona a velha Europa". 550

Para 'O Lábaro', os "invasores socialistas" estendem seus ataques contra todos os fundamentos sociais: Deus, pátria, família, propriedade, e para provar tal assertiva, a cada duas semanas, em média, o jornal publica artigos onde são dissecados, tema por tema, os pressupostos conceituais do socialismo, "questão interessante e de atualidade palpitante". ${ }^{551}$

548 DUFFY, Eamon. Santos \& Pecadores - História dos Papas. São Paulo: Cosac \& Naify Edições Ltda. 1998. p. 255. 
Assim, o confisco de propriedades é fartamente explorado em uma edição; noutra, essa "teoria que se salienta num tecido inextricável de utopias e ilusões" é acusada de eliminar a liberdade individual e de tornar o Estado o único herdeiro dos bens duramente conquistados pelas pessoas. ${ }^{552}$

A "hidra socialista" é, portanto, atacada com fôlego, e como "toda revolução é acompanhada de efusão de sangue" os articulistas não se admirarão do sangue que certamente verterá no Brasil, tudo isso causado por um regime que tem por objetivo "descristianizar a ordem social" e "desencaminhar e iludir o operário", operário esse que "a Igreja católica encontrou, há vinte séculos, nas cadeias da escravidão pagã, reduzido à condição de animal, tratado com crueldade e desprezo". ${ }^{553}$

Segundo 'O Lábaro', um dos maiores temores em relação ao socialismo consiste no fato de seus defensores elogiarem o operariado, descuidando de sua instrução, o que não se dá com a Igreja católica, uma vez que "é mais um bom serviço que o clero católico presta ao operário quando, em lugar de lisonjeá-lo, cuida de instruí-lo, e, em lugar de quimeras, mostra-lhes as realidades...". 554

Abordando as mais diversas especificidades do socialismo, volvendo a outras anteriormente exploradas, 'O Lábaro' não poupa tinta e espaço jornalístico em sua ofensiva. Pouco importa, diz uma matéria, que as promessas socialistas "acenem com a redução de duas ou mais horas de trabalho", pois mesmo assim é certo que o socialismo afastará o operariado "da influência protetora da Igreja". Considerando que o correto é que "quando alguém comete um roubo, é preso, julgado e condenado", como admitir, pergunta-se em outra edição, a existência de um regime que rouba a propriedade de cada indivíduo em favor do Estado? ${ }^{555}$

Alertando que no regime socialista o indivíduo estará reduzido a nada, e, humilhado, se verá na degradante condição de "pedir tudo ao Estado", o resultado, diz o jornal, não poderá ser outro senão o benefício exclusivo dos "socialistas energúmenos" que detêm o poder, ${ }^{556} \mathrm{e}$ insistentes na lembrança de que os ensinamentos socialistas se limitam a "instigar nos pobres o ódio invejoso contra os que possuem", os redatores do órgão oficial da diocese também alertavam que 
tendo "o Estado como único proprietário, ninguém se julgará com o direito de dizer; isto é minha propriedade, isto me pertence!" 557

A partir de 1920 os ataques e comentários às doutrinas socialistas, apesar de diminuírem de freqüência, continuam a surgir com regularidade. Temas versando sobre o 'trabalho infantil' ${ }^{558}$ e a noção de 'justiça distributiva' ocupam apenas quatro edições naquele ano, enquanto que em 1921 'O Lábaro' adverte que a propaganda a favor do socialismo é maior do que se pensa, e como essas publicações "fazem timbre em descristianizar o trabalho" é preciso "opor à inoportuna propaganda de subversivas teorias a indispensável pregação dos princípios genuinamente cristãos, de modo que todos respirem um puro ambiente". ${ }^{559}$

Também em 1921 o jornal renova suas acusações aos maçons, tomando-os agora como simpáticos à revolução russa: "Do convênio maçônico franco-italiano realizado ultimamente em Paris, aparece claro e evidente o papel que a maçonaria tem desempenhado em lançar o mundo nas garras mortíferas da revolução bolchevique". ${ }^{560}$ Denominando pejorativamente os membros das lojas maçônicas de "três pontinhos", 'O Lábaro' incansavelmente assevera que "em nenhum campo foi tão aclamada a revolução russa, como na maçonaria". 561

Em 1922 o "sectarismo ímpio do socialismo ateu" visa destruir todas as instituições do passado "numa revolução brusca e violenta", ${ }^{562}$ enquanto que em 1923 procura-se reforçar a idéia de que "o coletivismo subordina tudo às previsões e atrofia todo impulso de melhoramento, desanima toda iniciativa e condena toda invenção". 563

Em outro artigo a sensibilidade dos laços familiares é aguçada, e para o redator "é certo que a família, como se acha constituída em seus elementos harmônicos, jamais subsistirá sob o influxo do Estado coletivista". As argumentações prosseguem e, caso cumpra ao Estado socialista determinar o emprego das energias da nova geração, termina-se por ter "a inutilização da família". ${ }^{564}$

Encerrando o processo expositivo da visão conservadora d"O Lábaro' sobre o tema, apenas três matérias referentes ao socialismo foram editadas no decorrer de

557 O Lábaro, n. ${ }^{\circ}$ 508, X. 25 de setembro de 1919.

558 O Lábaro, n. ${ }^{\circ} 531$, XI. 4 de março de 1920.

559 O Lábaro, n. ${ }^{\circ} 583$, XII. 24 de fevereiro de 1921.

560 O Lábaro, n. ${ }^{\circ} 600$, XII. 23 de junho de 1921.

561 O Lábaro, n. ${ }^{\circ} 611$, XII. 15 de setembro de 1921.

562 O Lábaro, n. ${ }^{\circ} 662$, XIII. 19 de outubro de 1922.

563 O Lábaro, n. ${ }^{\circ} 718$, XIV. 15 de novembro de 1923.

564 O Lábaro, n. ${ }^{\circ}$ 721, XIV. 13 de dezembro de 1923. 
1924. Nelas, as apresentações argumentativas se concentravam na valorização do esforço individual e nos riscos contidos no socialismo em relação aos que supostamente poderiam apropriar-se dos resultados do trabalho alheio: "O socialismo, se, por um absurdo, fosse realizado, não poderia escapar da ação dissolvente que sobre ele necessariamente havia de exercer o parasitismo social corruptor em proveito dos inativos e dos indolentes." 565

Se nos primórdios da república o governo brasileiro julgou-se suficientemente autônomo, dispensando o concurso da Igreja mediante a proclamação da laicidade do Estado, a importância do catolicismo passou a ser reavaliada quando da organização de novas forças sociais, particularmente, mas de modo tímido e irregular, a partir da década de 20.

Para a Igreja, ao processo de reforma do clero e ao subseqüente processo de reorganização interna, seguiu-se como objetivo a maior participação do catolicismo na sociedade brasileira. Nessa fase, conhecida como "restauração católica" e considerada por Augustin Wernet como "o apogeu do catolicismo reformado", torna-se mais delineada a aproximação do Estado com a Igreja, e o poder político não se furtou em contar com a colaboração da instituição eclesiástica para manter a sociedade enquadrada nos moldes da ordem e do respeito aos governantes.

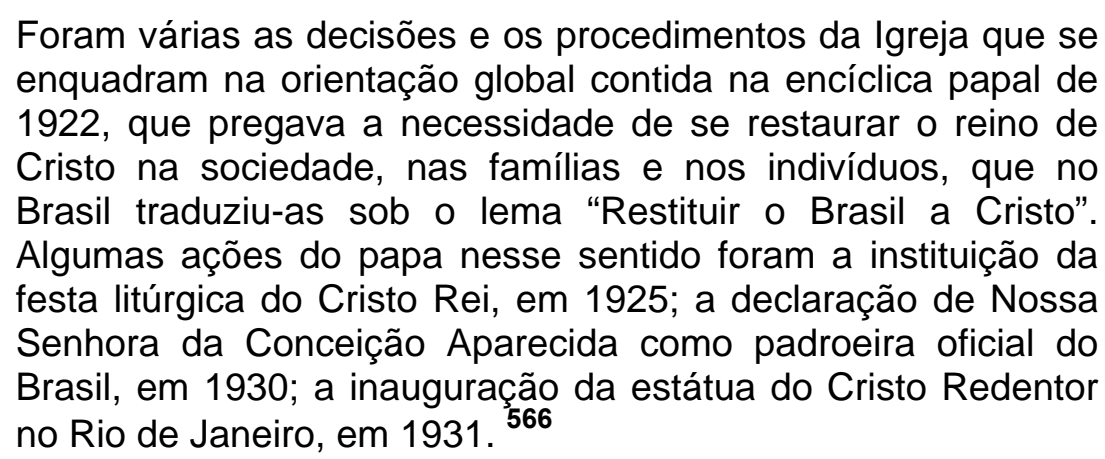

Segundo Riolando Azzi, "a preocupação dominante da Igreja, no Brasil, até os anos 50, é manter sob controle os movimentos populares, denunciando seu caráter revolucionário e ateu", ${ }^{567}$ e nesse sentido D. Epaminondas não se furtou a combater por meio d"O Lábaro' o movimento rebelde liderado pelo General Isidoro Dias Lopes. Na edição de 17 de julho de 1924, após declarar que a população de

565 O Lábaro, n. ${ }^{\circ} 725$, XV. 17 de janeiro de 1924.

566 WERNET, Augustin. Vida religiosa em São Paulo (1554-1954), In: PORTA, Paula (org.) História da cidade de São Paulo, v.1: A cidade colonial. São Paulo: Paz e Terra, 2004. p. 236. passim.

567 AZZI, Riolando. A neocristandade: um projeto restaurador. São Paulo: Paulus, 1994. p. 18. 
Taubaté e do resto do país sente-se alarmada com as notícias que circulam sobre o movimento revolucionário, o jornal fulmina:

O que há de real e verdadeiro nessas notícias é que um punhado de soldados indisciplinados, dominados e cegos pela paixão, não medindo as calamitosas conseqüências do seu gesto reprovável, impatriótico e indigno, se manifestou francamente hostil às autoridades constituídas, lançando aos quatro ventos o seu brado de revolta, de anarquia, de extermínio.

E como para "O Lábaro" qualquer momento é apropriado para o combate ao comunismo, a comparação é inevitável:

É a reprodução do gesto tresloucado dos rubros e sanguinários discípulos de Lenine, adeptos da desordem, da destruição social, da devastação, inimigos da autoridade, da sociedade, da Pátria!

Afirmando que o "quadro desolador" é nascido da descrença e da falta de fé em que permanece obstinadamente grande parte da população das grandes cidades, "desdenhando as sábias lições dos evangelhos, única escola capaz de restituir às nações a ambicionada paz, irmanando-as para a conquista de ideais elevados e puros", o texto materializa, em seu encerramento, o apoio da Igreja ao Estado:

Nós que, como bons católicos, respeitamos e obedecemos as autoridades legalmente constituídas, consignamos neste suelto o nosso veemente protesto a esse ato criminoso, e procuramos cooperar com as dignas e zelosas autoridades, pedindo aos prezados leitores que se abstenham de comentários inúteis, não dêem crédito às notícias espalhadas pelos boateiros, e conosco levantem a Deus preces fervorosas e ardentes, pela pacificação do nosso Estado, convulsionado pela rebelião audaciosa e traiçoeira de um grupo de orgulhosos e perversos amotinados. (os grifos são nossos)

O apoio ao governo não se limitou tão somente ao artigo; as colunas do órgão oficial da diocese se abriram para uma proclamação do então presidente de São Paulo, Carlos Campos, e para outra do ministro da guerra, General Setembrino de Carvalho. Além disso, Arthur Bernardes e Carlos de Campos receberam telegramas:

Ex. ${ }^{\text {mo }}$ Sr. Presidente Dr. Arthur Bernardes - Catete - Rio. Lamentando profundamente antipatriótico movimento perturbação ordem pública neste grande Estado, momento em que V.Ex. ${ }^{a}$ com tanta abnegação sacrifícios esclarecido patriotismo sabiamente encaminhava solução grandes problemas nacionais cumpro dever assegurar $\mathrm{V}$.Ex. ${ }^{a}$ inteira 
solidariedade Bispo, Clero, Católicos desta Diocese fazendo votos sincero Deus triunfo legalidade restabelecimento paz tão necessária vida prosperidade Brasil. Atenciosas saudações Bispo Taubaté.

Ex. ${ }^{\text {mo }}$ Sr. Presidente do Estado Sr. Dr. Carlos Campos Diocese Taubaté amargurada acompanha imensa calamidade produzida tão reprovável tentativa subversão ordem pública glorioso Estado. Bispo, Clero, Católicos solidários patriótico governo São Paulo oram Deus vitória legalidade restabelecimento paz. Atenciosas saudações - Bispo Taubaté. ${ }^{568}$

Na edição de 24 de julho o artigo de primeira página intitulado "As ambições criminosas" afirma que "para os espíritos em revolta contra o princípio da autoridade e da segurança nacional não há intuitos generosos nem boas intenções", enquanto que a matéria "A revolta em São Paulo" justifica a demora em debelar a situação, uma vez que os "ilustres generais" são forçados a agir com precaução, a fim de evitar danos maiores. A defesa ao Estado é patente:

Sem precipitações, obedecendo ordeiramente ao plano traçado pelos ilustres generais que estão à sua frente, prosseguem as forças legais nas operações, avançando os legionários da ordem, estreitando cada vez mais o cerco ao entrincheiramento dos rebeldes que, do desatino delituoso, passam ao desânimo dos desamparados. A população nutre o justo e natural desejo de ver terminada a luta: devem todos, porém, compreender que, forçado a agir com precaução para evitar danos materiais e sacrifícios maiores, o governo não dê, como pode e para o que está mais que suficientemente aparelhado, o caráter decisivo que abreviaria, ou melhor, poria termo imediato à completa jugulação da mazorca. Esse fato, a natural lentidão das operações, lentidão essa que não Ihe diminui, antes Ihe garante e assegura a eficácia, tem dado ensejo a comentários pessimistas de parte daqueles que entendem dever o governo, se está com forças para isso, dominar imediatamente a rebelião. Que o governo dispõe de forças e apoio moral de todos os bons brasileiros, não resta a menor dúvida. Ele domina inteiramente a situação. Cada dia que passa se assinala o avanço das tropas fiéis, que marcham firmes, serenas e confiantes na vitória final que, dentro de poucos dias, coroará os esforços do governo, e será o penhor da tranqüilidade, completa e estável que reinará então sobre o nosso amado país. À Terra de Santa Cruz, batidos e punidos os ousados aventureiros que contra ela se armaram, voltará a almejada paz, os dias alegres do trabalho abençoado e feliz.

A formação de um "Batalhão Patriótico", saudado e abençoado por D. Epaminondas em frente ao palácio episcopal, também foi notícia. O bispo, em

568 O Lábaro, n. ${ }^{\circ} 750$, XV. 17 de julho de 1924. 
"oração eloqüente", lançou solene protesto contra a revolução, e conjurava a todos os bons brasileiros que se levantassem em defesa da pátria ameaçada. ${ }^{569}$

“Conspiração criminosa" é o título da primeira página d”'O Lábaro' de 31 de julho, que denomina de "revolta satânica" o movimento, "provocando profunda amargura e dolorosa impressão no coração de todo o bom brasileiro que ama a sua pátria e acata o seu governo constituído". Na página seguinte, ao noticiar o encerramento dos combates, "O Lábaro" transcreve os telegramas de congratulações enviados a Arthur Bernardes, a Carlos Campos e a D. Duarte Leopoldo, ${ }^{570}$ que por ocasião do bombardeio da cidade de São Paulo "não abandonou o seu posto e abriu as igrejas à população desabrigada, sem distinção de credo ou postura política". ${ }^{571}$

Ainda que consolidando seu caráter jurídico-institucional com o Código de Direito Canônico de 1917, a Igreja católica no Brasil precisava prosseguir na conquista dos necessários instrumentos para uma melhor coordenação e uma feição nacional. Nessa latitude, os passos decisivos foram dados pelo sucessor do Cardeal Joaquim Arcoverde, D. Sebastião Leme da Silveira Cintra, Coadjutor (1921-1930) e depois Cardeal-arcebispo do Rio de Janeiro, e "nas vésperas da Revolução de 1930 a Igreja se tinha transformado num corpo coeso, potente e bem organizado, tendo no Cardeal Leme seu grande líder nacional". 572

Coerente com a cautela do momento, as jornadas de outubro de 1930 receberam de D. Epaminondas a atenção de apenas dois pequenos artigos. No primeiro, intitulado "O dever de todos os bons brasileiros e católicos na hora presente", o órgão oficial da diocese de Taubaté concita a todos "prestarem obediência aos poderes legitimamente constituídos". O texto, publicado em 26 de outubro, dois dias após a deposição de Washington Luís, também se encaixaria, de bom grado, no caso da vitória do "paulista de Macaé":

Sem ódios, sem partidarismo, sem espírito de regionalismo, na hora angustiosa por que passa a Pátria querida, convertida em vasto campo de lamentável luta fratricida, é dever de todos os brasileiros prestarem obediência aos poderes legitimamente constituídos e trabalharem, por todos os meios lícitos, máxime

569 O Lábaro, n. ${ }^{\circ} 751$, XV. 24 de julho de 1924.

570 O Lábaro, n. ${ }^{\circ} 752$, XV. 31 de julho de 1924.

571 WERNET, Augustin. Vida religiosa em São Paulo (1554-1954), In: PORTA, Paula (org.) História da cidade de São Paulo, v.1: A cidade colonial. São Paulo: Paz e Terra, 2004. p. 236. passim.

572 MATOS, Henrique Cristiano José. História do cristianismo. Belo Horizonte: Congregação dos Fráteres de Nossa Senhora Mãe de Misericórdia. Circulação interna "ad experimentum". Coleção Estudos e Documentos, v. 4, Período contemporâneo. 1990. p. 207. 
pela oração fervorosa e contínua, para obtermos do Deus dos exércitos, pela valiosa mediação da poderosa e misericordiosa Rainha da paz, o restabelecimento da ordem, o congraçamento da família brasileira, a restauração da paz em nossa Pátria convulsionada. ${ }^{573}$

Amarrados que foram os cavalos no obelisco da avenida Rio Branco, no Rio de Janeiro, e uma vez acalmados os ânimos, o 'Santuário de Santa Teresinha', em sua segunda nota, limitou-se à precisão jornalística.

GOVERNO PROVISÓRIO DO BRASIL Foi empossado no dia 3, no cargo de Chefe do Governo Provisório do Brasil, o Sr. Dr. Getúlio Vargas, tendo feito um forte discurso na entrega do poder, em nome da Junta Governativa provisória, o Sr. General Tasso Fragoso, ao qual respondeu o Sr. Getúlio Vargas, traçando os principais pontos de seu programa de governo. $O$ Ministério escolhido por S. Ex. é o seguinte: Exterior - Afrânio de Mello Franco; Viação - Juarez Távora; Agricultura - Assis Brasil; Fazenda - José Maria Whitaker; Guerra - General Leite de Castro; Marinha - Izaias de Noronha; Justiça e Interior Oswaldo Aranha. Para Chefe de Polícia do Distrito Federal foi escolhido o Sr. Baptista Luzardo e para Prefeito do Rio o Sr. Adolpho Bergamini. Consta do programa do Governo a criação de duas novas Pastas: a do Trabalho e a da Instrução. ${ }^{574}$

As ações bélicas do movimento constitucionalista não atingiram diretamente Taubaté; o engajamento por parte da diocese se materializou pelo Aviso n. ${ }^{\circ} 620$, versando sobre a assistência religiosa aos militares em campanha. No 'Aviso', o governo diocesano comunica que não obstante a autoridade eclesiástica de São Paulo ter tomado providências para que aos soldados em campanha não faltem os socorros espirituais,

o Ex. ${ }^{\text {mo }}$ Sr. Bispo diocesano recomenda, com especial encarecimento, aos Rev. ${ }^{\text {mos }}$ vigários e demais sacerdotes residentes nas zonas de operações militares que prestem, dedicada e abnegadamente, toda assistência espiritual aos ditos militares, fazendo-se, a exemplo do apóstolo das gentes, tudo para todos, a fim de ganhá-los para Jesus Cristo. ${ }^{575}$

Encerrado o conflito, a grande romaria promovida pelo Pe. Evaristo Campista César à Aparecida, padroeira do Brasil desde 31 de maio de 1931, "na qual tomarão parte todas as associações paroquiais e o povo em geral", tem por finalidade agradecer "os imensos benefícios dispensados a Taubaté, pela Excelsa 
Mãe, durante os acontecimentos de julho". ${ }^{576}$

A chamada Era Vargas conduziria a Igreja católica a um "posto de honra" na sociedade, e a ação diplomática de D. Leme e "sua capacidade de estabelecer relações de intimidade com os altos círculos lograram vários êxitos políticos". 577

Em estreita consonância política junto ao novo governo, a Igreja católica, agora conduzida por D. Leme, representava forte bastião de defesa aos propósitos governamentais e, "sentindo a influência da Igreja e a identificação do povo com a religião católica, Getúlio Vargas esteve presente nos grandes eventos católicos". ${ }^{578}$

Analisando o período, Augustin Wernet aborda uma das expressões políticas mais destacadas do período: a Liga Eleitoral Católica (LEC), criada por D. Leme em 1932.

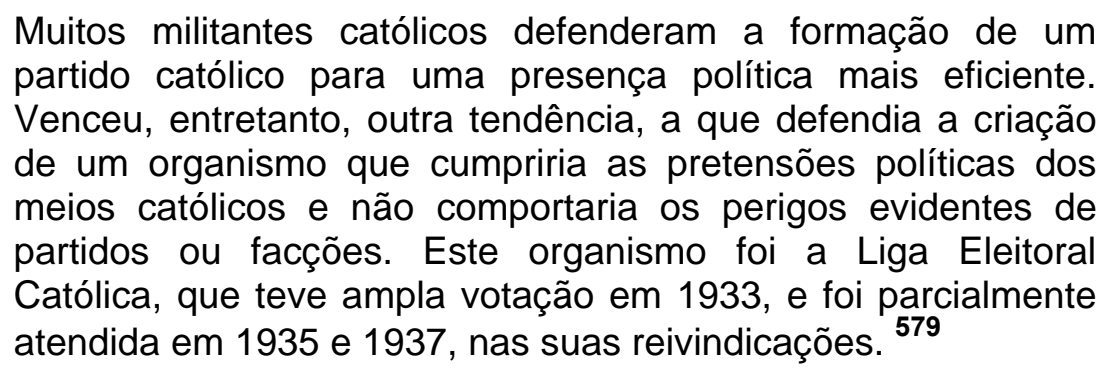

A partir de 1932, pari passu aos esforços para a arregimentação de católicos para a LEC, as páginas do jornal da diocese taubateana se enchem de artigos favoráveis à Liga. Com títulos de forte conteúdo emotivo, tais como "O dever eleitoral dos católicos", "O trabalho de arregimentação dos católicos" ou mesmo "Liga Eleitoral Católica - A POSTOS!", torna-se constante, em suas páginas, a presença de articulistas que compunham a intelectualidade católica leiga da época, sendo os mais freqüentes Alceu Amoroso Lima, o Tristão de Ataíde (1893 - 1983), e Plínio Corrêa de Oliveira, eleito deputado federal constituinte em 1933 na esteira da LEC e, posteriormente, fundador da Sociedade Brasileira de Defesa da Tradição, Família e Propriedade, a TFP. As recompensas pelos esforços empreendidos não tardaram, e

a Constituição de 1934 incorporou as principais exigências da LEC, incluindo o apoio financeiro do Estado à Igreja, a proibição do divórcio e o reconhecimento do casamento

576 Santuário de Santa Teresinha, n. ${ }^{\circ}$ 356. 25 de dezembro de 1932.

577 MAINWARING, Scott. Igreja católica e política no Brasil (1916-1985). São Paulo: Brasiliense, 2004. p. 48.

578 WERNET, Augustin. Vida religiosa em São Paulo (1554-1954), In: PORTA, Paula (org.) História da cidade de São Paulo, v.1: A cidade colonial. São Paulo: Paz e Terra, 2004. p. 239.

579 WERNET, Augustin. Vida religiosa em São Paulo (1554-1954), In: PORTA, Paula (org.) História da cidade de São Paulo, v.1: A cidade colonial. São Paulo: Paz e Terra, 2004. 
religioso, a educação religiosa durante o período escolar e subsídios do Estado para as escolas católicas. ${ }^{\mathbf{5 8 0}}$

Em clichê de grande dimensão, a fotografia de D. Leme torna-se parte integrante dos artigos laudatórios ao Cardeal por ocasião de seu "gratíssimo aniversário", e o caráter conservador da Igreja em Taubaté continuará a se materializar, ao longo de 1935, no combate ferrenho ao comunismo e na apologia à Ação Católica Brasileira, fundada nesse mesmo ano e destinada a melhor coordenar a participação leiga no âmbito católico. Encerrava-se, ao mesmo tempo da morte de D. Epaminondas, o tempo das "conquistas". Doravante, a igreja parte em busca de consolidação e de reforço de seus quadros internos.

\subsection{A resposta ultramontana: o Santuário de Santa Teresinha}

Pari passu aos trabalhos redentoristas, no sentido organizar as atividades do Santuário, o processo racionalizado de fazer convergir a devoção popular para Aparecida recebeu forte empuxo. A Conferência dos Bispos da Província Eclesiástica Meridional do Brasil, ocorrida em São Paulo entre 3 e 12 de novembro de 1901, examinou a proposta de coroação da imagem de Nossa Senhora Aparecida apresentada por Dom Joaquim Arcoverde, arcebispo do Rio de Janeiro, que formalizou o pedido junto a Santa Sé. As ânuas documentaram, fazendo constar a previsão entusiasta do cronista:

Na conferência dos bispos do sul do Brasil, foi resolvido, por proposta de D. Arcoverde, Arcebispo do Rio, a coroação da Imagem com a presença de todos os bispos. A data não está ainda marcada. Irá contribuir para o aumento dos romeiros. ${ }^{\mathbf{5 8 1}}$

Dando prosseguimento ao processo iniciado em 1901 por D. Arcoverde, o papa Pio X, em fevereiro de 1904, assinou o decreto de coroação da imagem de Nossa Senhora da Conceição Aparecida. A cerimônia de coroação da imagem, como não poderia deixar de ser, deu-se em grande estilo, caracterizando assim mais um passo no trabalho de consolidação do Santuário de Aparecida como catalisador da religiosidade ultramontana, administrada segundo os seus próprios padrões:

Fato de grande importância neste ano foi a coroação da imagem de Nossa Senhora Aparecida, a qual participaram 13 bispos; um abade delegado de 10 Ordens ou Congregações; muitas personalidades eclesiásticas e cerca de 15 mil pessoas.

580 MAINWARING, Scott. Igreja católica e política no Brasil (1916-1985). São Paulo: Brasiliense, 2004. p. 48.

581 ACPSR. Ânuas da Vice-Província de São Paulo, v. I (1896 - 1918). p. 65. 
Como recordação do evento foi levantado um monumento à Imaculada Conceição na praça, junto à igreja. ${ }^{582}$

O projeto regional de romanização, como se pode verificar, avançava a passos largos, acompanhado de um processo de racionalização administrativa que poderia facilmente se ombrear ao de uma grande empresa da atualidade. 0 monumento à Imaculada Conceição, na praça da igreja, e a festa da coroação, ressaltavam os primeiros passos para o caráter público da imagem.

Simultâneo ao crescimento de Aparecida, a decadência do Santuário do Bom Jesus já era discutida em junho do mesmo ano pelo recém fundado jornal 'A Vila do Tremembé', que reclamava serem ambas as devoções tão antigas quanto, e o artigo perguntava "por que o Santuário do Senhor Bom Jesus do Tremembé não há de ter uma concorrência igual de romeiros no decorrer do ano?" 583 ressaltando porém que Aparecida, diferente de Tremembé, era atendida vantajosamente pelo ramal ferroviário. Além disso, a concorrência com os santuários de Iguape e de Pirapora, os três de mesma invocação - o Bom Jesus da cana verde - era um fato a ser considerado em relação a imagem de Nossa Senhora recolhida por pescadores no rio Paraíba. Mas como Nossa Senhora é mãe de Jesus, o articulista entende que uma visita ao filho é sempre oportuna, uma vez que os pedidos dos romeiros serão levados a ele pela mãe celeste. Evitar a lenta, gradual e até mesmo prevista decadência do Santuário do Bom Jesus será objeto de esforços por parte de D. Epaminondas no sentido de manter o carisma e as rendas desta manifestação do sagrado. Em Aparecida, porém, já no ano de 1907:

Cresce de ano para ano o número daqueles que visitam o Santuário de Nossa Senhora Aparecida e se aproximam dos sacramentos. No dia 8 de setembro, grande multidão de peregrinos veio até aqui em dois trens especiais. ${ }^{\mathbf{5 8 4}}$

Em 31 de maio de 1908, momentos antes da instalação da diocese de Taubaté, o Santuário de Aparecida é elevado à condição de Basílica Menor, administrado por 10 padres e 9 irmãos leigos professos. As missões, razão de ser da Congregação do Santíssimo Redentor, ficam prejudicadas.

Como neste ano um dos missionários adoeceu por mais tempo e outros padres estão ocupados como professores no Seminário e no Estudantado, só pôde haver uma missão. Além disso há tanto trabalho em Aparecida que eles não podem

582 ACPSR. Ânuas da Vice-Província de São Paulo, v. I (1896 - 1918). p. 171.

583 A Vila do Tremembé, n. ${ }^{\circ}$ 9, I. 13 de junho de 1904.

584 ACPSR. Ânuas da Vice-Província de São Paulo, v. I (1896 - 1918). p. 252. 
atender trabalhos fora. ${ }^{585}$

Vê-se, portanto, que o objetivo final, qual seja, a administração e a pastoral do Santuário, encontravam seus caminhos. Faltava, entretanto, uma melhor ingerência à 'atividade meio'. Em outras palavras, racionalizar o processo das romarias.

Em todo o século XIX, portanto, havia pouca presença da Igreja, seja na organização e promoção da romaria, seja no caminho até o santuário, e mesmo no próprio santuário, não havia uma planejada ação pastoral. Predominou a peregrinação do povo, praxe comum da sua religiosidade tradicional: uma caminhada difícil e penosa ao lugar sagrado ao Santuário Nossa Senhora Aparecida. ${ }^{586}$

Por peregrinação entende-se, geralmente, um itinerário ou caminhada difícil a um lugar sagrado que seja símbolo e manifestação do sagrado. Tal peregrinação exige penitência, testemunho público de fé e ação de graças por se ter chegado ao lugar sagrado e alcançado alguma graça. Não é o homem que escolhe os lugares sagrados e os caminhos que a eles conduzem. Ele apenas os descobre. Foi este também o caso de Aparecida. ${ }^{\mathbf{5 8 7}}$

Em busca de uma reorientação para as romarias e para a pastoral do santuário, tendo em vista que "era necessário evangelizar os peregrinos, aperfeiçoar a sua religiosidade e moralizar o seu comportamento", ${ }^{588}$ concluíram os prelados do Rio de Janeiro e de São Paulo, juntamente com o Padre redentorista Gebardo Wiggermann, sobre a necessidade de uma melhor organização das mesmas pelas paróquias ou associações religiosas locais e paroquiais, bem como pelos próprios bispos em nível diocesano.

Assim se deu, e já em 1900 tem-se a primeira romaria programada. Em 8 de setembro, D. Antônio Cândido de Alvarenga, bispo de São Paulo, traz uma romaria daquela cidade. Mil e duzentos peregrinos participaram da primeira romaria oficial ao Santuário.

Ao lado das romarias individuais e grupais propunham a

585 ACPSR. Ânuas da Vice-Província de São Paulo, v. I (1896 - 1918). p. 275.

586 WERNET, Augustin. Peregrinação a Aparecida: das romarias programas ao turismo religioso. In: RODRIGUES, Adyr Balastreri (org.) Turismo. Modernidade. Globalização. São Paulo: Hucitec, 1977. p. 85.

587 WERNET, Augustin. Peregrinação a Aparecida: das romarias programas ao turismo religioso. In: RODRIGUES, Adyr Balastreri (org.) Turismo. Modernidade. Globalização. São Paulo: Hucitec, 1977. p. 84.

588 WERNET, Augustin. Peregrinação a Aparecida: das romarias programas ao turismo religioso. In: RODRIGUES, Adyr Balastreri (org.) Turismo. Modernidade. Globalização. São Paulo: Hucitec, 1977. p. 85 . 
organização de romarias oficiais, conduzidas e dirigidas por um padre como "Diretor de Romaria". Estas romarias foram chamadas de "Romarias programadas". Os padres redentoristas da Baviera conheciam esse procedimento no seu país de origem, no qual juntamente com os padres capuchinhos administravam o "Santuário da Baviera", o Santuário Mariano de Altötting. Dessa maneira nasceram as romarias programadas.

Em seqüência à de São Paulo, a 21 de novembro chega a Aparecida a romaria programada da arquidiocese do Rio de Janeiro, sob a direção de seu arcebispo, Dom Joaquim Arcoverde de Albuquerque Cavalcanti.

As romarias organizadas tinham um programa e cerimonial que eram racionalmente elaborados como os ritos na chegada e saída do Santuário. Os peregrinos eram recepcionados já na Estação Ferroviária e guiados até a Igreja-Santuário. Comumente quem os conduzia era um missionário redentorista. Eram recebidos por banda de música; entoavamse hinos e cânticos em louvor à Maria, Mãe de Jesus, N. S. Aparecida. Havia a cruz da procissão; os peregrinos saíam da estação ferroviária rezando, serpenteavam pelas ruas estreitas, escarpadas e íngremes, com uma topografia de aclives e declives abruptos e de difícil acesso da pequena cidade até o Santuário, no topo da colina. ${ }^{589}$

Havia horário previsto para as pregações, as confissões, as missas e comunhões, e, à tarde, antes da despedida, os peregrinos faziam a procissão com o Santíssimo Sacramento. Nessa ocasião costumava-se também organizar o "beija-mão" da Imagem da Nossa Senhora Aparecida. ${ }^{590}$

Programadas ou não, a verdade é que não faltavam romarias vindas da própria diocese de D. Epaminondas. As Ânuas de 1910 nos informam, em janeiro, sobre uma romaria de 400 pessoas de Caçapava, as quais, "comportaram-se muito bem", enquanto que a de Guaratinguetá, "muito numerosa" e tendo à frente o vigário, provocou "tremendo atropelo" por ocasião do beijamento da imagem. Ao longo do ano romarias de São Paulo, Rio de Janeiro, Juiz de Fora, Bananal, Barra Mansa, Salesópolis, São José dos Campos e, por último, mas não menos importante, Taubaté.

É natural que o afluxo de romeiros pertencentes à diocese de Taubaté não fosse visto com agrado pelo bispo. Ciente da drenagem de recursos em favor um

589 ARRUDA, Marcelo Pedro de. Triunfo católico no calendário secular: Nossa Senhora Aparecida no calendário republicano (1930-1980). 2005. Tese (Doutorado em História Social) - Universidade de São Paulo, São Paulo, 2005. p. 183.

590 WERNET, Augustin. Peregrinação a Aparecida: das romarias programas ao turismo religioso. In: RODRIGUES, Adyr Balastreri (org.) Turismo. Modernidade. Globalização. São Paulo: Hucitec, 1977. p. 86. 
Santuário fora de seu controle, D. Epaminondas busca amparo à questão na Pastoral Coletiva de 1910:

678. As peregrinações não são uma simples excursão, feita pôr curiosidade, para distrair o espírito, mas uma solene manifestação de fé, um ato coletivo de religião e de piedade, que deve ser praticado com espírito de oração, caridade e penitência. Quando são devidamente organizadas e dirigidas, contribuem admiravelmente para excitar a fé do povo e induzilo á pratica das virtudes cristãs.

679. Para que as peregrinações surtam os efeitos salutares, que todos desejamos, e não se convertam em ocasiões de escândalo para os fiéis, queremos e ordenamos que os Rev. ${ }^{\text {mos }}$ párocos e sacerdotes, em geral, não promovam, organizem nem dirijam peregrinações, senão raramente, e por motivos extraordinários, e sempre com audiência da autoridade diocesana, a cuja aprovação submeterão os respectivos programas.

Mandamento abaixo é bastante claro no sentido de reprimir o ímpeto dos fiéis que promovem romarias, ...

As peregrinações ou romarias religiosas, quando convenientemente realizadas, constituem um dos mais belos atos do culto público católico, umas das mais luminosas afirmações da fé cristã; neste sentido são muitos para serem louvadas, animadas e promovidas.

...cuja atenção é chamada sobre a verdadeira autoridade diocesana.

Infelizmente, porém, muita vez deviam-se algumas do seu verdadeiro espírito cristão, desconhecendo os seus promotores os deveres que têm para com a Autoridade Diocesana e Paroquial nesta matéria e deixando-se guiar mais por sentimentos mundanos e profanos, quais os de uma exibição vaidosa, um passeio de recreio e até, às vezes, uma exploração, do que uma pratica santa e salutar de nossa religião.

Fazendo lembrar também aos fiéis que quem manda é o bispo,...

Considerando que, em várias paróquias desta Diocese se têm dado diversos abusos neste sentido, chegando algumas pessoas a promoverem romarias com caráter religioso, sem de fato terem conhecimento os próprios Vigários e sem que para qual fazê-las tenha os tais promotores obtido da Autoridade Diocesana a necessária licença e também a aprovação dos programas, a que deve obedecer, indo assim de encontro a graves leis da Igreja;

...a admoestação se estende aos sacerdotes:

591 Pastoral Coletiva de 1910. 
no intuito de fazer cessar semelhantes irregularidades ordena o Ex. ${ }^{\text {mo }} \mathrm{Sr}$. Bispo Diocesano a todos os Rev. ${ }^{\text {mos }}$ Vigários de sua jurisdição que leiam e expliquem aos fiéis de todas as paróquias, a seu cargo, no primeiro domingo após o seu recebimento, o presente Mandamento com as determinações do Ex. ${ }^{\text {mo }}$ Episcopado do Sul do Brasil, contidas na ultima Pastoral Coletiva, cujos decretos passo a transcrever fielmente. (Segue a transcrição dos n. ${ }^{\circ} 677,678,679,680$ da Pastoral). Taubaté, 27 de novembro de 1911. De ordem do Ex. ${ }^{\text {mo }} \mathrm{Sr}$. Bispo Diocesano. Pe. José Alves de Moura, Secretário do Bispado. ${ }^{592}$ (os grifos são deles e os negritos, nossos)

O efeito do Mandamento, no entanto, parece ter sido insuficiente, e nova lembrança é feita em 1912:

Romarias e esmolas para fins religiosos. «O Ex. ${ }^{\text {mo }}$ Sr. Bispo Diocesano mais uma vez chama a atenção dos Rev. ${ }^{\text {mos }}$ párocos e dos fiéis desta diocese para a obrigação de submeterem à aprovação prévia da Autoridade Diocesana os programas das romarias e da mesma obterem a necessária licença para que possam efetuá-las, segundo as determinações da ultima Pastoral Coletiva [...] ${ }^{593}$

O mesmo se dando em agosto do mesmo ano!

[...] chama o mesmo Ex. ${ }^{\text {mo }}$ Ordinário a atenção dos Rev. ${ }^{\text {mos }}$ vigários e dos fiéis para as disposições da última Pastoral Coletiva, quanto às romarias, que só podem ser feitas «por motivo grave, com licença da Autoridade diocesana, com programa previamente aprovado pela mesma, sob a direção espiritual do Vigário da paróquia e com espírito verdadeiramente cristão. ${ }^{594}$

O problema não se extinguiu e, ao visto, piorou, pois agora são os vigários que também acompanham as romarias sem licença. A solução conciliatória, parece, passou pela taxação das romarias, ...

Tendo chegado ao conhecimento do Ex. ${ }^{\text {mo }}$ Sr. Bispo Diocesano, que alguns Vigários tem cantado solenemente TeDeum e acompanhado Romaria à Aparecida, sem a respectiva licença, recomenda aos Rev. ${ }^{\text {mos }}$ Vigários que verifiquem bem na Tabela Diocesana quais os atos que nela se acham taxados e que exigem licença da Autoridade Diocesana. Taubaté, 19 de julho de 1916. ${ }^{595}$

...sendo recorrente ao longo do tempo:

Romarias anticanônicas. O Ex. ${ }^{\text {mo }}$ Sr. Bispo chama a atenção dos católicos aos quais diga respeito para as determinações da

592 ACDT. Mandamento n. ${ }^{\circ} 4.27$ de novembro de 1911.

593 ACDT. Aviso n. ${ }^{\circ}$ 53. 29 de janeiro de 1912.

594 ACDT. Aviso n. ${ }^{\circ} 62.5$ de agosto de 1912.

595 ACDT. Aviso n. ${ }^{\circ}$ 154. 19 de julho de 1916. 
Igreja sobre Romarias, que, não sendo autorizado por quem de direito, devem ser consideradas como proibidas, não podendo nenhum católico tomar parte nelas. Em ordem a isto, determina S. Ex. ${ }^{a}$ que os Rev. ${ }^{\text {mos }}$ Vigários das duas paróquias desta cidade leiam e expliquem aos fiéis o que a este respeito prescrevem os Ex. ${ }^{\text {mos }}$ Bispos do Brasil nos n. ${ }^{\circ} 846,847,848$ e 849 da pastoral Coletiva.

Falamos em projeto regional de romanização, nos esforços de D. Joaquim Arcoverde para a sua implantação e, principalmente, nas lutas entre D. Epaminondas e D. Duarte, cada qual na defesa de seus objetivos e pontos de vista.

Seja como for, o Santuário de Aparecida recebia os mais diversos incentivos por parte da hierarquia católica, visando com isso reforçar e manter um pólo de atração de um catolicismo que, se ultramontano, nem por isso destituído da emotividade herdada do catolicismo luso-brasileiro. Orientar as práticas devocionais dos romeiros, depurá-las e enquadrá-las em um novo modelo era, portanto, o objetivo final, objetivo final esse cuja fonte alimentadora residia, única, e tão somente, na imagem de terracota de Nossa Senhora da Conceição, cuja ação, tida como milagrosa, corria entre as gentes.

Tendo servido como demonstração de força da Igreja em relação ao governo brasileiro, potencializando, desse modo, a aproximação em direção ao Estado, a solenidade de coroação da imagem também se prestou, com êxito, para iniciar um processo de expansão da imagética da virgem milagrosa, ampliando seu caráter geográfico e, consequentemente, sua devoção. Em outras palavras, uma santa de caráter regional buscava espaço em caráter nacional. Iniciava-se, assim, a vida pública da imagem, culminando com sua consagração como Padroeira do Brasil em 31 de maio de $1931 .^{597}$

Lourival dos Santos, em seu estudo sobre a evolução da produção das estampas impressas de Nossa Senhora Aparecida, ${ }^{598}$ chama a atenção para o fato de que a primeira imagem oficial mandada imprimir na França, em 1854, pelo nosso já conhecido D. Antônio Joaquim de Melo, possuía feições européias, pele branca e olhos claros. Tentava o bispo, evidentemente, disciplinar e romanizar uma devoção

596 ACDT. Aviso n. ${ }^{\circ} 490.6$ de maio de 1925.

597 Vale lembrar que em agosto de 1945 a Imagem realizou visita a São Paulo, contra o comunismo, em setembro de 1954 ocorreu o primeiro Congresso da Padroeira, e entre 1965 e 1968 a Imagem percorreu o Brasil em peregrinação.

598 SANTOS, Lourival dos. Igreja, nacionalismo e devoção popular: as estampas de Nossa Senhora Aparecida (1854-1978). 2000. Dissertação (Mestrado em História Social) - Universidade de São Paulo, São Paulo, 2000. 
advinda unicamente do povo, mandando, inclusive, queimar as imagens em papel:

Fomos à Capela de Nossa Senhora Aparecida, visitamos a Casa dos milagres e achamos muitas pinturas que não convém, inda mais as gravadas em papel. Nós proibimos com pena de culpa ao capelão que consinta mais pintura alguma em papel, consumindo desde já todas que existem: aceitará as em cera ou madeira... ${ }^{599}$

A produção das estampas materializa a encampação e o direcionamento da devoção da Imagem pela Igreja católica. Das "santinhas" com temática sobre a coroação, "portadora didática de uma mensagem e como uma espécie de moeda com a qual a Igreja passou a negociar com o Estado", ${ }^{600}$ passando pelas impressões onde a Imagem paira sobre o rio onde foi retirada, até chegar às em que Nossa Senhora Aparecida se assenta sobre o globo terrestre, tendo como destaque o mapa do Brasil, nota-se, nitidamente, e independente da composição plástica das estampas, um lento e gradual "escurecimento" das feições da santa, particularmente após 1929, até seu total enegrecimento em 1959.

As histórias dos milagres transmitidas e veiculadas pelas estampas também demonstram que foi necessária uma progressiva identificação entre a Imagem e a história do povo que construiu essa devoção. Não foi qualquer "imagem" representada nas estampas que conquistou a empatia dos fiéis. O peregrino de 'Aparecida' teve que se identificar com a Imagem e ver, de alguma forma, seu próprio rosto refletido na virgem milagrosa, identificando-se com a cor da sua pele, com os seus hábitos. ${ }^{601}$ (os grifos são nossos)

A Igreja católica, portanto, ao alterar, lenta e judiciosamente, a pigmentação da virgem, aproximou-a do romeiro, fazendo-o ver-se nela própria. Isso demonstra a capacidade política da Igreja católica em saber "negociar" com seus fiéis, avançando, ou retrocedendo, nas horas corretas. Nesse caso, a hierarquia católica foi ao encontro de seus fiéis, sem que, em nenhum momento, abdicasse da ortodoxia, mas, sim, absorvendo a emotividade do povo devoto. Nisso reside, ao nosso ver, um dos muitos aspectos que compõem a força da imagem de Nossa Senhora Aparecida.

Em vista disso, e considerando os interesses de sua diocese, D.

599 ACAA. Livro do Tombo. Visita pastoral de D. Antônio Joaquim de Melo na Capela. p. 150.

600 SANTOS, Lourival dos. Igreja, nacionalismo e devoção popular: as estampas de Nossa Senhora Aparecida (1854-1978). 2000. Dissertação (Mestrado em História Social) - Universidade de São Paulo, São Paulo, 2000. p. 93.

601 SANTOS, Lourival dos. Igreja, nacionalismo e devoção popular: as estampas de Nossa Senhora Aparecida (1854-1978). 2000. Dissertação (Mestrado em História Social) - Universidade de São Paulo, São Paulo, 2000. p. 93. 
Epaminondas tentaria, disciplinadamente, e consciente das amplas opções oferecidas pelo ultramontanismo, direcionar os fiéis residentes em núcleos urbanos, máxime os brancos e de classe média, para um novo modelo devocional que a Igreja católica apresentava: Santa Teresinha.

Iniciava-se, pois, no âmbito da diocese, um novo 'caminho de fé' que, sem desvincular piedade popular e autoridade papal, significava, em nosso entender, um confronto velado, ou mesmo um subconfronto, na disputa pelo simbólico, uma resposta às desavenças com $\mathrm{D}$. Duarte. Uma resposta, sim, mas inteiramente ultramontana.

Nascida Maria Francisca Teresa Martin, em Alençon, França, em 2 de janeiro de 1873, aos quatro anos perde sua mãe. O pai decide mudar-se para Lisieux, onde residia seu cunhado. De compleição fraca e saúde precária, seu desejo de tornar-se religiosa carmelita, em virtude de sua pouca idade, foi negado pelo pai e pelo próprio superior do Carmelo.

Em 7 de novembro de 1887, organizou-se em Paris uma peregrinação a Roma. Dela tomaram parte Teresa, seu pai e uma sua irmã no Vaticano, e os peregrinos forma recebidos pelo Papa Leão XIII. Apesar do coordenador da peregrinação ter avisado que os peregrinos não podiam falar com o Sumo Pontífice, Teresa não pode se conter e desobedeceu a ordem dada. Quando estava ajoelhada diante do Santo Padre, ela pediu que ele a autorizasse a entrar no carmelo aos 15 anos. ${ }^{602}$

Sua entrada no carmelo de Lisieux deu-se em 9 de abril de 1888, tendo recebido o hábito em 10 de janeiro de 1889; em 8 de setembro de 1890 ocorreu a sua profissão religiosa, vindo a falecer em 30 de setembro de 1897, aos 24 anos.

Os escritos de Santa Teresinha primam pela simplicidade, sequer tangenciando o aprofundamento vertical dos grandes teólogos. São poesias, cartas, manifestações de acendrado amor a Deus com o fito de demonstrar como chegar a Deus fazendo pequenas coisas, dentre elas, particularmente, a comunhão.

Pouco antes de morrer, Santa Teresa completou sua curta auto biografia, História de uma alma, que celebrou os detalhes mundanos da sua vida familiar e da sua curta vida como freira. A mensagem espiritual de Teresa era singela: qualquer pessoa pode ser santa fazendo as mais anônimas tarefas por amor ao Cristo. O que tomou a imaginação dos fiéis mais românticos foi, porém, a maneira pela qual essa freira tão jovem dramatizou sua mensagem com a aceitação de uma morte prematura e

602 SALLES, Benedito Galvão Patrício. Santa Teresinha e o seu primeiro santuário. Inédito. 1984. p. 12. 
dolorosa por tuberculose. ${ }^{603}$

A importância de Santa Teresa de Lisieux, ou Santa Teresinha, como é mais conhecida em nosso país, se enquadra na importância atribuída pela romanização à juventude. Primeira comunhão, Filhas de Maria, Congregação da Santa Infância e outras tantas iniciativas que a Igreja católica buscou promover e incentivar, faziam parte do processo de cooptação visando os fiéis de pouca idade.

Os redentoristas, em 21 de junho de 1910, por ocasião das comemorações de São Luís, também demonstram uma orientação pastoral dirigida às crianças:

Festa de São Luís. Bem poucas vezes terá sido tão bonita como desta vez. P. Provincial cantou a missa. P. Visitador foi o presbítero assistente; P. Reitor o diácono; P. Diretor o subdiácono. Da Penha veio o atraente amigo das crianças $P$. Afonso, para pregar. Fez uma linda alocução muito apropriada às crianças. A direção do coro foi do sacristão Sr. Benedito Barreto, que com a cooperação do P. Afonso e do P. Oto, executou uma bela missa com agrado de todos.

Os pequeninos, esperança dos padres, não poderiam se despedir sem os instrumentos da propaganda religiosa, e assim, "cada criança recebeu um belo terço e um santinho como lembrança da festa." 604

Pio $X$, que movia uma campanha permanente para levar o fiel a comungar com mais freqüência, reduziu para sete anos a idade da primeira comunhão. Costumando citar que "haverá santos entre as crianças", a redução de idade transformou substancialmente a experiência social e religiosa de milhões de cristãos.

Em torno às comunhões infantis surgiu uma verdadeira celebração da inocência e da família - as meninas de vestido e véus brancos, os meninos de roseta e boldriê, os parentes reunidos para comemorar em meio às procissões e aos desfiles dos comungantes - que ingressou rapidamente na cultura popular católica. ${ }^{605}$

Atingindo principalmente os mais jovens com sua mensagem de fácil compreensão, Sóror Teresa era denominada por Pio XI "a estrela de meu pontificado", e é possível que dois de seus decretos, Sacra Tridentina Synodus, sobre a comunhão freqüente, e Quam singulari, sobre a comunhão às crianças, tenham sido influenciados pela leitura dos escritos teresianos.

A devoção de D. Epaminondas a Santa Teresinha se deve, segundo seu

603 WOODWARD, Kenneth L. A fábrica de santos. São Paulo: Siciliano, 1992. p. 335.

604 ACPSR. Crônica da Comunidade Redentorista de Aparecida, v. II (1908-1922). pp.73-74.

605 DUFFY, Eamon. Santos \& Pecadores - História dos Papas. São Paulo: Cosac \& Naify Edições Ltda. 1998. p. 247. 
biógrafo, a um engano. Estando no Rio de Janeiro, em 1913, por motivo de saúde, ao procurar uma obra sobre a vida de Santa Teresa D’Ávila, D. Epaminondas encontrou a autobiografia de Santa Teresa de Lisieux, e "desde então nunca mais pode esquecer-se da querida santinha. Chamava-a na intimidade de uma devoção ardente: - a Teresinha." 606

Não obstante nenhuma carta referente ao tema ter sido por nós encontrada, Ascânio Brandão se refere a correspondência de D. Epaminondas com as carmelitas francesas:

De Lisieux as Carmelitas Irmãs da Santa, diversas vezes escreveram a D. Epaminondas e Ihes mandavam relíquias e estampas, com as mais consoladoras notícias do processo da beatificação introduzido pelo Santo Padre Pio X em 1914. ${ }^{607}$

A devoção de D. Epaminondas pela 'estrela do pontificado' de Pio XI é enfatizada pelo biógrafo:

A 'História de uma alma', este livro admirável que no mundo inteiro provocou uma verdadeira renascença espiritual no expressivo dizer do Pe. Petitot, autobiografia de Santa Teresinha, era o pábulo espiritual mais delicioso para o coração de D. Epaminondas. Não se cansava de ler e reler tudo quanto se referia à espiritualidade teresiana. Era um profundo conhecedor e mestre do 'Pequenino caminho da via da infância espiritual'. 608

$\mathrm{Na}$ configuração histórica e diplomática entre o Vaticano e a França, a proclamação da heroicidade de Sóror Teresa no consistório de 14 de agosto de 1921 representou uma renovação das boas relações entre os dois Estados, iniciada, como vimos anteriormente, com a canonização de Joana D’Arc.

Sóror Teresa adquiria, naquele momento, a condição de 'Venerável', e Ascânio Brandão, mais uma vez referindo-se a D. Epaminondas enfermo, assim retratou seu estado de ânimo ao tomar conhecimento da notícia: "O enfermo que há pouco gemia aflito em cólicas hepáticas e se afadigava com a dispnéia, estava sorridente, calmo, nada neurastênico, feliz como poucas vezes o tinha visto. Alguns dias após estava de pé.“ 609

606 BRANDÃO, Ascânio da Cunha. Dom Epaminondas. São Paulo: Oficinas gráficas da Ave Maria, 1941. pp. 225-226.

607 BRANDÃO, Ascânio da Cunha. Dom Epaminondas. São Paulo: Oficinas gráficas da Ave Maria, 1941. p. 226. A introdução da causa da beatificação de Teresa deu-se em 9 de junho de 1914.

608 BRANDÃO, Ascânio da Cunha. Dom Epaminondas. São Paulo: Oficinas gráficas da Ave Maria, 1941. p. 226.

609 BRANDÃO, Ascânio da Cunha. Dom Epaminondas. São Paulo: Oficinas gráficas da Ave Maria, 1941. p. 227. 
As primeiras referências à Sóror Teresa n' 'O Lábaro' são de agosto de 1916, mandada publicar por um certo Jacques Cardozo com o título "A florzinha do Carmelo de Lisieux (França)". Na parte superior da matéria, a foto de Teresa:

\begin{abstract}
Maria Francisca Thereza Martin, na religião Sóror Teresa do Menino Jesus e da Santa Face, nasceu em Alençon (França) aos 2 de janeiro de 1873. Aos 15 anos de idade entrou para o Carmelo de Lisieux, onde passou 9 anos e 6 meses na prática de todas as virtudes, distinguindo-se principalmente por um amor fervoroso para com Deus e uma admirável confiança nele. Morreu em odor de santidade, aos 30 de setembro de 1897, aos 24 anos de idade. Era tal a sua perfeição e santidade que todos a consideravam como um anjo na terra. Um dos últimos atos do Grande Pontífice Pio X foi a introdução da causa de sua beatificação. Podemos dizer: o último ato de um santo à beatificação de uma santa. Teresinha, como ela queira que a chamassem quando neste mundo vivia, não é menos querida do Sumo Pontífice reinante, que já concedeu licença para cunharem-se medalhas com o seu retrato. Dizia ela que "queria passar o seu céu fazendo o bem na terra". E, na verdade, desde sua morte, tem feito cair sobre a terra uma verdadeira chuva de graças e verdadeiros milagres.
\end{abstract}

Feita a apresentação da "florzinha do Carmelo de Lisieux", fala o depoente sobre o milagre:

A prova disso é o seguinte: achando-me gravemente enfermo e tendo sofrido uma operação, não fiquei são; dizendo-me o médico, que era muito provável que fosse preciso uma nova intervenção cirúrgica. Então, pessoas de minha amizade, com o meu consentimento, fizeram a promessa que se segue: que eu daria publicação desta graça, mandaria celebrar uma missa e faria uma comunhão. Hoje, gratíssimo a esta Serva de Deus, cumpro a promessa, pois, acho-me completamente restabelecido. ${ }^{610}$

As publicações sobre Sóror Teresa em 1916 são tímidas, limitando-se a apenas duas. Além da acima exposta, uma outra, em setembro. ${ }^{611}$

Em 1917 as publicações aumentam, e das cinqüenta e duas edições do jornal católico para aquele ano, verificamos a incidência de dezoito números onde constam as "Graças de Sóror Teresa". As notas, em geral pequenas, além de estarem localizadas em espaços pouco privilegiados do jornal, são fruto de publicação de uma só pessoa. No decorrer da pesquisa achamos apenas uma chamada com duas pessoas, feita na primeira página, ${ }^{612}$ bem como uma única outra

610 O Lábaro, n. ${ }^{\circ}$ 344, VII. 10 de agosto de 1916.

611 O Lábaro, n. ${ }^{\circ} 345$, VII. 14 de setembro de 1916.

612 O Lábaro, n. ${ }^{\circ}$ 391, VIII. 5 de julho de 1917. 
chamada de primeira página. ${ }^{613}$

As matérias, em geral, não especificam os favores recebidos pelos devotos, podendo-se classificar a grande maioria tão somente como "graças". As que especificam, entretanto, materializam a manipulação do sobrenatural para um proveito imediato, de "uso tópico", excluindo-se aí as noções de ética, pecado e salvação, caso típico de piedade antropocêntrica.

Em junho de 1917, por exemplo, a intercessão de Sóror Teresa em um parto bem sucedido faz com que a criança receba, em sua homenagem, o nome de Maria Theresa, ${ }^{614}$ e se "quando se perdia dedal, uma tesoura, uma moedinha, Santo Antônio que desse conta do objeto perdido," 615 nem por isso os devotos deixaram de apelar para a "florzinha de Lisieux" no sumiço de uma aliança ${ }^{616}$ e no furto de um relógio, 617 tendo sido, segundo os agradecimentos, muito bem atendidos. 0 catolicismo romanizado, como se pode verificar, tinha o poder de criar novas devoções, mas precisava compor com os velhos hábitos herdados do catolicismo luso-brasileiro.

A coluna "graças de sóror Teresa" inicia 1918 com os agradecimentos de alguém da cidade de Jacareí cuja filha foi "feliz nos exames", 618 e já na semana seguinte nota-se um ligeiro aumento na altura da coluna. Devotos de Taubaté, Pindamonhangaba, São José dos Campos, São Luis do Paraitinga, e mesmo de São Paulo, manifestam publicamente as graças alcançadas, aí inclusa a cura de "um grande defeito sobre os olhos" 619 de uma criança. Nota-se, também, uma certa elitização dos devotos, posto que muitos deles se apresentam com os respectivos títulos, como no caso do promotor público de Jambeiro, feliz pelo parto de sua esposa, ${ }^{620}$ e do delegado de polícia de São Luis do Paraitinga, reconhecido pela graça recebida. ${ }^{621}$

O ano de 1919 também é farto em publicações, e já em fevereiro uma

613 O Lábaro, n. ${ }^{\circ}$ 392, VIII. 12 de julho de 1917.

614 O Lábaro, n. ${ }^{\circ}$ 387, VIII. 7 de junho de 1917.

615 FREYRE, Gilberto. Casa-Grande \& Senzala. 27. ed. Rio de Janeiro: Record, 1990. p. LIX. Dentre as diversas "especialidades" de Santo Antônio uma delas é a busca de objetos perdidos. O "Responso de Santo Antônio" evoca tal poder: [...] Rompem-se as mais vis prisões, Recupera-se o perdido, Cede o mar embravecido, No maior dos furacões...

616 O Lábaro, n. ${ }^{\circ}$ 404, VIII. 4 de outubro de 1917.

617 O Lábaro, n. ${ }^{\circ} 412$, VIII. 29 de novembro de 1917.

618 O Lábaro, n. ${ }^{\circ} 420$, IX. 24 de janeiro de 1918.

619 O Lábaro, n. ${ }^{\circ} 434$, IX. 2 de maio de 1918.

620 O Lábaro, n. ${ }^{\circ} 438$, IX. 30 de maio de 1918.

621 O Lábaro, n. ${ }^{\circ} 440$, IX. 13 de junho de 1918. 
devota agradece a Sóror Teresa a recuperação de uma mala perdida em viagem, a qual, "depois de quase um mês de expectativa, sem saber como, chegou-Ihe às mãos a aludida mala, sem sofrer nenhuma avaria." ${ }^{622} \mathrm{E}$ se o imanente era a tônica, finalmente o transcendente se materializou nos agradecimentos do Padre José Benedito Alves Monteiro, vigário de Santa Branca, ao rogar, e obter, após entregar o caso à Sóror Teresa, a conversão de "dois pecadores obstinados, que já haviam resistido indiferentes às santas missões". ${ }^{623}$

$\mathrm{Na}$ edição de 20 de março de 1919, em diante, a coluna das "graças de Sóror Teresa" recebe, no alto, sua foto. Medindo $5 \times 4 \mathrm{~cm}$, ao lado da mesma, a cada número, lê-se uma pequena frase extraída dos seus pensamentos. Nesta mesma edição D. Epaminondas assina a "oração para se alcançar a beatificação da Serva de Deus". ${ }^{624}$ A construção da devoção agora prossegue com o lançamento de um livro: "Aos devotos da Beata Teresinha - Encontra-se na secretaria do bispado a interessante História de Sóror Teresa do Menino Jesus, pelo Padre J. Carbonel, SJ, Traduzida para o português pelo Pe. Armando Adriano Loche." 6250 ano prossegue, um preso da cadeia de Bananal agradece graça recebida, ${ }^{626}$ enquanto que o vigário de Redenção da Serra, Padre Laguna, também manda agradecer pela cura de uma prosaica dor de dentes. ${ }^{627}$ Já o capitão Antônio Constâncio de Santana, "membro do diretório político de Santa Branca", é vitimado por uma "hérnia de mau caráter"; do alto dos seus 78 anos, temia a cirurgia indicada pelo médico, quando "alguém lembrou-se de colocar uma relíquia de Teresinha sobre a parte doente e que se rezasse 3 Ave Marias, e dois dias depois estava curado." ${ }^{628}$ O ano vai se encerrando e, após tantas curas, Sóror Teresa ainda "abranda o fogo" proveniente de um ameaçador incêndio em um roçado. ${ }^{629}$

É nítido o aumento de publicações em 1920, ano em que apenas seis números d'O Lábaro' não apresentam as "graças de Sóror Tereza". A cura de doenças é o tema mais freqüente, particularmente o sarampo, a gripe e a bronquite, no caso de crianças, passando por inconvenientes "frieiras crônicas", onde a devota, após a intervenção de Sóror Teresa, "curou-se com um insignificante remédio

622 O Lábaro, n. ${ }^{\circ} 475$, X. 6 de fevereiro de 1919.

623 O Lábaro, n. ${ }^{\circ} 479$, X. 6 de março de 1919.

624 O Lábaro, n. ${ }^{\circ} 481$, X. 20 de março de 1919.

625 O Lábaro, n. ${ }^{\circ} 483$, X. 3 de abril de 1919.

626 O Lábaro, n. ${ }^{\circ} 488$, X. 8 de maio de 1919.

627 O Lábaro, n. ${ }^{\circ} 491$, X. 29 de maio de 1919.

628 O Lábaro, n. ${ }^{\circ} 498$, X. 17 de julho de 1919.

629 O Lábaro, n. ${ }^{\circ}$ 516, X. 20 de novembro de 1919. 
aconselhado por uma amiga". ${ }^{630}$ Mediante os auspícios de uma devota, o prelado de Taubaté foi também alvo das graças de Teresa, responsável pelo restabelecimento da força em suas pernas:

GRAÇAS DE SÓROR TERESA Uma devota de Sóror Teresa do Menino Jesus envia $2 \$ 000$ para a publicação de uma graça alcançada, por meio da novena que fez, em honra da S.S. Trindade, a fim de obter dela, por intercessão da grande Serva de Deus, em favor do Ex. ${ }^{\text {mo }}$ Sr. Bispo de Taubaté - D. Epaminondas, o restabelecimento das forças de suas pernas, que o privavam de exercer as funções do seu sagrado magistério - Córregos, Minas. ${ }^{631}$

O Padre jesuíta Henrique Rubillion atuava, no Brasil, como promotor ${ }^{632}$ da causa da canonização de Sóror Teresa. Em artigo n’'O Lábaro, Padre Henrique afirma que o Brasil ocupa em Lisieux um lugar de destaque, pois os muitos fatos "proclamam alto e bom som" o direito que têm os brasileiros à gratidão das irmãs da Serva de Deus e dela própria.

Afirmando suas relações próximas e por anos seguidos com muitas pessoas devotas da taumaturga na capital do país e em vários estados da União, o Padre, "de boa mente", presta-se aos pedidos que, de todas as partes, e quase todos os dias, Ihe chegam de estampas, relações das maravilhas, medalhas, novenas, relíquias e demais objetos, "que o amor e o zelo do Carmelo de Lisieux multiplicaram para espalhar no mundo o culto de Teresinha, hoje conhecida e amada em todos os recantos do nosso planeta", transmite aos fiéis um convite do Carmelo de Lisieux: "oferecer a urna de prata onde serão conservados os ossos da Serva de Deus no interior do relicário monumental!" Em epígrafe, as palavras do Bispo de Taubaté: "Aplaudo muito a belíssima idéia, que será geralmente bem recebida. + Epaminondas". Embaixo, uma "Nota": "Os donativos para a 'Urna' de prata que deverá guardar os 'ossos' da Serva de Deus, poderão ser enviados ao Rev. ${ }^{\text {mo }}$ Padre Henrique Rubillon, Colégio Anchieta - Nova Friburgo, ou à Secretaria do Bispado". 633

Em pouco tempo a nova devoção ultramontana se alastrava, e a diocese de Taubaté também tratava de angariar donativos para confecção da urna:

630 O Lábaro, n. ${ }^{\circ} 545, \mathrm{XI} .10$ de junho de 1920.

631 O Lábaro, n. ${ }^{\circ} 551$, XI. 22 de julho de 1920. p. 2

632 "Uma função essencial do promotor local é encorajar preces ao candidato na esperança de que algum dos favores divinos recebidos acabe sendo um possível milagre". WOODWARD, Kenneth L. $A$ fábrica de santos. São Paulo: Siciliano, 1992. p. 186.

633 O Lábaro, n. ${ }^{\circ}$ 573, XI. 16 de Dezembro de 1920. p. 2 


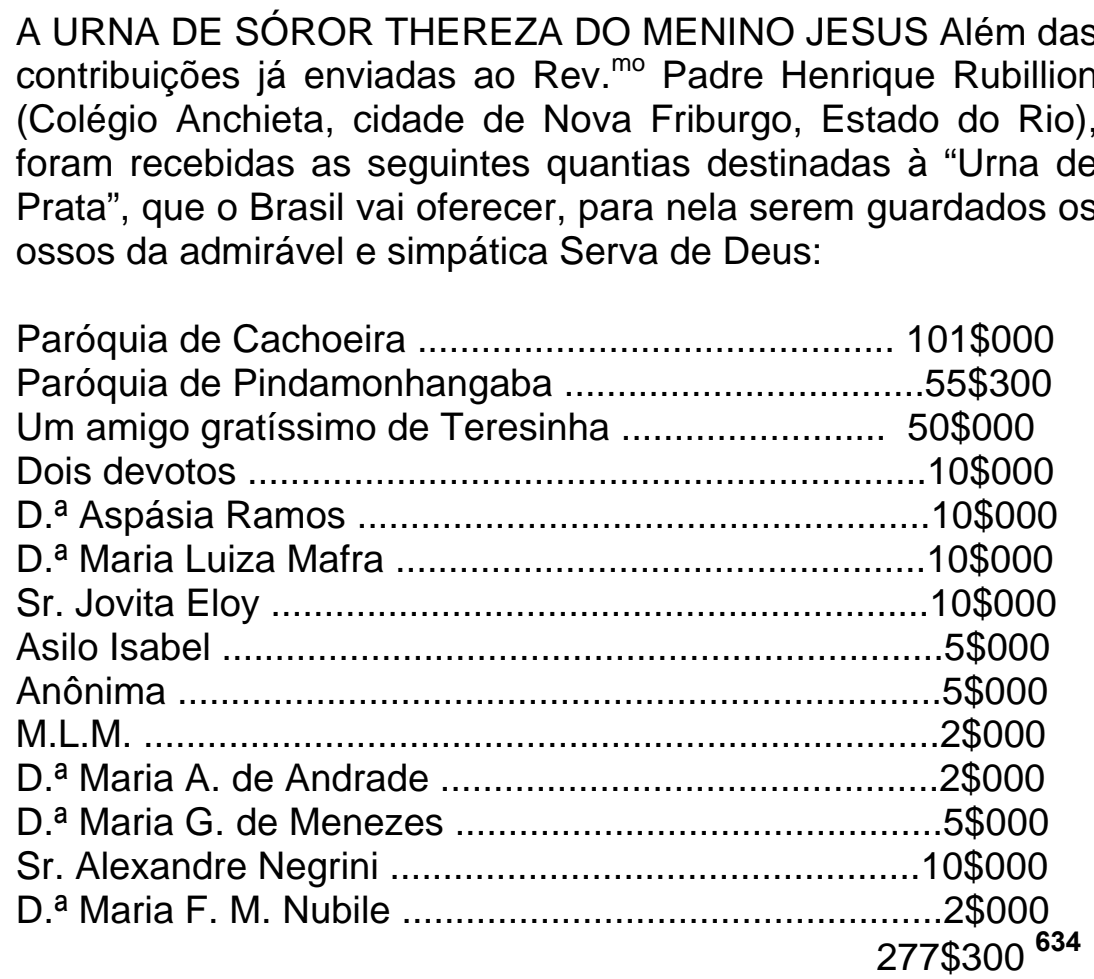

As declarações sobre as graças obtidas por intercessão de Sóror Teresa se avolumam ao longo dos meses seguintes, vindas de diversas cidades. Enfermidades pessoais, cura de filhos, sucesso nos negócios, dores no corpo e todas as demais vicissitudes humanas eram motivo para a ação milagrosa da 'santinha'. Alguns exemplos:

GRAÇAS DE SÓROR THEREZA Maria Francisca Nubile agradece à Teresinha do Menino Jesus três graças alcançadas por seu intermédio. Envia $2 \$ 000$ para a urna de prata e $1 \$ 000$ para a publicação.

Joaquim Celso da Silva Ramos agradece à Sóror Thereza muitas graças alcançadas por seu intermédio, principalmente a cura de uma filhinha e sucesso em um negócio importante. Envia 1\$ para a publicação. Jambeiro, 1921.

Eliza Reis, agradece à Teresinha a graça que alcançou por intermédio de novena da SS. Trindade. Envia $1 \$$ para a publicação.

Helena Cecy de Souza envia 3\$ para publicação de uma graça alcançada por intermédio da meiga Teresinha.

A bela florzinha do Carmelo, também se abriu para mim; o seu perfume, qual bálsamo sagrado, percorreu todo o meu corpo, quando pela primeira vez ouvi seu nome e meus olhos contemplaram sua imagem. A dor que me feria ao lado não mais existe, saiu repentinamente ! ... Estou curada ! Envio 1\$

634 O Lábaro, n. ${ }^{\circ}$ 588, XII. 31 de março de 1921; p.1 
para a publicação - Santa Isabel, 1921 - Benedicta Brazilina de Arantes.

Antonietta Albernaz Negrini, agradece à bela Teresinha grandes graças alcançadas por seu intermédio. Envia $2 \$$ para a publicação. - Santos, 1921.

Tenho alcançado uma graça especial, por intercessão da grande e bondosa Serva de Deus Sóror Thereza do Menino Jesus; cumpro, agradecida, a promessa que fiz de publicá-la, para o que envio a quantia de 2\$000 - Jambeiro, 14-3-1921. Maria Francisca Costa.

Anézia Ortiz Corsino agradece à Teresinha do Menino Jesus a graça alcançada por sua intercessão na ocasião da grave enfermidade de sua mãe; na maior das aflições recorri a irmã Teresinha que não a deixasse morrer sem os Sacramentos, se não fosse da vontade de Deus e sua cura. Logo ela foi sacramentada e pensei que falecesse naquela noite. No dia seguinte, com surpresa de toda família, começou a melhorar e acha-se restabelecida. Envio uma espórtula para a publicação. ${ }^{635}$

'O Lábaro' acompanhava, cotidianamente, a evolução dos acontecimentos a respeito de Irmã Teresa de Lisieux. Nos dias que precederam a decretação da heroicidade de suas virtudes, a folha diocesana novamente abre espaço para o Padre Henrique Rubillion anunciar o andamento de seus trabalhos no Brasil:

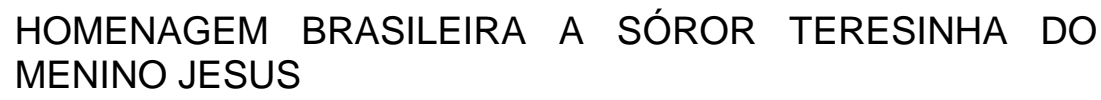

\section{FALA O SANTO PADRE}

Enquanto um piedoso afã de amor à santinha que lhes conquistou os corações agita tantos filhos desta terra, sedentos de lhe pagar um digno tributo de gratidão; enquanto se vão amontoando em Paris os generosos óbolos destinados à magnífica homenagem brasileira da urna preciosa ... Roma, a Roma que faz as santas, esquecida por uma vez da sua eternidade, não podendo resistir ao furacão de amor que desencadeou essa sua filha querida, Thereza do Menino Jesus, Roma se move, Roma caminha a passos de gigante, levando aos altares, onde há tanto tempo o mundo católico deseja vê-la a subir, a incomparável filha da Santa Igreja.

É a imensa alegria que do Mosteiro de Lisieux me comunicavam, há dias, as religiosas Carmelitas. Em data de 17 de junho escreviam-me:

"Não posso esperar para vos comunicar a boa nova. O Santo Padre dignou-se fixar a 2 de agosto p.p. a nossa Congregação

635 O Lábaro, n. ${ }^{0}$ 591. XII. 21 de abril de 1921. p. 3. 
geral, e, se tudo correr conforme os nossos desejos, a 15 de agosto proclamará o decreto sobre a heroicidade das virtudes, que daria a Sóror Thereza o título de "venerável".

Rezai e agradecei conosco a Deus esta imensa alegria. Chegamos ao porto!"

Feliz, rápida, única navegação esta para o porto onde é dado aos heróis privilegiados da nossa espécie receber um triunfo tão acima dos triunfos humanos. Alegram-se os católicos do Brasil, de, chefiados pelos seus piedosos Pastores, terem dado grande impulso a tamanha obra.

É de Lisieux sempre que recebo linhas como as seguintes: "Ontem, chegaram-nos vossas cópias de cartas episcopais, são eloqüentes e animadoras. Obrigado por terdes tomado este trabalho; a nossa Teresinha vo-lo pagará." (29 de maio) . "Obrigado pela nova transcrição das cartas episcopais. É admirável e quanto eloqüente." (7 de junho).

"Obrigado pelas novas cópias de cartas Episcopais. É um rico documento a apoiar a vossa obra" . (17 de junho).

Padre Henrique Rubillion, por sua vez, não se esquece das autoridades episcopais que o apóiam:

Por minha vez agradeço ao Ex. ${ }^{\text {mo }}$ Sr. Bispo de Corumbá as seguintes amáveis linhas que, a 29 de junho, se dignou mandar-me: "Queira V. Rev." ${ }^{\text {ma }}$ aceitar muitas cordiais felicitações pelo brilhante resultado dos abençoados esforços de $\mathrm{V}$. Rev. ${ }^{\mathrm{ma}}$ em prol da bela causa por que vem trabalhando, devendo sentir-se plenamente satisfeito com os tão eloqüentes testemunhos de quanto é querida no Brasil a admirável Irmã."

Pobres trabalhos meus, se não tivessem a apoiá-los vozes tão autorizadas e eloqüentes! Pe. Henrique Rubillion, S.J. ${ }^{636}$

O controle dos donativos para a confecção da urna de prata manifesta, ao nosso ver, um dos aspectos da racionalidade romanizadora. O ex-voto, figuras de cera, ou de madeira, de todo jeito e tamanho, representando crianças e adultos, ou então, partes do corpo: cabeça, peito, braço, pés, etc., trazido pelo romeiro ao santo de sua devoção como reconhecimento de uma graça, é inexistente no caso de Sóror Teresa, ao contrário de Aparecida, com sua sempre repleta "Sala dos Milagres".

Em relação à Sóror Teresa, a Igreja católica, particularmente a diocese de Taubaté, administrava a devoção dos fiéis, bem como suas doações, concentradas em um único "ex-voto": a urna de prata.

AOS DEVOTOS DA VENERÁVEL SÓROR TERESA DO MENINO JESUS. Avisamos aos devotos da Venerável Sóror

636 O Lábaro, n. ${ }^{\circ} 606$. XII. 11 de agosto de 1921. 
Teresa do Menino Jesus, que está encerrada a subscrição para compra da urna que o Brasil vai oferecer, para guardar os restos mortais da insigne carmelita.

Encerrado o momento de efervescência provocado pela urna, um novo exvoto coletivo é pensado, e sua obtenção é posta em andamento:

Aqueles, porém, que quiserem satisfazer a sua piedade, poderão fazê-lo contribuindo para a ereção da capela que se pretende construir nesta cidade e que, depois da sua beatificação, servatis servandis, Ihe será dedicada. ${ }^{637}$

Assim feito, as 'chamadas' faziam menção à capela:

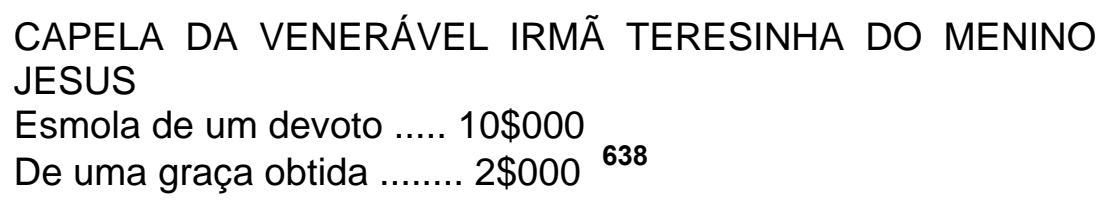

Morto Benedito XV em 22 de janeiro, em 6 de fevereiro de 1922 assume o trono de Pedro o papa Pio XI. que governaria os destinos da Igreja católica até 10 de fevereiro de 1939. 'O Lábaro', por sua vez, intensifica a propaganda, fazendo publicar em suas páginas dezenas de citações de "pensamentos", "trechos edificantes" e fatos curiosos em referência à Teresa, ou sobre sua vida, inaugurando, assim, uma nova estratégia de aproximação:

\footnotetext{
Venerável Teresinha do Menino Jesus

Um pensamento

Jesus! Jesus! Se é delicioso desejar o vosso amor, que não será gozá-lo para sempre?

Trecho edificante

Disseram a Teresinha um dia: Tendes sido fiel sempre à graça divina, não é? - Sim, desde a idade de três anos que eu nada hei recusado ao meu Deus. Entretanto, disto não posso gloriar. Vede como à tarde o sol, ao se pôr, doura o cume das árvores; assim minha alma vos parece brilhante e dourada, porque está exposta aos olhares do amor; se o sol divino não me enviasse seus raios, eu ficaria obscura e tenebrosa.

Novena de perfumes

No Carmelo de Vales Málaga (Espanha), as irmãs começaram uma novena à Teresinha do Menino Jesus. Desde o primeiro dia da novena um perfume delicioso de violetas se espalhou por todo o mosteiro, penetrando em todos os recantos e transformando-se logo em toda sorte de aromas. Ninguém sabia donde podiam vir aqueles perfumes esquisitos, tão suaves. Logo, porém, que terminou a novena, cessou o
}

637 O Lábaro, n. ${ }^{\circ}$ 647, XIII. 15 de junho de 1922. p. 2. Podemos traduzir "servatis servandis" como "conservando-se o que deve ser conservado".

638 O Lábaro, n. ${ }^{\circ} 654$, XIII. 17 de agosto de 1922. p. 2. 
perfume, deixando as irmãs piedosamente impressionadas.

639

A mudança de papa em nada alterou a devoção, e Sóror Teresa não seria esquecida. Ao contrário, 'O Lábaro', atento aos mais comezinhos acontecimentos versando sobre as intenções de canonização de Teresa, era pródigo em tudo informar:

No dia 30 do p. findo mês de janeiro, no Palácio Apostólico do Vaticano, na augusta presença do Santo Padre Pio XI. realizou-se a Congregação Geral dos Santos Ritos, na qual os Em. ${ }^{\text {mos }}$ Cardeais e Rev. ${ }^{\text {mos }}$ Prelados e Teólogos consultores, que a compõem, deram o seu voto sobre dois milagres que afirmaram ter Deus operado por intercessão da Venerável Serva de Deus do Menino Jesus. (Da "Acta Apostolicae Sedis n. ${ }^{\circ} 2$, de $1^{\circ}$ de fevereiro). ${ }^{640}$

De fato, em 29 de abril de 1923, Teresa era proclamada 'Bem-aventurada', recebendo, assim, por parte d'O Lábaro', a denominação de 'Beata Teresinha'. As contribuições para a construção da capela, em honra à sua beatificação, continuaram a acorrer logo no início do ano: "agradeço uma graça da Irmã Teresinha e remeto $2 \$ 000$ para a futura capela".

Alegre-se a diocese de Taubaté; alegrem-se os católicos em geral; alegrem-se os inúmeros devotos da querida, incomparável e Venerável Teresa do Menino Jesus. Segundo informação de fonte fidedigna, está marcada para o dia 29 do próximo mês de abril a Beatificação da grande e prodigiosa "Distribuidora de rosas celestiais". Beatificada, o nosso Ex. ${ }^{\text {mo }}$ bispo, que tão devoto seu é, vai pedir licença à Santa Sé para que seja dedicada à nossa amada Santinha uma capela que a Associação das Damas de Caridade vai construir na Vila Sóror Teresa do Menino Jesus nesta cidade e que será também o Centro das formosas "Obras dos Tabernáculos" e "Adoração do Santíssimo Sacramento". Continuem, pois, os devotos da grande Santa a mandar as suas esmolas para a Capela, a ser dedicada a ela. ${ }^{642}$ (o grifo é nosso)

Isto feito, as publicações constando de donativos para as obras aumentaram:

\section{GRAÇAS DA BEATA TERESINHA}

Porfírio Prado com intenção de obter várias graças por intercessão da Beata Teresinha, enviou-nos $10 \$$ para a futura capela que lhe será dedicada.

Em agradecimento de um favor alcançado por intercessão da Beata Teresinha, Amélia Nóbrega de Abreu envia $5 \$ 000$ para

639 O Lábaro, n. ${ }^{\circ}$ 664, XIII. 2 de novembro de 1922. p. 3

640 O Lábaro, n. ${ }^{\circ}$ 681, XIV. $1^{\circ}$ de março de 1923. p. 3

641 O Lábaro, n. ${ }^{\circ}$ 673, XIII. 4 de janeiro de 1923. p. 3.

642 O Lábaro, n. ${ }^{\circ}$ 684, XIV. 29 de março de 1923. p. 3. 
as obras da capela. $[\ldots]]^{643}$

Por intermédio do Sr. Jacques Cardoso, um anônimo remeteunos $20 \$ 000$ para as obras da capela.

Floripes Senne, agradece a Beata Teresinha do Menino Jesus, duas graças alcançadas pela sua intercessão e oferece $2 \$ 000$ para as obras da capela.

De um Vicentino de Jambeiro, para o mesmo fim, recebemos $10 \$ 000$.

Igual quantia enviou-nos uma devota residente em Bananal, para a construção da capela. ${ }^{644}$ (os grifos são nosso)

As notícias corriam, e a participação do Brasil nas festas religiosas, em Lisieux, também foram motivo de matéria n'O Lábaro', que transcreveu a carta que Monsenhor Lemonier, bispo de Bayeux e de Lisieux, enviou ao Dr. Luiz de Souza Dantas, embaixador do Brasil junto ao governo francês:

Sr. Embaixador - Tenho a honra de apresentar a V. Ex. os nossos respeitosos agradecimentos por se haver feito representar no "Triduum" de Lisieux. Sua grande nação teve o lugar de honra. Permita que digamos como nos satisfez o Sr. Secretário de Embaixada, Trajano Medeiros de Passo, delegado por V. Ex. A sua amabilidade, o seu trato e as palavras distintas que pronunciou no seu discurso, granjearamIhe as mais vivas e gerais simpatias. Aceite $V$. Ex. a expressão dos seus sentimentos respeitosos. + Thomas Lemonier, Bispo de Bayeux e Lisieux. ${ }^{645}$

O modesto plano de ereção de uma simples capela, localizada em área pobre da cidade, foi, em pouco tempo, substancialmente alterado. A intenção de se construir uma igreja em honra à Beata Teresinha envolvia autoridades municipais, doações de firmas e, obviamente, a burocracia da Santa Sé.

A idéia de construir nesta cidade uma igreja dedicada à Beata Teresinha do Menino Jesus vem sendo acolhida com gerais aplausos. De toda parte chegam palavras animadoras que, mesmo sem querer, vão criando um certo ambiente de confiança no êxito da obra. E, embora a ocasião não seja das mais oportunas para empreendimentos dessa natureza, com o concurso que deixam entrever esses aplausos, não será muito difícil dotar a cidade de um novo templo digno das suas tradições religiosas. $\mathrm{O} \mathrm{Dr}$. Prefeito Municipal acolheu favoravelmente a idéia, concorrendo pessoalmente com um conto de réis e oferecendo, em nome da Câmara, o terreno necessário para a Igreja. Os senhores Marinonio Piedade \& Comp., de São Paulo, oferecem para a igreja a imagem da

643 O Lábaro, n. ${ }^{0}$ 694, XIV. 31 de maio de 1923. 
Beata Teresinha, com 1,70 de altura. Além destes, há outros donativos que os numerosos devotos de Teresinha enviam para esse fim. Com tais elementos e confiados na proteção da B. Teresinha, não será aventurar-se demais o empreender nesta quadra uma obra que exige tantos recursos. Para dar começo à obra espera-se apenas a licença da Santa Sé, que há algumas semanas já foi pedida ${ }^{646}$

O que era para ser uma capela tornou-se igreja, e logo após é denominado de Santuário, exatamente como Aparecida. Em contraponto a Nossa Senhora Aparecida, uma santa de origens populares, cuja devoção sofria, ao longo do tempo, a depuração ultramontana, D. Epaminondas orientava o culto romanizado em direção a uma santa branca e européia, permitindo, todavia, o mesmo fulgor de piedade, tendo lugar a construção do templo com 969 metros quadrados, em estilo gótico, com terreno cedido pelo poder municipal.

Honra hoje a primeira página do nosso jornal o clichê da suntuosa igreja que se pretende levantar nesta cidade à Beata Teresinha.

A canonização de Sóror Teresa era tida como certa, e as obras não podiam esperar. O futuro era agora.

Esperava-se a competente licença para iniciar os serviços, mas visto que o processo de canonização vai correndo rápido e, segundo informações de Roma, estará terminado em 1925, deliberou-se dar começo aos trabalhos de construção, posto que, quando tiverem terminados, não será necessária a licença pedida.

A grandiosidade do templo, comparado às demais igrejas de Taubaté, pode ser avaliada pela largura e comprimento da construção:

Já estão abertos os alicerces e prontos para receber as bases de concreto de cimento sobre o qual serão levantadas as paredes. A igreja, de estilo gótico, terá 57 metros de fundo, incluída a sacristia, e 17 de largura, com três naves, divididas por colunatas. O clichê junto dá uma idéia da beleza do novo templo, embora nele não figurem as duas ordens de capitéis góticos, que muito hão de contribuir para o seu realce.

Por último, não poderiam faltar os pedidos de donativos para a obra da igreja:

Para levar a termo tão grande empreendimento conta-se com a proteção da Beata Teresinha, que saberá mover o coração dos seus devotos para que generosamente o auxilie. Muitos são os devotos da Beata Teresinha dentro e fora deste Bispado, a todos apela-se e a todos pede-se a sua cooperação. Os

646 O Lábaro, n. ${ }^{\circ} 701$, XIV. 19 de julho de 1923. p. 3. 
donativos podem ser enviados a esta Redação, com a declaração do nome do doante, para ser publicado juntamente com a quantia enviada. ${ }^{647}$

assunto, pelo que se pode verificar, correu as páginas de outros jornais:

SANTUÁRIO DA B. TERESINHA

Os nossos colegas do "Estado" publicaram domingo a seguinte notícia: "Depois de uma estadia [sic] no Rio de Janeiro, já se acha na sede de sua diocese em Taubaté, o Ex. ${ }^{\text {mo }}$ Sr. Bispo Diocesano, Monsenhor D. Epaminondas Nunes de Ávila e Silva. Sua Ex. ${ }^{a}$ Rev. ${ }^{\mathrm{ma}}$, na capital da República, recebeu a visita do revmo. Padre Henrique Roubillon, grande propagandista da devoção à Beata Teresinha do Menino Jesus, que regressou há pouco do Carmelo de Lisieux; onde representou os católicos brasileiros na cerimônia da beatificação da gloriosa beata. A propósito desse encontro "O Lábaro", órgão da diocese de Taubaté, anuncia que já estão prontos os alicerces para receber as bases de concreto de cimento sobre o qual serão levantadas as paredes da futura igreja em honra àquela que dentro em breve, será canonizada. Esse templo de estilo gótico terá 57 metros de fundo e 17 de largura, com três naves. Será pois, a florescente diocese de Taubaté, a primeira, talvez do Brasil, que levantará o templo em honra à Teresinha para o que muito se tem interessado o Sr. Bispo D. Epaminondas. $\mathrm{Na}$ redação do "O Lábaro", Taubaté, são recebidos os donativos que queiram enviar os devotos da mimosa florzinha do Carmelo. ${ }^{648}$

As ações em torno da nova devoção recebiam, agora, uma oração, devidamente autorizada por D. Epaminondas:

\begin{abstract}
A BEATA TERESINHA
Oração à bem-aventurada Teresinha do Menino Jesus, pelo clero. "Almas, Senhor, precisamos de almas! Principalmente, almas de apóstolos e de mártires, para que, por elas, abrasemos de vosso amor, a multidão dos pobres pecadores".

Por esta angélica e mimosa florzinha do Carmelo,a mais ardente súplica de vosso coração ao coração de vosso Deus. O grito de Jesus moribundo: "Eu tenho sede!" ressoava a cada instante em vosso coração. Tínheis a sede ardente de almas, e quisestes, a todo custo, arrancar das chamas eternas os pecadores. Ouvi, pois as suplicas ardentes que vos fazemos pelo nosso clero e por aqueles que aspiram ao ministério sublime da salvação das almas. Bem-aventurada Teresinha, pedi instantemente ao Senhor da Messe, numerosos e dedicados operários; seja esta vossa mais ardente súplica junto ao Trono do Eterno. Fazei cair sobre o Brasil, que tanto vos quer, uma chuva de rosas de vocações sacerdotais, e que, pela vossa valiosa proteção, perseverem na sublime carreira aqueles a quem Deus honrou com tão preciosa graça da vocação. Entrastes no Carmelo para rezar pelos padres e
\end{abstract}

647 O Lábaro, n. ${ }^{0} 706$, XIV. 23 de agosto de 1923. p. 1.

648 O Lábaro, n. ${ }^{\circ} 716$, XIV. $^{\circ}$ de novembro de 1923. 
vossa vida foi uma contínua imolação pelos apóstolos Evangélicos. Hoje que tanto podeis junto de Deus, hoje que Jesus faz a vossa vontade no céu, pois que fizestes a d'Ele sobre a terra, oh! Bem-aventurada Teresinha santificai, afervorai, abrasai d'aquele vosso zelo ardente o coração dos nossos padres. Não permitais, ah! sim, não permitais sejam profanados os mistérios do amor de Jesus por mãos de sacerdotes indignos, debaixo do céu deste Brasil, que amais. Bem-aventurada Teresinha! tende compaixão de tantos infelizes,desgraçados apóstatas, de tantos desertores das fileiras sagradas. Dissestes, Anjo de zelo e amor:Eu tenho compaixão das almas que se perdem. As almas que se perdem, Bem-aventurada Teresinha, pela escassez de padres para salva-las ... Oh! Pedi a Virgem Santíssima, nossa mãe querida, Rainha do clero,numerosos e santos sacerdotes para a Igreja de Deus! Imprima-se. Taubaté, $1^{\circ}$ de Novembro de 1923. + Epaminondas, Bispo de Taubaté. ${ }^{649}$

O ano de 1924 começou auspicioso, em termos de doações, tendo, inclusive, a colaboração do próprio Cardeal Arcoverde. Note-se, portanto, que as antigas publicações, onde tão somente eram relatadas as graças obtidas, dão lugar, agora, a uma troca simbólica entre a santa e o devoto, que, pelos favores espirituais alcançados colabora financeiramente para a construção do Santuário:

\begin{abstract}
A BEATA TERESINHA
É sempre com grande prazer que registramos aqui os donativos que semanalmente recebemos para as obras do Santuário da Beata Teresinha, que está sendo construído nesta cidade de Taubaté. Hoje publicamos a relação daquelas ofertas que nos foram enviadas durante a semana última, ao mesmo tempo em que elevamos as nossas preces para que a cândida flor de Lisieux recompense largamente os seus generosos devotos.
\end{abstract}

\title{
Graças
}

De S. Eminência o Sr. Cardeal Arcoverde,recebemos $500 \$ 000$ para as obras do Santuário.

De D. ${ }^{a}$ Escolástica Bicudo, recebemos $32 \$ 000$ para auxiliar a construção do Santuário.

Uma devota, residente em Lorena, nos enviou $10 \$ 000$ para o Santuário.

O Sr. José Nunes Fonseca, residente em Salesópolis, agradecendo um favor obtido por intercessão da Beata Teresinha, remeteu $2 \$ 000$ para o Santuário.

Do Sr. João Batista Nunes, recebemos $2 \$ 000$ também para o Santuário.

O "Corpo Cênico do Centro Operário Beneficente de Jacareí", enviou à esta redação $5 \$ 000$ para as obras do Santuário de Teresinha.

Tendo recebido uma graça por intercessão da gloriosa

649 O Lábaro, n. ${ }^{\circ}$ 719, XIV. 25 de novembro de 1923. 
Teresinha, Adelino Pimentel de Souza, residente em Silveiras, ofertou $5 \$ 000$ para as obras do Santuário.

De D. ${ }^{a}$ Benedita Freire de Macedo, de Jacareí, recebemos $5 \$ 000$ para o Santuário.

Satisfazendo um voto, um devoto de Cachoeira,mandou para o Santuário de Teresinha.

Uma devota de Beira Mar ofertou $5 \$ 000$ para auxiliar as obras da construção do Santuário.

Maria Tereza Gusmão, de Guaratinguetá, agradece um favor alcançado por intercessão da Beata Teresinha e envia $10 \$ 000$ para as obras do Santuário.

Duas devotas da Beata Teresinha, tendo obtido várias graças por sua intercessão, enviaram por intermédio de D. ${ }^{a}$ Anna Rosa Alves Motta, 32\$000 para o Santuário.

Recebemos mais para o Santuário: a D. ${ }^{a}$ Maria M. Moreira Ramos, 5\$000; de D. ${ }^{a}$ Áurea Mendonça, 5\$000; do Sr. Alfredo Barros, $1 \$ 000$; de uma devota, $2 \$ 000$; de D. ${ }^{\text {a }}$ Maria das Dores Almeida, $5 \$ 000$; de um devoto, $5 \$ 000$.

De D. ${ }^{a}$ Yayá Castro, para perfazer a sua oferta de 1:000\$000, mais $20 \$ 000$.

Da senhorita professora Miloca Araújo, de Taubaté, recebemos $10 \$ 000$ para o Santuário.

Recebemos do Sr. Jacyintho Fernandes Peixoto, de Pinhal, $1 \$ 000$ para o Santuário.

Uma devota, residente na mesma cidade, agradece à Beata Teresinha, diversas graças alcançadas de N. Senhor por sua bondosa e poderosa intercessão e envia $1 \$ 000$ para 0 Santuário.

Por uma graça alcançada D. ${ }^{a}$ Maria Francisca da Silva Negrini ofereceu $10 \$ 000$ para as obras do Santuário.

José Martins de Alvarenga, residente em S. José dos Campos, em agradecimento de um favor obtido por intercessão da Beata Teresinha, por pessoa de sua família, remete $5 \$ 000$ para o Santuário.

Uma devota da Beata Teresinha do Menino Jesus, cumprindo um voto, envia $10 \$ 000$ para as obras do seu Santuário.

Aracy Barros envia $2 \$ 000$ para ajudar na nova igreja. ${ }^{650}$

Kenneth Woodward, cuja obra objetiva mostrar como e por que a criação de santos se tornou um processo burocrático e altamente racionalizado, denomina, ao nosso ver apropriadamente, esse mesmo processo de "burocratização da santidade". ${ }^{651}$ Indo ao encontro dos ensinamentos desse autor, em resposta aos diversos pedidos que eram feitos ao Bispo no sentido de se colocar em igrejas e capelas da Diocese a imagem da Beata Teresinha do Menino Jesus, 'O Lábaro' publicou nota, esclarecendo as especificidades do culto público aos beatos.

A todos tem S. Ex. ${ }^{a}$ indeferido, pela razão muito simples de ser proibido pela Igreja, exporem-se ao culto público as imagens dos Beatos, sem um indulto especial da Santa Sé. Os

650 O Lábaro, n. ${ }^{\circ} 725$. XV. 17 de janeiro de 1924; p.3

651 WOODWARD, Kenneth L. A fábrica de santos. São Paulo: Siciliano, 1992. p. 72. 
decretos da Sagrada Congregação dos Ritos, e as prescrições do Código do Direito Canônico a este respeito são claros e terminantes. Os Bispos, sem especial indulto da Santa Sé, não só carecem de poder para permiti-las, como são obrigados a removê-las e proibi-las, diz o decreto n. ${ }^{\circ} 1097$ da S. Congregação dos Ritos. Faz-se esta declaração para se evitarem tais pedidos. Esperamos em Deus que, no próximo ano, após a canonização final da querida Santinha de Lisieux, se possa expor a sua imagem ao culto público. ${ }^{652}$ (os grifos são deles)

Menos de um ano depois, no entanto, um 'Aviso' anuncia a canonização da Beata Teresinha, estabelecendo, detalhadamente, a programação a ser seguida:

AVISO N. ${ }^{\circ} 489$ [...] O Ex. ${ }^{\text {mo }}$ Sr. Bispo ordena, pois, o seguinte, em todas paróquias desta Diocese: $1^{\circ}$. - Nos dias 17 e 31 do próximo mês de Maio, ao meio dia, sejam festivamente repicados os sinos das Matrizes, Igrejas e Capelas. $2^{\circ}$. - Nos ditos dias, à tarde, em todas as Matrizes, Igrejas e Capelas em que se conserva habitualmente a S.S. Sacramento, seja ele solenemente exposto, dando-se a benção aos fiéis. $3^{\circ}$. $-\mathrm{Na}$ Catedral, na Matriz e, podendo ser, nas mencionadas Igrejas e Capelas, faça-se pregação sobre a vida e virtudes dos dois Santos e cante-se solene Te Deum, em ação de graças pela sua glorificação.

A autorização para a exposição da imagem viria, inclusive com horário preciso:

$4^{\circ}$. - Do meio dia em diante, de 7 de Maio, poderá ser exposta nos altares, à veneração dos fiéis, a imagem de S. Teresinha do Menino Jesus e, após meio dia de 31 de Maio, a do Santo Cura d'Ars. [...] ${ }^{653}$ (o grifo é nosso)

Canonizada que foi Santa Teresinha em 17 de maio de 1925, 'O Lábaro', em sua edição de 25 de maio, afirma que: "Chegara, afinal, o dia! Agora todos os devotos da Santinha de Lisieux têm a ventura inefável de pronunciar o seu nome tão doce unido ao título glorioso de Santa." 654

A esse propósito é de se notar que a canonização de Santa Teresinha foi proclamada apenas 28 anos após seu falecimento, prazo extremamente curto para os padrões da Sagrada Congregação para as causas dos santos. ${ }^{655}$ A referência de

652 O Lábaro, n. ${ }^{\circ}$ 753. XV. 07 de agosto de 1924.

653 ACDT. Aviso n. ${ }^{\circ} 489$. Taubaté, 28 de abril de 1925

654 O Lábaro, n. ${ }^{\circ} 794$, XV. 21 de maio de 1925.

655 A Sagrada Congregação para as causas dos santos "ocupa-se dos processos por meio dos quais os membros da Igreja que praticaram as virtudes cristãs em grau heróico (fé, esperança, caridade; prudência, justiça, fortaleza, temperança etc.) são proclamados beatos ou santos (beatificação, canonização) e propostos, assim, à veneração e à imitação dos fiéis". CITTÀ DEL VATICANO. O Vaticano e Roma Cristã. Roma: Tipografia poliglota vaticana, 1973. p.19. 
Kenneth Woodward:

Alguns servos de Deus adquirem uma reputação quase instantânea de operar milagres. Por exemplo, Santa Teresa de Lisieux era desconhecida fora de seu pequeno convento Carmelita perto dos Alpes franceses, quando morreu em 1897 com idade de 24 anos. E, todavia, quando se espalhou (graças, sobretudo, ao seu livro de publicação póstuma, History of a soul - História de uma Alma, logo extremamente popular) que ela prometera passar o Céu fazendo bem na terra, milagres atribuídos a sua intercessão surgiram até em lugares remotos como o Alasca ou o Peru. ${ }^{656}$

As festas que se seguiram foram muitas. No dia 18 houve benção da imagem, da qual foram paraninfos os Alberto Guisard e esposa, com pregação do Diácono Ariovaldo Oliveira, que discorreu sobre Santa Teresinha e o sofrimento e abandono santo, seguindo-se a benção solene do Santíssimo Sacramento. Em 19 de maio, tríduo e pregação pelo Diácono Cícero Alvarenga, que falou sobre Santa Teresinha e a humildade. Houve benção solene com o Santíssimo Sacramento e os atos do mês de Maria. Em 20, o nosso já conhecido Padre Ascânio Brandão, desenvolveu o tema "Santa Teresinha vítima pelos sacerdotes e modelos das almas sacerdotais", e no dia 21 saiu da capela do Seminário diocesano uma imponente procissão com as imagens de Santa Teresinha e do padroeiro da casa, Santo Antônio, percorrendo as ruas Quinze de Novembro, Coronel Augusto, Praça Monsenhor Silva Barros, entrando depois pela Avenida Tindal. ${ }^{657}$ Após isso, o controle sobre o processo devocional se concretizava com a publicação dos "Estatutos da Irmandade de Santa Teresinha" ${ }^{658}$ e com a impressão da "Novena de Santa Teresinha", cujo produto das vendas seria destinado exclusivamente às obras do Santuário, contendo meditações e súplicas para cada dia, a ladainha da Santa, "bonitas orações e também a relação dos aniversários da meiga 'Florzinha de Lisieux'. Aos que quiserem adquiri-la pede-se a esmola de ao menos 500 réis para as obras do Santuário da amada Santinha". 659

A construção do Santuário de Santa Teresinha se iniciou em 18 de maio de 1923 e, em 1925, recebeu da Câmara Municipal de Taubaté nada menos que sessenta contos de réis, em auxílio às obras, em cotas mensais de 1 conto de réis. $A$ perfeita simbiose entre o poder público taubateano e a diocese, manifestada, no

656 WOODWARD, Kenneth L. A fábrica de santos. São Paulo: Siciliano, 1992. p. 186.

657 O Lábaro, n. ${ }^{\circ} 795$, XV. 28 de maio de 1925.

658 O Lábaro, n. ${ }^{\circ} 801$, XV. 9 de julho de 1925.

659 O Lábaro, n. ${ }^{\circ} 808$, XV. 27 de agosto de 1925. 
caso, pelo auxílio municipal às obras do Santuário de Santa Teresinha, decerto acelerou a construção.

Lei n. ${ }^{\circ} 243$ - Antônio Valente da Silva, vice-prefeito municipal em exercício, na forma da lei, etc. Faz saber que a Câmara Municipal, em sessão realizada hoje, aprovou e ele promulga a seguinte lei:

A Câmara Municipal de Taubaté decreta:

Art. $1^{\circ}$ - Fica concedido o auxílio de sessenta contos de réis (60:000\$000) para as obras da construção da Igreja de Santa Teresinha do Menino Jesus, que está sendo edificada pelo Bispado, na Praça Comendador Costa Guimarães, desta cidade.

$\S$ Único - Essa contribuição deverá ser feita em cotas mensais de um conto de réis (1:000\$000) cada uma.

Art. $2^{\circ}$ - A Câmara municipal deverá, nos orçamentos anuais, votar verbas para o cumprimento integral da presente lei.

Art. $3^{\circ}$ - Fica o prefeito autorizado a abrir créditos necessários para dar, neste exercício, cumprimento ao disposto no artigo primeiro.

Registrada e publicada, cumpra-se.

Taubaté, 26 de agosto de 1925.

Gabinete do Prefeito de Taubaté. Ex. ${ }^{\text {mo }}$ Sr. D. Epaminondas Nunes de Ávila e Silva, DD. Bispo de Taubaté. Respeitosas Saudações. Tem este o fim de comunicar a V. Ex. ${ }^{a}$ que apresentei hoje um projeto que foi convertido em lei, pela qual a Câmara votou um auxílio de 60:000\$000, para ajudar a construção da Igreja Santa Teresinha do Menino Jesus. A Câmara fará este pagamento em quotas mensais de 1:000\$000 cada uma. Levo este fato ao conhecimento de V. Ex. $^{a}$, lastimando que as nossas fracas forças não permitam melhor correspondência à belíssima iniciativa de V. Ex. ${ }^{\mathrm{a}}$, que, certamente, em breve será uma realidade. Sem mais, peço dar suas ordens ao amigo, crdo. e admirador muito obrdo. CÉSAR COSTA Taubaté, 26 de agosto de $1925 .{ }^{660}$

Ato contínuo, Padre Ascânio Brandão fundou um jornal intitulado Santuário de Santa Teresinha', no formato 32x24cm, com 4 colunas e 4 páginas, tendo começado a circular em julho de 1925, sendo "o primeiro jornal aqui publicado sob esse título". Órgão das obras do Santuário e da Irmandade de Santa Teresinha, trazia "bênção e licença do Ex. ${ }^{\text {mo }}$ Sr. Bispo" e aparecia "todo dia 30 de cada mês, publicando as graças e esmolas dos fiéis às obras do Santuário. Teve curta existência uma vez que, no final desse mesmo ano, o jornal diocesano "O Lábaro" tomou sua denominação e com ela foi publicado por mais de um decênio. ${ }^{661}$

De fato, seguindo os passos do "Santuário de Aparecida", semanário

660 O Lábaro, n. ${ }^{\circ} 809$, XV. 27 de agosto de 1925.

661 MELLO JÚNIOR, Antônio. Imprensa Taubateana: contribuição à sua história (1861-1981). Taubaté: Empresa gráfica Editora Taubaté Ltda., 1983. p. 185. 
publicado pelos redentoristas desde 10 de novembro de 1900, e que possuía uma seção versando sobre as "graças de Nossa Senhora Aparecida", 'O Lábaro', agora, mudava de nome, passando a adotar a denominação de 'Santuário de Santa Teresinha'. Em seu novo cabeçalho lê-se: Santuário de Santa Teresinha - Órgão oficial da Irmandade e do Santuário de Santa Teresinha em construção nesta episcopal cidade. Redator-chefe, Monsenhor Antônio Nascimento Castro - Diretorgerente, Pe. Ascânio da Cunha Brandão.

Para poucos dos nossos amáveis leitores foi uma surpresa a notícia que divulgamos. No dia do próximo mês de janeiro, apenas 7 dias antes do em que completava 16 anos de vida, toda empenhada em lutas e trabalhos "pro aris et focis" "O Lábaro", que, mercê de Deus, nenhuma interrupção sofreu durante esse longo período, cessará sua publicação. Morrerá então? Não! Passará apenas por uma metamorfose que, como a Fênix da fábula, o fará renascer glorioso e remoçado sob o belo e auspicioso título de "Santuário de Santa Teresinha". ${ }^{662}$

O templo, ainda inacabado, teve suas atividades inauguradas em 24 de setembro de 1929. A primeira romaria ao Santuário de Santa Teresinha, oriunda da paróquia de Silveiras, foi acompanhada do Vigário Pe. Antônio Pereira de Azevedo. Transportados em 'jardineiras', cerca de 50 romeiros, após visita ao Bispo, se dirigiram para o Santuário, tendo,

depois de suas preces e cânticos a amada Santinha, regressando para a sua paróquia, cheios de consolação e de admiração pela majestade do grandioso Santuário e da belíssima imagem de S. Teresinha, verdadeira obra prima, cujo custo - superior a trinta contos, bem indica o seu valor artístico. ${ }^{663}$

Os anos compreendidos entre 1925 e 1930 podem ser considerados como o período em que o racionalizado processo de implantação devocional floresceu, e mesmo moderado em sua exposição sobre o estado financeiro da diocese, D. Epaminondas demonstra relativa tranqüilidade quando se reporta à tão decantada acumulação patrimonial:

O patrimônio, tanto da mesa episcopal quanto do seminário, foi de tal modo ampliado que agora propicia quer ao Bispo, quer aos moradores do seminário, um sustento modesto, mas suficiente. Nas paróquias as igrejas e não poucos oratórios foram edificados e refeitos, manifestando-se maximamente

662 O Lábaro, n. ${ }^{8}$ 825, XV. 24 de dezembro de 1925. De autoria de Marco Túlio Cícero (106 a.C. - 43 a.C.) e constante em sua obra "De natura deorum" (Sobre a natureza dos deuses), a expressão "pro aris et focis" pode ser traduzida como "Pelos nossos altares e lares", qual seja, pela defesa da pátria. 663 Santuário de Santa Teresinha, n. ${ }^{\circ}$ 196. 3 de outubro de 1929. 
nessas pias obras o zelo dos párocos e a generosidade dos fiéis. Mas, sobretudo, nesses templos sobressai em beleza e grandeza o "Santuário de S. Teresa do Menino Jesus", que agora se constrói na mesma cidade episcopal, e recentemente foi bento e inaugurado com grande concurso de povo religioso. Em diversas paróquias foram adquiridas casas para residência do pároco, de modo que agora o número de paróquias que ainda carecem da comodidade é inferior a seis, e providenciase para que diminua. ${ }^{664}$

À Festa de Santa Teresinha, ocorrida normalmente entre 24 de setembro a 5 de outubro, somava-se um sem número de atividades visando acumulação financeira, tais como rifas, vendas de calendários e demais outras. No início de 1930, 'O Lábaro' noticiou a chegada de um relicário, confeccionado na Espanha, destinado a guardar "uma trancinha de cabelos, um pedacinho de osso e um pano embebido no sangue de Santa Teresinha", tendo sido as relíquias adquiridas em Roma. ${ }^{665}$

A partir de 1930 inicia-se, de modo lento, a rotinização, ou mesmo a decadência, em afirmativa mais veemente, da relação entre os fiéis de Santa Teresinha e os gerenciadores de sua devoção.

São recorrentes, em inúmeras edições, as solicitações de assinatura do jornal. Afirmando que um jornal católico não é uma obra de caridade, que os fiéis devem prover com as sobras do supérfluo, a direção do 'Santuário de Santa Teresinha' compara a "imprensa subversiva e anti-religiosa, cujas redações se instalam em verdadeiros palácios", com a "pobreza raquítica" da imprensa católica, sem recursos para viver. ${ }^{666}$ As notas referentes às 'chuvas de rosas', não obstante diminuírem a freqüência e o espaço a elas destinado, ainda noticiam donativos vindos de São Paulo, Minas Gerais, Rio de Janeiro, Rio Grande do Sul e Goiás. Para as obras do Santuário de Santa Teresinha, D. Domingas Perelli enviou uma toalha "para o altar da amada Santinha". ${ }^{667}$

Buscando prosseguir na mesma senda do 'caminho da infância', 'O Santuário de Santa Teresinha" abre espaço para "um lírio de Maria. O pequenino Guido de Fontgalland", nascido em 30 de novembro de 1913, em Paris, e falecido em 24 de janeiro de 1925. Guido, que não obstante a pouca idade demonstrava profunda fé em Jesus Cristo e na Virgem Maria, 
tem alcançado aos que o invocam não poucos favores. Mais de 250 curas milagrosas atestadas por médicos, já foram obtidas por sua valiosa intercessão. Rezemos para que dentro em breve seja elevado a honra dos altares o pequenino Guido.

O artigo termina solicitando aos "que alcançarem graças pela intercessão de Guido, queiram comunicar ao Rev. ${ }^{\text {mo }}$ Pe. Ascânio Brandão Seminário Diocesano Taubaté", ${ }^{668}$ mas a tentativa de diversificação não progrediu. Em 1932, outra edição, em primeira página, retrata Guido de Fontgalland em seu leito de morte, ${ }^{669} \mathrm{e}$ não mais se tocou no assunto.

Alegando deficiência de espaço, o jornal informa que não tem publicado "muitas chuvas de rosas de Santa Teresinha", mas que publicará à medida do possível, "pedindo aos nossos caros assinantes e interessados que nos queiram perdoar essa falta, aliás, involuntária, porquanto o nosso maior desejo é agradar aos nossos leitores e amigos". ${ }^{670}$

Em 1933, apenas nove exemplares do jornal 'Santuário' se referiram à Santa Teresinha; em 1934, quatorze, em pequeno formato. Em 11 de maio de 1935, D. Epaminondas, "em adeus saudoso", retirou-se para o Rio de Janeiro, vindo a falecer em 30 de junho. Na véspera, a solenidade de inauguração do carrilhão dos sinos da Basílica foi transmitida pela Rádio Difusora de São Paulo.

A partida do Sr. Bispo para o Rio - Retirando-nos para o Rio, a conselho médico, em tratamento da nossa saúde, consideravelmente alterada, não podemos deixar de dirigir ao nosso venerando clero e amados diocesanos um adeus saudoso, pedindo a Deus que a todos conceda a melhor de suas bênçãos, guardando-os em seu coração SS., como no nosso a todos levamos. Que todos tragam lembrado em suas orações o pastor amigo, que jamais os esquece diante de Nosso Senhor. Nossa residência será - R. Lúcio de Mendonça, 47 - Casa n. ${ }^{\circ} 14$ - Rio. Taubaté, 9 de maio de 1935. + Epaminondas, Bispo de Taubaté. ${ }^{671}$

A efervescência se passara, e as águas retornavam ao seu leito. Devidamente estabilizada, a devoção à Santa Teresinha não assumiu as proporções alcançadas por Nossa Senhora Aparecida. Branca, européia, e mesmo dotada de traços fisionômicos que acusavam sua beleza, a juventude feminina brasileira se apropriou de sua imagética, humanizando-a. Pouco depois da partida de D. 
Epaminondas, as diatribes de Padre Ascânio Brandão, em artigo intitulado "Santinha da moda", demonstram de forma inequívoca os caminhos tomados pela devoção à "florzinha de Lisieux". Nele, Padre Ascânio se irrita quando afirmam que Santa Teresinha é santa da moda.

Santidade não tem moda, não é fogo fátuo de um entusiasmo passageiro ou de qualquer leviandade elegante de uma época. Deus, na sua misericórdia, suscita na Igreja os santos para cada tempo, e com uma missão a cumprir. A de Santa Teresinha foi, no expressivo dizer do Cardeal Bourne, desentulhar o caminho da perfeição, que uma ascese jansenista tornava com rigorismo nada evangélico, quase intransitável.

Triste ao ver como se maltrata "o anjo do Carmelo" em certas estampas em que se representa o hábito de carmelita em pose de artistas de cinema, Padre Ascânio também se irrita ao saber que "correm por aí uns cartões postais simplesmente ridículos". Catolicismo luso-brasileiro, resistir quem há de?

Santa Teresinha nunca foi o que ali a representam. A pobre santinha de lábios pintados, olhares lânguidos de artista de Hollywood e sorrisos mundanos, sobraçando rosas em pose de cantora quando vem à cena. Que profanação. Às suas devotas, às brasileirinhas gentis e elegantes até na devoção, Santa Teresinha lhes pede um favor pelas suas irmãs aqui na terra: evitem toda moda que não seja absolutamente conforme as regras da modéstia cristã. Não senhoritas, não profaneis o culto tão belo de Santa Teresinha! Pe. Ascânio Brandão. ${ }^{672}$

O "Santuário de Santa Teresinha" resistiu até 4 de abril de 1937. Com o n. ${ }^{\circ}$ 572, retornava ao seu título inicial: 'O Lábaro'.

Nova fase de "O Lábaro" - Com a presente edição esta folha suspende a sua circulação, com este caráter de órgão diocesano, passando o "Santuário de Santa Teresinha" a ser boletim mensal, de devoção à santinha de Lisieux e órgão oficial do seu santuário diocesano e da Irmandade de Santa Teresinha em toda a diocese a cargo do Rev. ${ }^{\text {mo }}$ Vigário do mesmo Santuário. Como órgão diocesano ressurgirá no próximo domingo o antigo "O Lábaro", em nova fase, sob a direção do Conselho Diocesano da boa Imprensa, tendo como redator chefe o vulto venerando e eminente do Ex. ${ }^{\text {mo }}$ Sr. Mons. Nascimento Castro". 673

Localizado na sacristia da igreja matriz, o grande retrato de D. Epaminondas demonstra autoridade, ao contrário do semblante paternal de tantos bispos. Muito

672 Santuário de Santa Teresinha, n. ${ }^{\circ} 481.2$ de junho de 1935.

673 MELLO JÚNIOR, Antônio. Imprensa Taubateana: contribuição à sua história (1861-1981). Taubaté: Empresa gráfica Editora Taubaté Ltda., 1983. pp. 186-187. 
mais que a coragem moral demonstrada em suas atribulações com D. Duarte, o legado do primeiro bispo da diocese de Taubaté em muito excede a saga da construção do Santuário de Santa Teresinha. O destino, por vezes, prega peças, e seu sucessor foi D. André Arcoverde de Albuquerque Cavalcanti, sobrinho de D. Joaquim Arcoverde, que tantas articulações fez no sentido de manter o Santuário de Aparecida vinculado à Arquidiocese de São Paulo. D. André recebeu uma diocese organizada e plenamente enquadrada ao modelo da época. Wernet, de fato, tinha razão ao afirmar que esta história é certamente fascinante. 


\section{CONSIDERAÇÕES FINAIS}

Acreditamos que os encantos e as armadilhas da História residam em sua diversidade. Estudando o processo de desenvolvimento da Igreja católica no Brasil, particularmente o período conhecido por romanização, iniciamos o aprendizado por conceitos que, imaturamente, julgamos acabados. Em outras palavras, ao chamarmos a atenção em nossas palavras introdutórias para a fórmula "ausência de bispo romanizado = indiferentismo religioso; presença de bispo romanizado = situação religiosa corrigida", o que na verdade se faz é uma autocrítica à nossa condição de "aprendiz de feiticeiro" que só os anos, ainda que em parte, puderam corrigir.

O ultramontanismo no Brasil foi diverso e específico em cada localidade. Em Aparecida, por exemplo, a pastoral dos redentoristas bávaros em relação às heranças do catolicismo luso-brasileiro, materializadas na Festa de São Benedito, devoção típica do aparecidense, bem como nas práticas dos romeiros em relação à Nossa Senhora Aparecida, foram totalmente diversas da ação romanizadora de um D. Duarte, em São Paulo, ou mesmo de um Padre Epaminondas, no Serro. A pesquisa e o estudo de nossas fontes, portanto, buscaram palmilhar esse caminho, visando detalhar as possibilidades e limitações do modelo romanizador.

Ao ambientar o quadro geral em nosso primeiro capítulo, comprovamos que a presença ultramontana já se fazia sentir antes da criação da diocese, não só pela ação de D. Antônio Joaquim de Melo, passando pela presença do Apostolado da Oração do Sagrado Coração de Jesus e de tantas outras associações leigas de caráter romanizado, como, também, pelas missões redentoristas.

Ao longo da exposição, resgatamos uma Taubaté onde política e religião se imbricavam nos mais apaixonados debates pela imprensa, parte dos padres e frades primava por comportamentos pouco ortodoxos, e a permanência do catolicismo lusobrasileiro ainda se fazia sentir, no espaço urbano, nas festas de Santa Cruz e em outras ocasiões.

Passando pela necessidade de maior ação de presença da Igreja católica na vastidão territorial brasileira, estudamos os procedimentos que desaguaram na fragmentação da diocese em São Paulo, elevada à categoria de arquidiocese, e na conseqüente criação de cinco outras dioceses, entre elas a de Taubaté, esta última compreendendo o vale do Paraíba paulista, buscando fornecer ao leitor, em nosso 
"trabalho de carpintaria", as primícias da "Questão de Aparecida" e demais pistas que o conduzissem aos capítulos seguintes.

No caso da diocese de Taubaté, a despeito das permanências do catolicismo luso-brasileiro, e mesmo do avanço protestante, a ação romanizadora anterior à D. Epaminondas legou-Ihe saldo positivo, saldo esse que a administração racionalizada do bispo soube, por meio de procedimentos típicos de uma dominação burocrática, conservar e ampliar.

Isso não significa uma blindagem definitiva aos chamados "inimigos da Igreja". Na qualidade de máxima autoridade católica no âmbito da diocese, D. Epaminondas assistiu às investidas do protestantismo e da maçonaria, não deixando, porém, de combatê-los com os instrumentos de que dispunha.

Optamos por conduzir o primeiro bispo de Taubaté, logo de imediato, à arena das turbulências políticas e administrativas que teria de enfrentar. O capítulo dois, portanto, ao discorrer sobre o "Legado Wanderley", apresenta uma das principais incumbências dos bispos dessa geração, qual seja, possibilitar a acumulação patrimonial das dioceses a eles confiadas.

Isso posto, entendemos que o caráter de originalidade desse capítulo reside muito menos na apresentação, por vezes monótona, admitimos, da evolução de um processo jurídico, e muito mais na condição dos envolvidos, qual seja, uma querela entre bispos, incomum em nossa historiografia.

Utilizando-nos da expressão de Charles Ralph Boxer, seria impossível que as "dores do crescimento" da Igreja católica no Brasil não fossem sentidas pelos seus próprios integrantes. Em nosso país, é o momento de consolidação de uma Igreja que, sob o aspecto legal e administrativo, assume as especificidades de uma personalidade jurídica, tendo na pessoa dos bispos seus legítimos procuradores.

Ao unir-se aos principais membros de seu clero contra o que julgava contrário aos interesses diocesanos, D. Epaminondas expôs, humanamente, sua face política e administrativa. A D. Duarte, inequivocamente, o mesmo mérito. Fica patente que a Igreja católica, ao se ver desguarnecida da discrição com que opera assuntos de seu interesse, principalmente os de natureza patrimonial, terminou por optar por uma solução de caráter interno, por meio do arbitramento.

No capítulo terceiro meus esforços se concentraram em buscar o máximo grau de tensão que as "dores do crescimento" da Igreja católica em São Paulo poderiam alcançar naquela quadra do tempo. 
Iniciamos por firmar a importância de D. Joaquim Arcoverde junto à administração do Santuário de Aparecida e às atividades dos redentoristas. As correspondências demonstraram à nossa pesquisa não só a inquestionável autoridade exercida por esse bispo de São Paulo e primeiro cardeal latinoamericano, mas também a racionalização empregada no processo, bem como a evolução financeira de um santuário mariano que materializava a essência do projeto regional de romanização, parte integrante do projeto nacional de romanização.

Nesse cenário, um bispo vindo de Minas Gerais, estranho às relações de amizade e compadrio entre os membros da "Igreja paulista", passa a questionar, não o projeto regional de romanização, mas o modo pelo qual o Santuário de Aparecida não lhe é confiado.

Além da obrigação junto a uma nova diocese que necessitava operacionalizar sua acumulação patrimonial, D. Epaminondas vê-se próximo a um Santuário cuja atração gravitacional é suficientemente forte para drenar parte dos recursos que supostamente lhe caberiam. Daí as tensões manifestadas pelas cartas reservadas, pelos documentos que desaparecem, pela imprensa passional, pelas idas e vindas de D. Joaquim Arcoverde e de D. Duarte. Conchavos com a Nunciatura e com Núncios. Investigações conduzidas por um abade. A luta pelos interesses da diocese de Taubaté contra a paciente, racional e robusta construção de um pólo irradiador do ultramontanismo, saído dos planos de D. Joaquim Arcoverde e operacionalizado pela ação contínua e diligente dos padres redentoristas. A luta pelos princípios que, em nossa humana aventura, cada parte achava a mais correta. Enfim, a luta pelo cofre.

O quarto capítulo é o espaço de D. Epaminondas. Convergindo mais intensamente o foco de luz no principal ator social deste trabalho, buscamos evidenciar-Ihe a abrangência do religioso, do administrador e do político, bem como as bases que justificam nossa hipótese.

Filho do patriciado decadente, é possível que a Igreja tenha sido, como foi para tantos naquele momento, sua salvação social. Seja como for, percorreu os caminhos que lhe foram designados pela Igreja que o formou, e pela hierarquia que o acolheu e o consagrou bispo.

Ao chegar em Taubaté, além das iniciativas já esperadas, quais sejam, a fundação de um seminário, a implantação de um jornal católico e a visita pastoral, 
não se inibiu de suspender padres, disciplinar o clero e reforçar o culto católico de feições romanizadas no espaço urbano de cidade e, com menor intensidade, nas áreas rurais. A leitura de seus 'Avisos' e 'Mandamentos' nos mostram o refinamento burocrático atingido em seu episcopado, levando-nos a admitir a constituição de uma ampla rede de coleta de informações no âmbito de toda a diocese. Do que realmente lhe interessava tomar conhecimento é provável que muito pouco lhe escapava.

Mesmo mantendo o necessário e prudente afastamento das questiúnculas políticas de âmbito local, o engajamento de D. Epaminondas com as causas políticas nacionais que afetavam diretamente a Igreja, máxime por intermédio do órgão oficial da diocese, demonstra não só a liderança do Cardeal Leme na condução da hierarquia católica, mas também as primícias de uma unidade de voz política e doutrinária no âmbito episcopal, consubstanciada - fruto temporão - pela Conferência Nacional dos Bispos do Brasil (CNBB), fundada em 14 de outubro de 1952.

Consolidadas que foram, nos capítulos precedentes, as condições desfavoráveis a D. Epaminondas no cumprimento de uma suas missões, qual seja, a acumulação patrimonial, entendemos que, ao conduzir a devoção a Santa Teresinha, tendo até mesmo alterado a denominação do jornal da diocese, terminando pela edificação do santuário em honra a uma santa jovem, branca e européia, o primeiro bispo de Taubaté buscou uma solução tão romanizada quanto o tratamento dado à devoção a Nossa Senhora Aparecida, visando, principalmente, uma classe média branca, letrada e urbana.

O caleidoscópio ultramontano, portanto, exibia uma nova fase no vale do Paraíba. A devoção, no entanto, não nascendo das bases populares, estiolou-se, nada impedindo, todavia, que à mesma fossem agregados os valores e procedimentos típicos do catolicismo luso-brasileiro.

Falamos de romanização, de querelas entre prelados, mas falamos, principalmente, de seres humanos. Acompanhando diversos estudos sobre padres e bispos do período, é recorrente o caráter apologético com que os biógrafos os retratam. Caminhando pela senda da "santificação", não parecem humanizá-los, omitindo em suas ações o que de mais precioso possuem e apresentam, terminando por lançar fora não só a água, mas também a criança.

Ultramontano no espírito, empreendedor na vida prática, D. Epaminondas 
cumpriu, integralmente, o que a hierarquia católica esperava, e continua a esperar de um bispo: defender os interesses espirituais e patrimoniais de sua diocese.

Alceste Pinheiro nos lembra em sua tese que "A igreja católica romana ou santifica ou faz esquecer". É uma verdade. Não cabe a nós, no entanto, o julgamento desse mérito. É certo, porém, que nossa história, ao humanizar o primeiro bispo de Taubaté, termina por revelar seu "santo zelo". 


\section{FONTES E BIBLIOGRAFIA}

\section{I - Fontes}

\section{A - Fontes manuscritas}

\section{Arquivo Histórico Dr. Félix Guisard Filho - Cartório do $2^{\circ}$ Ofício de Taubaté}

Atas da Câmara Municipal de Taubaté, 1898.

Atas da Câmara Municipal de Taubaté, 1902.

Caixa Testamentos (1760 - 1764).

Carta Pastoral de D. Sebastião Pinto do Rego saudando seus diocesanos. 18 de maio de 1862. Suplementos de Tombos da Paróquia da cidade Taubaté (1853-1881) Carta Pastoral em que o Ex. ${ }^{\text {mo }}$ Bispo avisa a seus diocesanos de sua primeira e próxima visita. 19 de agosto de 1853. Suplementos de Tombos da Paróquia da cidade Taubaté (1853-1881).

Carta Pastoral pela qual V. Ex. ${ }^{a}$ Rev. ${ }^{\text {ma }}$ há por bem dar um Regulamento ao clero de sua diocese. 22 de agosto de 1852. Suplementos de Tombos da Paróquia da cidade de Taubaté (1853-1881).

Carta Pastoral pela qual V. Ex. ${ }^{\mathrm{a}}$ Rev. ${ }^{\mathrm{ma}}$ há por bem dar a segunda e última parte do Regulamento ao clero da diocese na forma acima declarada. 22 de agosto de 1852 . Suplementos de Tombos da Paróquia da cidade Taubaté (1853-1881).

\section{Arquivo da Cúria Metropolitana de São Paulo}

Pasta Aparecida

Testamento do Cônego José Bento de Andrade.

Ata da reunião do Tribunal Arbitral. Itu, 28 de maio de 1911.

Auto de Agravo Cível n. ${ }^{\circ}$ 4921. Comarca de Jacareí, 1907.

Ofício da Nunciatura Apostólica no Brasil n. ${ }^{\circ}$ 1669. 4 de março de 1910

\section{Correspondências}

Carta de Monsenhor Nascimento Castro a D. Duarte. 5 de fevereiro de 1910.

Carta da Cúria Metropolitana de São Paulo a Monsenhor Antônio do Nascimento Castro. 18 de abril de 1911.

Carta de D. Duarte a D. Arcoverde. 4 de janeiro de 1910.

Carta de D. Duarte a D. Epaminondas, 8 de maio de 1911 
Carta de D. Duarte a D. Lúcio. 17 de maio de 1911.

Carta de D. Duarte a D. Lúcio. 9 de maio de 1911.

Carta de D. Duarte a D. Nery. 9 de maio de 1911

Carta de D. Duarte a Monsenhor Nascimento Castro. 22 de janeiro de 1910.

Carta de D. Duarte ao advogado Antônio Lobo. 25 de maio de 1911

Carta de D. Duarte ao Núncio Apostólico. 3 de agosto de 1910

Carta de D. Duarte a D. Arcoverde. 24 de janeiro de 1910.

Carta de D. Duarte a D. Arcoverde. 8 de março de 1911.

Carta de D. Duarte a D. Epaminondas. 16 de maio de 1911.

Carta de D. Duarte a D. Epaminondas. 11 de maio de 1911.

Carta de D. Duarte a D. Epaminondas. 3 de janeiro de 1910.

Carta de D. Duarte a D. Epaminondas. 9 de dezembro de 1909.

Carta de D. Duarte a D. Epaminondas.10 de agosto de 1909.

Carta de D. Duarte a D. Arcoverde. 16 de abril de 1910.

Carta de D. Duarte a D. Arcoverde. 17 de abril de 1910.

Carta de D. Duarte a D. Arcoverde. 18 de janeiro de 1910.

Carta de D. Duarte a D. Arcoverde. 20 de janeiro de 1910.

Carta de D. Duarte a Monsenhor Nascimento Castro. 4 de janeiro de 1910.

Carta de D. Duarte a D. Arcoverde. 11 de março de 1911.

Carta de D. Duarte ao redator d'O Mensageiro. 5 de fevereiro de 1910.

Carta de D. Epaminondas ao Dr. Eusébio Inocêncio Vaz da Câmara Leal. 2 de janeiro de 1910.

Carta de D. Epaminondas a D. Duarte. 11 de outubro de 1909.

Carta de D. Epaminondas a D. Duarte. 12 de maio de 1911.

Carta de D. Epaminondas a D. Duarte. 17 de janeiro de 1909.

Carta de D. Epaminondas a D. Duarte. 2 de agosto de 1909.

Carta de D. Epaminondas a D. Duarte. 5 de fevereiro de 1909.

Carta de D. Epaminondas a D. Duarte. 9 de dezembro de 1909.

Carta de D. Epaminondas a D. Duarte. 17 de Maio de 1911.

Carta de D. Lúcio a D. Duarte. 28 de maio de 1911.

Carta de D. Lúcio a D. Duarte. s/d. Recebida em 17 de maio de 1911.

Carta de D. Lúcio a D. Duarte. 17 de maio de 1911.

Carta de D. Nery a D. Duarte. 11 de maio de 1911.

Carta de Monsenhor Miguel da Silva Martins para Monsenhor João Alves. 4 de 
janeiro de 1910.

Carta de Monsenhor Miguel da Silva Martins para o Cônego Ezechias. 2 de dezembro de 1909.

Carta do Padre Miguel Martins ao Seminário em Pirapora. 31 de dezembro de 1909. Carta de Monsenhor Miguel da Silva Martins para o reitor do Colégio Diocesano. 31 de dezembro de 1909.

Carta do advogado Antônio Lobo a D. Duarte, acompanhada de Parecer. Campinas, 23 de maio de 1911

Carta do bispo de Campinas ao arcebispo Metropolitano. Campinas, 28 de janeiro de 1910.

Carta do Cônego Amador Bueno de Barros para D. Arcoverde. 21 de fevereiro de 1906.

Carta do Dr. Eusébio Inocêncio Vaz da Câmara Leal a D. Epaminondas. 11 de janeiro de 1910.

Carta e minuta de Compromisso de D. Duarte para D. Epaminondas. 11 de maio de 1911.

Carta resposta do advogado Barão Brasílio Machado à D. Duarte. 16 de fevereiro de 1910.

Carta resposta do Advogado da Arquidiocese, Porphyrio de Aguiar, a D. Duarte. 18 de fevereiro de 1910.

\section{Arquivo da Cúria Diocesana de Taubaté}

Papéis avulsos

Criação do Bispado.

Relatório Ad Limina de D. Epaminondas, Bispo de Taubaté. 1914.

Relatório Ad Limina de D. Epaminondas, Bispo de Taubaté. 1929.

Pasta "Sacerdotes Falecidos", letra E.

Estatutos da Associação do Sr. Bom Jesus de Tremembé, em favor da Obra das Vocações Sacerdotais no Bispado. 17 de fevereiro de 1910.

Memorial de avisos, ensinamentos e advertências que, com proveito, poderão os reverendíssimos párocos dar aos fiéis camponeses, assim como bens que, frutuosamente, Ihes poderão dispensar.

Aviso n. ${ }^{0} 490.6$ de maio de 1925.

Aviso n. ${ }^{\circ}$ 620. 15 de julho de 1932. 
Pasta Atos do Governo Diocesano. D. Epaminondas (1908-1915)

Aviso do Monsenhor Governador, pedindo informações sobre Fabriqueiros e Sacristãos. 5 de maio de 1909.

Aviso n. ${ }^{\circ}$ 3. 1 de janeiro de 1910.

Aviso n. ${ }^{\circ} 4.1$ de janeiro de 1910.

Aviso n. ${ }^{0} 5.1$ de janeiro de 1910.

Aviso n. ${ }^{0}$ 6. 1 de janeiro de 1910.

Aviso n. ${ }^{\circ}$ 15. 31 de janeiro de 1910.

Aviso n. ${ }^{\circ}$ 17. 23 de fevereiro de 1910.

Aviso n. ${ }^{\circ}$ 24. 16 de março de 1910.

Aviso n. ${ }^{0} 35.17$ de abril de 1911.

Aviso n. ${ }^{\circ}$ 39. 20 de maio de 1911.

Aviso n. ${ }^{\circ} 42.4$ de julho de 1911.

Aviso n. ${ }^{\circ}$ 49. 15 de janeiro de 1912.

Aviso n. ${ }^{\circ}$ 53. 29 de janeiro de 1912.

Aviso n. ${ }^{\circ} 62.5$ de agosto de 1912.

Carta Circular de Dom Epaminondas. 1 de janeiro de 1913.

Carta Pastoral de D. Epaminondas, saudando seus diocesanos. $1^{\circ}$ de novembro de 1909.

Circular n. ${ }^{\circ} 1$ do Monsenhor Governador do Bispado, avisando que os negócios eclesiásticos das paróquias da diocese devem ser tratados na Cúria própria do Bispado.

Circular n. ${ }^{\circ}$ 5. Piquete, em visita pastoral, aos 19 de maio de 1911.

Circular n. ${ }^{0}$ 19. s.d.

Circular n. ${ }^{\circ} 29.20$ de fevereiro de 1914.

Circular n. ${ }^{\circ} 44.18$ de dezembro de 1914.

Circular n. ${ }^{\circ} 6.13$ de novembro de 1911.

Circular n. ${ }^{\circ} 16.22$ de janeiro de 1913.

Circular n. ${ }^{\circ} 28.5$ de janeiro de 1914.

Edital n. ${ }^{\circ}$ 2. 18 de agosto de 1910.

Mandamento n. ${ }^{\circ} 1.28$ de fevereiro de 1911.

Mandamento n. ${ }^{\circ}$ 4. 27 de novembro de 1911.

Pasta Avisos, Circulares, Pastorais e Mandamentos (1915-1919) 
Aviso n. ${ }^{\circ}$ 154. 19 de julho de 1916.

Edital de Dom Epaminondas. 17 de abril de 1917.

Carta Circular de Dom Epaminondas. 8 de fevereiro de 1918.

Carta Circular de Dom Epaminondas. 30 de abril de 1918.

\section{Arquivo da Cúria Arquidiocesana de Aparecida}

Livro de Atas da Irmandade de Nossa Senhora da Conceição Aparecida.

Livro do Tombo da Paróquia de Guaratinguetá (1757 a 1873).

Livro do Tombo da Paróquia de Nossa Senhora Conceição Aparecida (1893 a 1913).

\section{B - Fontes impressas}

\section{Leis, decretos, atas}

\section{Arquivo da Cúria Metropolitana de São Paulo}

Documentos sobre a Arquidiocese de São Paulo

Sagrada Congregação Consistorial: "Da Constituição de Nova Província Eclesiástica em São Paulo - Brasil", 7 de julho de 1908. Fotocópia datilografada. Inédito.

\section{Ofícios e Telegramas}

Ofício da Câmara Municipal de Jacareí ao Arcebispo, s/d.

Telegrama D. Epaminondas para D. Duarte. 11 de maio de 1911.

Telegrama de D. Lúcio, bispo de Botucatu, para D. Duarte. 17 de maio de 1911.

Telegrama de D. Nery, bispo de Campinas, para D. Duarte. 19 de maio de 1911.

\section{Almanaques, viajantes, memórias, pastorais e cronistas}

AGASSIZ, Jean Louis Rodolphe e AGASSIZ, Elizabeth Cabot Cary. Viagem ao Brasil (1865 - 1866). São Paulo: Companhia Editora Nacional, 1938.

MÜLLER, Daniel Pedro. Ensaio d'um quadro estatístico da Província de São Paulo. 3. ed. São Paulo: Governo do Estado, 1978.

PASTORAL coletiva dos senhores arcebispos e bispos das províncias eclesiásticas de S. Sebastião do Rio de Janeiro, Mariana, São Paulo, Cuiabá e Porto Alegre comunicando ao clero e aos fiéis o resultado das conferências dos mesmos realizadas na cidade de São Paulo de 25 de setembro a 10 de outubro de 1910 . Rio 
de Janeiro: Tipografia Leuzinger, 1911.

PASTORAL coletiva dos senhores bispos da província eclesiástica meridional do Brasil comunicando ao clero secular e regular o resultado das conferências realizadas em São Paulo: de 3 a 12 de Novembro de 1901. Rio de Janeiro: Tipografia Leuzinger, 1902.

POLIANTÉIA. Homenagem da diocese de Taubaté ao seu amado bispo D. Epaminondas Nunes de Ávila e Silva no seu festivo jubileu episcopal (1909-1934). Taubaté: Oficinas gráficas do Santuário de Santa Teresinha, 1934.

POLYANTHEA. Comemoração do cinqüentenário de fundação do Seminário Episcopal de São Paulo: 9 de novembro de 1856 a 9 de novembro de 1906, s.d.

SAINT-HILAIRE, Auguste de. Segunda viagem do Rio de Janeiro a Minas Gerais e a São Paulo, 1822. Belo Horizonte: Itatiaia; São Paulo: Editora da Universidade de São Paulo, 1974.

SAINT-HILAIRE, Auguste de. Viagem à Província de São Paulo. São Paulo: Martins Editora - Ed. USP, 1972.

SPIX. Johann Baptist Ritter von et MARTIUS, Karl Frederich Philipp von. Viagem pelo Brasil (1817 - 1820). Tomo I. São Paulo: Melhoramentos. 2. ed. s/d.

\section{C - Jornais e periódicos}

\section{Arquivo da Cúria Metropolitana de São Paulo}

Pasta Taubaté - recortes de jornais

A Federação. 23 de janeiro de 1910.

A Federação. 6 de fevereiro de 1910.

A Federação. 9 de fevereiro de 1910.

A Federação. Recorte. s.d.

Boa Imprensa. 5 de fevereiro de 1910.

O Mensageiro. Recorte. s.d.

O Norte, n. ${ }^{\circ}$ 447, VI. 6 de janeiro de 1910.

Divisão de Museus, Patrimônio e Arquivo Histórico de Taubaté - Hemeroteca Antônio Mello Júnior 


\section{Pasta Miscelânea n. ${ }^{\circ} 8$}

A Federação, n. ${ }^{\circ}$ 120, II, 20 de fevereiro de 1911.

A Federação, n. ${ }^{\circ}$ 126, III. 2 de abril de 1911.

A Liberdade, n. ${ }^{\circ}$ 187, V. 13 de maio de 1915.

A Liberdade, n. ${ }^{\circ}$ 7, I. 1 de fevereiro de 1911.

A Liberdade, n. ${ }^{\circ}$ 9, I. 15 de fevereiro de 1911.

O Paulista, n. ${ }^{\circ}$ 50, I. 10 de setembro de 1887.

O Paulista, n. ${ }^{\circ}$ 50, IV. 6 de Dezembro de 1868.

Paulista, n. ${ }^{\circ}$ 50, IV. 6 de dezembro de 1868.

Pasta Miscelânea n..$^{\circ} 10$

A Verdade, n. ${ }^{0}$ 113, III. 21 de março de 1905.

A Verdade, n. ${ }^{0}$ 115, III. 28 de Março de 1905.

A Verdade, n. ${ }^{\circ}$ 125, III. 9 de maio de 1905.

A Verdade, n. ${ }^{\circ}$ 150, III. 8 de Agosto de 1905.

A Verdade, n. ${ }^{\circ} 20$, I. 13 de agosto de 1903.

A Verdade, n. ${ }^{0}$ 213, III. 29 de março de 1906.

A Verdade, n. ${ }^{\circ}$ 231, IV. 9 de junho de 1906.

A Verdade, n. ${ }^{\circ}$ 259, IV. 26 de setembro de 1906.

A Verdade, n. ${ }^{\circ}$ 3, I. 16 de abril de 1903.

A Verdade, n. ${ }^{0}$ 56, II. 21 de abril de 1904.

A Verdade, n. ${ }^{\circ}$ 67, II. 7 de julho de 1904.

A Vila do Tremembé, n. ${ }^{\circ}$ 9, I. 13 de junho de 1904.

A Zagaia, n. ${ }^{\circ}$ 2, I. 30 de abril de 1896.

A Zagaia, n. ${ }^{\circ}$ 4, I. 7 de maio de 1896.

Gazeta de Taubaté, n. ${ }^{\circ} 33$, III. 14 de agosto de 1880.

Gazetinha, n. ${ }^{\circ}$ 897, IX. 19 de abril de 1896.

\section{Pasta Miscelânea n. ${ }^{\circ} 11$}

Jornal do Povo, n. ${ }^{\circ}$ 384, IX. 19 de novembro de 1895.

Jornal do Povo, n. ${ }^{0}$ 59, VI. 11 de agosto de 1892.

Liberal Taubateense, n. ${ }^{\circ}$ 1, I. 20 de Novembro de 1887.

O Caixeiro, n. ${ }^{0}$ 169, IV. 17 de março de 1907.

O Commércio, n. ${ }^{\circ}$ 10, I. 31 de maio de 1908. 
O Guarany, n. ${ }^{\circ}$ 39, I. 6 de julho de 1884.

O Luizense, n. ${ }^{0} 193$, III. 19 de julho de 1906.

\section{Pasta Jornal de Taubaté}

Jornal de Taubaté, n. ${ }^{\circ}$ 1178, VI. 29 de julho de 1900.

Jornal de Taubaté, n. ${ }^{\circ}$ 2302, XIII. 14 de abril de 1907.

Jornal de Taubaté, n. ${ }^{0}$ 2309, XII. 9 de maio de 1907.

Jornal de Taubaté, n. ${ }^{\circ}$ 2323, XIII. 27 de junho de 1907.

Jornal de Taubaté, n. ${ }^{\circ}$ 2337, XIV. 15 de agosto de 1907.

Jornal de Taubaté, n. ${ }^{\circ}$ 2399, XIV. 22 de março de 1908.

Jornal de Taubaté, n. ${ }^{\circ}$ 2400, XIV. 26 de março de 1908.

Jornal de Taubaté, n. ${ }^{\circ}$ 2403, XIV. 5 de abril de 1908.

Jornal de Taubaté, n. ${ }^{\circ}$ 2435, XV. 30 de julho de 1908.

Jornal de Taubaté, n. ${ }^{\circ}$ 2458, XV. 18 de outubro de 1908.

Jornal de Taubaté, n. ${ }^{\circ}$ 2461, XV. 29 de outubro de 1908.

Jornal de Taubaté, n. ${ }^{\circ}$ 2479, XV. 10 de janeiro de 1909.

Jornal de Taubaté, n. ${ }^{\circ}$ 2480, XVI. 14 de janeiro de 1909.

Jornal de Taubaté, n. ${ }^{\circ}$ 2533, XVI. 7 de novembro de 1909.

Jornal de Taubaté. n. ${ }^{\circ}$ 2561, XVII. 27 de fevereiro de 1910.

\section{Pasta O Norte}

O Norte, n. ${ }^{\circ}$ 30, I. 9 de fevereiro de 1905.

O Norte, n. ${ }^{\circ}$ 37, I. 5 de março de 1905.

O Norte, n. ${ }^{\circ} 45$, I. 2 de abril de 1905.

O Norte, n. ${ }^{\circ}$ 158, II. 6 de maio de 1906.

O Norte, n. ${ }^{0}$ 165, II. 31 de maio de 1906.

O Norte, n. ${ }^{\circ} 334$, IV. 9 de janeiro de 1908.

O Norte, n. ${ }^{\circ} 339$, IV. 26 de janeiro de 1908.

O Norte, n. ${ }^{\circ}$ 341, IV. 2 de fevereiro de 1908.

\section{Pasta O Noticiarista}

O Noticiarista, n. ${ }^{\circ}$ 96, I. 1 de agosto de 1889.

O Noticiarista, n. ${ }^{\circ}$ 100, I. 18 de agosto de 1889.

O Noticiarista, n. ${ }^{0}$ 199, II. 10 de agosto de 1890. 
O Noticiarista, n. ${ }^{\circ} 270$, III. 19 de abril de 1891.

\section{Pasta O Taubateano}

O Taubateano, n. ${ }^{0}$ 55, II. 14 de abril de 1901.

O Taubateano, n. ${ }^{0} 61$, II. 26 de maio de 1901.

O Taubateano, n. ${ }^{\circ}$ 63, II. 9 de junho de 1901.

O Taubateano, n. ${ }^{\circ}$ 63, II. 9 de junho de 1901.

O Taubateano, n. ${ }^{\circ}$ 67, II. 7 de julho de 1901.

O Taubateano, n. ${ }^{\circ}$ 72, II. 11 de agosto de 1901.

O Taubateano, n. ${ }^{\circ}$ 92, II. 5 de janeiro de 1902.

O Taubateano, n. ${ }^{\circ}$ 162, III. 30 de julho de 1903.

O Taubateano, n. ${ }^{\circ}$ 203, IV. 4 de maio de 1904.

\section{Arquivo da Cúria Diocesana de Taubaté}

O Lábaro, n. ํ 1, I. 09 de Janeiro de 1910.

O Lábaro, n. ${ }^{\circ}$ 3, I. 23 de janeiro de 1910.

O Lábaro, n. ${ }^{\circ} 4$, I. 30 de janeiro de 1910.

O Lábaro, n. ${ }^{\circ}$ 5, I. 6 de fevereiro de 1910.

O Lábaro, n. ${ }^{\circ}$ 8, I. 27 de fevereiro de 1910.

O Lábaro, n. ${ }^{\circ} 11$, I. 20 de março de 1910.

O Lábaro, n. ${ }^{\circ}$ 18, I. 5 de maio de 1910.

O Lábaro, n. ${ }^{\circ}$ 33, I. 18 de agosto de 1910.

O Lábaro, n. ${ }^{\circ} 73$, II. 25 de maio de 1911.

O Lábaro, n. ${ }^{0} 74$, II. 1 de junho de 1911.

O Lábaro, n. ${ }^{\circ}$ 94, II. 19 de outubro de 1911.

O Lábaro, n. ${ }^{0}$ 130, III. 20 de junho de 1912.

O Lábaro, n. ${ }^{\circ} 137$, III. 8 de agosto de 1912.

O Lábaro. n. ${ }^{\circ} 213$, V. 29 de janeiro de 1914.

O Lábaro. n. ${ }^{\circ} 225$, V. 23 de abril de 1914.

O Lábaro, n. ${ }^{\circ}$ 242, V. 20 de agosto de 1914.

O Lábaro, n. ${ }^{\circ}$ 245, V. 10 de setembro de 1914.

O Lábaro, n. ${ }^{\circ}$ 268, VI. 18 de fevereiro de 1915.

O Lábaro, n. ${ }^{\circ} 269$, VI. 25 de fevereiro de 1915. 
O Lábaro, n. ${ }^{\circ}$ 270, VI. 4 de março de 1915.

O Lábaro, n. ${ }^{\circ}$ 313, VII. 6 de janeiro de 1916.

O Lábaro, n. ${ }^{\circ} 329$, VII. 27 de abril de 1916.

O Lábaro, n. ${ }^{\circ} 335$, VII. 8 de junho de 1916.

O Lábaro, n. ${ }^{\circ}$ 341, VII. 20 de julho de 1916.

O Lábaro, n. ${ }^{0}$ 344, VII. 10 de agosto de 1916.

O Lábaro, n. ${ }^{\circ} 345$, VII. 14 de setembro de 1916.

O Lábaro, n. ${ }^{\circ} 386$, VIII. 31 de maio de 1917.

O Lábaro, n. ${ }^{\circ}$ 387, VIII. 7 de junho de 1917.

O Lábaro, n. ${ }^{\circ}$ 390, VIII. 28 de junho de 1917.

O Lábaro, n. ${ }^{0} 391$, VIII. 5 de julho de 1917.

O Lábaro, n. ${ }^{\circ}$ 392, VIII. 12 de julho de 1917.

O Lábaro, n. ${ }^{\circ} 398$, VIII. 23 de agosto de 1917.

O Lábaro, n. ${ }^{\circ}$ 404, VIII. 4 de outubro de 1917.

O Lábaro, n. ${ }^{\circ}$ 410, VIII. 15 de novembro de 1917.

O Lábaro, n. ${ }^{\circ}$ 412, VIII. 29 de novembro de 1917.

O Lábaro, n. ${ }^{\circ}$ 420, IX. 24 de janeiro de 1918.

O Lábaro, n. ${ }^{\circ} 422$, VIII. 7 de fevereiro de 1918.

O Lábaro, n. ${ }^{\circ} 425$, VIII. 28 de fevereiro de 1918.

O Lábaro, n. ${ }^{\circ}$ 434, IX. 2 de maio de 1918.

O Lábaro, n. ${ }^{\circ} 438$, IX. 30 de maio de 1918.

O Lábaro, n. ${ }^{\circ} 440$, IX. 13 de junho de 1918.

O Lábaro, n. ${ }^{\circ} 445$, IX. 18 de julho de 1918.

O Lábaro, n. ${ }^{\circ} 463$, IX. 14 de novembro de 1918.

O Lábaro, n. ${ }^{\circ} 467$, IX. 12 de dezembro de 1918.

O Lábaro, n. ${ }^{\circ}$ 475, X. 6 de fevereiro de 1919.

O Lábaro, n. ${ }^{\circ} 477$, X. 20 de fevereiro de 1919.

O Lábaro, n. ${ }^{\circ} 478$, X. 27 de fevereiro de 1919.

O Lábaro, n. ${ }^{\circ} 479$, X. 6 de março de 1919.

O Lábaro, n. ${ }^{\circ} 481$, X. 20 de março de 1919.

O Lábaro, n. ${ }^{\circ}$ 483, X. 3 de abril de 1919.

O Lábaro, n. ${ }^{\circ} 484$, X. 10 de abril de 1919.

O Lábaro, n. ${ }^{\circ} 486$, X. 24 de abril de 1919.

O Lábaro, n. ${ }^{\circ} 488$, X. 8 de maio de 1919. 
O Lábaro, n. ${ }^{\circ} 491$, X. 29 de maio de 1919.

O Lábaro, n. ${ }^{0} 498$, X. 17 de julho de 1919.

O Lábaro, n. ${ }^{\circ}$ 500, X. 31 de julho de 1919.

O Lábaro, n. ${ }^{\circ}$ 503, X. 21 de agosto de 1919.

O Lábaro, n. ${ }^{\circ}$ 505, X. 4 de setembro de 1919.

O Lábaro, n. ${ }^{0}$ 507, X. 18 de setembro de 1919.

O Lábaro, n. ${ }^{\circ}$ 508, X. 25 de setembro de 1919.

O Lábaro, n. ${ }^{\circ}$ 516, X. 20 de novembro de 1919.

O Lábaro, n. ${ }^{\circ}$ 531, XI. 4 de março de 1920.

O Lábaro, n. ${ }^{\circ}$ 545, XI. 10 de junho de 1920.

O Lábaro, n. ${ }^{0}$ 551, XI. 22 de julho de 1920.

O Lábaro, n. ${ }^{\circ}$ 573, XI. 16 de dezembro de 1920.

O Lábaro, n. ${ }^{\circ}$ 583, XII. 24 de fevereiro de 1921.

O Lábaro, n. ${ }^{\circ}$ 588, XII. 31 de março de 1921.

O Lábaro, n. ${ }^{0}$ 591, XII. 21 de abril de 1921.

O Lábaro, n. ${ }^{0}$ 600, XII. 23 de junho de 1921.

O Lábaro, n. ${ }^{\circ}$ 606, XII. 11 de agosto de 1921.

O Lábaro, n. ${ }^{\circ}$ 611, XII. 15 de setembro de 1921.

O Lábaro, n. ${ }^{\circ}$ 647, XIII. 15 de junho de 1922.

O Lábaro, n. ${ }^{\circ}$ 654, XIII. 17 de agosto de 1922.

O Lábaro, n. ${ }^{\circ}$ 662, XIII. 19 de outubro de 1922.

O Lábaro, n. ${ }^{\circ}$ 664, XIII. 2 de novembro de 1922.

O Lábaro, n. ${ }^{\circ} 673$, XIII. 4 de janeiro de 1923.

O Lábaro, n. ${ }^{\circ}$ 681, XIV. $1^{\circ}$ de março de 1923.

O Lábaro, n. ${ }^{\circ}$ 684, XIV. 29 de março de 1923.

O Lábaro, n. ${ }^{\circ}$ 694, XIV. 31 de maio de 1923.

O Lábaro, n. ${ }^{\circ}$ 700, XIV. 12 de julho de 1923.

O Lábaro, n. ${ }^{\circ}$ 701, XIV. 19 de julho de 1923.

O Lábaro, n. ${ }^{\circ} 703$, XIV. 2 de agosto de 1923.

O Lábaro, n. ${ }^{0} 706$, XIV. 23 de agosto de 1923.

O Lábaro, n. ${ }^{0} 716$, XIV. $1^{\circ}$ de novembro de 1923.

O Lábaro, n. ${ }^{\circ}$ 718, XIV. 15 de novembro de 1923.

O Lábaro, n. ${ }^{\circ} 719$, XIV. 25 de novembro de 1923.

O Lábaro, n. ${ }^{\circ}$ 721, XIV. 13 de dezembro de 1923. 
O Lábaro, n. ${ }^{\circ} 725$, XV. 17 de janeiro de 1924

O Lábaro, n. ${ }^{\circ} 747$, XV. 22 de junho de 1924.

O Lábaro, n. ${ }^{\circ} 753$, XV. 07 de agosto de 1924.

O Lábaro, n. ${ }^{\circ} 794$, XV. 21 de maio de 1925.

O Lábaro. n. ${ }^{0} 795$, XV. 28 de maio de 1925.

O Lábaro, n. ${ }^{\circ} 801$, XV. 9 de julho de 1925.

O Lábaro, n. ${ }^{\circ} 808$, XV. 27 de agosto de 1925.

O Lábaro. n. ${ }^{\circ} 809$, XV. 27 de agosto de 1925.

O Lábaro. n. ${ }^{\circ} 810$, XV. 10 de setembro de 1925.

O Lábaro. n. ${ }^{\circ} 825$, XV. 24 de dezembro de 1925.

Santuário de Santa Teresinha, n. ${ }^{\circ} 80.10$ de julho de 1927.

Santuário de Santa Teresinha, n. ${ }^{\circ}$ 98. 20 de novembro de 1927.

Santuário de Santa Teresinha, n. ${ }^{\circ}$ 196. 3 de outubro de 1929.

Santuário de Santa Teresinha, n. ${ }^{\circ} 211.12$ de janeiro de 1930.

Santuário de Santa Teresinha, n. ${ }^{\circ} 241.24$ de agosto de 1930.

Santuário de Santa Teresinha, n. ${ }^{\circ}$ 240. 26 de outubro de 1930.

Santuário de Santa Teresinha, n. ${ }^{\circ} 251.9$ de novembro de 1930.

Santuário de Santa Teresinha, n. ${ }^{\circ}$ 273. 26 de abril de 1931.

Santuário de Santa Teresinha, n. ${ }^{\circ}$ 286. 26 de julho de 1931.

Santuário de Santa Teresinha, n. ${ }^{\circ} 311.24$ de janeiro de 1932.

Santuário de Santa Teresinha, n. ${ }^{\circ}$ 328. 22 de maio de 1932.

Santuário de Santa Teresinha, n. ${ }^{\circ}$ 356. 25 de dezembro de 1932.

Santuário de Santa Teresinha, n. ${ }^{\circ}$ 365. 19 de fevereiro de 1933 .

Santuário de Santa Teresinha, n. ${ }^{\circ} 481.2$ de junho de 1935.

\section{Hemeroteca do Museu Frei Galvão}

\section{Pasta "Diversos", n. ${ }^{\circ} 11$}

Voz do Povo, n. ${ }^{\circ}$ 9, I. 3 de junho de 1906.

Gazeta Paulista, n. ${ }^{\circ}$ 64, II. 11 de março de 1906.

\section{Arquivo Edgar Leuenroth - Universidade de Campinas}

A Lanterna. 29 de janeiro de 1910. 


\section{Arquivo da Casa Provincial do Santíssimo Redentor - Aparecida-SP}

Ânuas da Vice-Província de São Paulo, v. I (1896 - 1918)

Correspondência da Província Redentorista de São Paulo - COPRESP, v. I (18171896)

Correspondência da Província Redentorista de São Paulo - COPRESP, v. III (19021904)

Correspondência da Província Redentorista de São Paulo - COPRESP, v. V (19091912)

Correspondência da Província Redentorista de São Paulo - COPRESP, v. VI (19131920)

Correspondência da Província Redentorista de São Paulo - COPRESP-B Suplemento, v. I (1874-1897)

Correspondência da Província Redentorista de São Paulo - COPRESP-B Suplemento, v. III (1906-1921)

Crônica da Comunidade Redentorista de Aparecida, v. I (1894-1907)

Crônica da Comunidade Redentorista de Aparecida, v. II (1908-1922)

Crônica das Missões da Casa de Aparecida (1897-1954)

\section{II - Bibliografia: livros e artigos, teses e dissertações}

\section{A - Bibliografia geral}

DURKHEIM, Émile. As formas elementares da vida religiosa. São Paulo. Martins Fontes, 1996.

ETZEL, Eduardo. Imagens religiosas de São Paulo. São Paulo: Melhoramentos USP, 1971.

FREYRE, Gilberto. Casa-Grande \& Senzala. 27. ed. Rio de Janeiro: Record, 1990. HOLANDA, Sérgio Buarque. Raízes do Brasil. 26. ed. São Paulo. Companhia das Letras, 1995.

HUIZINGA, Johan. O declínio da Idade Média. Lisboa: Ulissea, 1996.

LEITE, José Roberto Teixeira. A China no Brasil. Campinas: Editora da Unicamp, 1999. 
MELLO JÚNIOR, Antônio. Imprensa taubateana: contribuição à sua história (18611981). Taubaté: Empresa gráfica Editora Taubaté, 1983.

TOLEDO, Francisco de Paula. História do município de Taubaté. 2. ed. Taubaté: Prefeitura Municipal, 1976.

WEBER, Max. La ciencia como vocación. In: Hans Gerth; Carl Wright Mills (org.) Ensayos de sociología contemporânea. Barcelona: Martínez Roca, 1975.

. Economia e Sociedade: fundamentos da sociologia compreensiva. v. 2. Brasília: Editora da Universidade de Brasília, 2000.

.. Economia e Sociedade: fundamentos da sociologia compreensiva. v. 1. 4. ed. Brasília: Editora da Universidade de Brasília, 2000.

WIRTH, John D. O fiel da balança: Minas Gerais na federação brasileira, 1889-1937. Rio de Janeiro: Paz e Terra, 1982.

\section{B - Bibliografia específica}

ALBERIGO, Giuseppe. Novas fronteiras da História da Igreja?, Concilium: Revista Internacional de Teologia, n. ${ }^{0}$ 57. 1970.

ALMEIDA, Pe. Dr. Antônio José de. Modelos eclesiológicos e ministérios eclesiais, Revista Eclesiástica Brasileira, v. 48, jun. 1988.

ALVES, Márcio Moreira. A Igreja e a política no Brasil. São Paulo: Brasiliense. 1979. AUBERT, Roger. Editorial, Concilium: Revista Internacional de Teologia, n. ${ }^{0}$ 7. 1968. AZZI, Riolando; BEOZZO, José Oscar (organizadores). Os religiosos no Brasil: enfoques históricos. São Paulo: Paulinas. 1986.

AZZI, Riolando. A crise da cristandade e o projeto liberal. São Paulo. Paulinas, 1991. . A cristandade colonial: um projeto autoritário. São Paulo. Paulinas, 1987. . A neocristandade: um projeto restaurador. São Paulo: Paulus, 1994.

- A vinda dos redentoristas para o Brasil na última década do século passado, Revista Convergência, Ano X , N. 104, jul/ago 1977.

. As romarias no Brasil, Revista Vozes, n. ${ }^{\circ} 4$, LXXIII. maio de 1979.

. Catolicismo popular e autoridade eclesiástica na evolução histórica do

Brasil, Revista Religião e Sociedade, 1, 1, maio de 1977.

. Elementos para a história do catolicismo popular, Revista Eclesiástica Brasileira, 36, 141, março de 1976.

. O catolicismo popular no Brasil: aspectos históricos. Petrópolis: Vozes, 
1978.

. O episcopado do Brasil frente ao catolicismo popular. Petrópolis: Vozes, 1977.

AZEVEDO, Tales. O catolicismo no Brasil. Rio de Janeiro: MEC, 1955.

BARBOSA, Rui. (tradutor e prefaciador) O Papa e o concílio. Obras Completas de Rui Barbosa. v. IV. Rio de Janeiro. Ministério da Educação e Cultura/ Fundação Casa de Rui Barbosa, 1977.

BARTHOLO, Maria Elisa Carvalho. Uma presença tardia: raízes históricas da rede paroquial brasileira, Revista do mestrado de história, v.3. Vassouras: Universidade Severino Sombra, 2000.

BEOZZO, José Oscar. A Igreja no Brasil. Petrópolis: Vozes, 1994.

. Cristãos na universidade e na política. Petrópolis: Vozes, 1994.

. A Igreja no Brasil de João XXIII a João Paulo II, de Medellin a Santos Domingo. Petrópolis: Vozes, 1994.

- Irmandades, santuários, capelinhas de beira de estrada, Revista Eclesiástica Brasileira, 37, 148, dezembro de 1977.

BÍBLIA DE JERUSALÉM. São Paulo: Paulus, 1998.

BOLETIM ECLESIÁSTICO da Diocese de São Paulo, 1907-1910, Ano II.

BRANDÃO, Ascânio da Cunha. Dom Epaminondas. São Paulo: Oficinas gráficas da Ave Maria, 1941.

BRUNEAU, Thomás C. Catolicismo brasileiro em época de transição. São Paulo: Loyola, 1974.

BRUSTOLONI, João Júlio; GOMES, J. Pereira. História da Província Redentorista de São Paulo - 1894 a 1964. Aparecida. Inédito, 1991.

BRUSTOLONI, Júlio J. História da administração do Santuário de Aparecida. Aparecida: Inédito, 1998.

A Senhora da Conceição Aparecida: história da imagem, da capela e das romarias. 8. ed. Aparecida: Santuário, 1999.

. Contratos e remuneração no Santuário de Aparecida. Inédito, 1990.

CAMELLO, Maurílio José de Oliveira. Caraça, centro mineiro de educação e missão (1820-1830). Belo Horizonte: Imprensa Oficial, 1973.

CASALI, Alípio. Elite intelectual e restauração da Igreja. Petrópolis: Vozes, 1995.

CAVA, Ralph Della. Milagre em Juazeiro. Rio de Janeiro: Paz e Terra, 1977.

CITTÀ DEL VATICANO. O Vaticano e Roma Cristã. Roma: Tipografia Poliglota 
Vaticana, 1973.

CONCÍLIO ECUMÊNICO DE TRENTO. Coleção 19. Documentos Pontifícios. n. ${ }^{\circ} 95$. Petrópolis: Vozes, 1959.

CONGAR, Yves. A história da Igreja, 'lugar teológico', Concilium: Revista Internacional de Teologia, n. ${ }^{0}$ 57, 1970.

CONZIEMUS, Victor. A urgência de uma história crítica da Igreja contemporânea. Concilium: Revista Internacional de Teologia, n. ${ }^{0}$ 7, 1966.

DUFFY, Eamon. Santos \& Pecadores - História dos Papas. São Paulo: Cosac \& Naify Edições,1998.

FEBVRE, Lucien. Combats pour l'Histoire. Paris: Armand Colin, 1953.

FERNANDES, Geraldo. A religião nas constituições republicanas do Brasil, Revista Eclesiástica Brasileira, v. 8, fasc. 4, dez, 1948.

FISCHER-WOLLPERT, Rudolf. Os papas: de Pedro a João Paulo II. Petrópolis: Vozes. 5. ed., 1999.

GADILLE, Jacques. Panorama da literatura relativa à aplicação da sociologia religiosa. Concilium: Revista Internacional de Teologia, n. ${ }^{\circ}$ 57, 1970.

GUISARD FILHO, Félix. D. José Pereira da Silva Barros - sua vida e sua obra. São Paulo: Empresa Editorial Universal, 1945.

. Convento de Santa Clara: achegas à história de Taubaté. São Paulo: Athena Editora. 1938.

KOHNEN, Mansueto. Feição cultural da Igreja na Alta Idade Média, Revista Eclesiástica Brasileira, v. 14, fasc. 2, junho de 1954.

KRISCHKE, Paulo José. A Igreja e as crises no Brasil. Petrópolis: Vozes, 1981.

LACOMBE, Américo Jacobina. A Igreja no Brasil colonial. In: HOLANDA, Sérgio Buarque de. (org.). História da Civilização Brasileira - A época colonial: administração, economia e sociedade. 7. ed. Rio de Janeiro: Bertrand Brasil, Tomo I, 2 v, 1993.

LIMA, Luiz Gonzaga de Souza. Evolução política dos católicos e da Igreja no Brasil. Petrópolis: Vozes, 1979.

LUHMANN, Niklas. Religião institucionalizada segundo a sociologia funcional, Concilium: Revista Internacional de Teologia, n. ${ }^{\circ}$ 1, 1974.

LUSTOSA, Oscar de Figueiredo. Situação religiosa da capitania de São Paulo na palavra de seu bispo, D. Frei Manuel da Ressurreição, Revista de História, v. LII, n. ${ }^{\circ}$ 104, Ano XXVI. out./dez, 1975. 
A presença da Igreja no Brasil - histórias e problemas (1500-1968). São Paulo: Giro, 1975.

. A Igreja católica no Brasil República. São Paulo: Paulinas, 1991.

MATOS, Henrique Cristiano José. História do cristianismo. Belo Horizonte: Congregação dos Fráteres de Nossa Senhora Mãe de Misericórdia. Circulação interna "ad experimentum". Coleção Estudos e Documentos, v. 4, Período contemporâneo, 1990.

MATOS, Henrique de Morais. A Igreja brasileira de Itapira, Revista Eclesiástica Brasileira, v.13, fasc. 3, setembro de 1953.

MAINWARING, Scott. Igreja Católica e política no Brasil (1916-1985). São Paulo: Brasiliense, 2004.

MARROU, Henri Irené. De la conaissance historique. Paris: Seuil, 1958. . Théologie de l'Histoire. Paris: Seuil, 1968.

MICELI, Sérgio. A elite eclesiástica brasileira. (1890-1930). São Paulo: Bertrand do Brasil, 1988.

MONNICH, C.W. A História da Igreja no conjunto das ciências do Homem, Concilium: Revista Internacional de Teologia, n. ${ }^{\circ}$ 57, 1970.

MONTENEGRO, João Alfredo de Souza. Evolução do catolicismo no Brasil. Petrópolis: Vozes, 1972.

MORAES JÚNIOR, Antônio d'Almeida. Uma página de Mons. Antônio Nascimento Castro sobre "Misticismo e Histeria", Revista Eclesiástica Brasileira, v. 4, fasc. 2, jun, 1944.

MOTT, Luiz. Cotidiano e vivência religiosa: entre a capela e o calundu. In: NOVAIS, Fernando A. (org.). História da vida privada no Brasil, v. 1. São Paulo: Companhia das Letras, 1997.

OLIVEIRA, Pedro A. Ribeiro de. Catolicismo popular e romanização do catolicismo brasileiro, Revista Eclesiástica Brasileira, 36, 141, março de 1976. . Religião e dominação de classe. Petrópolis: Vozes, 1985.

PASSARELLI, Humberto. Contribuição à história de Taubaté. Taubaté: JAC Gráfica e Editora, 1996.

PIMENTA, Silvério Gomes. Vida de D. Antônio Ferreira Viçoso. Mariana: Tipografia do Bom Ladrão, 1876.

PLONGERON, Bernard. A História da Igreja na encruzilhada das ciências, Concilium: Revista Internacional de Teologia, n. ${ }^{\circ}$ 57, 1970. 
POULAT, Émile. Compreensão histórica da Igreja e compreensão eclesiástica da História, Concilium. Revista Internacional de Teologia, n. ${ }^{\circ} 67,1971 / 7$.

PRATTA, Marco Antônio. Mestres, santos e pecadores: educação, religião e ideologia na primeira república brasileira. São Carlos: Rima, 2002.

REIS, João José. O cotidiano da morte no Brasil oitocentista. In: Novais, Fernando A. (coordenador geral). História da vida privada no Brasil. v. 2. São Paulo: Companhia das Letras, 1997.

RODRIGUES, Anna Maria Moog. A Igreja na república, Brasília: Editora Universidade de Brasília, 1981.

ROMANO, Roberto. Brasil: Igreja contra Estado. São Paulo: Kairos, 1979.

SALLES, Benedito Galvão Patrício. Santa Teresinha e o seu primeiro santuário. Inédito. 1984.

SAUCEROTTE, A. As sucessivas autocompreensões da Igreja vistas por um marxista, Concilium. Revista Internacional de Teologia. n. ${ }^{0}$ 67, 1971/7.

SCAMBINI, José. A liberdade religiosa nas constituições brasileiras. Petrópolis: Vozes, 1978.

SERVUS MARIAE. (Raimundo Caramuru de Barros). Para entender a Igreja no Brasil: a caminhada que culminou no Vaticano II (1930/1968). Petrópolis: Vozes, 1994.

SETÚBAL, Paulo. Confiteor. 3. ed. São Paulo: Companhia Editora Nacional, 1937.

SIEBERT, Rudolf. A religião na perspectiva da Sociologia crítica. Concilium: Revista Internacional de Teologia, n. ${ }^{0}$ 1, 1974.

SILVA, J. Trindade da Fonseca e. Lugares e pessoas: subsídios eclesiásticos para a história de Goiás. São Paulo: Escolas Profissionais Salesianas, 1948.

SIQUEIRA, A.A. Dom Duarte Leopoldo e Silva, Revista Eclesiástica Brasileira, v. 1, mar.-jun, 1941.

SÖDERBLOM, Nathan. Manuel de I'Historie des religions. Paris: Leroux, 1925.

SOUZA, Laura de Mello e. O Diabo e a Terra de Santa Cruz. 5. ed. São Paulo: Companhia das Letras, 1995.

SOUZA, Ney de (org.). Catolicismo em São Paulo: 450 anos de presença da Igreja católica em São Paulo (1554-2004). São Paulo: Paulinas, 2004.

TORRES, João Camilo de Oliveira. História das idéias religiosas no Brasil. São Paulo: Grijalbo, 1968.

VALLE, Edênio. Religiosidade popular, evangelização e vida religiosa. Petrópolis: 
Vozes, 1975.

VIOTTI, Hélio Abranches. Expansão da Igreja no Brasil Independente, Revista de História. V. XVL. n. ${ }^{\circ}$ 92. ano XXIII. 1972.

WEILER, Anton. História da Igreja e nova orientação da historiologia, Concilium. Revista Internacional de Teologia. n. ${ }^{\circ}$ 57, 1970.

. História Eclesiástica como autocompreensão da Igreja, Concilium. Revista Internacional de Teologia. n. ${ }^{\circ}$ 67, 1971/7.

WERNET, Augustin. A Igreja paulista no século XIX. São Paulo: Ática, 1987.

. A imprensa católica em São Paulo durante o segundo reinado, Revista Relações Humanas, São Bernardo do Campo, Instituto de Relações Sociais e Industriais (IRESI), n. ${ }^{\circ} 7,1986$.

. A presença de beneditinos alemães na restauração da Ordem de São Bento em São Paulo, Inédito.

. A reforma do clero paulista de Dom Antônio Joaquim de Melo, Revista da Sociedade Brasileira de Pesquisa Histórica - SBPH. Anais da III reunião, São Paulo, 1984.

Antigas irmandades e novas associações religiosas, Revista da Sociedade Brasileira de Pesquisa Histórica - SBPH, Anais da XI reunião, Curitiba, 1992.

. O Auge da romanização: O concílio plenário da América Latina, Revista da Sociedade Brasileira de Pesquisa Histórica - SBPH. Anais da X reunião, Curitiba, 1991.

. Os bispos de São Paulo durante o segundo reinado e a romanização da igreja paulista, Revista Relações Humanas, São Bernardo do Campo, Instituto de Relações Sociais e Industriais (IRESI), n. ${ }^{\circ}$ 8, 1987.

. Os primórdios do ultramontanismo em São Paulo (1851-1906), Revista da Sociedade Brasileira de Pesquisa Histórica (SPBH), Anais da IV reunião. São Paulo, 1985.

. Os redentoristas no Brasil. Aparecida: Santuário, 1995, 3 v.

. Peregrinação a Aparecida: das romarias programas ao turismo religioso. In:

RODRIGUES, Adyr Balastreri (org.) Turismo. Modernidade. Globalização. São Paulo: Hucitec, 1977.

. Vida religiosa em São Paulo (1554-1954), In: PORTA, Paula (org.) História da cidade de São Paulo, v.1: A cidade colonial. São Paulo: Paz e Terra, 2004.

WOODWARD, Kenneth L. A fábrica de santos. São Paulo: Siciliano, 1992. 


\section{C - Teses e Dissertações}

ALMEIDA, Cláudio Aguiar. Meios de comunicação católicos na construção de uma ordem autoritária: 1907/1937. 2002. Tese (Doutorado em História Social) Universidade de São Paulo, São Paulo, 2002.

ALMEIDA, Jaime de. Foliões. 1987. Tese (Doutorado em História Social). Universidade de São Paulo, São Paulo, 1987.

ARRUDA, Marcelo Pedro de. Triunfo católico no calendário secular: Nossa Senhora Aparecida no calendário republicano (1930-1980). 2005. Tese (Doutorado em História Social) - Universidade de São Paulo, São Paulo, 2005.

BENCOSTTA, Marcus Levy Albino. Igreja e Poder em São Paulo: D. João Batista Corrêa Nery e a Romanização do Catolicismo Brasileiro (1908 - 1920). 2002. Tese (Doutorado em História Social) - Universidade de São Paulo, São Paulo, 2002.

CÂMARA NETO, Isnard de Albuquerque. Um caso de sobrevivência: os redentoristas e a festa de São Benedito em Aparecida (1894-1922). 2000. Dissertação (Mestrado em História Social) - Universidade de São Paulo, São Paulo, 2000.

CAMELLO, Maurílio José de Oliveira. Dom Antônio Ferreira Viçoso e a Reforma do Clero de Minas Gerais no Século XIX. 1986. Tese (Doutorado em História Social) Universidade de São Paulo, São Paulo, 1986.

CHIZOTI, Geraldo. Os operários da caridade: a Sociedade de São Vicente de Paulo em São Paulo (1874-1946). 1991. Tese (Doutorado em História Social) Universidade de São Paulo, São Paulo, 1991.

FAUSTINO, Evandro. O Renitente Catolicismo Popular. 1996. Tese (Doutorado em História Social) - Universidade de São Paulo, São Paulo, 1996.

GAETA, Maria Aparecida Junqueira Veiga. Os percursos do ultramontanismo em São Paulo no episcopado de D. Lino Deodato Rodrigues de Carvalho (1873-1894). 1992.Tese (Doutorado em História Social) - Universidade de São Paulo, São Paulo, 1992.

MANOEL, Ivan Aparecido. Igreja e educação feminina: os colégios das irmãs de São José de Chamberry (1859-1919). 1998. Tese (Doutorado em História Social) Universidade de São Paulo, São Paulo, 1988.

MEIHY, José Carlos Bon. Vale de lágrimas: História da pobreza em Taubaté. 1980. Tese (Livre docência ) - Universidade de São Paulo, São Paulo, 1980. 
PINHEIRO, Alceste. O Cardeal Arcoverde e a reorganização eclesiástica. 2003. Tese (Doutorado em História Social) - Universidade de São Paulo, São Paulo, 2003. Raveli, Flávia Albergaria. A reforma ultramontana e a festa do Divino: São Luiz do Paraitinga entre os séculos XIX e XX. 1998. Dissertação (Mestrado em História Social) - Universidade de São Paulo, São Paulo, 1998.

REIS, Fábio José Garcia dos. Os Redentoristas, o Cônego Antônio Marques Henriques e a Romanização da Igreja Paulista (1888-1917). 1993. Dissertação (Mestrado em História Social) - Universidade de São Paulo, São Paulo, 1993.

RIBEIRO, Maria Alice de Morais. Taubaté e a alternativa industrial: 1891-1933. 1982. Dissertação (Mestrado em História Social) Universidade de São Paulo, São Paulo, 1982.

SANTOS, Lourival dos. Igreja, nacionalismo e devoção popular: as estampas de Nossa Senhora Aparecida (1854-1978). 2000. Dissertação (Mestrado em História Social) - Universidade de São Paulo, São Paulo, 2000.

\section{III - Internet}

http://catholic-hierarchy.org 